\title{
Análise numérica e experimental de blocos de concreto armado sobre duas estacas com cálice externo, parcialmente embutido e embutido utilizado na ligação pilar-fundação
}

\author{
Rodrigo Barros
}

\section{VERSÃO CORRIGIDA}

A versão original encontra-se na Escola de Engenharia de São Carlos.

\begin{abstract}
Tese apresentada ao Departamento de Engenharia de Estruturas da Escola de Engenharia de São Carlos, Universidade de São Paulo, como parte dos requisitos para obtenção do Título de Doutor em Engenharia Civil.
\end{abstract}

Área de concentração: Engenharia de Estruturas

Orientador: José Samuel Giongo

São Carlos 
AUTORIZO A REPRODUÇÃO E DIVULGAÇÃO TOTAL OU PARCIAL DESTE TRABALHO, POR QUALQUER MEIO CONVENCIONAL OU ELETRÔNICO, PARA FINS DE ESTUDO E PESQUISA, DESDE QUE CITADA A FONTE.

Ficha catalográfica preparada pela Seção de Tratamento da Informação do Serviço de Biblioteca - EESC/USP

B277a

Barros, Rodrigo

Análise numérica e experimental de blocos de concreto armado sobre duas estacas com cálice externo, parcialmente embutido e embutido utilizado na ligação pilar-fundação / Rodrigo Barros; orientador José Samuel Giongo. São Carlos, 2013.

Tese (Doutorado)-Programa de Pós-Graduação em Engenharia de Estruturas -- Escola de Engenharia de São Carlos da Universidade de São Paulo, 2013.

1. Concreto armado. 2. Blocos sobre estacas. 3. Cálice de fundação. 4. Análise experimental. 5. Análise numérica.

I. Título. 


\section{FOLHA DE JULGAMENTO}

Candidato: Engenheiro RODRIGO BARROS.

Título da tese: "Análise numérica e experimental de blocos de concreto armado sobre duas estacas com cálice externo, parcialmente embutido e embutido utilizado na ligação pilar-fundação".

Data da defesa: 08/11/2013

\section{Comissão Julgadora:}

Resultado:

Prof. Dr. José Samuel Giongo (Orientador)

(Escola de Engenharia de São Carlos/EESC)

Prof. Dr. Ricardo Carrazedo

APROVADO

(Escola de Engenharia de São Carlos/EESC)

Prof. Titular Mounir Khalil El Debs

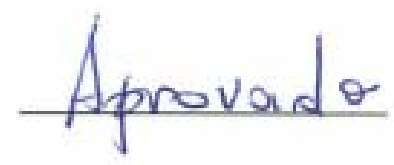

(Escola de Engenharia de São Carlos/EESC)

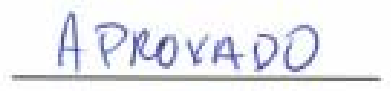

Prof. Dr. Ângelo Rubens Migliore Junior

APROVATO

(Centro Universitário de Lins/UNILINS)

Prof. Dr. João Carlos Della Bella

APROVADO

(Escola Politécnica/USP)

Coordenadora do Programa de Pós-Graduação em Engenharia Civil (Engenharia de Estruturas):

Profa. Associada Ana Lucia Homce de Cresce El Debs

Presidente da Comissão de Pós-Graduação:

Prof. Titular Denis Vinicius Coury 

Aos meus pais, Denilde e José, e as minhas irmãs Kátia, Cássia e Claudia, com amor e gratidão. 



\section{Agradecimentos}

Ao final de mais uma etapa da minha vida, agradeço primeiramente a Deus por ter abençoado e me guiado nas minhas escolhas.

Aos meus pais: Denilde e José; minhas irmãs: Kátia, Cássia e Claudia e minha tia Marisa, pelo apoio de sempre e por acreditarem e confiarem nas minhas decisões.

A minha namorada Maria Laura, pela paciência e apoio nos momentos difíceis.

Aos meus grandes amigos da cidade de Natal: Arthunio, Morais, Thyago, Guru, Moreno, Gustavo, Pablo, Iuri, Marcelão e André Felipe. Aos amigos da UFRN, em especial Tommy, Marcelo, Vinícius, Diogo e Jocilene.

Aos professores da UFRN Roberto José de Medeiros, Joel Araújo, Pétrus Nóbrega e Selma da Nóbrega pelo incentivo ao ingresso na pós-graduação, e a todos os outros professores, inclusive dos ensinos médio e fundamental, que contribuíram com a minha formação.

Ao professor José Samuel Giongo pelas orientações do mestrado e no doutorado, amizade, conselhos e por acreditar na realização desse trabalho.

Aos amigos Giovanni, Hugo e Wanderson, com os quais tive a oportunidade de morar na cidade de São Carlos. A todos os colegas e amigos do departamento de estruturas, em especial a Ana Paula, Cynthia e Renata. A Ellen Kellen e Fabiana Munhoz pela ajuda no Laboratório durante a preparação e realização dos ensaios.

Aos funcionários e amigos da CAT Engenharia, Raquel, Adriano, Hugo, Pedro, em especial ao Eng ${ }^{\circ}$ Claudio Augusto Tomazela.

Aos funcionários do Laboratório de Estruturas e do Departamento de Engenharia de Estruturas e da marcenaria da EESC, que de uma forma ou de outra contribuíram para a realização desse trabalho. 

BARROS, R. (2013). Análise numérica e experimental de blocos de concreto armado sobre duas estacas com cálice externo, parcialmente embutido e embutido utilizado na ligação pilar-fundação. São Carlos, 2013. Tese (Doutorado) - Escola de Engenharia de São Carlos, Universidade de São Paulo.

Esta pesquisa estuda o comportamento de blocos de concreto armado sobre duas estacas utilizado na ligação pilar-fundação de estruturas de concreto pré-moldado, submetida a ação de força centrada. Nessa situação, a ligação pilar-fundação pode ocorrer por meio do cálice de fundação, que por sua vez pode estar embutido, parcialmente embutido com parte do colarinho saliente, ou externo com o colarinho saliente em relação ao bloco de fundação. Apresenta-se nesta pesquisa o estudo experimental e numérico de blocos de fundação sobre duas estacas com cálice externo, parcialmente embutido e embutido, submetidos à ação centrada utilizando modelos em escala reduzida 1:2. Nos modelos analisados, considerou-se a conformação das paredes do cálice e do pilar com e sem rugosidade. Os resultados são comparados a dois blocos de referência, os quais apresentaram ligação monolítica entre o pilar e o bloco. Foi desenvolvida análise numérica tridimensional utilizando programa baseado no método dos elementos finitos (MEF), na qual foi considerada a não-linearidade física dos materiais. Observa-se que os blocos da série com rugosidade apresentaram maior rigidez e maior força última comparados aos blocos da série sem rugosidade. A armadura adicional utilizada nos modelos sem interface rugosa conferiu aumento na resistência dos modelos na ordem de 15\%, o que não ocorreu nos modelos com rugosidade. Particularmente, no caso de blocos com cálice embutido e sem rugosidade, observou-se comportamento de bloco flexível, diferente dos demais modelos.

Palavras-chave: Concreto armado, Blocos sobre estacas, Cálice de fundação, Análise experimental, Análise numérica. 

Abstract

BARROS, R. (2013). Numerical and experimental analysis of two pile caps reinforced concrete with external, partially embedded and embedded socket used in column-foundation connection. São Carlos, 2013. Thesis (Doctorate) - School of Engineering of São Carlos, University of São Paulo.

The present research studies the behavior of two pile caps reinforced concrete used in column-foundation connection of precast concrete structures, submitted to centered load. This situation allows that pile-foundation connection can occur by socket, which can be embedded, partially embedded or external, with socket walls over the pile caps. The research presents an experimental and numerical study of two pile caps reinforced concrete with external, partially embedded and embedded socket, submitted to centered load, using 1:2 scaled models. These models present the socket walls with rough and smooth interface. The results are compared with two reference models, which present a monolithic connection between pile caps and column. Threedimensional numerical analyses using software based on finite element method (FEM) were developed considering the nonlinear physical behavior of the material. It was observed that pile caps with rough interface present stiffness and ultimate load greater than pile caps with smooth interface. Additional reinforcement using on models with smooth interface add a $15 \%$ resistance on models, but this effect did was not observed on the model with rough interface.. Particularly, models with smooth interface and embedded socket present a flexible pile caps behavior.

Keywords: Reinforced concrete, Pile caps; Socket foundation; Experimental analysis; Numerical analysis 



\section{CAPÍTULO 1 - INTRODUÇÃO}

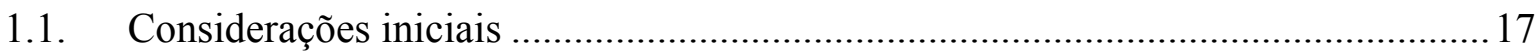

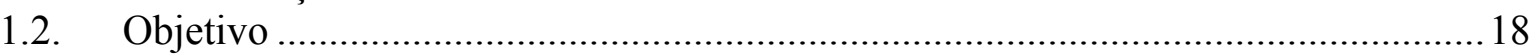

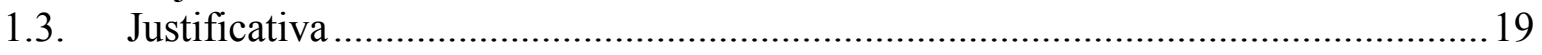

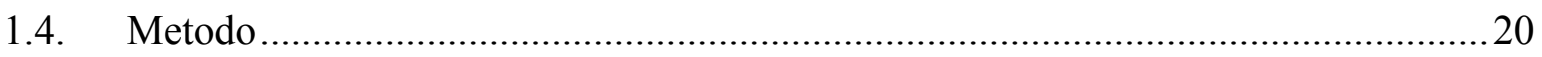

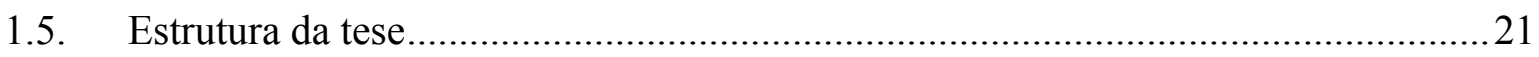

\section{CAPÍTULO 2 - REVISÃO BIBLIOGRÁFICA}

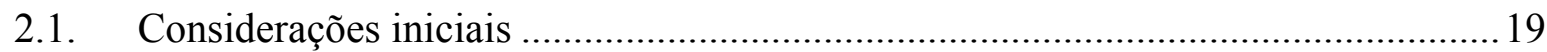

2.2. Pesquisas com ênfase experimental................................................................ 19

2.3. Pesquisas com ênfase teórica e numérica ............................................................... 38

2.4. Pesquisas com ênfase no cálice de fundação........................................................ 46

2.5. Recomendações Para Projetos de blocos sobre estacas de acordo com normas

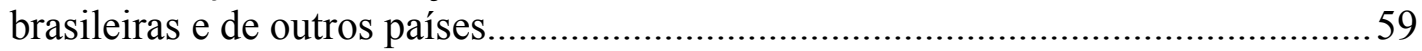

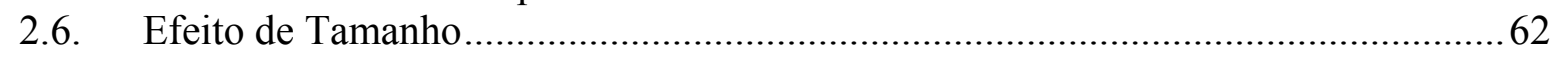

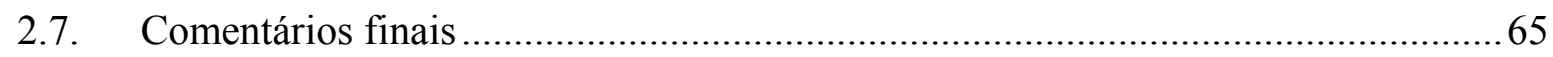

\section{CAPÍTULO 3 - ANÁLISE TEÓRICA E DIMENSIONAMENTO}

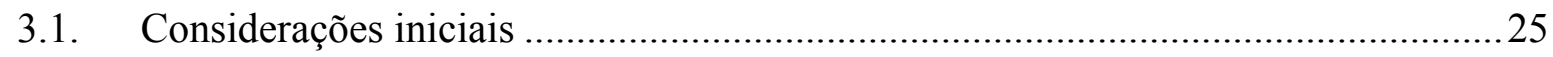

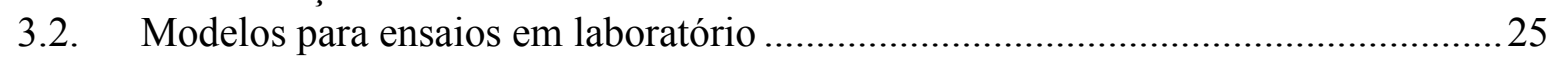

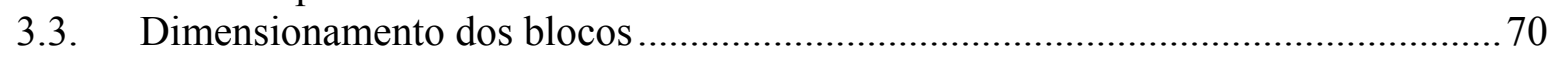

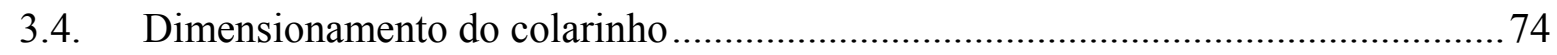

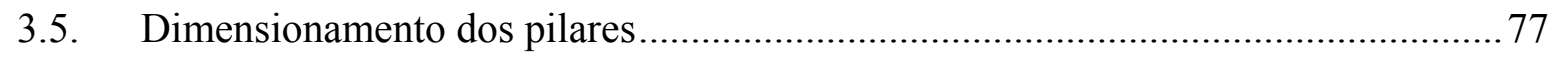

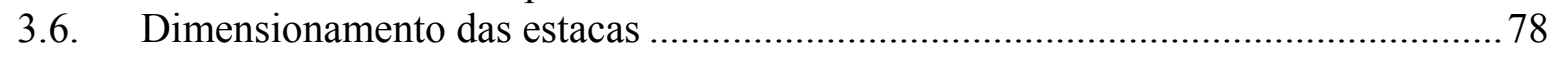

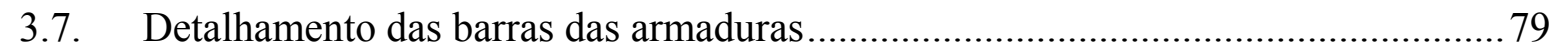

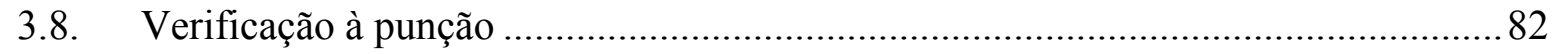

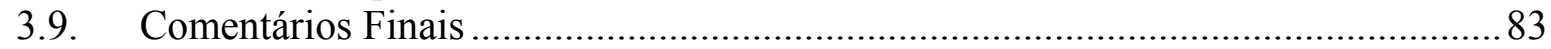

\section{CAPÍTULO 4 - PROGRAMA EXPERIMENTAL}

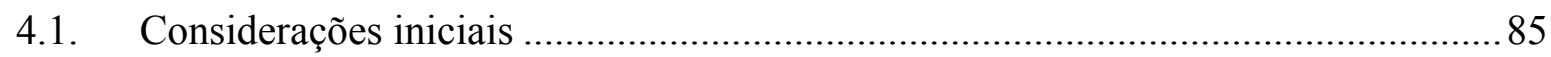

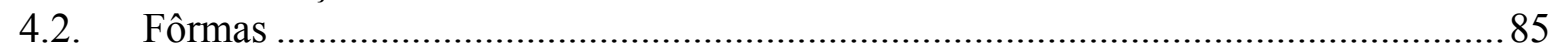

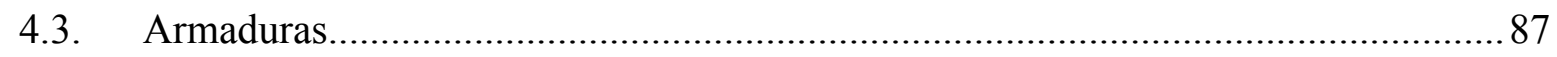

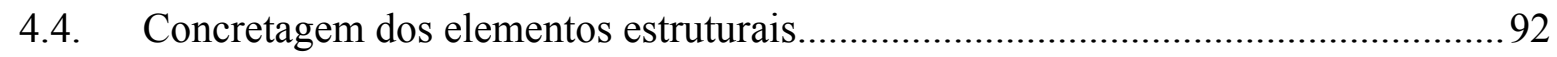

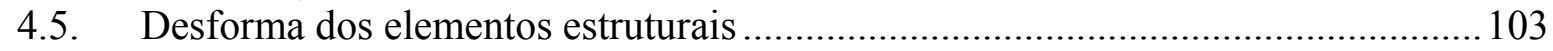

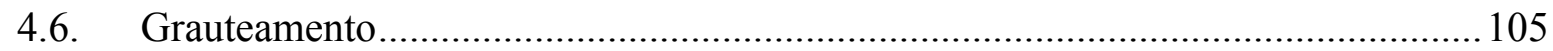

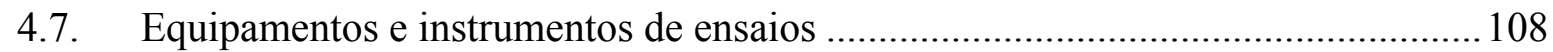

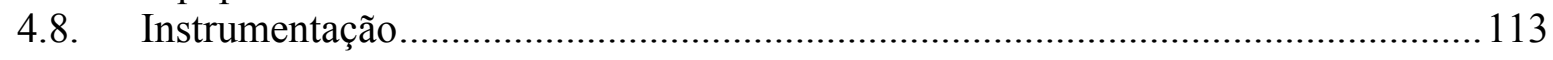

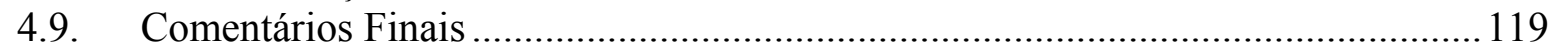




\section{CAPÍTULO 5 - RESULTADOS EXPERIMENTAIS}

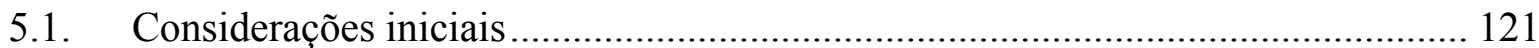

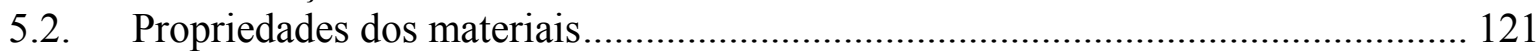

5.2.1. Ensaios à compressão em corpos-de-prova de concreto ................................ 121

5.2.2. Ensaios à tração por compressão diametral em corpos-de-prova de concreto 124

5.2.3. Ensaios para determinação do módulo de elasticidade estático do concreto .. 126

5.2.4. Ensaios para determinação do módulo de elasticidade dinâmico do concreto 129

5.2.5. Resistência ao escoamento e módulo de elasticidade das barras de aço......... 134

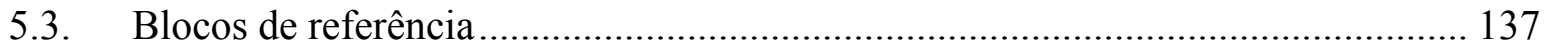

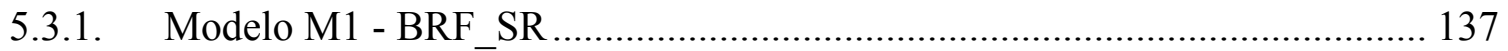

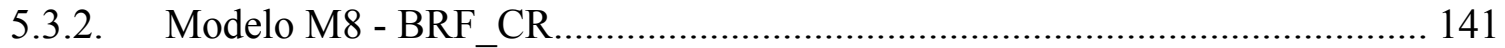

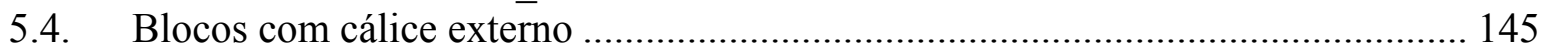

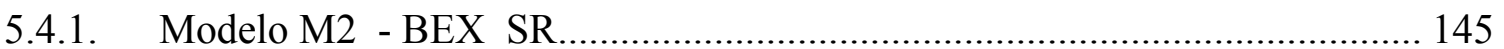

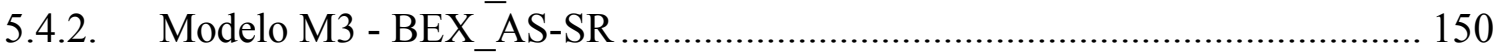

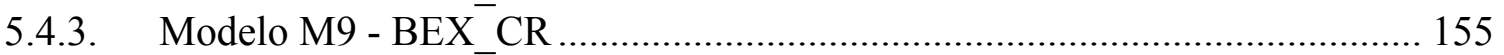

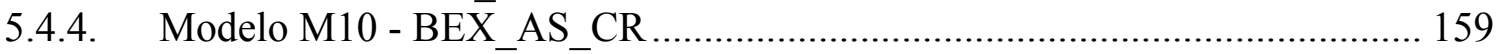

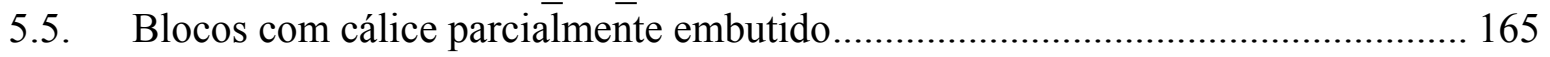

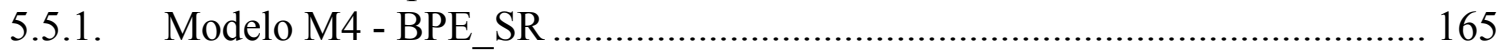

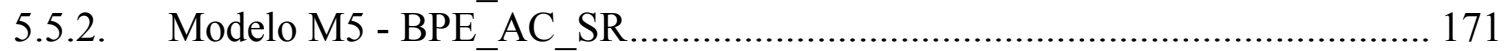

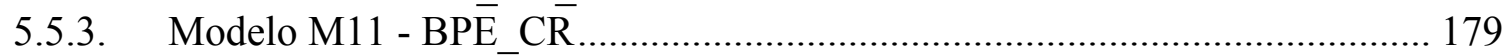

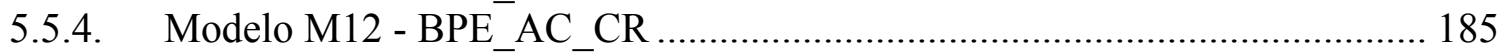

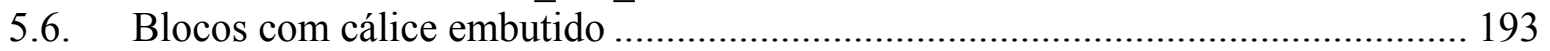

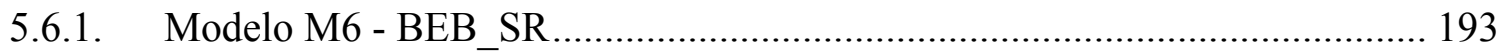

5.6.2. Modelo M7 - BEB_AC_SR ………........................................................... 199

5.6.3. Modelo M13 - BEB_CR ….................................................................... 207

5.6.4. Modelo M14 - BEB_AC_CR ................................................................... 213

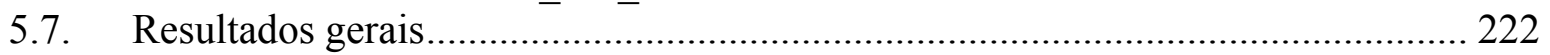

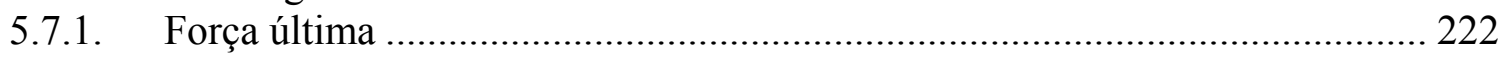

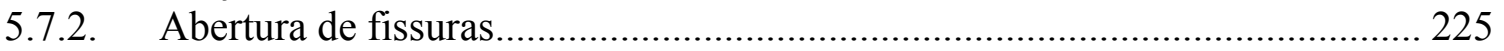

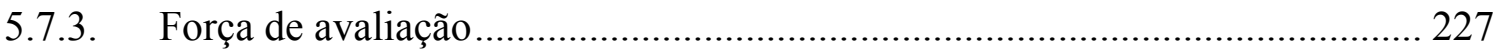

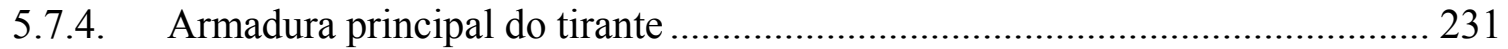

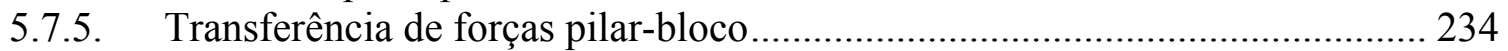

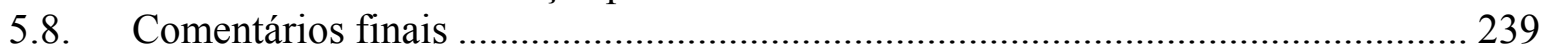

\section{CAPÍTULO 6 - SIMULAÇÃO NUMÉRICA}

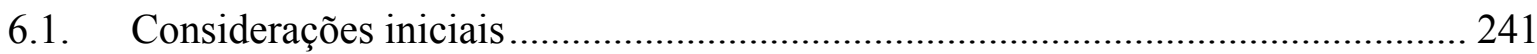

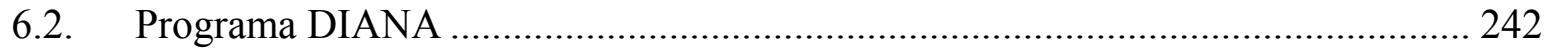

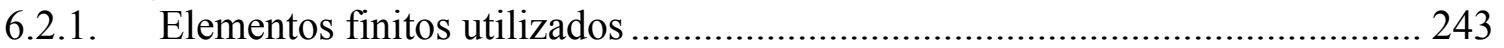

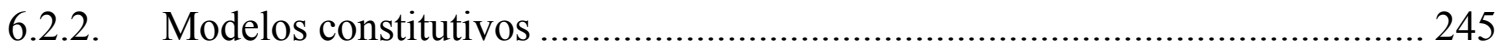

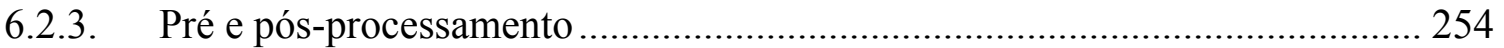

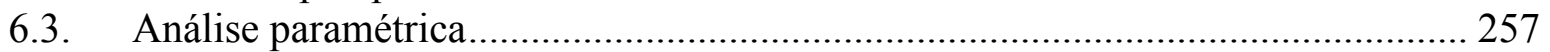

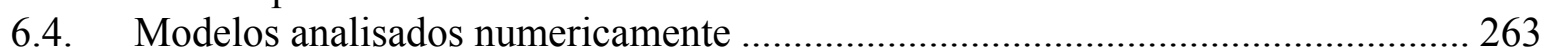

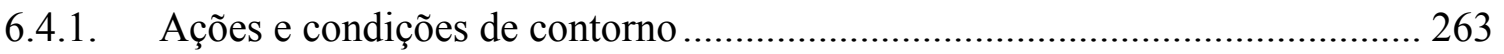

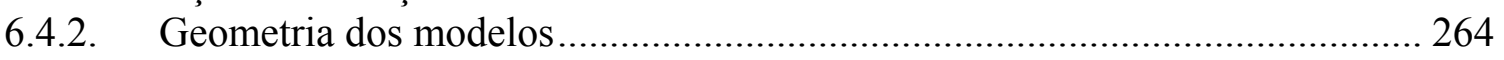




\section{Sumário}

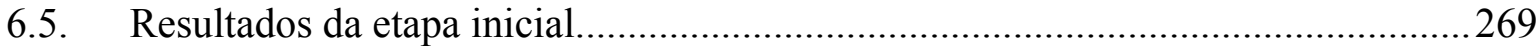

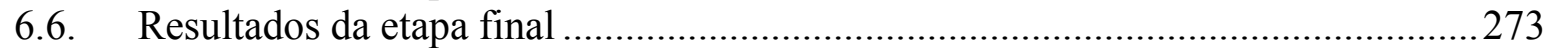

6.6.1. Deslocamentos no modelo numérico..............................................................2 275

6.6.2. Deformações das barras da armadura principal do bloco ...............................2277

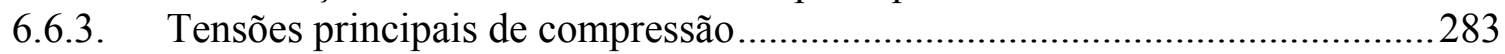

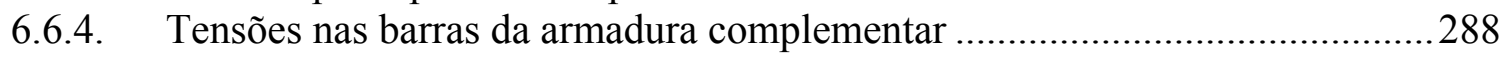

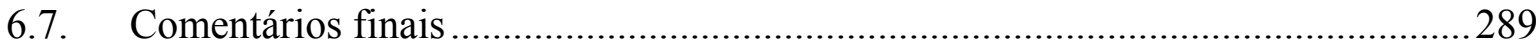

\section{CAPÍTULO 7 - MODELO TEÓRICO PROPOSTO}

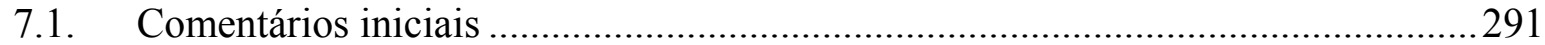

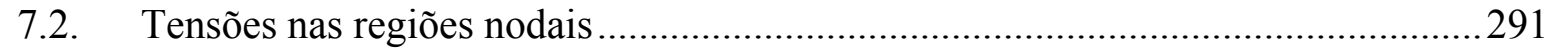

7.3. Critério proposto para verificação da região nodal superior ..................................2295

7.4. Avaliação dos blocos com cálice embutido sem rugosidade...................................297

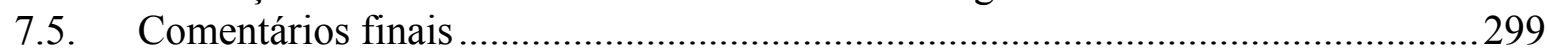

\section{CAPÍTULO 8 - CONCLUSÃO}

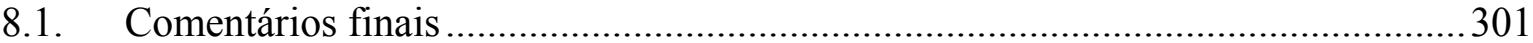

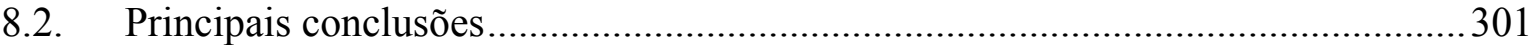

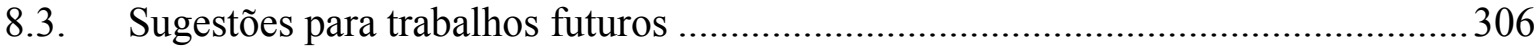

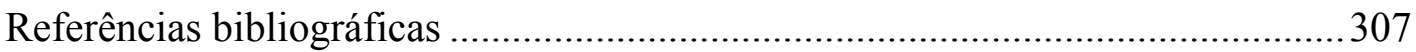

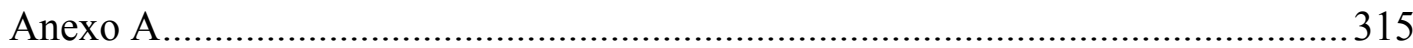

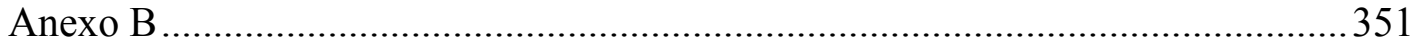





\section{Introdução}

\subsection{Considerações iniciais}

A escolha do tipo de fundação a ser utilizada numa obra depende essencialmente de parâmetros técnicos e econômicos que devem ser avaliados pelo engenheiro responsável pelo projeto. Diversos parâmetros a respeito do solo, tais como estratificação do terreno, situações topográficas, intensidade das ações, disposição das edificações limítrofes, bem como os tipos de fundação possíveis de serem realizados, são importantes para que seja obtida a melhor solução em termos da fundação.

Quando as camadas superiores do terreno não são capazes de resistir às ações provenientes da superestrutura, é necessário recorrer às camadas mais profundas do solo, realizando, portanto, o uso de fundações profundas. Dentre as soluções possíveis destacam-se o uso das estacas e dos tubulões. O uso de estacas de concreto armado é uma das soluções mais difundidas no meio técnico, e o dimensionamento desse elemento pode ser feito considerando apenas a resistência de ponta ou com o uso de atrito lateral, dependendo da situação. Entretanto, o uso de fundações profundas requer um elemento estrutural capaz de realizar a ligação entre os pilares e as estacas. Tal elemento é conhecido como bloco de coroamento, bloco de fundação ou mesmo bloco sobre estacas. Segundo a ABNT NBR 6118:2007, "blocos são estruturas de volume usadas para transmitir às estacas as cargas de fundação".

O bloco sobre estacas é um importante elemento estrutural cuja função é transferir as ações da superestrutura para as camadas inferiores do terreno por meio de estacas ou tubulões. Esse elemento estrutural, apesar de ser fundamental para a segurança da superestrutura, geralmente não permite a inspeção visual quando em serviço, sendo essa uma das razões para que se conheça o seu comportamento estrutural.

Quando são utilizadas estruturas de concreto pré-moldado, além da construção do bloco de coroamento, faz-se necessário também à construção de outro elemento estrutural, denominado cálice. Os cálices têm função de auxiliar a transmissão das ações dos elementos da superestrutura (em geral pilares) para a fundação. A ligação por meio de cálice é realizada 
embutindo um trecho do pilar (comprimento de embutimento, $\ell_{\text {emb }}$ ) em uma abertura do elemento de fundação que possibilite seu encaixe. O cálice, por sua vez, pode ser construído externamente ao bloco, parcialmente embutido ou embutido no bloco. A Figura 1.1 indica em perspectiva as três possíveis configurações para o cálice.
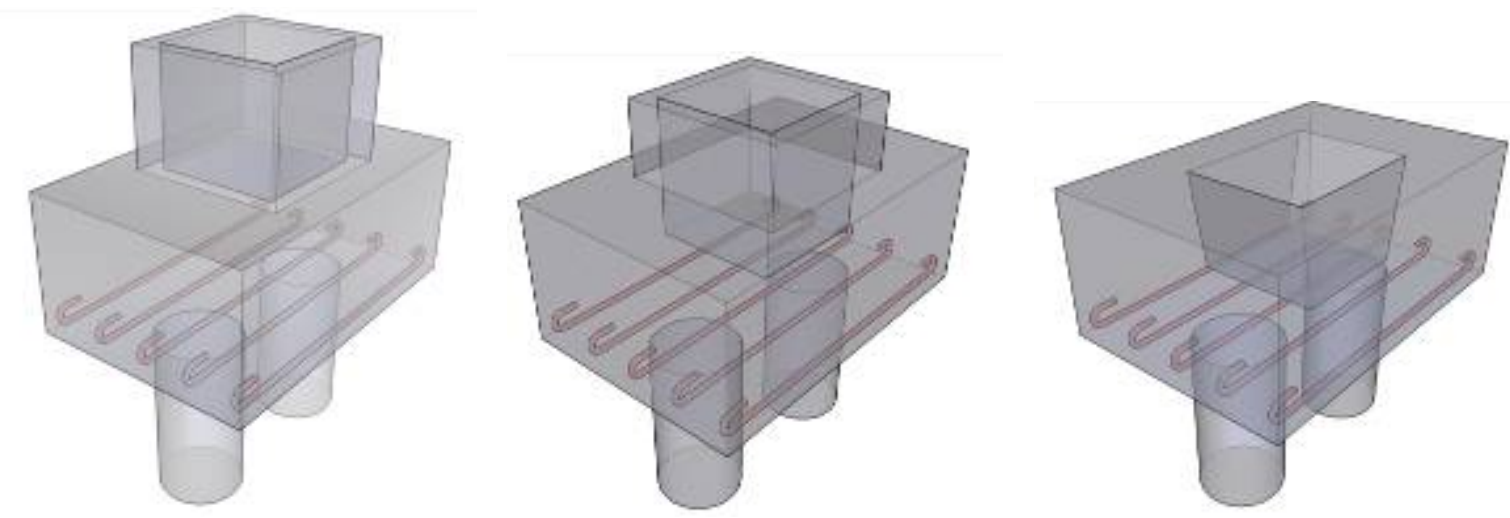

Figura 1.1 - Perspectivas dos blocos sobre duas estacas com cálice externo, parcialmente embutido e embutido, BARROS (2009).

Na literatura técnica, verifica-se que a maioria dos métodos de projeto restringem-se aos cálices externos, os quais são construídos sobre os blocos ou sapatas. Porém, pouco se conhece a respeito das demais situações, com o cálice embutido e parcialmente embutido. Em virtude da falta de conhecimento do comportamento estrutural do bloco de fundação na presença de cálice, desenvolveu-se uma pesquisa que possibilite o melhor entendimento do comportamento estrutural desse elemento.

\subsection{Objetivo}

O objetivo principal desta pesquisa é analisar e discutir o comportamento de blocos de fundação sobre duas estacas, utilizados na ligação pilar-fundação por meio de cálice. São consideradas três situações possíveis para o cálice: externo ao bloco, embutido no bloco e parcialmente embutido no bloco. Os objetivos específicos são:

- Analisar a influência do tipo de cálice na ligação pilar-fundação em bloco sobre duas estacas, por meio de cálice externo, embutido e parcialmente embutido;

- Analisar a formação das bielas de compressão por meio de comparação de resultados experimentais e numéricos; 
- Analisar a influência das conformações das paredes do pilar e do colarinho, isto é, com rugosidade ou sem rugosidade, no comportamento estrutural dos blocos;

- Analisar a região compreendida entre o fundo do cálice e o fundo do bloco, principalmente na situação em que o cálice encontra-se embutido no bloco;

- Analisar os modos de transferência da força oriunda do pilar para o bloco de fundação na presença de cálice;

- Propor um critério para verificação do modelo de bielas e tirantes aplicado a blocos de fundação sobre duas estacas com, em função do tipo de cálice;

- Propor valores para verificação das tensões nas regiões nodais desse tipo de bloco de fundação.

\subsection{Justificativa}

Este trabalho justifica-se pela importância que o elemento estrutural bloco sobre estacas apresenta na estrutura de uma edificação, sobretudo nas concebidas em concreto pré-moldado. O pouco conhecimento do comportamento do bloco quando da ligação por meio de cálice, principalmente nas situações em que se tem cálice embutido e parcialmente embutido, as divergências entre os métodos analíticos utilizados no dimensionamento e verificação dos blocos aliado à falta de normalização para este elemento estrutural, são alguns aspectos que justificam a realização deste trabalho.

Diante desse cenário, entende-se que o elemento bloco sobre estacas utilizado na ligação pilar-fundação ainda apresenta comportamento em parte desconhecido pelo meio técnico, principalmente nos casos em que o cálice se apresenta totalmente embutido no bloco.

A pouca literatura técnica a respeito de critérios para projeto de blocos sobre estacas com cálice embutido e parcialmente embutido aliado à escassez de resultados experimentais sobre o assunto, são fatores que indicam a importância que os resultados dessa pesquisa podem apresentar para o meio técnico.

Assim, em virtude da ausência de bibliografia específica a respeito de cálice totalmente embutido e, dando continuidade aos estudos a respeito de ligações em estruturas de concreto pré-moldado realizadas pelo Departamento de Engenharia de Estruturas da EESC-USP, justifica-se a realização desse trabalho. 


\subsection{Método}

Com o intuito de se obter os objetivos propostos nesse trabalho, foi utilizado o método apresentado a seguir.

Os métodos empregados nessa pesquisa são a análise numérica e experimental. Inicialmente foi coletado o máximo de informações a respeito dos blocos sobre estacas para elaboração da revisão bibliográfica. Com base nos estudos feitos na revisão bibliográfica e nas variáveis de interesse, foram definidos os modelos a serem estudados. Em seguida, uma análise numérica inicial foi desenvolvida com o intuito de criar subsídios para a análise experimental feita em etapa posterior.

Os blocos de concreto armado sobre estacas foram analisados numericamente por meio de programa computacional DIANA, baseado no método dos elementos finitos. A não linearidade física dos materiais foi considerada, sendo avaliados os efeitos da fissuração do concreto, a posição das armaduras do bloco, bem como o atrito existente entre as paredes do cálice e do pilar.

O programa DIANA é baseado no método dos elementos finitos e apresenta vários critérios de ruína que podem ser empregados na modelagem de concreto armado. Foram utilizados resultados experimentais e numéricos obtidos em projetos de pesquisa como os de DELALIBERA (2006) e BARROS (2009), para a verificação dos modelos de blocos sobre estacas.

O programa experimental realizou investigação em quatorze blocos sobre duas estacas. Para tanto, foram confeccionados modelos experimentais em escala reduzida 1:2, cujos detalhes estão apresentados no capítulo 3 deste texto. Foram realizados os seguintes ensaios:

- Ensaios para determinação das propriedades mecânicas das barras de aço das armaduras;

- Ensaios de corpos-de-prova cilíndricos para controle da resistência do concreto e determinação de propriedades mecânicas;

- Ensaios de quatorze blocos sobre duas estacas em escala reduzida 1:2, realizados no Laboratório de Estruturas da EESC-USP. 


\subsection{Estrutura da tese}

A tese encontra-se dividida em oito capítulos, sendo que o primeiro apresenta as considerações iniciais, os objetivos gerais e específicos, a justificativa e o método para realização do trabalho.

O capítulo dois apresenta a revisão bibliográfica, na qual é feito um apanhado geral dos trabalhos relacionados ao tema. A revisão encontra-se dividida em trabalhos com ênfase experimental, trabalhos com ênfase numérica e trabalhos com ênfase ma análise do cálice de fundação.

O capítulo três apresenta a análise teórica e os critérios utilizados para a definição e para o dimensionamento dos modelos que foram estudados em laboratório.

O capítulo quatro apresenta o desenvolvimento do programa experimental, o qual foi realizado no Laboratório de Estruturas da Escola de Engenharia de São Carlos, Universidade de São Paulo. São apresentados os materiais e equipamento necessários para pesquisa, bem como uma descrição minuciosa da etapa de confecção dos modelos.

O capítulo cinco contém os resultados da análise experimentais, sendo apresentados os resultados das propriedades mecânicas dos materiais, seguido dos resultados dos modelos propriamente ditos.

O capítulo seis apresenta a etapa de simulação numérica, sendo apresentadas as etapas de análise numérica inicial e final, na qual são feitas comparações com os resultados experimentais.

O capítulo sete apresenta uma proposta de um modelo teórico que possa ser utilizado no dimensionamento e nas verificações de blocos sobre estacas, em função do tipo de cálice adotado.

O capítulo oito apresenta as principais conclusões obtidas no trabalho, bem como são feitas sugestões para trabalhos futuros. 



\section{Revisão bibliográfica}

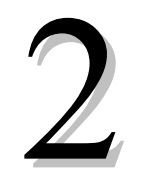

\subsection{Considerações iniciais}

Neste capítulo é apresentado um resumo das pesquisas a respeito de blocos de fundação. A revisão bibliográfica procurou compreender o que vem sendo estudado a respeito do tema bloco sobre estacas e, quando julgou-se oportuno, foi emitida a opinião crítica do autor sobre o tema. $\mathrm{O}$ texto encontra-se segmentado em três partes distintas, sendo que na primeira delas apresentam-se os trabalhos com ênfase experimental, na segunda encontram-se os trabalhos com ênfase em simulações numéricas e a terceira apresenta um resumo dos estudos focados na análise do cálice de fundações. Como não é objeto de estudo dessa pesquisa o comportamento do cálice de fundação propriamente dito, mas sim do comportamento do bloco quando da utilização do cálice, foco maior foi dado às pesquisas referentes ao bloco de fundação.

\subsection{Pesquisas com ênfase experimental}

HOBBS \& STEIN (1957) realizaram ensaios em 70 modelos de blocos sobre duas estacas concebidos em escala 1:3. A análise teórica foi desenvolvida por meio de solução analítica baseada na teoria da elasticidade bidimensional. Até então, o dimensionamento de blocos era feito como vigas, uma vez que não se consideravam as distinções entre regiões B e D. A comparação com resultados experimentais levou a um avanço no dimensionamento dos blocos de fundação.

Tratando do tema bloco sobre estacas, é de reconhecimento no meio técnico que os pesquisadores franceses BLÉVOT \& FRÉMY (1967) apresentam um dos principais estudos sobre o tema. Buscando compreender o comportamento do método das bielas, os pesquisadores realizaram ensaios em blocos sobre duas, três e quatro estacas, submetidos à ação de força centrada. Em todas as situações foi analisado o comportamento do bloco mediante diversos arranjos da armadura. 
No caso dos blocos sobre duas estacas, foi adotada a largura do bloco igual $40 \mathrm{~cm}$, e dimensões do pilar e das estacas igual a $30 \mathrm{~cm}$. O arranjo das barras da armadura, por sua vez, foi dividido em dois grupos: o primeiro deles com barras lisas dispostas sobre as estacas e com ganchos nas extremidades, e o segundo composto por barras com nervuras, porém desprovidas de ganchos. Para ambos os modelos, a distância entre as estacas foi de quatro vezes o diâmetro da mesma, e a biela de compressão se manteve sempre com uma inclinação superior a $40^{\circ}$ em relação à face inferior do bloco. A Figura 2.1 representa os modelos ensaiados.
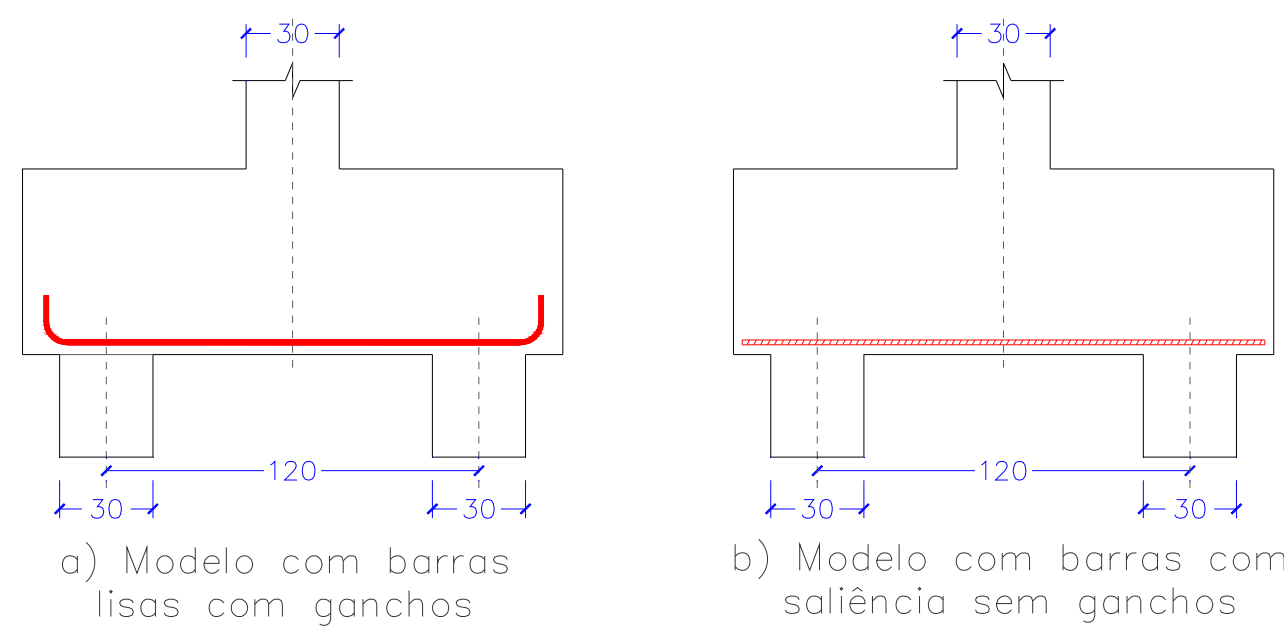

Figura 2. 1- Blocos sobre duas estacas, BLÉVOT \& FRÉMY (1967)

Após os ensaios, BLÉVOT \& FRÉMY (1967) observaram a ocorrência de diversas fissuras ao longo da face lateral do bloco e na face inferior, antes da ruína, que por sua vez aconteceu de três modos: ruína por ruptura da biela de concreto próximo as estacas; ruptura da biela de compressão próximo ao pilar; e ruptura da biela de compressão próximo às estacas e ao pilar simultaneamente.

Verificou-se, também, que a tensão de compressão no concreto no encontro do pilar com o bloco superou em cerca de $40 \%$ o valor da sua resistência característica $\mathrm{f}_{\text {ck. }}$ Já nas armaduras, constatou-se o escorregamento das barras com saliências e sem ganchos, o que não ocorreu nos modelos com barras lisas.

Nos modelos com ângulo de inclinação da biela entre $40^{\circ}$ e $55^{\circ}$, a força de ruína obtida nos ensaios foi superior ao previsto pela analogia das bielas. Entretanto, nos casos em que as bielas se encontram com uma inclinação inferior a $40^{\circ}$, os fenômenos de ruptura ocorreram de forma complexa e, no caso de inclinação superior a $55^{\circ}$, ocorreu fendilhamento das bielas de 
compressão, indicando um comportamento típico de consolo curto. Para a situação de inclinação inferior a $40^{\circ}$, os valores de ruína obtidos nos ensaios foram inferiores aos de dimensionamento mostrando-se, portanto, contra a segurança.

Em função dos resultados, BLÉVOT \& FRÉMY (1967) concluíram que os blocos sobre duas estacas devem ter a biela de compressão inclinada em relação à face inferior do mesmo com ângulo variando entre $45^{\circ}$ e $55^{\circ}$. Apesar dos ensaios serem favoráveis à utilização de blocos com inclinação a partir de $40^{\circ}$, os pesquisadores optaram por adotar como limite inferior o valor de $45^{\circ}$. Como não foi encontrada justificativa, entende-se tratar de uma opção conservadora por parte dos pesquisadores.

Em relação aos modelos superarem em cerca de $40 \%$ o valor da resistência característica do concreto, durante um bom tempo o meio técnico utilizou-se detse valor como limitador das tensões nodais no encontro do bloco com o pilar. Este autor considera o valor de $40 \%$ elevado, principalmente quando comparado com os valores recomendados por outros pesquisadores e em normas técnicas, conforme apresentado em BARROS \& GIONGO (2010). Considera-se, ainda, que o aumento de $40 \%$ aplicado à resistência característica dos concretos usuais pode tornar-se contra a segurança.

MAUTONI (1972) realizou ensaios em blocos sobre duas estacas, com o intuito de analisar os mecanismos de ruína e determinar a força última no bloco, em função da ruína por ruptura das bielas de compressão. Para tanto, fez uso de uma expressão desenvolvida por ele e que leva em consideração a taxa mecânica de armadura no bloco.

Os blocos tiveram largura fixada em $15 \mathrm{~cm}$, assim como a largura do pilar. As estacas possuíam largura de $10 \mathrm{~cm}$, e espaçamento entre eixos variando entre $30 \mathrm{~cm}$ e $45 \mathrm{~cm}$. A altura dos blocos teve valor mínimo de $25 \mathrm{~cm}$, e também foi variada nos modelos. A Figura 2.2 apresenta um dos blocos ensaiados por MAUTONI (1972).

Os modelos ensaiados são representativos de blocos sobre duas estacas, bem como podem ser utilizados para estudos de consolo sem armadura de costura. No total, foram ensaiados vinte blocos com duas disposições das barras das armaduras: a) barras da armadura em laçada contínua na horizontal; b) barras com gancho diferenciado nas extremidades, conforme Figura 2.3. 


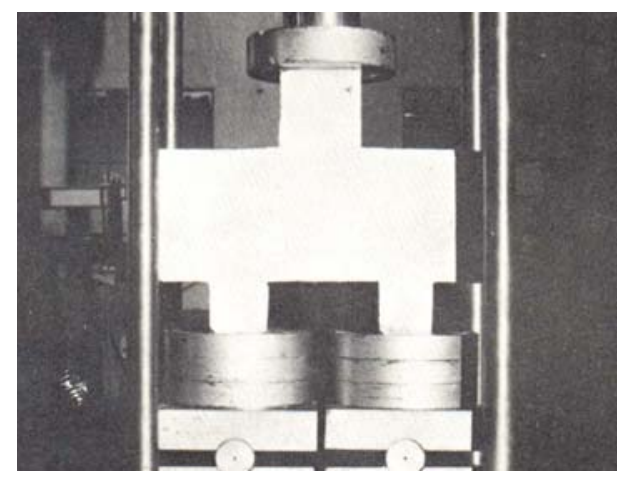

Figura 2. 2 - Bloco ensaiado por MAUTONI (1972)

A armadura com gancho nas extremidades possuía dois trechos semicirculares, melhorando as condições de ancoragem, além de ter ganchos nas extremidades. As barras da armadura em laçada contínua foram dispostas em camadas, sendo que suas extremidades eram semicirculares e separadas por um trecho central retangular.

Durante a realização dos ensaios, MAUTONI (1972) observou que as fissuras tornaramse visíveis e ocorreram quando a força aplicada atingiu cerca de $40 \%$ da força de ruína, e surgiram no meio do vão na região inferior do bloco. Quando as forças atingiram por volta de $70 \%$ da força última, não houve o surgimento de novas fissuras, ocorrendo apenas aumento das aberturas das existentes. Observou-se, também, que as fissuras ocorriam sempre paralelas às bielas de compressão.

A principal conclusão dos ensaios de MAUTONI (1972) para blocos sobre duas estacas foi o estabelecimento de um método capaz de determinar a força última no bloco, bem como os mecanismos de ruína. A ruína ocorreu sempre por fendilhamento das bielas de compressão, apresentando ruptura entre as faces interna da estaca e do pilar. Esse tipo de ruína não é o ideal, por tratar-se de ruptura frágil, sendo que a situação ideal é a de que ocorresse o prévio escoamento das barras das armaduras, ocasionando assim uma ruptura dúctil.

Por fim, MAUTONI (1972) relatou as desvantagens de cada tipo de armadura. A armadura em laçada horizontal apresentou dificuldades de execução, e por se apresentar em diversas camadas, provocou redução da altura útil dos blocos. Já a armadura com gancho nas extremidades apresentou um grande consumo de aço, além de possuir inconvenientes na sua ancoragem. A Figura 2.3 apresenta as propriedades geométricas de um bloco com gancho nas extremidades. 


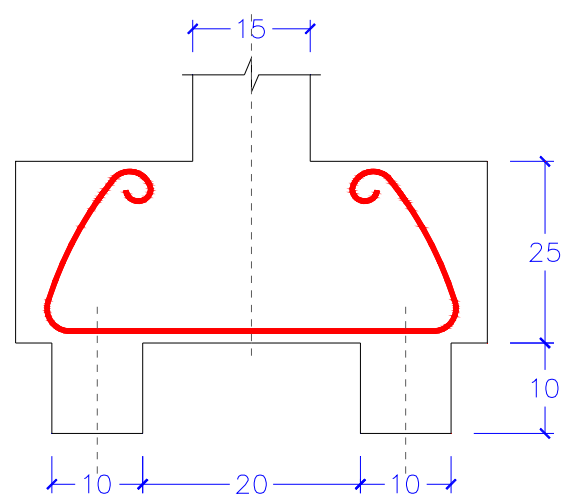

Figura 2. 3 - Propriedades geométricas de bloco com armadura com gancho, MAUTONI (1972)

Em relação aos ensaios realizados por MAUTONI (1972), destaca-se que o esquema de ensaio utilizado considera as estacas apoiadas sobre roletes, e livres para deslocarem na direção horizontal. Apesar de possuírem pequeno diâmetro, dependendo do tipo de solo em que estão assentes, as estacas apresentam uma resistência a forças horizontais que impedem o deslocamento do conjunto estaca bloco. Usualmente essa resistência não é considerara nos projetos de fundação. Quanto ao tipo de armadura utilizada nos modelos, entende-se que a opção por armadura com gancho diferenciado não seria a mais prática e, portanto, dificilmente aceita no meio técnico dada a sua dificuldade executiva.

TAYLOR \& CLARKE (1976) apresentaram resultados de ensaios experimentais realizados em blocos sobre quatro estacas. O principal objetivo foi analisar a influência das disposições das armaduras. Para tanto, foram estudados três distribuições de barras da armadura e quatro diferentes tipos de ancoragem. Apesar dos ensaios não tratarem de blocos sobre duas estacas, os resultados referentes às ancoragens das barras da armadura principal são importantes, e podem ser utilizados em blocos sobre duas estacas.

A distribuição das barras das armaduras foi feita em três grupos conforme Figura 2.4: a) barras da armadura distribuída em malha; b) barras da armadura segundo os lados; c) barras da armadura segundo as diagonais do bloco. Os quatro tipos de ancoragem usados foram: 1) ancoragem reta; 2) ancoragem com gancho; 3) ancoragem com gancho prolongado até a face superior do bloco; 4) ancoragem até a face superior do bloco, com gancho na extremidade. 

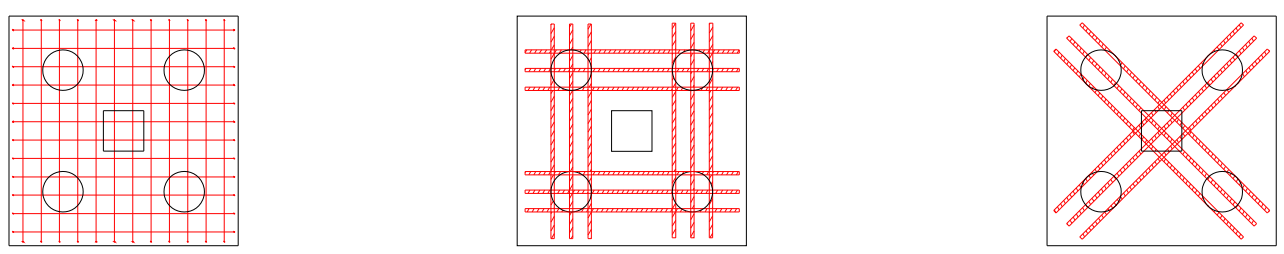

a) Armadura distribuida

b) armadura

armadura segundo em malha

os lados e sobre as ostacto

Desenho das armaduras
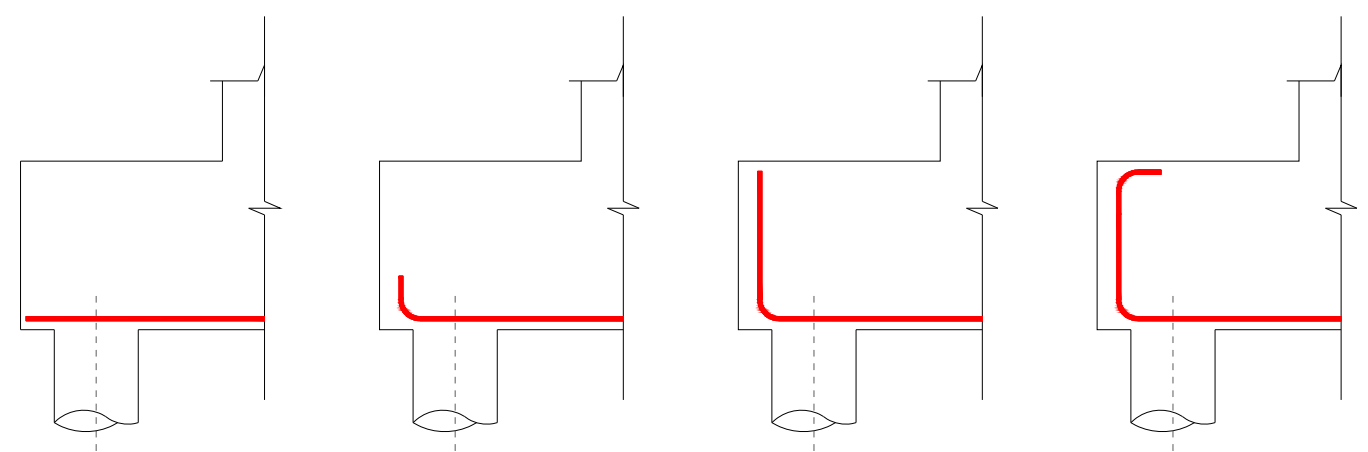

Figura 2. 4 - Detalhamento e ancoragem das barras, TAYLOR \& CLARKE (1976)

A altura dos blocos foi fixada em $45 \mathrm{~cm}$. O diâmetro das estacas bem como a dimensão do pilar, possuía $20 \mathrm{~cm}$, e o espaçamento entre estacas adotado foi de duas vezes o diâmetro. Foram ensaiados blocos quadrados com larguras de $75 \mathrm{~cm}$ e de $95 \mathrm{~cm}$. Essas dimensões indicam que a biela de compressão possuía uma inclinação superior a $60^{\circ}$, estando em desacordo com os valores recomendados por BLÉVOT \& FRÉMY (1967).

Durante a realização dos ensaios, os blocos tiveram praticamente o mesmo comportamento, surgindo fissuras verticais nas linhas entre estacas nas quatro faces do bloco. Semelhante aos ensaios de MAUTONI (1972), a ruína se deu por fendilhamento, em virtude das fissuras inclinadas que surgiram de modo brusco e paralelas à biela de compressão. Foram observadas duas formas diferentes de ruptura por fendilhamento. A primeira delas é própria da ruptura por cisalhamento em vigas, e pode ser vista na Figura 2.5-a, enquanto que a segunda pode ser observada na Figura 2.5-b. 


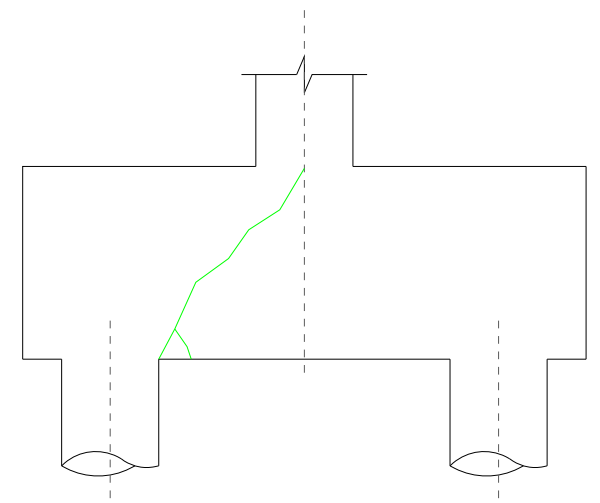

(a)

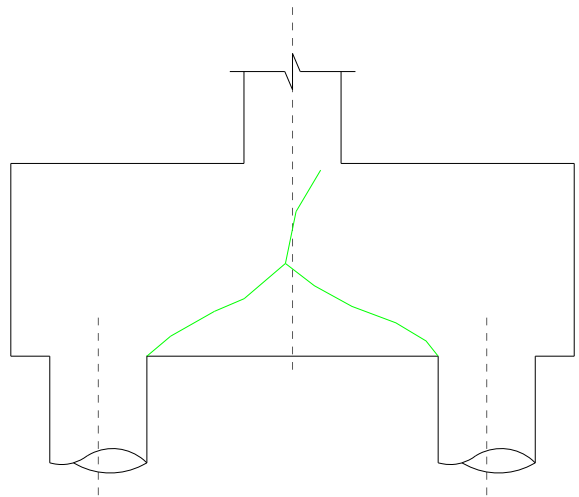

(b)

Figura 2. 5 - Configurações de ruína observadas por TAYLOR \& CLARKE (1976) - vista lateral

A respeito do comportamento das ancoragens das barras, observou-se que as do tipo 1 e 2, combinadas com barras distribuídas segundo os lados, obtiveram uma força de ruína cerca de $15 \%$ superior às demais configurações. As armaduras com distribuição em malha e segundo as diagonais tiveram praticamente a mesma força de ruína e apresentaram-se inferiores aos modelos cujas barras estavam distribuídas segundo os lados.

No caso de armadura distribuída em malha, verificou-se uma maior influência do tipo de ancoragem. Nesse caso, a ancoragem do tipo 3 forneceu uma força última cerca de $30 \%$ maior do que as do tipo 1 e 2 . Segundo TAYLOR \& CLARKE (1976), isso se deve ao fato de que quando as barras da armadura são detalhadas com prolongamento vertical, a mesma funciona como armadura de suspensão, além de aumentar a capacidade resistente do bloco à força cortante. Em relação ao tipo de ancoragem 4, nenhum aumento significativo da força de ruína foi registrado.

SABNIS \& GOGATE (1984) realizaram ensaios em blocos sobre quatro estacas, nos quais variou-se a taxa geométrica da armadura principal. Os pesquisadores verificaram que valores superiores a $0,2 \%$ para essa taxa não provocam aumento na força de ruína dos blocos. Desse modo, concluíram que a ruína dos blocos depende do concreto suportar as tensões de compressão na direção longitudinal das bielas e de tração na direção perpendicular das bielas, o que provoca fendilhamento do concreto.

ADEBAR et al. (1990) realizaram ensaios em blocos de concreto armado sobre quatro e seis estacas, com o intuito de verificar a viabilidade do modelo tridimensional para o método de bielas e tirantes. 
Foram observadas relações do tipo força versus deslocamento, valores de forças de reação nas estacas, deformações nas barras da armadura longitudinal, bem como valores de forças que provocaram fissuração e ruína dos modelos.

A respeito da geometria dos blocos, os mesmos possuíam estacas com $20 \mathrm{~cm}$ de diâmetro e a força era aplicada numa área de $30 \mathrm{~cm}$ x $30 \mathrm{~cm}$, sendo que todos os modelos tinham altura útil em torno de $60 \mathrm{~cm}$. Os diversos modelos bem como a distribuição das barras das armaduras podem ser verificados na Figura 2.6.

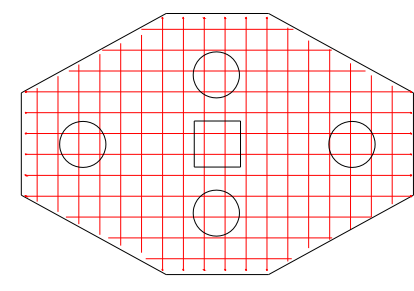

Bloco

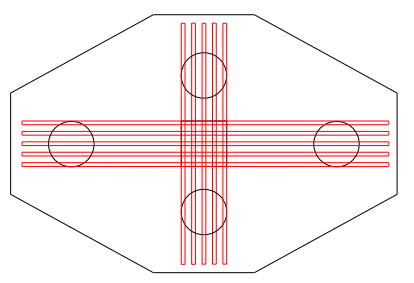

Bloco
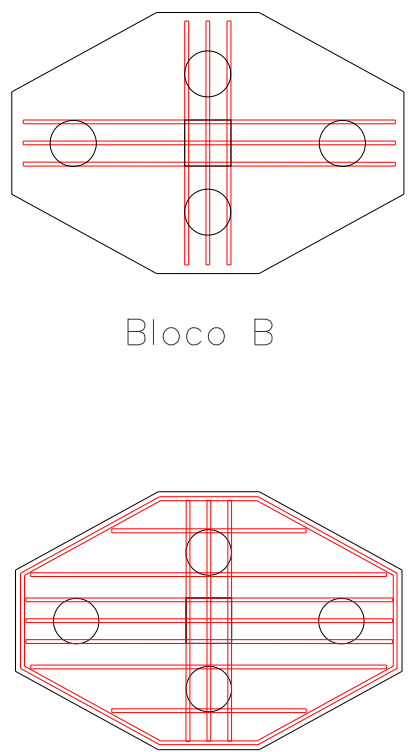

Bloco E
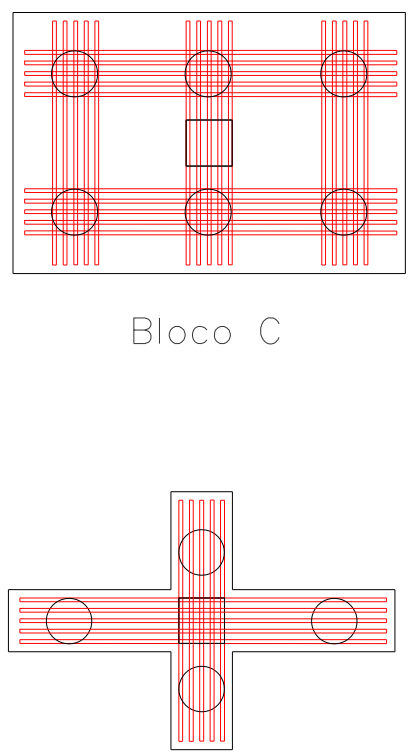

Bloco F

Figura 2. 6 - Blocos ensaiados por ADEBAR et al. (1990)

Os blocos foram dimensionados segundo os critérios do ACI 318-83 e algumas recomendações do método de bielas e tirantes, sendo que sua principal diferença era o arranjo das armaduras. O bloco A foi dimensionado segundo critérios do ACI 318-83 e era o bloco que possuía a menor área de barras da armadura longitudinal, estando as mesmas dispostas em forma de malha. Os blocos B, C e D foram dimensionados segundo o modelo de bielas e tirantes, sendo que o bloco D possuía o dobro da área das barras da armadura do bloco B. $\mathrm{O}$ bloco $\mathrm{E}$ tinha as mesmas propriedades do bloco $\mathrm{D}$, porém possuía a armadura de distribuição segundo critérios do ACI 318-83. O último bloco foi construído para investigar uma hipótese do ACI 318-83 na qual o bloco tinha arranjo de armadura idêntico ao do bloco D, porém possuía reentrância nos quatro lados. De acordo com o ACI 318-83, esse bloco deveria ter a 
força de ruína inferior a do bloco $\mathrm{D}$, enquanto que no modelo de bielas e tirantes, a força de ruína deveria ser a mesma para os dois blocos.

As principais conclusões obtidas por ADEBAR et al. (1990) indicaram que o código do ACI 318-83, em parte, não se mostrou compatível com os resultados experimentais, sendo que resultados melhores foram obtidos de acordo com o modelo de bielas e tirantes. O bloco A apresentou força de ruína em torno de $83 \%$ do valor esperado, enquanto que o bloco B teve força de ruína em cerca de $10 \%$ superior ao valor de dimensionamento. Porém, em relação ao bloco F, verificou-se o comportamento do mesmo como duas vigas interceptadas ortogonalmente, comprovando a hipótese do ACI 318-83 em relação ao modelo de Bielas e Tirantes.

Segundo os pesquisadores, os resultados do bloco A não foram compatíveis com as previsões teóricas pelo fato do ACI 318-83 não considerar a altura do bloco no modelo de cálculo, e desprezar a influência da quantidade e da distribuição das barras da armadura longitudinal no bloco. Os blocos de grandes alturas, por suas vezes, sofreram grandes deformações antes da ruína, pois não foram flexíveis o suficiente para redistribuir os esforços solicitantes.

Quanto à ruína dos modelos, os mesmos apresentaram ruína por fendilhamento da biela de compressão, e não por ruptura das mesmas. O fendilhamento ocorreu em virtude da expansão das tensões de compressão provocar tração na direção perpendicular das bielas. $\mathrm{O}$ bloco $\mathrm{F}$, que teve comportamento de viga, apresentou ruína por cisalhamento da viga mais curta, e não houve escoamento das barras da armadura longitudinal.

Com base nos resultados experimentais e em modelos numéricos baseados no método dos elementos finitos, ADEBAR et al. (1990) sugeriram um modelo refinado de biela e tirantes para dimensionamento de blocos sobre estacas. De acordo com a Figura 2.7, nota-se a expansão das tensões de compressão na biela de concreto e o surgimento de tensões de tração perpendicular a biela. Assim, os pesquisadores sugeriram a existência de um tirante extra perpendicular à biela, com o intuito de absorver essas tensões. O tirante pode ser de concreto, desde que a resistência à tração do material seja respeitada. 

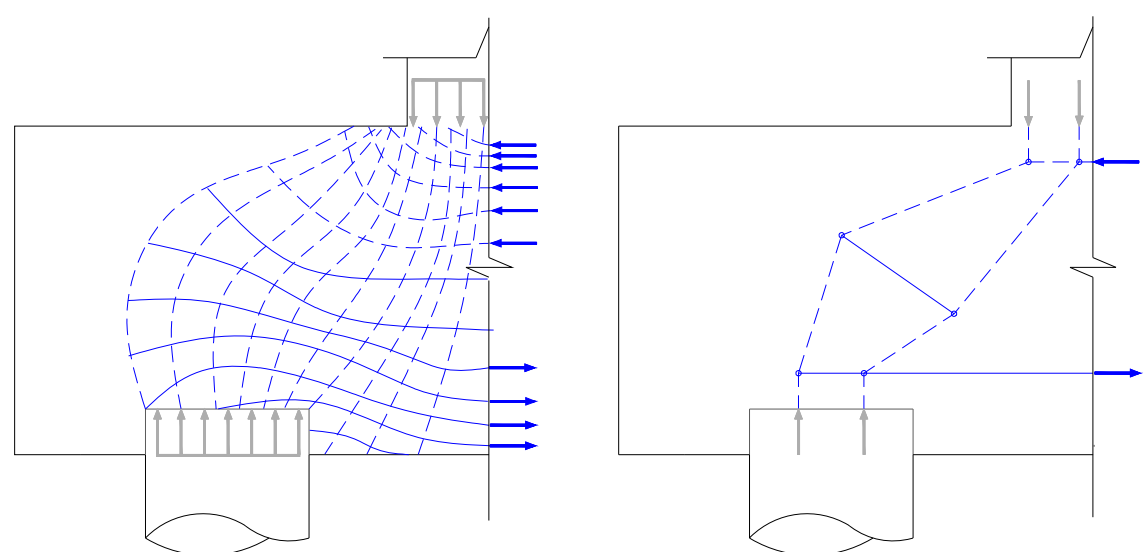

Figura 2. 7 - Modelo de Biela e Tirante sugerido por ADEBAR et al. (1990)

CARVALHO (1995) Realizou ensaios em blocos sobre grupos de estacas de pequeno diâmetro, de modo a obter o comportamento conjunto do bloco, estaca e solo. Foram avaliados blocos sobre uma, duas, três e quatro estacas, sendo que na situação de bloco sobre três estacas também foram considerados os casos de estacas formando um triângulo eqüilátero e dispostas em linha. Foram utilizadas estacas escavadas e os ensaios realizados no campo experimental do Departamento de Geotecnia da Escola de Engenharia de São Carlos-USP.

Durante a realização dos ensaios, observou-se recalque das estacas ocasionado pela ruptura do solo, fazendo com que as barras de aço da armadura principal do bloco apresentassem tensões com pequenas intensidades. Essa situação ocorreu para valores de força vertical bastante inferior à força de cálculo utilizada para o dimensionamento dos blocos. Esse resultado foi observado para todos os modelos ensaiados, e o pesquisador sugeriu que, para melhor estudar o comportamento do bloco e das barras das armaduras, fossem realizados ensaios que permitissem conduzir o bloco até a sua ruína.

RAUSH et al. (1997) ensaiaram blocos de concreto armado sobre duas estacas em escala reduzida (1:2). Para o dimensionamento do bloco utilizaram o modelo de bielas e tirantes. Os autores obtiveram algumas conclusões como: o método das bielas supõe que as barras inferiores (tirantes) se deformem livremente, porém, como as estacas atuam limitando essa deformação, parte da componente horizontal da biela de compressão é absorvida pelas estacas; os ensaios demonstraram que a armadura do tirante calculada pelo modelo de bielas e tirantes apresentou resultados a favor da segurança, indicando que a área das barras da armadura pode ser diminuída; no modelo teórico, admitiu-se que o tirante tinha deformações constantes ao longo de seu comprimento, isso não foi observado nos ensaios, pois, para 
valores de forças próximas da força de ruína do bloco, as deformações obtidas no tirante na região das estacas tiveram valores próximos à zero, e em alguns casos valores negativos.

MIGUEL (2000) realizou ensaios experimentais e numéricos em blocos sobre três estacas, verificando também a ocorrência de escorregamento de barras com nervuras. Entretanto, tal escorregamento só ocorreu após a ruptura da biela de compressão.

A pesquisadora concluiu que o método das bielas sugerido por BLÉVOT \& FRÉMY (1967) mostrou-se conservador em relação à força de ruína. Em todos os modelos, a ruína ocorreu por fendilhamento da diagonal comprimida, acompanhada do escoamento das barras da armadura longitudinal.

MIGUEL (2000) propôs valores limites para as tensões normais nas regiões nodais do bloco, isto é, no encontro pilar bloco e estaca bloco. Para a região nodal superior, a tensão ficou limitada em $0,40 \cdot f_{c m}$ independente do diâmetro da estaca. Na região nodal inferior, a tensão foi limitada a $0,50 \cdot f_{c m}$ para estacas com diâmetro de $20 \mathrm{~cm}$, e $0,30 \cdot f_{c m}$ para estacas com diâmetro de $30 \mathrm{~cm}$.

CHAN \& POH (2000) realizaram estudo experimental em três blocos sobre quatro estacas. No estudo foram realizadas comparações de dois blocos feitos em concreto prémoldado, e um bloco moldado no local. Dentre as vantagens da utilização dos blocos prémoldados, os pesquisadores chineses citam a melhoria da produtividade da obra e a diminuição dos riscos de desmoronamento durante as escavações, destacando sua utilização em regiões de inverno rigoroso e com solo mole ou de pouca estabilidade.

Utilizando-se o método convencional para blocos de fundação moldados in loco, requerse uma etapa inicial de escavação, seguida da preparação da base utilizando concreto não estrutural, construção e montagem das fôrmas, lançamento do concreto usinado ou feito na obra, o que levaria facilmente de um a dois dias de serviços na obra.

O bloco de fundação em concreto pré-moldado sugerido por CHAN \& POH (2000) é na verdade uma caixa feita em concreto pré-moldado, com armadura prévia, que serve para substituir as fôrmas de madeira, seguida do preenchimento interno do bloco utilizando concreto moldado in loco, conforme pode ser observado na Figura 2.8, que representa um bloco sobre quatro estacas estudado pelos pesquisadores. Os pesquisadores sugeriram que as placas que formam a caixa tenham espessura mínima de $70 \mathrm{~mm}$, em virtude da necessidade de proteção das barras da armadura, recomendando o uso de $5 \mathrm{~cm}$ para cobrimento externo. $\mathrm{O}$ cobrimento interno, por sua vez, não fica prejudicado, uma vez que o concreto de preenchimento interno da caixa é suficiente para proteção interna das barras. 

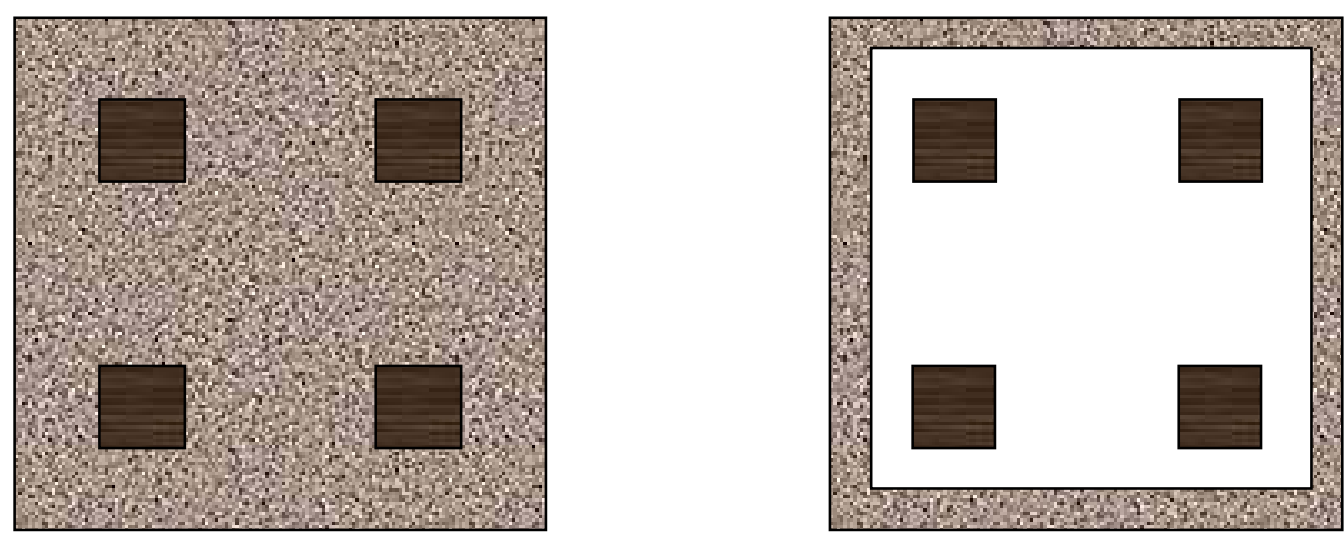

Figura 2. 8 - Bloco pré-moldado estudado por CHAN \& POH (2000)

CHAN \& POH (2000) realizaram estudo experimental em três blocos sobre quatro estacas. O primeiro bloco estudado, chamado de bloco A, seguiu os padrões de um bloco moldado in loco, e possui $40 \mathrm{~cm}$ de altura, $100 \mathrm{~cm}$ de comprimento e $100 \mathrm{~cm}$ de largura. $\mathrm{O}$ segundo bloco, chamado de bloco B, tinha as mesmas dimensões do bloco A, porém possuía a caixa externa feita em concreto pré-moldado, com $75 \mathrm{~mm}$ de espessura. Já o terceiro bloco, denominado bloco $\mathrm{C}$, tinha as mesmas características do bloco $\mathrm{B}$, sendo que a altura total era de $30 \mathrm{~cm}$, o que resulta num bloco classificado como flexível de acordo com a ABNT NBR 6118:2007.

Para dimensionamento dos blocos, os pesquisadores utilizaram o código Inglês BS 8110 (1985), que permite que blocos de fundação sejam dimensionados utilizando o modelo de vigas, ou o modelo de bielas e tirantes. Os pesquisadores procederam ao dimensionamento utilizando a teoria de flexão.

Os pesquisadores verificaram que os blocos A e B apresentaram força última, em média, $40 \%$ superior a força máxima utilizada para dimensionamento segundo a norma inglesa BS 8110 (1985). Em relação ao bloco C observou-se um aumento de apenas 7\% comparando a força última com a força utilizada para dimensionamento do mesmo. CHAN \& POH (2000) não realizaram comparações entre os blocos $\mathrm{A}$ e $\mathrm{B}$, isto é, entre os blocos concebidos de modo tradicional e pré-moldado. Entretanto, observa-se que a força última apresentada pelos dois blocos foi praticamente a mesma, não sendo possível, portanto, afirmar que um bloco apresenta maior capacidade portante em relação ao outro.

DELALIBERA (2006) estudou numérica e experimentalmente blocos sobre duas estacas submetidos à ação de força centrada e excêntrica. Inicialmente, procedeu-se uma análise numérica tridimensional com a consideração da não-linearidade física e geométrica, 
assim como o efeito da fissuração e do posicionamento das barras de aço da armadura longitudinal.

O pesquisador constatou que a geometria da biela de compressão diverge dos modelos usualmente sugeridos por outros autores. Por meio do critério ANOVA (análise de variância) o autor verificou que as variáveis preponderantes no comportamento do bloco sobre estacas são: o ângulo de inclinação da biela de compressão, a área da seção transversal do pilar e a posição da força de compressão.

Assim sendo, DELALIBERA (2006) realizou ensaio experimental em quatorze blocos, com o intuito de observar a geometria da biela de compressão, bem como verificar a eficiência dos ganchos das barras da armadura longitudinal na ancoragem das mesmas. $\mathrm{O}$ pesquisador constatou que, no caso de blocos rígidos, a deformação nos ganchos foi próxima de zero. Comportamento semelhante foi observado por ADEBAR et al. (1990) e MIGUEL (2000). Tratando de blocos rígidos, a ABNT NBR 6118:2007 exige a presença desses ganchos no detalhamento das barras da armadura principal de tração. O autor verificou também que as deformações nas barras de aço não são constantes, sofrendo significativa redução nas seções de interseção com a biela de compressão. Esse efeito ocorre em virtude do confinamento que a biela comprimida provoca nas barras da armadura longitudinal, principalmente na região sobre as estacas. Esses resultados foram confirmados por meio de análise numérica não-linear e tridimensional, na qual foi considerado o fenômeno da fissuração do concreto. Em função dos resultados obtidos, o autor propôs modelos de bielas e tirantes aplicados a bloco sobre duas estacas.

CAMPOS (2007) analisou o comportamento de blocos de fundação sobre duas estacas para estruturas pré-moldadas, utilizando cálice externo. Foram realizados ensaios em três protótipos de blocos na escala 1:2 variando a altura do colarinho, nos quais o objetivo principal era avaliar a influência que o comprimento de embutimento $\ell_{\text {emb }}$ provoca na base do bloco, bem como as diferenças na formação do fluxo de tensões. $\mathrm{O}$ dimensionamento dos protótipos seguiu as recomendações de MELO (2004) e as indicações das normas brasileiras ABNT NBR 6118:2003 e ABNT NBR 9062:2006.

Os resultados indicaram que o modelo proposto por MELO (2004) é conservador em relação às forças últimas obtidas experimentalmente. Verificou-se também que não é necessário considerar a altura de $2 / 3$ do comprimento de embutimento $\ell_{\text {emb }}$ para a transferência das forças por atrito, na situação de força centrada ou com pequena excentricidade. Destaca-se que o trabalho desenvolvido por CAMPOS (2007) é um dos 
poucos encontrados na literatura técnica que estuda o comportamento do bloco sobre estacas com a utilização de cálice para ligação do pilar pré-moldado com a fundação. A utilização de modelos em escala reduzida não prejudicou os resultados quando comparados com as previsões de modelos em escala reduzida. Os resultados de CAMPOS (2007) motivaram o uso de modelos em escala reduzida nesta pesquisa.

DELALIBERA (2009) realizou estudo numérico e experimental em blocos sobre duas estacas com cálice embutido. O objetivo inicial da análise numérica era observar quais fatores tinham maior importância no comportamento estrutural dos blocos e, de posse desses parâmetros, proceder ao experimento em laboratório. O pesquisador concluiu que os fatores que mais influenciam no comportamento estrutural do bloco com configuração da parede do cálice sem rugosidade são o comprimento de embutimento do pilar $\ell_{\mathrm{emb}}$ e a distância entre o fundo do bloco e o fundo do cálice. Para o bloco com configuração da parede com rugosidade, esses fatores não são relevantes, em virtude da chave de cisalhamento conferir ao bloco um comportamento de ligação monolítica.

Em função dos resultados numéricos, o pesquisador optou por realizar ensaio experimental em dois modelos de blocos com cálice embutido em escala real, no qual a variável estudada foi a configuração das paredes do cálice. Os ensaios foram realizados no Laboratório de Estruturas da Escola de Engenharia de São Carlos, Universidade de São Paulo.

A Figura 2.9 e $\mathbf{2 . 1 0}$ apresentam a forma do bloco com cálice embutido.

Os resultados experimentais mostraram que o bloco com conformação das paredes do cálice com rugosidade apresentou força última superior a do bloco com conformação das paredes do cálice sem rugosidade. A diferença obtida entre a força última nos blocos ensaiados foi de $25 \%$. Observou-se ainda que o bloco com conformação das paredes do cálice sem rugosidade apresentou comportamento semelhante à de elementos lineares submetidos à flexão, indicando que as paredes do cálice sem rugosidade não conseguiram transmitir de modo eficaz a força oriunda do pilar para o bloco, e que uma parcela significativa dessa força migrou diretamente para o fundo do bloco.

Por fim, constatou-se que tanto o bloco com paredes rugosas como o bloco com paredes sem rugosidade apresentaram força última inferior a obtida do estudo analítico e utilizada no dimensionamento dos blocos. Esses resultados indicaram que, tratando-se de blocos com cálice embutido, é preciso haver alguma alteração no modelo de bielas e tirantes utilizado para esse tipo de bloco. Entretanto, em face do número restrito de modelos utilizados nessa pesquisa, faz-se necessário comprovar os resultados com um número maior de modelos. Estes 
resultados também motivaram a realização dessa pesquisa. A seguir apresenta-se um detalhe do projeto do bloco e esquema de ensaio realizado por DELALIBERA (2009).
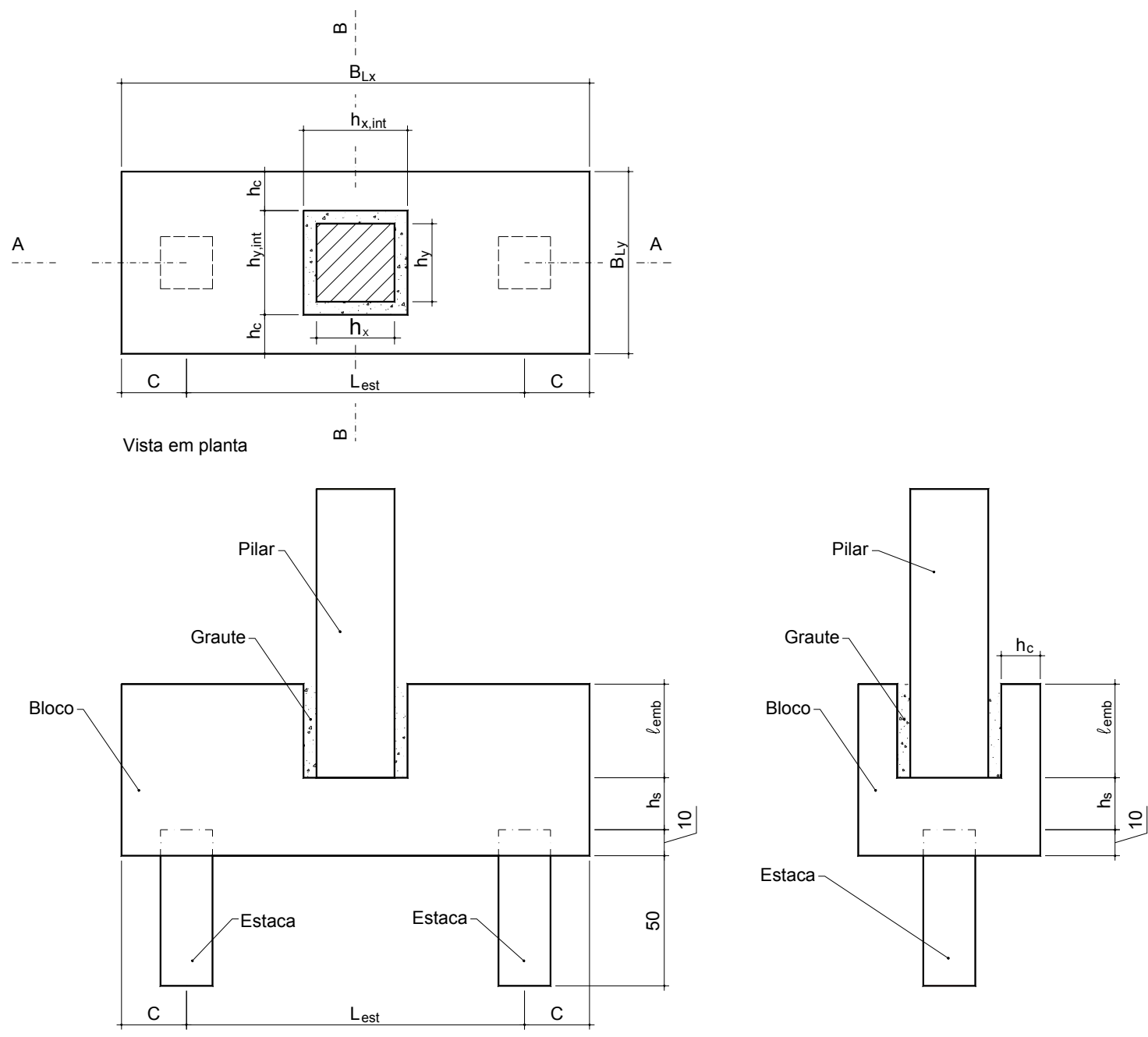

Corte A-A

Corte B-B

Figura 2. 9- Projeto de bloco sobre duas estacas analisado por DELALIBERA (2009)

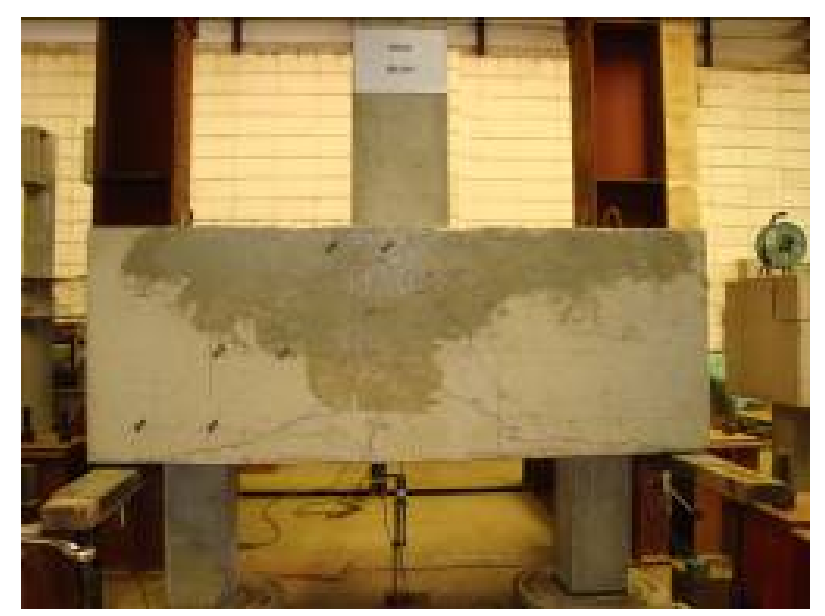

Figura 2. 10 - Bloco sobre duas estacas analisado por DELALIBERA (2009) 


\subsection{Pesquisas com ênfase teórica e numérica}

IYER \& SAM (1991) procederam análise elástica linear tridimensional em blocos sobre três estacas. As distribuições de tensões foram obtidas em função das condições de contorno, considerando a superposição dos efeitos de quatro soluções elásticas tridimensionais, para bloco retangular submetidos a diversos carregamentos. O bloco analisado está apresentado na Figura 2.11.
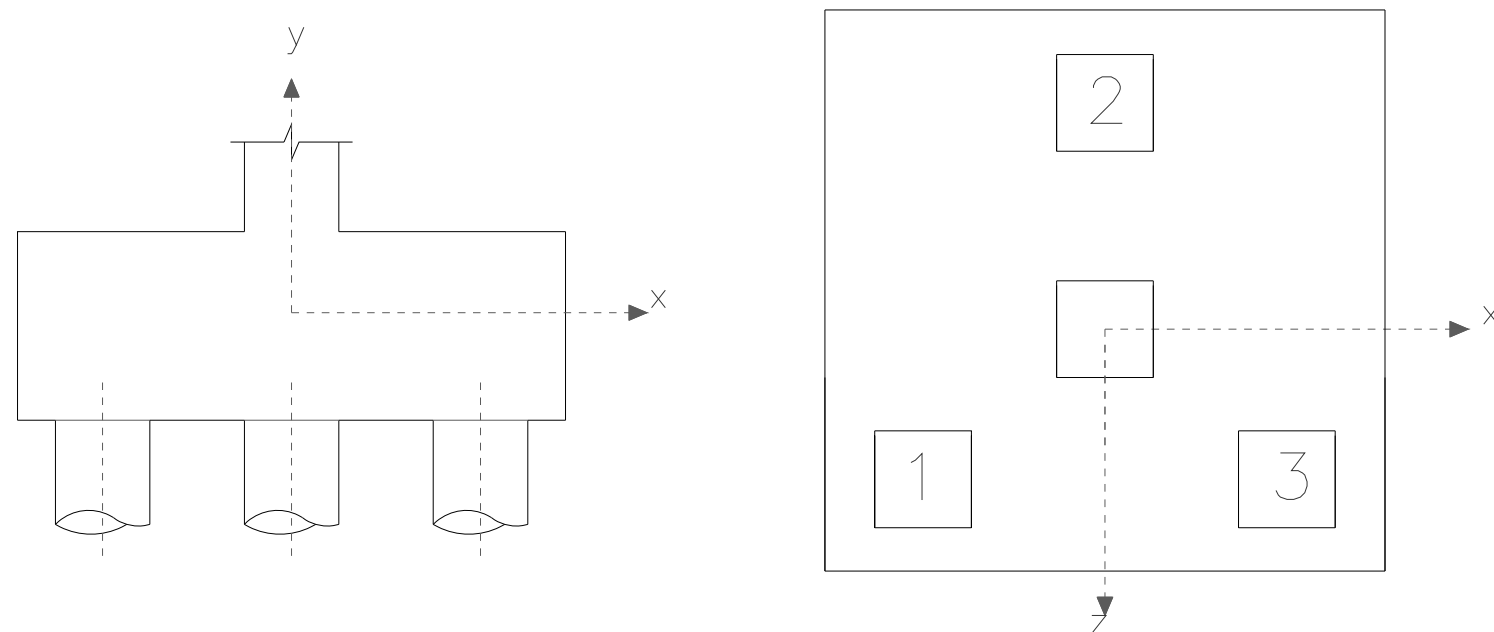

Figura 2. 11 - Bloco sobre três estacas analisado por IYER \& SAM (1991)

Embora o bloco fosse de concreto armado, as análises feitas pelos pesquisadores consideraram o material com comportamento elástico linear, homogêneo e isotrópico. A análise indicou que as tensões máximas de tração na direção X ocorrem no plano YZ, em uma seção posicionada entre as estacas 1 e 3, quando se tem uma relação entre altura do bloco e espaçamento entre estacas igual à unidade. À medida que essa relação vai diminuindo, percebe-se que a seção onde atuam as máximas tensões de tração se aproxima da seção que contém o centro de gravidade do bloco. Com relação à direção $Z$, ocorre comportamento semelhante, porém a seção com as máximas tensões de tração se situa no plano XY, entre a face do pilar e a estaca 2.

Os pesquisadores concluíram que dos métodos existentes, tanto a analogia de treliça de BLÉVOT \& FRÉMY (1967) como a teoria de flexão, que considera o bloco como uma viga simplesmente apoiada nas estacas, apresentam resultados satisfatórios, mesmo não apresentando posição e magnitude das tensões de tração com requerida precisão. 
IYER \& SAM (1992) repetiram as mesmas análises feitas no ano anterior, porém utilizando blocos sobre duas e quatro estacas.

IYER \& SAM (1995) realizaram uma análise numérica não-linear, via método dos elementos finitos, para blocos sobre quatro estacas. O objetivo dessa análise era obter o comportamento das tensões, deslocamentos, deformações nas barras das armaduras, panorama de fissuração e a força de ruína.

Os modelos analisados tinham a mesma geometria, resistência do concreto e taxa geométrica de armadura, sendo variado apenas o arranjo das mesmas. Para o bloco sobre quatro estacas, foram consideradas três disposições para as barras das armaduras: barras distribuídas em malha; barras sobre estacas e barras em diagonal passando pelas estacas e pela projeção do pilar. Os modelos foram submetidos a diferentes carregamentos e, para consideração da não linearidade foi adotado o comportamento multiaxial de compressão do concreto incluindo deformações plásticas, fissuração do concreto e alteração do coeficiente de Poisson.

Os resultados obtidos por meio da análise numérica foram divergentes dos resultados apresentados em outras pesquisas baseadas em ensaios experimentais. Segundo IYER \& SAM (1995), o arranjo das barras das armaduras que resultou maior capacidade resistente ao bloco foi o que possuía distribuição das armaduras em malha, enquanto que o arranjo com distribuição sobre as estacas obteve menor força última. Entende-se que esse resultado pode ter ocorrido por causa do tipo de elemento finito utilizado para representar o concreto e as barras das armaduras, que provavelmente não conseguiu representar bem o comportamento existente entre esses materiais. Os pesquisadores perceberam ainda que, para pequenas intensidades de força, o comportamento de viga foi predominante no bloco, enquanto que para maiores intensidades a responsável pela resistência do bloco foi a diagonal comprimida.

ITURRIOZ et al. (2000) realizaram análise numérica simulando um bloco ensaiado experimentalmente por RAUSCH et al. (1997). O programa de computador utilizado foi o ANSYS e o elemento finito utilizado o SOLID 95. A armadura foi considerada distribuída ao longo dos elementos que representavam o concreto, sendo que a aderência entre as barras da armadura e o concreto foi considerada perfeita. O fenômeno da fissuração do concreto foi considerado e os resultados obtidos foram satisfatórios.

MUNHOZ (2004) realizou um estudo comparativo por meio de modelos analíticos e numéricos baseados no método dos elementos finitos. Nesse estudo foi considerada a ação de força centrada em blocos sobre uma, duas, três, quatro e cinco estacas, e optou-se por variar 
as dimensões do diâmetro das estacas, bem como as da seção transversal do pilar. Como o intuito do trabalho era analisar o fluxo e a distribuição das tensões principais, não foi considerada a presença das barras das armaduras nos blocos. A autora adotou o comportamento do material como elástico linear, na qual não pôde ser considerado o efeito da perda de rigidez do bloco causada pela fissuração.

MUNHOZ (2004) constatou diferenças entre os modelos analíticos e numéricos, bem como no fluxo de tensões, quando da formação dos campos e trajetórias das mesmas. Analisando as direções das tensões principais, a pesquisadora propôs um modelo mais refinado de biela e tirante. Outra conclusão da pesquisadora foi que, no caso de blocos sobre cinco estacas, a disposição das estacas segundo os vértices de um quadrado e uma estaca no centro geométrico, não é a melhor alternativa a ser utilizada, visto que a estaca central recebe a maior parte da força aplicada. Uma solução melhor seria a adoção de estacas dispostas nos vértices de um pentágono regular.

SOUZA (2004) estudou elementos estruturais nos quais não é válida a hipótese de Bernoulli de que seções planas permanecem planas após a deformação do elemento. Como exemplos desses elementos, citam-se os dentes Gerber, vigas-parede, consolos e blocos de fundação. Esses elementos podem ser divididos em regiões B e D, ou seja, regiões de Bernoulli e regiões de descontinuidade.

Para análise das regiões $\mathrm{D}$, o pesquisador utilizou o método dos elementos finitos, modelos de bielas e tirantes e método Corda-Painel. Destaca-se nesse trabalho a utilização do programa DIANA, baseado no método dos elementos finitos, no qual o efeito da nãolinearidade física do concreto é facilmente representado quando comparado a outros programas.

SOUZA (2004) simulou no programa DIANA blocos sobre duas estacas ensaiados por MAUTONI (1972). Os resultados obtidos por meio da análise não-linear indicaram uma grande variação dos valores e, sua aplicabilidade nos escritórios de projeto é questionada, haja vista o tempo requerido para obtenção dos resultados. O autor recomenda que a analise nãolinear seja feita apenas para projeto de obras de grande porte, que necessitem de uma análise mais criteriosa.

DELALIBERA \& GIONGO (2004) simularam numericamente blocos sobre duas estacas, com o intuito de investigar a influência das dimensões do pilar e das estacas no comportamento estrutural do elemento bloco de fundação. Para tanto, foi considerado na análise numérica o efeito da não-linearidade física, bem como a aderência perfeita entre aço e 
concreto. Os autores concluíram, por meio de uma análise estatística, que o fator preponderante na determinação dos valores das tensões nas regiões nodal superior e inferior, é a altura do bloco.

SOUZA \& BITTENCOURT (2006) analisaram numericamente o comportamento de blocos sobre estacas com o objetivo de discutir a classificação dos blocos em rígidos ou flexíveis, propondo o Método das Bielas e o Modelo de Viga como soluções viáveis para o problema de dimensionamento. Os autores apresentam resultados de análises não-lineares, efetuadas para blocos rígidos sobre quatro estacas com diferentes disposições para as barras de aço da armadura longitudinal, com o objetivo de apresentar as potencialidades do Método dos Elementos Finitos e dos modelos de fissuração distribuída em problemas de fraturamento tridimensionais.

Após análise de vários ensaios experimentais relatados na literatura técnica, os pesquisadores concluíram que a ruína dos modelos se deu por fendilhamento da diagonal comprimida seguido da ruptura da mesma junto às zonas nodais inferior e superior, ou seja, no encontro estaca-bloco e pilar-bloco. Por fim, sugerem que se utilize uma malha na face inferior do bloco com intuito de limitar as aberturas de fissuras e evitar a ruína prematura dos blocos.

RAMOS (2007) realizou análise numérica em um bloco de fundação sobre dez estacas. O objetivo da pesquisa foi estudar o comportamento das reações de apoio nas estacas do bloco de fundação, quando da variação de alguns parâmetros. Nesse caso, variou-se a altura do bloco, a intensidade das ações (força concentrada e momento) e o tipo de apoio proporcionado pelo solo, sendo deformável ou indeformável.

O pesquisador concluiu que os resultados obtidos por meio da análise numérica divergem dos obtidos com base nos critérios usuais de dimensionamento de blocos sobre várias estacas, uma vez que esses critérios não levam em conta a altura do bloco nem o tipo de vinculação empregado.

RAMOS (2007) verificou ainda que, na pior situação, houve variação de mais de $200 \%$ nas reações das estacas comparando com os valores obtidos analiticamente, e percebeu também que as estacas mais próximas ao pilar recebem uma maior parcela da ação solicitante. $\mathrm{O}$ autor verificou ainda que a resistência característica à compressão do concreto tem pouca influência na determinação da rigidez dos blocos, sendo a altura dos blocos e o tipo de vinculação fatores de maior relevância. 
NORI \& THARVAL (2007) apresentam aplicações do método de bielas e tirantes para blocos sobre duas, três e quatro estacas. Os pesquisadores comparam os valores das forças nos blocos sobre estacas obtidos por meio do modelo de biela e tirante, com os obtidos levando-se em conta o comportamento de viga, no qual são calculadas as forças numa seção de referência, que é a face do pilar.

Os pesquisadores utilizaram espaçamento entre estacas de duas vezes e meia o diâmetro da estaca e recomendam que, na utilização de bielas e tirantes, a altura do bloco não seja inferior à metade do espaçamento entre as mesmas. A Figura 2.12 apresenta a geometria e as forças em dois diferentes modelos de bielas e tirantes para blocos sobre duas estacas.
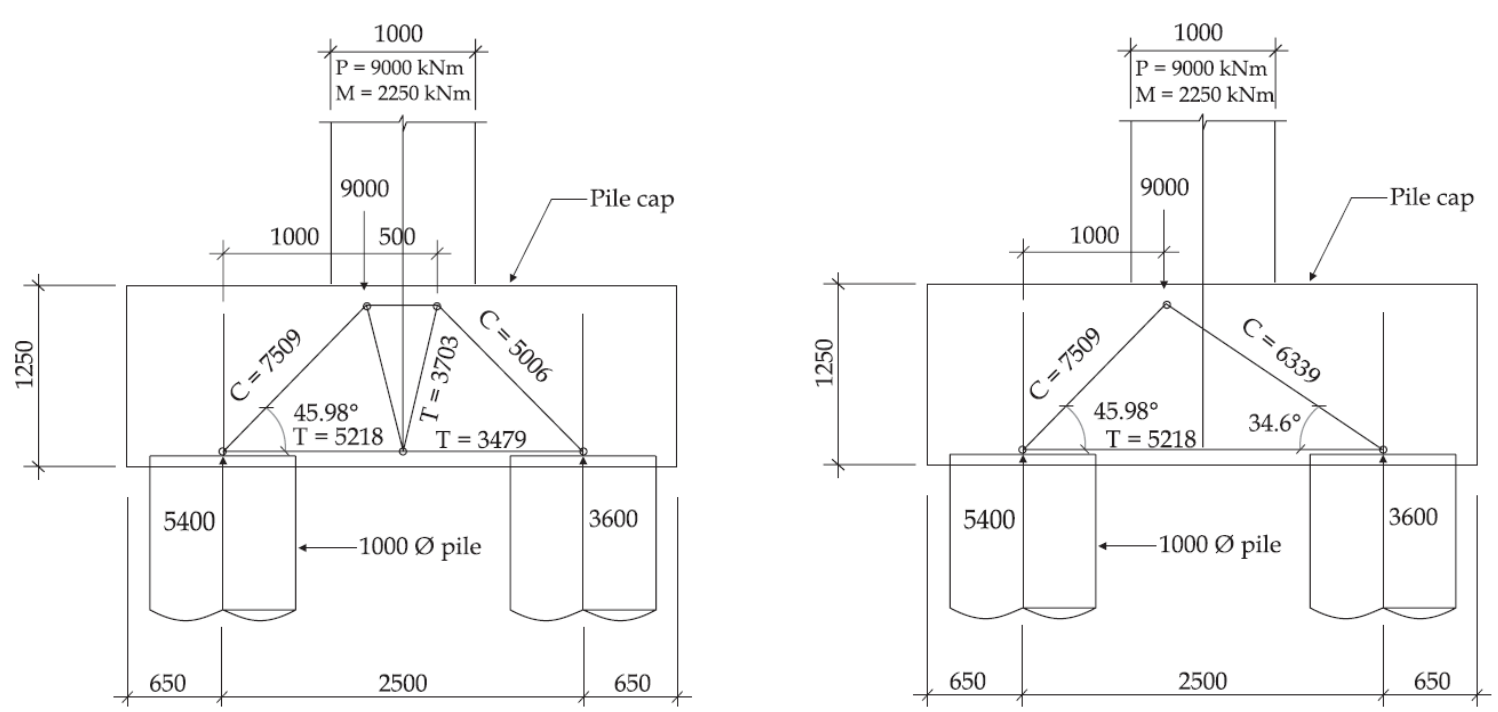

Figura 2. 12 - Modelos de biela e tirante para blocos sobre duas estacas, NORI \& THARVAL (2007)

A respeito do modelo, os pesquisadores afirmam que a posição das bielas e dos tirantes depende não somente da estrutura, mas também do tipo de ação que atua sobre a mesma. Por mais simples que seja uma estrutura, existem várias combinações de ações possíveis, o que conduz a diversas configurações de bielas e tirantes. Os pesquisadores atentaram para o fato de que as maiores forças nos tirantes ocorrem para as maiores reações nas estacas. Dentre as várias configurações possíveis para o posicionamento das bielas e dos tirantes, é recomendando utilizar o modelo em que exista o menor número de tirantes.

NORI \& THARVAL (2007) sugerem verificar as tensões nas regiões nodais baseado nas expressões do ACI 318-05. Recomendam ainda que não se utilize ângulos pequenos entre bielas e tirantes, devendo sempre que possível utilizar valores superiores a $45^{\circ}$, embora o ACI 318-05 permita ângulos de até $25^{\circ}$. Por fim, os pesquisadores concluem que o modelo de 
bielas e tirantes resulta em valores confiáveis para dimensionamento do estado limite último, evitando a ruína da estrutura. Recomenda também dispor de armaduras adicionais além das dos tirantes, que têm outras finalidades, como construtiva e de evitar fissuração excessiva do bloco de fundação.

OLIVEIRA (2009) apresentou um estudo teórico a respeito das diretrizes de projetos de blocos sobre estacas, na qual apresentou as diferenças entre os métodos de cálculo existentes. A pesquisadora desenvolveu um modelo teórico a partir das recomendações de FUSCO (1994), considerando que a seção para verificação da tensão nodal no encontro da biela com o pilar ocorre a uma profundidade $\mathrm{x}$ do topo do bloco, numa seção horizontal em que a tensão normal foi reduzida para aproximadamente $20 \%$ do valor da resistência à compressão de cálculo do concreto. Essa seção, por sua vez, se relaciona com a seção transversal do pilar por meio de um coeficiente "fm", o qual depende da profundidade x/d e da resistência à compressão do concreto.

O modelo proposto pela pesquisadora difere do modelo de FUSCO em relação ao ângulo de propagação da área do pilar que, segundo OLIVEIRA (2009), deve ter abatimento igual ao da biela teórica, enquanto que FUSCO (1994) considera que a ampliação da área se dá com uma inclinação constante. Com os resultados obtidos, foi possível traçar curvas em função da resistência à compressão do concreto e da profundidade $\mathrm{x} / \mathrm{d}$, a partir da qual se obtém, por interpolação linear, o fator de multiplicação "fm" da área do pilar. Entende-se que no modelo proposto, o valor da resistência à compressão do concreto a ser considerado deve ser o menor entre a resistência do concreto do pilar e do bloco.

BARROS (2009) avaliou numericamente a influência que a viga de travamento provoca no comportamento estrutural dos blocos de fundações sobre duas estacas com cálice embutido, utilizado na ligação pilar-fundação de estruturas pré-moldadas. Foram analisados vinte e quatro blocos sobre duas estacas por meio do programa DIANA, versão 9.2, na qual foi considerada a não linearidade física dos materiais. Os blocos foram agrupados de acordo com a conformação das paredes do cálice, com ou sem rugosidade, e de acordo com a geometria do bloco que refletia no ângulo de inclinação da biela durante a etapa de projeto, sendo avaliados blocos com ângulos de $45^{\circ}$ e $55^{\circ}$. A Figura 2.13 apresenta um dos blocos estudados. Nesse estudo não foi considerado excentricidade entre as estacas.

O pesquisador concluiu que a presença da viga de travamento na direção perpendicular ao alinhamento das estacas não provoca alteração no comportamento estrutural do bloco, e que as paredes do cálice são capazes de transferir de modo eficaz a força proveniente da viga 
de travamento em direção as estacas. Esse resultado só foi diferente para os blocos com configuração da parede rugosa e inclinação da biela igual a $55^{\circ}$, nos quais a presença da viga de travamento fez com que a força última dos blocos diminuísse entre $7 \%$ e $14 \%$ em relação ao mesmo bloco sem a presença da viga.
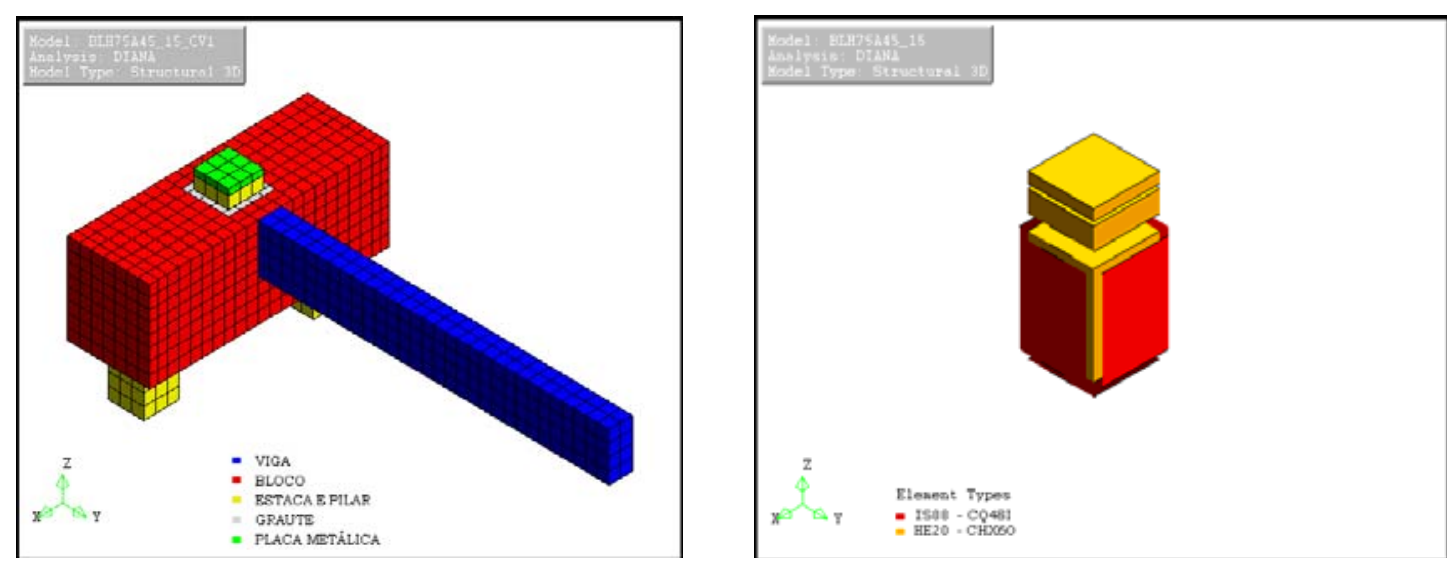

Figura 2. 13 - Bloco sobre duas estacas com viga de travamento e superfície de interface estudado por BARROS (2009)

MAREK FILHO (2010) analisou numericamente o comportamento de blocos sobre quatro estacas com cálice embutido submetidos à ação de força normal com excentricidade nas duas direções. Foi feita análise não-linear tridimensional utilizando o método dos elementos finitos. Tratando do cálice com conformação da parede sem rugosidade, os resultados indicaram a transferência de ações do pilar para a fundação a partir das paredes, entretanto com intensidade insuficiente para a formação de bielas de compressão, e risco da ocorrência de punção nesses blocos. Na situação de cálice com conformação das paredes rugosas, observou-se a formação das bielas de compressão a partir do encontro do bloco com o pilar, assim como ocorre nos blocos com ligação monolítica. Os resultados apresentados em MAREK FILHO (2010) corroboram com os obtidos por BARROS (2009).

BARROS \& GIONGO (2010) realizaram análise numérica em dezesseis blocos sobre duas estacas, no qual o principal objetivo foi avaliar os valores das tensões nas regiões nodais dos blocos, e comparar esses valores com as recomendações normativas. Foram avaliados as recomendações de BLÉVOT \& FRÉMY (1967), SCHÄFER \& SCHLAICH (1988), SCHLAICH \& SCHÄFER (1991), do CEB-FIP (1990), da norma canadense CSA A.23.3.04 e do código americano ACI 318-08. Verificou-se uma grande variabilidade nos valores de tensões limites que são apresentados nos códigos normativos, porém, os valores máximos de 
tensões obtidos nos modelos numéricos foram superiores aos valores limites normativos, indicando que os modelos de cálculo utilizado para o dimensionamento apresentam-se a favor da segurança.

CHANTELOT (2010) desenvolveu estudo a respeito de blocos de fundação, comparando o dimensionamento por meio das normas suecas, inglesa e européias, O objetivo do autor era o de compreender os modos de ruína dos blocos, em virtude da ocorrência de fissuração excessiva, bem como dos diferentes mecanismos de transferência de cisalhamento capazes de provocar a ruptura por cisalhamento desses blocos. Por meio de simulações numéricas baseada no método dos elementos finitos, o autor propôs um modelo de bielas e tirantes tridimensional aplicado a blocos sobre seis estacas.

PAGNUSSAT (2011) realizou simulação numérica em blocos de fundação sobre quatro estacas, considerando cálice parcialmente embutido, solicitado por momentos nas duas direções. Estudou por meio de análise numérica não-linear o comportamento de dois blocos que fizeram parte de edifícios industriais e comerciais tomados como modelos.

Os resultados indicaram que, para o caso de ligação com rugosidade, ocorreu a formação de bielas que se formam a partir do topo do colarinho. Entretanto, o modelo espacial e o método das bielas não descrevem com precisão o seu comportamento, pois há uma tendência das bielas se formarem com grandes ângulos de inclinações e, assim, as forças são transmitidas diretamente para as estacas. Já para o caso de ligação sem rugosidade, PAGNUSSAT (2011) observou-se que a transferência das ações atuantes no pilar para o bloco ocorreu por meio da força de atrito das paredes do pilar com o colarinho e principalmente pelo contato da base do pilar com o bloco.

OLIVEIRA (2013) realizou simulações numéricas em blocos de fundação sobre cinco estacas dispostas no vértice de um trapézio, e sobre seis estacas, com arranjo retangular. O autor estudou diversos métodos analíticos para o dimensionamento dos blocos, no intuito de avaliar a compatibilidade entre o comportamento dos blocos e as hipóteses de cada método. Desenvolveu análise numérica tridimensional utilizando programa baseado no método dos elementos finitos. Nos blocos estudados variou-se a deformabilidade do solo de apoio das estacas, por meio de molas elásticas, a seção transversal do pilar, considerando pilar quadrado e pilar retangular, as alturas dos blocos sobre estacas e a resistência do concreto.

O pesquisador observou que quanto mais deformável foi o solo, mais uniforme foi a distribuição das reações entre as estacas e das tensões de tração nas barras das armaduras principais. Verificou-se que as configurações das bielas mudaram conforme se alterou a seção 
transversal do pilar, indicando a importância de se considerar esse aspecto no dimensionamento analítico dos blocos. Observou também que o aumento da resistência do concreto acarretou no aumento da resistência dos blocos, porém não influenciou na rigidez de modo significativo.

OLIVEIRA (2013) concluiu que os métodos analíticos que se baseiam nas verificações das resistências a momento fletor e à força cortante não foram compatíveis com o fluxo de tensões obtidos em suas análises, que por sua vez indicou melhor compatibilidade com o método de bielas e tirantes.

BUTTIGNOL \& ALMEIDA (2013) desenvolveram um estudo numérico em blocos de fundação sobre três estacas no qual verificaram que a resistência característica à compressão do concreto pouco influencia na capacidade resistente do bloco. Por meio do programa computacional ATHENA, os pesquisadores simularam numericamente alguns blocos de fundação ensaiados por DELALIBERA 2006.

Conclui-se, portanto, que existe pouca informação na literatura técnica a respeito do comportamento estrutural dos blocos de fundação com a presença de cálice, sendo que a maioria dos estudos que foram desenvolvidos baseiam-se em análises teóricas e simulações numéricas.

\subsection{Pesquisas com ênfase no cálice de fundação}

Conforme dito anteriormente, não é objeto de estudo deste trabalho o comportamento do cálice de fundação em específico, mas sim do comportamento do bloco sobre estacas quando da existência da ligação com a utilização de cálice. Todavia, o autor julga necessário apresentar um resumo das recomendações técnicas e das últimas pesquisas sobre o assunto, sendo que parte dessas pesquisas foram desenvolvidas no Departamento de Estruturas da Escola de Engenharia de São Carlos.

O cálice é a parte do bloco que recebe o pilar pré-moldado, funcionando como um encaixe entre esses elementos, podendo ter as paredes com ou sem rugosidade aparente. $\mathrm{O}$ pilar fica em contato com o cálice num trecho denominado comprimento de embutimento $\ell_{\text {emb }}$. Nesse tipo de ligação, três situações de cálices são admitidas: externo ao bloco, ou seja, com colarinho saliente; parcialmente embutido, em que o comprimento de embutimento é 
dividido na parte referente ao colarinho externo e na parte embutida no bloco; ou embutido no bloco, onde não se tem colarinho

Os modelos de cálculo adotados para dimensionamento da ligação pilar-fundação por meio de cálice externo baseiam-se nas recomendações feitas por LEONHARDT \& MÖNNIG (1978) e pela ABNT NBR 9062:2006. Esses modelos apresentam algumas simplificações, como por exemplo a não consideração das forças de atrito que surgem nas paredes do cálice quando da transmissão da força oriunda do pilar para as paredes do colarinho.

Os modelos de cálculo diferenciam-se de acordo com a conformação da superfície da parede do cálice, podendo os cálices apresentarem-se sem rugosidade ou com rugosidade. Para qualquer dessas superfícies, tanto a ABNT NBR 9062:2006 como LEONHARDT \& MÖNNIG (1978) recomendam que o trecho do pilar em contato com a parede do cálice tenha a mesma conformação. A Figura $\mathbf{2 . 1 4}$ reproduz um esquema geral da geometria e das forças transmitidas à fundação.
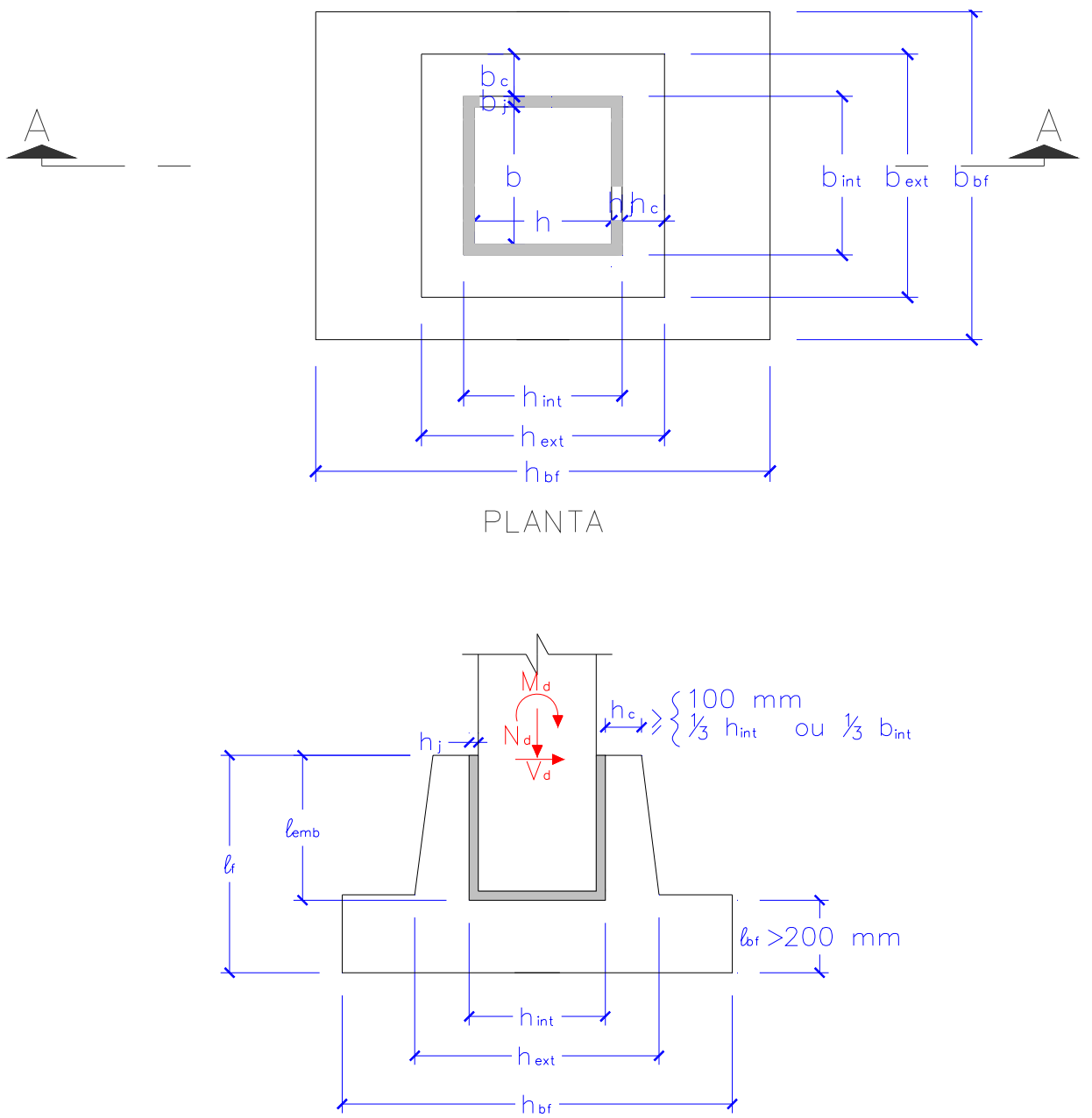

Figura 2. 14 - Geometria do cálice e forças transmitidas à fundação - adaptado de EL DEBS (2000) 
A espessura da parede deve ser igual a um terço da menor distância interna entre as paredes do cálice, ou a $10 \mathrm{~cm}$, utilizando sempre o maior desses valores. A distância entre o fundo do cálice e o fundo da sapata (ou do bloco) deve ter um valor mínimo de $20 \mathrm{~cm}$. Para o caso de superfícies rugosas, recomenda-se que a superfície lateral do pilar e a parede do cálice tenham nervuras, que podem ser obtidas com a utilização de fôrmas onduladas ou denteadas. Será considerada superfície rugosa aquela que possuir ao menos $1 \mathrm{~cm}$ de saliência nas direções vertical e horizontal a cada $10 \mathrm{~cm}$ de profundidade da parede.

A ligação pilar-fundação está garantida quando do preenchimento do espaço entre as paredes do cálice e do pilar. Esse espaço tem a finalidade de facilitar o posicionamento do pilar na horizontal e na vertical, por meio do uso de cunhas dispostas nas quatro paredes do cálice. As cunhas têm a função de impedir o movimento lateral do pilar, e só são removidas quando do preenchimento desse espaço, que deve ser feito com graute ou concreto. $\mathrm{O}$ concreto de preenchimento deve ter resistência igual ou superior à do pilar ou do colarinho e ser adensado preferencialmente por meio de vibrador de agulha. Não se recomenda para essa distância valor inferior a $5 \mathrm{~cm}$, a menos do uso de graute auto adensável.

A parcela do pilar que permanece em contato com o cálice é chamada de comprimento de embutimento $\ell_{e m b}$. Esse comprimento, por sua vez, é função da excentricidade da ação vertical, da dimensão " $h$ " do lado do pilar e da interface das paredes do cálice. A tabela a seguir contém os valores sugeridos por LEONHARDT \& MÖNNIG (1978) e pela ABNT NBR 9062:2006.

Tabela 2.1 - Comprimento de embutimento do pilar segundo LEONHARDT \& MÖNNIG (1978) e ABNT NBR 9062:2006

\begin{tabular}{c|c|c|c|c}
\hline \hline \multirow{2}{*}{ Interface } & \multicolumn{2}{|c|}{$\frac{M_{d}}{N_{d} h} \leq 0,15$} & \multicolumn{2}{c}{$\frac{M_{d}}{N_{d} h} \geq 2,00$} \\
\cline { 2 - 5 } & $\begin{array}{c}\text { ABNT NBR } \\
9062: 2006\end{array}$ & $\begin{array}{c}\text { LEONHARDT \& } \\
\text { MÖNNIG (1978) }\end{array}$ & $\begin{array}{c}\text { ABNT NBR } \\
\mathbf{9 0 6 2 : 2 0 0 6}\end{array}$ & $\begin{array}{c}\text { LEONHARDT \& } \\
\text { MÖNNIG (1978) }\end{array}$ \\
\hline Lisa & $1,50 h$ & $1,68 h$ & $2,00 h$ & $2,80 h$ \\
\hline Rugosa & $1,20 h$ & $1,20 h$ & $1,60 h$ & $2,00 h$ \\
\hline \hline
\end{tabular}

Para valores intermediários de excentricidade entre 0,15 e 2,0 pode-se interpolar linearmente a relação do momento fletor e da força normal para definição do comprimento de 
embutimento $\ell_{e m b}$. A ABNT NBR 9062:2006 recomenda que não se utilizem valores inferiores a $40 \mathrm{~cm}$ para o comprimento de embutimento.

Conforme a Figura 2.15 a resultante das tensões nas paredes do cálice também é influenciada pela interface das mesmas. Quando se trata de parede rugosa, supõe-se que a resultante horizontal $H_{i n f, d}$ é transmitida de forma concentrada para o fundo da parede transversal 2, aumentando assim o braço de alavanca $\mathrm{z}$ e reduzindo a intensidade das tensões.

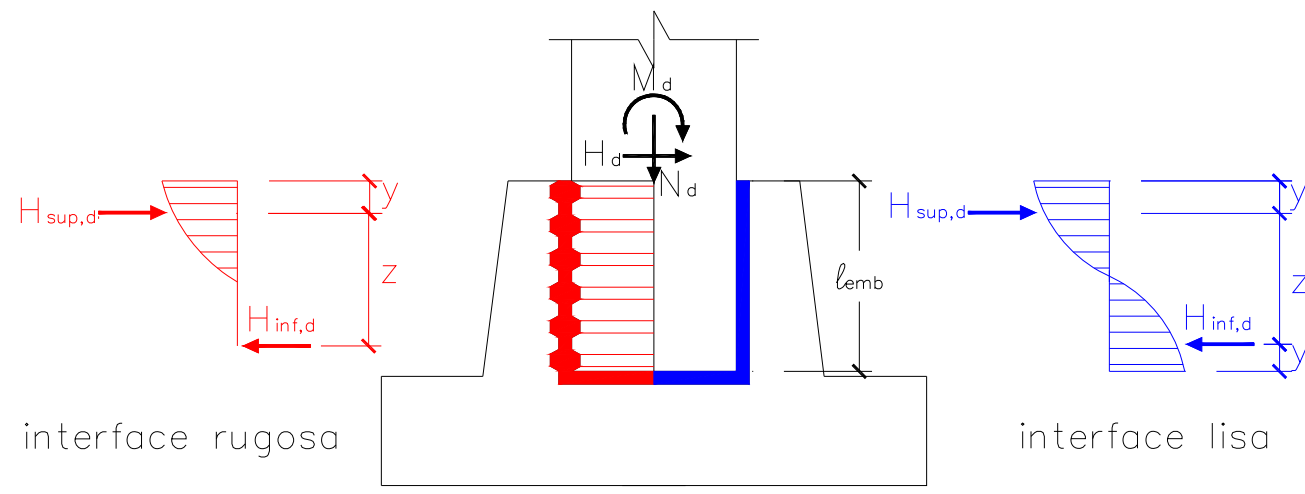

Figura 2. 15 - Forças nas paredes do cálice com interface lisa e rugosa - adaptado de LEONHARDT \& MÖNNIG (1978)

As pressões resultantes indicadas pela ABNT NBR 9062:2006 são semelhantes aos valores apresentados por LEONHARDT \& MÖNNIG (1978). A diferença encontra-se nos modelos de cálculo para interface rugosa, por meio do ponto de aplicação da força $H_{\text {sup,d, }}$ e do coeficiente da primeira parcela na determinação da força $H_{\text {sup,d, }}$ e $H_{\text {inf,d }}$, conforme apresentado nas tabelas 2.2 e 2.3 .

Tabela 2.2 - Valores e posições das forças horizontais -

LEONHARDT \& MÖNNIG (1978).

\begin{tabular}{c|c|c}
\hline \hline Força & Interface Lisa & Interface Rugosa \\
\hline$H_{\text {sup }, d}$ & $1,5 \cdot \frac{M_{d}}{\ell_{e m b}}+1,25 \cdot V_{d}$ & $1,2 \cdot \frac{M_{d}}{\ell_{e m b}}+1,2 \cdot V_{d}$ \\
\hline$H_{\text {inf,d }}$ & $1,5 \cdot \frac{M_{d}}{\ell_{e m b}}+0,25 \cdot V_{d}$ & $1,2 \cdot \frac{M_{d}}{\ell_{e m b}}+0,2 \cdot V_{d}$ \\
\hline$y$ & $0,167 \cdot \ell_{e m b}$ & $0,15 \cdot \ell_{\mathrm{emb}}$ \\
\hline \hline
\end{tabular}


Tabela 2.3 - Valores e posições das forças horizontais - ABNT NBR 9062:2006.

\begin{tabular}{c|c|c}
\hline \hline Força & Interface Lisa & Interface Rugosa \\
\hline$H_{\text {sup }, d}$ & $1,5 \cdot \frac{M_{d}}{\ell_{e m b}}+1,25 \cdot V_{d}$ & $1,2 \cdot \frac{M_{d}}{\ell_{e m b}}+1,2 \cdot V_{d}$ \\
\hline$H_{\text {inf,d }}$ & $1,5 \cdot \frac{M_{d}}{\ell_{e m b}}+0,25 \cdot V_{d}$ & $1,2 \cdot \frac{M_{d}}{\ell_{e m b}}+0,2 \cdot V_{d}$ \\
\hline$y$ & $0,167 \cdot \ell_{e m b}$ & $0,150 \cdot \ell_{e m b}$ \\
\hline \hline
\end{tabular}

A força $H_{\text {sup,d }}$ que solicita a parede 1, é transferida para as paredes longitudinais 3 e 4 que têm o comportamento de consolo engastado no fundo do bloco e, portanto, devem ser dimensionadas como tal. Esse esquema pode ser observado nas Figuras 2.16a e 2.16b.

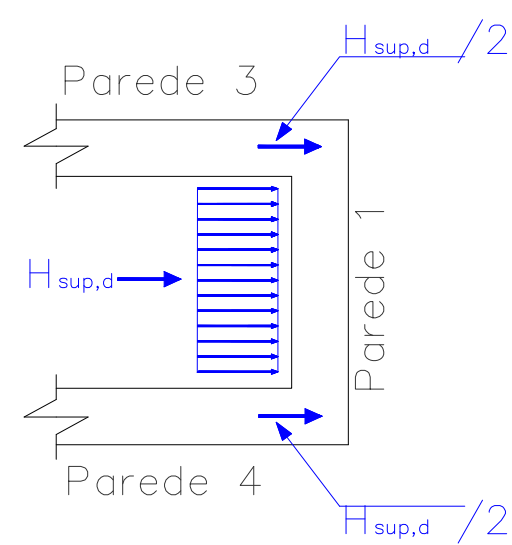

(a)

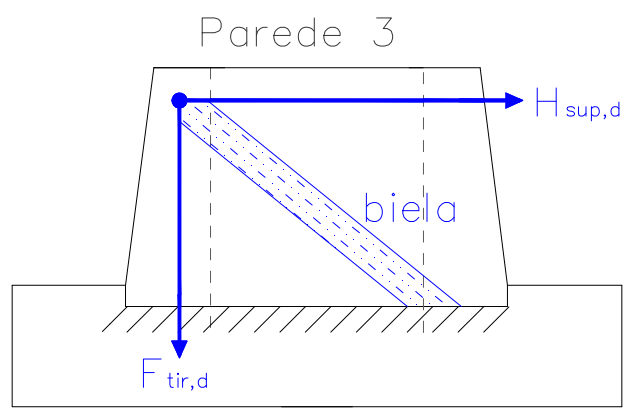

(b)

Figura 2. 16 - Transferência de esforços no colarinho segundo LEONHARDT \& MÖNNIG (1978) adaptado de EL DEBS (2000)

Como as paredes longitudinais 3 e 4 possuem uma elevada rigidez à flexão, e admiti-se que a resultante das pressões na parede 2 atua diretamente na base da fundação, apenas a parede 1 estará solicitada à flexão. Esse modelo foi baseado na antiga Norma Italiana CNR10025 (1984), e funciona apenas para cálice com conformação de parede lisa. Recomendações de EL DEBS (2000) sugerem que a flexão na parede 1 desenvolve-se num trecho de altura igual a um terço de $\ell_{e m b}$ a partir do topo do colarinho. Deve-se dispor de armadura longitudinal para absorver as tensões de tração nesse trecho. 
As paredes longitudinais 3 e 4, como dito anteriormente, devem ser dimensionadas como consolo. Além disso, devem dispor de uma armadura horizontal principal $A_{s h p}$ capaz de absorver a força transmitida pela parede 1. Deve-se distribuir essa armadura numa altura de $2 \cdot y$ a partir do topo do colarinho, sendo y a distância entre a força resultante $H_{\text {sup }, d}$ e o topo do colarinho, conforme dito anteriormente. Essa armadura pode ser obtida, a partir da expressão 2.1 apresentada a seguir.

$$
A_{\text {shp }}=\frac{H_{\text {sup }, d}}{2 \cdot f_{y d}}
$$

A determinação das demais armaduras (armadura vertical principal $A_{s v p}$, armadura vertical secundária $A_{s v s}$ e armadura horizontal secundária $A_{s h s}$ ) são obtidas a partir do modelo de consolo mais adequado. Podem-se classificar os consolos em três tipos, de acordo com a inclinação $\beta$ da biela de compressão. São eles:

- Consolo curto $(1 \geq \operatorname{tg} \beta \geq 0,5)$ : Modelo de bielas e tirantes;

- Consolo muito curto ( $\operatorname{tg} \beta \leq 0,5)$ : Modelo atrito-cisalhamento;

- Consolo longo ( $\operatorname{tg} \beta \geq 1$ ): Modelo da Teoria de Flexão

Como a maioria dos casos recai na situação de consolo curto, será mostrado apenas esse modelo de cálculo, conforme Figura 2.17. Para os demais modelos, recomenda-se consultar o trabalho de CANHA (2004).

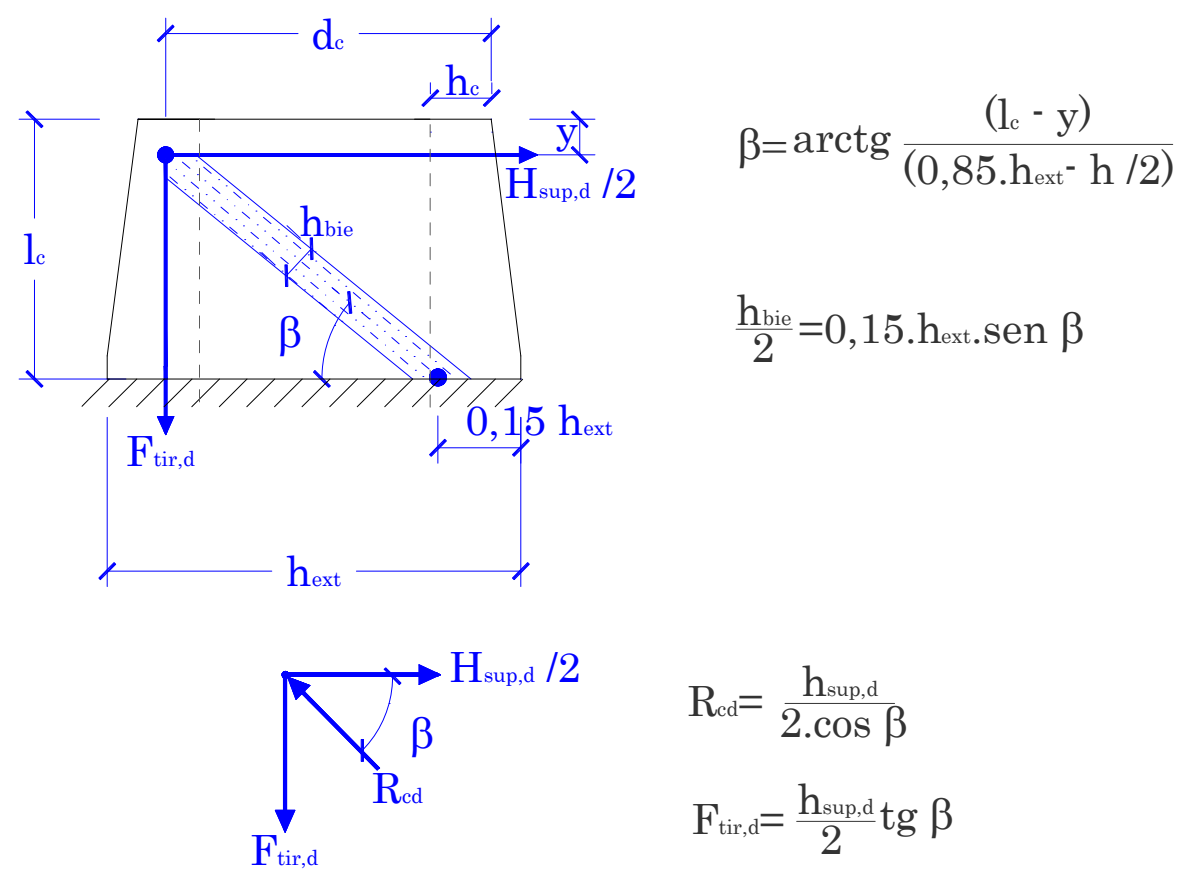

Figura 2. 17 - Indicações de dimensionamento das paredes 3 e 4 como consolo curto adaptado de EL DEBS (2000) 
Pode-se determinar a armadura vertical principal $A_{s v p}$ bem como a tensão na biela comprimida a partir das seguintes expressões:

$$
\begin{gathered}
A_{s v p}=\frac{F_{t i r, d}}{f_{y d}} \\
\sigma_{c d}=\frac{R_{c d}}{h_{b i e} \cdot h_{c}} \leq 0,85 f_{c d}
\end{gathered}
$$

As demais armaduras, vertical e horizontal secundárias funcionam como armaduras de distribuição e de costura, e são obtidas a partir das expressões 2.5 e 2.6:

$$
A_{s v s}=0,4 \cdot A_{s v p}
$$

$$
A_{\text {shs }} \geq\left\{\begin{array}{l}
0,15 \% \cdot h_{c} \cdot h_{\text {ext }} \\
0,2 \cdot A_{s v p}
\end{array}\right.
$$

Essas armaduras também devem ser dispostas nas paredes transversais 1 e 2 . A distribuição das mesmas pode ser vista na Figura 2.18 sugerida por LEONHARDT \& MÖNNIG (1978) e adaptada por EL DEBS (2000).

Para os cálices com interface lisa e comprimento de embutimento inferiores a $2,00 \cdot h$, permite-se fazer uma redução da força $H_{i n f, d}$ na proporção $\ell_{\text {emb }} / 2,00 \cdot h$ quando do dimensionamento da armadura horizontal secundária. Entretanto, deve-se manter seu valor total na verificação da biela comprimida.

No caso de interface lisa, deve-se garantir a ancoragem das barras da armadura longitudinal do pilar, quando as mesmas estiverem solicitadas à tração. LEONHARDT \& MÖNNIG (1978) sugerem que essa ancoragem tenha início a meia altura de $\ell_{e m b}$. EBELING (2006) sugere que a ancoragem tenha início no ponto de aplicação da força horizontal $H_{\text {sup }, d}$.

Nos casos em que a base da fundação for de pequena espessura, recomenda-se proceder a uma verificação quanto à punção. No cálice de interface lisa, a seção de ruína tem início a partir do pilar, enquanto que no cálice rugoso, admite-se que o conjunto pilar colarinho funciona de forma integrada, estando a superfície de ruína de acordo com as dimensões externas do colarinho. 


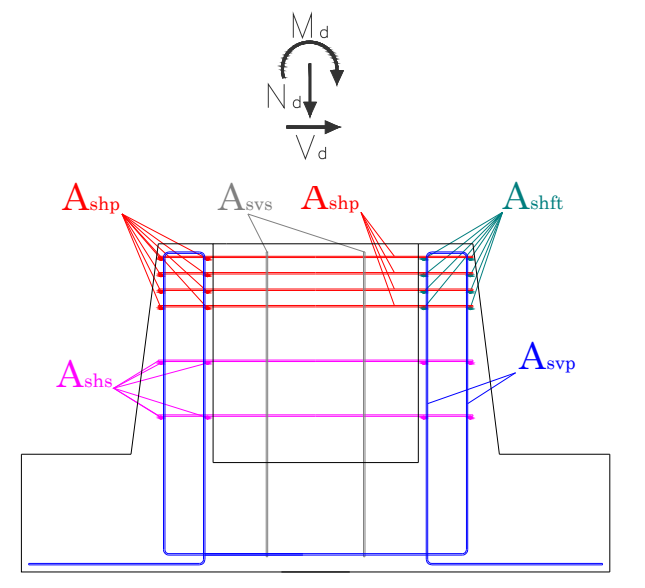

VISTA FRONTAL

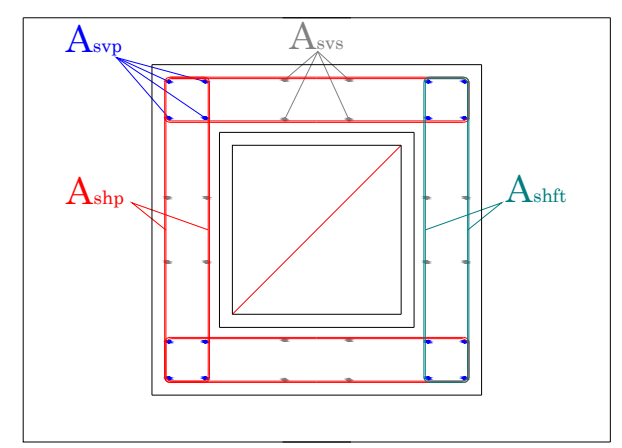

PLANTA
$\mathrm{A}_{\text {svp }}$ - Armadura vertical principal

(tirante do consolo)

Ashft - Armadura de flexão da parede 1 (cálice de paredes lisas)

Ashp - Armadura horizontal principal (transmitir hsup do consolo)

Asvs - Armadura vertical secundária (costura e distribuição)

Ashs - Armadura horizontal secundária (costura e distribuição)

Figura 2. 18 - Esquema das principais armaduras do cálice

Em SILVA (1998), encontra-se um modelo de cálculo para blocos com e sem colarinho. Segundo o autor, o comportamento das forças internas atuantes no pilar é o mesmo para cálice externo ou embutido no bloco. Um dos modelos admite que a reação vertical da força normal atuante no pilar, é transmitida para a sapata sem excentricidade. Essa reação, por sua vez, não é transmitida diretamente à base, mas sim por meio de bielas inclinadas e tirantes horizontais desenvolvidos no interior do pilar, conforme Figura 2.19.

A força horizontal $V_{d}$ tem o mesmo valor da força cortante atuante no pilar, e como as tensões de compressão devem ser limitadas a $0,6 \cdot f_{c d}$, pode-se encontrar a altura da região comprimida $\ell_{v}$ a partir da expressão 2.6.

$V_{d}=0,6 \cdot f_{c d} \cdot b \cdot \ell_{v}$ 


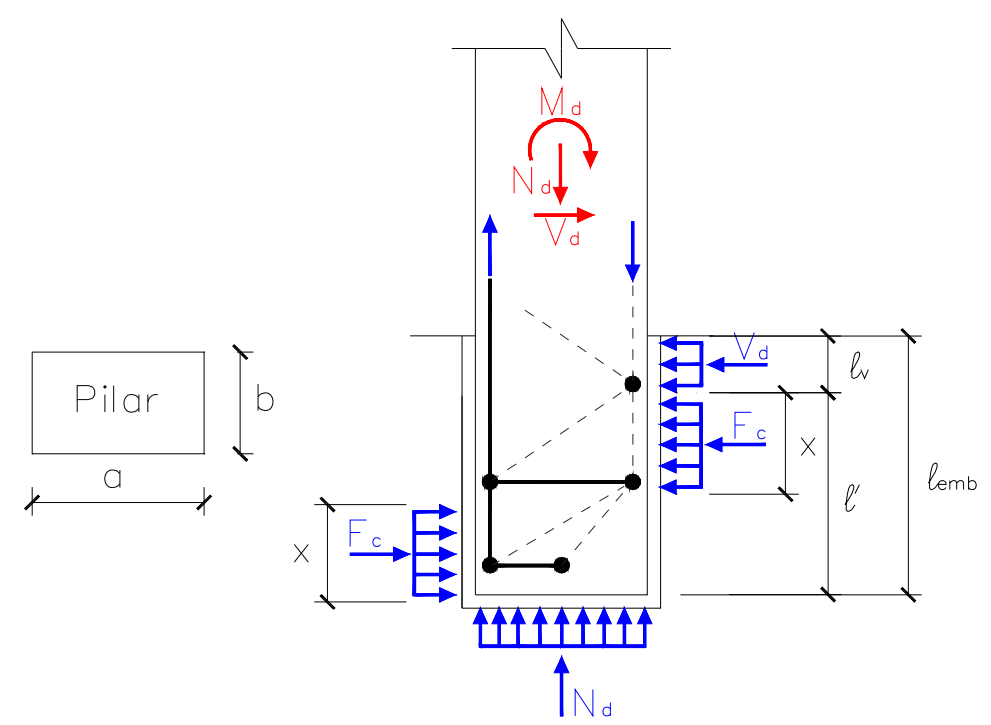

Figura 2. 19 - Esquema de forças atuantes no pilar - SILVA (1998)

Como existe uma excentricidade entre a reação $V_{d}$ e a força cortante atuante no pilar, há um acréscimo no valor do momento, dado pela expressão 2.7 :

$$
M^{\prime}=M+V_{d} \cdot \frac{\ell_{v}}{2}
$$

O momento $M^{\prime}$, por sua vez, é equilibrado pelo binário de forças de compressão $F_{c}$ no topo e na base da parede do cálice, segundo a expressão 2.8 :

$$
F_{c}=0,6 \cdot f_{c d} \cdot b \cdot x
$$

Igualando o momento $M^{\prime}$ ao binário das forças de compressão, têm-se:

$M^{\prime}=F_{c} \cdot\left(\ell^{\prime}-x\right)=0,6 \cdot f_{c d} \cdot b \cdot x \cdot\left(\ell^{\prime}-x\right)$

O valor de $x$ pode ser obtido calculando-se as raízes da seguinte equação do segundo grau:

$$
x^{2}-\ell^{\prime} \cdot x+\frac{M^{\prime}}{0,6 \cdot b \cdot f_{c d}}=0
$$

Na situação de cálice embutido, pode-se utilizar o modelo anterior para comportamento das forças internas do pilar, considerando-se a força normal transmitida à base do bloco sem excentricidade. Outra simplificação é admitir que a reação horizontal do terreno exista a partir do topo do bloco, e que atue de modo colinear com as forças $F_{c}$ e $V_{d}$. Esse procedimento 
permite a simplificação do modelo, sendo facilmente determinadas as forças de tração nos tirantes em função da geometria do bloco e das cargas atuantes, conforme Figura 2.20.
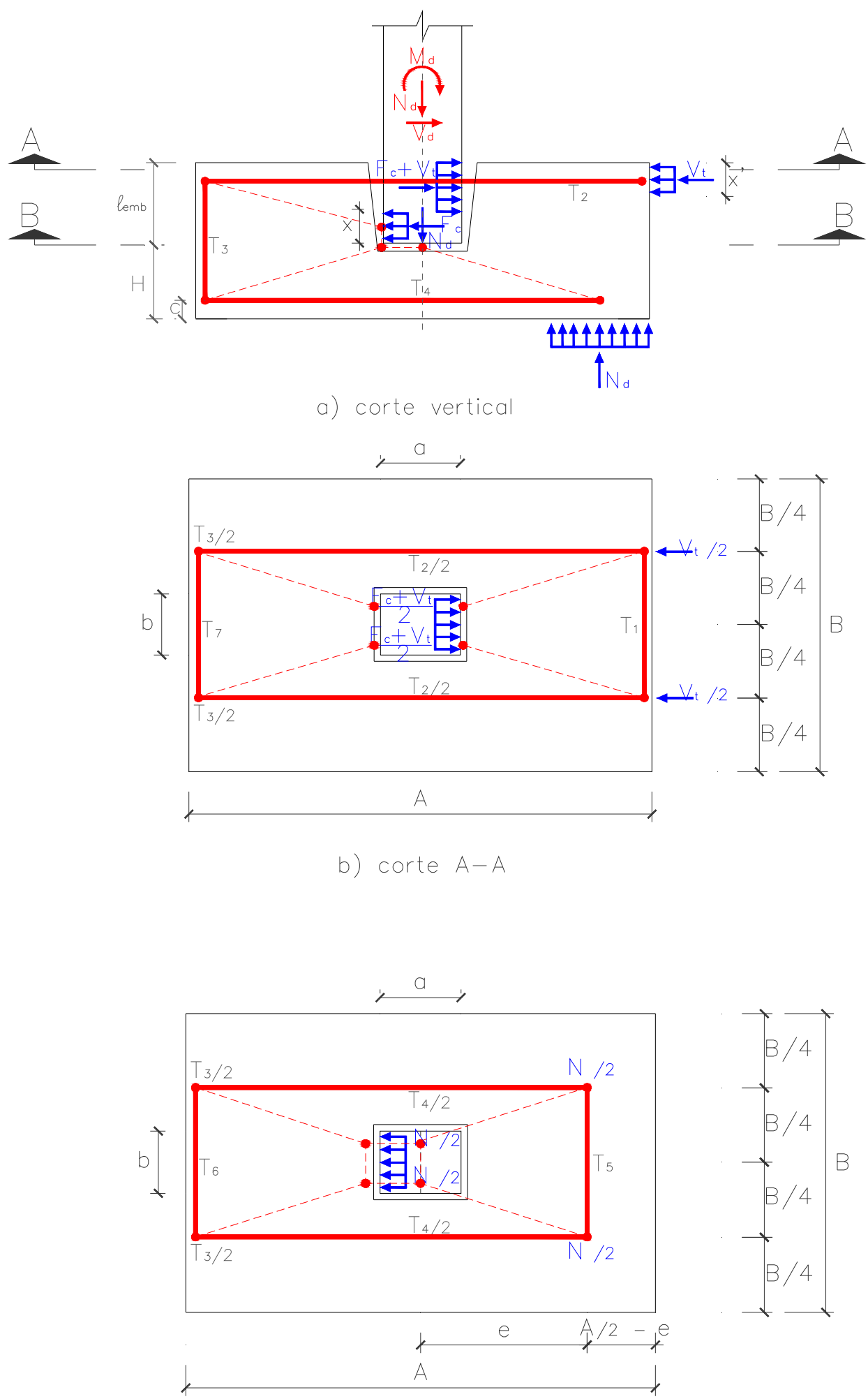

Figura 2. 20 - Modelo de cálculo para bloco com cálice embutido, sem considerar o atrito na junta pilarbloco - SILVA (1998) 
A força $F_{c}+V_{d}$ atua numa altura x', dada pela soma dos valores de $l_{v}$ e $x$, calculados com as expressões anteriores. Admite-se que essa força atua em $x^{\prime} / 2$, causando uma excentricidade da reação $N$ na base do bloco, dada pela expressão 2.11:

$e=\frac{M+V \cdot \frac{x^{\prime}}{2}}{N}$

A força $F_{c}+V_{d}$ é equilibrada pela reação do terreno $V_{t}$, pelo tirante horizontal $\mathrm{T}_{1}$, e pelas forças de tração nos tirantes $T_{2}$. No canto superior esquerdo do bloco, o tirante horizontal $T_{2}$ encontra com o tirante vertical $\mathrm{T}_{3}$ e com uma biela inclinada que sai da face inferior do pilar. $\mathrm{O}$ tirante $\mathrm{T}_{3}$ se liga na face inferior do bloco com dois tirantes horizontais, $\mathrm{T}_{4}$ e $\mathrm{T}_{6}$, e por uma biela inclinada que também sai da extremidade inferior do pilar. A reação do terreno $N$, concentrada a uma distância maior que $0,25 \cdot A$ do eixo do pilar, equilibra a biela proveniente da face inferior do mesmo, e os tirantes horizontais $\mathrm{T}_{4} \mathrm{e} \mathrm{T}_{5}$.

CANHA (2004) realizou uma investigação experimental que é considerada a mais completa no que diz respeito à ligação pilar fundação por meio de cálice externo, com ênfase no colarinho. Foram ensaiados cinco modelos em escala real submetidos a força normal com grande excentricidade, e variou-se a conformação das paredes do cálice, sendo três com interface lisa e dois com interface rugosa.

Em apenas um modelo com interface lisa não foi aplicado desmoldante. Nos demais, assim como nos de interface rugosa, o desmoldante serviu para simular melhor a situação de projeto, já que não se pode garantir um perfeito contato entre as interfaces do pilar e do cálice. Também no cálice com interface rugosa, foram analisadas diferentes configurações de chave de cisalhamento.

As propriedades geométricas dos modelos foram baseadas nas recomendações da ABNT NBR 9062:1985 (atualmente, ABNT NBR 9062:2006) e de LEONHARDT \& MÖNNIG (1978). O comprimento de embutimento seguiu as prescrições da ABNT NBR 9062:1985; a espessura das paredes do cálice foi o maior valor entre $10 \mathrm{~cm}$ e $1 / 3$ da menor distância interna entre paredes; a espessura utilizada para a base foi de $35 \mathrm{~cm}$, maior que a dimensão mínima de $20 \mathrm{~cm}$ recomendada pela norma; a espessura da junta foi de $5 \mathrm{~cm}$, possibilitando o uso de vibrador quando do adensamento do concreto da junta.

Por fim, baseado nos resultados teóricos e experimentais, CANHA (2004) propôs um modelo de projeto para o cálice com interface lisa, na qual é considerada a contribuição das forças de atrito $F_{a t, s u p, d}, F_{a t, i n f, d}$ e $F_{a t, b f, d}$ e a existência da excentricidade $e_{n b}$ da força normal 
atuante na base do cálice. $\mathrm{O}$ valor sugerido pela pesquisadora para a excentricidade $e_{n b}$ após a aferição do modelo é de $h / 4$, sendo $h$ a menor dimensão da seção transversal do pilar. A distribuição de pressões nas paredes 1 e 2 do cálice assumem uma distribuição triangular. $\mathrm{O}$ valor do coeficiente de atrito $\mu$ indicado é de 0,6. A Figura 2.21 ilustra o esquema de representação das forças atuantes no cálice.

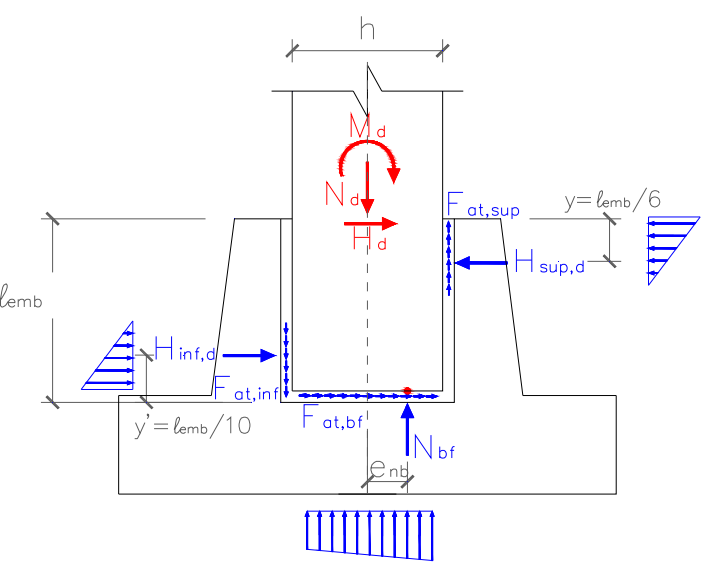

Figura 2. 21 - Forças atuantes no cálice de fundação, CANHA (2004)

Os resultados para o cálice com conformação das paredes rugosas apresentaram um comportamento próximo de uma ligação monolítica. Em função desse comportamento, CANHA (2004) recomenda que a armadura vertical das paredes do colarinho seja dimensionada admitindo a transferência total das ações. Para as paredes longitudinais, podemse considerar as mesmas como consolos quando do dimensionamento.

JAGUARIBE JÚNIOR (2005) prosseguiu com os estudos em ligação pilar fundação por meio de cálice externo, com enfoque no comprimento de embutimento do pilar. Foram estudados dois protótipos, um com interface lisa e outro com interface rugosa, nos quais foi reduzido o comprimento de embutimento. Os resultados experimentais foram comparados com os obtidos por CANHA (2004) e com outras recomendações da literatura técnica. O pesquisador concluiu que ao se reduzir o comprimento de embutimento recomendado pela ABNT NBR 9062:1985, há incoerência entre o resultado teórico e experimental.

EBELING, (2006) realizou pesquisa experimental e numérica com o intuito de analisar a base dos pilares na ligação com cálice de fundação. Foram analisados experimentalmente dois modelos de cálice com conformação de paredes lisas. Um fato importante dessa pesquisa, é que houve reaproveitamento de cálices usados em pesquisas anteriormente realizadas por 
JAGUARIBE JÚNIOR (2005) e CANHA (2004). Em função desse reaproveitamento, foi necessário proceder a um reforço estrutural com fibra de carbono nas paredes do cálice.

EBELING, (2006) concluiu que a base dos pilares na ligação com cálice de fundação apresenta boa segurança, visto que a ruína dos modelos ocorreu fora da região de embutimento, por escoamento da armadura longitudinal tracionada das paredes do cálice. Esse resultado pode ser confirmado nos modelos experimentais e numéricos. Verificou também que a altura do colarinho influencia diretamente na rigidez do cálice, tendo em vista que os menores deslocamentos no topo do colarinho foram obtidos nos cálices com maior comprimento de embutimento. Outra observação importante é que a armadura transversal do cálice foi pouco solicitada, provavelmente por conta do reforço em fibras de carbono realizado nos modelos. Por fim, o pesquisador sugeriu um modelo de bielas e tirantes aplicado ao dimensionamento do cálice de fundação.

NUNES (2009) realizou pesquisa experimental para estudo da ligação pilar-fundação com cálice externo, com ênfase nos esforços solicitantes nas paredes transversais do cálice. $\mathrm{O}$ principal objetivo da pesquisa era avançar no conhecimento desse tipo de ligação, dando prosseguimento aos estudos iniciados por CANHA (2004). Nesse aspecto, foram estudados dois protótipos de cálice externo, sendo um com configuração da parede lisa e outro com configuração da parede rugosa, nos quais foi avaliado o comportamento das armaduras verticais principais, situadas no encontro das paredes transversais e longitudinais.

Os resultados obtidos experimentalmente por NUNES (2009) foram comparados com o modelo de cálculo proposto por CANHA (2004), e indicaram que a parede transversal está submetida à flexo-tração, na qual os valores teóricos de $15 \%$ de flexão e $85 \%$ de tração conduzem aos melhores resultados. Constatou-se também que para o protótipo com configuração da parede lisa, as armaduras principais contribuíram efetivamente para a resistência do modelo após o desprendimento dos elementos da junta.

CAMPOS (2010) realizou trabalho sobre recomendações para o projeto de cálice de fundações. Nesse trabalho, a pesquisadora apresenta uma síntese de normas técnicas e das pesquisas sobre o assunto realizadas no Departamento de Estruturas da Escola de Engenharia de São Carlos. A partir dos resultados dessa pesquisas, foram elaboradas recomendações para o projeto de cálices com interface lisa e rugosa, incluindo ainda avaliação da situação de montagem e sobre disposições construtivas. As principais conclusões incorporadas às recomendações de projeto se referem a: a) posição da aplicação da resultante de pressão superior na parede frontal; b) comportamento das paredes transversais; c) força normal com 
pequena excentricidade; d) espessura mínima das paredes do cálice; e) adaptação do modelo de comportamento da base do pilar pré-moldado com o modelo do cálice. Por fim, apresentase um roteiro simplificado para elaboração de projeto desses elementos.

CARVALHO et al. (2013) apresentam propostas de modelos de bielas e tirantes aplicados a blocos com cálice embutido sobre duas, três e quatro estacas. Os modelos propostos consideram um coeficiente de atrito de 0,30 na situação de paredes do cálice sem rugosidade, e recomendam-se a verificação de todas as bielas, por se tratarem de modelos tridimensionais. Entretanto, entende-se que os modelos teóricos propostos precisam ser comprovados de acordo com resultados experimentais.

\subsection{Recomendações Para Projetos de blocos sobre estacas de acordo com normas brasileiras e de outros países}

São apresentadas as principais recomendações a respeito de blocos de fundação. Apresentam-se os procedimentos das normas ABNT NBR 6118:2007, EHE (2008), ACI 31808, pelo CSA A.23.3.04 e pelo boletim 73 do CEB-FIP (1970).

Segundo a ABNT NBR 6118:2007, dependendo do valor adotado para altura, o bloco pode ser classificado como rígido ou flexível. Bloco rígido é aquele que têm comportamento estrutural definido por flexão nas duas direções, mas com trações essencialmente concentradas nas linhas sobre estacas. Além disso, não pode ser considerada a hipótese das seções planas. A ABNT NBR 6118:2007 recomenda ainda que as barras da armadura principal sejam distribuídas em faixas de larguras iguais a 1,2 vez o diâmetro da estaca. As forças são transmitidas do pilar para as estacas por meio de bielas de compressão, cuja forma e dimensões são complexas. A expressão 2.12 define a altura mínima para que o bloco seja classificado como rígido.

$h \geq \frac{a-a_{p}}{3}$

sendo que:

$a$ é a dimensão do bloco em uma determinada direção;

$a_{p} \quad$ é a dimensão do pilar na mesma direção;

$h \quad$ é a altura do bloco. 
Blocos flexíveis, por suas vezes, são aqueles que têm comportamento semelhante ao de vigas, sendo o dimensionamento feito baseado em seções de referência. A norma recomenda realizar uma análise mais completa, desde a distribuição das ações nas estacas, dos tirantes de tração, até a necessidade de verificação à punção.

A ABNT NBR 6118:2007 não apresenta em seu texto nenhuma recomendação para verificação do cisalhamento nos blocos, nem em relação ao valor limite das tensões nas bielas e nas regiões nodais. A referida norma sugere ainda a utilização de modelos tridimensionais, lineares ou não, e modelos de bielas e tirantes, sendo esse último recomendado por melhor definir a distribuição de esforços no interior do elemento estrutural.

Destaca-se que a ABNT NBR 6118:2007 encontra-se em fase de revisão, estando em consulta pública e devendo entrar em vigor a partir de 2014. Nessa revisão, foram considerados modelos de bielas e tirantes, sendo acrescentados valores limites par as tensões nas regiões nodais, de acordo com as recomendações do CEB FIP (1990). Porém, nessa revisão não está apresentado nenhum critério que possa ser utilizado para classificação dos blocos em rígidos ou flexíveis.

O boletim 73 do CEB-FIP (1970) considera como hipótese de cálculo dos blocos sobre estacas, a situação de que as reações das estacas atuam sobre a superfície de um plano. $\mathrm{O}$ dimensionamento da armadura longitudinal do bloco se dá a partir do cálculo do momento fletor atuando numa seção de referência $S_{1}$ que dista $0,15 a_{p}$ internamente a face do pilar, conforme Figura 2.22.

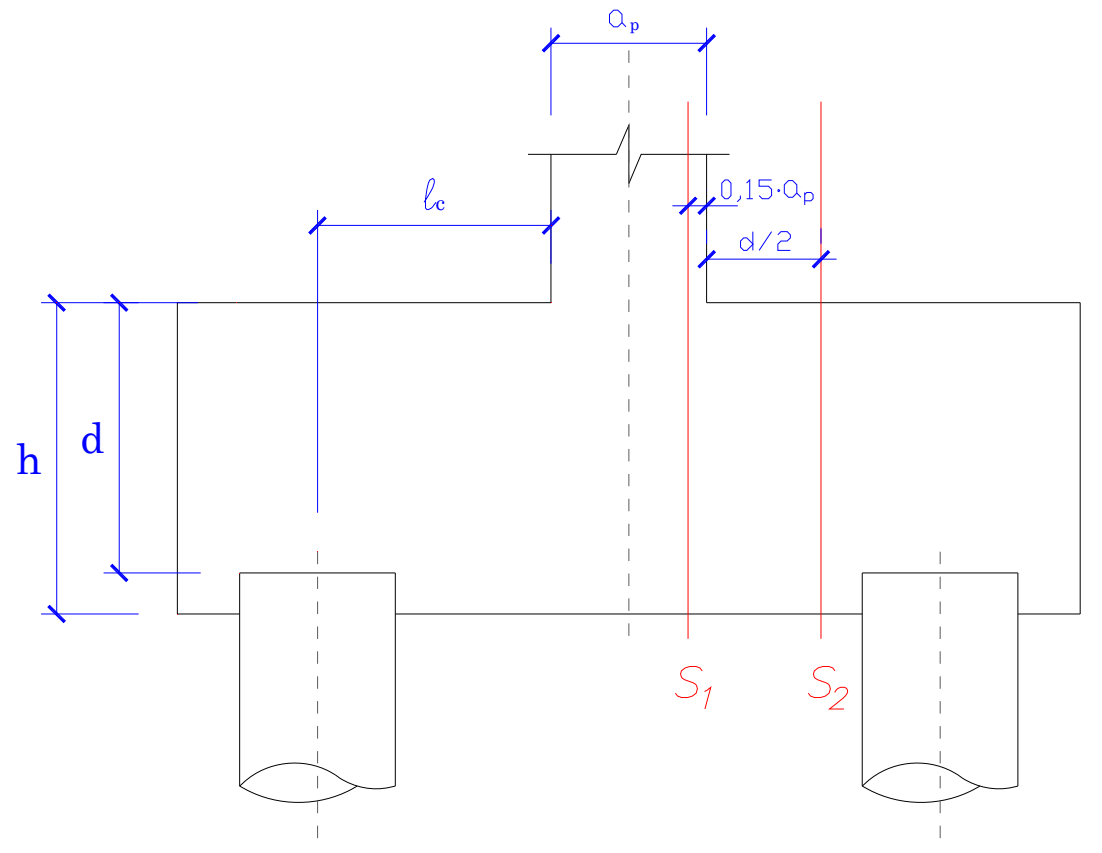

Figura 2. 22 - Seções de referência $S_{1}$ e $S_{2}$ - CEB-FIP (1970) 
A altura útil da seção $\mathrm{S} 1$ deve ser igual à altura de uma seção paralela a S1 situada na face do pilar, tendo como valor máximo 1,5 vez o valor $\ell_{\mathrm{c}}$, que representa a distância entre o eixo da estaca e a face mais próxima do pilar. Para a situação de blocos sobre várias estacas, a distância lc é tomada a partir da estaca mais afastada. O CEB-FIP (1970) recomenda a verificação do cisalhamento para ma força cortante que atua numa seção S2 que dista metade da altura útil do bloco a partir da face externa do pilar.

A instrução normativa espanhola EHE (2008) recomenda a utilização do modelo de bielas e tirantes para dimensionamento de elementos caracterizados pela região D. Ao contrário de sua versão anterior EHE (2002), a atual norma apresenta valores limites para tensões nas bielas e nas regiões nodais. Tratando dos blocos flexíveis, o dimensionamento da armadura longitudinal do bloco é feito segundo uma seção de referência semelhante a indicada no boletim 73 do CEB-FIP (1970). Nessa situação, é recomendado a utilização de armadura com distribuição em malha caso o bloco sejas solicitado por momentos fletores nas duas direções.

O código americano ACI 318-08 não classifica o bloco em flexível ou rígido, porém recomenda o uso da teoria de flexão para os blocos em que a distância entre estacas é superior em pelo menos duas vezes a altura útil do bloco. Nessa situação, é necessário realizar o cálculo do momento fletor na seção que atravessa a face do pilar mais próxima em relação ao lado considerado. O momento fletor, por sua vez, é calculado considerando todas as forças que atuam em um dos lados da referida seção. Em relação ao cisalhamento, é necessário verificar o mesmo em uma seção de referência que dista d/2 (altura útil) da face do pilar.

Quando a relação entre a distância entre estacas e a altura útil do bloco for inferior a dois, pode-se utilizar modelos de bielas e tirantes de acordo com as recomendações do apêndice A do referido código. No apêndice estão definidos valores limites para tensões nas bielas e regiões nodais, assim como valor mínimo de inclinação da biela. Ressalta-se que o ACI 318-05 permite a utilização de ângulos da biela a partir de $25^{\circ}$.

A norma canadense CSA A23.3.04 não classifica os blocos em rígidos e flexíveis, entretanto tal distinção é feita em função da relação entre a altura útil do bloco e a distância entre estaca. Quando a distância entre estacas é inferior a duas vezes a altura útil do bloco, recomenda-se a utilização do modelo de bielas e tirantes modificado adaptado da formulação proposta por ADEBAR \& ZHOU (1996). Nesse modelo são verificados os valores das tensões nas regiões nodais e nas bielas, bem como é feita a consideração do efeito favorável do confinamento do concreto no interior do bloco. No caso de blocos em que a relação da 
distância entre estacas e a altura útil do bloco for superior a dois, o dimensionamento do bloco é feito semelhante ao dimensionamento de vigas, e consiste na verificação ao momento fletor e a força cortante.

\subsection{Efeito de Tamanho}

Para análise em laboratório dos blocos sobre duas estacas, foram utilizados modelos físicos em escala reduzida. A utilização desses modelos com dimensões inferiores as usuais justifica-se pelo elevado custo de produção e pelas dificuldades inerentes aos procedimentos de ensaio quando se utilizam blocos de fundação em escala real. A utilização de protótipos em tamanho reduzido conduz a uma pergunta a respeito da validade ou não da teoria da semelhança física aos elementos de concreto armado, os quais serão discutidos nesse item.

O primeiro estudo a respeito dos efeitos de escala que se tem notícia é do século XVI e de autoria do cientista Galileu Galilei, o qual apresenta em sua obra "A fraqueza relativa dos grandes", a necessidade de se estudarem os fenômenos naturais intrínsecos as dimensões dos elementos. Ao longo dos anos, diversos cientistas contribuíram para o desenvolvimento da teoria da Análise Dimensional e Semelhança dos Modelos Físicos que se tem conhecimento, atualmente.

ROCHA (1952) apresenta alguns fatores que, quando presentes em determinada situação, justificam a utilização de modelos físicos na comprovação de um comportamento estrutural ou de uma teoria analítica, os quais são reproduzidos a seguir.

- Existência de questões insolúveis quando da aplicação de métodos analíticos usuais a novas e complexas formas estruturais;

- Aproximações analíticas insuficientes para tratar o comportamento não-linear de estruturas de concreto armado, sobretudo naquelas em que não são válidas as hipóteses de Bernoulli;

- As conseqüências de ruína da estrutura são desastrosas ao ponto de exigirem uma confirmação experimental independente das previsões analíticas.

Em ANDOLFATO (2002) encontra-se algumas estruturas que, segundo ROCHA (1952) podem necessitar de ensaios em modelos físicos, sendo elas:

- Estruturas consideradas lineares, as quais estejam submetidas às ações sísmicas; 
- Lajes com geometria irregular que apresentam condições de apoio ou carregamentos não usuais;

- Coberturas em cascas com geometria complexa;

- Recipientes de reatores nucleares;

- Novos sistemas construtivos envolvendo interação entre novos materiais

- Barragens.

A utilização de modelos físicos é permitida por normas, desde que se respeitem os critérios de semelhança mecânica. O código americano ACI 318-08 e a ABNT NBR 6118:2007 permitem que a análise estrutural seja desenvolvida baseada em modelos físicos.

A exigência de semelhança entre um modelo físico e uma estrutura real deve ser considerada no projeto, análise e interpretação dos resultados de um modelo físico. CARNEIRO (1996) apresenta o "Teorema de PI de Buckingham", o qual se aplica as leis de escala. Esse teorema baseia-se no fato de que, formando fatores independentes e adimensionais das variáveis envolvidas no problema estrutural, a semelhança é garantida caso esses fatores sejam idênticos no modelo real e no modelo físico.

A teoria de semelhança física pode ser aplicada aos materiais homogêneos e que apresentam comportamento elástico e linear. O concreto armado, por sua vez, é um material heterogêneo e que apresenta comportamento essencialmente não-linear, sendo difícil estabelecer leis físicas que relacione a teoria de semelhança física aos elementos de concreto armado. Analisando duas vigas de concreto armado, sendo que uma delas apresenta altura igual ao dobro da outra, ao se utilizar concreto com mesmo tipo de agregado, verifica-se que a teoria de semelhança física não se aplica a essa situação. Situação semelhante ocorre me vigas com largura constante e altura variável.

Ainda em relação ao concreto armado, há uma preocupação a respeito da influência que o efeito de escala possa provocar nas propriedades mecânicas do material. O concreto dos modelos físicos deve apresentar as mesmas propriedades de tensão-deformação, físsuração e resistência do concreto do modelo real. Essas condições normalmente são alcançadas quando a escala utilizada é maior do que 1:4, a menos da resistência à tração do concreto que, com a diminuição do diâmetro máximo do agregado em função dos espaçamentos, tende a se apresentar maior nos modelos em escala [KUCHMA (2010)] ${ }^{1}$.

\footnotetext{
1 Informação obtida pessoalmente em conversa no Departamento de Engenharia de Estruturas, EESC-USP em agosto de 2010
} 
Em relação ao efeito de tamanho, é necessário estabelecer semelhança geométrica entre os protótipos e o modelo real. A relação entre as magnitudes de uma grandeza nos modelos real e físico é chamada de fator de escala. Desse modo, em um ensaio experimental, se o modelo é reduzido, a escala geométrica é menor do que a unidade, conforme apresentado na equação 2.13 .

$$
\mathrm{k}_{\mathrm{i}}=\lambda_{\mathrm{i}}=\frac{\mathrm{x}_{\mathrm{m}}}{\mathrm{x}_{\mathrm{p}}}=\frac{1}{\frac{\mathrm{x}_{\mathrm{p}}}{\mathrm{x}_{\mathrm{m}}}}=1:\left(\mathrm{x}_{\mathrm{p}} / \mathrm{x}_{\mathrm{m}}\right)
$$

Desse modo, o comportamento semelhante do protótipo e do modelo fica garantido multiplicando a medida do protótipo pelo fator de escala, conforme equação 2.14

$$
\mathrm{x}_{\mathrm{m}}=\mathrm{k}_{\mathrm{i}} \cdot \mathrm{x}_{\mathrm{p}}
$$

A tabela 2.4 apresenta os fatores de escala para as variáveis dependentes, independentes e constantes físicas.

Tabela 2.4 - Fatores de escala

\begin{tabular}{c|c|c}
\hline \hline Grandeza & Dimensão & Fatores de escala \\
\hline Ângulo $(\alpha)$ & - & 1 \\
\hline Coeficiente de expansão linear $\left(\alpha_{\mathrm{T}}\right)$ & $\theta^{-1}$ & 1 \\
\hline Coeficiente de Poisson & - & 1 \\
\hline Deformação $(\varepsilon)$ & - & $\mathrm{K}_{\mathrm{i}}$ \\
\hline Deslocamento $(\delta)$ & $\mathrm{L}$ & $\mathrm{K}_{\mathrm{i}}$ \\
\hline Diâmetro $(\mathrm{D})$ & $\mathrm{L}$ & $\mathrm{K}_{\mathrm{i}}$ \\
\hline Dimensão Linear $(\mathrm{L})$ & $\mathrm{L}$ & $\mathrm{K}_{\mathrm{i}}$ \\
\hline Espessura (t) & $\mathrm{L}$ & $\mathrm{K}_{\mathrm{i}}{ }^{2}$ \\
\hline Força concentrada $(\mathrm{F})$ & $\mathrm{F}$ & $\mathrm{K}_{\mathrm{i}}$ \\
\hline Força por unidade de comprimento $((\mathrm{F} / \mathrm{L})$ & $\mathrm{F} \mathrm{L}^{-1}$ & 1 \\
\hline Módulo de Elasticidade $(\mathrm{E})$ & $\mathrm{F} \mathrm{L}^{-2}$ & 1 \\
\hline Pressão $(\mathrm{p})$ & $\mathrm{F} \mathrm{L}^{-2}$ & 1 \\
\hline Temperatura $(\theta)$ & $\Theta$ & $\mathrm{K}_{\mathrm{i}}{ }^{2}$ \\
\hline Tempo $(\mathrm{T})$ & $\mathrm{T}$ & 1 \\
\hline \hline Tensão $(\sigma)$ & $\mathrm{F} \mathrm{L}^{-2}$ & \\
\hline
\end{tabular}


Nos modelos estudados nessa pesquisa, utilizou-se fator de escala igual a 2. Destaca-se que nesse estudo o fator foi aplicado nas três direções do elemento estrutural. Porém, para blocos de blocos de fundação rígidos sobre duas estacas, a largura do bloco não influencia no dimensionamento do mesmo, de modo que essa terceira dimensão não precisaria necessariamente ter o fator de escala igual ao das demais direções.

\subsection{Comentários finais}

Este capítulo apresentou um resumo das principais pesquisas que tratam do assunto bloco sobre estacas. A revisão bibliográfica foi dividida em trabalhos com ênfase experimental, trabalhos com ênfase numérica, cálice de fundação e recomendações normativas. Apresentou-se também algumas informações a respeito do modelo de bielas e tirantes e suas aplicações em blocos sobre estacas, bem como alguns comentários do efeito de tamanho e da teoria da semelhança física em elementos de concreto armado. 



\subsection{Considerações iniciais}

Este capítulo apresenta o dimensionamento dos modelos de blocos sobre duas estacas que fizeram parte do programa experimental desenvolvido ao longo da pesquisa. Os ensaios foram realizados no Laboratório de Estruturas da Escola de Engenharia de São Carlos, Universidade de São Paulo. O objetivo do programa experimental foi verificar o comportamento dos blocos de fundação sobre duas estacas, quando da utilização do cálice de fundação. Para tanto, foram ensaiados em laboratório blocos sobre duas estacas utilizados na ligação pilar-fundação, nos quais foram avaliados a conformação das paredes do cálice e o tipo de ligação, utilizando três situações possíveis para o cálice: externo, embutido e parcialmente embutido. Nesse aspecto, foram fixadas as geometrias dos blocos, pilares e estacas, de modo que as mesmas não provocaram interferência nos parâmetros analisados. Os modelos foram construídos em escala reduzida 1:2, e os dimensionamentos encontram-se apresentados a seguir. Por tratar-se de etapa de projeto, foram utilizados valores característicos das resistências dos materiais para o bloco, e valores de cálculo para os demais elementos, afim de que a ruína ocorra no bloco. Após a obtenção das propriedades mecânicas dos materiais, os valores teóricos serão ajustados em função desses novos valores.

\subsection{Modelos para ensaios em laboratório}

Em função de estudos preliminares e das recomendações feitas por DELALIBERA (2006), optou-se por fixar a altura $\mathrm{h}$ dos blocos. Essa altura foi constante em todos os modelos, assim como o valor do comprimento de embutimento $\ell_{\mathrm{emb}}$, de modo que, quando da variação da distância entre o fundo do pilar e o fundo do bloco, a variação dessa distância seja convertida em colarinho. Desse modo, a distância entre o fundo do pilar e o fundo do bloco denominada $\mathrm{h}_{\text {fund, }}$ assume três valores distintos, conforme apresentado na tabela 3.1. Para cada situação acima descrita, foram consideradas as paredes do cálice com interface com rugosidade e sem rugosidade, totalizando assim seis modelos. 
Tabela 3.1 - Situações de cálice propostas para ensaios em laboratório.

Cálice embutido:

$\mathrm{h}_{\text {fund }}=\mathrm{h}-\ell_{\mathrm{emb}}$

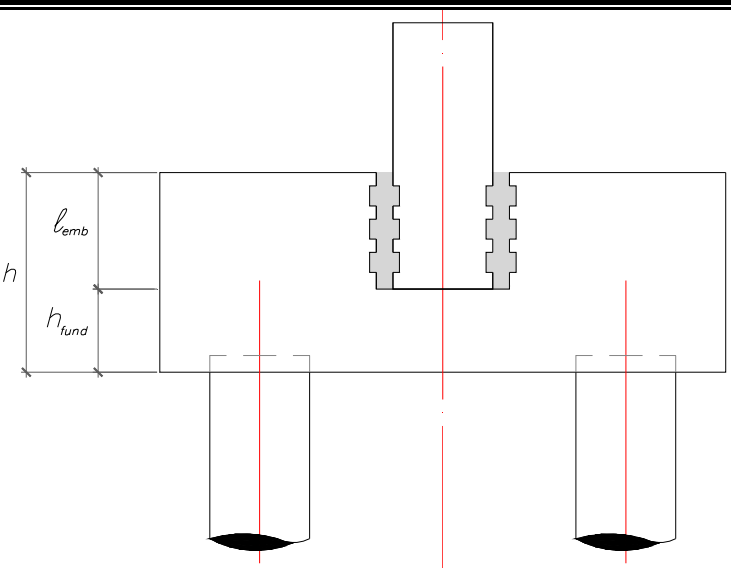

Cálice parcialmente embutido:

$$
\begin{aligned}
& \ell_{\text {fund }}=\mathrm{h}-\ell_{\mathrm{emb}} / 2 \\
& \mathrm{~h}_{\text {fund }}=\mathrm{h}-\frac{\ell_{\mathrm{emb}}}{2}
\end{aligned}
$$

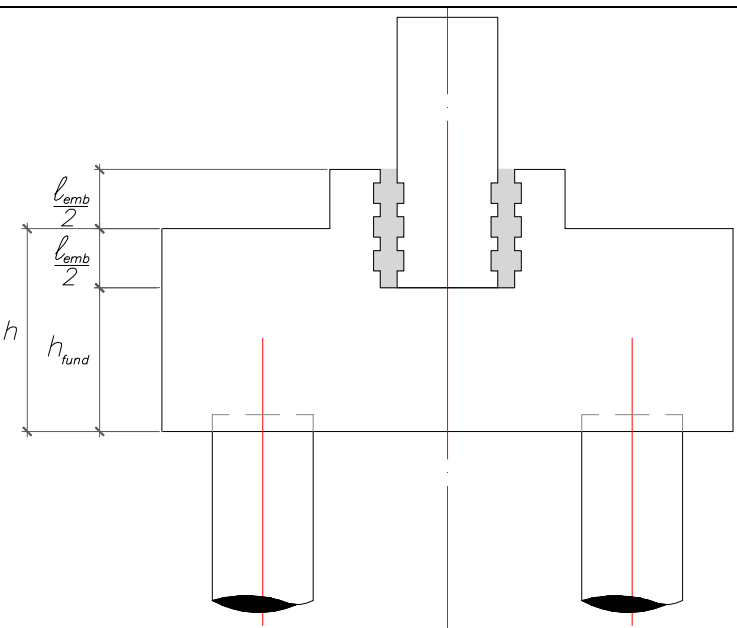

Cálice externo:

$$
\mathrm{h}_{\text {fund }}=\mathrm{h}
$$

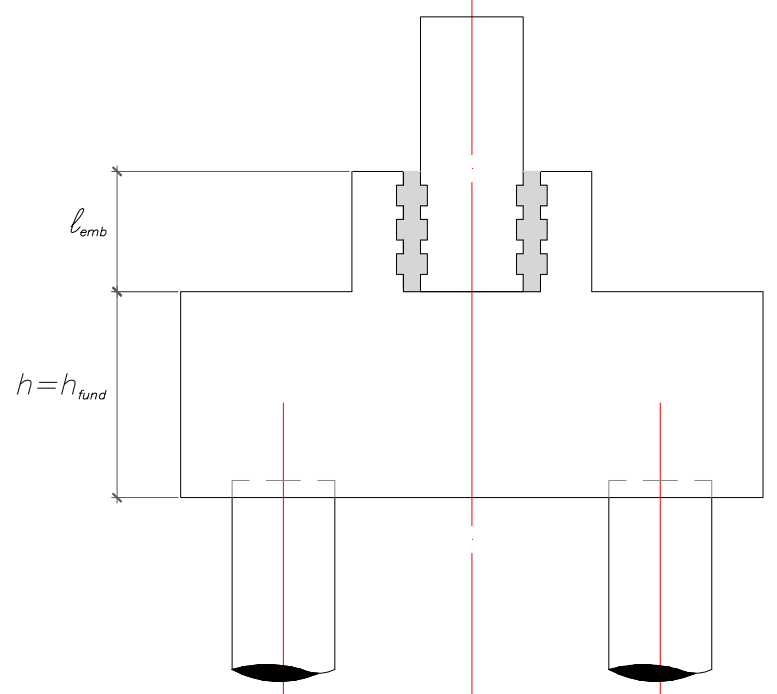


Foi considerada a influência de uma armadura complementar posicionada no meio dos blocos, em forma de estribos, existente nos modelos com cálice embutido e parcialmente embutido e com conformação da parede com e sem rugosidade, gerando mais quatro modelos. Para os blocos com cálice externo foi verificada a influência do aumento da armadura longitudinal, sendo detalhada barras de armadura com área superior a necessária (M3 e M10). Foram construídos dois modelos com ligação monolítica entre o pilar e o bloco, os quais serviram de referência para a comparação com os resultados dos blocos que utilizam cálice, perfazendo um total de 14 modelos. A comparação desses resultados permitirá estabelecer analogias entre os blocos que utilizam cálices e os blocos com ligação monolítica, verificando assim a viabilidade da utilização de modelos de bielas e tirantes para o dimensionamento dos blocos com cálice de fundação. A tabela 3.2 apresenta um resumo dos blocos ensaiados.

Tabela 3.2 - Resumo dos modelos ensaiados em laboratório

\begin{tabular}{|c|c|c|c|c|}
\hline Série & Tipo de Cálice & $A_{s}$ Complementar & Modelo & Código \\
\hline \multirow{7}{*}{$\begin{array}{l}\text { Sem } \\
\text { rugosidade }\end{array}$} & Referência & - & M1 & BRF_SR \\
\hline & \multirow{2}{*}{ Externo } & Sem & M2 & BEX_SR \\
\hline & & Sem & M3 & BEX_AS_SR \\
\hline & \multirow{2}{*}{$\begin{array}{l}\text { Parcialmente } \\
\text { Embutido }\end{array}$} & Sem & M4 & BPE_SR \\
\hline & & Com & M5 & BPE_AC_SR \\
\hline & \multirow{2}{*}{ Embutido } & Sem & M6 & BEB_SR \\
\hline & & Com & M7 & BEB_AC_SR \\
\hline \multirow{7}{*}{$\begin{array}{l}\text { Com } \\
\text { rugosidade }\end{array}$} & Referência & - & M8 & BRF_CR \\
\hline & \multirow{2}{*}{ Externo } & Sem & M9 & BEX_CR \\
\hline & & Sem & M10 & BEX_AS_CR \\
\hline & \multirow{2}{*}{$\begin{array}{l}\text { Parcialmente } \\
\text { Embutido }\end{array}$} & Sem & M11 & BPE_CR \\
\hline & & Com & M12 & BPE_AC_CR \\
\hline & \multirow{2}{*}{ Embutido } & Sem & M13 & BEB_CR \\
\hline & & Com & M14 & BEB_AC_CR \\
\hline
\end{tabular}




\subsection{Dimensionamento dos blocos}

O dimensionamento dos blocos foi feito a partir do modelo em escala real, com aresta do pilar medindo $30 \mathrm{~cm}$ de comprimento e estacas quadradas cujas arestas possuem a mesma medida do pilar.

A altura dos blocos foi definida a partir do comprimento mínimo de embutimento recomendado pela ABNT NBR 9062:2006 para força normal com pequena excentricidade. Desse modo, obtém-se para bloco com interface sem rugosidade (SR) e com rugosidade (CR), os seguintes valores:

$$
\begin{aligned}
& \ell_{\mathrm{emb}}=1,5 \cdot 30=45 \mathrm{~cm} \quad(\mathrm{SR}) \\
& \ell_{\mathrm{emb}}=1,2 \cdot 30=36 \mathrm{~cm} .(\mathrm{CR})
\end{aligned}
$$

Considerando um comprimento mínimo de embutimento das estacas igual a $5 \mathrm{~cm}$ e a distância mínima do fundo do cálice ao fundo do bloco igual a $20 \mathrm{~cm}$, obtém-se como altura mínima dos blocos :

$$
\begin{aligned}
& \mathrm{h}_{\text {min }}=45+5+20=70 \mathrm{~cm} \quad(\mathrm{SR}) \\
& \mathrm{h}_{\text {mín }}=36+5+20=61 \mathrm{~cm} \quad(\mathrm{CR})
\end{aligned}
$$

A partir das recomendações de BLÉVOT \& FRÉMY (1967), o ângulo de inclinação da biela deve estar entre $45^{\circ}$ e $55^{\circ}$. Optou-se por adotar o ângulo igual a $50^{\circ}$. Desse modo, é possível determinar a distância entre eixos das estacas a partir da relação:

$$
\begin{aligned}
& \operatorname{tg} \theta=\frac{(\mathrm{h}-5)}{\ell} \rightarrow \operatorname{tg} 50^{\circ}=\frac{65}{\ell} \rightarrow \ell=54,5 \mathrm{~cm}(\mathrm{SR}) \\
& \operatorname{tg} \theta=\frac{(\mathrm{h}-5)}{\ell} \rightarrow \operatorname{tg} 50^{\circ}=\frac{56}{\ell} \rightarrow \ell=47 \mathrm{~cm}(\mathrm{CR})
\end{aligned}
$$

Considerando que cada biela se forma a uma distância de 0,25 vez a aresta do pilar, o afastamento entre os eixos das estacas é calculado por:

$$
\begin{aligned}
& \ell_{\text {eixos }}=2 \cdot(54,5+0,25 \cdot 30)=124 \mathrm{~cm}(\mathrm{SR}) \\
& \ell_{\text {eixos }}=2 \cdot(47+0,25 \cdot 30)=109 \mathrm{~cm}(\mathrm{CR})
\end{aligned}
$$

Adotou-se, portanto, afastamento entre estacas igual a $125 \mathrm{~cm}$ para a situação de blocos com interface sem rugosidade e $110 \mathrm{~cm}$ para os blocos com interface com rugosidade, conforme Figura 3.1. 

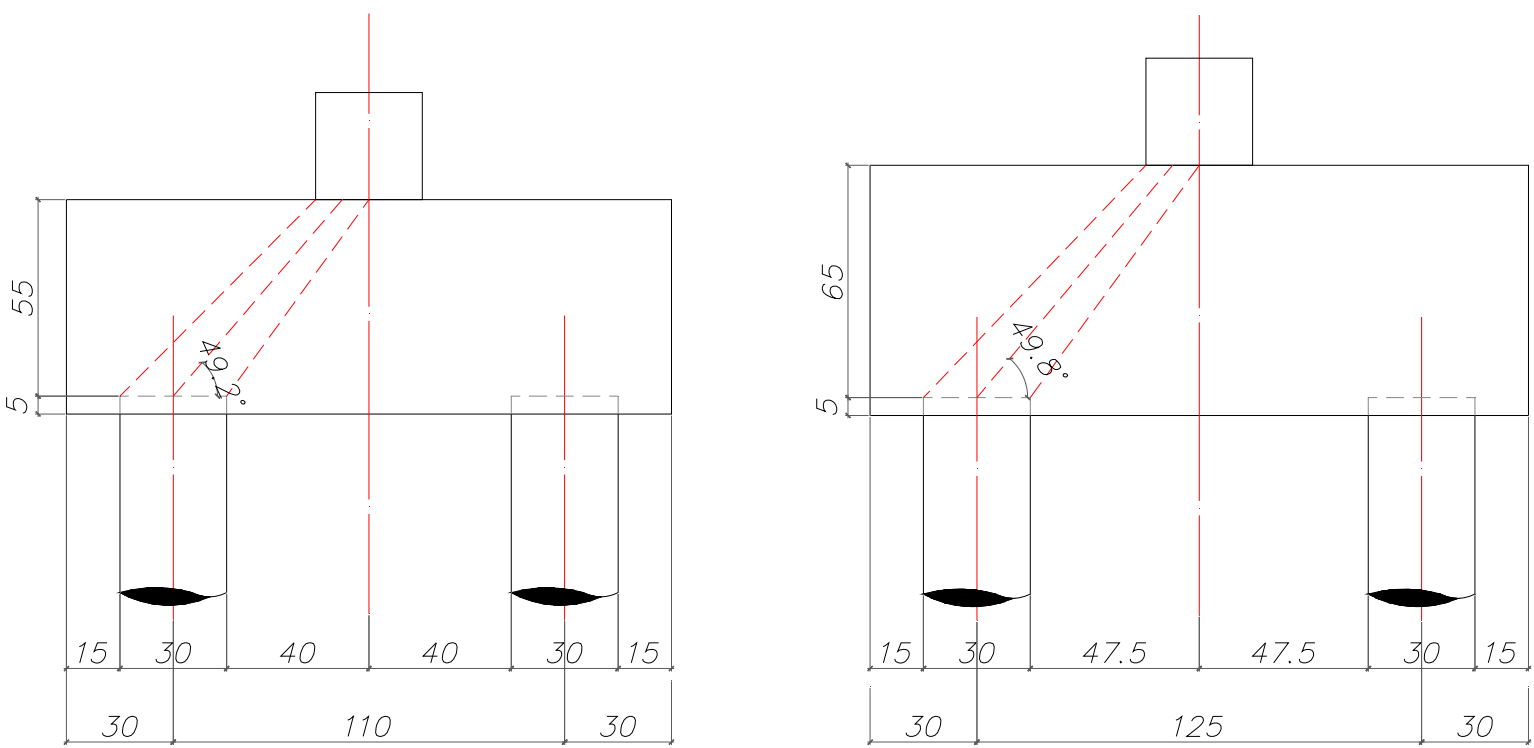

Figura 3. 1 - Dimensões dos Modelos em escala real

Para obtenção da força normal teórica suportada pelo bloco, utilizam-se como limitadores os valores das tensões limites nas regiões nodais, isto é, no encontro da biela com o pilar e da biela com a estaca, a partir das expressões 3.9 e 3.10, apresentadas a seguir.

$$
\begin{aligned}
& \mathrm{F}_{\mathrm{d}}=\sigma_{\mathrm{cb}, \mathrm{p}} \cdot \mathrm{A}_{\mathrm{p}} \cdot \operatorname{sen}^{2} \theta \\
& \mathrm{F}_{\mathrm{d}}=\sigma_{\mathrm{cb}, \mathrm{e}} \cdot 2 \cdot \mathrm{A}_{\mathrm{e}} \cdot \operatorname{sen}^{2} \theta
\end{aligned}
$$

Os valores encontrados para $F_{d}$ representam valores de cálculo, isto é, valores utilizados em projeto. Como trata-se do dimensionamento de elementos que foram ensaiados em laboratório, não deve-se utilizar o valor de $F_{d}$ ponderado pelo coeficiente de segurança majorador das ações. Desse modo, adota-se $\gamma_{\mathrm{f}}=1$ o que implica considerar a força de cálculo com seu valor de avaliação, $\mathrm{F}_{\text {ava. }}$ Em relação ao valor limite das tensões nas regiões nodais, os coeficientes redutores das tensões indicados em normas foram obtidos a partir de observações experimentais, como as realizadas por BLÉVOT \& FRÉMY (1967). Como uma das propostas desse trabalho é propor valores limites para as tensões nodais na utilização de cálice, as tensões limites não foram minoradas por nenhum coeficiente redutor, sendo adotado o valor da resistência característica à compressão do concreto, $\mathrm{f}_{\mathrm{ck}}$. Em relação a pequena variação no ângulo da biela dos modelos das séries sem rugosidade e com rugosidade, obtém-se:

$$
\begin{aligned}
& F_{a v a}=f_{c k} \cdot A_{p} \cdot \operatorname{sen}^{2} 49,8=0,58 \cdot f_{c k} \cdot A_{p}(S R) \\
& F_{\text {ava }}=f_{c k} \cdot A_{p} \cdot \operatorname{sen}^{2} 49,2=0,57 \cdot f_{c k} \cdot A_{p}(C R)
\end{aligned}
$$


Como as estacas e o pilar apresentam a mesma área, verifica-se que a condição limitante para o dimensionamento é a tensão no encontro da biela com o pilar. Assim, utilizando concreto usual com resistência característica à compressão, $\mathrm{f}_{\mathrm{ck}}=25 \mathrm{MPa}$, obtém-se:

$$
\begin{aligned}
& \mathrm{F}_{\text {ava }}=0,57 \cdot 2,5 \cdot 30 \cdot 30=1282,5 \mathrm{kN}(\mathrm{SR}) \\
& \mathrm{F}_{\text {ava }}=0,58 \cdot 2,5 \cdot 30 \cdot 30=1305 \mathrm{kN}(\mathrm{CR})
\end{aligned}
$$

O cálculo da força no tirante é feito por meio do equilíbrio do triângulo de forças no encontro da biela com a estaca, sendo que a força $\mathrm{R}_{\mathrm{st}}$ é obtida a partir da relação com a tangente do ângulo de inclinação da biela e da força atuante na mesma, conforme expressão 3.15

$$
\mathrm{R}_{\mathrm{st}}=\frac{\mathrm{F}_{\text {biela }}}{2 \cdot \operatorname{tg} \theta}
$$

Portanto:

$$
\begin{aligned}
& \mathrm{R}_{\mathrm{st}}=\frac{1282,5}{2 \cdot \operatorname{tg} 49,2}=553,5 \mathrm{kN}(\mathrm{SR}) \\
& \mathrm{R}_{\mathrm{st}}=\frac{1305}{2 \cdot \operatorname{tg} 49,8}=551,4 \mathrm{kN}(\mathrm{CR})
\end{aligned}
$$

O cálculo da armadura necessária é obtido diretamente a partir da relação da força no tirante $\mathrm{R}_{\mathrm{st}}$ e da resistência ao escoamento das barras da armadura de aço, $\mathrm{f}_{\mathrm{yk}}$. Por tratar-se de modelos a serem ensaiados, deve-se suprimir o coeficiente minorador da resistência do aço, adotando-se, portanto, $\gamma_{\mathrm{s}}=1$, o que equivale adotar $\mathrm{f}_{\mathrm{yd}}$ igual a $\mathrm{f}_{\mathrm{yk}}$.

$$
A_{s t}=\frac{R_{s t}}{f_{y k}}
$$

Portanto:

$$
\begin{aligned}
& \mathrm{A}_{\mathrm{st}}=\frac{553,5}{50}=11,07 \mathrm{~cm}^{2}(\mathrm{SR}) \\
& \mathrm{A}_{\mathrm{st}}=\frac{551,4}{50}=11,03 \mathrm{~cm}^{2}(\mathrm{CR})
\end{aligned}
$$

Como os modelos reduzidos mantêm a escala 1:2, o dimensionamento desses modelos é feito do mesmo modo, alterando a geometria dos blocos, ou aplicando-se diretamente os 
fatores de escala envolvidos no problema. Refazendo o dimensionamento para o bloco com interface lisa, têm-se:

$\mathrm{F}_{\mathrm{ava}}=0,57 \cdot 2,5 \cdot 15 \cdot 15=320,625 \mathrm{kN}$

$\mathrm{R}_{\mathrm{st}}=\frac{320,625}{2 \cdot \operatorname{tg} 49,2}=138,3 \mathrm{kN}$

$\mathrm{A}_{\mathrm{st}}=\frac{138,3}{50}=2,77 \mathrm{~cm}^{2}$

Na situação de bloco de interface com rugosidade, têm-se:

$\mathrm{F}_{\mathrm{ava}}=0,58 \cdot 2,5 \cdot 15 \cdot 15=326,25 \mathrm{kN}$

$\mathrm{R}_{\mathrm{st}}=\frac{326,25}{2 \cdot \operatorname{tg} 49,8}=137,8 \mathrm{kN}$

$\mathrm{A}_{\mathrm{st}}=\frac{137,8}{50}=2,76 \mathrm{~cm}^{2}$

Outro modo de se obter os valores apresentados anteriormente é fazendo aplicação direta dos fatores de escala. Como a escala utilizada foi $\mathrm{k}=2$, tanto as grandezas força como área se relacionam com o quadrado do inverso do fator de escala, ou seja, $(1 / \mathrm{k})^{2}$. Desse modo, para o bloco de interface sem rugosidade, têm-se:

$$
\begin{aligned}
& \mathrm{F}_{\mathrm{ava}}=1282,5 \cdot\left(\frac{1}{2}\right)^{2}=320,625 \mathrm{kN} \\
& \mathrm{R}_{\mathrm{st}}=553,5 \cdot\left(\frac{1}{2}\right)^{2}=138,3 \mathrm{kN} \\
& \mathrm{A}_{\mathrm{st}}=11,07 \cdot\left(\frac{1}{2}\right)^{2}=2,77 \mathrm{~cm}^{2}
\end{aligned}
$$

Na situação bloco de interface com rugosidade, têm-se:

$$
\begin{aligned}
& \mathrm{F}_{\mathrm{ava}}=1305 \cdot\left(\frac{1}{2}\right)^{2}=326,25 \mathrm{kN} \\
& \mathrm{R}_{\mathrm{st}}=551,4 \cdot\left(\frac{1}{2}\right)^{2}=137,8 \mathrm{kN} \\
& \mathrm{A}_{\mathrm{st}}=11,03 \cdot\left(\frac{1}{2}\right)^{2}=2,76 \mathrm{~cm}^{2}
\end{aligned}
$$




\subsection{Dimensionamento do colarinho}

Uma vez que os ensaios fizeram uso de força centrada aplicada no pilar, o dimensionamento do colarinho para o cálice externo e parcialmente embutido seguiu as recomendações de pequena excentricidade. Adotou-se uma armadura mínima e considerou-se um momento mínimo obtido a partir da relação:

$$
\frac{\mathrm{M}_{\mathrm{d}}}{\mathrm{N}_{\mathrm{d}} \cdot \mathrm{h}}=0,15
$$

Diferentemente do que foi feito no dimensionamento dos blocos, o dimensionamento do colarinho foi feito com a consideração dos coeficientes de segurança majoradores das ações e minoradores das resistências. Essa opção se deu por não ser objetivo da pesquisa estudar o comportamento das paredes do cálice, uma vez que o estudo específico desse item pode ser encontrado com maiores detalhes nos trabalhos de CANHA (2004) e CAMPOS (2010). Outro fator é que, como será visto a seguir, os valores encontrados para a área das barras das armaduras do colarinho são muito pequenos, recaindo na utilização dos coeficientes de segurança ao se adotar uma armadura mínima para as paredes do cálice.

O dimensionamento das paredes do cálice com interface sem rugosidade se deu a partir dos seguintes ações:

$$
\begin{aligned}
& \mathrm{N}_{\mathrm{d}}=320,625 \cdot 1,4=448,9 \mathrm{kN} \\
& \mathrm{M}_{\mathrm{d}}=448,9 \cdot 0,15 \cdot 0,15=10,10 \mathrm{kN} . \mathrm{m}
\end{aligned}
$$

A espessura mínima das paredes do colarinho deve ser maior que $50 \mathrm{~mm}$ ou um terço da abertura interna do colarinho, resultando em:

$$
h_{c} \geq\left\{\begin{array}{l}
50 \mathrm{~mm} \\
\frac{200}{3}=66,7 \mathrm{~mm}
\end{array}\right.
$$

Adotou-se $\mathrm{h}_{\mathrm{c}}$ igual a $7,5 \mathrm{~cm}$, o que resulta $\mathrm{em} \mathrm{h}_{\mathrm{ext}}$ igual a $35 \mathrm{~cm}$.

Em relação ao comprimento de embutimento, adotaram-se os valores mínimos recomendados pela ABNT NBR 9062:2006.

$$
\ell_{\mathrm{emb}}=1,5 \cdot 15=22,5 \mathrm{~cm}(\mathrm{SR})
$$

Considerando o ponto de aplicação das forças $h_{\text {sup } f}$ e $h_{\text {inf }}$ iguais a $10 \%$ do valor de $\ell_{\mathrm{emb}}$, ou seja, 2,25 cm, tem-se: 


$$
\mathrm{h}_{\text {sup }, \mathrm{f}}=\frac{10,10 \cdot 100}{22,5-2,5-2,5}=56,11 \mathrm{kN}
$$

As paredes do cálice se comportam como consolo curto, uma vez que a tangente do ângulo de inclinação da biela nas paredes transversais resulta no intervalo entre 0,5 e 1,0 , conforme demonstrado a seguir.

$$
\operatorname{tg} \beta=\frac{22,5-2,5}{0,85 \cdot 35-0,5 \cdot 7,5}=0,78 \rightarrow \beta=37,9^{\circ}
$$

Portanto, a força vertical $\mathrm{R}_{\mathrm{vp}}$ que atua na armadura vertical principal resulta em:

$$
\mathrm{R}_{\mathrm{vp}}=0,5 \cdot 56,11 \cdot 0,78=21,85 \mathrm{kN}
$$

A verificação da ruptura do concreto é feita limitando a tensão normal na biela em 0,85 vez o valor da resistência à compressão de cálculo do concreto. A altura da biela é definida a partir da expressão a seguir:

$\mathrm{h}_{\mathrm{bie}}=2 \cdot\left(0,15 \cdot \mathrm{h}_{\mathrm{ext}} \cdot \operatorname{sen} \beta\right)=2 \cdot(0,15 \cdot 35 \cdot \operatorname{sen} 37,9)=6,45 \mathrm{~cm}$

O cálculo da força de compressão $\mathrm{R}_{\mathrm{cb}}$ é feito a partir da seguinte expressão:

$$
\mathrm{R}_{\mathrm{cb}}=\frac{56,11}{2 \cdot(\cos 37,9))}=35,56 \mathrm{kN}
$$

A tensão na biela encontra-se, portanto, inferior a tensão limite, indicando que há pouca probabilidade de ocorrer ruptura da biela.

$$
\sigma_{\text {bie }}=\frac{35,56}{6,45 \cdot 7,5}=0,73 \mathrm{kN} / \mathrm{cm}^{2} \leq \frac{0,85 \cdot 2,5}{1,4}=1,52 \mathrm{kN} / \mathrm{cm}^{2}
$$

Desse modo, as áreas das barras das armaduras do colarinho são facilmente calculadas utilizando os valores das forças $h_{\text {sup,f }}$ e $R_{v p}$ adotando aço CA-50 com valor de $f_{y d}=43,5$ $\mathrm{kN} / \mathrm{cm}^{2}$. Portanto:

$$
\begin{aligned}
& A_{s, h p l}=\frac{56,11}{2 \cdot 43,5}=0,64 \mathrm{~cm}^{2} \\
& A_{s, h p t}=A_{s, h p l}=0,64 \mathrm{~cm}^{2} \\
& A_{s, v p}=\frac{21,85}{43,5}=0,50 \mathrm{~cm}^{2}
\end{aligned}
$$


A armadura vertical secundária e a horizontal secundária são obtidas a partir do valor da armadura vertical principal calculada anteriormente, resultando em:

$$
\begin{aligned}
& A_{\mathrm{s}, \mathrm{vs}}=0,4 \cdot \mathrm{A}_{\mathrm{s}, \mathrm{vp}}=0,20 \mathrm{~cm}^{2} \\
& \mathrm{~A}_{\mathrm{s}, \mathrm{hs}}=0,25 \cdot \mathrm{A}_{\mathrm{s}, \mathrm{vs}}=0,13 \mathrm{~cm}^{2}
\end{aligned}
$$

Na situação de cálice com rugosidade e com pequena excentricidade, CAMPOS (2010) afirma que o dimensionamento pode ser feito segundo a teoria de flexão. Nesse trabalho foi adotado as recomendações de CANHA et al. (2009) para cálice com interface rugosa. Os resultados obtidos são próximos aos da situação de cálice liso, e estão apresentados na tabela 3.3. Em função da situação de pequena excentricidade, adotou-se a excentricidade da resultante na base do pilar igual a zero.

Tabela 3.3 - Resumo de dimensionamento do cálice rugoso com pequena excentricidade.

\begin{tabular}{c|c}
\hline \hline Item & Resultado \\
\hline $\mathrm{N}_{\mathrm{d}}$ & $456,75 \mathrm{kN}$ \\
\hline $\mathrm{M}_{\mathrm{d}}$ & $10,27 \mathrm{kN} \cdot \mathrm{m}$ \\
\hline $\mathrm{h}_{\mathrm{c}}$ & $7,5 \mathrm{~cm}$ \\
\hline$\ell_{\mathrm{emb}}$ & $17,5 \mathrm{~cm}$ \\
\hline $\mathrm{e}_{\mathrm{nb}}$ & 0 \\
\hline $\mathrm{y}=\mathrm{y}{ }^{\prime}$ & $1,75 \mathrm{~cm}^{\prime}$ \\
\hline $\mathrm{h}_{\mathrm{sup}}$ & $58,91 \mathrm{kN}$ \\
\hline $\mathrm{A}_{\mathrm{s}, \mathrm{hpl}}$ & $0,67 \mathrm{~cm}^{2}$ \\
\hline $\mathrm{A}_{\mathrm{s}, \mathrm{hpt}}$ & $0,66 \mathrm{~cm}^{2}$ \\
\hline $\mathrm{A}_{\mathrm{s}, \mathrm{vp}}$ & $0,41 \mathrm{~cm}^{2}$ \\
\hline $\mathrm{A}_{\mathrm{s}, \mathrm{vs}}$ & $0,16 \mathrm{~cm}^{2}$ \\
\hline $\mathrm{A}_{\mathrm{s}, \mathrm{hs}}$ & $0,11 \mathrm{~cm}^{2}$ \\
\hline \hline
\end{tabular}




\subsection{Dimensionamento dos pilares}

O dimensionamento dos pilares seguiu as recomendações da ABNT NBR 6118:2007, a menos da verificação da seção mínima de concreto inferior a $360 \mathrm{~cm}^{2}$, condição necessária em função da escala dos modelos. Com o objetivo de evitar a ruína dos pilares antes da ruína dos blocos, optou-se por adotar concreto com resistência característica à compressão maior do que a dos blocos, utilizando concreto da classe C50. Esse procedimento também foi adotado para as estacas.

Em virtude do bloco estar submetido a força normal centrada, foi utilizado para dimensionamento um momento mínimo atuante nas duas direções dos pilar, obtidos a partir da expressão a seguir.

$\mathrm{M}_{\mathrm{d}}=\mathrm{N}_{\mathrm{d}} \cdot(0,015+0,03 \cdot \mathrm{h})$

Assim como no dimensionamento do colarinho, para o dimensionamento dos pilares foram considerados os coeficientes majoradores das ações e minoradores das resistências dos materiais. A seguir é apresentado o dimensionamento dos pilares.

$$
\begin{aligned}
& \mathrm{N}_{\mathrm{d}}=1,4 \cdot 326,25=456,75 \mathrm{kN} \\
& \mathrm{M}_{\mathrm{d}}=456,75 \cdot(0,015+0,03 \cdot 0,15)=8,91 \mathrm{kN} \cdot \mathrm{m}
\end{aligned}
$$

A força normal reduzida resulta em:

$$
v=\frac{456,75}{15 \cdot 15 \cdot \frac{5}{1,4}}=0,56
$$

Os momentos reduzidos apresentam os mesmos valores nas direções x e y, portanto:

$$
\mu_{\mathrm{x}}=\frac{8,91 \cdot 100}{15 \cdot 15 \cdot 15 \cdot \frac{5}{1,4}}=0,073
$$

Considerando ábaco com distribuição das armaduras nos vértices do pilar, obtém-se $\omega=0,25$ e, logo:

$$
\omega=\frac{A_{s} \cdot f_{y d}}{A_{c} \cdot f_{c d}} \rightarrow A_{s}=\frac{0,25 \cdot 15 \cdot 15 \cdot \frac{5}{1,4}}{\frac{50}{1,15}}=4,62 \mathrm{~cm}^{2}
$$


Os valores mínimos e máximos para as áreas das barras da armadura são apresentados a seguir. Verifica-se que os valores encontrados no dimensionamento são compatíveis com os apresentados em 3.55 e 3.56 .

$$
\mathrm{A}_{\mathrm{s}, \min }=0,15 \cdot \frac{456,75}{\frac{50}{1,15}} \geq 0,004 \cdot 15 \cdot 15 \rightarrow 1,57 \mathrm{~cm}^{2}
$$

$$
\mathrm{A}_{\mathrm{s}, \text { máx }}=0,08 \cdot 15 \cdot 15=18 \mathrm{~cm}^{2}
$$

\subsection{Dimensionamento das estacas}

O dimensionamento das estacas foi feito semelhante ao dimensionamento dos pilares, considerando concreto da classe C50 e com a consideração dos coeficientes de segurança. A força normal utilizada no dimensionamento foi igual a metade da força máxima atuante no pilar, resultando em 228,38 kN. Também foi considerada a atuação de um momento mínimo nas estacas, obtidos do mesmo modo como no dimensionamento dos pilares. A seguir é apresentado os cálculos:

$$
\begin{aligned}
& \mathrm{N}_{\mathrm{d}}=0,5 \cdot 456,75=228,38 \mathrm{kN} \\
& \mathrm{M}_{\mathrm{d}}=228,38 \cdot(0,015+0,03 \cdot 0,15)=4,45 \mathrm{kN} \cdot \mathrm{m}
\end{aligned}
$$

A força normal reduzida resulta em:

$$
v=\frac{228,38}{15 \cdot 15 \cdot \frac{5}{1,4}}=0,28
$$

Os momentos reduzidos apresentam os mesmos valores nas direções x e y, portanto:

$$
\mu_{\mathrm{x}}=\frac{4,45 \cdot 100}{15 \cdot 15 \cdot 15 \cdot \frac{5}{1,4}}=0,037
$$

Considerando ábaco com distribuição das armaduras nos vértices do pilar, obtém-se $\omega=0,10$ e, logo:

$$
\omega=\frac{A_{s} \cdot f_{y d}}{A_{c} \cdot f_{c d}} \rightarrow A_{s}=\frac{0,10 \cdot 15 \cdot 15 \cdot \frac{5}{1,4}}{\frac{50}{1,15}}=1,84 \mathrm{~cm}^{2}
$$




$$
\mathrm{A}_{\mathrm{s}, \text { mín }}=0,15 \cdot \frac{228,38}{\frac{50}{1,15}} \geq 0,004 \cdot 15 \cdot 15 \rightarrow 0,90 \mathrm{~cm}^{2}
$$

O valor máximo para a área das barras da armadura das estacas é o mesmo calculado no dimensionamento dos pilares, apresentado na expressão em 3.56.

\subsection{Detalhamento das barras das armaduras}

Após o dimensionamento dos elementos apresentados nos itens anteriores, foi feito o detalhamento das armaduras. Foram feitas as verificações de ancoragem das barras das armaduras dos blocos, pilares e estacas, de acordo com as recomendações da ABNT NBR 6118:2007.

No caso de blocos sobre estacas, a ancoragem das barras da armadura deve ser garantida a partir da face da estaca, porém a ABNT NBR 6118:2007 não especifica se é a face interna, externa ou a que engloba o centro geométrico da estaca. $\mathrm{O}$ autor entende tratar-se da face interna da estaca. Na expressão 3.63 são apresentados os critérios de verificação de ancoragem das barras da armadura principal.

$$
\ell_{b, \text { nec }}=\alpha \cdot \ell_{b} \frac{A_{s, \text { calc }}}{A_{s, e f}} \geq \ell_{b, \text { min }}
$$

sendo:

$\ell_{b, \text { nec }} \quad$ o comprimento de ancoragem necessário;

$\alpha=1 \quad$ para barras sem gancho;

$\alpha=0,7$ para barras tracionadas com gancho, com cobrimento no plano normal ao do gancho maior ou igual a três vezes o diâmetro da barra a ancorar;

$\ell_{b, \min } \quad$ comprimento de ancoragem mínimo, sendo o menor valor entre $0,3 \cdot \ell_{\mathrm{b}}, 10 \cdot \phi$ ou 100 $\mathrm{mm}$.

O valor do comprimento de ancoragem básico $\ell_{b}$ pode ser calculado por meio da expressão 3.64 . 


$$
\ell_{b}=\frac{\phi}{4} \cdot \frac{f_{y d}}{f_{b d}}
$$

sendo:

$\phi \quad$ é o diâmetro da barra a ser ancorada;

$f_{y d} \quad$ é a resistência de cálculo ao escoamento da barra a ser ancorada, em MPa;

$f_{b d} \quad$ é a resistência de aderência, calculada pela expressão 3.65.

$$
f_{b d}=\eta_{1} \cdot \eta_{2} \cdot \eta_{3} \cdot \frac{f_{c t k, \mathrm{inf}}}{\gamma_{c}}
$$

sendo:

$\eta_{1}=2,25 \quad$ para barras nervuradas;

$\eta_{2}=1,0 \quad$ para regiões de boa aderência;

$\eta_{3}=1,0 \quad$ para barras com diâmetro inferior a $32 \mathrm{~mm}$;

$\gamma_{c} \quad$ é o coeficiente de segurança do concreto;

$f_{c t k, i n f} \quad$ é a resistência característica a tração direta, com seu valor inferior dado pela expressão 3.66, na qual $f_{c k}$ é a resistência característica do concreto a compressão, expresso em MPa.

$$
\mathrm{f}_{\mathrm{ctk}, \mathrm{inf}}=0,21 \cdot \mathrm{f}_{\mathrm{ck}}{ }^{\frac{2}{3}}
$$

Assim, para os blocos sobre estacas, tem-se:

$$
\begin{aligned}
& \mathrm{f}_{\text {ctk,inf }}=0,21 \cdot 25^{\frac{2}{3}}=1,79 \mathrm{MPa} \\
& \mathrm{f}_{\mathrm{bd}}=2,25 \cdot 1 \cdot 1 \cdot \frac{1,79}{1,4}=2,87 \mathrm{MPa} \\
& \ell_{\mathrm{b}}=\frac{1}{4} \cdot \frac{435}{2,87}=37,9 \mathrm{~cm} \\
& \ell_{\mathrm{b}, \text { minn }}\left\{\begin{array}{l}
0,3 \cdot 37,9=11,36 \mathrm{~cm} \\
10 \cdot 1=10 \mathrm{~cm} \\
100 \mathrm{~mm}
\end{array}\right.
\end{aligned}
$$


Com a adoção dos ganchos, o valor do comprimento de ancoragem básico pode ser reduzido para $70 \%$ do seu valor, resultando em $26,5 \mathrm{~cm}$. Apesar da distância disponível para ancoragem das barras ser inferior a esse valor, em virtude do resultado de outros pesquisadores indicarem que a deformação nas barras das armaduras posicionadas sobre as estacas diminuem consideravelmente em virtude das bielas, optou-se por adotar um comprimento de ancoragem menor do que o recomendado pela ABNT NBR 6118:2007.

Para verificação da ancoragem do pilar, considera-se que a ancoragem se inicia a partir da metade do comprimento $\ell_{\text {emb }}$ conforme recomendações de LEONHARDT \& MÖNNIG (1978), EBELING (2006) e CAMPOS (2010). A seguir é apresentada a verificação da ancoragem para as barras do pilar.

$$
\begin{aligned}
& \mathrm{f}_{\text {ctk,inf }}=0,21 \cdot 50^{\frac{2}{3}}=2,85 \mathrm{MPa} \\
& \mathrm{f}_{\mathrm{bd}}=2,25 \cdot 1 \cdot 1 \cdot \frac{2,85}{1,4}=4,58 \mathrm{MPa} \\
& \ell_{\mathrm{b}}=\frac{1}{4} \cdot \frac{435}{4,58}=23,74 \mathrm{~cm} \\
& \ell_{\mathrm{b}, \text { nec }}=23,74 \cdot \frac{4,62}{4,92}=22,3 \mathrm{~cm} \\
& \ell_{\mathrm{b}, \text { mín }}\left\{\begin{array}{l}
0,3 \cdot 22,3=6,69 \mathrm{~cm} \\
10 \cdot 1,25=12,5 \mathrm{~cm} \\
100 \mathrm{~mm}
\end{array}\right.
\end{aligned}
$$

Verifica-se que o comprimento de ancoragem necessário é de 22,3 cm, valor superior a metade do comprimento de embutimento, $\ell_{\text {emb }}$. Entende-se, porém, que o valor do comprimento de ancoragem calculado poderia ter resultado menor, caso não fosse considerada a ocorrência de momento mínimo no pilar, o qual foi responsável pelo valor da armadura detalhada. O detalhamento das armaduras dos blocos, cálices, pilares e estacas estão apresentados no anexo A. 


\subsection{Verificação à punção}

Para os blocos que apresentam cálices embutidos procedeu-se uma verificação ao fenômeno da punção. Caso a transferência dos esforços oriundos do pilar não ocorra por meio da formação de bielas, parte da ação será transmitida ao bloco por meio de uma força concentrada aplicada no fundo do cálice. Como essa região apresenta uma pequena espessura, entende-se que é necessário verificar o comportamento desse elemento semelhante a verificação de uma laje sujeita a ocorrência de punção. Caso a ruína do bloco ocorra tal qual em uma laje em que exista punção, as barras da armadura longitudinal do bloco funcionarão como armadura necessária para evitar o colapso progressivo. Entretanto, as verificações indicam pequena probabilidade de ocorrência de punção. Tais verificações foram feitas de acordo com os procedimentos da ABNT NBR 6118:2007, os quais são apresentados a seguir.

De acordo com a ABNT NBR 6118:2007 a verificação à punção é feita em duas seções críticas, sendo a primeira delas no contorno do pilar, denominada seção c, e a segunda numa seção cujo perímetro é definido a partir de uma distância igual a $2 \mathrm{~d}$ da seção c, chamada de c'. Caso não seja verificada a segurança na seção c', é necessário dispor de armaduras para evitar a ocorrência de punção, verificando o valor da tensão em uma nova seção c'.

Em todas as verificações, "d" representa a altura útil da laje. A segurança à punção está garantida caso a tensão cisalhante calculadas nas seções c e c' sejam inferiores as tensões resistentes $\tau_{\mathrm{Rd} 2}$ e $\tau_{\mathrm{Rd} 1}$, respectivamente. Em função da geometria do bloco, não é possível determinar a seção critica c'. Por esse motivo, a verificação à punção ocorreu apenas na seção crítica c. Nessas verificações não foi considerado nenhum coeficientes de segurança.

$$
\begin{aligned}
& \tau_{\mathrm{s}}=\frac{326,25}{7 \times 4 \times 15}=0,77 \mathrm{kN} / \mathrm{cm}^{2} \\
& \tau_{\mathrm{Rd} 2}=0,27 \times\left(1-\frac{25}{250}\right) \times 2,5=0,60 \mathrm{kN} / \mathrm{cm}^{2}
\end{aligned}
$$

De acordo com as expressões 3.76 e 3.77 verifica-se que a tensão cisalhante atuante é superior ao valor da tensão resistente. Nessa situação, considerou-se a altura útil da laje igual a $7 \mathrm{~cm}$ e o lado do pilar igual a $15 \mathrm{~cm}$. Entretanto, em virtude da existência do graute entre o 
pilar e o bloco, julga-se razoável considerar que o graute fará parte da seção do pilar, podendo ser considerado no cálculo da tensão cisalhante atuante. Nesse caso, o novo valor de tensão $\tau_{\mathrm{s}}$ resulta no valor apresentado na expressão 3.78 .

$\tau_{\mathrm{s}}=\frac{326,25}{7 \times 4 \times 20}=0,58 \mathrm{kN} / \mathrm{cm}^{2}$

Verifica-se que o valor de $0,58 \mathrm{kN} / \mathrm{cm}^{2}$ para a tensão cisalhante atuante encontra-se superior ao valor das tensão cisalhante resistente, calculada em 3.77 o que indica uma pequena probabilidade de ocorrência de punção nos blocos de fundação.

\subsection{Comentários Finais}

Apresentou-se neste capítulo o dimensionamento e as verificações dos modelos de blocos sobre duas estacas que fizeram parte do programa experimental. Por tratar-se de etapa de projeto, não foram utilizados coeficientes de segurança para o bloco de fundação, sendo considerados apenas no dimensionamento das estacas, pilares e cálices. 



\section{Programa experimental}

\subsection{Considerações iniciais}

O programa experimental teve por objetivo analisar o comportamento de blocos de fundação sobre duas estacas, utilizados na ligação pilar fundação de estruturas pré-moldadas. Para tanto, foram consideradas três situações possíveis para o cálice: externo, embutido e parcialmente embutido.

Em virtude do pequeno número de trabalhos científicos encontrados na literatura técnica, optou-se pela utilização de modelos em escala reduzida 1:2, de modo a ampliar o número de modelos ensaiados. Assim, foram ensaiados um total de quatorze blocos sobre duas estacas, sendo doze utilizando cálice, e dois com ligação monolítica para referência.

Este capítulo tem como objetivo apresentar as etapas de construção dos modelos, os quais envolveram as etapas de construção das fôrmas, montagem das armaduras dos elementos estruturais, concretagem, grauteamento dos modelos, e preparação para os ensaios. Apresenta-se também uma descrição dos equipamentos e dispositivos utilizados nos ensaios.

\subsection{Fôrmas}

As fôrmas utilizadas nas moldagens dos blocos, pilares e estacas utilizaram madeira compensada plastificada com $17 \mathrm{~mm}$ de espessura, e foram feitas na marcenaria da EESCUSP no primeiro semestre de 2011. Além da madeira compensada, foram utilizados caibros para contenção lateral das fôrmas, pregos, parafusos e cola. Para a construção da chave de cisalhamento, utilizou-se Poliestireno expandido (Isopor) para o cálice e madeira para a fôrma dos pilares. Após a confecção, as fôrmas permaneceram estocadas no laboratório de Estruturas aguardando as etapas seguintes para que fossem utilizadas.

Entre estacas, pilares, caixotes externos e internos (necessários nas moldagens dos cálices) e blocos, foram produzidas um total de 76 peças. A tabela 4.1 apresenta um resumo das fôrmas com os respectivos códigos e quantidades. Estes códigos serviram para identificar as fôrmas de cada elementos, tendo em vista o tempo que as mesmas permaneceram 
estocadas. As Figuras 4.1 (a) e 4.1 (b) apresentam, respectivamente, os caixotes externos e internos, enquanto que as Figuras 4.2 (a) e 4.2 (b) apresentam o detalhe da forma dos pilares e da união do caixote externo e interno, a ser fixado na fôrma do bloco na etapa de concretagem.

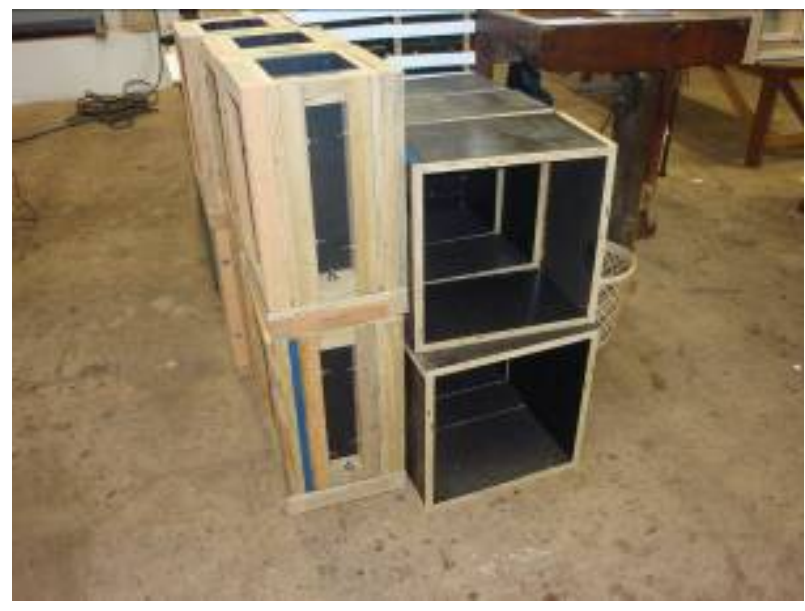

(a)

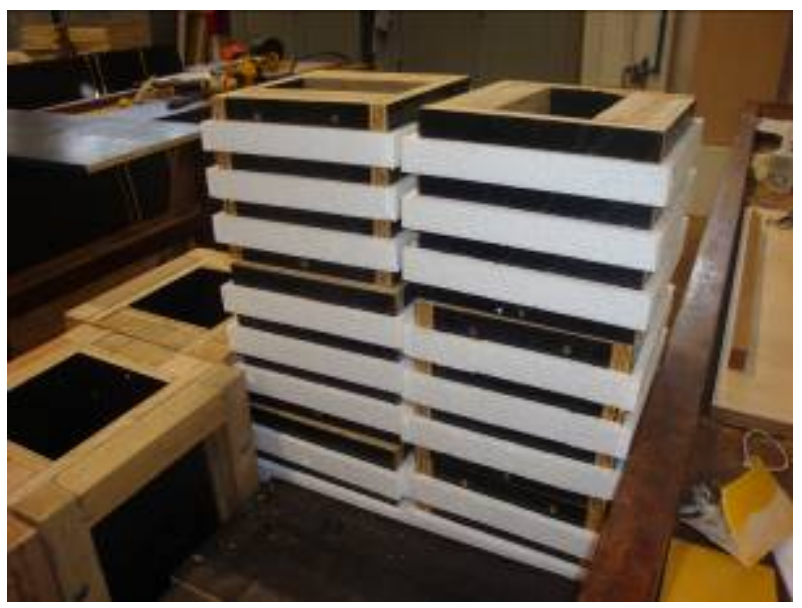

(b)

Figura 4. 1 -Fôrma do caixote externo (CER) e interno (CIR)

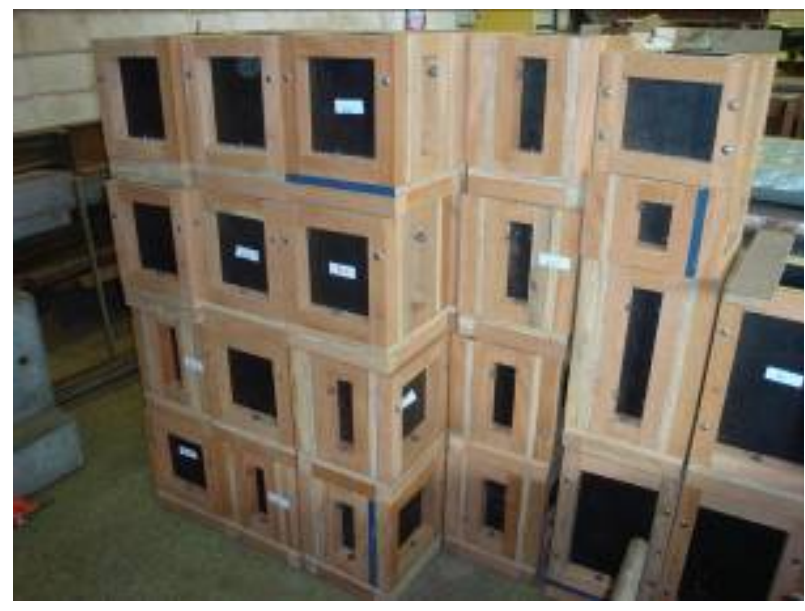

(a)

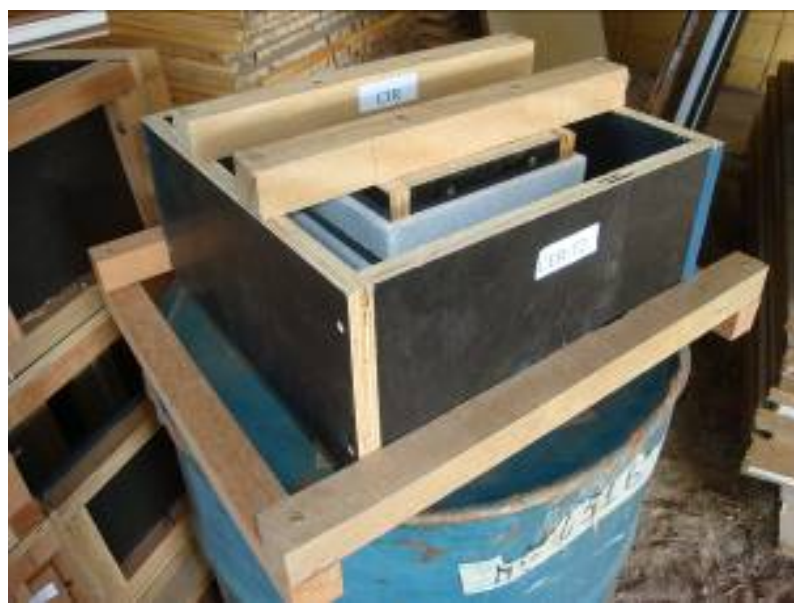

(b)

Figura 4. 2 -Fôrma dos pilares e da união dos caixotes externo (CER) e interno (CIR)

Para fixação do caixote interno no caixote externo foram criadas hastes em madeira, as quais foram fixadas na parte superior do caixote. Em relação à fixação do caixote externo na fôrma do bloco, utilizou-se dispositivo semelhante, porém fixado na parte inferior do caixote, conforme pode ser observado na Figura 4.2 (b). 
Tabela 4.1 - Resumo das fôrmas utilizadas

\begin{tabular}{c|c|c}
\hline \hline Código & Descrição & Quantidade \\
\hline EST & Blocos & 28 \\
\hline PRL & Pilar de referência liso & 1 \\
\hline PRR & Pilar de referência rugoso & 1 \\
\hline PL & Pilar liso & 6 \\
\hline PR & Pilar rugoso & 6 \\
\hline CIL & Caixote interno liso & 6 \\
\hline CEL-T1 & Caixote externo liso - Tipo 1 & 2 \\
\hline CEL-T2 & Caixote externo liso - Tipo 2 & 2 \\
\hline CIR & Caixote interno rugoso & 6 \\
\hline CER-T1 & Caixote externo rugoso - Tipo 1 & 2 \\
\hline CER-T2 & Caixote externo rugoso - Tipo 2 & 2 \\
\hline BR & Bloco Rugoso & 7 \\
\hline BL & Bloco Liso & 7 \\
\hline \hline
\end{tabular}

\subsection{Armaduras}

As barras das armaduras foram adquiridas no segundo semestre de 2011. Foram utilizadas barras de aço do tipo CA-50 com diâmetros de $6,3 \mathrm{~mm}, 8 \mathrm{~mm}, 10 \mathrm{~mm}$ e 12,5 mm e fios de aço CA-60 com diâmetro nominal de 5,0 mm. As barras e fios de aço foram adquiridos em empresa especializada de corte e dobra, situada na cidade de São Carlos, sendo que o projeto das armaduras encontra-se no anexo A.

Apesar das barras das armaduras terem sido adquiridas cortadas e dobradas, foi necessário proceder à dobra dos estribos da armadura de fretagem nos pilares, uma vez que os equipamentos da central de corte e dobra não foram capazes de atender as dimensões da 
armadura especificada em projeto. Além do corte dessa armadura, foi necessário proceder a montagem das mesmas, que ocorreu no Laboratório de Estruturas. Esse serviço foi realizado pelos funcionários do laboratório e pelo autor, entre os meses de fevereiro e abril de 2012 . Anteriormente ao início da montagem, procedeu-se a fixação dos extensômetros elétricos de resistência uniaxiais da marca Kyowa. A seguir são apresentadas figuras que ilustram as etapas de montagem.

Os primeiros elementos a serem montados foram às estacas, uma vez que as mesmas não possuíam extensômetros nas suas barras. Em seguida foram montadas as armaduras dos pilares e, por último, as armaduras dos blocos de fundação juntamente com as dos cálices.

Para as estacas foram utilizadas barras longitudinais com diâmetro igual a 10,0 mm e estribos transversais com diâmetro de 5,0 mm. As barras da armadura longitudinal das estacas foram prolongadas em $20 \mathrm{~cm}$ acima do topo, as quais ficaram inseridas no bloco de fundação durante a concretagem. As Figuras 4.3 (a) à 4.3 (c) apresentam a estaca após montagem e posicionada na forma antes da concretagem.

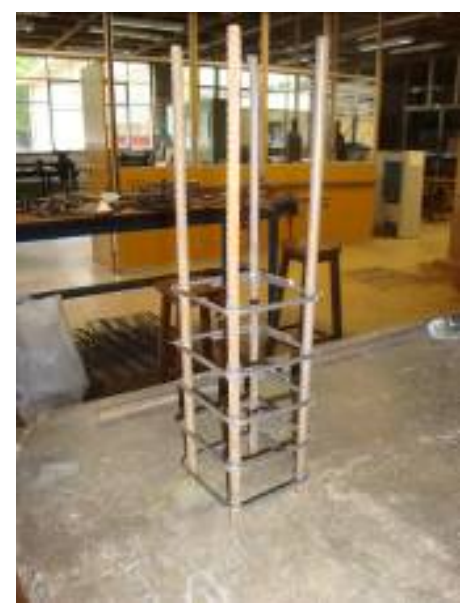

(a)

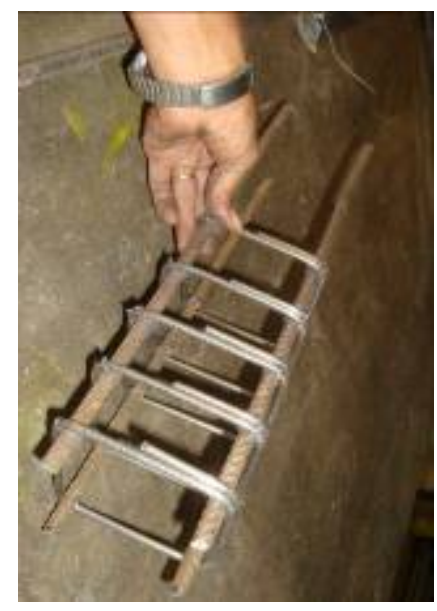

(b)

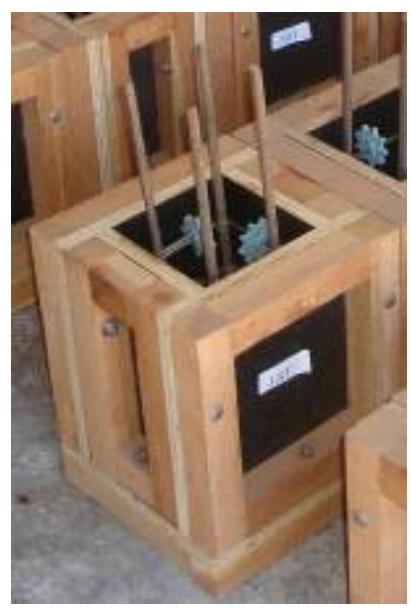

(c)

Figura 4. 3 - Armaduras das estacas após montagem

O detalhamento das armaduras dos pilares foi semelhante ao das estacas. Entretanto, as barras da armadura longitudinal apresentavam diâmetro de $12,5 \mathrm{~mm}$, e não possuíam prolongamento, tendo em vista que os pilares foram concretados de modo independente, sendo posicionados nos blocos após a concretagem dos mesmos, tal qual ocorre na montagem de estruturas pré-moldadas. Além dos estribos com diâmetro de 5,0 mm, foi posicionada uma armadura de fretagem na parte superior do pilar. As Figuras 4.4 (a) à 4.4 (c) apresentam a etapa de projeto, e as armaduras dos pilares após montagem. 


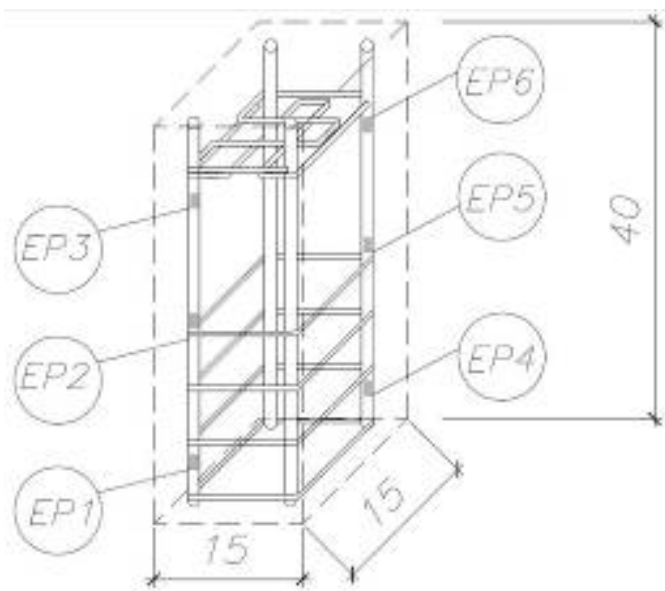

(a)

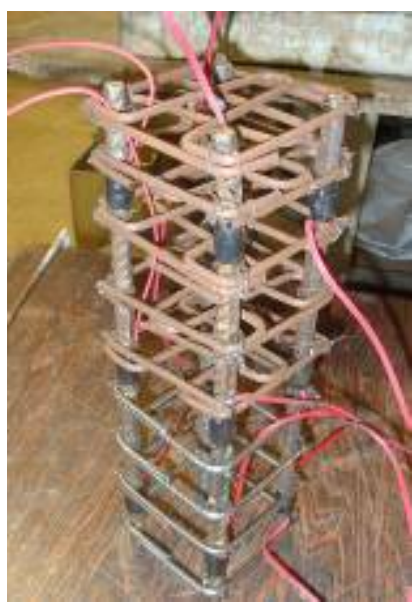

(b)

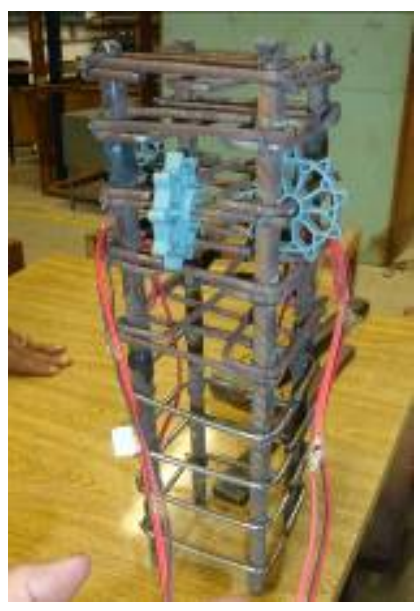

(c)

Figura 4. 4 - Armaduras dos pilares após montagem

As Figuras 4.5 (a) e 4.5 (b), por suas vezes, apresentam o detalhe da armadura de fretagem posicionada na parte superior dos pilares, e a colocação da armadura do pilar na fôrma antes da concretagem. Destaca-se que os fios dos extensômetros não podiam passar pela abertura superior das formas em virtude dessa superfície receber a força oriunda do atuador hidráulico, o que poderia danificar os fios dos extensômetros. Assim, foi necessário realizar um furo na lateral das fôrmas, o qual serviu para passagem dos fios, sendo preenchido com massa plástica antes da concretagem.

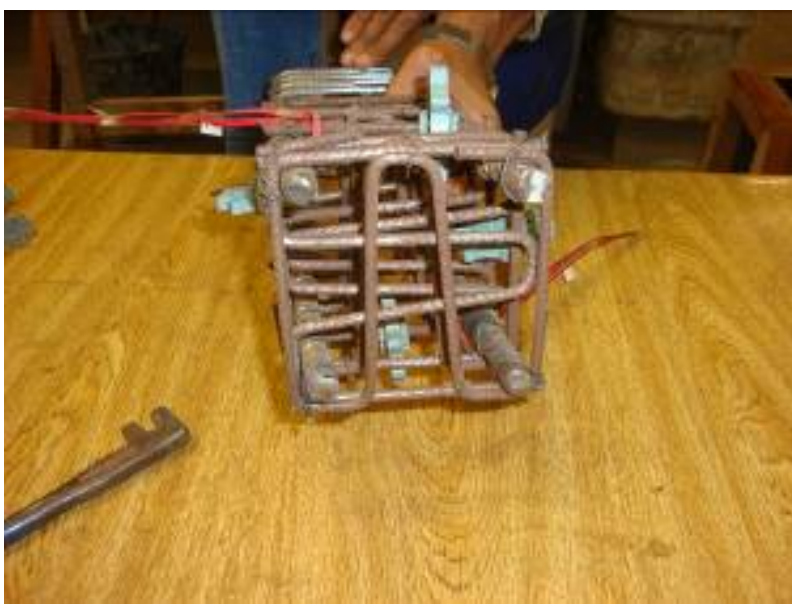

(a)

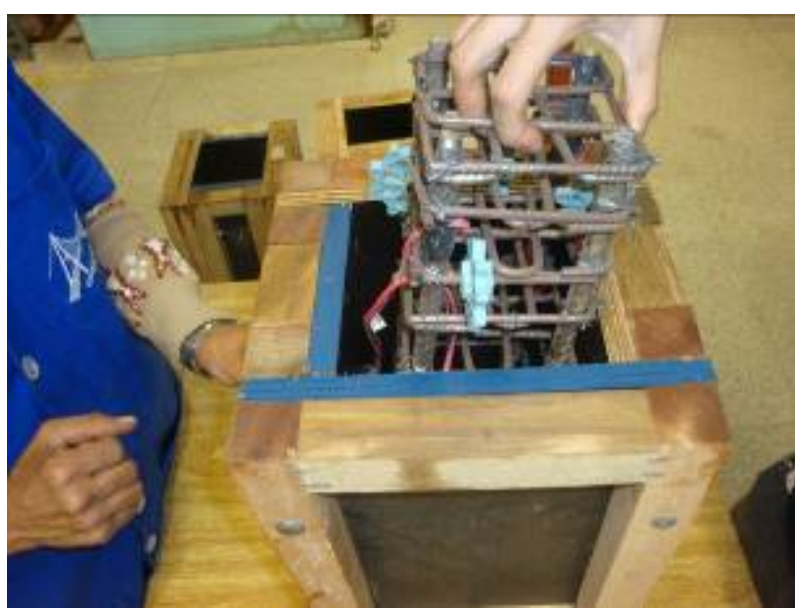

(b)

Figura 4. 5 - Detalhe da armadura de fretagem e colocação do pilar

Após a montagem das armaduras das estacas e dos pilares, procedeu-se a montagem das armaduras dos blocos de fundação em conjunto com a armadura do cálice. Para todos os blocos a montagem foi feita na mesma seqüência: posicionou-se a armadura principal, 
mantendo-se o afastamento mínimo entre barras, seguido do posicionamento e amarração da armadura transversal. Em seguida o bloco era posicionado invertendo-se sua posição, e amarrava-se as barras da armadura superior. Após esta amarração, colocava-se as barras da armadura lateral, concluindo a "gaiola" do bloco. Por último, eram posicionadas as barras das armaduras verticais do cálice, as quais ficavam amarradas na armadura inferior e lateral do bloco, seguido da armadura horizontal do cálice. As Figuras 4.6 (a), 4.6 (b), 4.7(a) e 4.7 (b) ilustram algumas das etapas de montagem das armaduras dos blocos e cálices.

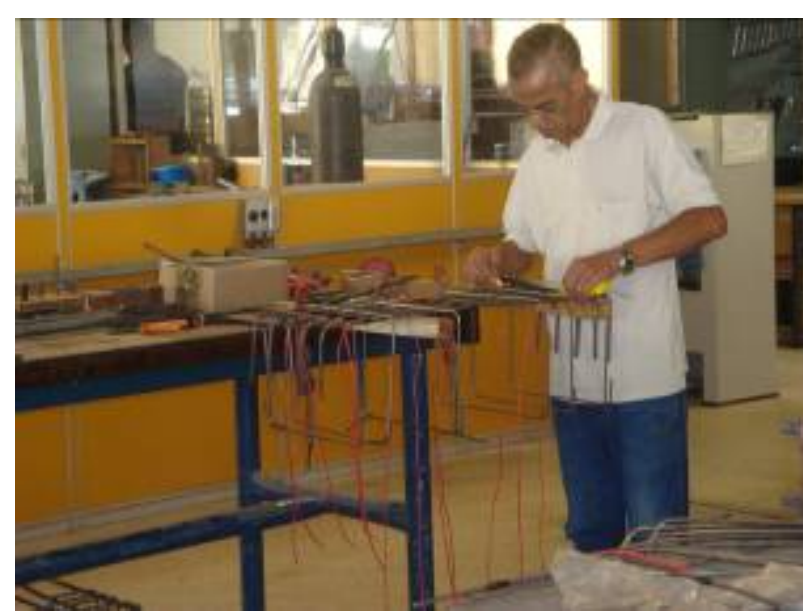

(a)

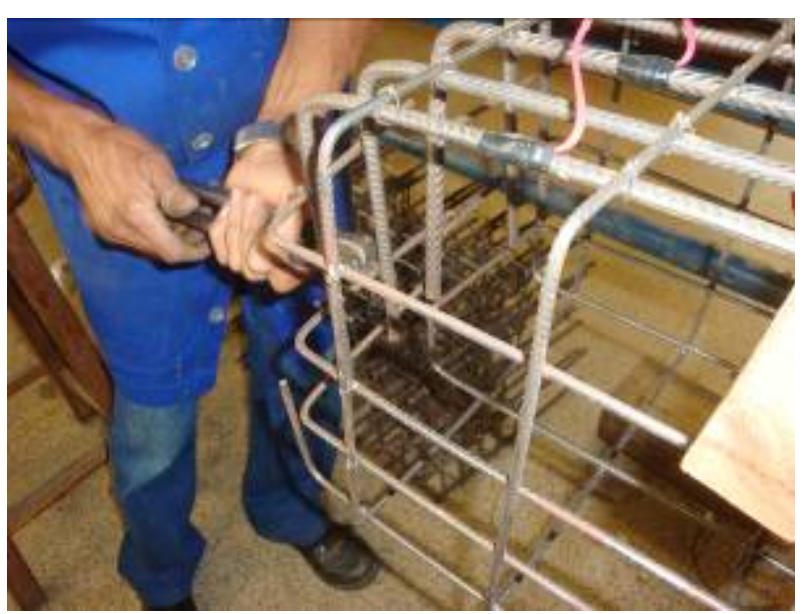

(b)

Figura 4. 6 - Montagem das armaduras dos blocos

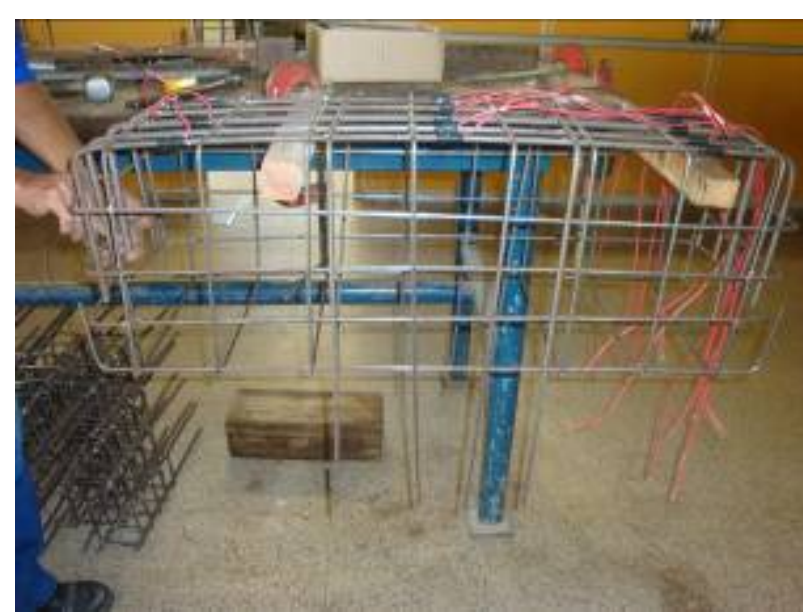

(a)

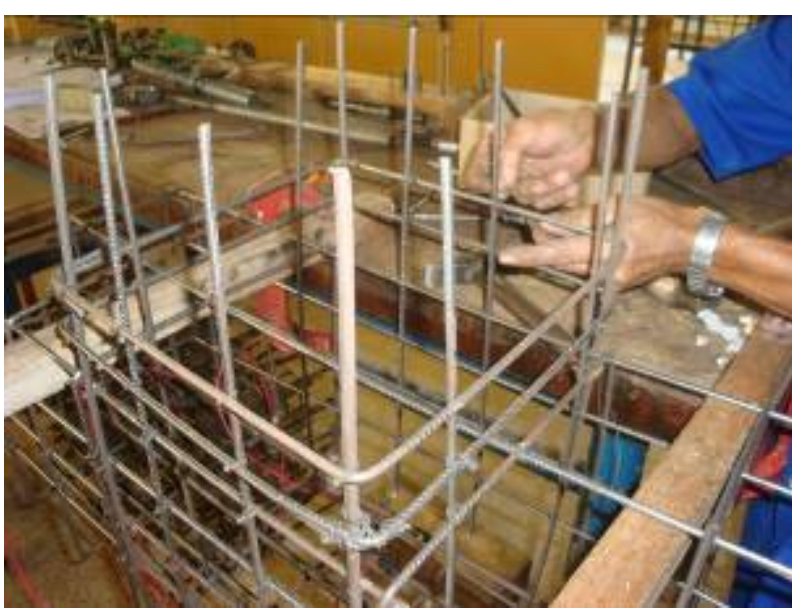

(b)

Figura 4. 7 - Montagem das armaduras dos blocos e cálices

A seguir são apresentadas uma vista frontal e uma perspectiva das armaduras dos blocos de referência, blocos com cálice externo, blocos com cálice parcialmente embutido e blocos com cálice embutido após concluída a etapa de montagem. 


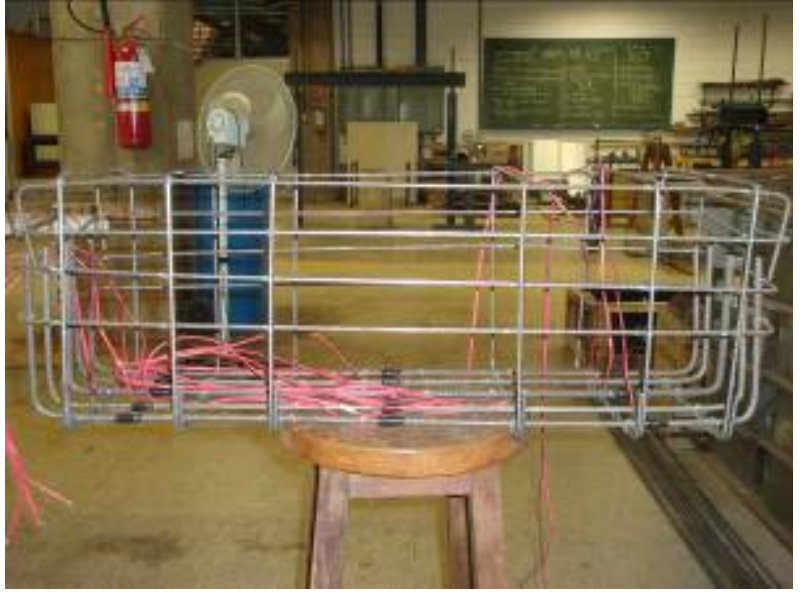

(a)

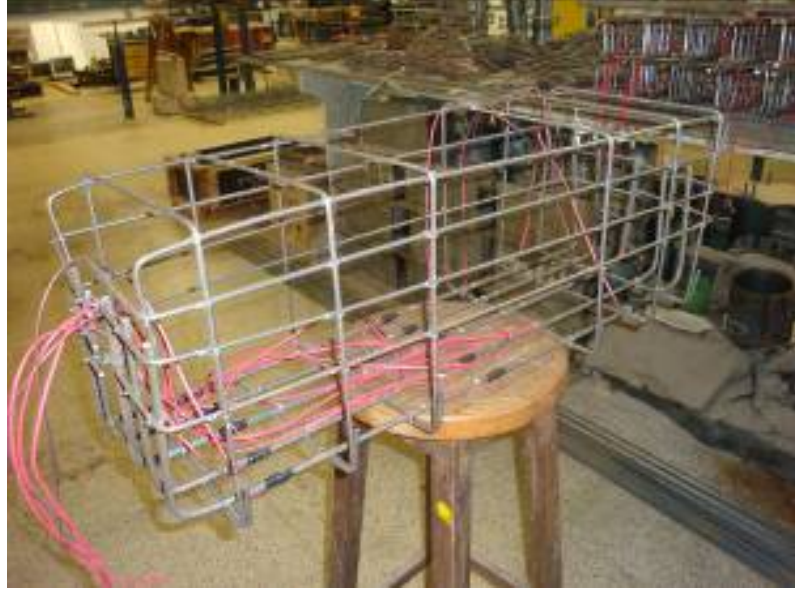

(b)

Figura 4. 8 - Armaduras dos blocos de referência

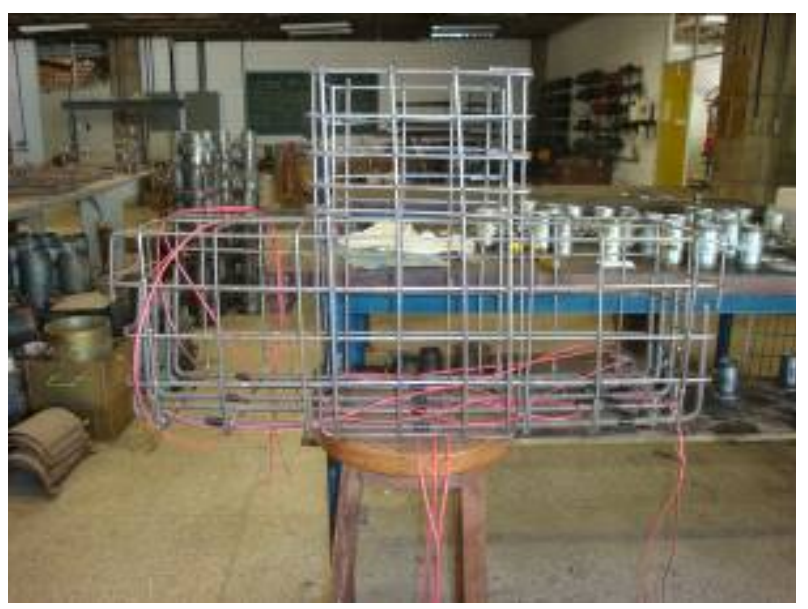

(a)

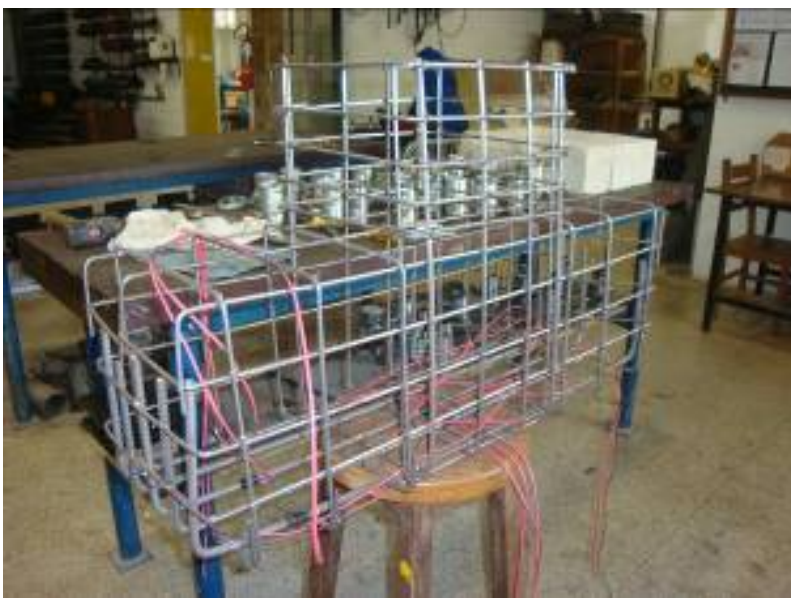

(b)

Figura 4. 9 - Armaduras dos blocos com cálice externo

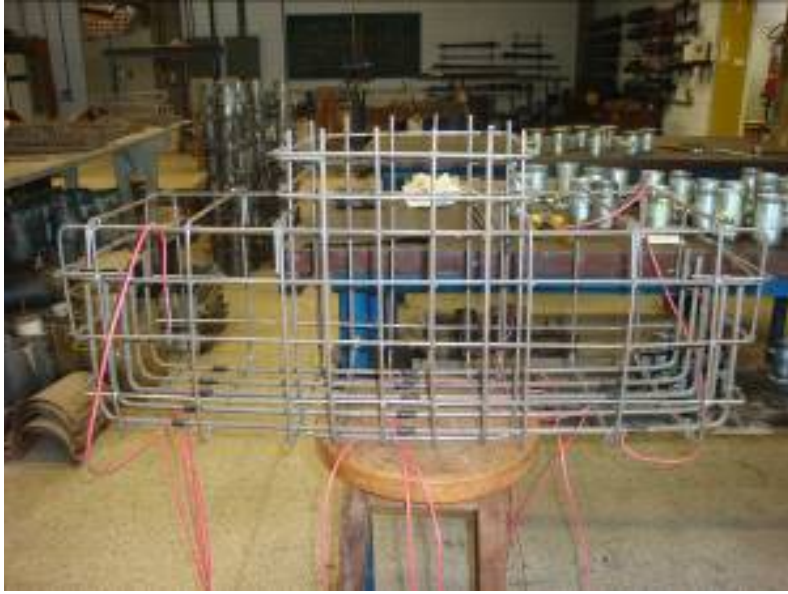

(a)

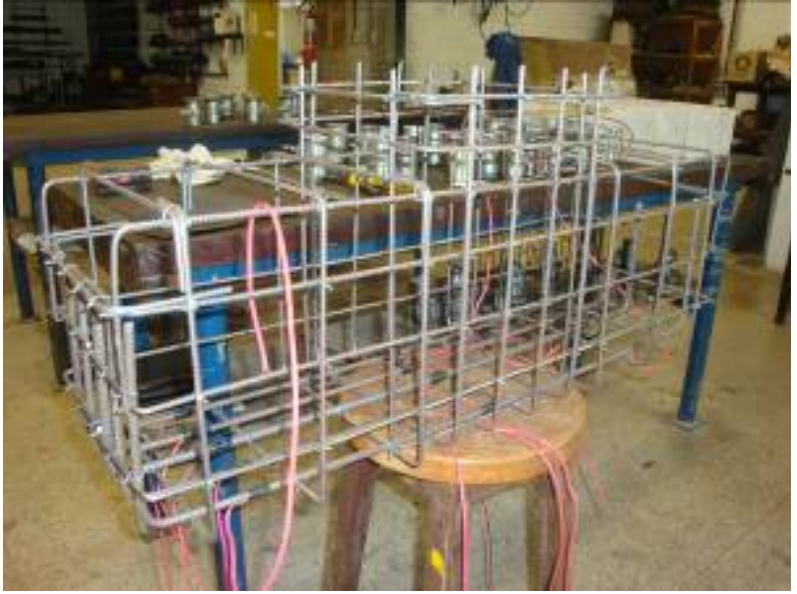

(b)

Figura 4. 10 - Armaduras dos blocos com cálice parcialmente embutido 


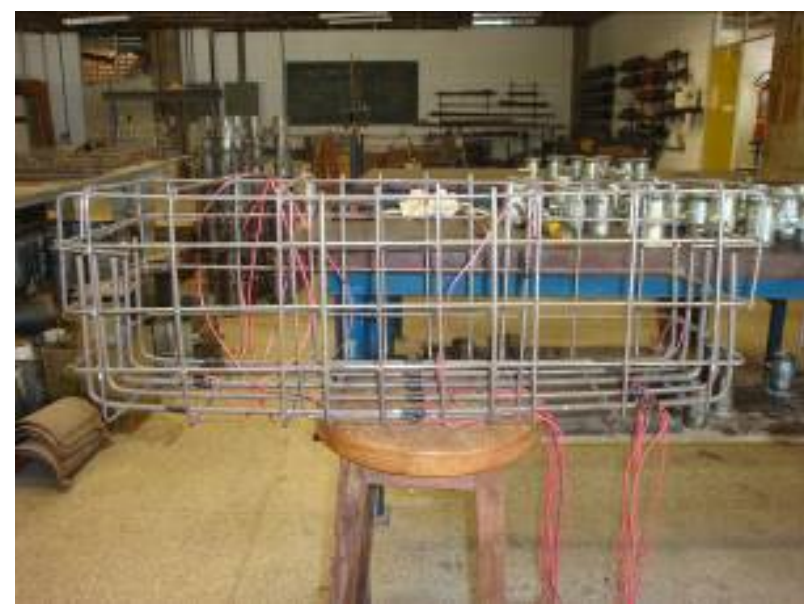

(a)

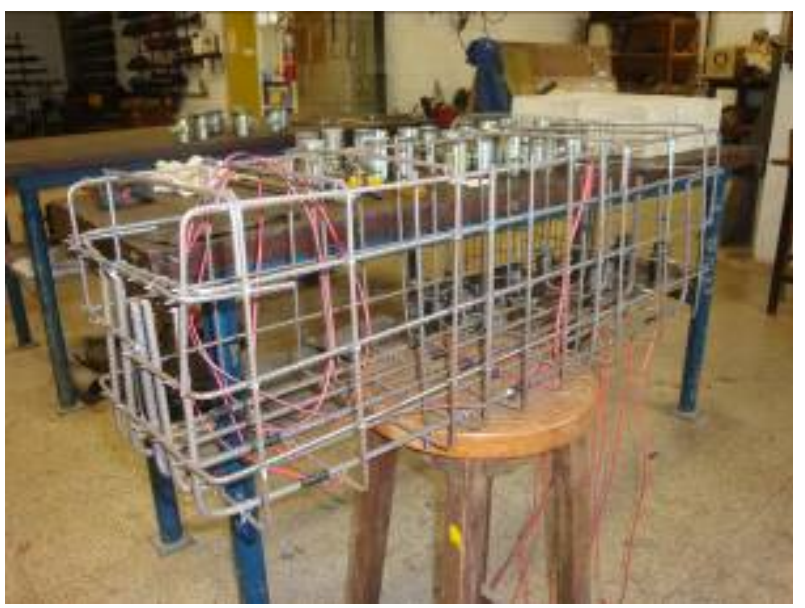

(b)

Figura 4. 11 - Armaduras dos blocos com cálice embutido

\subsection{Concretagem dos elementos estruturais}

Após a conclusão da montagem das barras das armaduras, teve início a etapa de concretagem dos elementos estruturais que compõe o bloco de fundação. Inicialmente foram moldadas as estacas. Posteriormente foram concretados os blocos e cálices e, por último, os pilares. A seqüência de concretagem ocorreu nessa ordem com o intuito de otimizar o tempo total despendido nessa etapa. A concretagem teve início com as estacas, pois as mesmas precisavam estar posicionadas na fôrma antes da concretagem dos blocos. A etapa de concretagem teve início no mês de abril de 2012 e foi concluída em junho de 2012.

$\mathrm{Na}$ etapa de projeto, o concreto utilizado para as estacas e pilares apresentava resistência à compressão superior à resistência dos blocos. Para pilares e estacas utilizou-se concreto da classe C50 e para os blocos e cálices utilizou-se concreto da classe C25. A diferença na resistência dos elementos teve por objetivo evitar que a ruína ocorresse nas estacas e nos pilares. O concreto da classe C50 foi feito no Laboratório de Estruturas enquanto que o concreto da classe C25 foi adquirido de empresa fornecedora de concreto usinado.

Para a concretagem das estacas, utilizou-se inicialmente um traço indicado em DELALIBERA (2006) o qual foi obtido por meio de estudos de dosagem desenvolvido pelo pesquisador. $O$ traço adotado inicialmente foi 1:2,66:3,66:0,49:0,01 (cimento, areia, pedra britada, água e aditivo superplastificante). Repetiu-se a dosagem utilizada por DELALIBERA 
(2006) com o intuito de verificar se o traço forneceria os mesmos resultados para os materiais disponíveis no Departamento de Estruturas.

Foram moldados 8 corpos-de-prova, sendo que essa concretagem inicial foi desenvolvida no LCC - Laboratório de Construção Civil - IAU - USP. A dosagem se deu no LCC em virtude do pequeno volume necessário para preencher os 8 corpos-de-prova (15 litros). O Laboratório de Estruturas dispõe de betoneiras horizontais e de eixo inclinado, porém a mistura dos materiais não ocorre perfeitamente quando se utilizam pequenas quantidades de material. Assim, foi utilizada uma betoneira de menor capacidade (50 litros), a qual se encontrava disponível no LCC - IAU - USP.

Os resultados dos ensaios nos corpos-de-prova obtidos aos 7 e 14 dias indicaram um concreto com resistência à compressão igual a $28 \mathrm{MPa}$ e $31 \mathrm{MPa}$, respectivamente, valores esses inferiores ao esperado. Analisando o traço sugerido por DELALIBERA (2006), observa-se um valor elevado para a relação água cimento. A ABNT NBR 6118:2003 indica que, para concretos com resistência superior a $40 \mathrm{MPa}$, deve ser utilizado uma relação a/c inferior a 0,45 . Por esse motivo, foi necessário proceder a um novo estudo de traço, a fim de se obter uma nova dosagem para o concreto da classe C50.

O novo traço utilizado para os concretos da classe C50 foi estabelecido de acordo com AITCIN (2000). A dosagem utilizada para as estacas e pilares foi de 1:2,36:2,54:0,33:0,03, estando o consumo de materiais e os detalhes da dosagem apresentados no anexo B.

Nas dosagens feitas no Departamento de Engenharia de Estruturas, utilizou-se cimento CPV-ARI (Cimento de alta resistência inicial) da marca Cauê. A massa específica fornecida pelo fabricante varia de $3,10 \mathrm{~g} / \mathrm{cm}^{3}$ a $3,15 \mathrm{~g} / \mathrm{cm}^{3}$. Quando da dosagem do concreto para os pilares, não encontrou-se no mercado o cimento da marca Cauê utilizado para as estacas. Por esse motivo, foi utilizado o cimento CPV-ARI da marca Holcim, com propriedades semelhantes aos da primeira marca. O agregado miúdo utilizado foi areia quartzoza disponível na região de São Carlos. O agregado graúdo foi pedra britada de origem basáltica com diâmetro máximo de $19 \mathrm{~mm}$. A água utilizada nas dosagens foi a fornecida pela rede pública de distribuição de água da cidade de São Carlos, e o aditivo superplastificante utilizado foi o Glenium 51, aditivo a base de uma cadeia de éter carboxílico modificado, isento de cloretos. As Figura 4.12 e 4.13 apresentam alguns dos materiais utilizados na dosagem. 


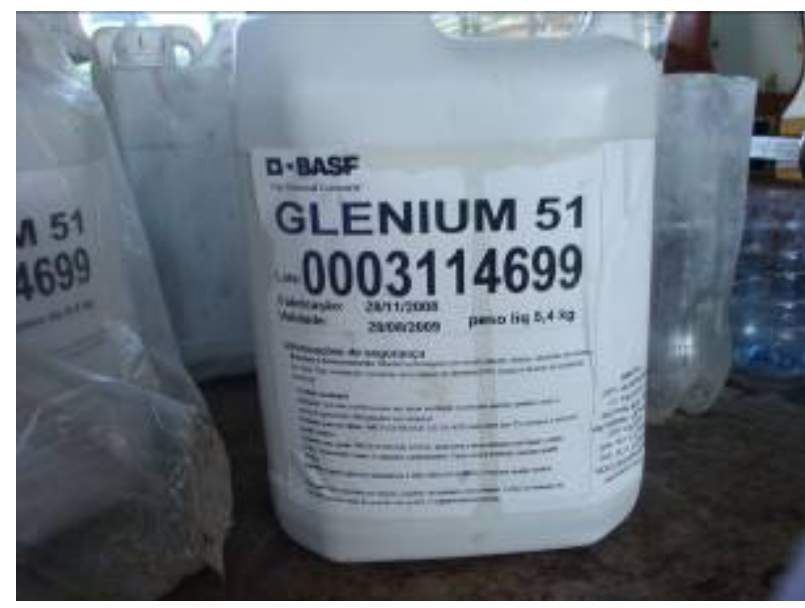

(a)

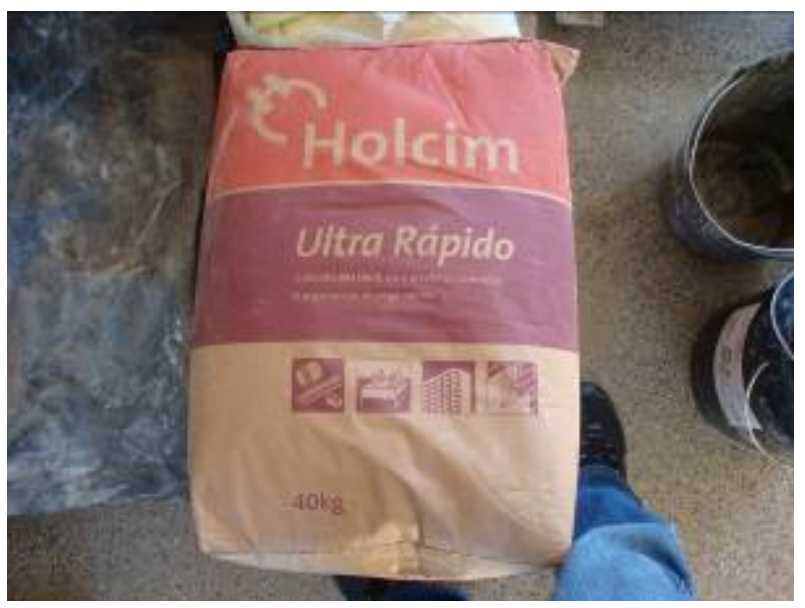

(b)

Figura 4. 12 - Glenium e Cimento CPV-ARI utilizados na concretagem

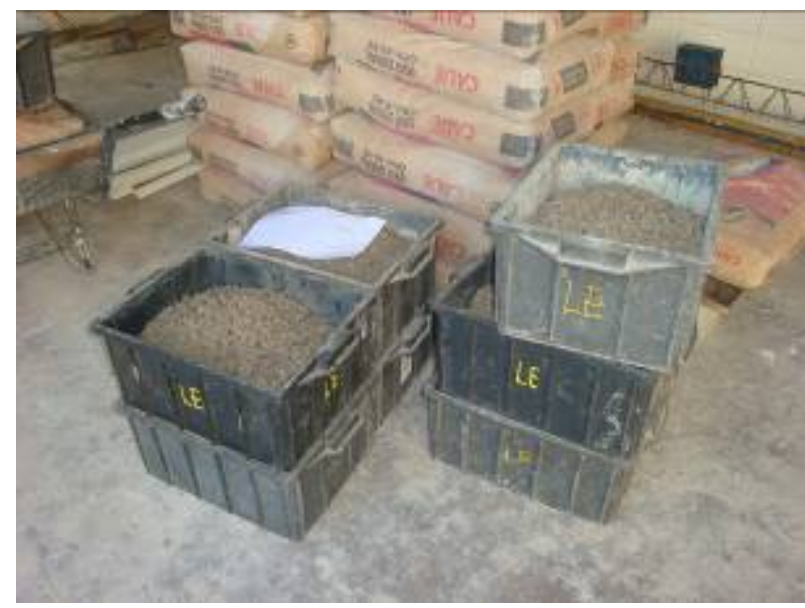

(a)

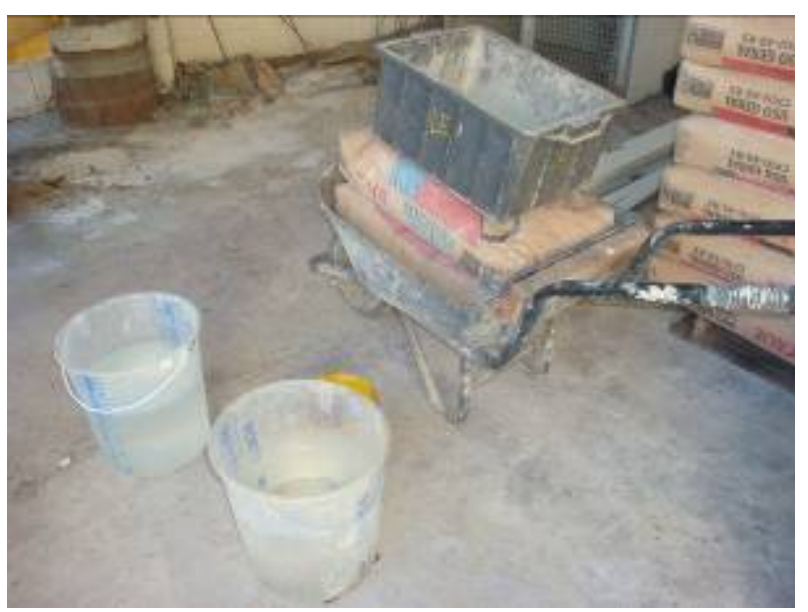

(b)

Figura 4. 13 - Materiais utilizados no concreto das estacas

A concretagem das estacas e dos corpos-de-prova demandou um volume de 210 litros de concreto. Para produção desse concreto, utilizou-se uma betoneira horizontal com capacidade para 300 litros. A concretagem das 28 estacas e dos 12 corpos-de-provas ocorreu em etapa única, estando as fôrmas posicionadas em quatro linhas com 7 estacas cada uma, disposta de modo a permitir a entrada do carro de mão com o concreto entre as linhas de estacas, facilitando a moldagem das mesmas. As estacas foram posicionadas em fôrmas untadas com óleo para facilitar a desmoldagem, utilizando espaçadores plásticos visando garantir um cobrimento mínimo de $2,50 \mathrm{~cm}$. Para a concretagem desses elementos participaram o autor e mais um funcionário do Laboratório de Estruturas. As Figuras 4.14 e 4.15 apresentam imagens da etapa de concretagem das estacas. Após a concretagem as estacas permaneceram guardadas até a desforma, que teve inicio com 7 dias. 


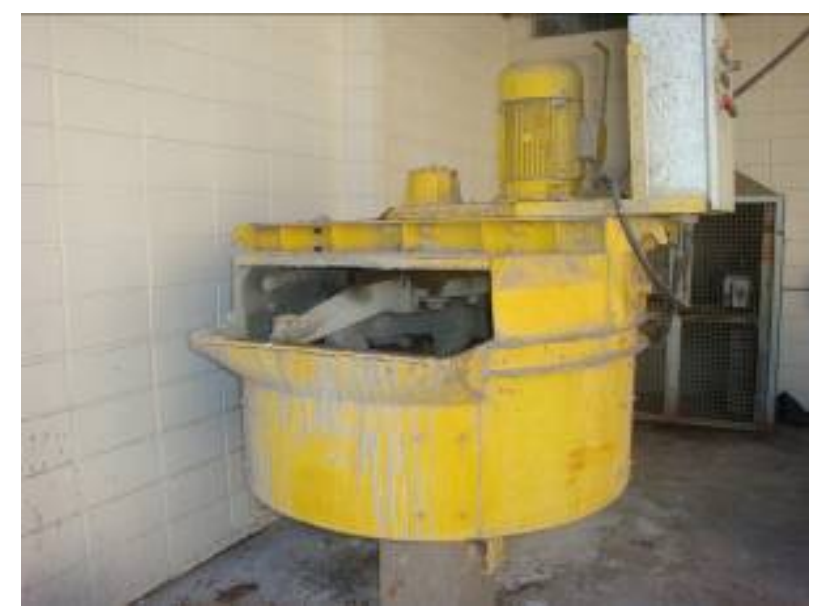

(a)

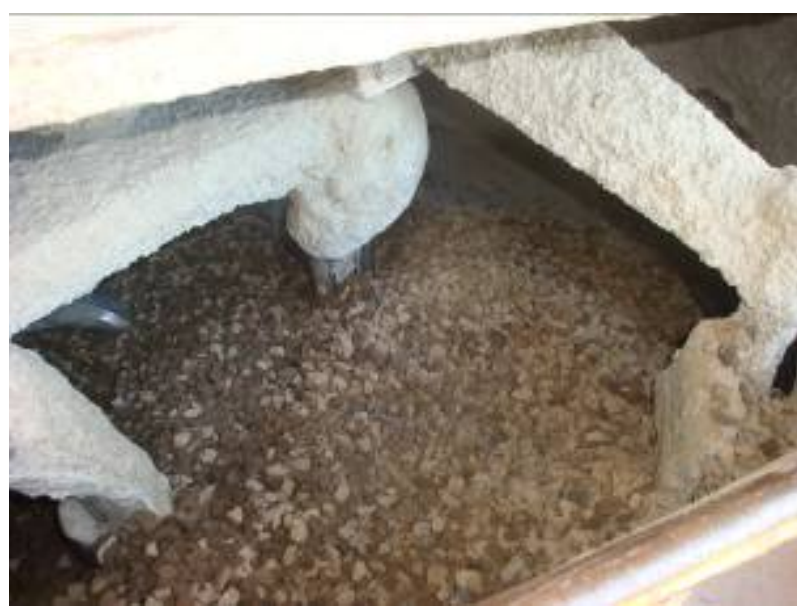

(b)

Figura 4. 14 - Betoneira Horizontal utilizada para o concreto das estacas

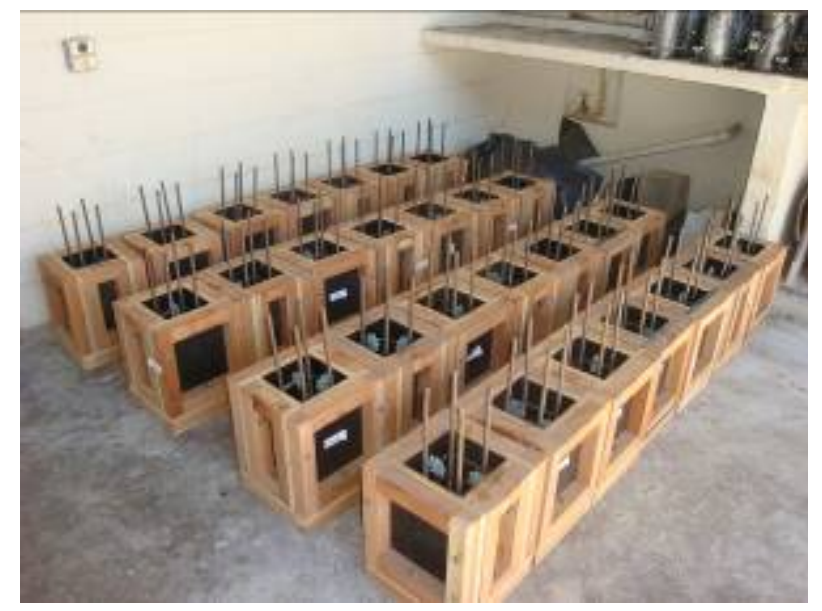

(a)

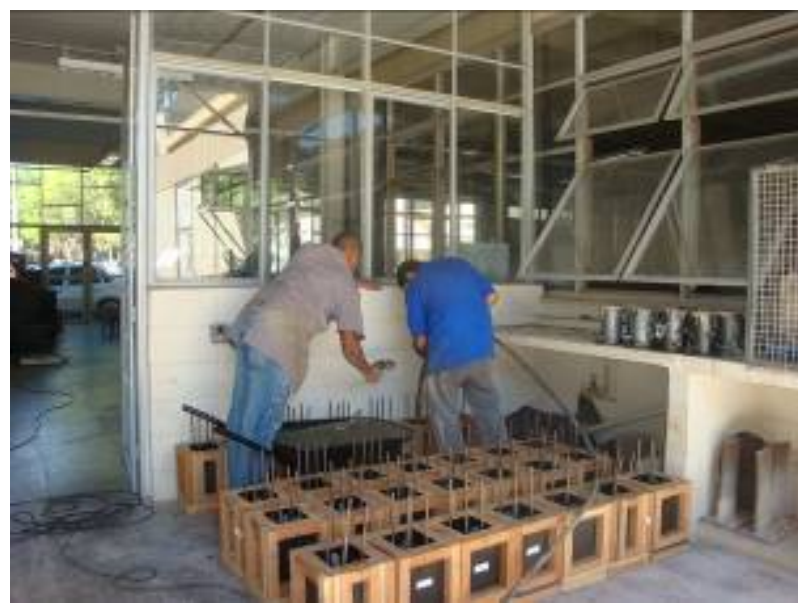

(b)

Figura 4. 15 - Disposição das estacas durante a etapa de concretagem.

Após a concretagem das estacas, deu-se início a preparação da etapa de concretagem dos blocos de fundação e dos cálices. As fôrmas dos blocos foram posicionadas no espaço pertencente à ampliação do Laboratório de Estruturas, ocupando uma área de aproximadamente $30 \mathrm{~m}^{2}$.

O concreto utilizado para os blocos foi da classe C25. Em função do volume de concreto necessário para concretagem dos blocos e cálices, utilizou-se concreto usinado obtido de uma central dosadora da cidade de São Carlos. Foram utilizados aproximadamente 2,10 $\mathrm{m}^{3}$ de concreto para preencher o volume dos 14 blocos, 8 cálices e 16 corpos-de-prova.

As fôrmas dos blocos ficaram apoiadas em tijolos cerâmicos nas suas extremidades. Além disso, essas fôrmas apresentavam duas aberturas na região inferior, servindo para 
posicionamento das estacas concretadas anteriormente, as quais ficaram embutidas em aproximadamente $2,50 \mathrm{~cm}$ dentro do bloco.

O posicionamento das estacas antes da concretagem dos blocos foi necessário para proporcionar a ligação da estaca com o bloco. Em virtude da folga existente entre as aberturas e as estacas, foi necessário vedar essas aberturas utilizando isopor e massa plástica, de modo a impedir que o concreto em estado fresco escorresse por essa região. Antes do posicionamento das armaduras, foi necessário aplicar desmoldante nas fôrmas, utilizando-se para tanto óleo oriundo da manutenção das máquinas do Laboratório de Estruturas. As Figuras 4.16 a 4.18 apresentam os detalhes do posicionamento das fôrmas dos blocos, e da ligação das estacas com os mesmos.

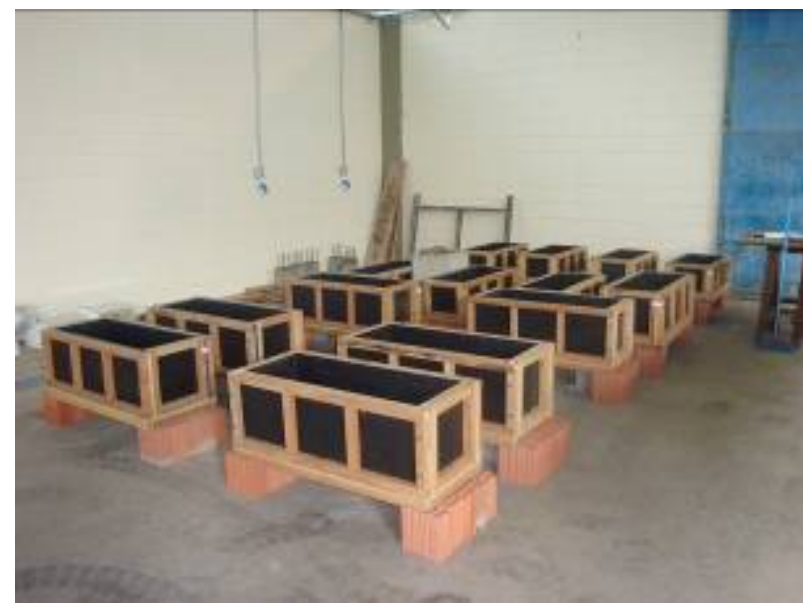

(a)

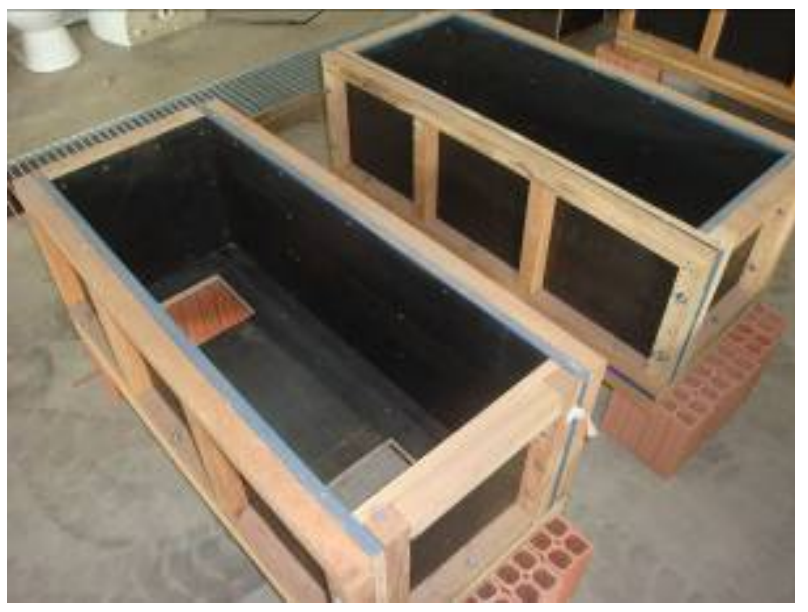

(b)

Figura 4. 16 - Posicionamento das fôrmas dos blocos sobre tijolo cerâmico

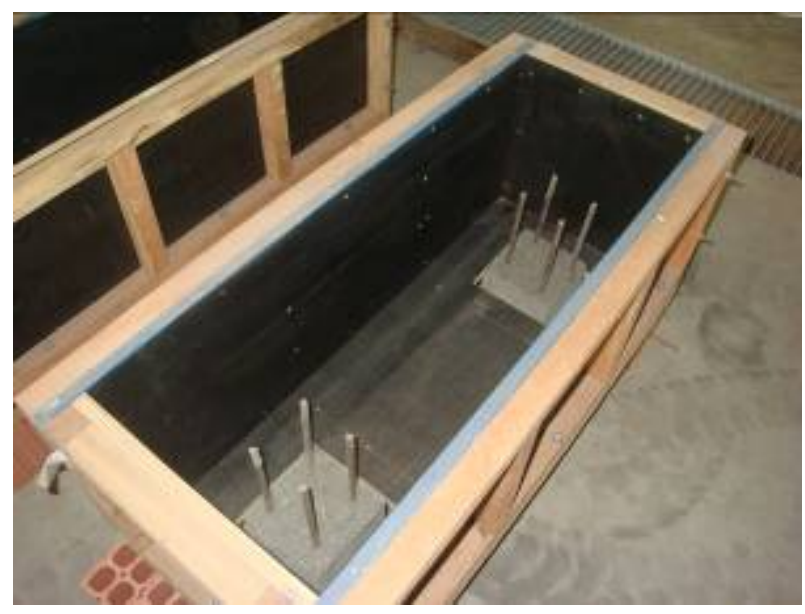

(a)

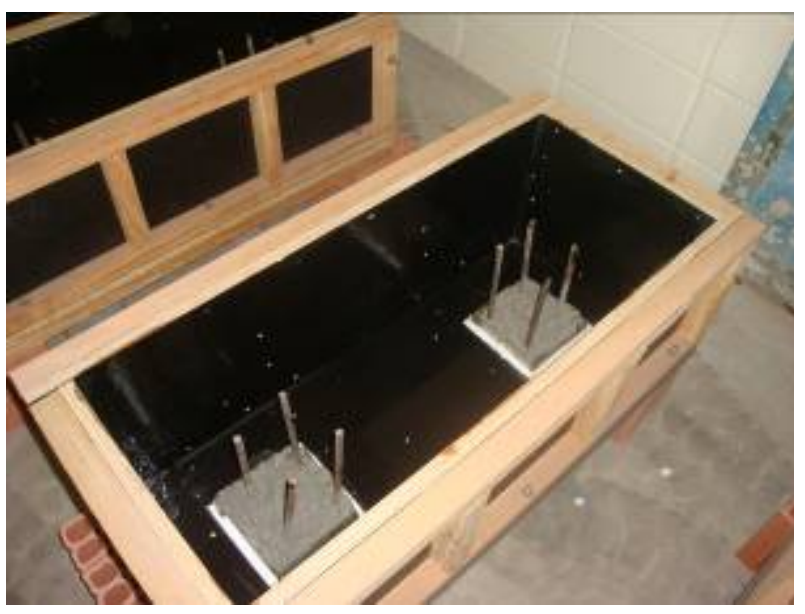

(b)

Figura 4. 17 - Posicionamento das estacas antes da concretagem dos blocos antes e após aplicação do desmoldante 


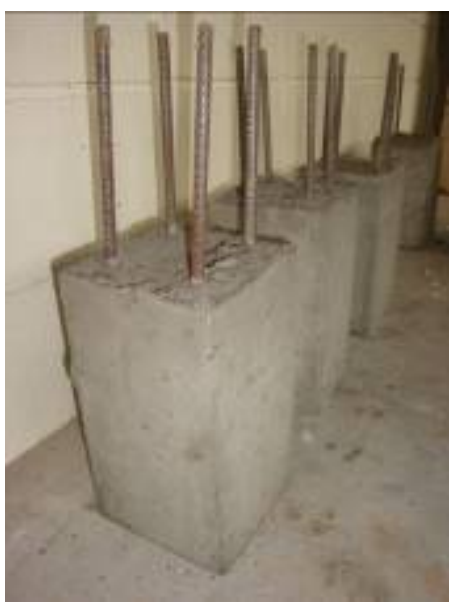

(a)

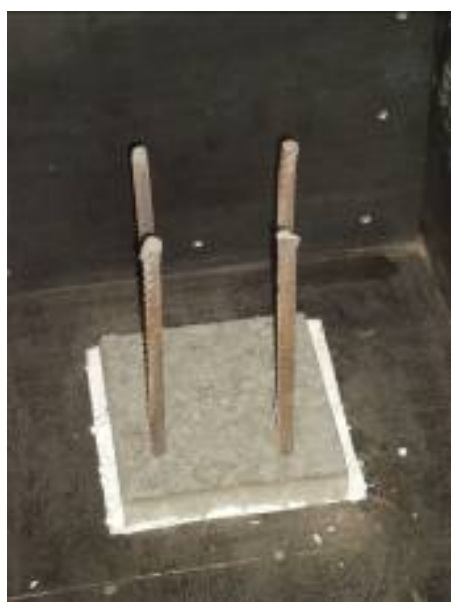

(b)

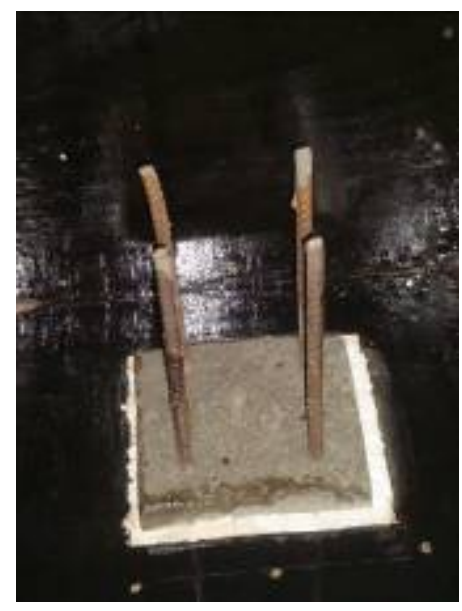

(c)

Figura 4. 18 - Detalhe das estacas e da ligação com o bloco de fundação

Após a preparação das fôrmas dos blocos e aplicação do desmoldante, foi necessário posicionar as barras das armaduras dos blocos e dos cálices dentro das formas. Nos blocos com cálice, foi preciso retirar as fôrmas dos caixotes externos e internos, reposicionando-os após a colocação das barras das armaduras. O posicionamento das armaduras seguiu um determinado padrão em relação à disposição dos extensômetros elétricos fixados nas barras das armaduras, de modo que a região que possuía as cinco barras da armadura longitudinal instrumentadas permanecessem sempre do lado esquerdo do bloco. Maiores detalhes dessa instrumentação são apresentados em item específico.

No posicionamento das barras das armaduras nas fôrmas dos blocos foram utilizados espaçadores plásticos, de modo a garantir um cobrimento mínimo de 2,50 $\mathrm{cm}$ para as armaduras. As pontas dos fios dos extensômetros foram envolvidas com plásticos, evitando que os fios fossem danificados pelo concreto em estado fresco. As Figuras 4.19 a 4.21 apresentam detalhes desse posicionamento das armaduras e as fôrmas dos blocos com cálice externo, parcialmente embutido, embutido e bloco de referência. Observa-se que no bloco de referência foi preciso posicionar a armadura do pilar antes da concretagem do bloco, uma vez que nesse tipo de bloco a ligação pilar fundação é monolítica. Na ligação das estacas com o bloco, posicionaram-se as barras das armaduras das estacas entre as barras centrais das armaduras dos blocos, conforme pode ser visto na Figura 4.22. 


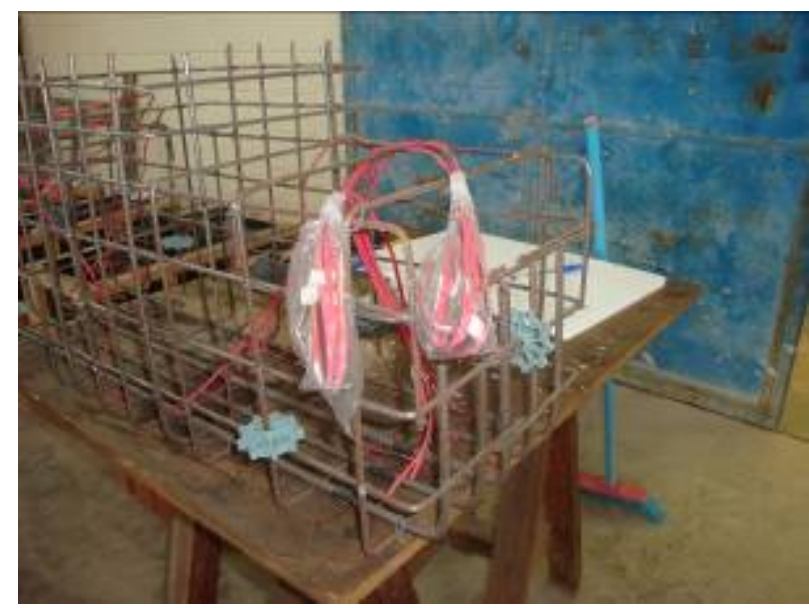

(a)

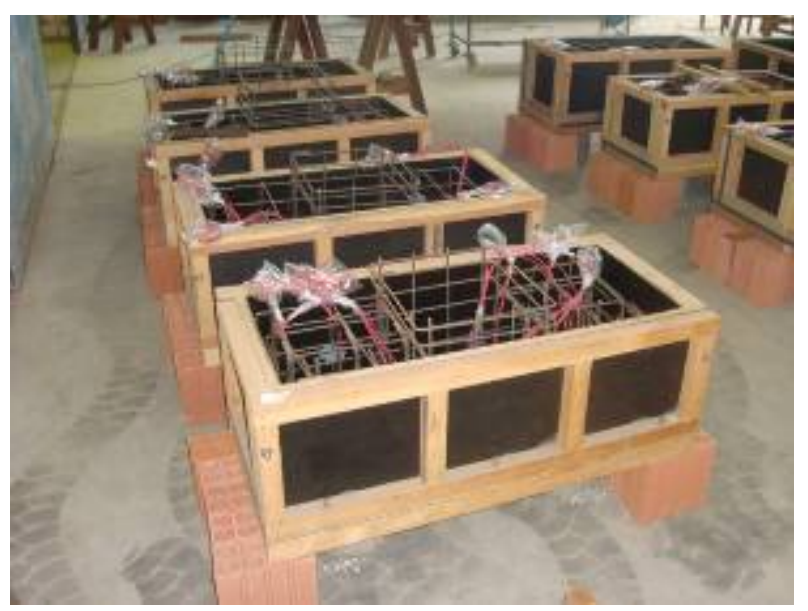

(b)

Figura 4. 19 - Detalhe dos espaçadores plásticos e posicionamento das armaduras dos blocos sem os caixotes externos e internos

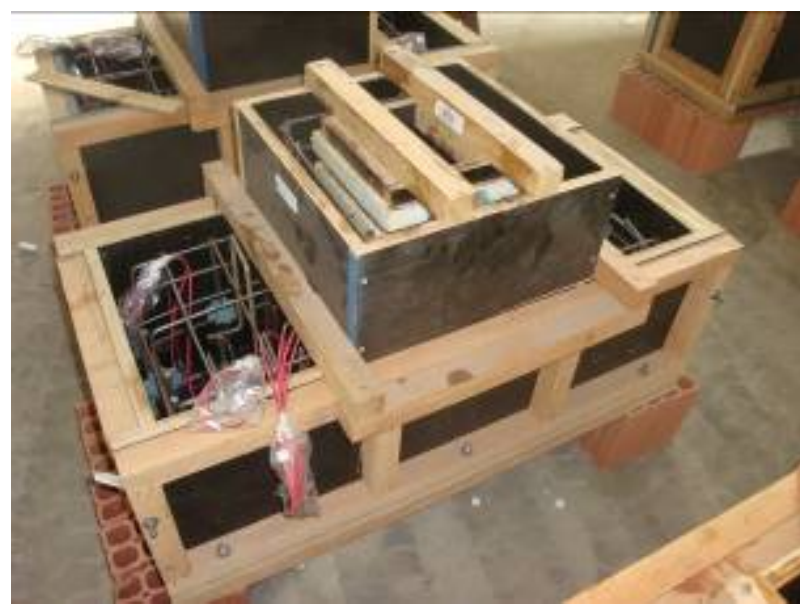

(a)

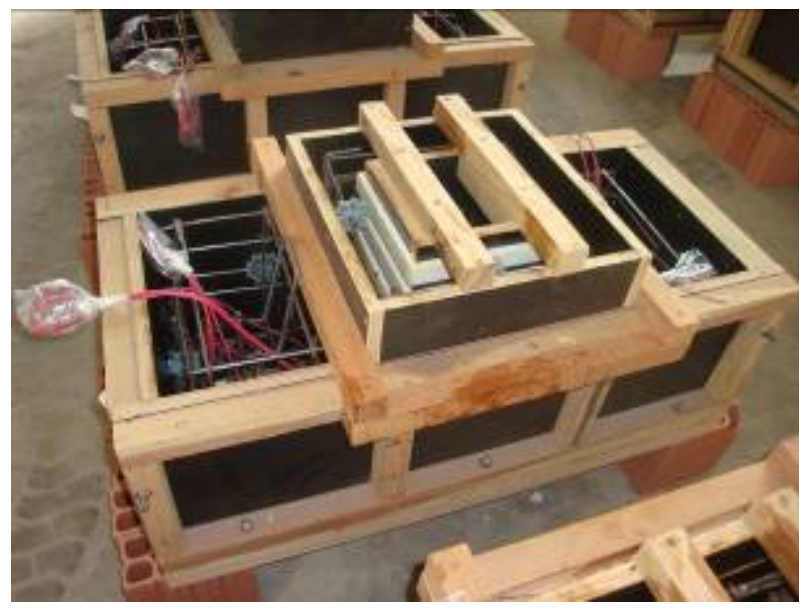

(b)

Figura 4. 20 - Fôrma dos blocos com cálice externo e parcialmente embutido

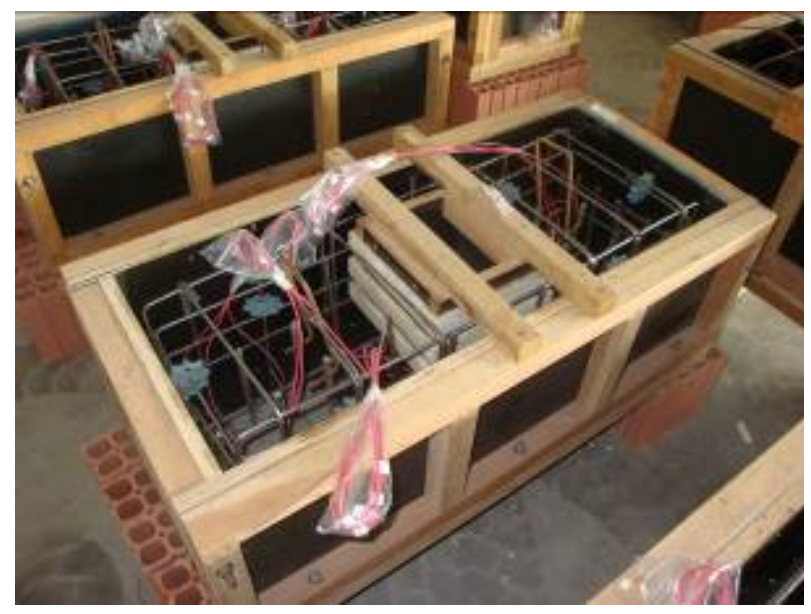

(a)

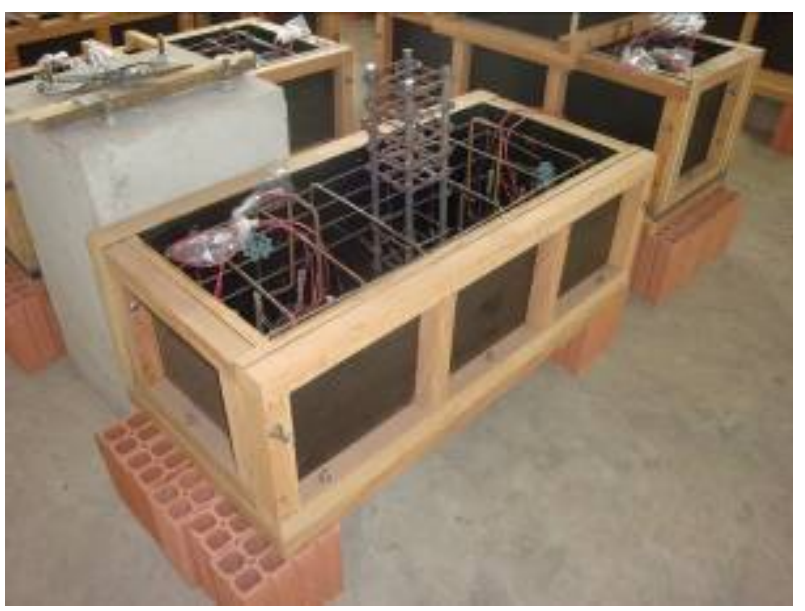

(b)

Figura 4. 21 - Fôrma dos blocos com cálice embutido e do bloco de referência 


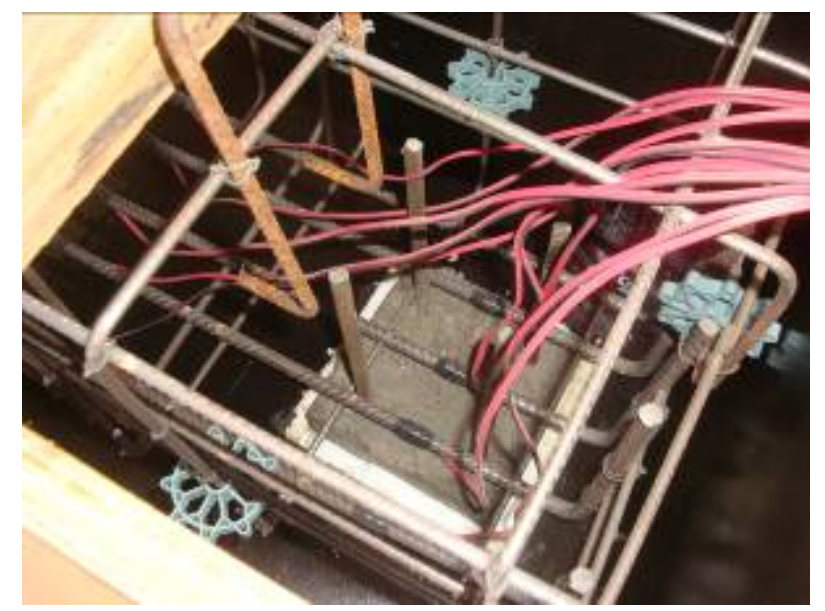

(a)

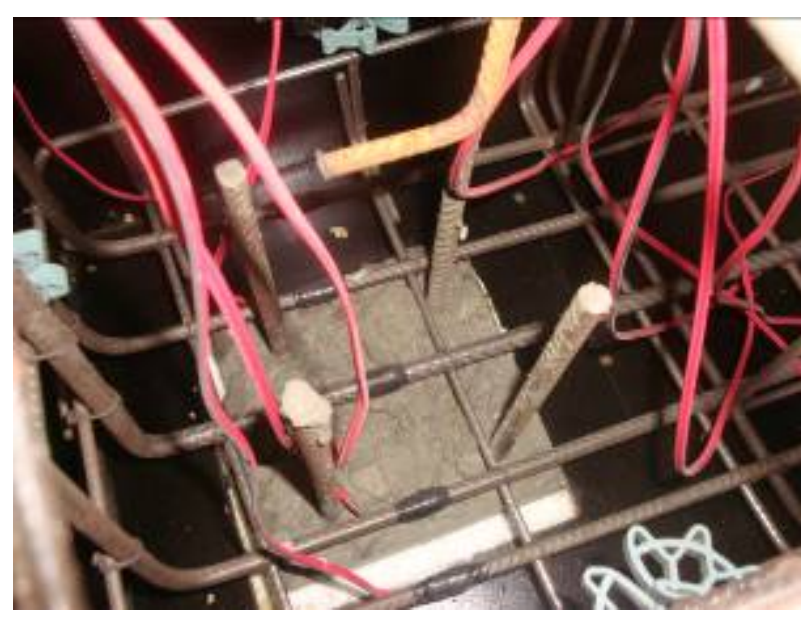

(b)

Figura 4. 22 - Detalhe da ligação das armaduras da estaca com o bloco

A concretagem dos blocos ocorreu em etapa única no início do mês de junho de 2012. O concreto da classe C25 foi adquirido da empresa Concreband, localizada na zona industrial da cidade de São Carlos. Para a concretagem dos blocos participaram o autor e mais quatro funcionários do Laboratório de Estruturas. Antes do início da concretagem verificou-se o valor do Slump do concreto, cujo valor foi de 9,3 cm, conforme apresentado na Figura 4.23. Durante a concretagem utilizou-se um vibrador mecânico cujo diâmetro da agulha foi de 20 $\mathrm{mm}$, e o tempo total decorrido na concretagem foi de aproximadamente 90 minutos As Figuras 4.24 a 4.28 apresentam algumas imagens da etapa de concretagem dos blocos.

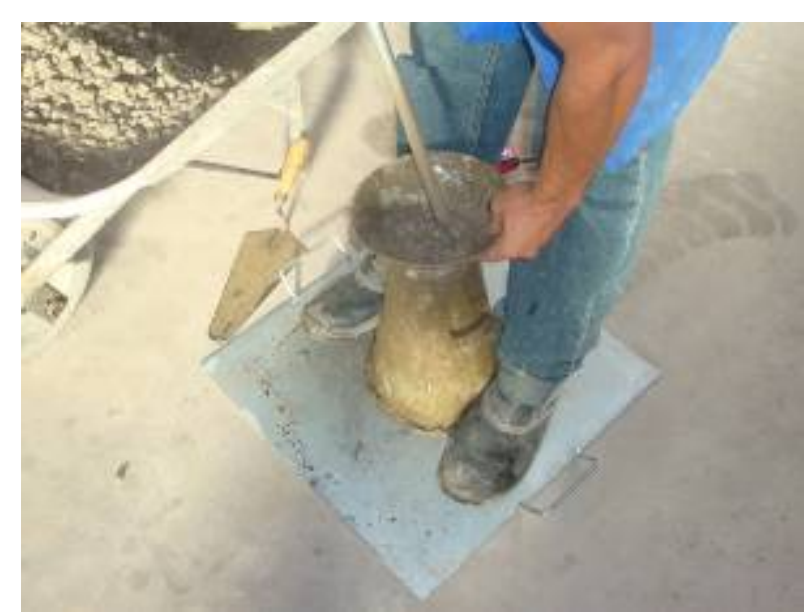

(a)

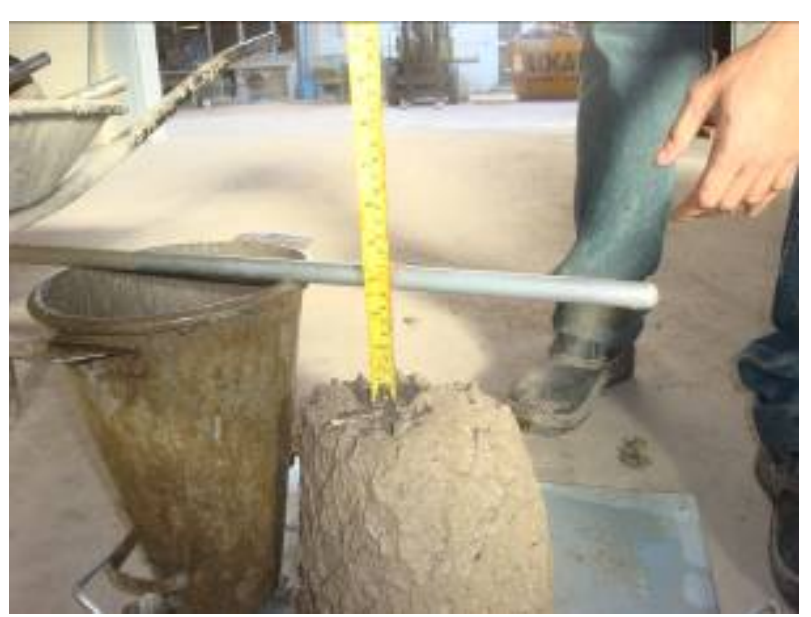

(b)

Figura 4. 23 - Realização do Slump test antes do início da concretagem 


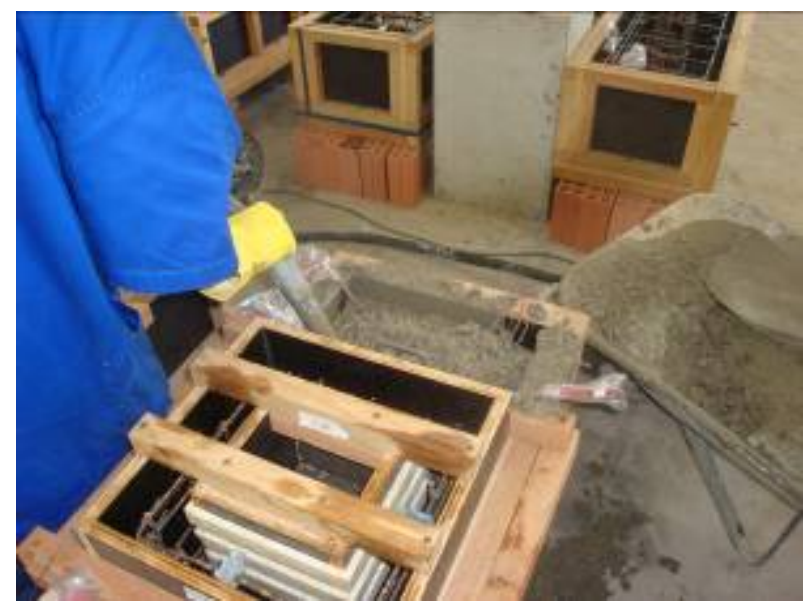

(a)

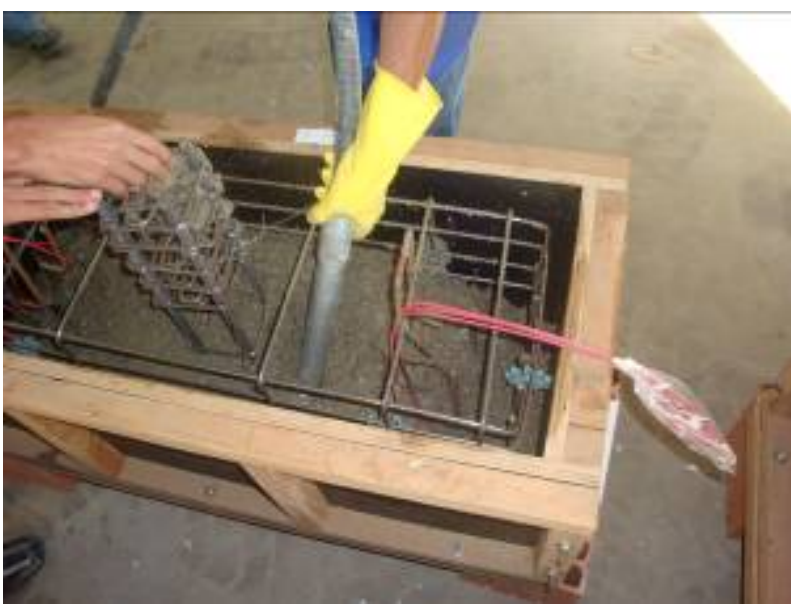

(b)

Figura 4. 24 - Concretagem dos blocos de fundação

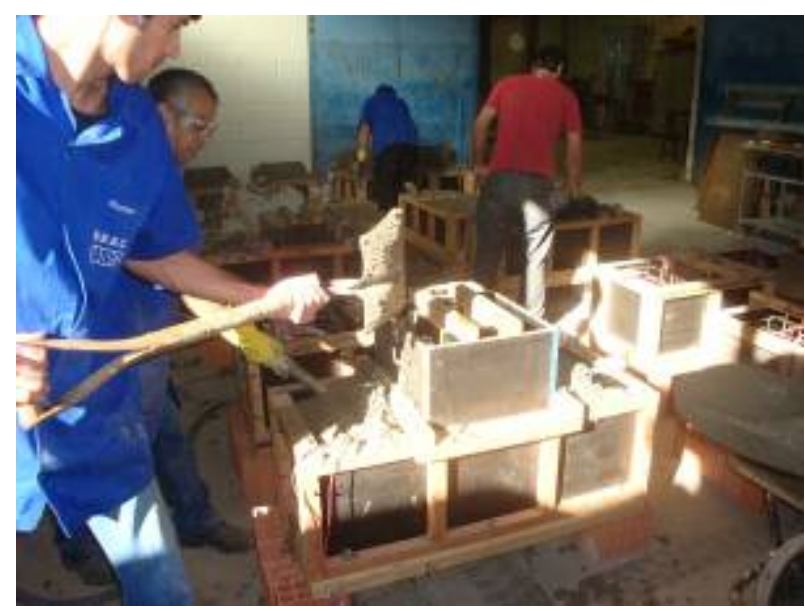

(a)

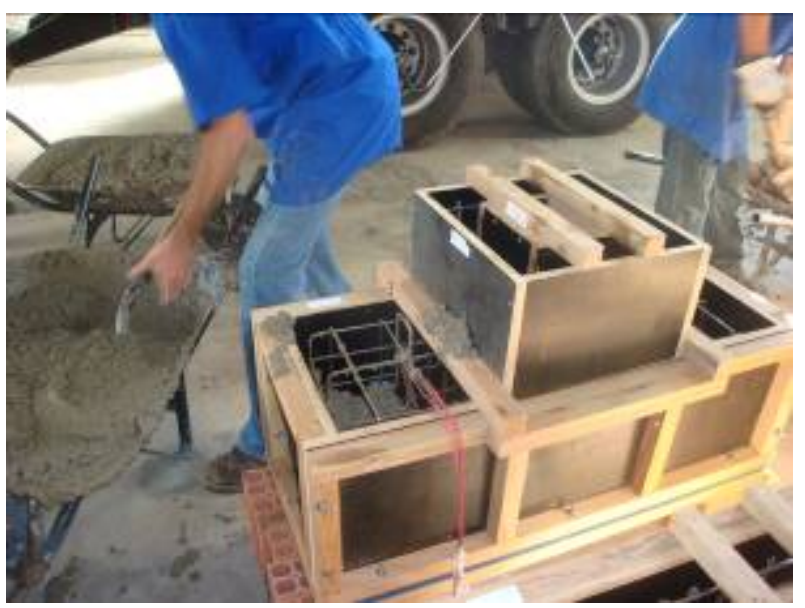

(b)

Figura 4. 25 - Concretagem dos blocos de fundação

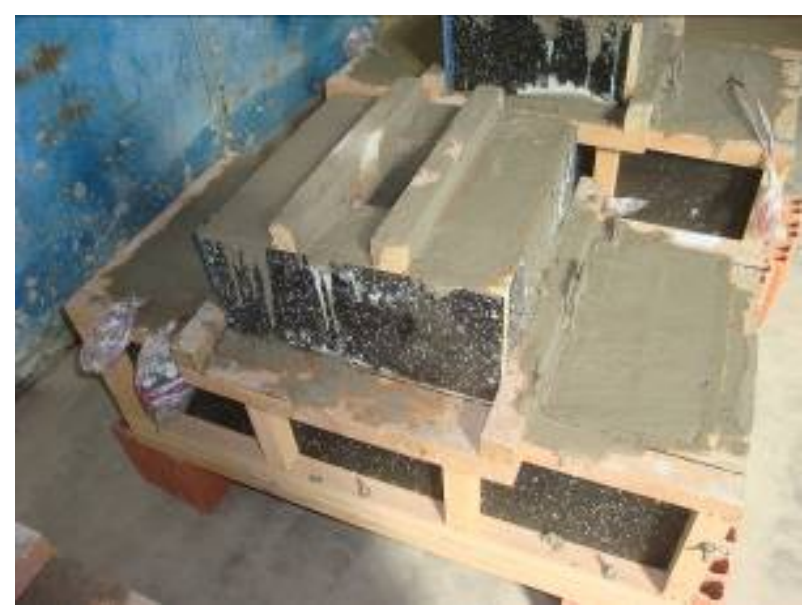

(a)

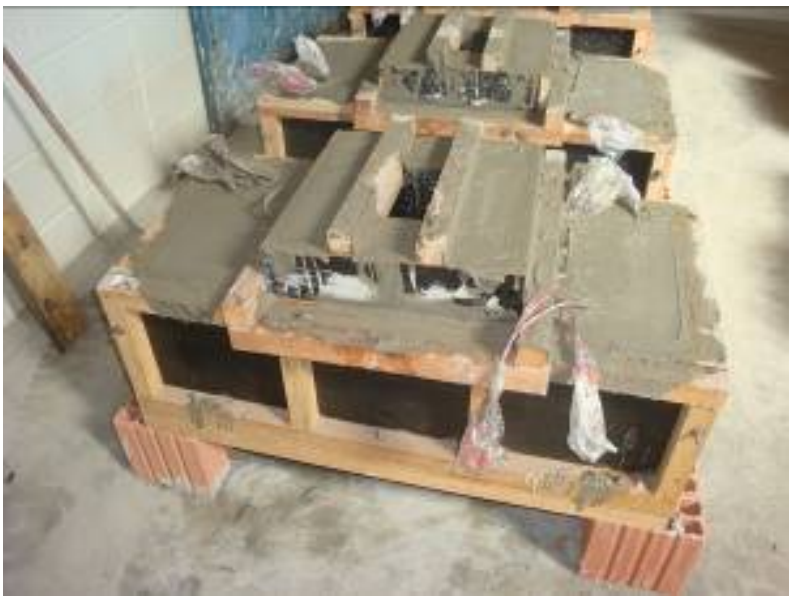

(b)

Figura 4. 26 - Blocos com cálice externo e parcialmente embutido após concretagem 


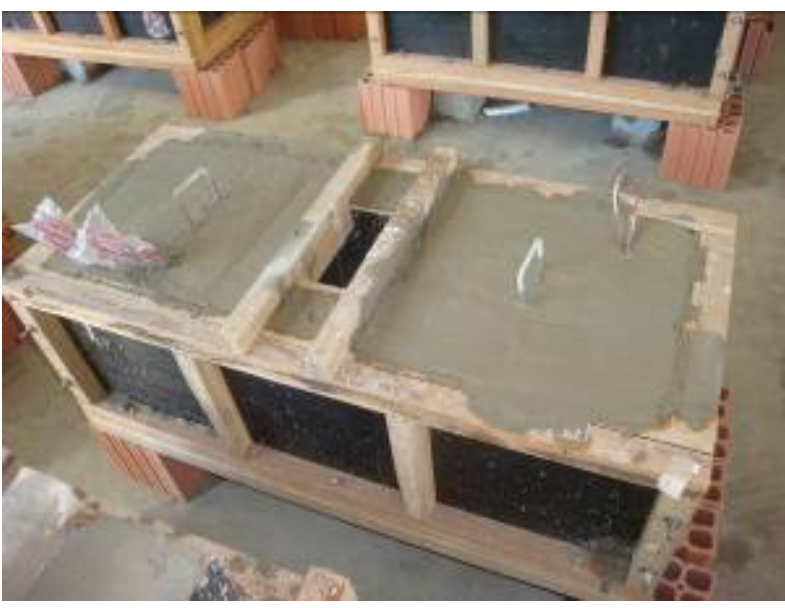

(a)

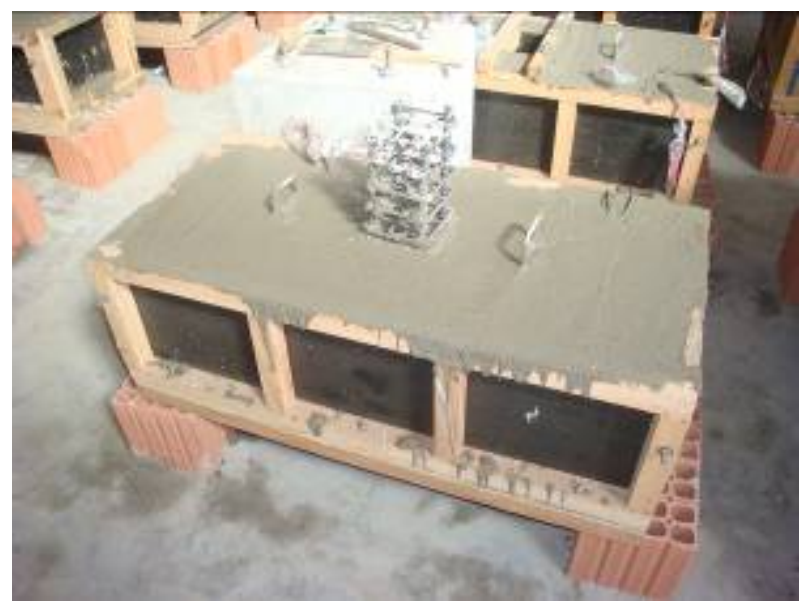

(b)

Figura 4. 27 - Blocos com cálice embutido e bloco de referência após concretagem

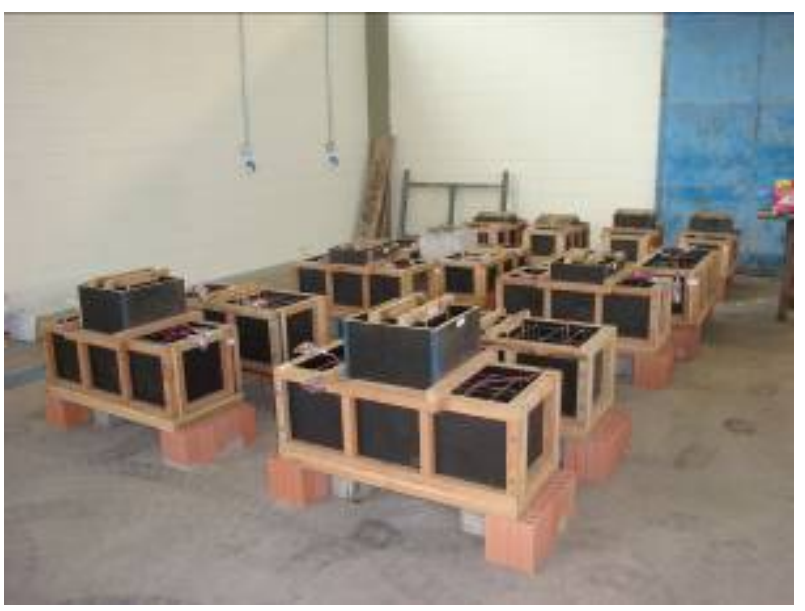

(a)

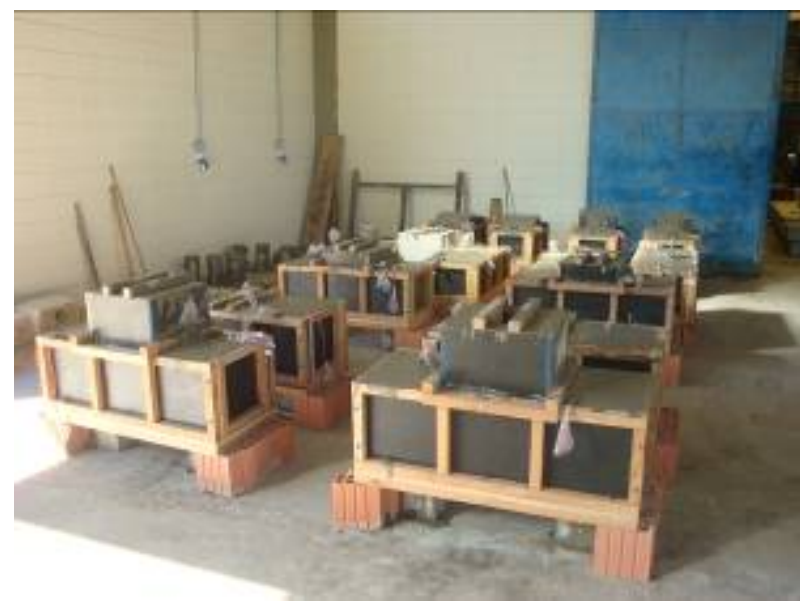

(b)

Figura 4. 28 - Blocos de fundação antes e após a etapa de concretagem

A concretagem dos pilares ocorreu na segunda quinzena do mês de junho de 2012 . Conforme dito anteriormente, o concreto utilizado nos pilares foi o mesmo utilizado nas estacas, sendo dosado no Laboratório de Estruturas a partir de um traço para concreto da classe C50. A única diferença em relação à concretagem das estacas foi a marca do cimento utilizado, sendo que nas estacas utilizou-se cimento da marca Cauê enquanto que nos pilares utilizou-se cimento da marca Holcim.

Foram concretados doze pilares pré-moldados sendo seis com rugosidade e seis sem rugosidade, os quais foram utilizados posteriormente para os blocos com cálice. Outros dois pilares foram moldados para os blocos de referência, os quais foram concretados diretamente sobre os blocos, conforme apresentado na Figura 4.29. 


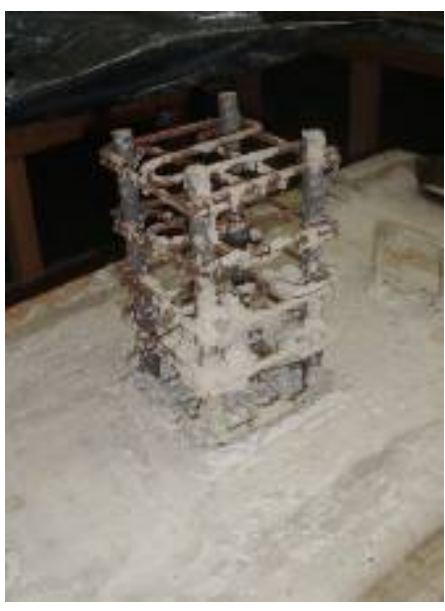

(a)

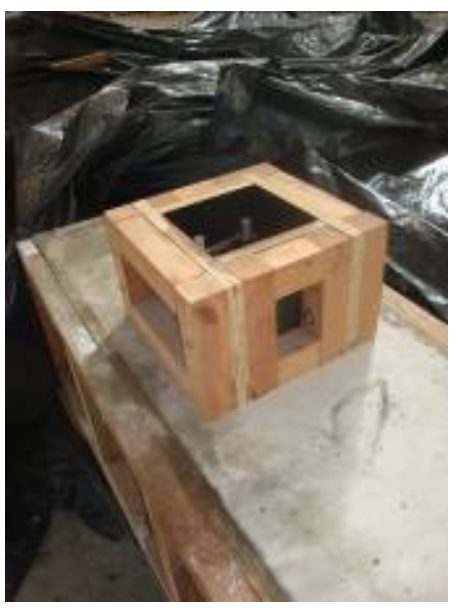

(b)

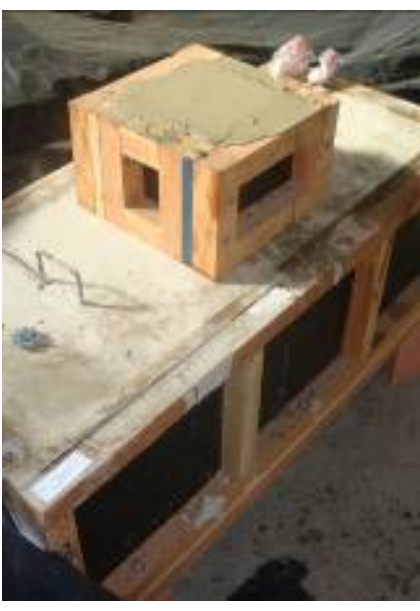

(c)

Figura 4. 29 - Armação, fôrma e concretagem do bloco de referência rugoso

A concretagem dos pilares foi feita de modo semelhante ao das estacas, utilizando os mesmos materiais e equipamentos, sendo moldados, além dos pilares, doze corpos-de-prova. Os pilares foram dispostos em duas linhas com seis pilares, de modo a facilitar a passagem da carriola durante a concretagem. Procedeu-se inicialmente a limpeza das fôrmas, aplicação de desmoldante e posicionamento das armaduras com espaçadores plásticos para garantir o cobrimento mínimo de $2,0 \mathrm{~cm}$. Nessas fôrmas foi preciso realizar um furo horizontal para permitir a passagem dos fios dos extensômetros elétricos das armaduras dos pilares antes da concretagem. Esse furo foi realizado na parte lateral da fôrma, sendo posteriormente preenchido com massa de calafetar. A chave de cisalhamento existente nos pilares rugosos foi feita a partir da fixação de ripas de madeira na fôrma dos pilares. A Figura 4.30 apresenta detalhes da fôrma e a Figura 4.31 a etapa de concretagem dos pilares.

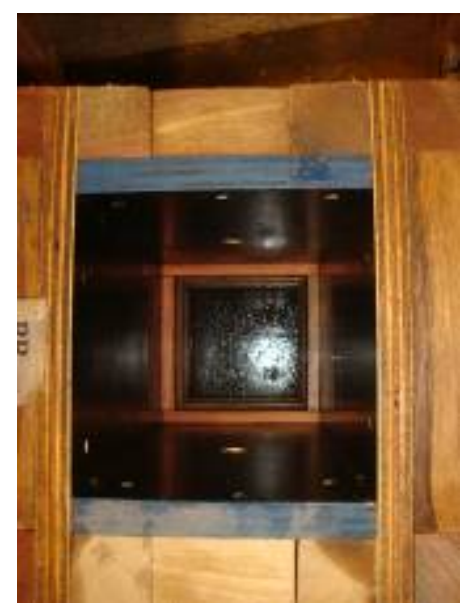

(a)

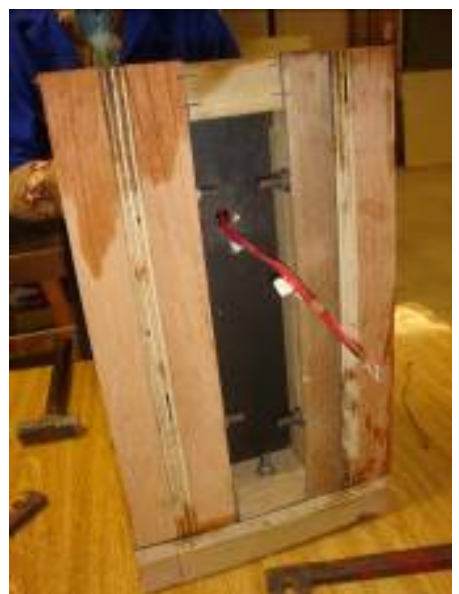

(b)

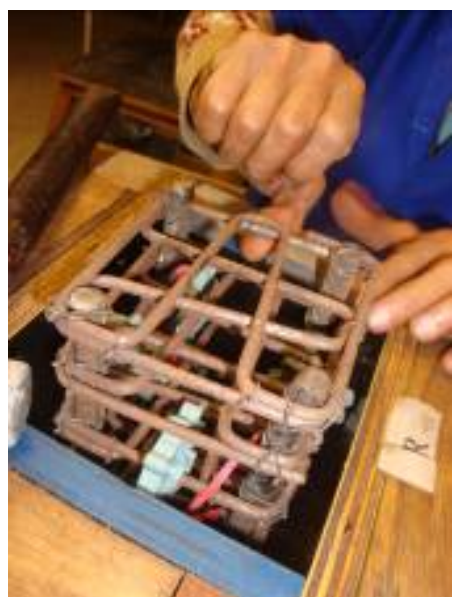

(c)

Figura 4. 30 - Fôrma e armação dos pilares 


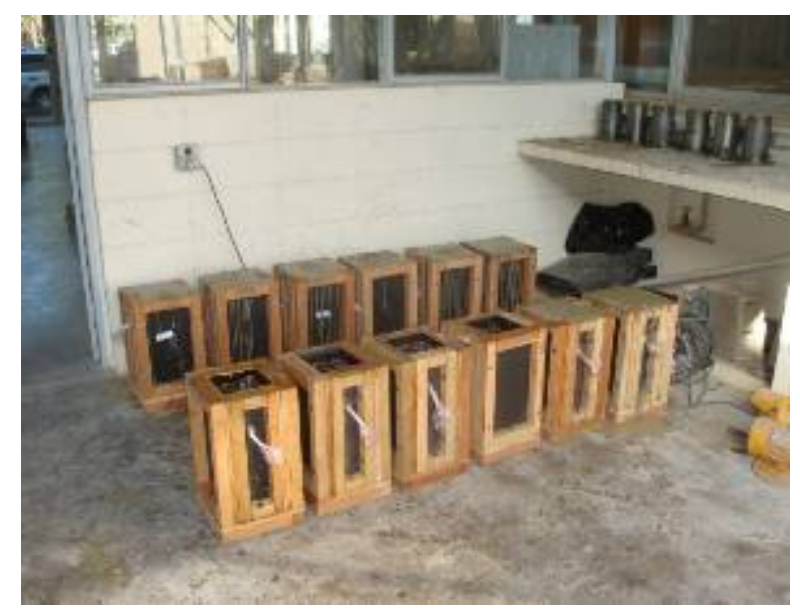

(a)

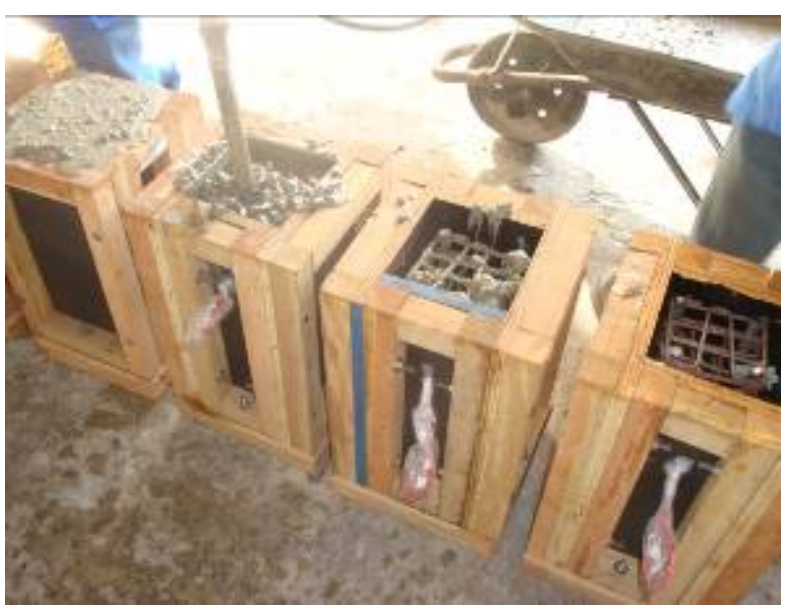

(b)

Figura 4. 31 - Concretagem dos pilares

\subsection{Desforma dos elementos estruturais}

A desforma dos elementos estruturais ocorreu por etapas, sendo realizado primeiro a desforma das estacas antes da etapa de concretagem dos blocos. Após a concretagem dos pilares, foi realizada a desforma dos blocos e, por último, a desforma dos pilares. Destaca-se neste item dois problemas que ocorreram na desforma dos elementos.

A desforma dos blocos teve início dez dias após a sua concretagem, tendo ocorrido após a concretagem dos pilares. A remoção das fôrmas laterais dos blocos ocorreu facilmente após a retirada dos parafusos. A fôrma inferior foi retirada apenas nos dias dos ensaios dos modelos, em virtude da necessidade de utilização da ponte rolante do laboratório para se erguerem os blocos.

Quando da retirada da fôrma dos cálices, constatou-se que a madeira da fôrma expandiu-se em função da umidade, o que dificultou a sua retirada. As fôrmas dos caixotes internos precisaram ser cuidadosamente cortadas sem danificar a estrutura do bloco, sendo necessário aproximadamente duas semanas para retirada de todas as fôrmas dos cálices. As Figuras 4.32 e 4.33 apresentam os blocos após a retirada das fôrmas. 


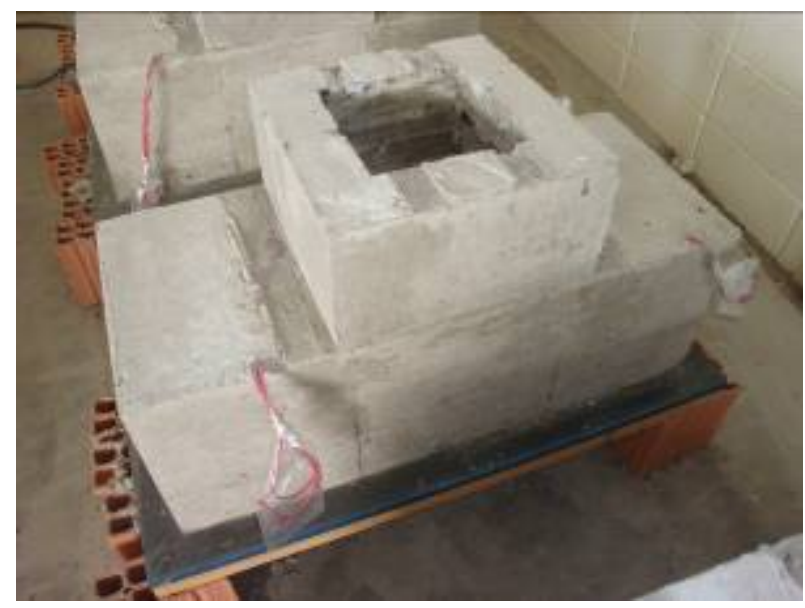

(a)

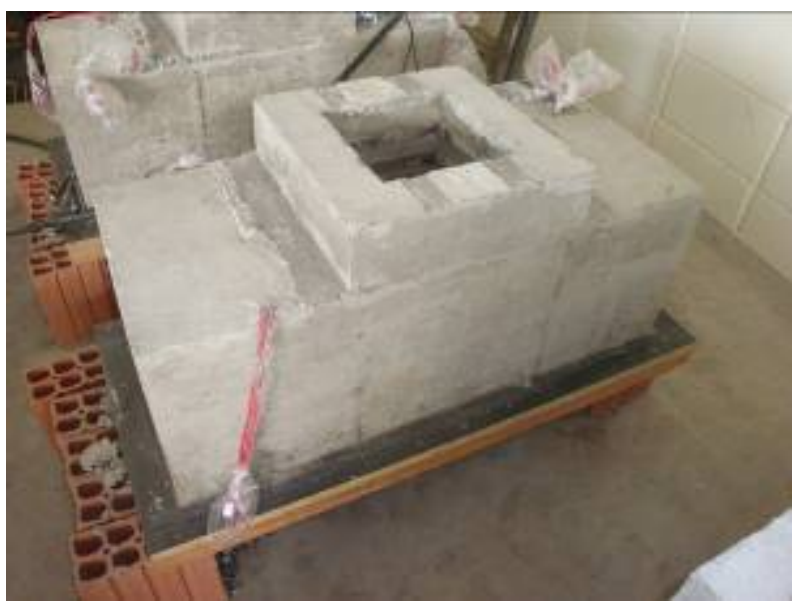

(b)

Figura 4. 32 - Blocos com cálice externo e parcialmente embutido após desforma

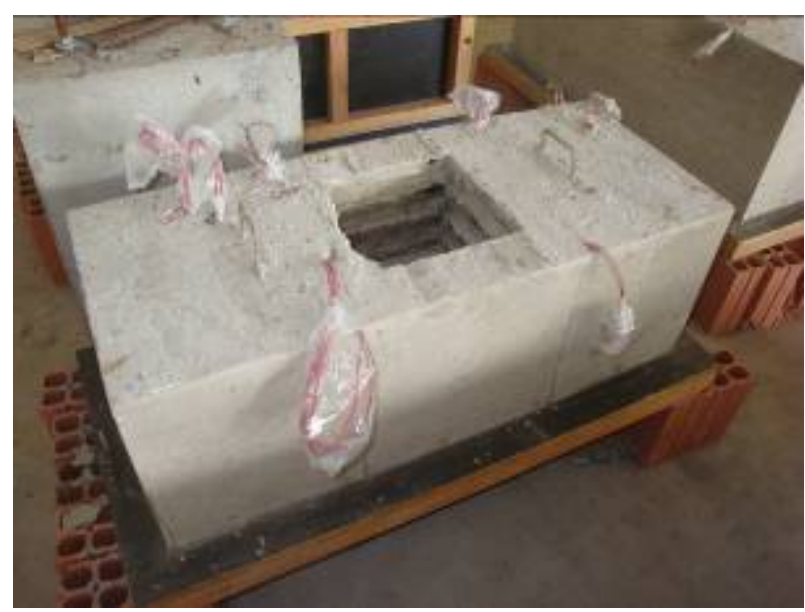

(a)

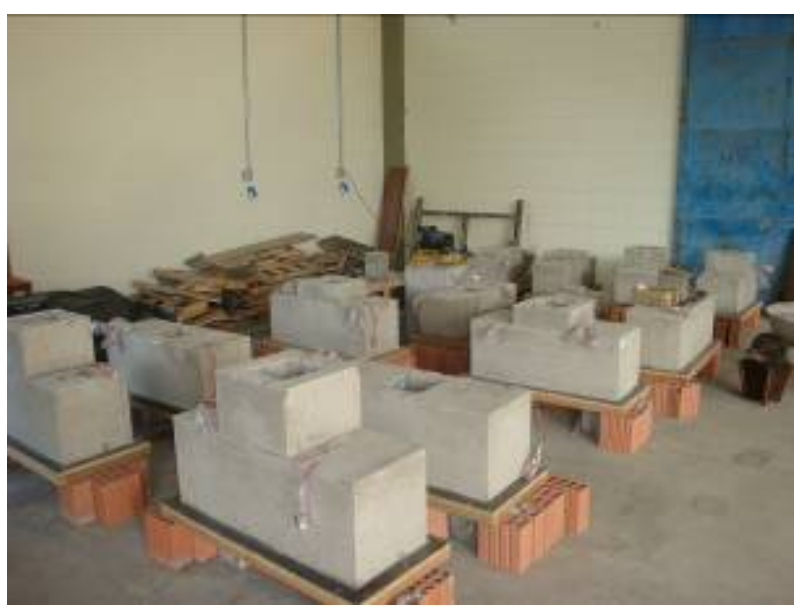

(b)

Figura 4. 33 - Blocos de fundação com cálice embutido e vista geral dos blocos após desforma

Quanto a desforma dos pilares, constatou-se que as ripas de madeira utilizadas para formar a chave de cisalhamento também sofreram expansão, de modo que, quando da retirada da forma lateral, as ripas que formavam a rugosidade do pilar se destacaram e permaneceram presas aos pilares, conforme pode ser observado na Figura 4.34. A retirada dessa fôrma precisou ser feita cuidadosamente, a fim de não danificar as rugosidades criadas nos pilares. Esse problema poderia ter sido evitado caso as chaves de cisalhamento tivessem sido feitas com isopor, semelhante ao dos caixotes internos, ou então criando um chanfro nas ripas, de modo a facilitar sua retirada. 


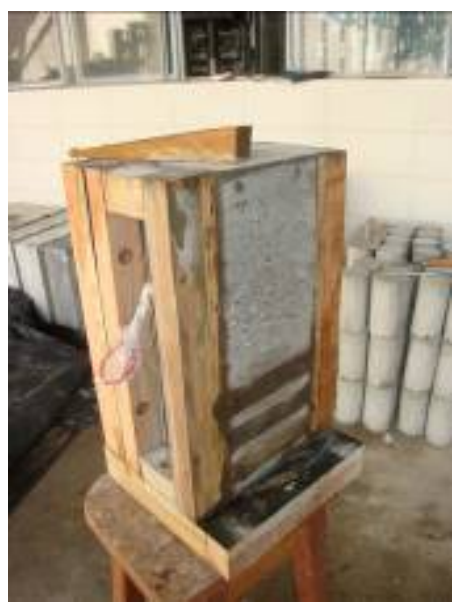

(a)

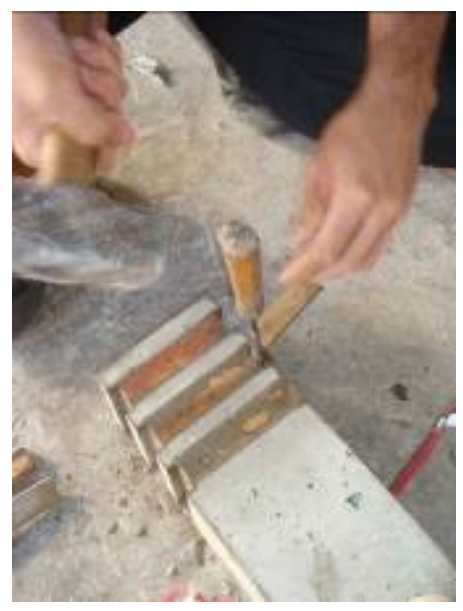

(b)

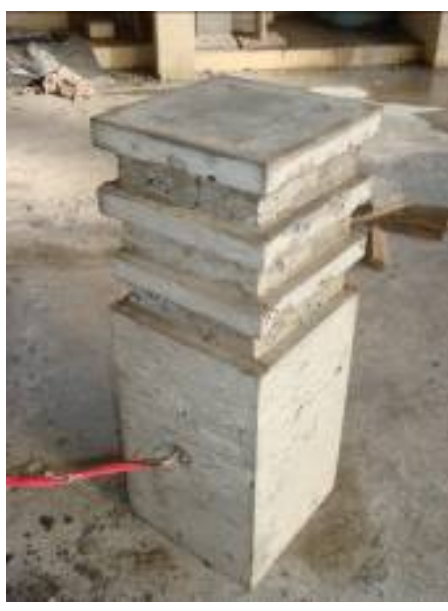

(c)

Figura 4. 34 - Etapa de desforma: pilares com rugosidade

\subsection{Grauteamento}

Após a desforma de todos os elementos, foi preciso realizar a ligação dos pilares com os blocos de fundação. Essa ligação foi feita posicionando os pilares dentro dos cálices de fundação. Inicialmente procedeu-se a limpeza e retirada do pó que havia se acumulado dentro dos cálices. As paredes dos cálices foram limpas com um pano úmido. Concluída a limpeza, procedeu-se ao posicionamento dos pilares que foram moldados separadamente.

Para o posicionamento dos pilares foi necessário verificar o nível e o prumo dos mesmos em relação à superfície. O prumo e o nível foram mantidos com o auxílio de cunhas de madeira. Em seguida, o espaço existente entre os pilares e os cálices foi preenchido com graute autoadensável da marca Botagrout. Esse graute possui densidade da argamassa seca igual a $2,28 \mathrm{~g} / \mathrm{cm}^{3}$, tempo de trabalhabilidade de 30 minutos e um consumo estimado de 2000 $\mathrm{kg} / \mathrm{m}^{3}$.

A preparação do graute foi feita com auxílio de uma batedeira horizontal existente no Laboratório de Estruturas. Em virtude da capacidade da batedeira e do tempo de trabalhabilidade do graute, que era de 30 minutos, optou-se por realizar a etapa de grauteamento em dois dias, sendo preenchidos os cálices de seis blocos em cada dia. Além do preenchimento dos vazios dos cálices, forma moldados doze corpos-de-prova cilíndricos medindo cinco centímetros de diâmetro e dez centímetros de altura. 
A mistura dos materiais foi feita em função do volume de material suportado na batedeira. Em cada dia foram realizados quatro etapas de misturas, sendo que a cada etapa utilizou-se 12,5 $\mathrm{kg}$ de graute e 1,3 litros de água. Essa proporção foi fornecida pelo fabricante do graute, a qual conduziria a uma resistência estimada de $50 \mathrm{MPa}$ aos 28 dias. As Figuras 4.35 (a) e (b) apresentam os materiais utilizados na dosagem do graute, enquanto que a Figura 4.35 (c) apresenta a batedeira utilizada para proceder a mistura dos materiais.

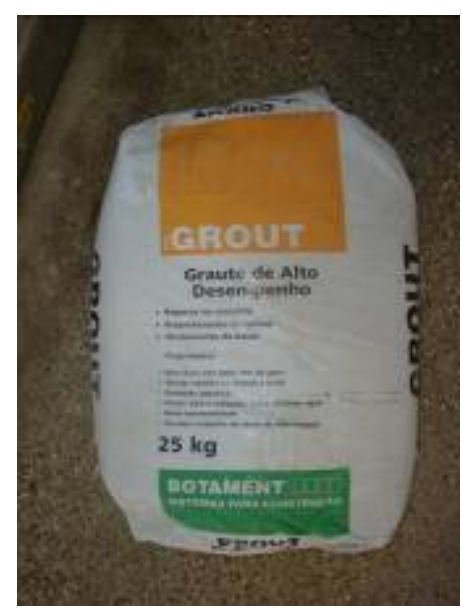

(a)

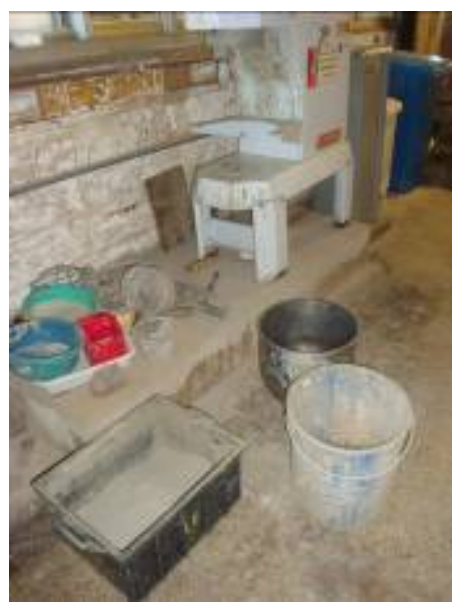

(b)

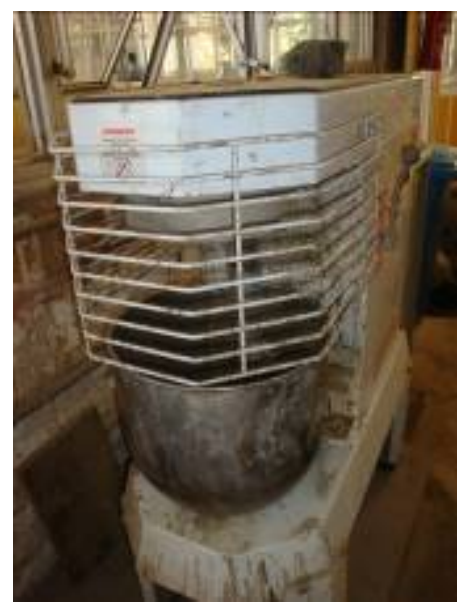

(c)

Figura 4. 35 - Materiais e equipamentos utilizados na preparação do graute

O graute e a água foram colocados alternadamente na batedeira, utilizando-a com pequena rotação. Algumas vezes foi preciso utilizar uma colher de pedreiro para remover parte do material que ficava grudado na bacia. Após a mistura na batedeira por aproximadamente 5 minutos até se obter uma mistura homogênea, o graute foi conduzido até o local onde se encontravam os blocos de fundação, onde o mesmo foi utilizado para preenchimento do vazio existente entre os pilares e os cálices. Por se tratar de graute autoadensável, dispensou-se o uso de vibrador mecânico, sendo utilizada apenas uma barra de aço para adensamento manual e retirada de bolhas de ar que ocasionalmente poderiam ser formadas.

A etapa de grauteamento ocorreu no início do mês de Julho de 2012, finalizando as etapas de preparação dos modelos para os ensaios finais. As Figuras 4.36 a 4.38, por suas vezes, apresentam as etapas de preparação das superfícies e grauteamento dos blocos de fundação. 


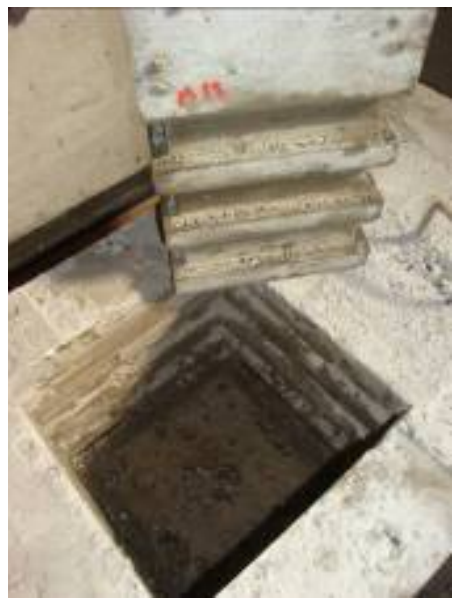

(a)

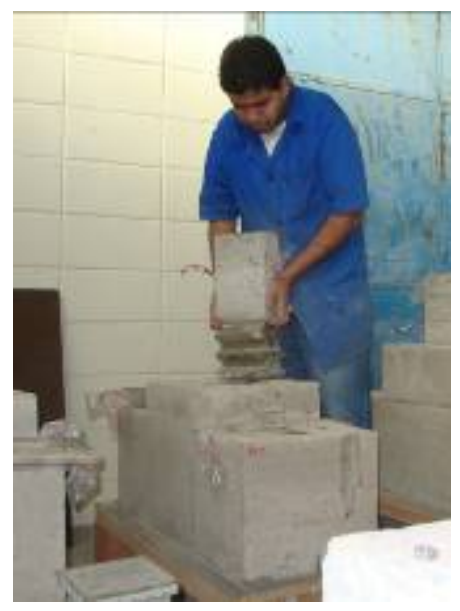

(b)

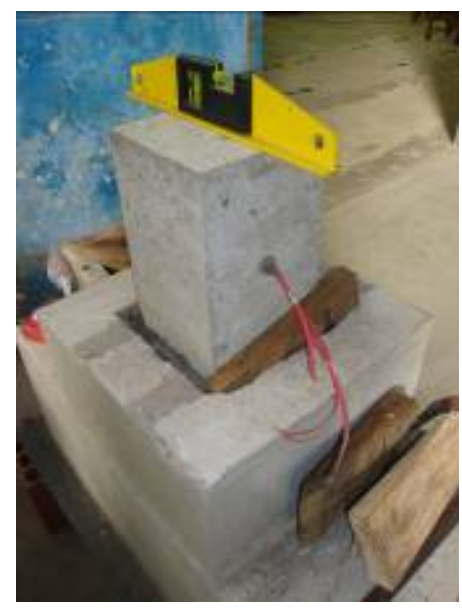

(c)

Figura 4. 36 - Detalhe da chave de cisalhamento e colocação dos pilares nos blocos de fundação

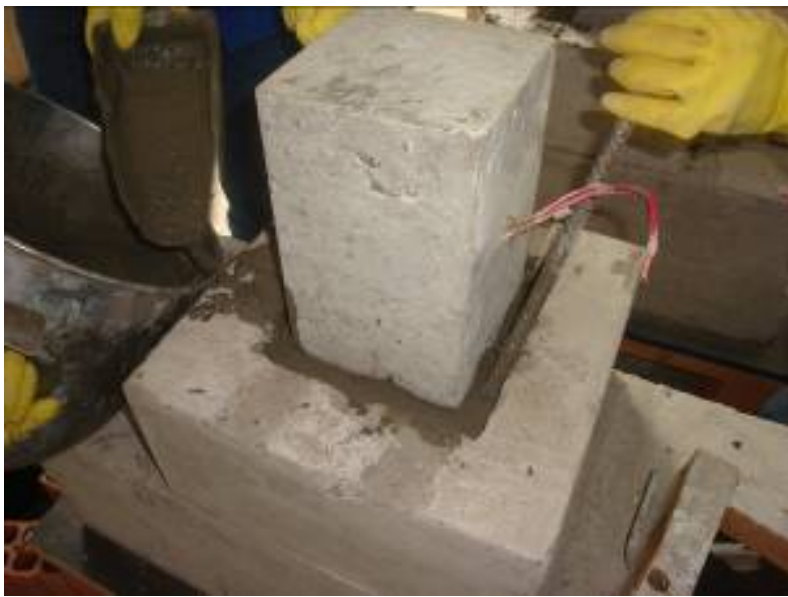

(a)

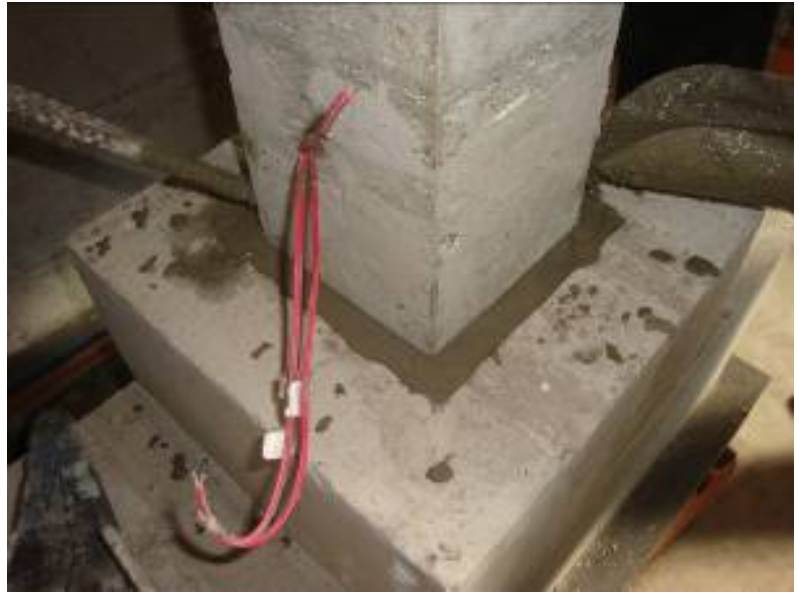

(b)

Figura 4. 37 - Etapa de grauteamento dos blocos de fundação

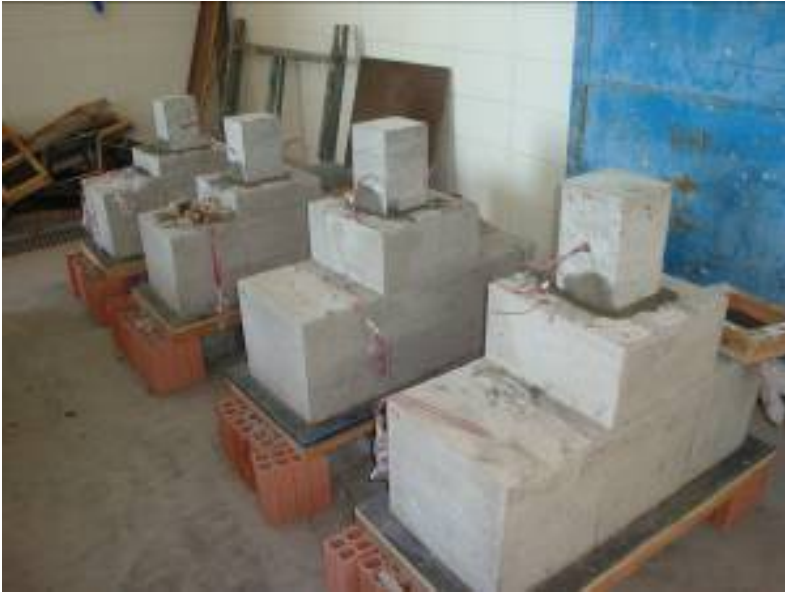

(a)

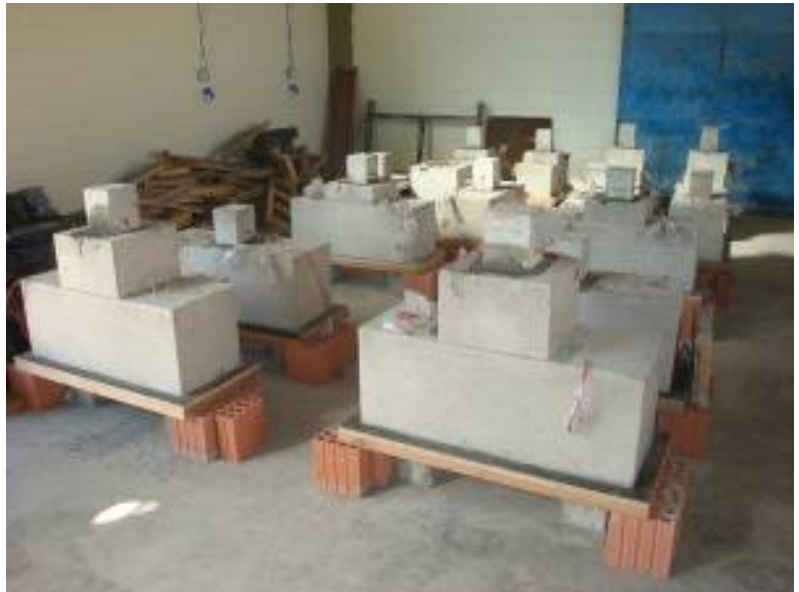

(b)

Figura 4. 38 - Blocos de fundação após etapa de grauteamento 


\subsection{Equipamentos e instrumentos de ensaios}

Os ensaios foram realizados no Laboratório de Estruturas da Escola de Engenharia de São Carlos, Universidade de São Paulo, utilizando a maquina universal de ensaios servocontrolada, Instron 8506, com capacidade nominal de força igual a $2500 \mathrm{kN}$. A utilização da máquina Instron 8506 pode ser feita pelo fato dos modelos em escala reduzida apresentarem dimensões compatíveis com as disponíveis no equipamento.

A máquina Instron foi utilizada para realização dos ensaios nos modelos de blocos sobre estacas e para realização dos ensaios de caracterização das barras das armaduras de aço, os quais foram conduzidos de acordo com a ABNT NBR 6152:2002. A Figura 4.39 apresenta a máquina Instron 8506 e um dos modelos de bloco posicionado para o ensaio.

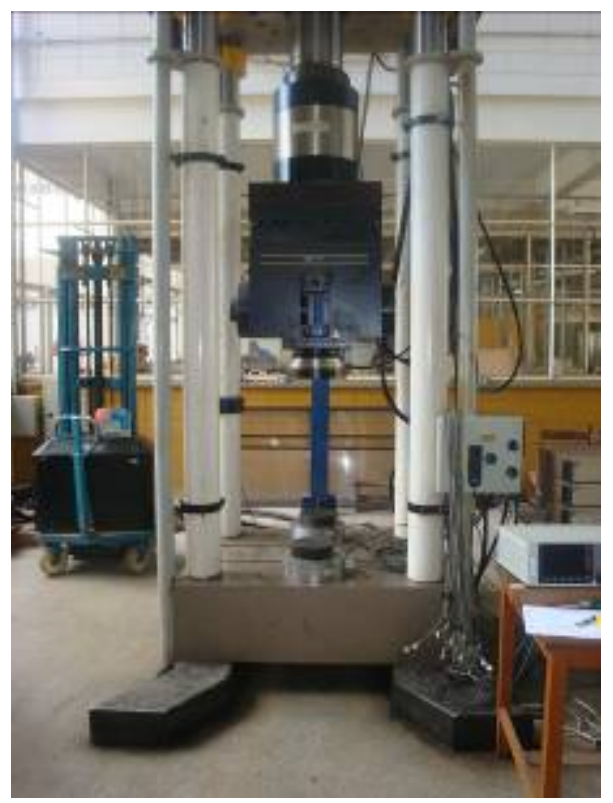

(a)

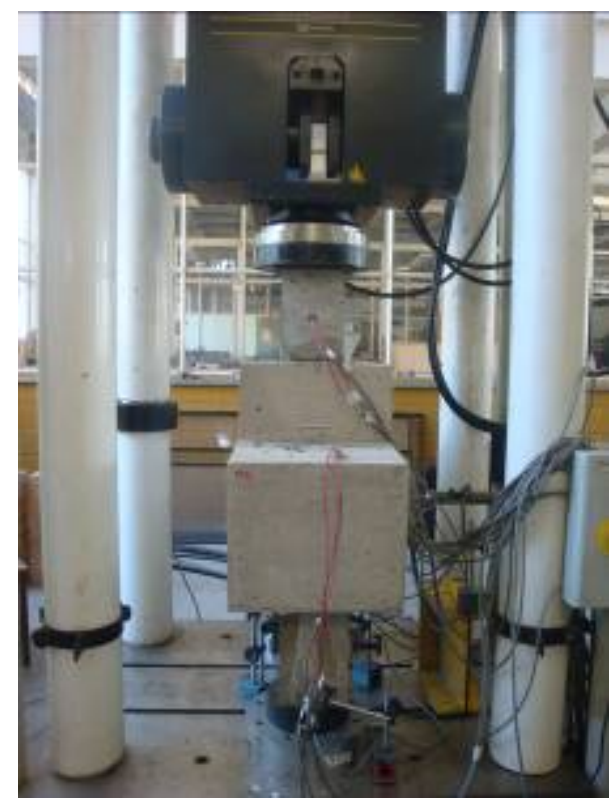

(b)

Figura 4. 39- máquina universal servo-controlada Instron 8506

Os blocos foram posicionados transversalmente a máquina, estando apoiados sobre duas células de carga com capacidade para $2000 \mathrm{kN}$ cada uma. Para obtenção dos dados referentes às medidas de deformação e deslocamento obtidos com os extensômetros e com os transdutores de deslocamento, foi utilizado o sistema System 5000 para aquisição automática dos dados. A Figura 4.40 apresenta o sistema de aquisição de dados. Trata-se de um sistema computadorizado da marca Measurements Group, na qual foram utilizados até 43 canais para captação dos dados. 


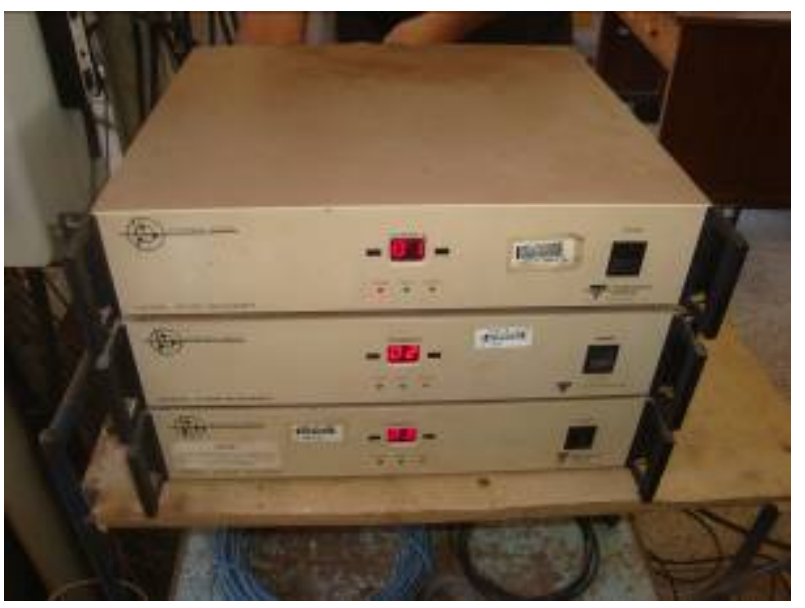

(a)

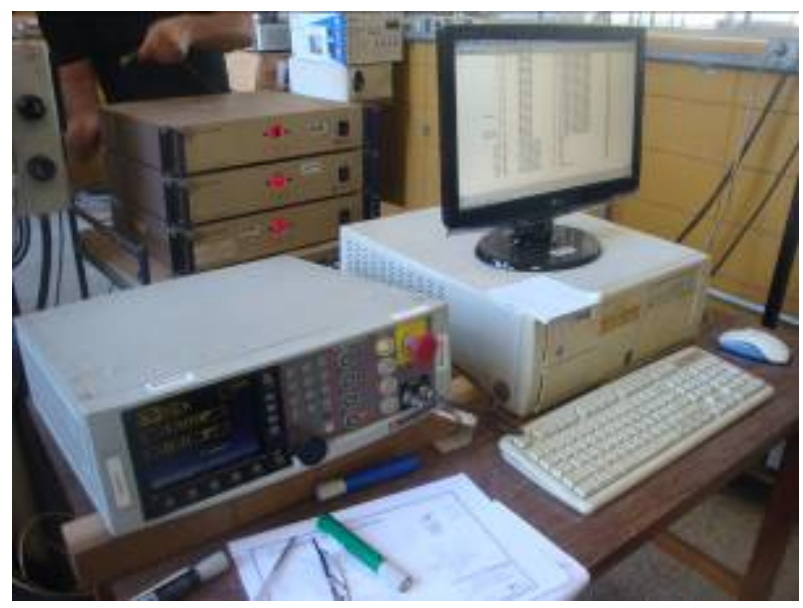

(b)

Figura 4. 40- Sistema de aquisição de dados System 5000 e Módulo controlador

As propriedades mecânicas dos materiais concreto, aço e graute foram obtidas por meio de ensaios destrutivos e não-destrutivos. Para os concretos dos blocos, pilares e estacas foram utilizado corpos-de-prova cilíndricos medindo dez centímetros de diâmetro e vinte centímetros de altura, enquanto que para o graute utilizou-se corpos-de-prova cilíndricos medindo cinco centímetros de diâmetro e dez centímetros de altura.

Os ensaios ditos destrutivos utilizaram equipamentos disponíveis no Laboratório de Estruturas. Para caracterização do concreto (resistência à compressão e tração por compressão diametral) foi utilizado a máquina hidráulica automática ELE, modelo Autotest 2000 com capacidade força igual a $1500 \mathrm{kN}$. Esses ensaios foram feitos de acordo com as recomendações propostas pelas normas ABNT NBR 5738:2008, ABNT NBR 5739:2007 e ABNT NBR 7222:2011.

Antes da realização dos ensaios de caracterização foi necessário retificar as superfícies dos corpos-de-prova para melhorar o contato entre os pratos da máquina de ensaio e o elemento a ser ensaiado. Para esse procedimento, foi utilizada a máquina retificadora existente no laboratório de estruturas, a qual está apresentada na Figura 4.41 assim como a máquina ELE, modelo Autotest 2000. As Figuras 4.42 e 4.43, por suas vezes, apresentam a preparação e o ensaio de tração por compressão diametral. 


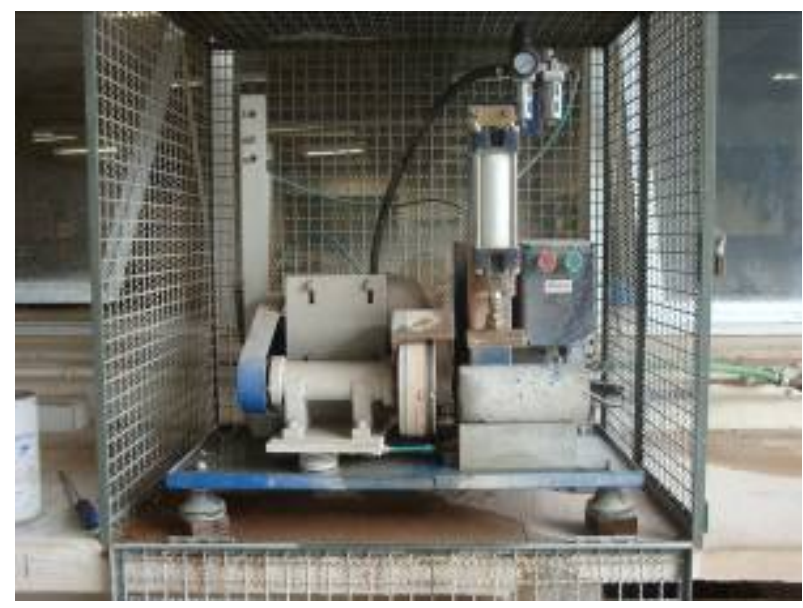

(a)

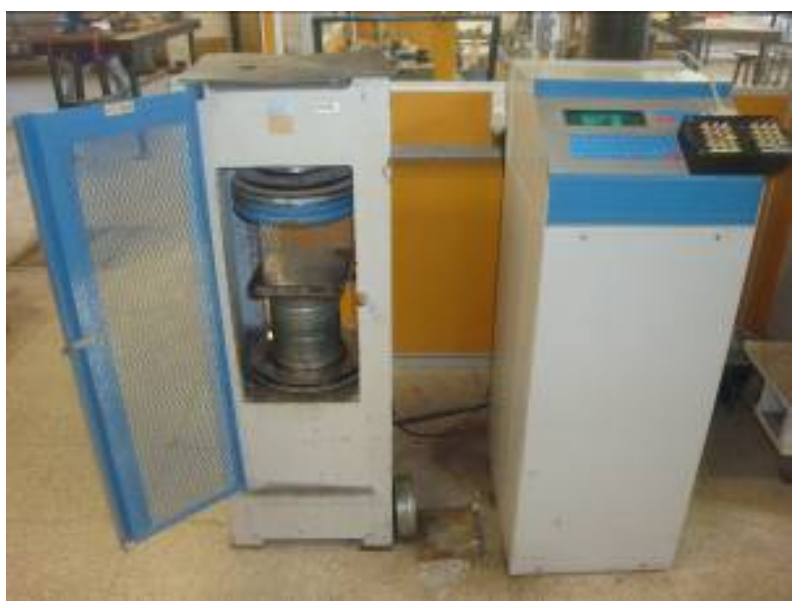

(b)

Figura 4. 41- Máquina retificadora e Máquina hidráulica ELE, Autotest 2000

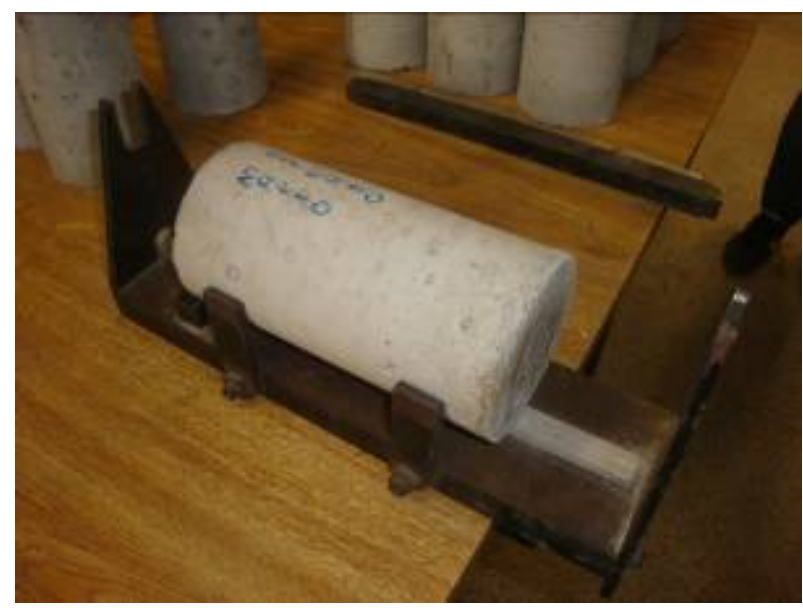

(a)

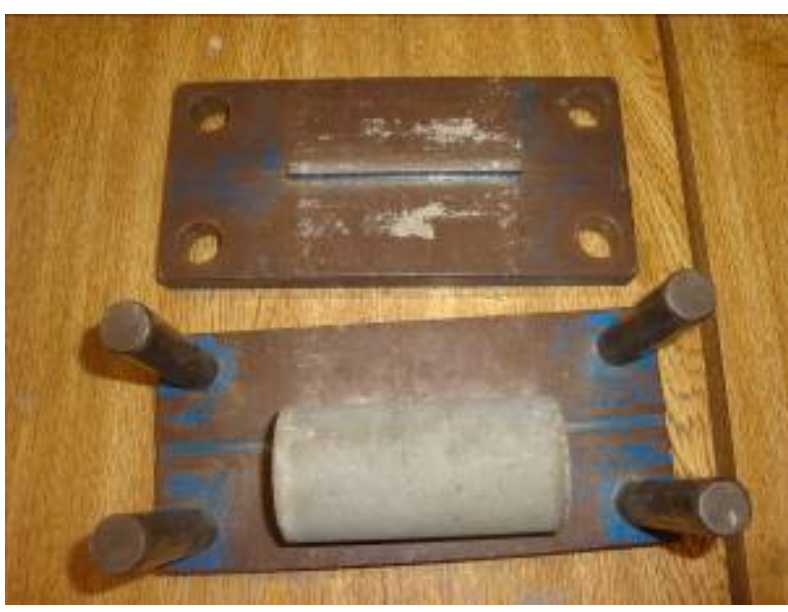

(b)

Figura 4. 42- Corpos-de-prova para ensaio de tração por compressão diametral

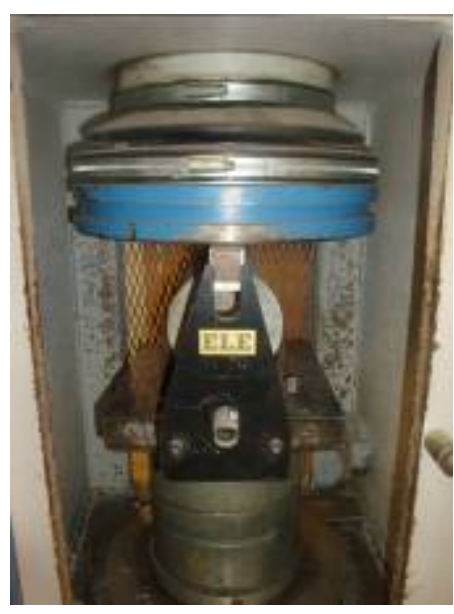

(a)

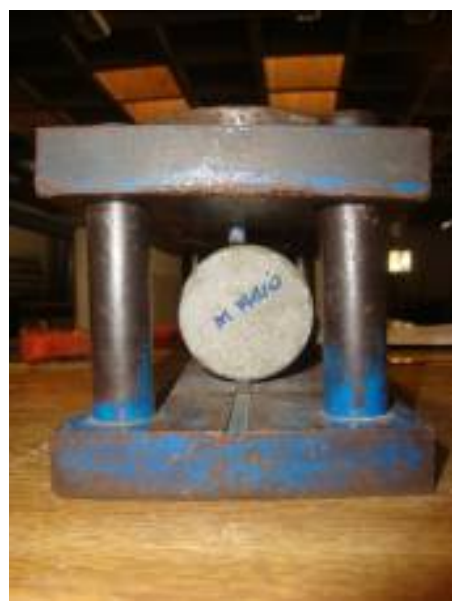

(b)

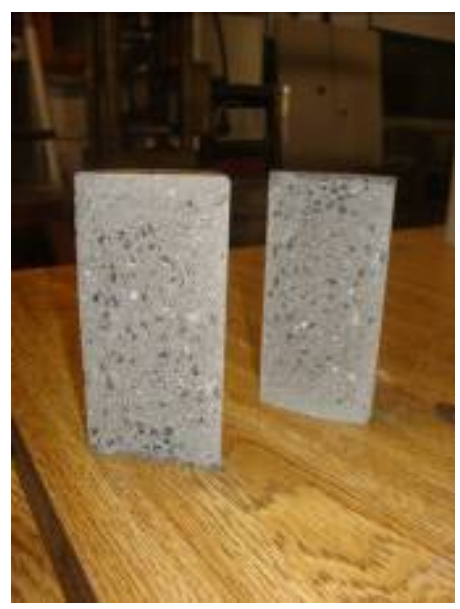

(c)

Figura 4. 43-Detalhe do ensaio de tração por compressão diametral 
O módulo de elasticidade longitudinal estático e a curva tensão versus deformação do concreto foram obtidos por meio de ensaios em corpos-de-prova na máquina Instron 5595300 HVL, de acordo com as recomendações da ABNT NBR 8522:2003. A Figura 4.44 apresenta os ensaios em corpos-de-prova $10 \mathrm{~cm}$ x $20 \mathrm{~cm}$ e $5 \mathrm{~cm}$ x $10 \mathrm{~cm}$ para obtenção do módulo de elasticidade estático. Conforme dito anteriormente, a determinação das propriedades das barras de aço das armaduras foi feita utilizando a máquina Instron 8506,

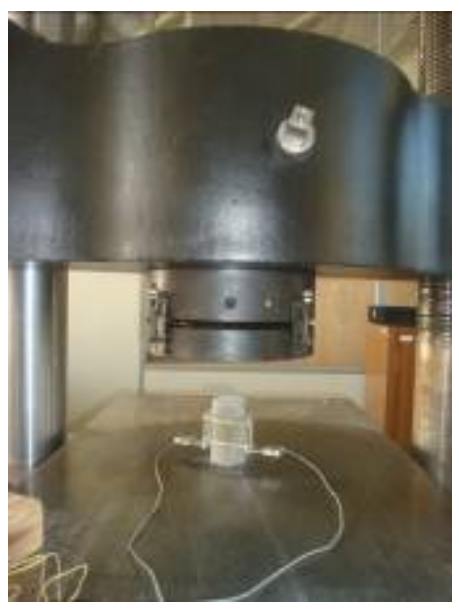

(a)

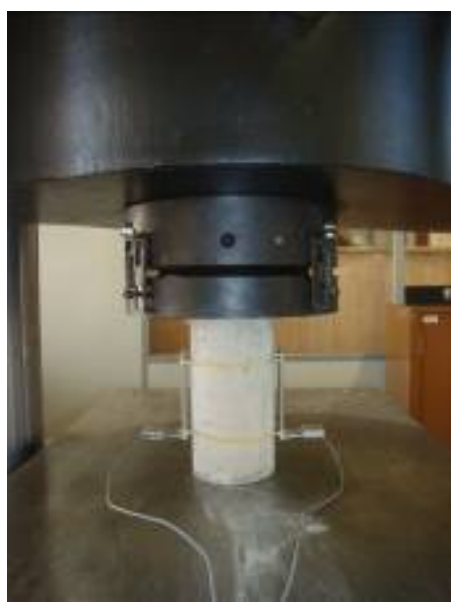

(b)

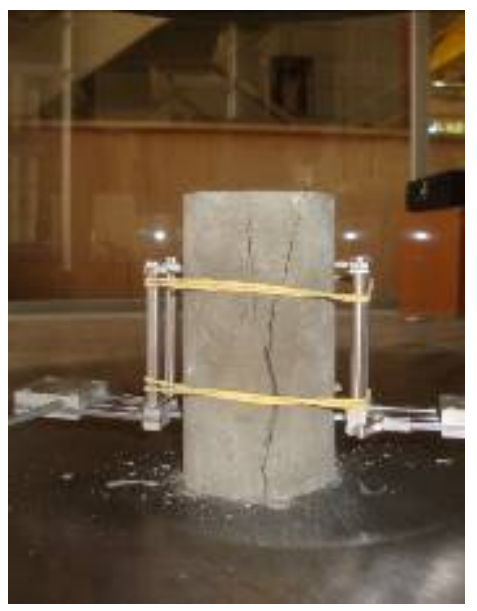

(c)

Figura 4. 44-Detalhe do ensaio de módulo de elasticidade estático

Além dos ensaios de caracterização apresentados anteriormente, procederam-se ensaios não-destrutivos em corpos-de-prova cilíndricos do concreto e do graute utilizados nos modelos. A realização dos ensaios não destrutivos foi sugerida na etapa de qualificação desse trabalho, e foi utilizado para obtenção do módulo de elasticidade dinâmico dos concretos e do graute, de acordo com a norma ASTM C215:2008.

Os ensaios não-destrutivos têm como vantagens a facilidade de realização desde que se disponha dos equipamentos necessários, a possibilidade de repetição dos ensaios, além de apresentar pouquíssima variabilidade nos resultados, o que normalmente não ocorre com os ensaios de módulo de elasticidade estático do concreto. Além da obtenção de propriedades mecânicas nos materiais, a realização dos ensaios não destrutivos visou contribuir para a formação de um banco de dados no Laboratório de Estruturas, que apresente relações entre os módulos de elasticidade dinâmico e estático do material concreto, em função da resistência característica à compressão do mesmo. As Figuras 4.45 e 4.46 apresentam o esquema do ensaio realizado. 


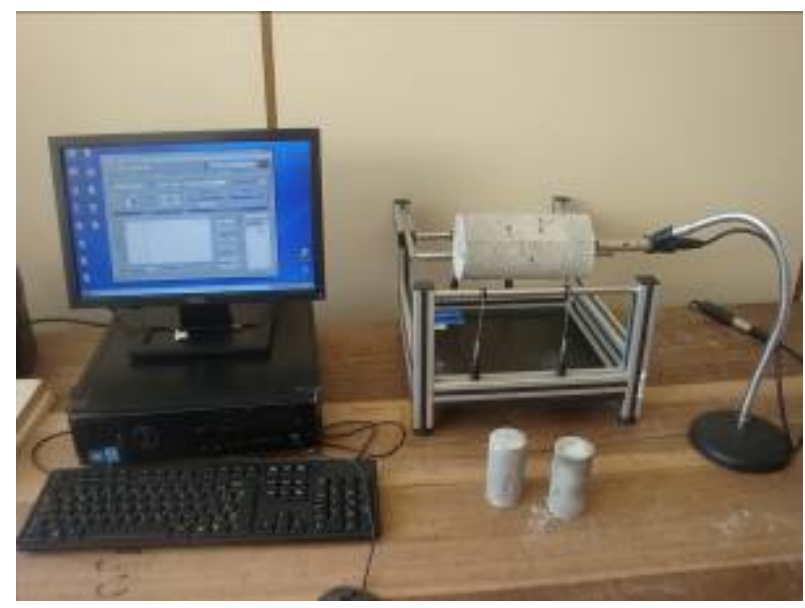

(a)

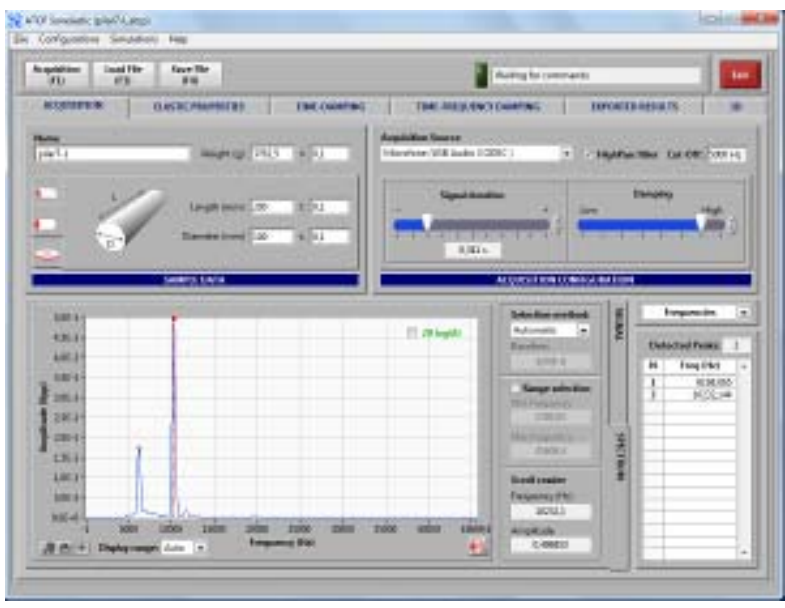

(b)

Figura 4. 45- Esquema de ensaio não-destrutivo e tela do programa Sonelastic

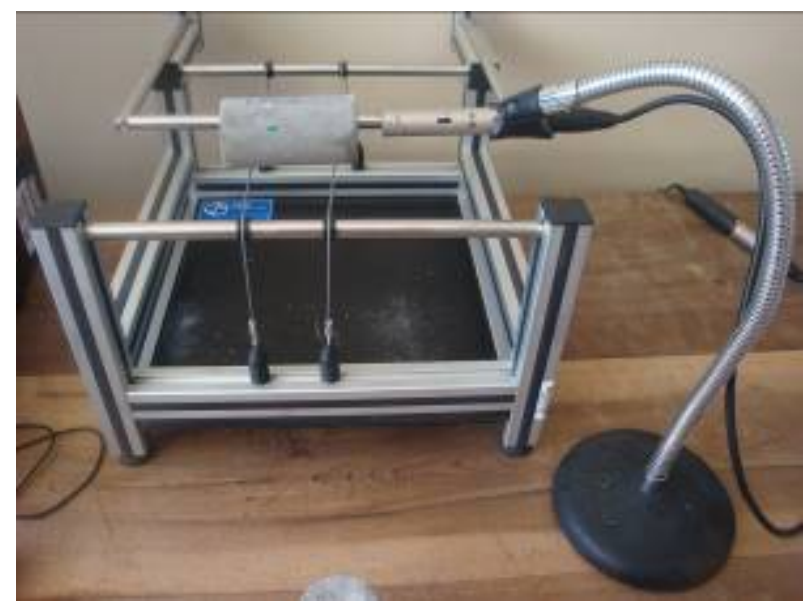

(a)

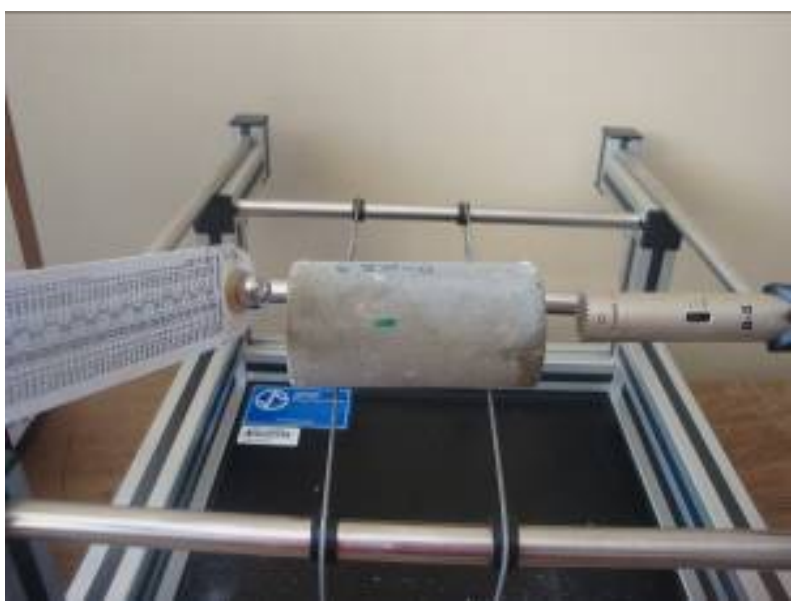

(b)

Figura 4. 46- Plataforma de apoio para realização dos ensaios não destrutivos

A realização desses ensaios foi feita com auxilio do programa Sonelastic desenvolvido pela ATCP Engenharia Física. Nesse programa os dados de entrada são o tipo, as dimensões e o peso do corpo-de-prova. Posiciona-se o elemento numa plataforma e, com auxílio de uma régua com uma esfera metálica na extremidade, excita-se o corpo-de-prova por meio de uma batida que varia de acordo com o tipo de dado que se deseja obter.

É preciso também que o ambiente em que ocorrem os ensaios esteja isento de ruídos que possam interferir nos resultados dos ensaios. Utiliza-se um microfone para captação da onda em função da vibração que ocorre no corpo-de-prova. A partir dessa onda e dos dados de entrada, o programa estima o valor do módulo de elasticidade. Neste trabalho, aplicou-se uma batida na direção longitudinal do corpo-de-prova, tendo como resposta o módulo de elasticidade dinâmico longitudinal e flexional do concreto e do graute. 
Os ensaios nos modelos físicos foram realizados entre os dias 03 e 24 do mês de agosto de 2012, e tiveram duração média de aproximadamente 90 minutos, seguindo a ordem em que estão apresentados na tabela 4.2.

Tabela 4.2 - Datas e tempo de realização dos ensaios

\begin{tabular}{c|c|c|c}
\hline \hline Data & Modelo & Início & Término \\
\hline $03 / 08 / 12$ & M1 & $13 \mathrm{~h} 30 \mathrm{~min}$ & $14 \mathrm{~h} 40 \mathrm{~min}$ \\
\hline $06 / 08 / 12$ & M8 & $08 \mathrm{~h} 50 \mathrm{~min}$ & $10 \mathrm{~h} 30 \mathrm{~min}$ \\
\hline $07 / 08 / 12$ & M9 & $14 \mathrm{~h} 20 \mathrm{~min}$ & $15 \mathrm{~h} 10 \mathrm{~min}$ \\
\hline $08 / 08 / 12$ & M10 & $13 \mathrm{~h} 30 \mathrm{~min}$ & $14 \mathrm{~h} 10 \mathrm{~min}$ \\
\hline $09 / 08 / 12$ & M2 & $08 \mathrm{~h} 15 \mathrm{~min}$ & $09 \mathrm{~h} 15 \mathrm{~min}$ \\
\hline $09 / 08 / 12$ & M3 & $13 \mathrm{~h} 30 \mathrm{~min}$ & $14 \mathrm{~h} 45 \mathrm{~min}$ \\
\hline $20 / 08 / 12$ & M11 & $08 \mathrm{~h} 15 \mathrm{~min}$ & $09 \mathrm{~h} 10 \mathrm{~min}$ \\
\hline $20 / 08 / 12$ & M13 & $13 \mathrm{~h} 40 \mathrm{~min}$ & $14 \mathrm{~h} 35 \mathrm{~min}$ \\
\hline $21 / 08 / 12$ & M4 & $08 \mathrm{~h} 15 \mathrm{~min}$ & $09 \mathrm{~h} 15 \mathrm{~min}$ \\
\hline $21 / 08 / 12$ & M6 & $13 \mathrm{~h} 35 \mathrm{~min}$ & $14 \mathrm{~h} 50 \mathrm{~min}$ \\
\hline $22 / 08 / 12$ & M12 & $09 \mathrm{~h} 10 \mathrm{~min}$ & $10 \mathrm{~h} 05 \mathrm{~min}$ \\
\hline $22 / 08 / 12$ & M14 & $15 \mathrm{~h} 20 \mathrm{~min}$ & $16 \mathrm{~h} 10 \mathrm{~min}$ \\
\hline \hline $2 / 08 / 12$ & M5 & $13 \mathrm{~h} 40 \mathrm{~min}$ & $14 \mathrm{~h} 40 \mathrm{~min}$ \\
\hline M7 & $08 \mathrm{~h} 50 \mathrm{~min}$ & $10 \mathrm{~h} 05 \mathrm{~min}$ \\
\hline
\end{tabular}

\subsection{Instrumentação}

As medidas de deformações nas barras das armaduras dos modelos foram obtidas por meio de extensômetros elétricos de resistência uniaxiais da marca Kyowa, com base de medida de $5 \mathrm{~mm}$ e fator de extensômetro igual a 2,10, os quais foram colados nas barras das armaduras dos blocos, cálices e pilares. 
Em todos os blocos foram instrumentadas as barras das armaduras principais do tirante. Esses extensômetros foram posicionados em três seções específicas, sendo duas delas posicionadas sobre o centro geométrico das estacas e a outra na região central do bloco. Em cada uma dessas seções, cogitou-se instrumentar as cinco barras da armadura principal do tirante. Porém, em virtude da simetria dos modelos, optou-se por utilizar apenas três extensômetros em uma das seções sobre as estacas, conforme Figura 4.47.

A armadura dos pilares foi instrumentada em duas barras longitudinais com três extensômetros em cada barra, totalizando seis extensômetros por pilar. O objetivo da utilização desses extensômetros era verificar por meio das medidas das deformações nessas barras se a força proveniente do pilar era transferida para o bloco ao longo do embutimento do pilar, ou se a transferência de força ocorria diretamente pela região inferior do pilar.

A armadura do cálice foi instrumentada em dois pontos, sendo um deles na posição horizontal na região central do bloco e outro na posição vertical. O objetivo dessa instrumentação foi o mesmo apresentado para os pilares, sendo que apenas os blocos com cálice parcialmente embutido e embutido tiveram sua armadura instrumentada. Quanto a armadura complementar utilizada nos blocos com cálice parcialmente embutido e embutido, instrumentou-se essas armaduras em duas posições ao longo da vertical. A utilização dessa armadura complementar na região central do bloco tinha como objetivo auxiliar na suspensão da força oriunda do pilar, caso a transmissão dessa força não ocorresse a partir do encontro do pilar com o bloco.
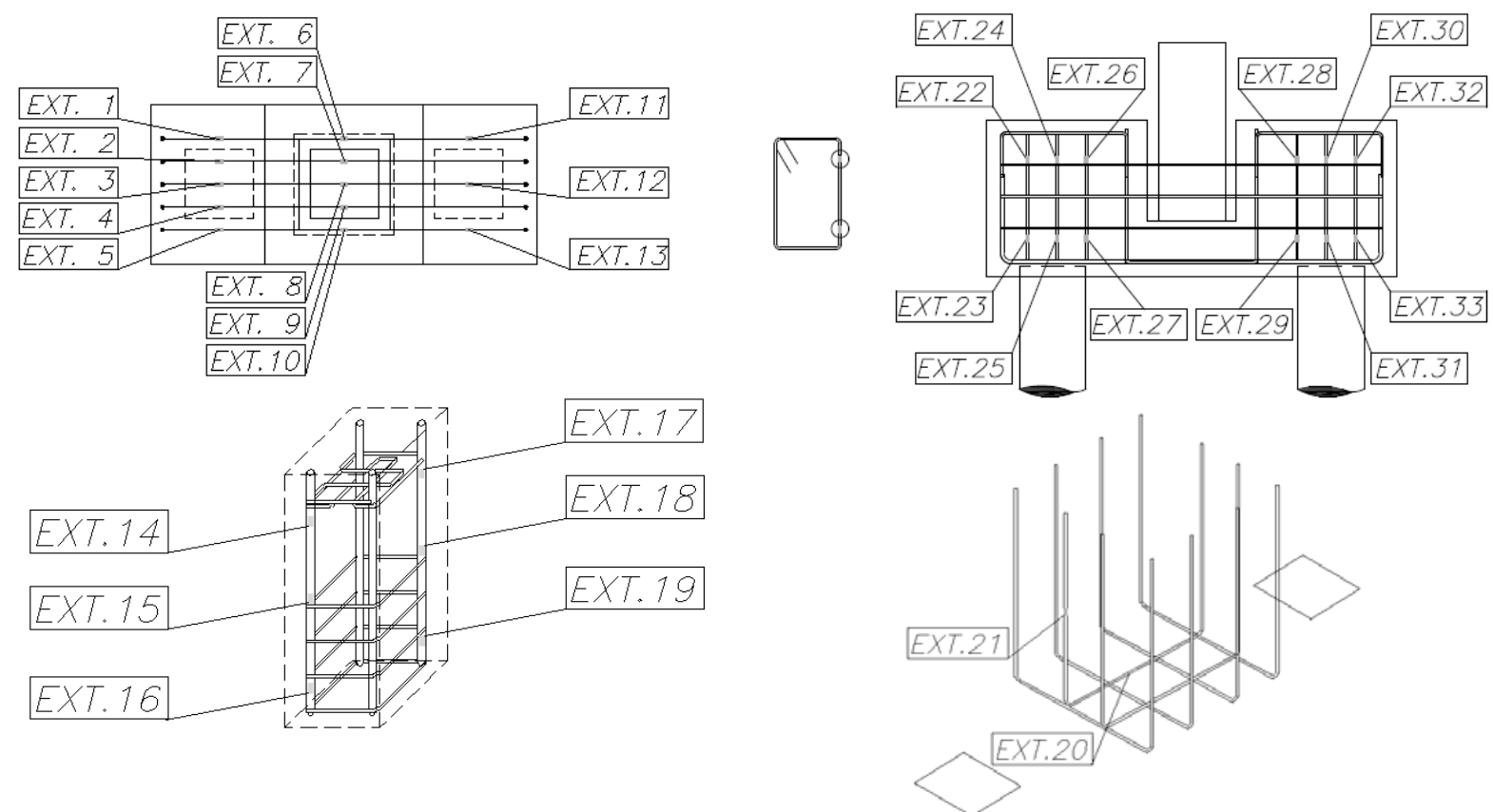

Figura 4. 47- Posicionamento dos extensômetros nas barras das armaduras 
A quantidade de extensômetros utilizados em cada modelo variou em função das armaduras que foram instrumentadas. Os modelos que apresentaram menor quantidade de extensômetros foram os dos blocos de referência (M1 e M8), que possuíam extensômetros apenas nas barras da armadura principal do bloco, enquanto que os modelos que apresentaram maior quantidade de extensômetros foram os de cálice parcialmente embutido e embutido com armadura complementar (M5, M7, M12 e M14), os quais apresentaram 33 extensômetros cada um. A Tabela 4.3 apresenta o total de extensômetros utilizados em cada modelo.

Tabela 4.3 - Total de extensômetros em cada modelo

\begin{tabular}{|c|c|c|}
\hline Modelo & Posição e quantidades & Total \\
\hline M1 & Armadura do Bloco (13) & 13 \\
\hline M2 & Armadura do Bloco (13) e Pilares (6) & 19 \\
\hline M3 & Armadura do Bloco (13) e Pilares (6) & 19 \\
\hline M4 & Armadura do Bloco (13) e Pilares (6) e Cálices (2) & 21 \\
\hline M5 & Armadura do Bloco (13) e Pilares (6) e Cálices (2) e complementar (12) & 33 \\
\hline M6 & Armadura do Bloco (13) e Pilares (6) e Cálices (2) & 21 \\
\hline M7 & Armadura do Bloco (13) e Pilares (6) e Cálices (2) e complementar (12) & 33 \\
\hline M8 & Armadura do Bloco (13) & 13 \\
\hline M9 & Armadura do Bloco (13) e Pilares (6) & 19 \\
\hline M10 & Armadura do Bloco (13) e Pilares (6) & 19 \\
\hline M11 & Armadura do Bloco (13) e Pilares (6) e Cálices (2) & 21 \\
\hline M12 & Armadura do Bloco (13) e Pilares (6) e Cálices (2) e complementar (12) & 33 \\
\hline M13 & Armadura do Bloco (13) e Pilares (6) e Cálices (2) & 21 \\
\hline M14 & Armadura do Bloco (13) e Pilares (6) e Cálices (2) e complementar (12) & 33 \\
\hline
\end{tabular}

As deformações no concreto dos blocos foram medidas por meio da utilização de pastilhas de aço fixadas em uma das faces dos blocos. A utilização dessas pastilhas mostrouse eficiente nos ensaios de blocos de fundação realizados por DELALIBERA (2006). Trata-se de uma pastilha de aço com uma esfera metálica fixada no centro da pastilha. A medida de 
deformação foi realizada por meio de extensômetro mecânico removível, modelo Tensotast, fabricado pela Hugenberger. Foram utilizados extensômetros mecânicos com sensibilidade de $0,001 \mathrm{~mm}$ e base de $50 \mathrm{~mm}$, possibilitando a obtenção de valores de deformação de até 0,02\%. A Figura 4.48 apresenta as pastilhas e o extensômetro removível mecânico utilizado para realizar as leituras de deformação.

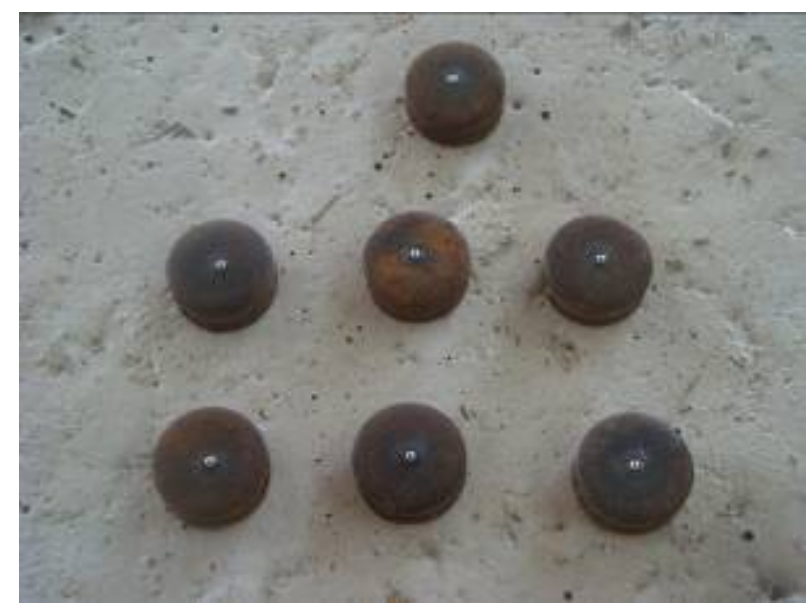

(a)

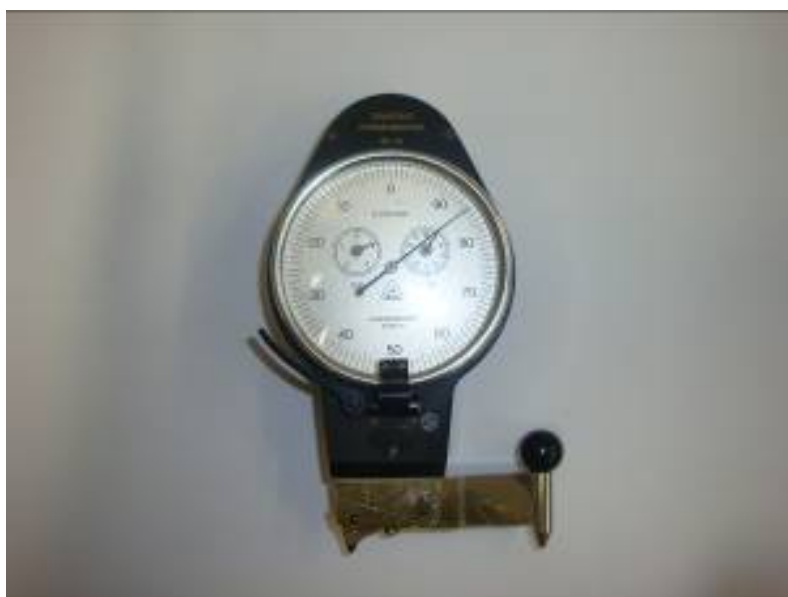

(b)

Figura 4. 48- Pastilhas de aço e extensômetro removível mecânico

Em função da simetria dos blocos sobre duas estacas e da ação ser aplicada no pilar de modo centrado, optou-se por instrumentar apenas um dos lados dos modelos, diminuindo assim a quantidade de pastilhas de aço utilizadas. Foi utilizada como padrão a fixação das pastilhas de aço no lado do bloco que possuía todas as barras da armadura longitudinal instrumentadas. As pastilhas foram fixadas em forma de roseta, a partir das quais obtiveramse as medidas de deformações $\varepsilon_{0^{\circ}}(1$ e 2$), \varepsilon_{90^{\circ}}(3$ e 4$)$ e $\varepsilon_{45^{\circ}}$ (5 e 6), conforme Figura 4.49.

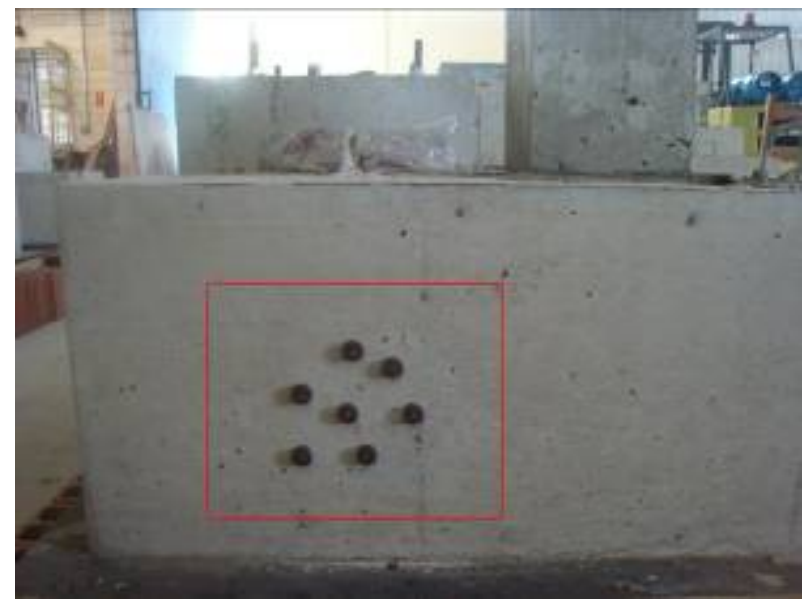

(a)

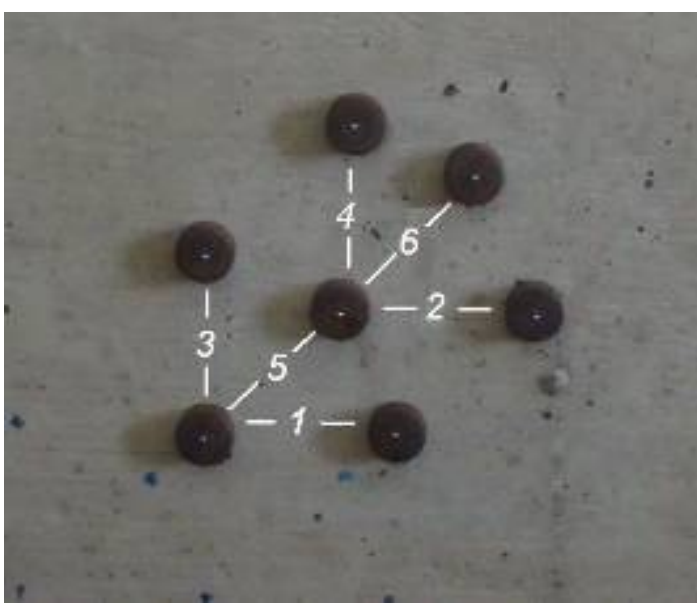

(b)

Figura 4. 49- Indicação das leituras de deformações no concreto dos blocos 
Para obtenção dos seis valores de deformação apresentados na figura anterior, foram utilizadas sete pastilhas em cada modelo, totalizando 98 pastilhas de aço. As deformações principais $\varepsilon_{1}$ e $\varepsilon_{2}$ podem ser obtidas por meio das equações 4.1 e 4.2 , e as direções $\alpha_{1}$ e $\alpha_{2}$ em que ocorrem essas deformações por meio das equações 4.3 e 4.4. Outras informações sobre a obtenção das medidas de deformações utilizando extensômetro mecânico removível podem ser encontradas em TAKEYA (2001).

$$
\begin{aligned}
& \varepsilon_{1}=\frac{1}{2} \cdot\left[\varepsilon_{0^{\circ}}+\varepsilon_{90^{\circ}}+\sqrt{\left(\varepsilon_{0^{\circ}}-\varepsilon_{90^{\circ}}\right)^{2}+\left(2 \cdot \varepsilon_{45^{\circ}}-\varepsilon_{0^{\circ}}-\varepsilon_{90^{\circ}}\right)^{2}}\right] \\
& \varepsilon_{2}=\frac{1}{2} \cdot\left[\varepsilon_{0^{\circ}}+\varepsilon_{90^{\circ}}-\sqrt{\left(\varepsilon_{0^{\circ}}-\varepsilon_{90^{\circ}}\right)^{2}+\left(2 \cdot \varepsilon_{45^{\circ}}-\varepsilon_{0^{\circ}}-\varepsilon_{90^{\circ}}\right)^{2}}\right] \\
& \alpha_{1}=\frac{1}{2} \arctan \cdot\left(\frac{2 \cdot \varepsilon_{45^{\circ}}-\varepsilon_{0^{\circ}}-\varepsilon_{90^{\circ}}}{\varepsilon_{0^{\circ}}-\varepsilon_{90^{\circ}}}\right) \\
& \alpha_{2}=\alpha_{1}+90^{\circ}
\end{aligned}
$$

As medidas dos deslocamentos nos modelos foram obtidas por meio da utilização de cinco transdutores de deslocamento com curso de $50 \mathrm{~mm}$, posicionados em pontos específicos do bloco. Posicionaram-se dois transdutores $T_{1}$ e $T_{2}$ na região inferior do bloco para medir o deslocamento na direção vertical (direção $\mathrm{z}$ ), um transdutor $\mathrm{T}_{3}$ na lateral oposta a que foi fixada as pastilhas de aço (direção y), um transdutor $\mathrm{T}_{4}$ na direção longitudinal (direção $\mathrm{x}$ ) e um último transdutor $\mathrm{T}_{5}$ na região inferior de uma das estacas. Com os valores de deslocamentos obtidos com os transdutores T3, T4 e T5, foi possível avaliar se o modelo estava tombando lateralmente, e se as estacas estavam se deslocando em relação aos aparelhos de apoio.

Como aparelho de apoio utilizaram-se duas células de carga com capacidade de 2000 $\mathrm{kN}$ cada uma. Sobre essas células foi posicionada uma base de aço cilíndrica, utilizada para dar altura aos modelos e facilitar a centralização dos mesmos na máquina de ensaio. Essas células de carga foram utilizadas por DELALIBERA (2006), e encontravam-se disponíveis no laboratório de estruturas. As Figuras 4.50 a 4.52 apresentam o posicionamento do bloco na máquina de ensaio, o aparelho de apoio e os transdutores de deslocamento utilizados. 


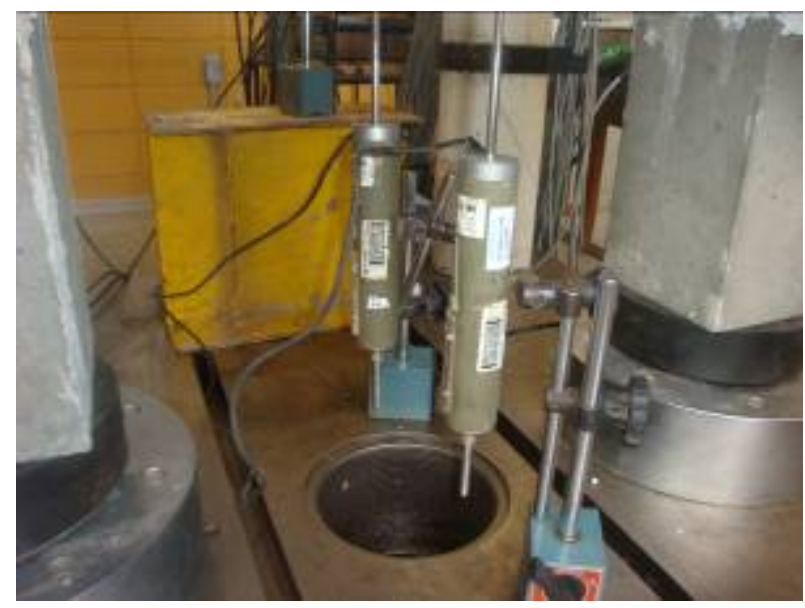

(a)

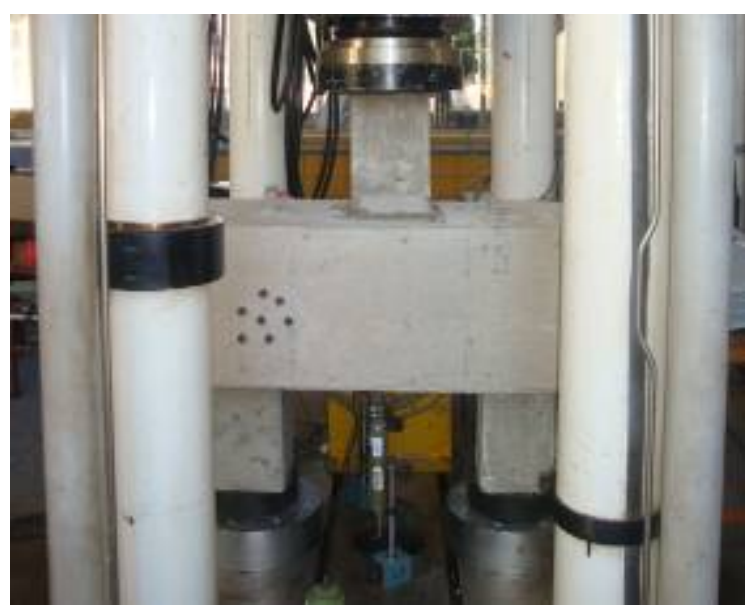

(b)

Figura 4. 50 - Transdutores de deslocamento T1 e T2

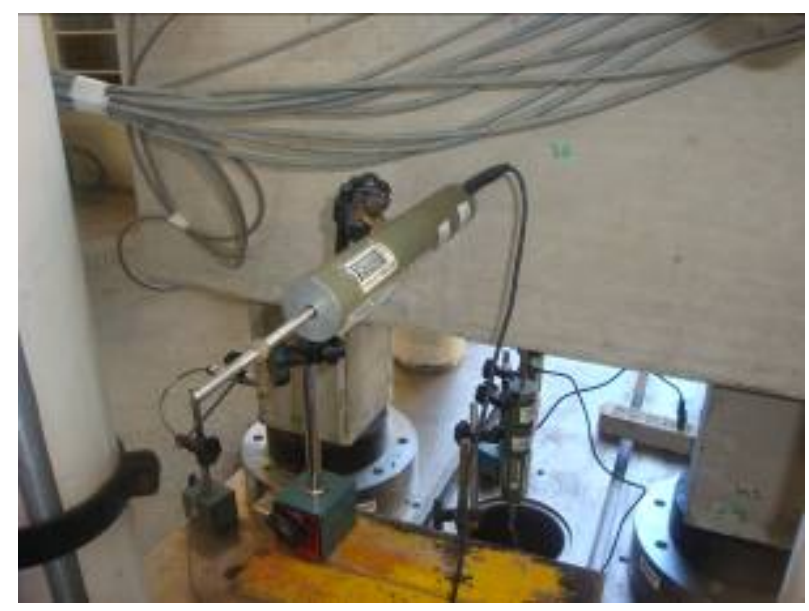

(a)

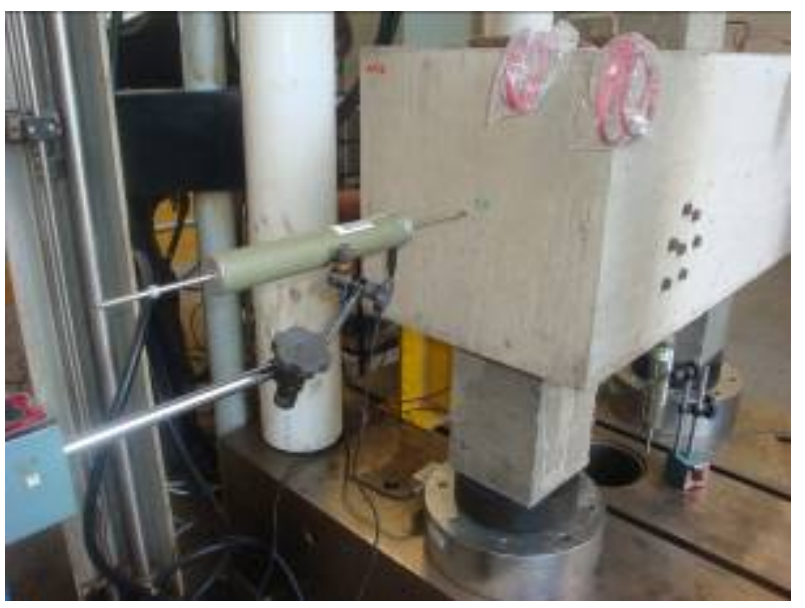

(b)

Figura 4. 51 - Transdutores de deslocamento T3 e T4

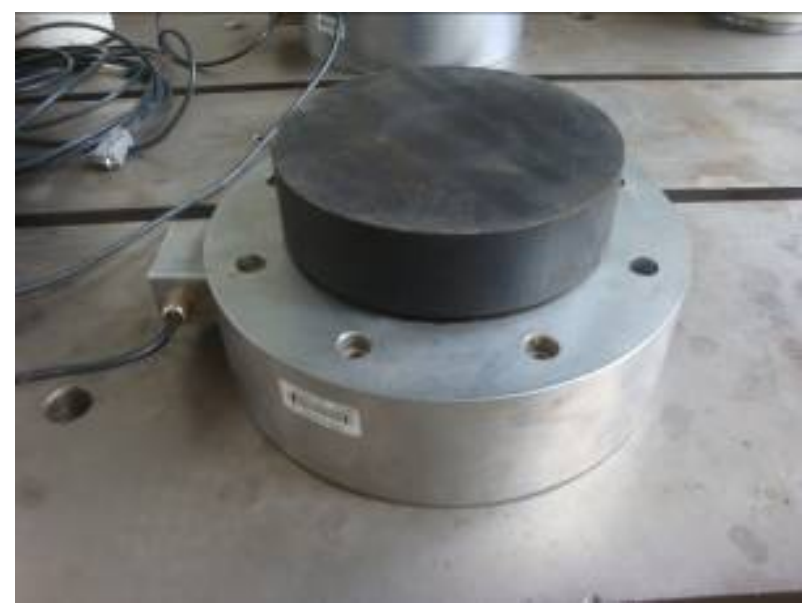

(a)

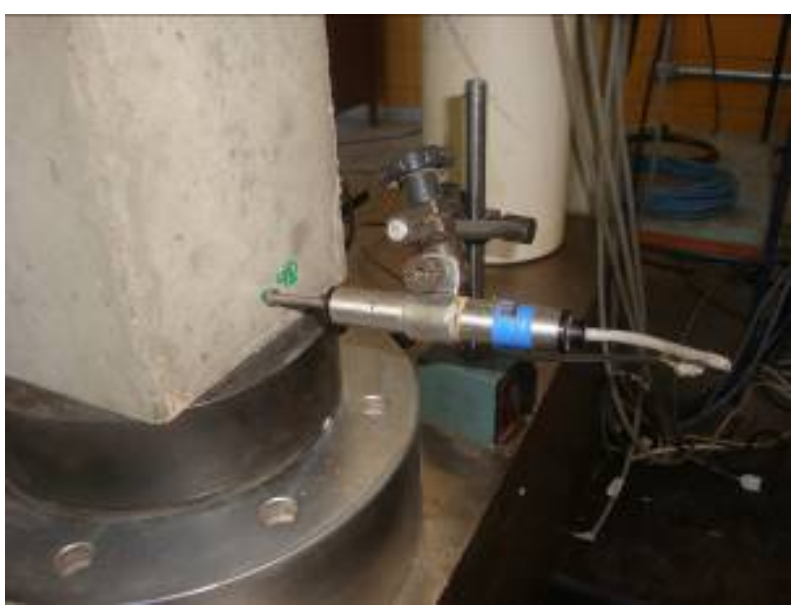

(b)

Figura 4. 52 - Transdutor de deslocamento $T_{5}$ e aparelho de apoio 
A utilização da placa rígida sob as estacas apresentada na Figura 4.52 foi feita para manter o padrão dos ensaios realizados anteriormente por outros pesquisadores nesta instituição. Além disso, verificou-se por meio de simulações numéricas que a utilização desse tipo de apoio não provoca alteração na distribuição de tensões no interior do bloco de fundação.

O transporte dos blocos foi feito com auxílio da ponte rolante existente no Laboratório de Estruturas, e o posicionamento se deu com auxílio de um macaco hidráulico, conforme apresentado na Figura 4.53. A centralização do bloco na máquina foi feita manualmente. A aplicação da força nos pilares foi feita por meio da máquina universal Instron 8506, com deslocamento controlado, e velocidade constante e igual a $0,002 \mathrm{~mm} / \mathrm{s}$.

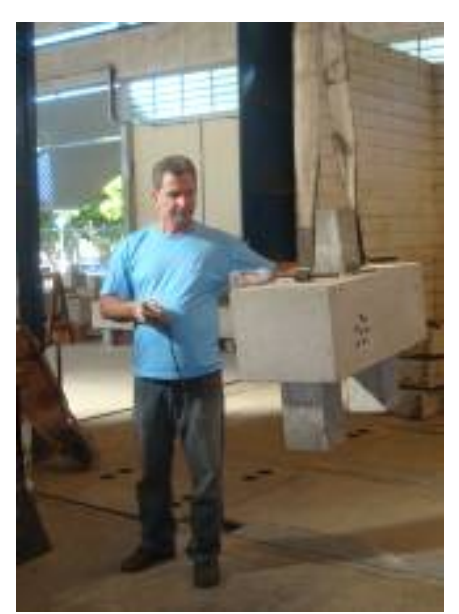

(a)

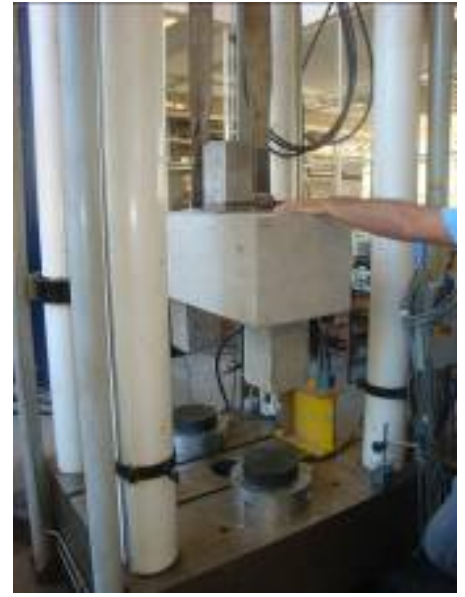

(b)

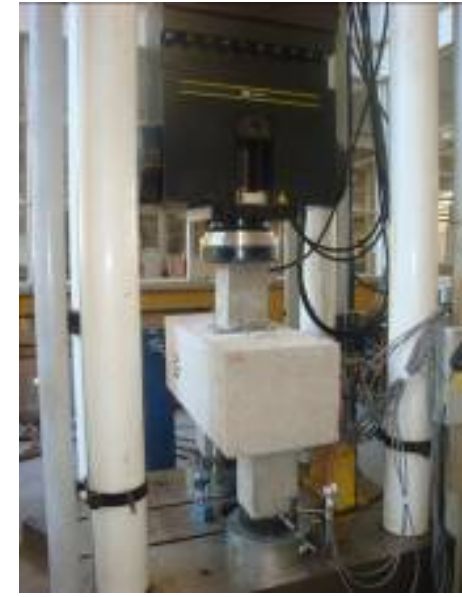

(c)

Figura 4. 53- Posicionamento dos blocos na máquina de ensaio

\subsection{Comentários Finais}

Apresentou-se nesse capítulo o programa experimental que foi realizado no laboratório de estruturas da escola de engenharia de São Carlos. Foram apresentadas as etapas de montagem das fôrmas e das armaduras, bem como da concretagem dos elementos estruturais. Apresentou-se ainda os equipamentos que foram utilizados nos ensaios e a instrumentação necessária para a realização dos ensaios. O Capítulo a seguir apresenta os resultados do programa experimental. 



\section{Resultados experimentais}

\subsection{Considerações iniciais}

Apresentam-se neste capítulo os prinicipais resultados obtidos nos ensaios do programa experimental descrito no capítulo 4. Inicialmente são apresentados os resultados das propriedades dos materiais, seguido dos resultados dos ensaios dos modelos em escala reduzida.

\subsection{Propriedades dos materiais}

Este item apresenta os resultados da análise das propriedades dos materiais utilizados na montagem dos modelos. Para o graute e o concreto utilizados nos modelos são apresentados resultados de resitência à compressão, resistência à tração e módulos de elasticidade estático e dinâmico. Ao todo foram moldados cinquenta e dois corpos-de-prova cilíndricos, sendo 40 com dimensões iguais a dez centímetros de diâmetro e vinte centímetros de altura, e outros 12 com cinco centímetros de diâmetro e dez centímetros de altura.

Em relação às barras de aço das armaduras, foram obtidos valores de resistência à tração simples e módulo de elasticidade, sendo utilizadas três barras para cada diâmetro estudado.

\subsubsection{Ensaios de compressão em corpos-de-prova de concreto}

Para determinação da resistência à compressão dos corpos-de-prova cilíndricos de concreto, utilizaram-se as recomendações da ABNT NBR 5739:2007. Os resultados para os concretos das estacas, pilares e grautes foram obtidos a partir de quatro corpos-de-prova, enquanto que para o concreto dos blocos utilizaram-se seis corpos-de-prova. Os ensaios foram realizados na máquina hidráulica ELE, Autotest 2000, com taxa de carregamento igual a 0,5 $\mathrm{MPa} / \mathrm{s}$. As tabelas 5.1 à 5.4 apresentam os valores de força última $\left(\mathrm{F}_{\text {últ }}\right)$, resistência à compressão de cada corpo-de-prova $\left(f_{c}\right)$, resistência à compressão média $\left(f_{c, m}\right)$ e desvio padrão 
dos resultados dos ensaios. Todos os corpos-de-prova apresentaram ruptura por cisalhamento conforme ABNT NBR 5739:2007.

Tabela 5.1 - Valores de resistência à compressão para o concreto dos pilares

\begin{tabular}{c|c|c|c|c|c|c}
\hline \hline \multirow{2}{*}{ Elemento } & Idade & $\mathbf{C P}$ & $\mathbf{F}_{\text {últ }}(\mathbf{k N})$ & $\mathbf{f}_{\mathbf{c}}(\mathbf{M P a})$ & $\mathbf{f}_{\mathbf{c}, \mathbf{m}} \mathbf{( M P a )}$ & $\begin{array}{c}\text { desvio } \\
\text { (MPa) }\end{array}$ \\
\hline \multirow{2}{*}{ Pilares } & \multirow{2}{*}{51 dias } & 1 & 351,80 & 44,8 & & \\
\cline { 3 - 5 } & & 2 & 310,80 & 39,6 & \multirow{2}{*}{37,7} & 5,67 \\
\cline { 3 - 5 } & & 3 & 254,00 & 32,4 & & \\
\cline { 3 - 5 } & & 4 & 266,00 & 33,9 & & \\
\hline \hline
\end{tabular}

Tabela 5.2 - Valores de resistência à compressão para o concreto das estacas

\begin{tabular}{c|c|c|c|c|c|c}
\hline \hline \multirow{2}{*}{ Elemento } & Idade & $\mathbf{C P}$ & $\mathbf{F}_{\text {últ }}(\mathbf{k N})$ & $\mathbf{f}_{\mathbf{c}}(\mathbf{M P a})$ & $\mathbf{f}_{\mathbf{c}, \mathbf{m}}(\mathbf{M P a})$ & $\begin{array}{c}\text { desvio } \\
\text { (MPa) }\end{array}$ \\
\hline \multirow{2}{*}{ Estacas } & \multirow{2}{*}{93 dias } & 1 & 603,00 & 76,8 & & \\
\cline { 3 - 5 } & & 2 & 627,50 & 80,0 & \multirow{2}{*}{70,5} & \multirow{2}{*}{9,1} \\
\cline { 3 - 5 } & & 4 & 488,00 & 62,3 & & \\
\cline { 3 - 5 } & & 4 & 494,00 & 63,0 & & \\
\hline \hline
\end{tabular}

Tabela 5.3 - Valores de resistência à compressão do graute

\begin{tabular}{c|c|c|c|c|c|c}
\hline \hline \multirow{2}{*}{ Elemento } & Idade & $\mathbf{C P}$ & $\mathbf{F}_{\text {últ }}(\mathbf{k N})$ & $\mathbf{f}_{\mathbf{c}}(\mathbf{M P a})$ & $\mathbf{f}_{\mathbf{c}, \mathbf{m}}(\mathbf{M P a})$ & $\begin{array}{c}\text { desvio } \\
\text { (MPa) }\end{array}$ \\
\hline \multirow{2}{*}{ Graute } & \multirow{2}{*}{37 dias } & 1 & 131,00 & 66,7 & & \\
\cline { 3 - 5 } & & 2 & 126,50 & 64,4 & \multirow{2}{*}{64,2} & \multirow{2}{*}{2,69} \\
\cline { 3 - 5 } & & 4 & 128,00 & 65,2 & & \\
\hline \hline
\end{tabular}


Tabela 5.4 - Valores de resistência à compressão para o concreto dos blocos

\begin{tabular}{|c|c|c|c|c|c|c|}
\hline Elemento & Idade & $\mathbf{C P}$ & $F_{\text {últ }}$ & $\mathbf{f}_{\mathrm{c}}(\mathbf{M P a})$ & $\mathbf{f}_{\mathrm{c}, \mathrm{m}}(\mathrm{MPa})$ & $\begin{array}{l}\text { desvio } \\
\text { (MPa) }\end{array}$ \\
\hline \multirow{6}{*}{ Blocos } & \multirow{6}{*}{59 dias } & 1 & 228,00 & 29,2 & \multirow{6}{*}{33,1} & \multirow{6}{*}{2,56} \\
\hline & & 2 & 246,00 & 31,4 & & \\
\hline & & 3 & 280,00 & 35,7 & & \\
\hline & & 4 & 277,00 & 35,4 & & \\
\hline & & 5 & 270,00 & 34,5 & & \\
\hline & & 6 & 252,00 & 32,2 & & \\
\hline
\end{tabular}

O resultado para resistência média de $37,7 \mathrm{MPa}$ para o concreto dos pilares foi muito aquém do esperado, não correpondendo ao traço utilizado. Nesse aspecto, destaca-se que a única diferença entre o traço utilizado no concreto das estacas e o traço do concreto dos pilares foi a marca do cimento utilizado. Enquanto para as estacas utilizou-se cimento da marca Cauê, para os pilares utilizou-se cimento da marca Holcim. Entende-se que a mudança da marca do cimento não deve ser a única responsável pelos resultados, porém toda a medição e controle dos materiais foi feita cuidadosamente pelo autor antes e durante a concretagem.

A separação dos materiais para pesagem e secagem ocorreu, no caso dos pilares, cinco dias antes da concretagem, de modo que a brita e a areia utilizadas não foram afetadas pelas chuvas que ocorreram no final de semana anterior a concretagem. Em função dos resultados obtidos para a resistência à compressão dos pilares, existiu a possibilidade de ruína desse elemento antes da ruína do bloco.

Verifica-se por meio dos resultados apresentados nas tabelas 5.1 à 5.4 que o concreto das estacas foi o que apresentou maior resistência à compressão, porém com variabilidade elevada. O valor de resistência média igual a 70,5 $\mathrm{MPa}$ indica ser pouco provável que ocorra a ruína desse elemento estrutural antes da ruína do bloco. Situação semelhante ocorreu para o graute utilizado, sendo que esse elemento apresentou pouca variabilidade nos resultados, apresentando valor de resisência média à compressão igual a 64,2 MPa.

O concreto utilizado nos blocos foi fornecido por central dosadora de concreto, e apresentou resistência média à compressão igual a 33,1 MPa, valor esse compatível com o 
concreto da classe C25 que foi encomendado. Verifica-se que esse concreto foi o que apresentou menor variabilidade nos resultados. Apesar do valor de resistência apresentado pelo concreto dos pilares, verifica-se que o menor valor de resistência à compressão ocorreu para o concreto dos blocos, conforme previsto na etapa de dimensionamento dos modelos.

\subsubsection{Ensaios à tração por compressão diametral em corpos-de-prova de concreto}

Os ensaios à tração por compressão diametral foram realizados na máquina ELE, Autotest 2000, de acordo com as recomendações da ABNT NBR 7222:2011. Os resultados para os concretos das estacas, pilares, grautes e blocos foram obtidos a partir de quatro corpos-de-prova. Os ensaiso foram realizados com taxa de carregamento igual a $0,06 \mathrm{MPa} / \mathrm{s}$, e a resistência à tração por compressão diametral foi obtida a partir da equação 5.1

$\mathrm{f}_{\mathrm{tD}}=\frac{2 \cdot \mathrm{F}}{\pi \cdot \mathrm{d} \cdot \mathrm{L}}$

Sendo que:

$\mathrm{f}_{\mathrm{tD}}$ é o valor da resistência à tração por compressão diametral;

F é a força máxima obtida no ensaio;

d é o diâmetro da seção do corpo-de-prova e;

L é o comprimento do corpo-de-prova.

A partir dos valores de resistência à tração por compressão diâmetral, pode-se estimar o valor da resistência à tração direta, $f_{c t}$. De acordo com METHA e MONTEIRO (2008) a resistência a tração direta é de $10 \%$ a $15 \%$ menor do que a resistência a tração indireta, obtida por meio do ensaio de compressão diametral. A ABNT NBR 6118:2007 estabelece que a resistência a tração direta pode ser estimada como sendo $90 \%$ do valor da resistência a tração indireta. Desse modo, optou-se por apresentar os valores de resitência de acordo com o sugerido na referida norma, isto é, multiplicando os resultados obtidos nos ensaios por 0,90.

As tabelas 5.5 à 5.8 apresentam os valores de força última $\left(\mathrm{F}_{\text {últ }}\right)$, resistência à tração por compressão diametral de cada corpo-de-prova $\left(\mathrm{f}_{\mathrm{tD}}\right)$, resistência à tração direta de cada corpode-prova $\left(\mathrm{f}_{\mathrm{ct}}\right)$, resistência à tração por compressão diametral média $\left(\mathrm{f}_{\mathrm{t}, \mathrm{m}}\right)$, resistência média à tração direta $\left(\mathrm{f}_{\mathrm{ct}, \mathrm{m}}\right)$, e desvio padrão dos resultados dos corpos-de-prova. 
Resultados experimentais

Tabela 5.5 - Valores de resistência à tração para o concreto dos pilares

\begin{tabular}{|c|c|c|c|c|c|c|}
\hline Elemento & Idade & $\mathbf{C P}$ & $F_{\text {últ }}(\mathbf{k N})$ & $\begin{array}{l}\mathbf{f}_{\mathrm{tD}} / \mathbf{f}_{\mathrm{ct}} \\
(\mathrm{MPa})\end{array}$ & $\begin{array}{c}\mathbf{f}_{\mathrm{t}, \mathrm{m}} / \mathbf{f}_{\mathrm{ct}, \mathrm{m}} \\
(\mathbf{M P a})\end{array}$ & $\begin{array}{l}\text { desvio } \\
\text { (MPa) }\end{array}$ \\
\hline \multirow{4}{*}{ Pilares } & \multirow{4}{*}{50 dias } & 1 & 89,10 & $2,84 / 2,56$ & \multirow{4}{*}{$3,09 / 2,78$} & \multirow{4}{*}{$0,26 / 0,23$} \\
\hline & & 2 & 93,10 & $2,96 / 2,66$ & & \\
\hline & & 3 & 108,30 & $3,44 / 3,10$ & & \\
\hline & & 4 & 98,50 & $3,13 / 2,82$ & & \\
\hline
\end{tabular}

Tabela 5.6 - Valores de resistência à tração para o concreto das estacas

\begin{tabular}{|c|c|c|c|c|c|c|}
\hline Elemento & Idade & $\mathrm{CP}$ & $\mathbf{F}_{\text {últ }}(\mathbf{k N})$ & $\begin{array}{l}\mathbf{f}_{\mathrm{tD}} / \mathbf{f}_{\mathrm{ct}} \\
(\mathrm{MPa})\end{array}$ & $\begin{array}{c}\mathbf{f}_{\mathrm{t}, \mathrm{m}} / \mathbf{f}_{\mathrm{ct}, \mathrm{m}} \\
(\mathbf{M P a})\end{array}$ & $\begin{array}{l}\text { desvio } \\
\text { (MPa) }\end{array}$ \\
\hline \multirow{4}{*}{ Estacas } & \multirow{4}{*}{92 dias } & 1 & 137,3 & $4,37 / 3,93$ & \multirow{4}{*}{$4,89 / 4,40$} & \multirow{4}{*}{$0,63 / 0,57$} \\
\hline & & 2 & 140,3 & $4,46 / 4,01$ & & \\
\hline & & 3 & 156,0 & $4,97 / 4,47$ & & \\
\hline & & 4 & 180,7 & $5,75 / 5,18$ & & \\
\hline
\end{tabular}

Tabela 5.7 - Valores de resistência à tração para o graute

\begin{tabular}{|c|c|c|c|c|c|c|}
\hline Elemento & Idade & $\mathbf{C P}$ & $F_{\text {últ }}(\mathbf{k N})$ & $\begin{array}{l}\mathbf{f}_{\mathrm{tD}} / \mathbf{f}_{\mathrm{ct}} \\
(\mathrm{MPa})\end{array}$ & $\begin{array}{c}\mathbf{f}_{\mathrm{t}, \mathrm{m}} / \mathbf{f}_{\mathrm{ct}, \mathrm{m}} \\
(\mathbf{M P a})\end{array}$ & $\begin{array}{l}\text { desvio } \\
\text { (MPa) }\end{array}$ \\
\hline \multirow{4}{*}{ Graute } & \multirow{4}{*}{36 dias } & 1 & 30,7 & $3,90 / 3,51$ & \multirow{4}{*}{$3,56 / 3,20$} & \multirow{4}{*}{$0,63 / 0,57$} \\
\hline & & 2 & 22,9 & $2,91 / 2,62$ & & \\
\hline & & 3 & 24,7 & $3,15 / 2,84$ & & \\
\hline & & 4 & 33,5 & $4,26 / 3,83$ & & \\
\hline
\end{tabular}


Tabela 5.8 - Valores de resistência à tração para o concreto dos blocos

\begin{tabular}{|c|c|c|c|c|c|c|}
\hline Elemento & Idade & $\mathbf{C P}$ & $\mathbf{F}_{\text {últ }}(\mathbf{k N})$ & $\begin{array}{l}\mathbf{f}_{\mathrm{tD}} / \mathbf{f}_{\mathrm{ct}} \\
(\mathrm{MPa})\end{array}$ & $\begin{array}{c}\mathbf{f}_{\mathrm{t}, \mathrm{m}} / \mathbf{f}_{\mathrm{ct}, \mathrm{m}} \\
(\mathbf{M P a})\end{array}$ & $\begin{array}{l}\text { desvio } \\
\text { (MPa) }\end{array}$ \\
\hline \multirow{4}{*}{ blocos } & \multirow{4}{*}{58 dias } & 1 & 76,7 & $2,44 / 2,20$ & \multirow{4}{*}{$2,47 / 2,22$} & \multirow{4}{*}{$0,15 / 0,14$} \\
\hline & & 2 & 84,3 & $2,68 / 2,41$ & & \\
\hline & & 3 & 72,9 & $2,32 / 2,09$ & & \\
\hline & & 4 & 76,3 & $2,43 / 2,19$ & & \\
\hline
\end{tabular}

Observa-se por meio dos resultados apresentados anteriormente que o concreto com maior resistência à tração direta foi o das estacas, apresentando uma resistência igual a 4,40 $\mathrm{MPa}$, e que o menor valor de resistência média a tração direta foi o dos blocos, com valor igual a 2,22 MPa. Verifica-se ainda que a variabilidade nos resultados foi pequena em todos os elementos analisados.

\subsubsection{Ensaios para determinação do módulo de elasticidade estático do concreto}

Este item apresenta os valores de módulo de elasticidade do concreto. Conforme apresentado no capítulo 4, foram realizados ensaios para determinação dos valores de módulo de elasticidade estático e dinâmico. O módulo de elasticidade estático ou módulo de deformação tangente inicial foi obtido a partir das recomendações da ABNT NBR 8522:2003, na qual determinou-se a inclinação da reta que corta o gráfico tensão versus deformação no concreto, nos pontos cuja tensão corresponde a $0,5 \mathrm{MPa}$ e $30 \%$ de $\mathrm{f}_{\mathrm{c}}$. A ABNT NBR 6118:2007 permite que na etapa de projeto o módulo de deformação inicial do concreto seja estimado a partir da resistência característica à compressão $\mathrm{f}_{\mathrm{ck}}$, conforme equação 5.2.

$\mathrm{E}_{\mathrm{ci}}=5600 \cdot \sqrt{\mathrm{f}_{\mathrm{ck}}}$

As tabelas 5.9 a 5.12 apresentam os valores de módulo de deformação tangente incial experimental de cada corpo-de-prova $\left(\mathrm{E}_{\mathrm{ci}, \exp }\right)$, módulo de deformação tangente incial experimental médio ( $\left.\mathrm{E}_{\mathrm{ci} \text { exp,m }}\right)$, módulo de deformação tangente inicial estimado a partir da NBR 6118:2003 ( $\left.\mathrm{E}_{\mathrm{ci}}\right)$, e desvio padrão dos corpos-de-prova. 
Resultados experimentais

Tabela 5.9 - Módulo de deformação tangente inicial para o concreto dos pilares

\begin{tabular}{|c|c|c|c|c|c|c|c|}
\hline Elemento & Idade & $\mathbf{C P}$ & $\begin{array}{l}\mathbf{E}_{\text {ci,exp }} \\
\text { (GPa) }\end{array}$ & $\begin{array}{c}\text { E }_{\text {ci,exp,m }} \\
\text { (GPa) }\end{array}$ & $\begin{array}{c}\mathbf{E}_{\mathbf{c i}} \\
(\mathbf{G P a})\end{array}$ & $\underset{\mathbf{E}_{\mathbf{c i}, \exp , \mathbf{m}} /}{\mathbf{E}_{\mathbf{c i}}}$ & $\begin{array}{l}\text { desvio } \\
\text { (GPa) }\end{array}$ \\
\hline \multirow{4}{*}{ Pilares } & \multirow{4}{*}{53 dias } & 5 & 28,8 & \multirow{4}{*}{30,05} & \multirow{4}{*}{39,6} & \multirow{4}{*}{0,76} & \multirow{4}{*}{1,07} \\
\hline & & 6 & 29,9 & & & & \\
\hline & & 7 & 31,4 & & & & \\
\hline & & 8 & 30,1 & & & & \\
\hline
\end{tabular}

Tabela 5.10 - Módulo de deformação tangente inicial para o concreto das estacas

\begin{tabular}{|c|c|c|c|c|c|c|c|}
\hline Elemento & Idade & $\mathbf{C P}$ & $\begin{array}{l}\mathbf{E}_{\text {ci,exp }} \\
\text { (GPa) }\end{array}$ & $\begin{array}{c}\text { E }_{\text {ci,exp,m }} \\
\text { (GPa) }\end{array}$ & $\underset{(\mathbf{G P a})}{\mathbf{E}_{\mathrm{ci}}}$ & $\underset{\mathbf{E}}{\mathbf{E}_{\mathbf{c i} \text { exp,m }} /} /$ & $\begin{array}{l}\text { desvio } \\
\text { (GPa) }\end{array}$ \\
\hline \multirow{4}{*}{ Estacas } & \multirow{4}{*}{95 dias } & 5 & 33,0 & \multirow{4}{*}{42,9} & \multirow{4}{*}{39,6} & \multirow{4}{*}{1,08} & \multirow{4}{*}{7,92} \\
\hline & & 6 & 50,4 & & & & \\
\hline & & 7 & 48,0 & & & & \\
\hline & & 8 & 40,1 & & & & \\
\hline
\end{tabular}

Tabela 5.11 - Módulo de deformação tangente inicial para o graute

\begin{tabular}{|c|c|c|c|c|c|c|c|}
\hline Elemento & Idade & $\mathbf{C P}$ & $\begin{array}{c}\mathbf{E}_{\text {ci,exp }} \\
(\mathbf{G P a})\end{array}$ & $\begin{array}{c}\mathbf{E}_{\text {ci,exp,m }} \\
\text { (GPa) }\end{array}$ & $\begin{array}{c}\mathbf{E}_{\mathrm{ci}} \\
(\mathrm{GPa})\end{array}$ & $\begin{array}{c}\mathbf{E}_{\mathbf{c i}, \exp , \mathbf{m}} / \\
\mathbf{E}_{\mathbf{c i}}\end{array}$ & $\begin{array}{l}\text { desvio } \\
\text { (GPa) }\end{array}$ \\
\hline \multirow{4}{*}{ Graute } & \multirow{4}{*}{39 dias } & 5 & 40,8 & \multirow{4}{*}{41,8} & \multirow{4}{*}{39,6} & \multirow{4}{*}{1,05} & \multirow{4}{*}{1,91} \\
\hline & & 6 & 41,6 & & & & \\
\hline & & 7 & 40,20 & & & & \\
\hline & & 8 & 44,50 & & & & \\
\hline
\end{tabular}


Tabela 5.12 - Módulo de deformação tangente inicial para o concreto dos blocos

\begin{tabular}{|c|c|c|c|c|c|c|c|}
\hline Elemento & Idade & $\mathbf{C P}$ & $\begin{array}{l}\mathbf{E}_{\text {ci,exp }} \\
(\mathrm{GPa})\end{array}$ & $\begin{array}{c}\mathbf{E}_{\text {ci,exp,m }} \\
(\text { GPa) }\end{array}$ & $\begin{array}{c}\mathbf{E}_{\mathbf{c i}} \\
(\mathbf{G P a})\end{array}$ & $\underset{\mathbf{E}_{\mathbf{c i}, \exp , \mathbf{m}} /}{\mathbf{E}_{\mathbf{c i}}}$ & $\begin{array}{l}\text { desvio } \\
\text { (GPa) }\end{array}$ \\
\hline \multirow{6}{*}{ blocos } & \multirow{6}{*}{61 dias } & 7 & 23,6 & \multirow{6}{*}{25,2} & \multirow{6}{*}{28,0} & \multirow{6}{*}{0,90} & \multirow{6}{*}{2,43} \\
\hline & & 8 & 28,1 & & & & \\
\hline & & 9 & 22,5 & & & & \\
\hline & & 10 & 26,6 & & & & \\
\hline & & 11 & 27,3 & & & & \\
\hline & & 12 & 23,0 & & & & \\
\hline
\end{tabular}

Observa-se por meio dos resultados apresentados nas tabelas 5.9 à 5.12 que os módulos de deformação tangente para os diversos elementos apresentaram pequena variabilidade, a menos do concreto das estacas que apresentou um desvio padrão igual a 7,92. Atribui-se esse desvio ao valor do módulo de deformação do corpo-de-prova 5, que apresentou um valor igual a 33,0 GPa, valor este destoante dos demais. Acredita-se que pode ter ocorrido um problema durante o ensaio ou durante a etapa de moldagem do corpo-de-prova. Caso esse valor fosse desconsiderado, a variabilidade nos resultados seria menor.

Em relação a comparação dos valores médios experimentais com o valor estimado sugerido pela ABNT NBR 6118:2007, destaca-se que o concreto dos blocos e dos pilares apresentaram-se inferiores as estimativas sugeridas pela norma brasileira. No caso dos pilares, em que o valor de resistência à compressão médio dos pilares foi menor do que o esperado, o módulo de elasticidade inicial estimado pela norma tenderia a ser maior, tendo em vista que o concreto dos pilares não se aproximou da classe C50. Caso tivessem sido encontrados valores de resistência que conduzissem a um concreto da classe C50, o módulo de deformação obtido experimentalmente deveria ser superior ao estimado pela norma. Porém, no caso dos blocos em que a resistência média à compressão indica que este concreto está próximo da classe $\mathrm{C} 25$, o valor estimado pela norma apresentou-se superior aos obtidos em laboratório, o que indica que, para o concreto dos blocos analisados neste trabalho, as estimativas de módulo de deformação tangente utiliziando a ABNT NBR 6118:2003 apresentam-se contra a segurança. 


\subsubsection{Ensaios para determinação do módulo de elasticidade dinâmico do concreto}

Conforme informado no capítulo 4, procedeu-se a realização de ensaios não-destrutivos em corpos-de-prova cilíndricos de concreto. Por meio do programa Sonelastic, foram determinados os valores do módulo de elasticidade dinâmico à flexão e longitudinal. Esses valores são calculados automaticamente pelo programa citado, de acordo com as recomendações da ASTM C215:2008, na qual dependem da geometria e do peso dos corposde-prova, bem como das freqüências naturais de vibração após o impacto mecânico.

Por se tratarem de ensaios não-destrutivos, foi possível realizar os ensaios em um maior número de corpos-de-prova, aproveitando assim os corpos-de-prova que foram utilizados para obtenção da resistência à compressão e do módulo de elasticidade estático do concreto. Apresentam-se nas tabelas 5.13 à 5.16 os resultados dos ensaios dinâmicos, sendo que nas tabelas $\mathrm{E}_{\mathrm{c}, \text { flex }}$ é o módulo de elasticidade dinâmico à flexão de cada corpo-de-prova; $\mathrm{E}_{\mathrm{c}, \text { flex,m }}$ é o módulo de elasticidade dinâmico à flexão médio; $\mathrm{E}_{\mathrm{c}, \text { long }}$ é o módulo de elasticidade dinâmico longitudinal de cada corpo-de-prova; e $\mathrm{E}_{\mathrm{c}, \text { long,m }}$ é o módulo de elasticidade dinâmico longitudinal médio.

Tabela 5.13 - Módulo de elasticidade dinâmico à flexão e longitudinal do concreto dos pilares

\begin{tabular}{|c|c|c|c|c|c|c|c|c|}
\hline Elemento & $\mathbf{C P}$ & Peso (g) & $\begin{array}{c}\mathbf{E}_{\mathbf{c}, \text { flex }} \\
(\mathrm{GPa})\end{array}$ & $\begin{array}{c}\mathbf{E}_{\mathbf{c}, \text { flex,m }} \\
(\mathrm{GPa})\end{array}$ & $\begin{array}{l}\text { desvio } \\
\text { (GPa) }\end{array}$ & $\begin{array}{l}\mathbf{E}_{\mathbf{c}, \text { long }} \\
\text { (GPa) }\end{array}$ & $\begin{array}{c}\mathbf{E}_{c, l o n g, m} \\
\text { (GPa) }\end{array}$ & $\begin{array}{l}\text { desvio } \\
\text { (GPa) }\end{array}$ \\
\hline \multirow{8}{*}{ Pilar } & 1 & 3819,0 & 47,7 & \multirow{8}{*}{42,1} & \multirow{8}{*}{3,78} & 48,1 & \multirow{8}{*}{44,8} & \multirow{8}{*}{3,29} \\
\hline & 2 & 3845,9 & 46,8 & & & 47,9 & & \\
\hline & 3 & 2762,5 & 39,0 & & & 47,0 & & \\
\hline & 4 & 3869,7 & 41,9 & & & 45,4 & & \\
\hline & 5 & 3838,1 & 37,7 & & & 39,1 & & \\
\hline & 6 & 3807,4 & 38,0 & & & 40,6 & & \\
\hline & 7 & 3733,4 & 43,2 & & & 45,3 & & \\
\hline & 8 & 3864,9 & 42,2 & & & 45,1 & & \\
\hline
\end{tabular}


Tabela 5.14 - Módulo de elasticidade dinâmico à flexão e longitudinal do concreto das estacas

\begin{tabular}{|c|c|c|c|c|c|c|c|c|}
\hline Elemento & $\mathbf{C P}$ & Peso (g) & $\begin{array}{c}\mathbf{E}_{c, \text { flex }} \\
(\mathbf{G P a})\end{array}$ & $\begin{array}{c}\mathbf{E}_{\mathrm{c}, \mathrm{flex,m}} \\
(\mathrm{GPa})\end{array}$ & $\begin{array}{l}\text { desvio } \\
\text { (GPa) }\end{array}$ & $\begin{array}{l}\mathbf{E}_{\mathbf{c}, \text { long }} \\
(\mathbf{G P a})\end{array}$ & $\begin{array}{c}\mathbf{E}_{\mathbf{c}, \text { long,m }} \\
\text { (GPa) }\end{array}$ & $\begin{array}{l}\text { desvio } \\
\text { (GPa) }\end{array}$ \\
\hline \multirow{8}{*}{ Estacas } & 1 & 3819,8 & 43,0 & \multirow{8}{*}{49,7} & \multirow{8}{*}{5,32} & 43,2 & \multirow{8}{*}{49,3} & \multirow{8}{*}{4,62} \\
\hline & 2 & 3894,8 & 52,2 & & & 52,2 & & \\
\hline & 3 & 3901,9 & 54,4 & & & 53,2 & & \\
\hline & 4 & 3835,5 & 55,0 & & & 53,0 & & \\
\hline & 5 & 3822,2 & 41,9 & & & 42,8 & & \\
\hline & 6 & 3831,2 & 55,0 & & & 53,0 & & \\
\hline & 7 & 3917,1 & 51,5 & & & 51,3 & & \\
\hline & 8 & 3835,6 & 44,4 & & & 45,4 & & \\
\hline
\end{tabular}

Tabela 5.15 - Módulo de elasticidade dinâmico à flexão e longitudinal do graute

\begin{tabular}{|c|c|c|c|c|c|c|c|c|}
\hline Elemento & $\mathbf{C P}$ & Peso (g) & $\begin{array}{c}\mathbf{E}_{c, f l e x} \\
(\mathbf{G P a})\end{array}$ & $\begin{array}{c}\mathbf{E}_{\mathrm{c,flex,m}} \\
(\mathbf{G P a})\end{array}$ & $\begin{array}{l}\text { desvio } \\
\text { (GPa) }\end{array}$ & $\begin{array}{l}\mathbf{E}_{\mathbf{c}, \text { long }} \\
\text { (GPa) }\end{array}$ & $\begin{array}{c}\mathbf{E}_{\mathbf{c}, \text { long,m }} \\
\text { (GPa) }\end{array}$ & $\begin{array}{l}\text { desvio } \\
\text { (GPa) }\end{array}$ \\
\hline \multirow{8}{*}{ Graute } & 1 & 427,3 & 41,3 & \multirow{8}{*}{41,0} & \multirow{8}{*}{0,50} & 39,9 & \multirow{8}{*}{40,0} & \multirow{8}{*}{0,46} \\
\hline & 2 & 435,1 & 41,4 & & & 40,0 & & \\
\hline & 3 & 429,6 & 40,5 & & & 39,6 & & \\
\hline & 4 & 435,9 & 41,1 & & & 40,2 & & \\
\hline & 5 & 435,3 & 41,4 & & & 40,3 & & \\
\hline & 6 & 446,8 & 41,6 & & & 41,0 & & \\
\hline & 7 & 435,6 & 40,3 & & & 39,6 & & \\
\hline & 8 & 429,1 & 40,6 & & & 39,7 & & \\
\hline
\end{tabular}


Tabela 5.16- Módulo de elasticidade dinâmico à flexão e longitudinal do concreto dos blocos

\begin{tabular}{|c|c|c|c|c|c|c|c|c|}
\hline Elemento & $\mathbf{C P}$ & Peso (g) & $\begin{array}{c}\mathbf{E}_{\mathbf{c}, \text { flex }} \\
(\mathbf{G P a})\end{array}$ & $\begin{array}{c}\mathbf{E}_{\mathbf{c}, \text { flex,m }} \\
\text { (GPa) }\end{array}$ & $\begin{array}{l}\text { desvio } \\
\text { (GPa) }\end{array}$ & $\begin{array}{l}\mathbf{E}_{\text {c,long }} \\
\text { (GPa) }\end{array}$ & $\begin{array}{c}\mathbf{E}_{\mathrm{c}, \text { long,m }} \\
\text { (GPa) }\end{array}$ & $\begin{array}{l}\text { desvio } \\
\text { (GPa) }\end{array}$ \\
\hline \multirow{12}{*}{ Blocos } & 1 & 3714,5 & 30,6 & \multirow{12}{*}{29,9} & \multirow{12}{*}{0,97} & 32,0 & \multirow{12}{*}{31,5} & \multirow{12}{*}{0,75} \\
\hline & 2 & 3727,0 & 29,3 & & & 30,6 & & \\
\hline & 3 & 3713,0 & 30,1 & & & 32,2 & & \\
\hline & 4 & 3743,8 & 29,4 & & & 31,0 & & \\
\hline & 5 & 3725,3 & 29,9 & & & 31,8 & & \\
\hline & 6 & 3699,6 & 27,4 & & & 29,9 & & \\
\hline & 7 & 3748,0 & 30,9 & & & 32,7 & & \\
\hline & 8 & 3720,1 & 30,2 & & & 31,5 & & \\
\hline & 9 & 3744,0 & 30,8 & & & 31,9 & & \\
\hline & 10 & 3646,8 & 30,6 & & & 31,5 & & \\
\hline & 11 & 3691,7 & 30,3 & & & 31,9 & & \\
\hline & 12 & 3729,3 & 29,4 & & & 31,1 & & \\
\hline
\end{tabular}

Verifica-se que em relação ao concreto dos blocos e dos pilares, o módulo de elasticidade dinâmico longitudinal resulta superior ao módulo de elasticidade dinâmico flexional. No caso do concreto das estacas, não observou-se uma uniformização dos valores, sendo que em alguns corpos-de-prova o módulo dinâmico flexional resultou superior ao módulo dinâmico longitudinal. Observa-se que os valores médios desses módulos resultaram muito próximos, sendo 49,7 GPa para o módulo flexional e 49,3 GPa para o módulo longitudinal. Em relação ao graute observa-se que, diferente do concreto das estacas e dos blocos, em todos os corpos-de-prova o módulo de elasticidade dinâmico longitudinal resultou inferior ao módulo de elasticidade dinâmico flexional.

Com o intuito de comparação, apresenta-se nas tabelas 5.17 à 5.20 a relação entre os módulos de elasticidade estático e dinâmico dos concretos dos pilares, estacas, blocos e do graute. Nessa comparação consideraram-se apenas os corpos-de-prova os quais foram utilizados para os ensaios de módulo de elasticidade estático. 
Tabela 5.17 - Relação entre os módulos de elasticidade estático e dinâmico dos pilares

\begin{tabular}{|c|c|c|c|c|c|c|c|}
\hline Elemento & $\mathbf{C P}$ & $\begin{array}{c}\mathbf{E}_{\text {ci,exp }} \\
\text { (GPa) }\end{array}$ & $\begin{array}{c}\mathbf{E}_{\text {c,flex }} \\
(\mathbf{G P a})\end{array}$ & $\begin{array}{r}\mathbf{E}_{\mathrm{c}, \text { long }} \\
(\mathbf{G P a})\end{array}$ & $\begin{array}{c}\mathbf{E}_{\mathbf{c i}, \exp } / \\
\mathbf{E}_{\mathrm{c}, \text { flex }}\end{array}$ & $\begin{array}{c}\mathbf{E}_{\mathbf{c i}, \exp } / \\
\mathbf{E}_{\mathbf{c}, \text { long }}\end{array}$ & $\begin{array}{l}\mathbf{E}_{\mathbf{c}, \text { flex }} / \\
\mathbf{E}_{\mathbf{c}, \text { long }}\end{array}$ \\
\hline \multirow{4}{*}{ Pilares } & 5 & 28,8 & 37,7 & 39,1 & 0,76 & 0,74 & 0,96 \\
\hline & 6 & 29,9 & 38,0 & 40,6 & 0,79 & 0,74 & 0,94 \\
\hline & 7 & 31,4 & 43,2 & 45,3 & 0,73 & 0,69 & 0,95 \\
\hline & 8 & 30,1 & 42,2 & 45,1 & 0,71 & 0,67 & 0,93 \\
\hline \multicolumn{2}{|c|}{ média } & 30,05 & 40,3 & 42,5 & 0,75 & 0,71 & 0,95 \\
\hline
\end{tabular}

Tabela 5.18 - Relação entre os módulos de elasticidade estático e dinâmico das estacas

\begin{tabular}{|c|c|c|c|c|c|c|c|}
\hline Elemento & $\mathbf{C P}$ & $\begin{array}{c}\mathbf{E}_{\text {ci,exp }} \\
(\mathbf{G P a})\end{array}$ & $\begin{array}{c}\mathbf{E}_{c, \text { flex }} \\
\text { (GPa) }\end{array}$ & $\begin{array}{c}\mathbf{E}_{\mathbf{c}, \text { long }} \\
(\mathbf{G P a})\end{array}$ & $\begin{array}{c}\mathbf{E}_{\mathbf{c i}, \exp } / \\
\mathbf{E}_{\mathbf{c}, \text { flex }}\end{array}$ & $\begin{array}{c}\mathbf{E}_{\mathbf{c i}, \exp } / \\
\mathbf{E}_{\mathbf{c}, \text { long }} /\end{array}$ & $\begin{array}{l}\mathbf{E}_{\mathbf{c}, \text { flex }} / \\
\mathbf{E}_{\mathbf{c}, \text { long }} /\end{array}$ \\
\hline \multirow{4}{*}{ Estacas } & 5 & 33,0 & 41,9 & 42,8 & 0,79 & 0,77 & 0,98 \\
\hline & 6 & 50,4 & 55,0 & 53,0 & 0,92 & 0,95 & 1,04 \\
\hline & 7 & 48,0 & 51,5 & 51,3 & 0,93 & 0,94 & 1,01 \\
\hline & 8 & 40,1 & 44,4 & 45,4 & 0,90 & 0,88 & 0,98 \\
\hline \multicolumn{2}{|c|}{ média } & 42,9 & 48,2 & 48,1 & 0,88 & 0,89 & 1,00 \\
\hline
\end{tabular}

Tabela 5.19 - Relação entre os módulos de elasticidade estático e dinâmico do graute

\begin{tabular}{|c|c|c|c|c|c|c|c|}
\hline Elemento & $\mathbf{C P}$ & $\begin{array}{c}\mathbf{E}_{\text {ci,exp }} \\
(\mathbf{G P a})\end{array}$ & $\begin{array}{c}\mathbf{E}_{c, f l e x} \\
(\mathbf{G P a})\end{array}$ & $\begin{array}{l}\mathbf{E}_{\text {c,long }} \\
(\mathbf{G P a})\end{array}$ & $\begin{array}{c}\mathbf{E}_{\mathbf{c i}, \exp } / \\
\mathbf{E}_{\mathbf{c}, \text { flex }}\end{array}$ & $\begin{array}{c}\mathbf{E}_{\text {ci,exp }} / \\
\mathbf{E}_{c, \text { long }}\end{array}$ & $\begin{array}{l}\mathbf{E}_{\mathbf{c}, \text { flex }} / \\
\mathbf{E}_{\mathbf{c}, \text { long }}\end{array}$ \\
\hline \multirow{4}{*}{ Graute } & 5 & 40,8 & 41,4 & 40,3 & 0,98 & 1,01 & 1,03 \\
\hline & 6 & 41,6 & 41,6 & 41,0 & 1,00 & 1,01 & 1,01 \\
\hline & 7 & 40,20 & 40,3 & 39,6 & 1,00 & 1,01 & 1,02 \\
\hline & 8 & 44,50 & 40,6 & 39,7 & 1,10 & 1,12 & 1,02 \\
\hline \multicolumn{2}{|c|}{ média } & 41,8 & 41,0 & 40,1 & 1,02 & 1,04 & 1,02 \\
\hline
\end{tabular}


Tabela 5.20 - Relação entre os módulos de elasticidade estático e dinâmico dos blocos

\begin{tabular}{|c|c|c|c|c|c|c|c|}
\hline Elemento & $\mathbf{C P}$ & $\begin{array}{l}E_{\text {ci,exp }} \\
(G P a)\end{array}$ & $\begin{array}{c}\mathbf{E}_{\mathrm{c}, \mathrm{flex}} \\
(\mathrm{GPa})\end{array}$ & $\begin{array}{l}\mathbf{E}_{\text {c,long }} \\
(\mathbf{G P a})\end{array}$ & $\begin{array}{c}\mathbf{E}_{\mathbf{c i}, \exp } / \\
\mathbf{E}_{\mathbf{c}, \text { flex }}\end{array}$ & $\begin{array}{l}\mathbf{E}_{\mathbf{c i}, \exp } / \\
\mathbf{E}_{\mathbf{c}, \text { long }}\end{array}$ & $\begin{array}{l}\mathbf{E}_{\mathbf{c}, \text { flex }} / \\
\mathbf{E}_{\mathbf{c}, \text { long }}\end{array}$ \\
\hline \multirow{6}{*}{ Blocos } & 7 & 23,6 & 30,9 & 32,7 & 0,76 & 0,72 & 0,95 \\
\hline & 8 & 28,1 & 30,2 & 31,5 & 0,93 & 0,89 & 0,96 \\
\hline & 9 & 22,5 & 30,8 & 31,9 & 0,73 & 0,71 & 0,97 \\
\hline & 10 & 26,6 & 30,6 & 31,5 & 0,87 & 0,84 & 0,97 \\
\hline & 11 & 27,3 & 30,3 & 31,9 & 0,90 & 0,86 & 0,95 \\
\hline & 12 & 23,0 & 29,4 & 31,1 & 0,78 & 0,74 & 0,94 \\
\hline \multicolumn{2}{|l|}{ média } & 25,2 & 30,4 & 31,8 & 0,82 & 0,79 & 0,96 \\
\hline
\end{tabular}

A partir dos resultados apresentados anteriormente pode-se obter algumas conclusões. Em todos os elementos verificou-se que o módulo de elasticidade estático resultou inferior ao módulo de elasticidade dinâmico, seja ele à flexão ou longitudinal. Observou-se ainda que essa relação variou de $70 \%$ a $90 \%$ para os concretos dos pilares estacas e blocos. Para o concreto dos pilares a relação entre os módulos estáticos e dinâmicos foi de aproximadamente $70 \%$, para o concreto dos blocos próximo a $80 \%$ e para o concreto das estacas próximo a $90 \%$. Para o graute verificou-se que os resultado dos módulos dinâmicos resultaram idênticos aos dos módulos estáticos, estando a relação entre as médias dos módulos próximo a unidade.

De acordo com METHA \& MONTHEIRO (2008), o módulo de elasticidade dinâmico é aproximadamente $20 \%, 30 \%$ e $40 \%$ maior do que o módulo estático de deformação para o concreto de alta, média e pequena resistência, respectivamente. Observa-se que para o concreto dos pilares essa relação ficou próxima dos $40 \%$, porém para o as estacas e blocos, esse valor foi de $11 \%$ e $25 \%$, respectivamente. Portanto, verifica-se que com os dados obtidos nos ensaios de caracterização, não foi possível estabelecer uma relação precisa entre o módulo de elasticidade dinâmico e a resistência à compressão dos elementos.

Em relação à resistência à compressão e o módulo de elasticidade dinâmico, foi possível estabelecer uma relação polinomial do $2^{\circ}$ grau, na qual relaciona-se o valor do módulo de elasticidade dinâmico à flexão com a resistência à compressão dos corpos-de-prova. Nesta relação consideraram-se apenas os resultados dos ensaios de compressão e de módulo de elasticidade dinâmico dos concretos dos pilares, estacas e blocos, sem considerar os valores 
obtidos para o graute, que comparado ao concreto, possui características distintas. O gráfico da Figura 5.1 apresenta a distribuição de dados com a função polinomial do $2^{\circ}$ grau, cujo valor estimado do coeficiente de determinação da regressão $\mathrm{R}^{2}$ resultou em 0,80 .

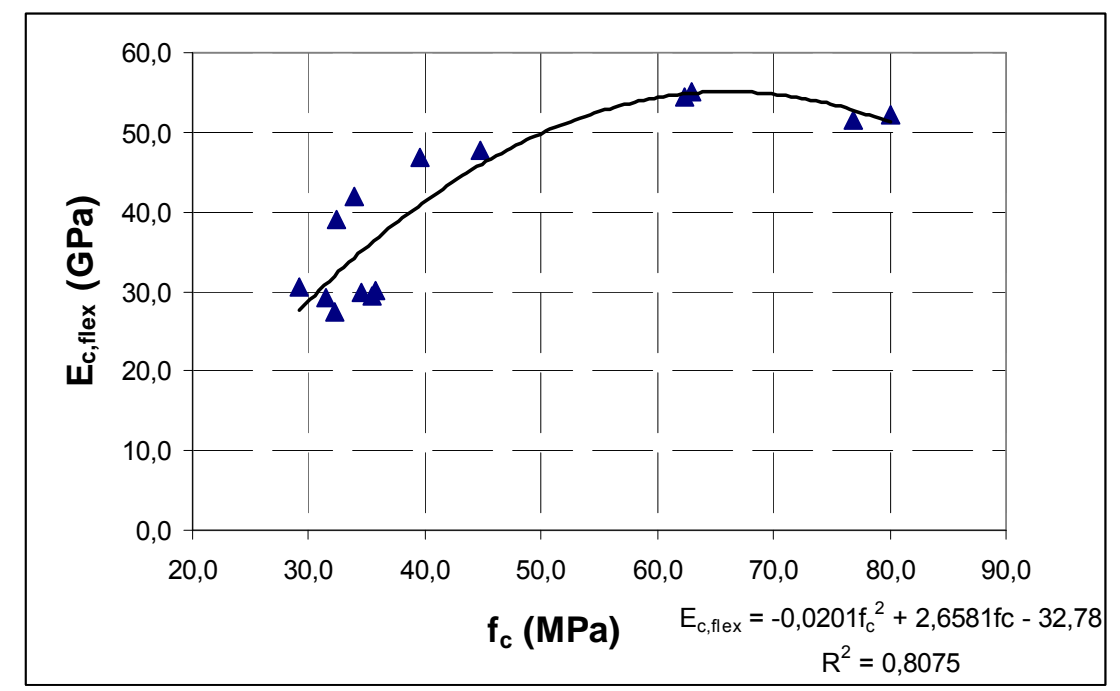

Figura 5. 1- Relação entre a resistência à compressão no corpo-de-prova e módulo de elasticidade dinâmico à flexão

\subsubsection{Resistência ao escoamento e módulo de elasticidade das barras de aço}

A determinação da resistência ao escoamento e do módulo de elasticidade das barras e fios de aço foi feita por meio de ensaios em barras do mesmo lote das que foram utilizadas nos modelos. Para cada diâmetro utilizado foram ensaiadas três barras com comprimento aproximado de cem centímetros. Em todas as barras utilizou-se extensômetro removível com base igual a $100 \mathrm{~mm}$, e sistema de aquisição de dados System 5000 .

Os procedimentos de ensaios seguiram as recomendações da ABNT NBR 6152:2002. Por meio do peso e do comprimento de cada barra, e considerando o peso específico do aço igual a 78,5 kN/m³ conforme ABNT NBR 7480:2007, obtiveram-se os diâmetros estimados para cada barra. O valor do diâmetro estimado foi utilizado para determinação das curvas tensão versus deformação para cada uma das barras das armaduras ensaiadas.

Observa-se nos resultados que os fios de aço com diâmetro nominal de 5,0 mm não apresentaram patamar de escoamento bem definido, caracterizando-as assim como fios da categoria CA-60. Desse modo, a determinação da resistência ao escoamento nessas barras foi feita traçando uma reta paralela ao trecho reto da curva tensão versus deformação, passando pelo valor de deformação igual a $2 \%$. 
Na determinação do módulo de elasticidade das barras de aço, utilizou-se o trecho reto das curvas tensão versus deformação. No caso das barras com diâmetro nominal igual a 8 mm, o módulo de elasticidade das barras de aço resultou num valor médio igual a $203 \mathrm{GPa}$, enquanto que a deformação média a partir da qual se iniciou o escoamento da armadura foi de 2,81\%, correspondente a uma tensão igual a $569 \mathrm{MPa}$. A tabela 5.21 a seguir apresenta os resultados da caracterização das barras de aço, enquanto que as Figuras 5.2, 5.3 e 5.4 apresentam os diagramas tensão versus deformação obtidos na caracterização dos aços.

Tabela 5.21 - Propriedades mecânicas das barras de aço

\begin{tabular}{|c|c|c|c|c|c|c|c|}
\hline $\begin{array}{c}\phi_{\text {nom }} \\
(\mathrm{mm})\end{array}$ & $\begin{array}{l}\phi_{\text {efetivo }} \\
(\mathbf{m m})\end{array}$ & $\begin{array}{c}\mathbf{f}_{\mathbf{y}} \\
(\mathbf{M P a})\end{array}$ & $\varepsilon_{\mathrm{y}}(\% \mathrm{o})$ & $\begin{array}{c}E_{s} \\
(\mathrm{GPa})\end{array}$ & $\begin{array}{c}\mathbf{f}_{\mathbf{y}, \mathrm{m}} \\
(\mathrm{MPa})\end{array}$ & $\begin{array}{l}\varepsilon_{\mathrm{y}, \mathrm{m}} \\
(\% \mathrm{o})\end{array}$ & $\begin{array}{c}\mathbf{E}_{\mathrm{s}, \mathrm{m}} \\
(\mathrm{GPa})\end{array}$ \\
\hline \multirow{3}{*}{5,0} & 4,96 & 679 & 5,33 & 186 & \multirow{3}{*}{667} & \multirow{3}{*}{5,09} & \multirow{3}{*}{195} \\
\hline & 4,96 & 663 & 4,79 & 201 & & & \\
\hline & 4,94 & 680 & 5,15 & 197 & & & \\
\hline \multirow{3}{*}{6,3} & 6,25 & 604 & 3,16 & 191 & \multirow{3}{*}{597} & \multirow{3}{*}{2,90} & \multirow{3}{*}{206} \\
\hline & 6,33 & 603 & 2,87 & 210 & & & \\
\hline & 6,35 & 585 & 2,68 & 218 & & & \\
\hline \multirow{3}{*}{8,0} & 7,88 & 557 & 2,87 & 194 & \multirow{3}{*}{569} & \multirow{3}{*}{2,81} & \multirow{3}{*}{203} \\
\hline & 7,89 & 566 & 2,69 & 210 & & & \\
\hline & 7,88 & 586 & 2,86 & 205 & & & \\
\hline \multirow{3}{*}{10,0} & 9,84 & 587 & 2,89 & 203 & \multirow{3}{*}{574} & \multirow{3}{*}{2,91} & \multirow{3}{*}{198} \\
\hline & 8,90 & 556 & 2,96 & 188 & & & \\
\hline & 9,84 & 679 & 2,86 & 202 & & & \\
\hline \multirow{3}{*}{12,5} & 12,32 & 568 & 3,03 & 187 & \multirow{3}{*}{564} & \multirow{3}{*}{2,87} & \multirow{3}{*}{197} \\
\hline & 12,33 & 558 & 2,95 & 189 & & & \\
\hline & 12,32 & 566 & 2,63 & 215 & & & \\
\hline
\end{tabular}

Obs: diâmetro nominal calculado a partir do peso e do comprimento de cada corpo-de-prova, considerando o peso específico do aço igual a $7850 \mathrm{kgf} / \mathrm{m}^{3}$ conforme ABNT NBR 7480:2007 


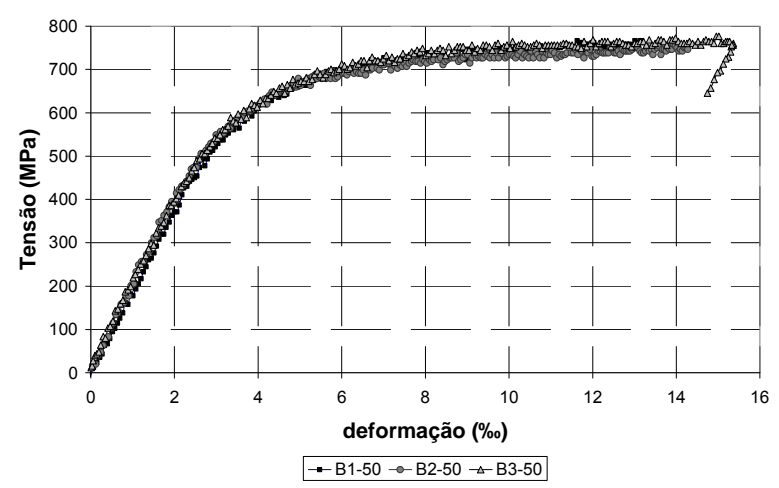

Figura 5. 2- Curva tensão versus deformação para os fios de aço $\phi 5.0 \mathrm{~mm}$

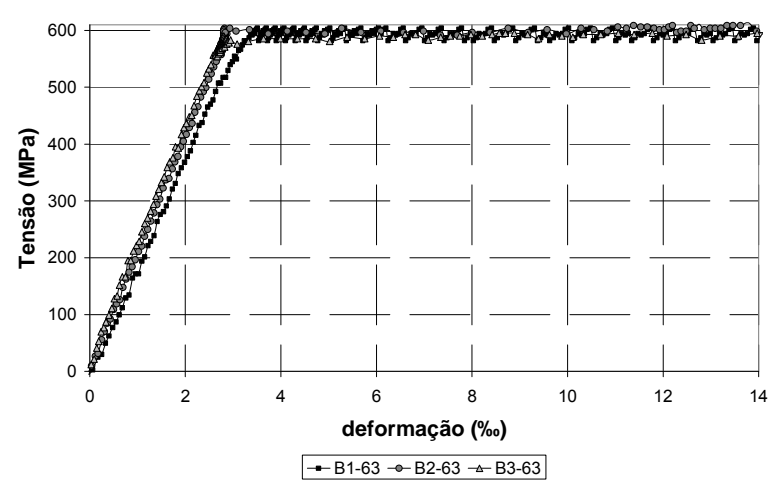

(a)

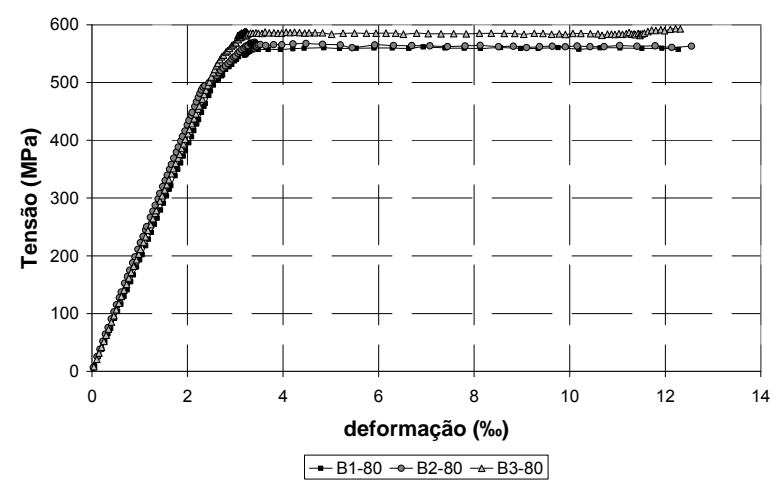

(b)

Figura 5. 3- Curva tensão versus deformação para as barras de aço $\phi 6.3 \mathrm{~mm}$ e $8.0 \mathrm{~mm}$

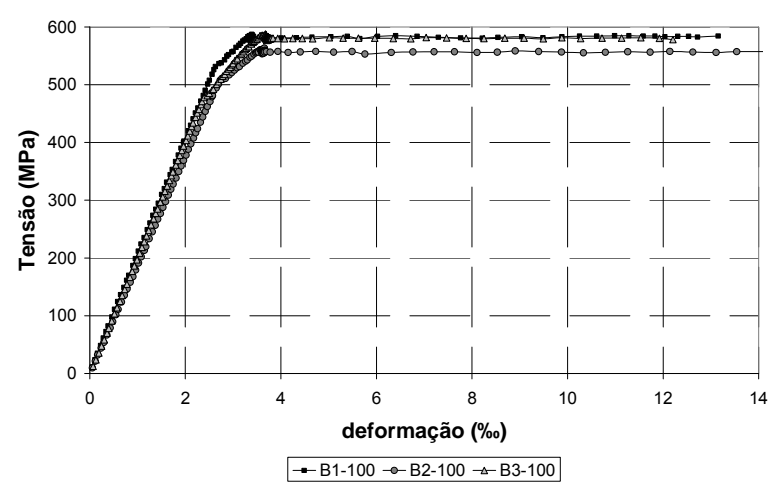

(a)

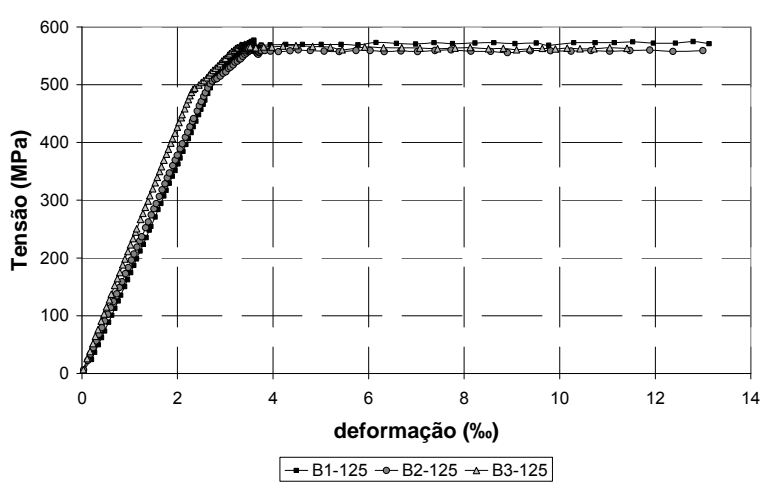

(b)

Figura 5. 4- Curva tensão versus deformação para as barras de aço $\phi 10.0 \mathrm{~mm}$ e $12.5 \mathrm{~mm}$ 


\subsection{Blocos de referência}

Os primeiros blocos ensaiados foram os blocos de referência, isto é, os blocos que apresentavam ligação monolítica com o pilar. O modelo M1 usado como referência para os blocos da série sem rugosidade, e o modelo M8 usado como referência para os blocos da série com rugosidade.

\subsubsection{Modelo M1 - BRF_SR}

O modelo M1 apresentou comportamento de bloco rígido, estando de acordo com o modelo teórico previsto. Foi registrada uma pequena excentricidade na força aplicada no pilar da ordem de 1,65 $\mathrm{cm}$. A ruína do modelo se deu por escoamento de todas as barras da armadura principal do tirante, localizadas na região central do bloco.

A força máxima registrada para esse modelo foi de $756 \mathrm{kN}$, força essa superior a força calculada com o modelo teórico utilizado para o dimensionamento. O modelo apresentou resistência crescente até atingir uma força de $743 \mathrm{kN}$, quando houve uma pequena diminuição no seu valor, porém voltou a apresentar aumento de força, até atingir a ruína para uma força última igual a $756 \mathrm{kN}$.

A primeira fissura visível no modelo apresentou abertura da ordem de $0,05 \mathrm{~mm}$, e ocorreu na região inferior da face lateral do bloco, para uma força no pilar igual a $230 \mathrm{kN}$. Nessa etapa, a deformação máxima nas cinco barras das armaduras do tirante foi de 0,596 \%o, o que resulta numa tensão igual a $119 \mathrm{MPa}$. Observou-se que o modelo apresentou perda de rigidez com uma força próxima de $210 \mathrm{kN}$, conforme pode ser observado na figura 5.5, que apresenta o gráfico força versus deformação das barras das armaduras posicionadas na região central do bloco. A Figura $\mathbf{5 . 5}$ apresenta o gráfico força versus deformação em cada barra, enquanto que a Figura 5.6 apresenta a curva força versus deformação média em relação as armaduras posicionadas na seção central do bloco.

As Figuras 5.7 e $\mathbf{5 . 8}$ apresentam os gráficos força versus deformação nas barras das armaduras posicionadas sobre as estacas. Observa-se por meio desses gráficos que as deformações nas armaduras apresentam valores pequenos quando comparados as deformações medidas nas armaduras posicionadas na região central do bloco. Isso ocorre em virtude da formação da biela sobre as estacas, o que provoca diminuição na força do tirante nessa região. A figura 5.9 apresenta a curva força versus deslocamento do modelo M1, a partir da qual 
pode-se observar um deslocamento máximo próximo a 2,3 $\mathrm{mm}$, o qual ocorreu na região central do bloco.

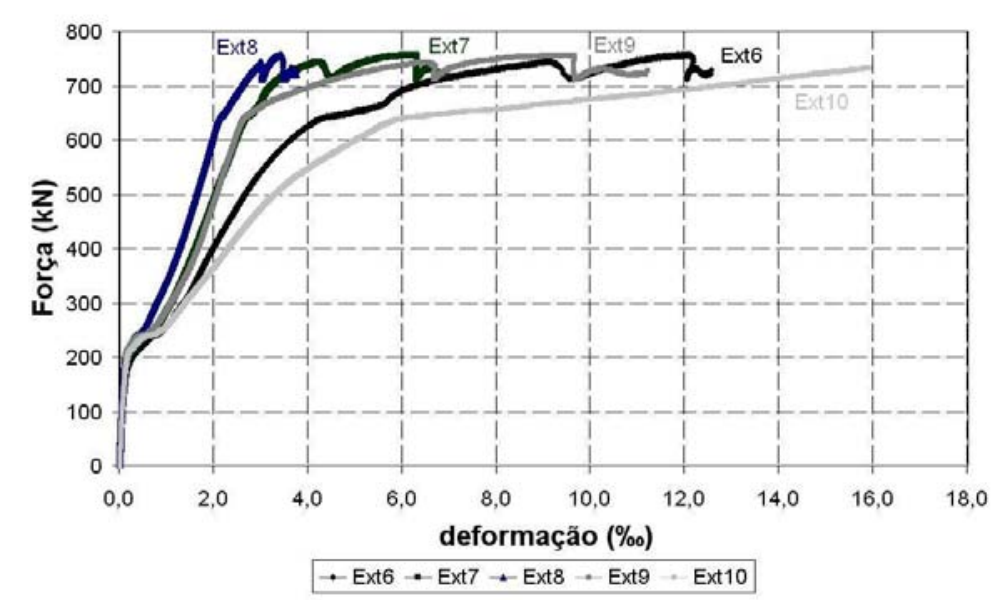

Figura 5. 5- Curva força versus deformação nas armaduras da região central do modelo M1

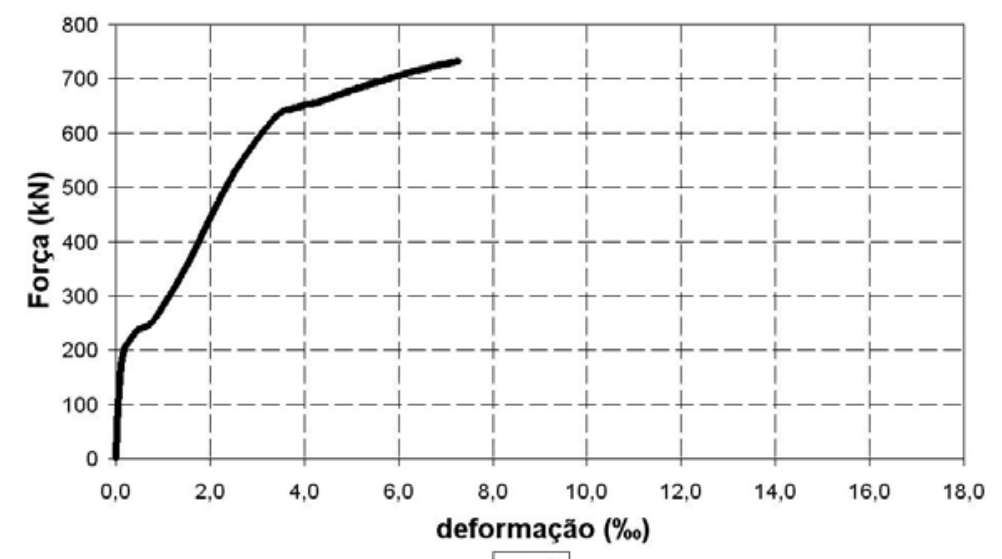

$\rightarrow \mathrm{M} 1$

Figura 5. 6- Curva força versus deformação média nas armaduras da região central do modelo M1

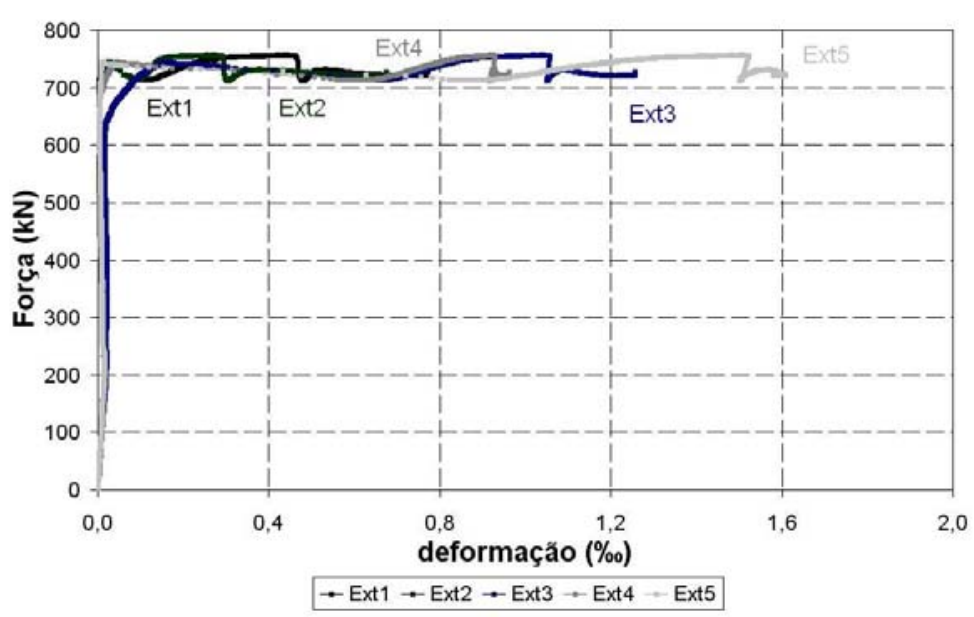

Figura 5. 7- Curva força versus deformação nas armaduras sobre as estacas do modelo M1 


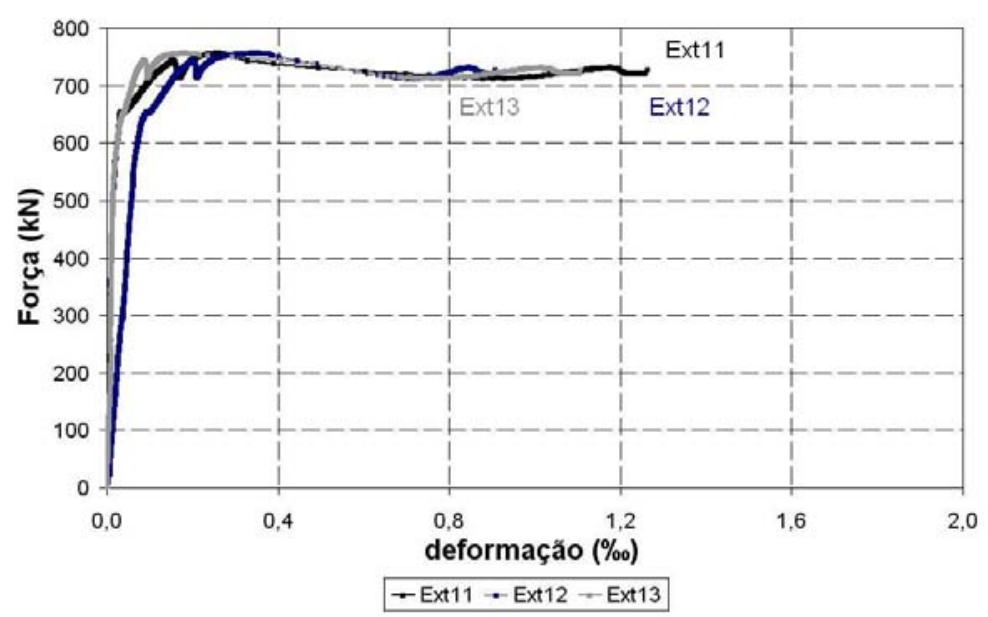

Figura 5. 8- Curva força versus deformação nas armaduras sobre as estacas do modelo M1

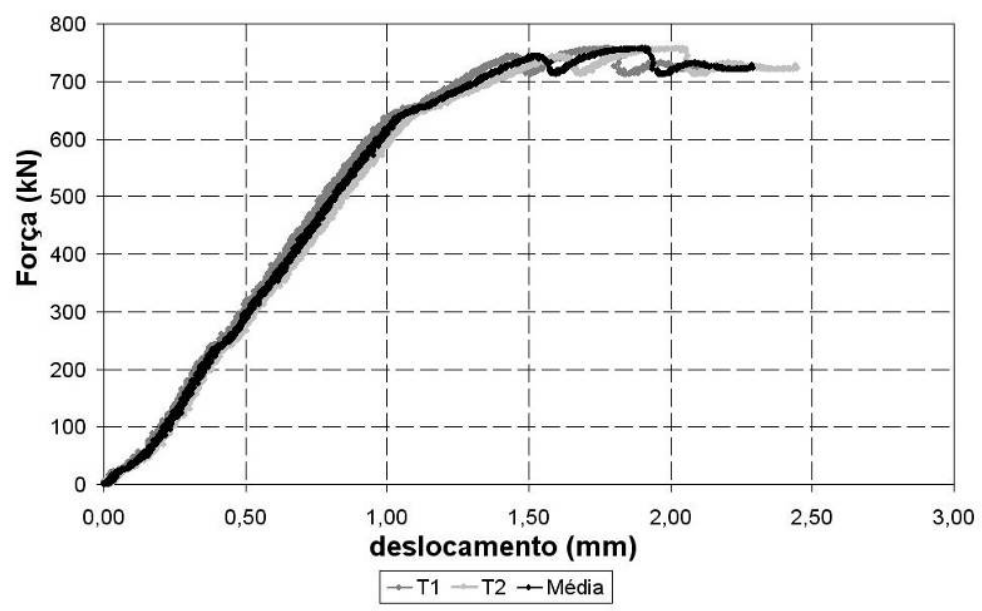

Figura 5. 9- Curva força versus deslocamento médio medido nos transdutores T1 e T2 do modelo M1

Nesse modelo não houve perda de nenhum dos extensômetros elétricos de resistência. A medida que a força no pistão aumentava, verificou-se o surgimento de novas fissuras e aumento da abertura das fissuras existentes. Constataram-se aberturas de fissuras da ordem de $0,1 \mathrm{~mm}$ correspondente a força de $360 \mathrm{kN} ; 0,25 \mathrm{~mm}$ para uma força de $660 \mathrm{kN}$; e abertura igual a $0,8 \mathrm{~mm}$ correspondente a uma força igual a $720 \mathrm{kN}$. As fissuras que se iniciaram na região central do bloco prolongaram-se até a região superior, formando dois planos visíveis de fissuras, dividindo o bloco em três partes distintas. A Figura 5.10 (a) apresenta o modelo M1 durante o ensaio, e a Figura 5.10 (b) mostra o panorama de fissuração após o ensaio. 


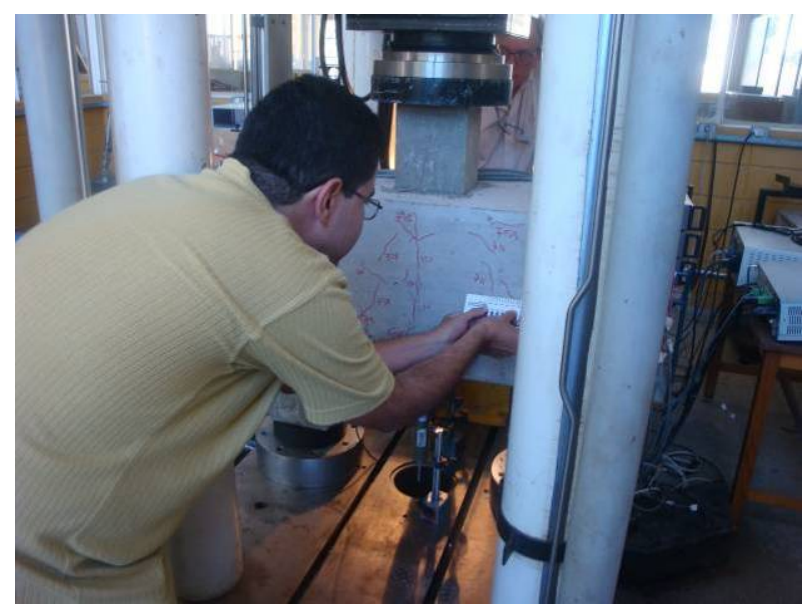

(a)

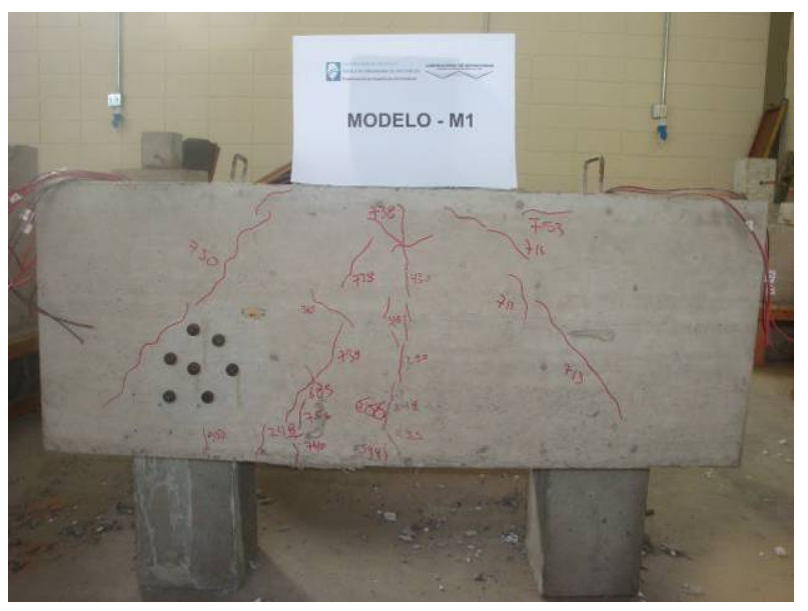

(b)

Figura 5. 10- Modelo M1 durante o ensaio e panorama de fissuração após o ensaio

Obtiveram-se valores pequenos para as medidas de deformações no concreto, uma vez que com as leituras efetuadas nas pastilhas de aço, as quais estavam fixadas nas faces laterais dos blocos, foi possível calcular as deformações na face externa do bloco. Em função dos valores obtidos, constatou-se que as deformações ficaram aquém das deformações existentes nas bielas. Desse modo, considera-se que a utilização das pastilhas de aço não conferiu bons resultados para a estimativa das deformações do concreto. Apresentam-se na tabela 5.22 os valores de deformações principais e as direções principais em relação a quatro intensidades de força. As direções apresentadas referem-se ao esquema apresentado na Figura 4.49 (b).

Tabela 5.22 - Deformação no concreto do modelo M1

\begin{tabular}{|c|c|c|c|c|c|c|c|c|}
\hline \multirow{2}{*}{$\begin{array}{c}\text { Força } \\
(\mathbf{k N})\end{array}$} & \multirow[t]{2}{*}{ Direção } & \multicolumn{3}{|c|}{ Deformações (\%o) } & \multicolumn{2}{|c|}{$\begin{array}{c}\text { Deformações } \\
\text { Principais (\%o) }\end{array}$} & \multicolumn{2}{|c|}{$\begin{array}{c}\text { Direções } \\
\text { Principais }\left({ }^{\circ}\right)\end{array}$} \\
\hline & & $\varepsilon_{0^{\circ}}$ & $\varepsilon_{45^{\circ}}$ & $\varepsilon_{90^{\circ}}$ & $\varepsilon_{1}$ & $\varepsilon_{2}$ & $\alpha_{1}$ & $\alpha_{2}$ \\
\hline \multirow{2}{*}{50} & $1,5,3$ & $-0,013$ & 0,026 & 0,005 & 0,03 & $-0,04$ & $-36,6$ & 53,3 \\
\hline & $2,6,4$ & $-0,090$ & 0,030 & $-0,003$ & 0,03 & $-0,04$ & $-42,6$ & 47,3 \\
\hline \multirow{2}{*}{200} & $1,5,3$ & $-0,011$ & 0,013 & $-0,010$ & 0,01 & $-0,03$ & $-44,4$ & 45,6 \\
\hline & $2,6,4$ & $-0,002$ & 0,020 & $-0,001$ & 0,02 & $-0,02$ & $-44,3$ & 45,6 \\
\hline \multirow{2}{*}{350} & $1,5,3$ & $-0,013$ & 0,023 & $-0,015$ & 0,02 & $-0,05$ & 44,23 & 134,2 \\
\hline & $2,6,4$ & 0,05 & 0,014 & 0,008 & 0,01 & 0,00 & $-39,35$ & 50,6 \\
\hline \multirow{2}{*}{550} & $1,5,3$ & 0,007 & 0,082 & $-0,02$ & 0,08 & $-0,10$ & 40,66 & 130,6 \\
\hline & $2,6,4$ & 0,005 & 0,112 & 0,019 & 0,11 & $-0,09$ & -43 & 47,0 \\
\hline
\end{tabular}




\subsubsection{Modelo M8 - BRF_CR}

Assim como o modelo M1, o modelo M8 apresentou comportamento de bloco rígido de acordo com o modelo teórico previsto. Inicialmente foi detectada uma excentricidade na força aplicada no pilar, a qual foi diminuindo e se estabilizando a medida que a força no modelo aumentava. Ao final, foi registrada uma pequena excentricidade da ordem de $0,45 \mathrm{~cm}$. A ruína do modelo se deu por escoamento de todas as barras da armadura principal do tirante localizadas na região central do bloco.

A força máxima registrada para esse modelo foi de $728 \mathrm{kN}$, força essa superior a força calculada com o modelo teórico utilizado para o dimensionamento. O modelo apresentou resistência crescente até atingir a força última, sem apresentar diminuição no seu valor ao longo do ensaio.

A primeira fissura visível no modelo apresentou abertura da ordem de $0,05 \mathrm{~mm}$, e ocorreu na região inferior da face lateral do bloco, para uma força no pilar igual a $208 \mathrm{kN}$. Nessa etapa a deformação máxima nas cinco barras das armaduras do tirante foi de 0,34 \%o, o que resulta numa tensão igual a $69 \mathrm{MPa}$. Observou-se que o modelo apresentou perda de rigidez com uma força próxima de $200 \mathrm{kN}$, conforme pode ser observado nos gráficos força versus deformação das barras das armaduras posicionadas na região central do bloco. A Figura 5.11 apresenta o gráfico força versus deformação em cada barra, enquanto que a Figura 5.12 apresenta a curva força versus deformação média em relação as armaduras posicionadas na seção central do bloco para os modelos M8 e M1. Observa-se por meio dessa figura que o modelo M8 apresentou-se um pouco mais rígido do que o modelo M1. Verificase ainda que o modelo M8 apresentou deformações médias nas armaduras inferiores as obtidas no modelo M1.

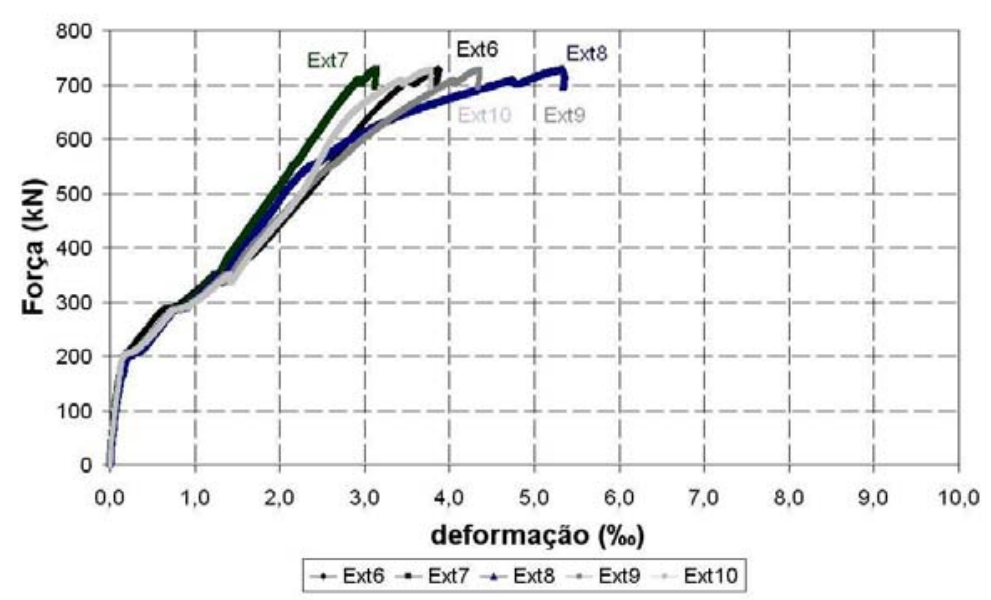

Figura 5. 11- Curva força versus deformação nas armaduras da região central do modelo M8 


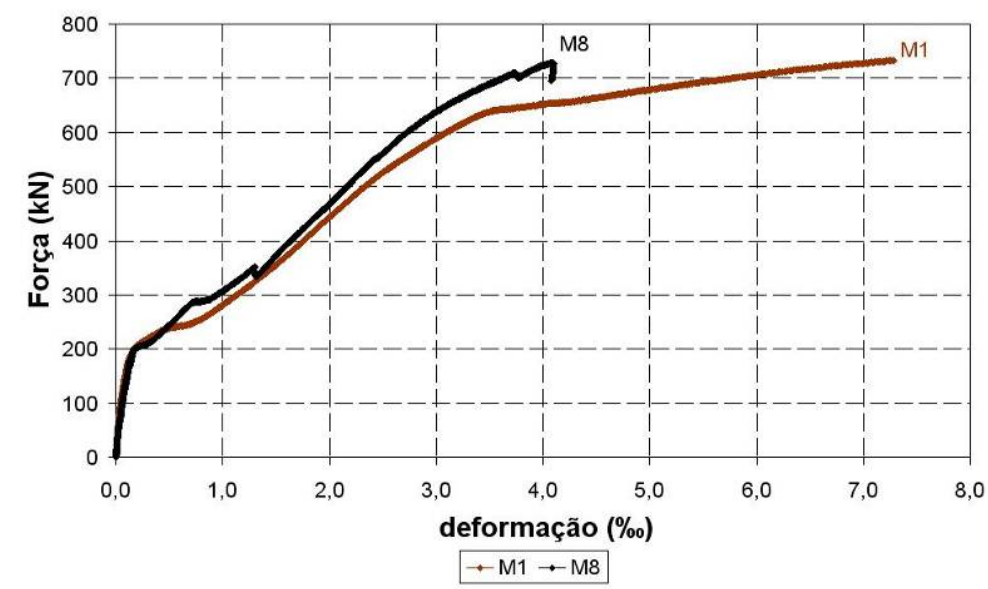

Figura 5. 12- Curva força versus deformação média nas armaduras da região central dos modelos M1 e M8

As Figuras 5.13 e $\mathbf{5 . 1 4}$ apresentam os gráficos força versus deformação nas barras das armaduras posicionadas sobre as estacas. Destaca-se que nesse modelo houve perda dos extensômetros elétricos de resistência das posições 1, 2 e 3, extensômetros esses posicionados na região sobre as estacas. Assim como no modelo M1, observa-se que as deformações nas armaduras apresentam valores pequenos quando comparados as deformações medidas nas armaduras posicionadas na região central do bloco. Isso ocorre em virtude da formação da biela sobre as estacas, o que provoca diminuição na força do tirante nessa região. A figura 5.15 apresenta a curva força versus deslocamento do modelo M8, a partir da qual pode-se observar um deslocamento máximo próximo a 3,1 mm, o qual ocorreu na região central do bloco.

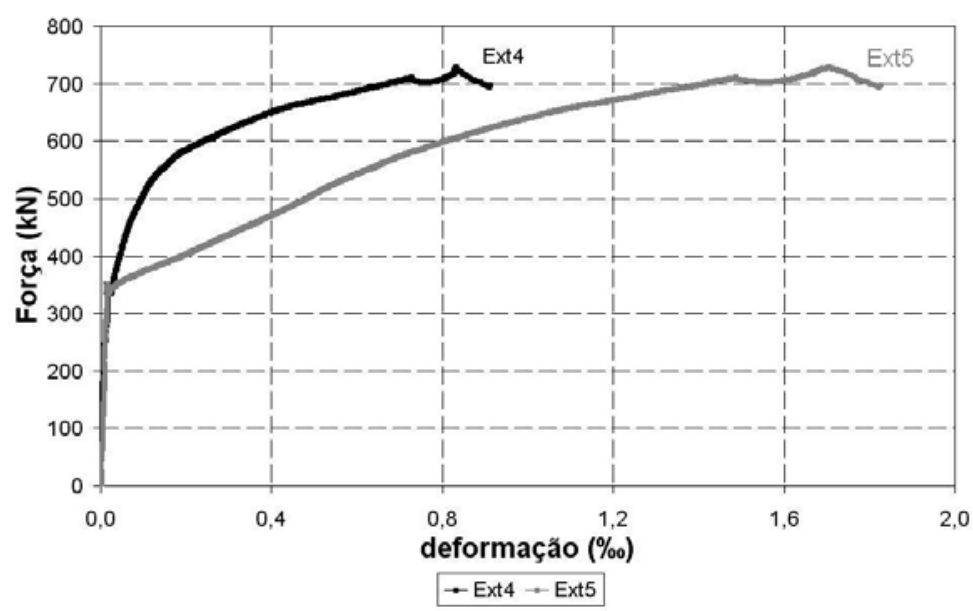

Figura 5. 13- Curva força versus deformação nas armaduras sobre as estacas do modelo M8 


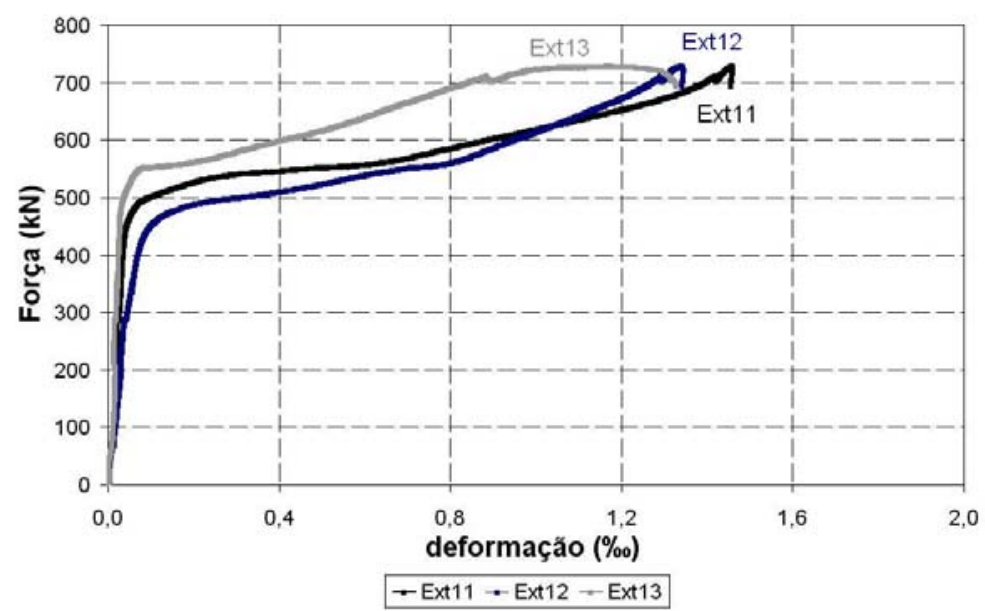

Figura 5. 14- Curva força versus deformação nas armaduras sobre as estacas do modelo M8

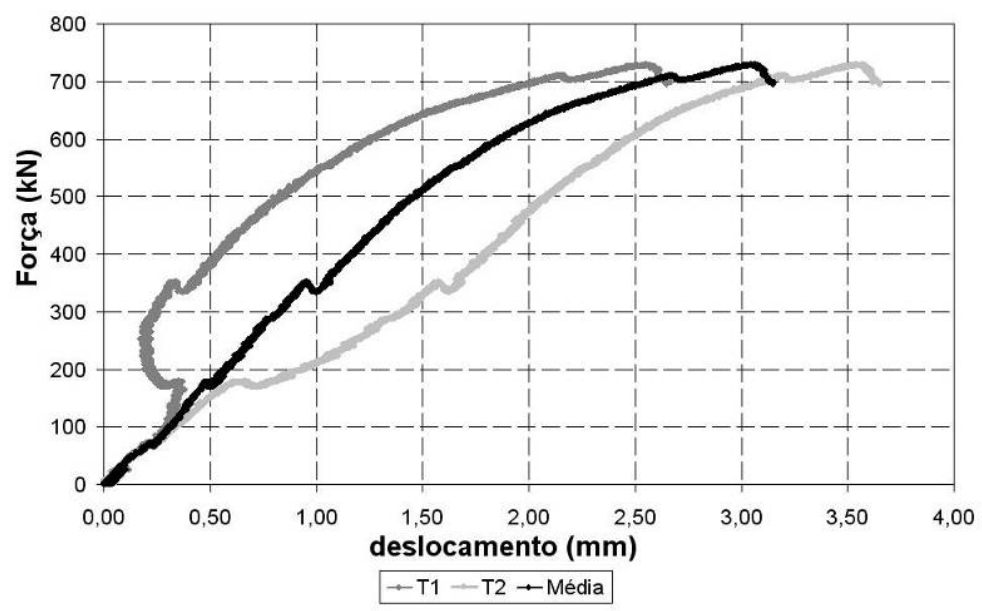

Figura 5. 15-Curva força versus deslocamento médio medido nos transdutores T1 e T2 do modelo M8

A medida que a força no pistão aumentava, verificou-se o surgimento de novas fissuras e aumento da abertura das fissuras existentes. Verificaram-se aberturas de fissuras da ordem de $0,1 \mathrm{~mm}$ correspondente a força de $345 \mathrm{kN}$ e $0,20 \mathrm{~mm}$ para uma força de $460 \mathrm{kN}$. Aos 700 $\mathrm{kN}$ verificou-se o surgimento de uma fissura diagonal, indicando a formação da biela em um dos lados do modelo, conforme pode ser visto na Figura 5.16 (a), a qual apresenta o panorama de fissuração do modelo M8 após a realização do ensaio. As fissuras que se iniciaram na região central do bloco prolongaram-se até a região superior do mesmo, formando dois planos visíveis de fissuras, dividindo o bloco em três partes distintas. Essas fissuras se prolongaram de um lado a outro do bloco, passando pela região inferior do mesmo, conforme pode ser observado na Figura 5.16 (b). 


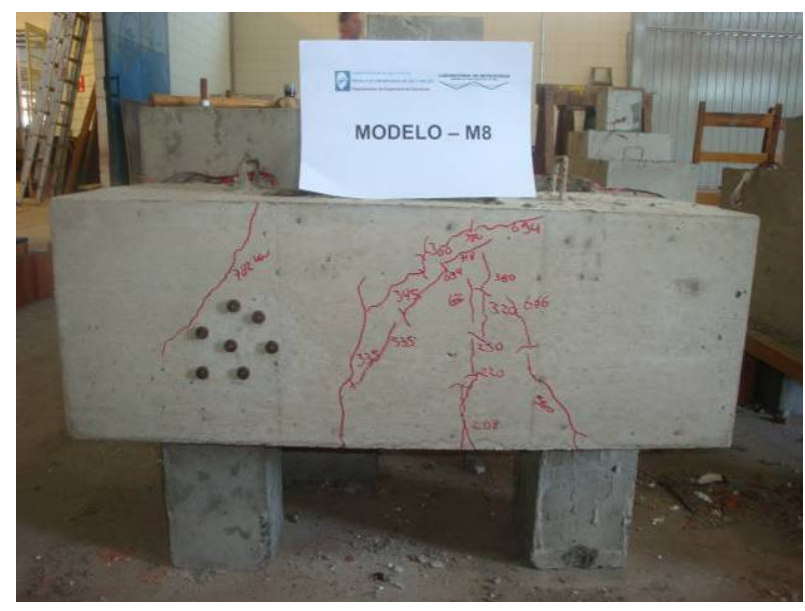

(a)

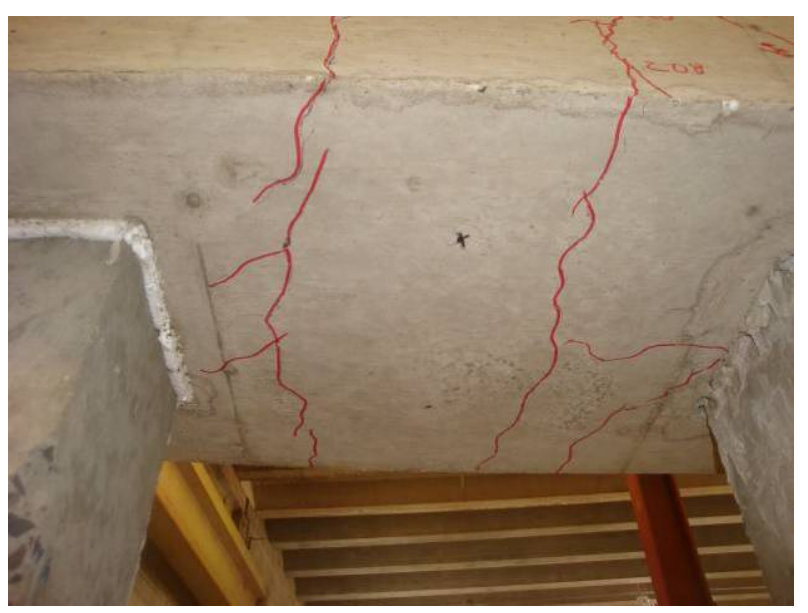

(b)

Figura 5. 16-Fissuras na face lateral e inferior do Modelo M8

Assim como no modelo M1, obtiveram-se valores pequenos para as medidas de deformações no concreto, uma vez que com as leituras efetuadas nas pastilhas de aço, as quais estavam fixadas nas faces laterais dos blocos, foi possível calcular as deformações na face externa do bloco. Em função dos valores obtidos, constatou-se que as deformações ficaram aquém das deformações existentes nas bielas. Desse modo, considera-se que a utilização das pastilhas de aço não conferiu bons resultados para a estimativa das deformações do concreto. Apresentam-se na tabela 5.23 os valores de deformações principais e as direções principais em relação a quatro intensidades de força. As direções apresentadas referem-se ao esquema apresentado na Figura 4.49 (b).

Tabela 5.23 - Deformação no concreto do modelo M8

\begin{tabular}{|c|c|c|c|c|c|c|c|c|}
\hline \multirow{2}{*}{$\begin{array}{c}\text { Força } \\
(\mathbf{k N})\end{array}$} & \multirow[t]{2}{*}{ Direção } & \multicolumn{3}{|c|}{ Deformações (\%o) } & \multicolumn{2}{|c|}{$\begin{array}{c}\text { Deformações } \\
\text { Principais (\%o) }\end{array}$} & \multicolumn{2}{|c|}{$\begin{array}{c}\text { Direções } \\
\text { Principais }\left({ }^{(}\right)\end{array}$} \\
\hline & & $\varepsilon_{0^{\circ}}$ & $\varepsilon_{45^{\circ}}$ & $\varepsilon_{90^{\circ}}$ & $\varepsilon_{1}$ & $\varepsilon_{2}$ & $\alpha_{1}$ & $\alpha_{2}$ \\
\hline \multirow{2}{*}{50} & $1,5,3$ & $-0,001$ & 0,079 & 0,135 & 0,14 & 0 & $-5,0$ & 85,0 \\
\hline & $2,6,4$ & $-0,002$ & 0,227 & 0,131 & 0,24 & $-0,11$ & $-33,8$ & 56,1 \\
\hline \multirow{2}{*}{200} & $1,5,3$ & 0,004 & 0,066 & 0,146 & 0,15 & 0 & 3,61 & 93,61 \\
\hline & $2,6,4$ & $-0,02$ & 0,324 & 0,13 & 0,33 & $-0,20$ & $-37,88$ & 52,12 \\
\hline \multirow{2}{*}{350} & $1,5,3$ & 0,022 & 0,067 & 0,142 & 0,14 & 0,02 & 7,0 & 97,0 \\
\hline & $2,6,4$ & 0,010 & 0,320 & 0,172 & 0,33 & $-0,15$ & $-35,26$ & 54,7 \\
\hline \multirow{2}{*}{550} & $1,5,3$ & 0,026 & 0,067 & 0,135 & 0,14 & 0,02 & 6,96 & 96,9 \\
\hline & $2,6,4$ & $-0,01$ & 0,220 & 0,131 & 0,230 & $-0,10$ & $-33,4$ & 56,3 \\
\hline
\end{tabular}




\subsection{Blocos com cálice externo}

Os blocos com cálice externo foram ensaiados após os blocos de referência. Foram ensaiados os modelos M2 e M3, os quais apresentavam paredes do cálice e do pilar sem rugosidade, e os modelo M9 e M10, os quais apresentavam rugosidade. Destaca-se nesse item que um dos modelos de bloco com cálice externo apresentou ruína por ruptura do concreto do pilar antes da ruína do bloco, o qual será explicado nos itens que se seguem.

\subsubsection{Modelo M2 - BEX_SR}

O modelo M2 apresentou comportamento de bloco rígido. Foi registrada uma pequena excentricidade na força aplicada no pilar da ordem de $1,38 \mathrm{~cm}$. A ruína do modelo se deu por escoamento de todas as barras da armadura principal do tirante, localizadas na região central do bloco.

A força máxima suportada por esse modelo foi de $772 \mathrm{kN}$, força essa superior a força calculada com o modelo teórico utilizado para o dimensionamento. O modelo apresentou resistência crescente até atingir uma força de $690 \mathrm{kN}$, quando houve diminuição no seu valor até $650 \mathrm{kN}$. Em seguida, o bloco voltou a apresentar aumento de força, até atingir a ruína para uma força igual a $772 \mathrm{kN}$. Observa-se que o valor da força última do modelo M2 foi próximo ao valor da força última de $756 \mathrm{kN}$ obtida no bloco de referência do modelo M1.

Diferente dos demais modelos, a primeira fissura visível no modelo M2 surgiu na região superior do bloco próximo ao cálice de fundação, para uma força de $100 \mathrm{kN}$. Em seguida, aberturas de fissuras da ordem de $0,05 \mathrm{~mm}$ ocorreram na região inferior central do bloco, para uma força no pilar igual a $320 \mathrm{kN}$. Nessa etapa, a deformação máxima nas cinco barras das armaduras do tirante foi de $0,38 \%$, o que resulta numa tensão igual a $77 \mathrm{MPa}$. Observou-se que o modelo apresentou perda de rigidez com uma força próxima de $310 \mathrm{kN}$, conforme pode ser observado nos gráficos força versus deformação das barras das armaduras posicionadas na região central do bloco.

A Figura 5.17 apresenta o gráfico força versus deformação em cada barra, enquanto que a Figura 5.18 apresenta a curva força versus deformação média em relação as armaduras posicionadas na seção central do bloco para os modelos M2 e M1. Observa-se por meio dessa figura que o bloco com cálice externo apresentou-se mais rígido do que o bloco do modelo M1. Verifica-se também que o modelo M2 apresentou deformações médias nas armaduras 
inferiores às obtidas no modelo M1, indicando que a biela de compressão no modelo M2 se iniciou ao longo do cálice, apresentando inclinação com o tirante superior a do bloco de referência dessa série.

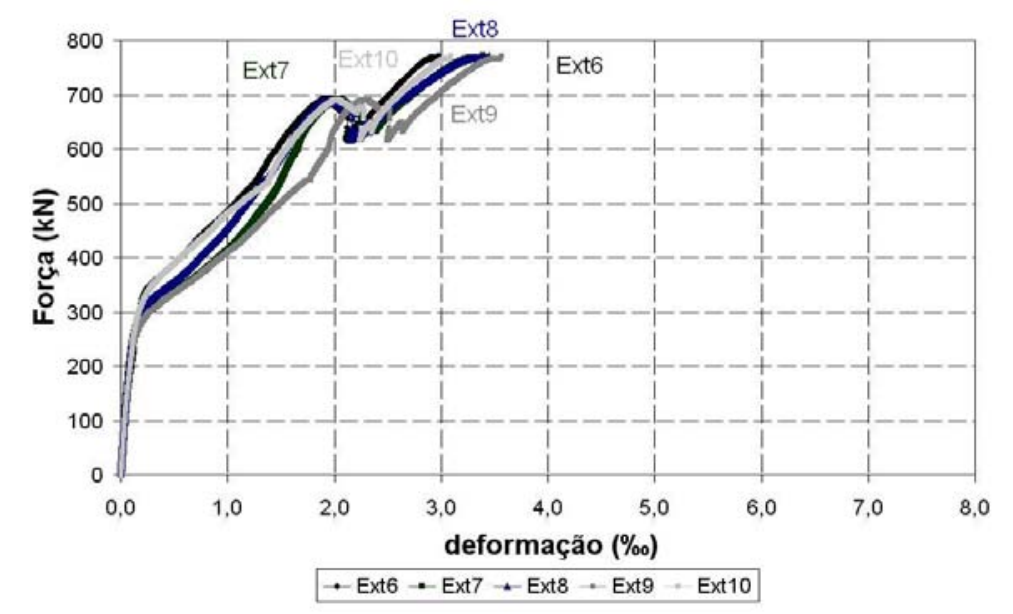

Figura 5. 17- Curva força versus deformação nas armaduras da região central do modelo M2

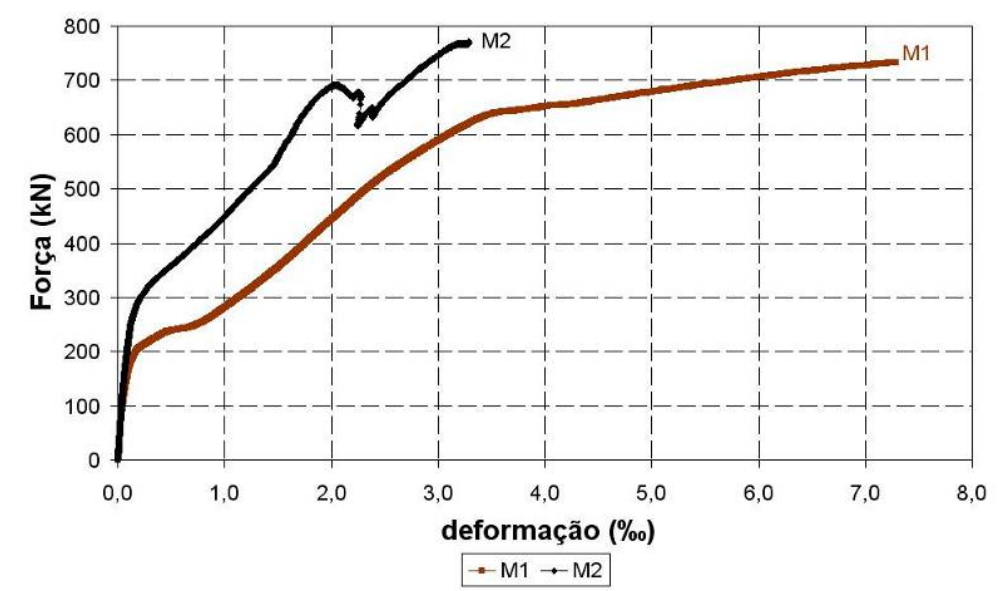

Figura 5. 18- Curva força versus deformação média nas armaduras da região central dos modelos M1 e M2

As Figuras 5.19 e $\mathbf{5 . 2 0}$ apresentam os gráficos força versus deformação nas barras das armaduras posicionadas sobre as estacas. Observa-se por meio desses gráficos que as deformações nas armaduras apresentam valores pequenos quando comparados as deformações obtidas nas armaduras posicionadas na região central do bloco. Isso ocorre em virtude da formação da biela sobre as estacas, o que provoca diminuição da força no tirante nessa região.

A Figura 5.21 apresenta o gráfico força versus deformação nas barras das armaduras do pilar. Observa-se que as deformações nas barras das armaduras tornam-se menores à medida que o pilar se aproxima do fundo do cálice, conforme pode ser observado nas medidas de 
deformação dos extensômetro de números 16 e 19. Esse fato é outro indício de que a biela de compressão é formada ao longo da altura do cálice.

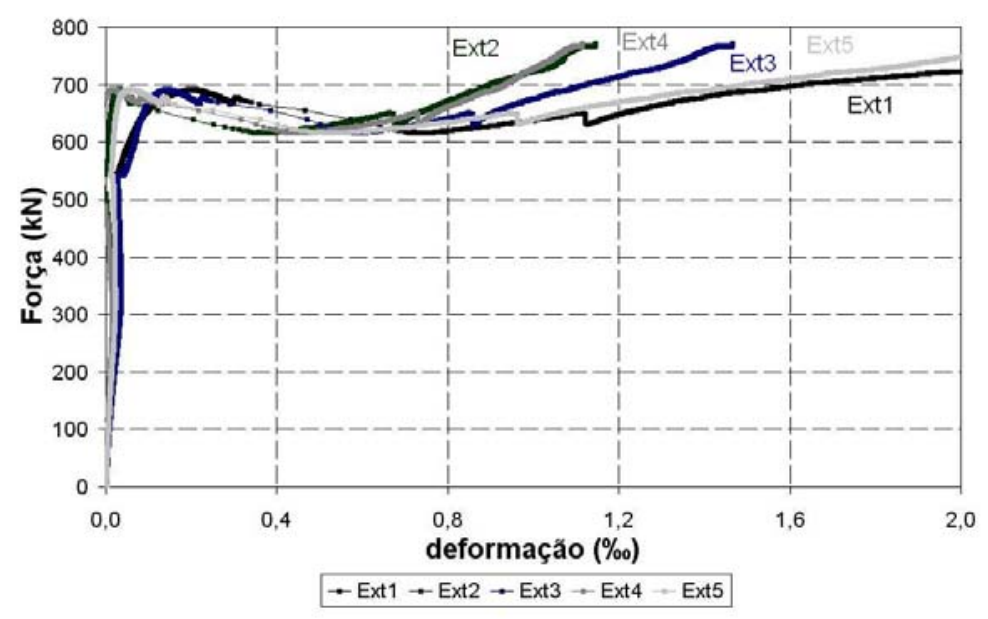

Figura 5. 19- Curva força versus deformação nas armaduras sobre as estacas do modelo M2

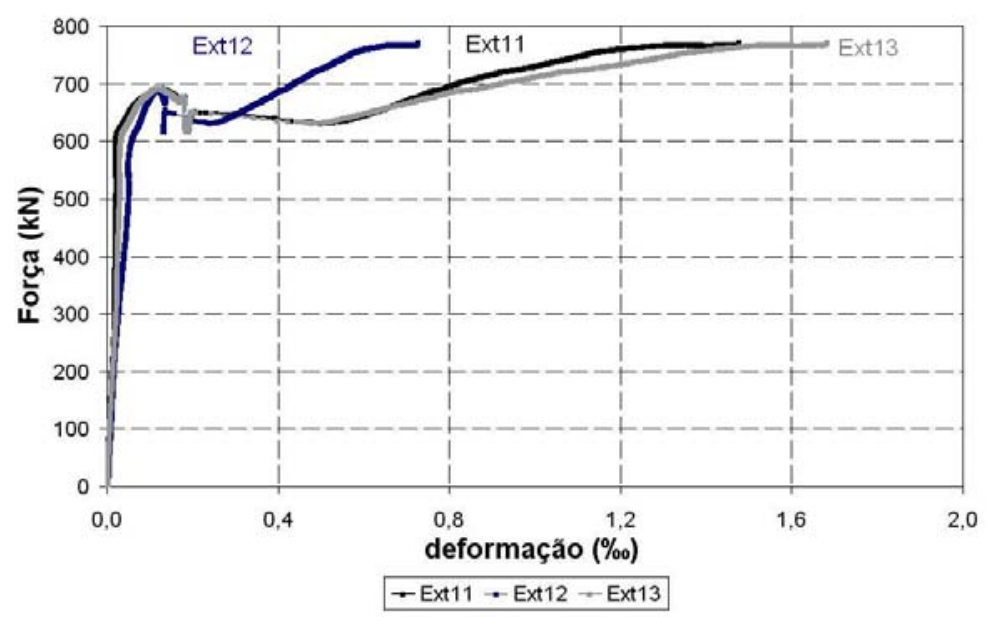

Figura 5. 20- Curva força versus deformação nas armaduras sobre as estacas do modelo M2

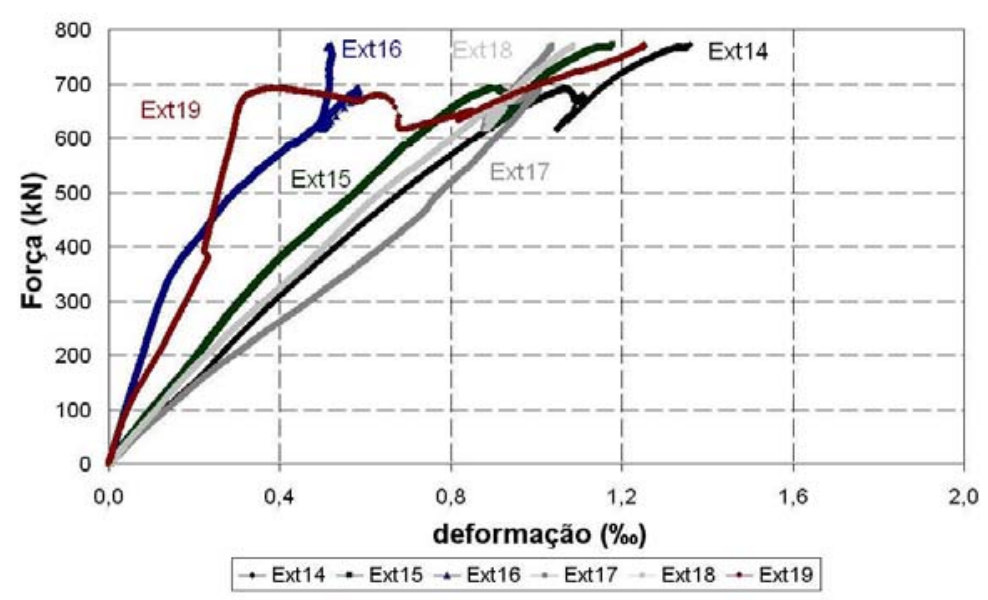

Figura 5. 21- Curva força versus deformação nas armaduras do pilar do modelo M2 
A Figura 5.22 apresenta a curva força versus deslocamento do modelo M2, a partir da qual pode-se observar um deslocamento médio próximo a $1,2 \mathrm{~mm}$ na etapa em que a força foi igual a $690 \mathrm{kN}$, e próximo a 3,3 mm próximo a ruína do modelo, sendo que ambos os deslocamentos foram medidos na região central no bloco.

Nesse modelo não houve perda de nenhum dos extensômetros elétricos de resistência. A medida que a força no pistão aumentava, verificou-se o surgimento de novas fissuras e aumento da abertura das fissuras existentes. Verificaram-se aberturas de fissuras da ordem de $0,15 \mathrm{~mm}$ correspondente a força de $420 \mathrm{kN} ; 0,25 \mathrm{~mm}$ para uma força de $500 \mathrm{kN}$; e abertura de fissura igual a $0,3 \mathrm{~mm}$ correspondente a uma força igual a $620 \mathrm{kN}$.

Verificaram-se quatro linhas de fissuras na região central do bloco, as quais prolongaram-se até a região superior. Observou-se ainda a formação de fissuras horizontais na região próxima ao encontro do bloco com o cálice, conforme pode ser observado na Figura 5.23 (a), e fissuras na região do cálice, conforme Figura 5.23 (b). Destaca-se que as fissuras na região do cálice surgiram para forças próximas a ruína do modelo. Nessas figuras, as fissuras marcadas em vermelho surgiram até o modelo apresentar a primeira queda de força de $690 \mathrm{kN}$ para $650 \mathrm{kN}$. As fissuras marcadas em verde surgiram após o modelo voltar a apresentar aumento de força, até atingir a ruína aos $772 \mathrm{kN}$.

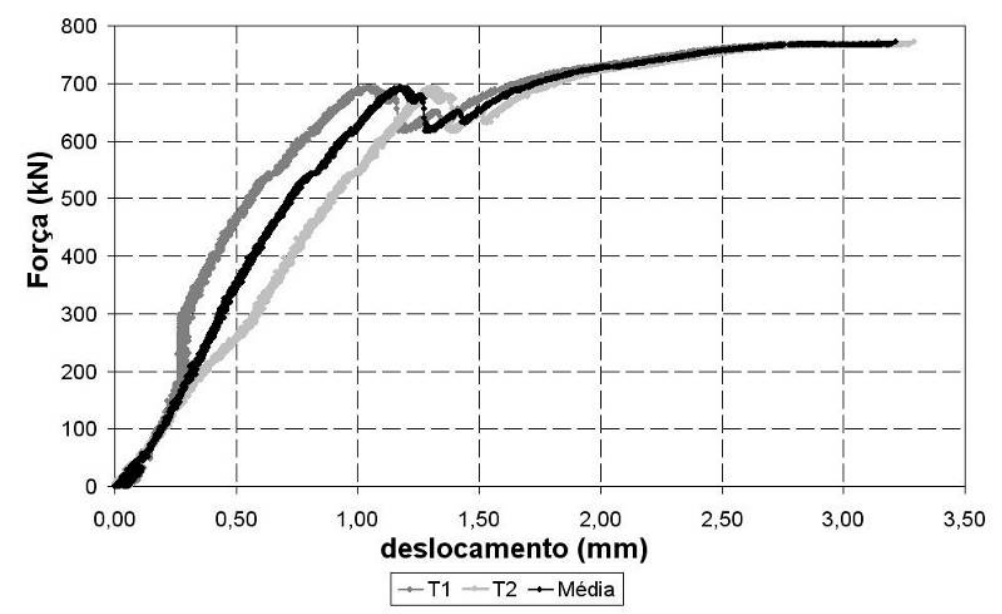

Figura 5. 22- Curva força versus deslocamento médio medido nos transdutores T1 e T2 do modelo M2 


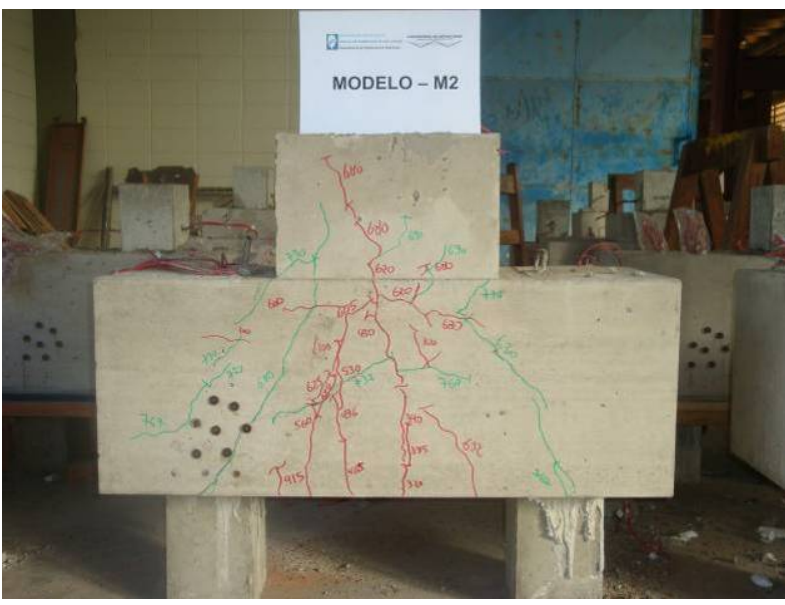

(a)

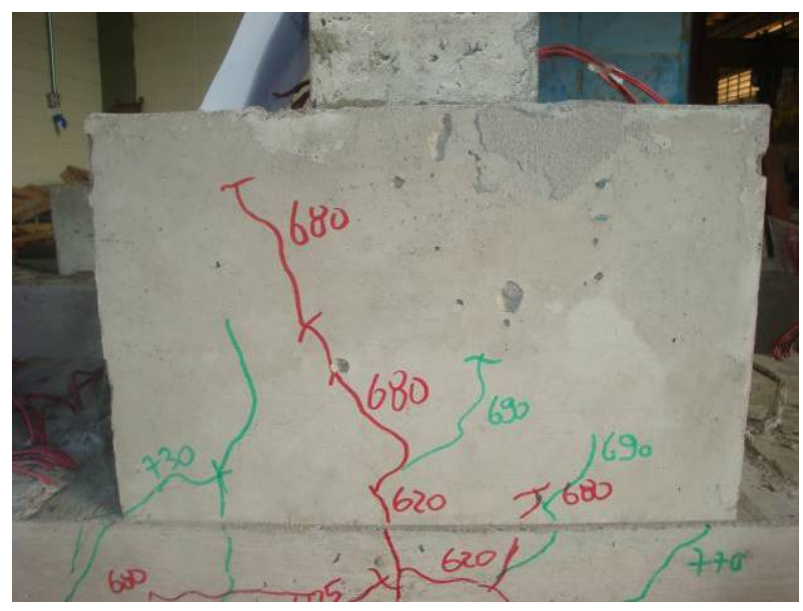

(b)

Figura 5. 23-Fissuras na face lateral e no cálice do Modelo M2

Assim como nos blocos de referência, obtiveram-se valores pequenos para as medidas de deformações no concreto, uma vez que com as leituras efetuadas nas pastilhas de aço, as quais estavam fixadas nas faces laterais dos blocos, foi possível calcular as deformações na face externa do bloco. Em função dos valores obtidos, constatou-se que as deformações ficaram aquém das deformações existentes nas bielas. Desse modo, considera-se que a utilização das pastilhas de aço não conferiu bons resultados para a estimativa das deformações do concreto. Apresentam-se na tabela 5.24 os valores de deformações principais e as direções principais em relação a quatro intensidades de força. As direções apresentadas referem-se ao esquema apresentado na Figura 4.49 (b).

Tabela 5.24 - Deformação no concreto do modelo M2

\begin{tabular}{c|c|c|c|c|c|c|c|c}
\hline \hline \multirow{2}{*}{$\begin{array}{c}\text { Força } \\
\text { (kN) }\end{array}$} & \multirow{2}{*}{ Direção } & \multicolumn{3}{|c|}{ Deformações (\%) } & \multicolumn{2}{c|}{$\begin{array}{c}\text { Deformações } \\
\text { Principais (\%o) }\end{array}$} & \multicolumn{2}{c}{$\begin{array}{c}\text { Direções } \\
\text { Principais ( }\end{array}$} \\
& & $\boldsymbol{\varepsilon}_{\mathbf{0}^{\circ}}$ & $\boldsymbol{\varepsilon}_{\mathbf{4 5}^{\circ}}$ & $\boldsymbol{\varepsilon}_{\mathbf{9 0}^{\circ}}$ & $\boldsymbol{\varepsilon}_{\mathbf{1}}$ & $\boldsymbol{\varepsilon}_{\mathbf{2}}$ & $\boldsymbol{\alpha}_{\mathbf{1}}$ & $\boldsymbol{\alpha}_{\mathbf{2}}$ \\
\hline \multirow{2}{*}{50} & $1,5,3$ & 0,016 & $-0,004$ & $-0,010$ & 0,02 & $-0,01$ & $-14,1$ & 75,8 \\
\cline { 2 - 9 } & $2,6,4$ & $-0,005$ & $-0,012$ & 0,001 & 0,01 & $-0,01$ & 36,6 & 126,6 \\
\hline \multirow{2}{*}{200} & $1,5,3$ & $-0,003$ & 0,014 & 0,023 & 0,02 & 0,0 & $-8,5$ & 84,4 \\
\cline { 2 - 9 } & $2,6,4$ & $-0,005$ & $-0,059$ & 0,001 & 0,06 & $-0,06$ & 43,4 & 133,4 \\
\hline \multirow{2}{*}{350} & $1,5,3$ & $-0,015$ & 0,011 & 0,009 & 0,02 & $-0,02$ & $-24,7$ & 65,3 \\
\cline { 2 - 9 } & $2,6,4$ & $-0,005$ & $-0,011$ & $-0,001$ & 0,01 & $-0,01$ & 37,9 & 127,9 \\
\hline \multirow{2}{*}{550} & $1,5,3$ & 0,006 & 0,014 & 0,036 & 0,04 & 0,0 & 12,5 & 102,5 \\
\cline { 2 - 9 } & $2,6,4$ & 0,029 & $-0,017$ & $-0,003$ & 0,05 & $-0,02$ & $-30,9$ & 59,0 \\
\hline \hline
\end{tabular}




\subsubsection{Modelo M3 - BEX_AS_SR}

O modelo M3 teve a área da armadura principal detalhada maior que a necessária calculada com o modelo teórico. Assim como o modelo M2, o modelo M3 apresentou comportamento de bloco rígido. Foi registrada uma excentricidade inicial na força aplicada no pilar da ordem de 2,65 cm, a qual se manteve até o final do ensaio. A ruína do modelo se deu por ruptura do concreto do pilar, sem que ocorresse escoamento das barras da armadura principal do tirante, localizada na região central do bloco. Não houve indícios de ruptura do concreto do bloco, o que indica que o aumento da área de armadura principal do tirante conduziria a uma maior capacidade resistente do bloco, tendo em vista que não houve escoamento das barras da armadura do tirante.

A força máxima suportada por esse modelo foi de $724 \mathrm{kN}$, força essa superior a força calculada com o modelo teórico utilizado para o dimensionamento. O modelo apresentou resistência crescente até atingir uma força próxima de $705 \mathrm{kN}$, quando houve uma pequena diminuição na força até o valor de $680 \mathrm{kN}$. Em seguida, o bloco voltou a apresentar aumento de força, até atingir a ruína por ruptura do concreto do pilar para uma força igual a $724 \mathrm{kN}$. Observa-se que o valor da força última do modelo M3 foi inferior ao valor de $756 \mathrm{kN}$ do bloco de referência. Destaca-se nesse quesito que, caso não houvesse a ruína do modelo por ruptura do concreto do pilar, a força última nesse modelo tenderia a ser próxima a do bloco de referência. Constatou-se que o concreto do bloco de fundação não apresentou indícios de ruptura, e que o concreto utilizado nos pilares não apresentou resistência suficiente para que se conduzisse o ensaio até a ruína do bloco.

A primeira fissura visível no modelo M3 apresentou abertura da ordem de 0,05 mm, e surgiu em diagonal na direção da biela para uma força de $130 \mathrm{kN}$, a qual se prolongou até a região dos extensômetros removíveis. Em seguida, surgiu uma fissura horizontal próximo ao encontro do bloco com o cálice para uma força de $220 \mathrm{kN}$. A primeira fissura na região inferior central do bloco ocorreu para uma força de $310 \mathrm{kN}$. Nessa etapa, a deformação máxima medida nas barras das armaduras do tirante foi de $0,83 \%$, o que resulta numa tensão igual a $169 \mathrm{MPa}$. Observou-se que o modelo apresentou perda de rigidez com uma força próxima a $260 \mathrm{kN}$, conforme pode ser observado nos gráficos força versus deformação das barras das armaduras posicionadas na região central do bloco.

A Figura 5.24 apresenta o gráfico força versus deformação em cada barra, enquanto que a Figura 5.25 apresenta a curva força versus deformação média em relação as armaduras posicionadas na seção central do bloco para os modelos M1, M2 e M3. Observa-se por meio 
dessa figura que os dois blocos com cálice externo apresentaram-se mais rígidos do que o bloco de referência. Verifica-se também que o modelo M3 apresentou deformações médias nas armaduras inferiores às obtidas no modelo M1, indicando que a biela de compressão no modelo M3 se iniciou ao longo do cálice, apresentando inclinação com o tirante superior a do bloco de referência dessa série. Comparando as deformações médias nas barras da armadura principal do tirante do modelo M3, verificam-se valores superiores aos obtidos no modelo M2 para uma mesma intensidade de força, o que não era esperado em virtude da maior área de aço utilizada nesse modelo.

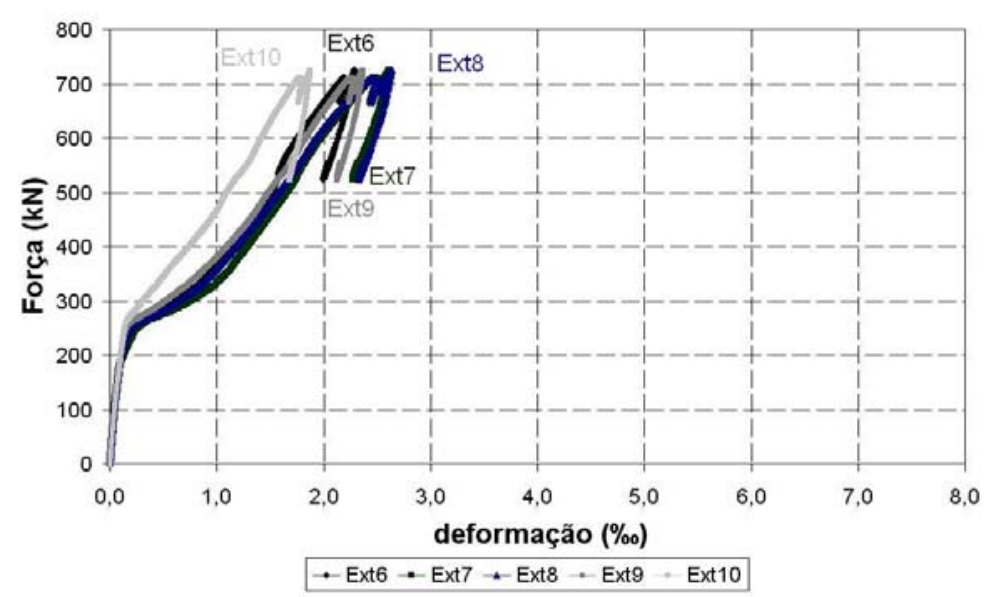

Figura 5. 24- Curva força versus deformação nas armaduras da região central do modelo M3

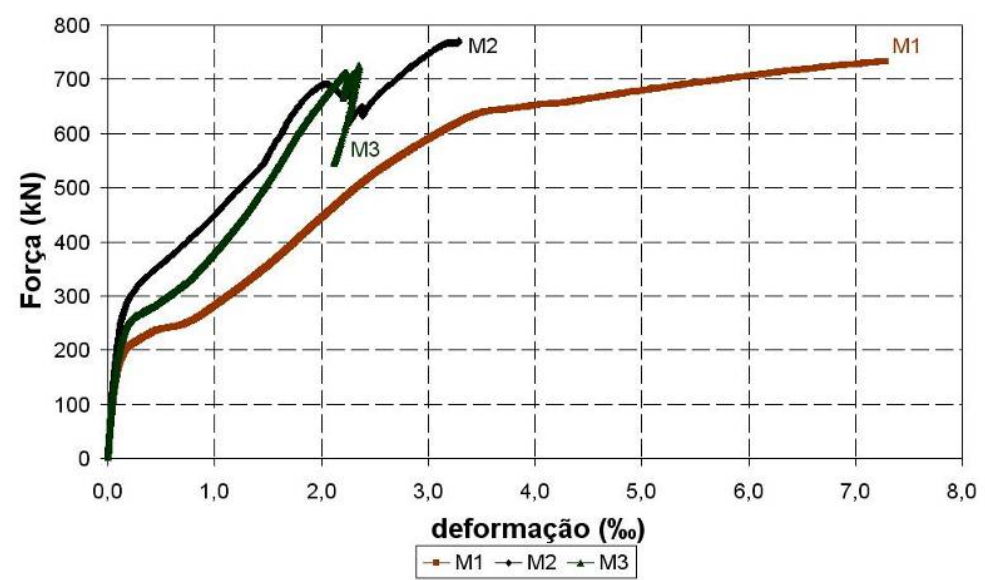

Figura 5. 25- Curva força versus deformação média nas armaduras da região central dos modelos M1, M2 e M3

As Figuras 5.26 e 5.27 apresentam os gráficos força versus deformação nas barras das armaduras posicionadas sobre as estacas. Observa-se por meio desses gráficos que as deformações nas armaduras apresentam valores da ordem de 0,3\%o, valores esses pequenos 
quando comparados com as deformações obtidas nas armaduras posicionadas na região central do bloco. Isso ocorre em virtude da formação da biela sobre as estacas, o que provoca diminuição da força no tirante nessa região.

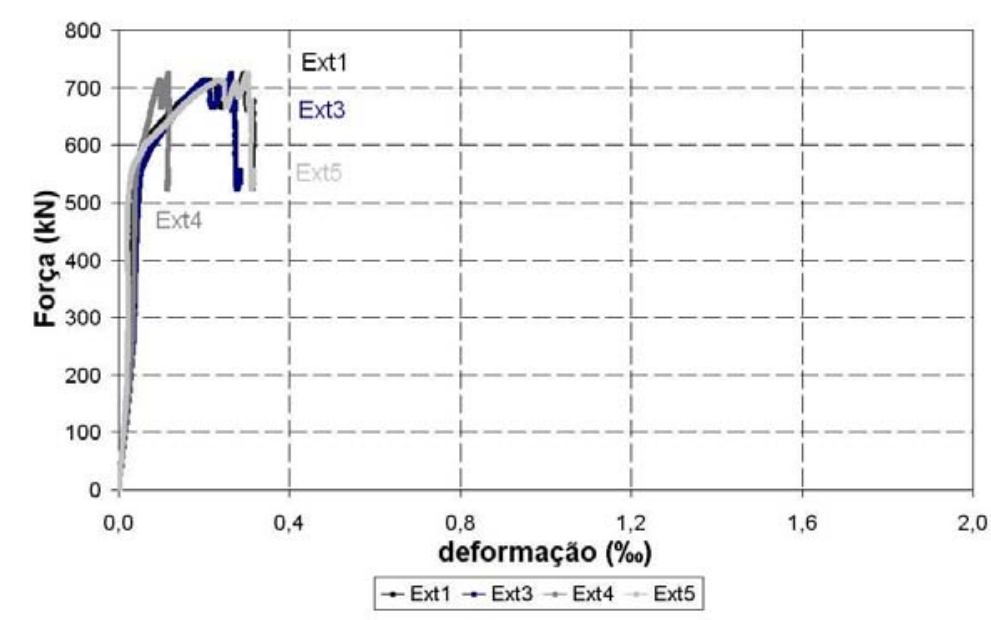

Figura 5. 26- Curva força versus deformação nas armaduras sobre as estacas do modelo M3

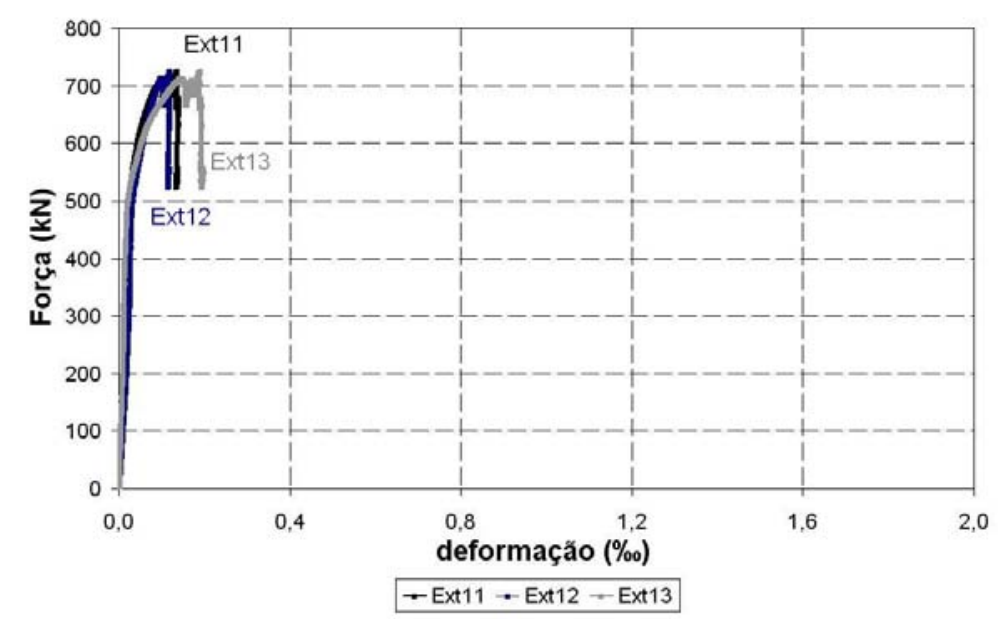

Figura 5. 27-Curva força versus deformação nas armaduras sobre as estacas do modelo M3

A Figura 5.28 apresenta o gráfico força versus deformação nas barras das armaduras do pilar. Observa-se que, semelhante ao modelo M2, as deformações nas barras das armaduras tornam-se menores à medida que o pilar se aproxima do fundo do cálice, conforme pode ser observado nas medidas de deformação dos extensômetro de números 16 e 18. Esse fato é outro indício de que a biela de compressão é formada ao longo da altura do cálice.

A Figura 5.29 apresenta a curva força versus deslocamento do modelo M3, a partir da qual pode-se observar um deslocamento médio próximo a $1,4 \mathrm{~mm}$ próximo à ruína do modelo, o qual ocorreu na região central do bloco. 


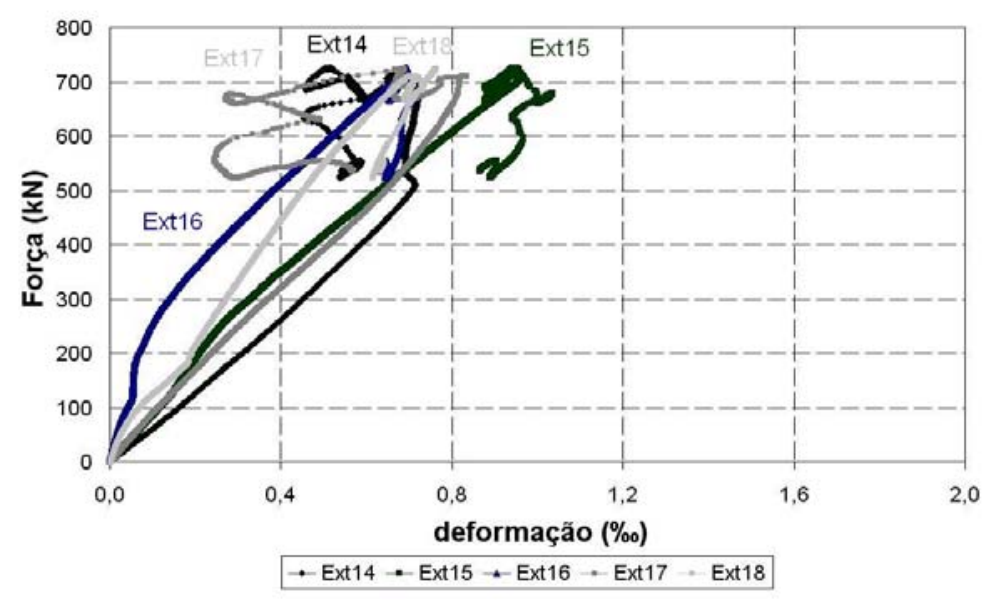

Figura 5. 28- Curva força versus deformação nas armaduras do pilar do modelo M3

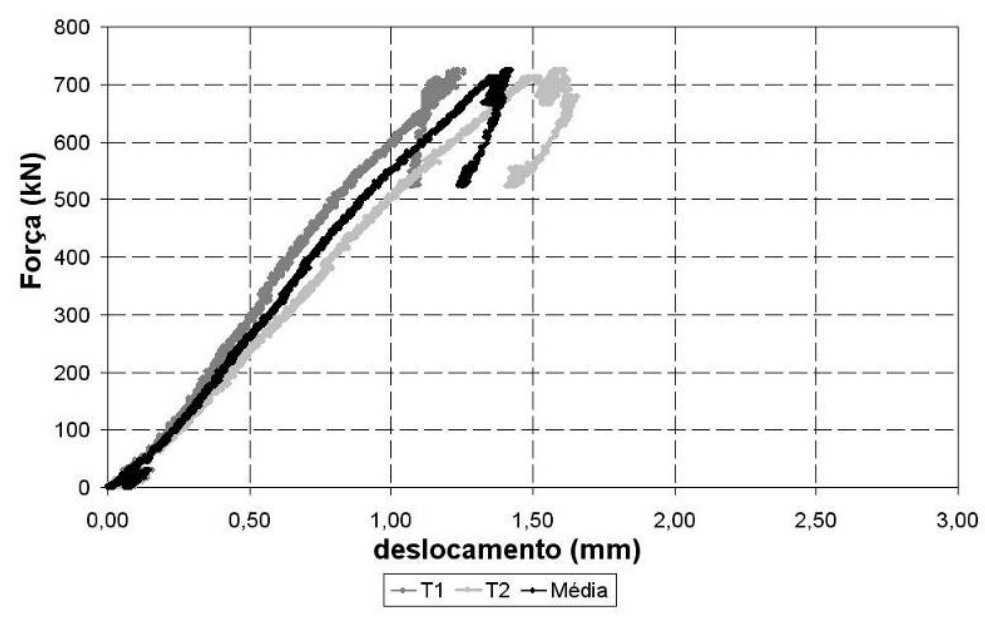

Figura 5. 29-Curva força versus deslocamento médio medido nos transdutores T1 e T2 do modelo M3

Nesse modelo constatou-se a perda do extensômetro de número 2 e 19, posicionados sobre as estacas e no pilar. Nesse modelo verificou-se um fissura horizontal que se estendeu ao longo do encontro do cálice com o bloco a partir de uma força igual a $530 \mathrm{kN}$. Verificaram-se aberturas de fissuras da ordem de $0,10 \mathrm{~mm}$ correspondente a força de $360 \mathrm{kN}$; $0,20 \mathrm{~mm}$ para uma força de $450 \mathrm{kN}$; e aberturas de fissuras iguais a 0,4 $\mathrm{mm}$ correspondente a uma força igual a $670 \mathrm{kN}$. Verificaram-se três linhas de fissuras na região central do bloco, praticamente inclinadas a $90^{\circ}$ em relação a horizontal, as quais prolongaram-se até a região superior do bloco. Diferente do modelo M2, o modelo M3 não apresentou fissuras na região do cálice. A Figura 5.30 (a) apresenta a ruína do pilar; a Figura 5.30 (b) apresenta o panorama de fissuras do modelo M3 após a realização dos ensaios, e a Figura 5.30 (c) apresenta a fissura em diagonal na região dos extensômetros removíveis. 


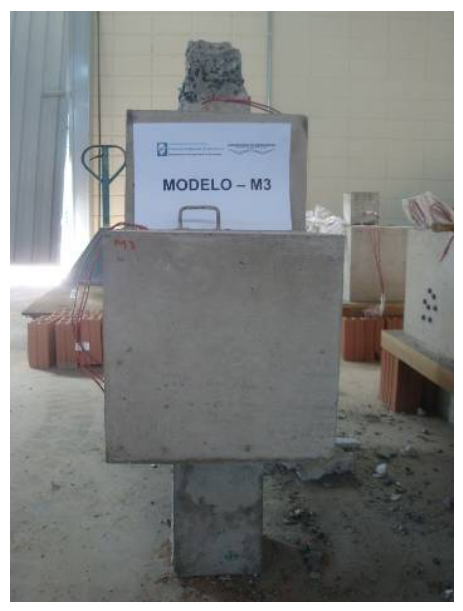

(a)

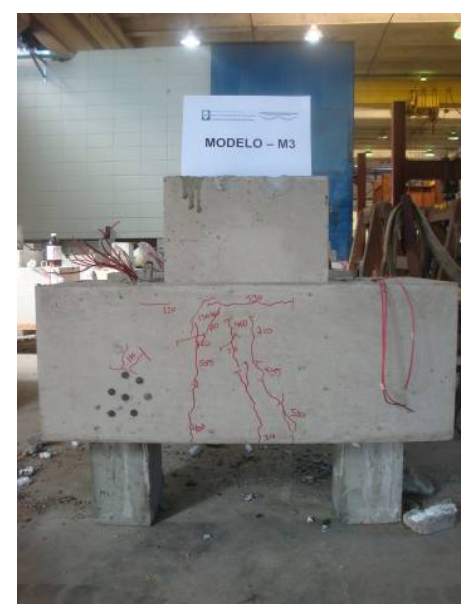

(b)

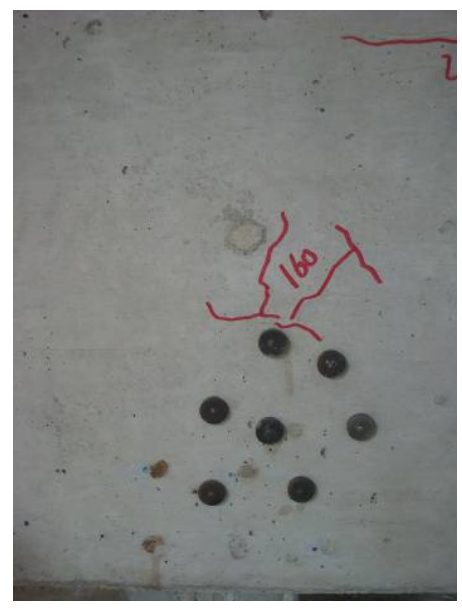

(c)

Figura 5. 30-Fissuras na face lateral e inferior do Modelo M3

Obtiveram-se valores pequenos para as medidas de deformações no concreto, uma vez que com as leituras efetuadas nas pastilhas de aço, as quais estavam fixadas nas faces laterais dos blocos, foi possível calcular as deformações na face externa do bloco. Em função dos valores obtidos, constatou-se que as deformações ficaram aquém das deformações existentes nas bielas. Desse modo, considera-se que a utilização das pastilhas de aço não conferiu bons resultados para a estimativa das deformações do concreto. Apresentam-se na tabela 5.25 os valores de deformações principais e as direções principais em relação a quatro intensidades de força. As direções apresentadas referem-se ao esquema apresentado na Figura 4.49 (b).

Tabela 5.25 - Deformação no concreto do modelo M3

\begin{tabular}{|c|c|c|c|c|c|c|c|c|}
\hline \multirow{2}{*}{$\begin{array}{l}\text { Força } \\
(\mathbf{k N})\end{array}$} & \multirow[t]{2}{*}{ Direção } & \multicolumn{3}{|c|}{ Deformações (\%o) } & \multicolumn{2}{|c|}{$\begin{array}{l}\text { Deformações } \\
\text { Principais (\%) }\end{array}$} & \multicolumn{2}{|c|}{$\begin{array}{c}\text { Direções } \\
\text { Principais }\left({ }^{(}\right)\end{array}$} \\
\hline & & $\varepsilon_{0^{\circ}}$ & $\varepsilon_{45^{\circ}}$ & $\varepsilon_{90^{\circ}}$ & $\varepsilon_{1}$ & $\varepsilon_{2}$ & $\alpha_{1}$ & $\alpha_{2}$ \\
\hline \multirow{2}{*}{50} & $1,5,3$ & 0,003 & 0,003 & $-0,003$ & 0,0 & 0,0 & 22,5 & 112,5 \\
\hline & $2,6,4$ & 0,005 & 0,002 & $-0,011$ & 0,01 & $-0,01$ & 16,0 & 106,0 \\
\hline \multirow{2}{*}{200} & $1,5,3$ & 0,002 & 0,002 & $-0,002$ & 0,0 & 0,0 & 22,5 & 112,5 \\
\hline & $2,6,4$ & 0,009 & 0,0 & $-0,017$ & 0,01 & $-0,02$ & 8,55 & 98,5 \\
\hline \multirow{2}{*}{350} & $1,5,3$ & 0,002 & 0,005 & 0,003 & 0,01 & 0,0 & $-39,3$ & 50,6 \\
\hline & $2,6,4$ & 0,015 & $-0,01$ & $-0,017$ & 0,02 & $-0,02$ & $-16,0$ & $-74,0$ \\
\hline \multirow{2}{*}{550} & $1,5,3$ & 0,006 & 0,003 & 0,020 & 0,03 & 0,0 & 27,5 & 117,5 \\
\hline & $2,6,4$ & 0,022 & $-0,003$ & $-0,008$ & 0,03 & $-0,01$ & $-16,8$ & 73,1 \\
\hline
\end{tabular}




\subsubsection{Modelo M9 - BEX_CR}

O modelo M9 apresentou comportamento de bloco rígido. Foi registrada uma excentricidade na força aplicada no pilar da ordem de $2,85 \mathrm{~cm}$, e a ruína do modelo se deu por ruptura do concreto do bloco, com escoamento de apenas uma das barras da armadura principal do tirante, localizadas na região central do bloco.

A força máxima suportada por esse modelo foi de $916 \mathrm{kN}$, força essa superior a força calculada com o modelo teórico utilizado para o dimensionamento. O modelo apresentou resistência crescente ao longo de todo o ensaio, até atingir a ruína para uma força igual a 916 $\mathrm{kN}$. Observa-se que o valor da força última do modelo M9 foi superior ao valor máximo de $728 \mathrm{kN}$ do bloco de referência dessa série.

A primeira fissura visível no modelo M9 surgiu na região inferior central do bloco, para uma força de $320 \mathrm{kN}$, e apresentou abertura da ordem de $0,05 \mathrm{~mm}$. Nessa etapa, a deformação máxima nas cinco barras da armadura do tirante foi de $0,38 \%$, o que resulta numa tensão igual a $78 \mathrm{MPa}$. Observou-se que o modelo apresentou perda de rigidez com uma força próxima de $300 \mathrm{kN}$, conforme pode ser observado nos gráficos força versus deformação das barras das armaduras posicionadas na região central do bloco.

A Figura 5.31 apresenta o gráfico força versus deformação em cada barra, enquanto que a Figura 5.32 apresenta a curva força versus deformação média em relação as armaduras posicionadas na seção central do bloco para os modelos M9 e M8. Observa-se por meio dessa figura que o bloco com cálice externo apresentou-se mais rígido do que o bloco de referência. Verifica-se também que o modelo M9 apresentou deformações médias nas armaduras inferiores às obtidas no modelo M8, indicando que a biela de compressão no modelo M9 se iniciou ao longo do cálice, apresentando inclinação com o tirante superior a do bloco de referência dessa série. Observando os valores de deformação nas barras das armaduras, verifica-se que o maior valor de deformação das armadura posicionadas na região central do bloco foi igual a 3\%, valor esse próximo a deformação que provoca escoamento das barras da armadura.

As Figuras 5.33 e 5.34 apresentam os gráficos força versus deformação nas barras das armaduras posicionadas sobre as estacas. Observa-se por meio desses gráficos que as deformações nas armaduras apresentam valores inferiores a $0,8 \%$, valores esses pequenos quando comparados as deformações obtidas nas armaduras posicionadas na região central do bloco. Isso ocorre em virtude da formação da biela sobre as estacas, o que provoca diminuição da força no tirante nessa região. 


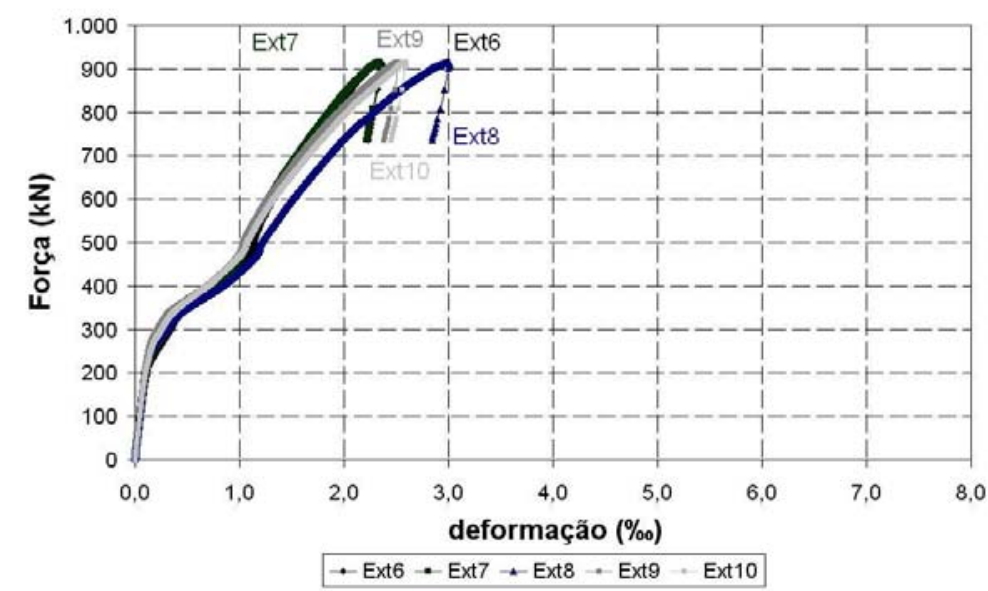

Figura 5. 31- Curva força versus deformação nas armaduras da região central do modelo M9

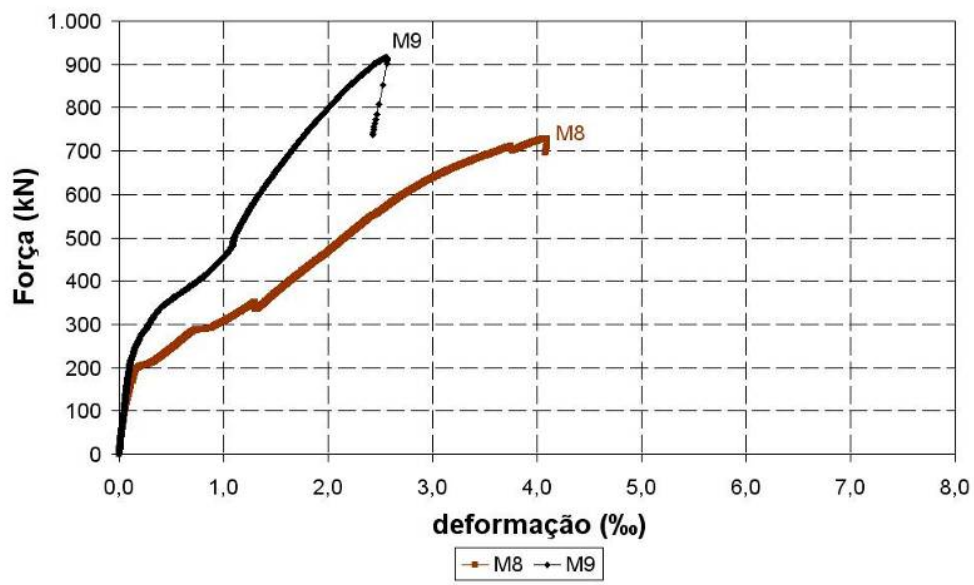

Figura 5. 32-Curva força versus deformação média nas armaduras da região central dos modelos M8 e M9

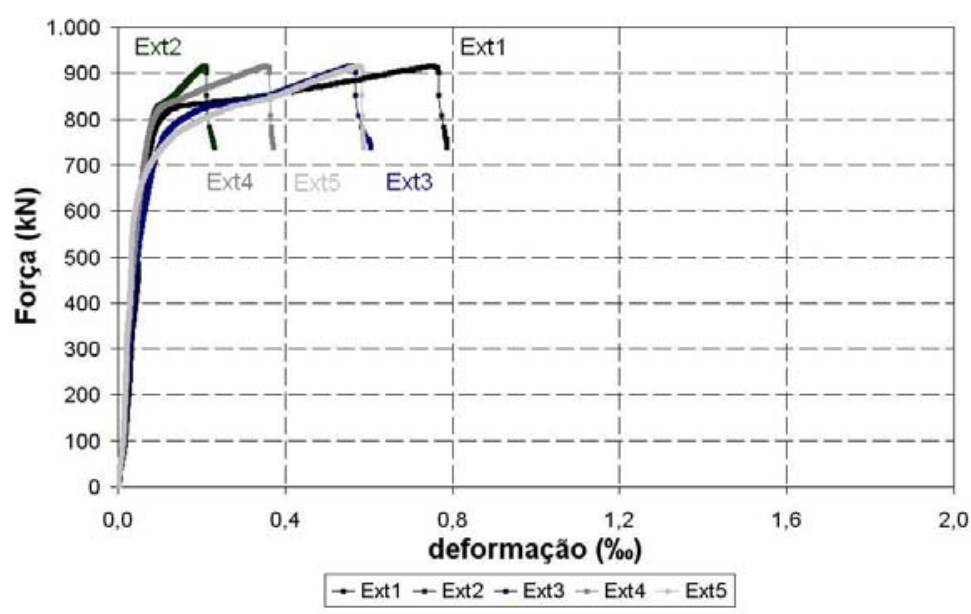

Figura 5. 33- Curva força versus deformação nas armaduras sobre as estacas do modelo M9 


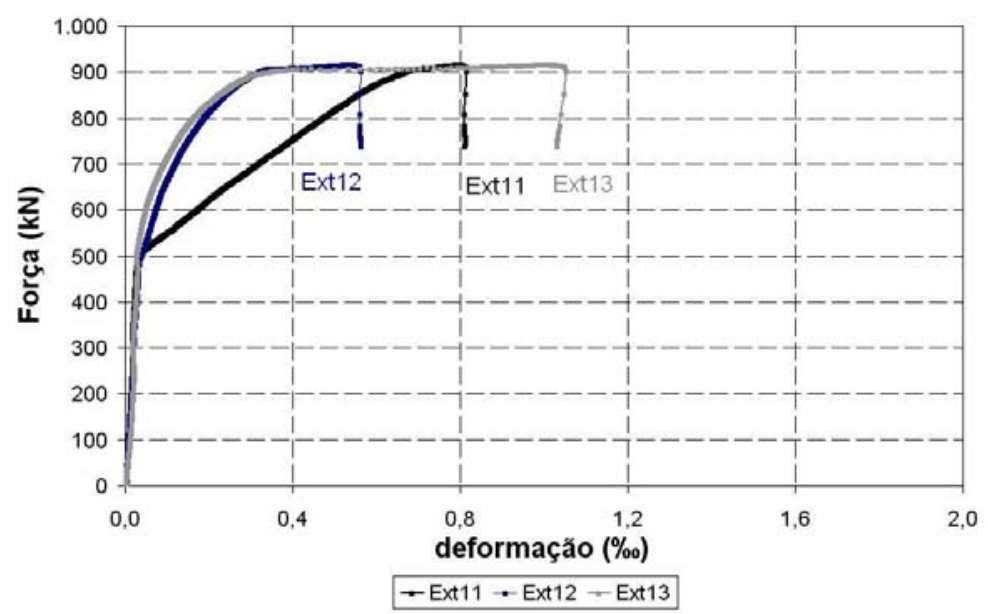

Figura 5. 34- Curva força versus deformação nas armaduras sobre as estacas do modelo M9

A Figura 5.35 apresenta o gráfico força versus deformação nas barras das armaduras do pilar. Semelhante ao que ocorreu nos blocos com cálice externo e sem rugosidade, observa-se que as deformações nas barras das armaduras tornam-se menores à medida que o pilar se aproxima do fundo do cálice, conforme pode ser observado nos extensômetro posicionados nas barras das armaduras do pilar. Essa transferência, por sua vez, foi mais acentuada do que as que ocorreram nos modelos M2 e M3, ocasionada pela existência da chave de cisalhamento no modelo M9. Esse fato é outro indício de que a biela de compressão é formada ao longo da altura do cálice.

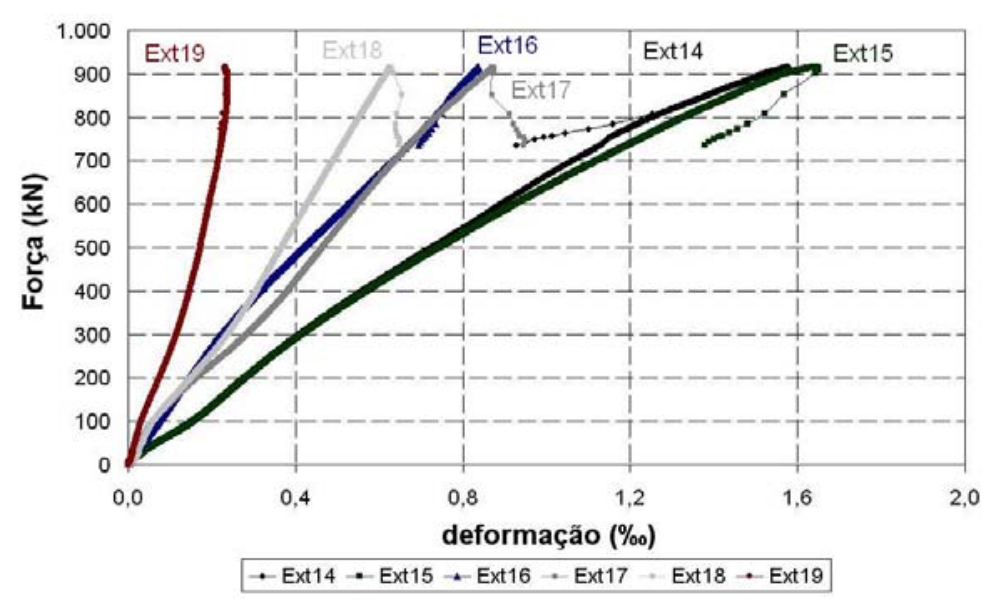

Figura 5. 35- Curva força versus deformação nas armaduras do pilar do modelo M9

A Figura 5.36 apresenta a curva força versus deslocamento do modelo M9, a partir da qual pode-se observar um deslocamento médio próximo a $1,7 \mathrm{~mm}$ próximo a ruína do modelo, o qual ocorreu na região central do bloco. Nesse modelo não houve perda de nenhum extensômetro elétrico de resistência. 


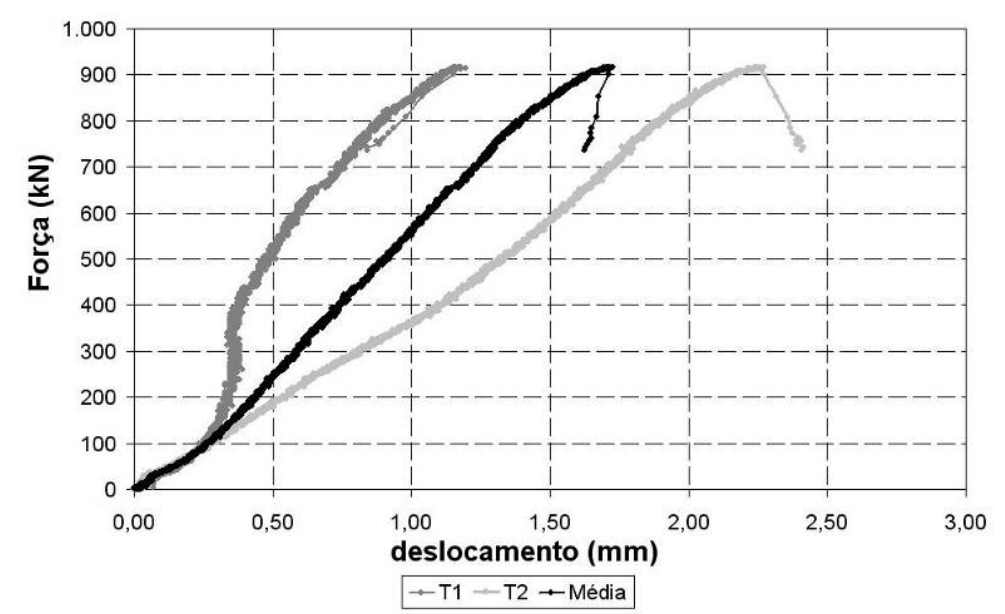

Figura 5. 36- Curva força versus deslocamento médio medido nos transdutores T1 e T2 do modelo M9

A medida que a força no pistão aumentava, verificou-se o surgimento de novas fissuras e aumento da abertura das fissuras existentes. Verificaram-se aberturas de fissuras da ordem de 0,10 mm na região inferior do bloco, para uma força no pilar igual a $400 \mathrm{kN} ; 0,20 \mathrm{~mm}$ para uma força de $600 \mathrm{kN}$; e $0,3 \mathrm{~mm}$ para uma força de $800 \mathrm{kN}$. Próximo a ruína do modelo, não havia mais formação de novas fissuras, ocorrendo apenas aumento da abertura das fissuras existentes.

A Figura 5.37 (a) apresenta o panorama de fissuração do modelo M9 após a realização do ensaio. Constatou-se a existência de algumas fissuras que atravessaram o bloco em direção ao colarinho, conforme pode ser observado na Figura 5.37 (b). Não foi observada formação de fissuras diagonais aparentes, indicando a formação da biela do bloco. Entretanto, acreditase que fissuras internas tenham ocorrido no bloco na região da biela de compressão, sem que atingissem a face externa do bloco.

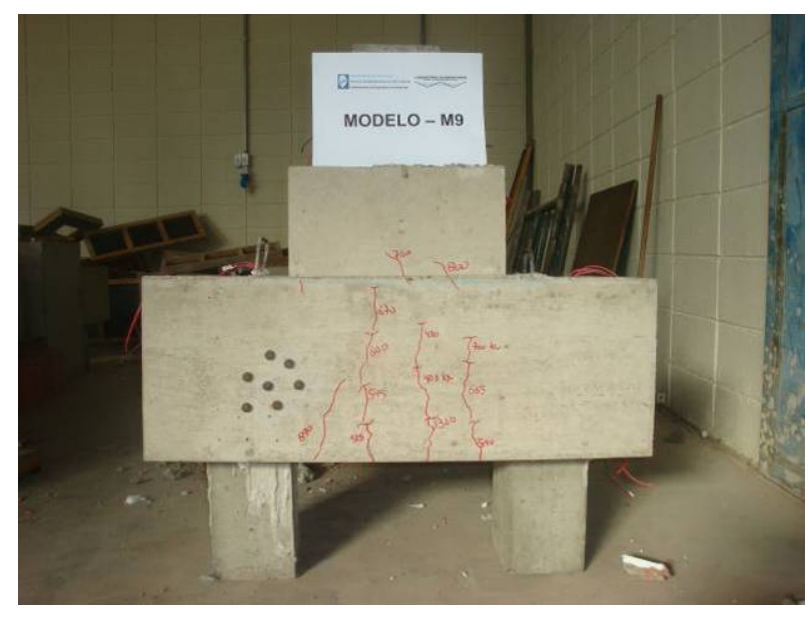

(a)

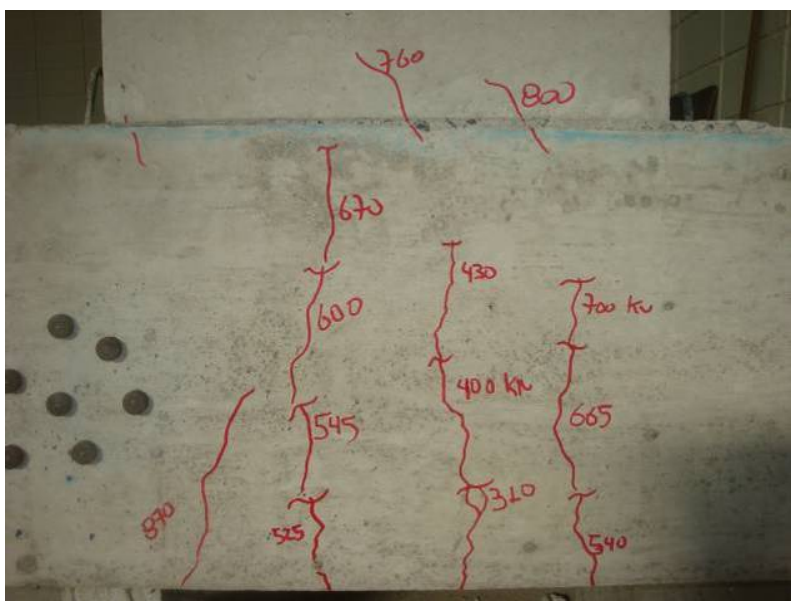

(b)

Figura 5. 37-Fissuras na face lateral do Modelo M9 
Obtiveram-se valores pequenos para as medidas de deformações no concreto, uma vez que com as leituras efetuadas nas pastilhas de aço, as quais estavam fixadas nas faces laterais dos blocos, foi possível calcular as deformações na face externa do bloco. Em função dos valores obtidos, constatou-se que as deformações ficaram aquém das deformações existentes nas bielas. Desse modo, considera-se que a utilização das pastilhas de aço não conferiu bons resultados para a estimativa das deformações do concreto. Apresentam-se na tabela 5.26 os valores de deformações principais e as direções principais em relação a quatro intensidades de força. As direções apresentadas referem-se ao esquema apresentado na Figura 4.49 (b).

Tabela 5.26 - Deformação no concreto do modelo M9

\begin{tabular}{|c|c|c|c|c|c|c|c|c|}
\hline \multirow{2}{*}{$\begin{array}{l}\text { Força } \\
(\mathbf{k N})\end{array}$} & \multirow[t]{2}{*}{ Direção } & \multicolumn{3}{|c|}{ Deformações (\%o) } & \multicolumn{2}{|c|}{$\begin{array}{c}\text { Deformações } \\
\text { Principais (\%o) }\end{array}$} & \multicolumn{2}{|c|}{$\begin{array}{c}\text { Direções } \\
\text { Principais ( }{ }^{\circ} \text { ) }\end{array}$} \\
\hline & & $\varepsilon_{0^{\circ}}$ & $\varepsilon_{45^{\circ}}$ & $\varepsilon_{90^{\circ}}$ & $\varepsilon_{1}$ & $\varepsilon_{2}$ & $\alpha_{1}$ & $\alpha_{2}$ \\
\hline \multirow{2}{*}{50} & $1,5,3$ & 0 & 0,024 & 0,020 & 0,03 & $-0,01$ & $-27,2$ & 62,7 \\
\hline & $2,6,4$ & $-0,024$ & 0,011 & 0,090 & 0,09 & $-0,03$ & 10,5 & 100,5 \\
\hline \multirow{2}{*}{200} & $1,5,3$ & 0,007 & 0,0 & $-0,010$ & 0,01 & $-0,01$ & 5,0 & 95,0 \\
\hline & $2,6,4$ & $-0,009$ & 0,010 & $-0,006$ & 0,01 & $-0,03$ & $-42,5$ & 47,4 \\
\hline \multirow{2}{*}{350} & $1,5,3$ & 0,047 & 0,010 & 0,016 & 0,06 & 0,00 & $-27,1$ & 62,8 \\
\hline & $2,6,4$ & $-0,016$ & 0,004 & 0,019 & 0,02 & $-0,02$ & $-4,0$ & 85,9 \\
\hline \multirow{2}{*}{500} & $1,5,3$ & 0,022 & $-0,002$ & $-0,006$ & 0,03 & $-0,01$ & $-17,7$ & 72,2 \\
\hline & $2,6,4$ & $-0,004$ & 0,019 & $-0,021$ & 0,02 & $-0,05$ & 37,4 & 127,4 \\
\hline
\end{tabular}

\subsubsection{Modelo M10 - BEX_AS_CR}

O modelo M10 teve a armadura principal detalhada superior à armadura necessária calculada com o modelo teórico. Assim como o modelo M9, o modelo M10 apresentou comportamento de bloco rígido. Foi registrada uma pequena excentricidade inicial na força aplicada no pilar da ordem de $0,17 \mathrm{~cm}$, a qual se manteve até o final do ensaio. A ruína do modelo se deu por ruptura do concreto do pilar, sem que ocorresse escoamento das barras da armadura principal do tirante, localizada na região central do bloco. Tal qual ocorreu no modelo M3, não houve indícios de ruptura do concreto do bloco, indicando que o aumento da 
área de armadura principal do tirante conduziria a uma maior capacidade resistente do bloco, tendo em vista que não houve escoamento das barras da armadura do tirante.

A força máxima suportada por esse modelo foi de $632 \mathrm{kN}$, força essa superior a força calculada com o modelo teórico utilizado para o dimensionamento. O modelo apresentou resistência crescente até atingir a ruína, que ocorreu de forma frágil com ruptura do concreto do pilar. Observa-se que o valor da força última do modelo M10 foi inferior ao valor de 728 $\mathrm{kN}$ do bloco de referência. Destaca-se nesse quesito que, caso não houvesse a ruína do modelo por ruptura do concreto do pilar, a força última nesse modelo tenderia a ser superior a do bloco de referência. Constatou-se que o concreto do bloco de fundação não apresentou indícios de ruptura, e que o concreto utilizado nos pilares não apresentou resistência suficiente para que se conduzisse o ensaio até a ruína do bloco.

A primeira fissura visível no modelo M10 apresentou abertura da ordem de $0,05 \mathrm{~mm}$, e surgiu na região inferior central do bloco para uma força de $370 \mathrm{kN}$. Nessa etapa, a deformação máxima medida nas barras das armaduras do tirante foi de $0,21 \%$, o que resulta numa tensão igual a $42 \mathrm{MPa}$. Observou-se que o modelo apresentou perda de rigidez com uma força próxima a $400 \mathrm{kN}$, conforme pode ser observado nos gráficos força versus deformação das barras das armaduras posicionadas na região central do bloco.

A Figura 5.38 apresenta o gráfico força versus deformação em cada barra, enquanto que a Figura 5.39 apresenta a curva força versus deformação média em relação as armaduras posicionadas na seção central do bloco para os modelos M8, M9 e M10. Observa-se por meio dessa figura que os dois blocos com cálice externo apresentaram-se mais rígidos do que o bloco de referência. Verifica-se também que o modelo M10 apresentou deformações médias nas armaduras inferiores às obtidas no modelo M8, indicando que a biela de compressão no modelo M10 se iniciou ao longo do cálice, apresentando inclinação com o tirante superior a do bloco de referência dessa série. Comparando as deformações médias nas barras da armadura principal do tirante do modelo M10, verificam-se valores inferiores aos obtidos no modelo M9, o que era esperado em virtude da maior área de aço utilizada nesse modelo. Todavia, em função da ruptura brusca do concreto do pilar, não foi possível estabelecer qual o aumento de capacidade resistente do bloco quando do aumento da taxa de armadura no mesmo. Destaca-se que esse fato ocorreu nos modelos M3 e M10, os quais apresentavam armadura detalhada superior à armadura calculada, não sendo possível estabelecer o ganho de capacidade resistente do bloco em decorrência do aumento da área de aço no tirante principal. 
Resultados experimentais

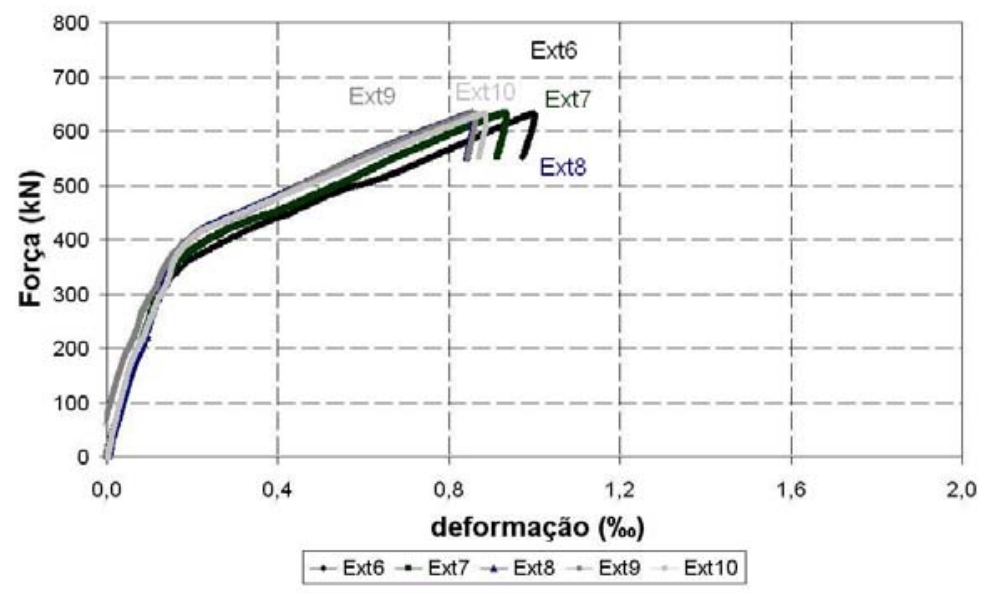

Figura 5. 38- Curva força versus deformação nas armaduras da região central do modelo M10

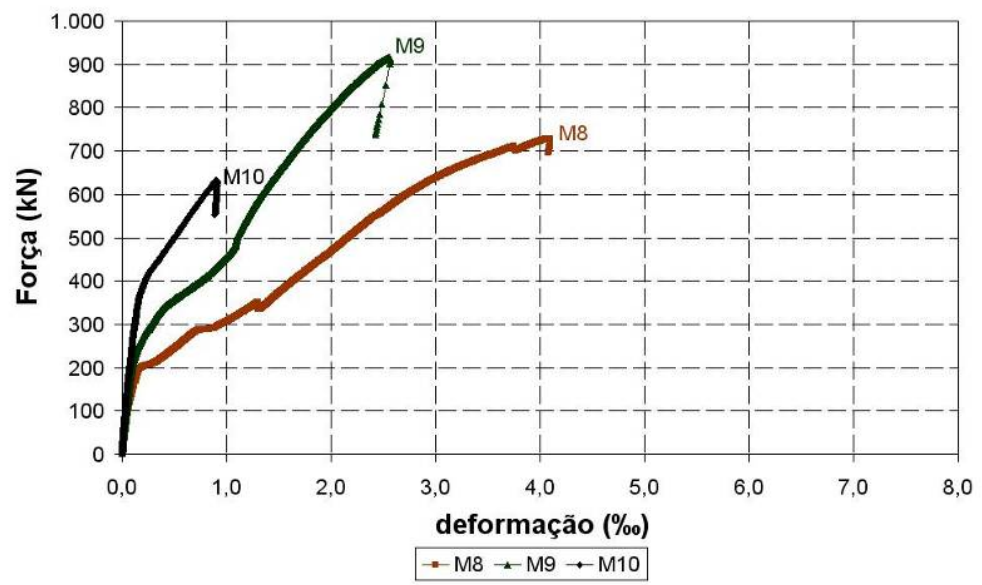

Figura 5. 39- Curva força versus deformação média nas armaduras da região central dos modelos M8, M9 e M10

As Figuras 5.40 e $\mathbf{5 . 4 1}$ apresentam os gráficos força versus deformação nas barras das armaduras posicionadas sobre as estacas. Observa-se por meio desses gráficos que as deformações nas armaduras apresentam valores da ordem de 0,1\%, valores esses pequenos quando comparados as deformações obtidas nas armaduras posicionadas na região central do bloco. Isso ocorre em virtude da formação da biela sobre as estacas, o que provoca diminuição da força no tirante nessa região. 


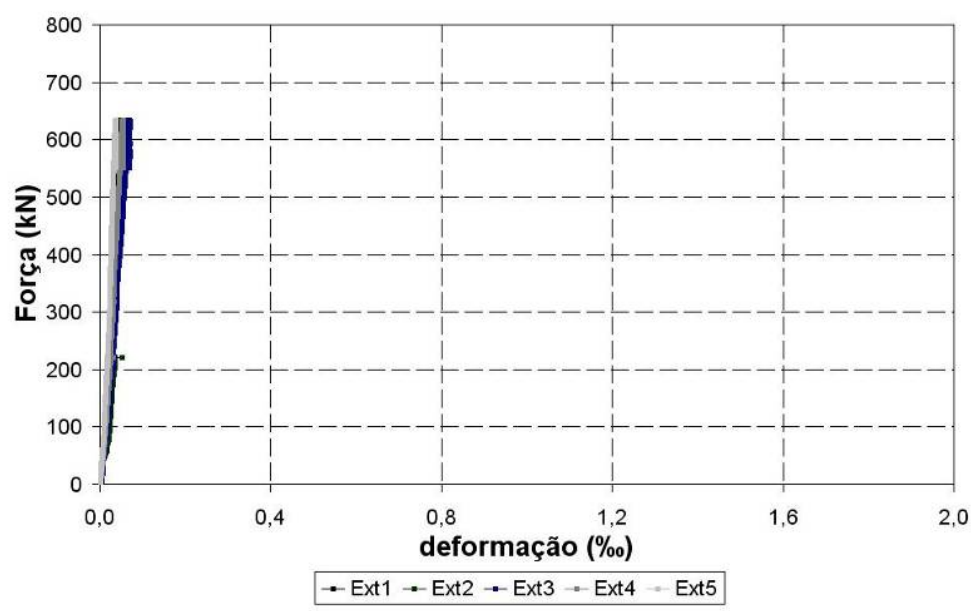

Figura 5. 40- Curva força versus deformação nas armaduras sobre as estacas do modelo M10

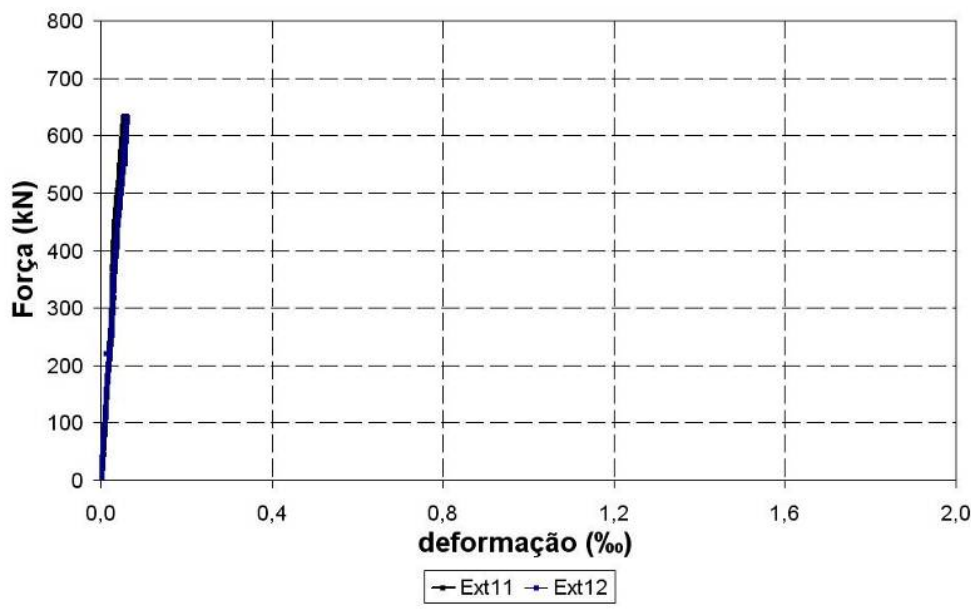

Figura 5. 41- Curva força versus deformação nas armaduras sobre as estacas do modelo M10

A Figura 5.42 apresenta o gráfico força versus deformação nas barras das armaduras do pilar. Semelhante ao que ocorreu nos blocos com cálice externo e sem rugosidade, observa-se que as deformações nas barras das armaduras tornam-se menores à medida que o pilar se aproxima do fundo do cálice, conforme pode ser observado nos extensômetro posicionados nas barras das armaduras do pilar. Assim como ocorreu no modelo M9, essa transferência foi mais acentuada do que as que ocorreram nos modelos M2 e M3, sendo ocasionada pela existência da chave de cisalhamento existente no modelo M10. Esse fato é outro indício de que a biela de compressão é formada ao longo da altura do cálice. A Figura 5.43, por sua vez, apresenta a curva força versus deslocamento do modelo M10, a partir da qual pode-se observar um deslocamento médio próximo a $0,9 \mathrm{~mm}$ próximo a ruína do modelo, o qual ocorreu na região central do bloco. 


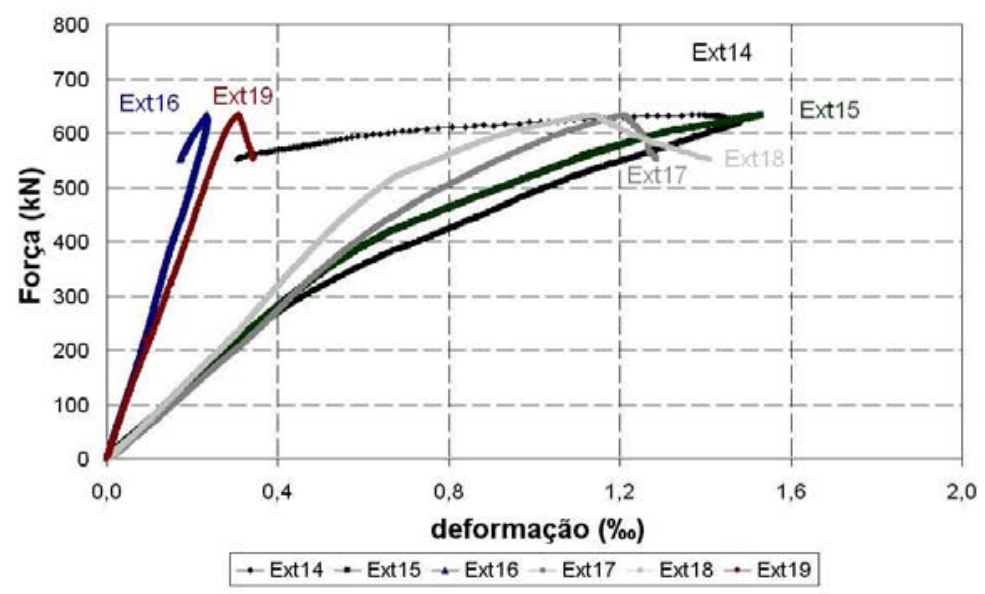

Figura 5. 42- Curva força versus deformação nas armaduras do pilar do modelo M10

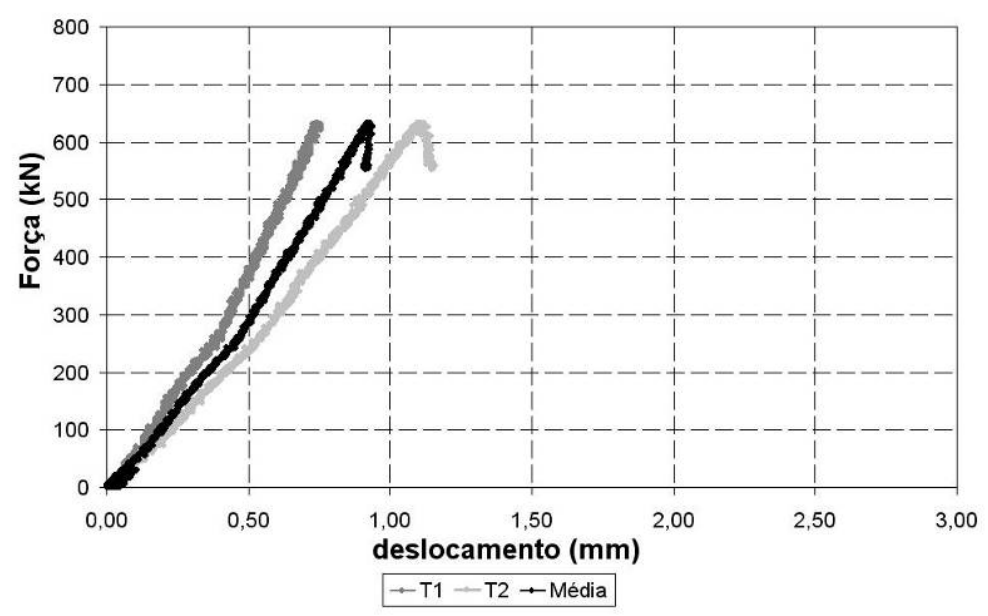

Figura 5. 43-Curva força versus deslocamento médio medido nos transdutores T1 e T2 do modelo M10

As ruínas precoces dos pilares apresentadas pelos modelos M3 e M10 podem ser atribuídas às pequenas resistências obtidas nos ensaios de caracterização dos concretos dos pilares. No caso específico do modelo M10, a situação foi pior do que a ocorrida no modelo M3, uma vez que nesse modelo nenhum das barras da armadura do tirante estava próxima de apresentar escoamento, além do fato de ter ocorrido uma diminuição da resistência do bloco antes da ruptura do concreto do pilar. Como a área da armadura detalhada foi superior a área da armadura calculada, e a deformação das barras da armadura do pilar indicavam formação da biela a partir do colarinho, era esperado que a força última no bloco fosse superior a do bloco de referência. Assim, não se conseguiu registrar para esse modelo resultados significativos que possam conduzir a alguma conclusão a respeito da utilização de armadura superior a detalhada, porém a ruína do pilar serviu de alerta, indicando que cuidados deveriam ser tomados em relação aos próximos ensaios. A Figura 5.44 (a) apresenta o modelo após o ensaio e a Figura 5.44 (b) apresenta uma parte do pilar após a ruptura. 


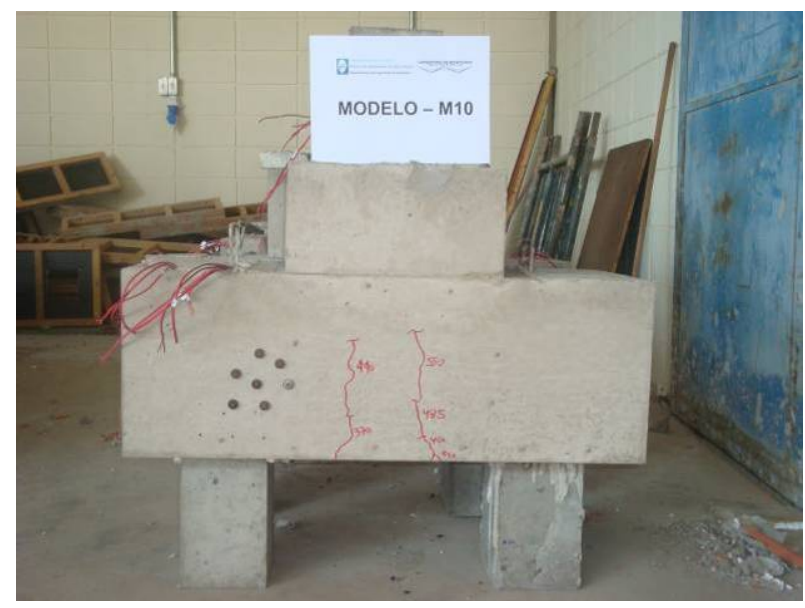

(a)

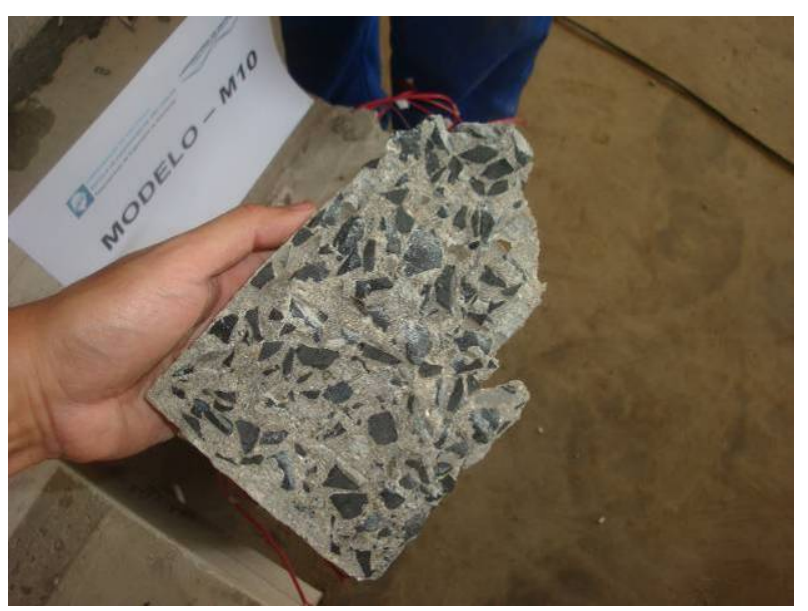

(b)

Figura 5. 44-Modelo M10 e ruptura do concreto do pilar

Obtiveram-se valores pequenos para as medidas de deformações no concreto, uma vez que com as leituras efetuadas nas pastilhas de aço, as quais estavam fixadas nas faces laterais dos blocos, foi possível calcular as deformações na face externa do bloco. Em função dos valores obtidos, constatou-se que as deformações ficaram aquém das deformações existentes nas bielas. Desse modo, considera-se que a utilização das pastilhas de aço não conferiu bons resultados para a estimativa das deformações do concreto. Apresentam-se na tabela 5.27 os valores de deformações principais e as direções principais em relação a quatro intensidades de força. As direções apresentadas referem-se ao esquema apresentado na Figura 4.49 (b).

Tabela 5.27 - Deformação no concreto do modelo M10

\begin{tabular}{|c|c|c|c|c|c|c|c|c|}
\hline \multirow{2}{*}{$\begin{array}{c}\text { Força } \\
(\mathbf{k N})\end{array}$} & \multirow[t]{2}{*}{ Direção } & \multicolumn{3}{|c|}{ Deformações (\%o) } & \multicolumn{2}{|c|}{$\begin{array}{c}\text { Deformações } \\
\text { Principais (\%o) }\end{array}$} & \multicolumn{2}{|c|}{$\begin{array}{c}\text { Direções } \\
\text { Principais }\left({ }^{(}\right)\end{array}$} \\
\hline & & $\varepsilon_{0^{\circ}}$ & $\varepsilon_{45^{\circ}}$ & $\varepsilon_{90^{\circ}}$ & $\varepsilon_{1}$ & $\varepsilon_{2}$ & $\alpha_{1}$ & $\alpha_{2}$ \\
\hline \multirow{2}{*}{50} & $1,5,3$ & 0,004 & $-0,009$ & $-0,007$ & 0,01 & $-0,01$ & $-26,9$ & 63,1 \\
\hline & $2,6,4$ & $-0,001$ & $-0,093$ & $-0,007$ & 0,09 & $-0,09$ & $-44,0$ & 46,0 \\
\hline \multirow{2}{*}{200} & $1,5,3$ & 0,004 & $-0,013$ & $-0,005$ & 0,01 & $-0,01$ & $-35,1$ & 54,9 \\
\hline & $2,6,4$ & 0,008 & $-0,097$ & 0,005 & 0,11 & $-0,10$ & $-44,6$ & 45,4 \\
\hline \multirow{2}{*}{350} & $1,5,3$ & 0,0 & $-0,109$ & $-0,005$ & 0,10 & $-0,11$ & $-44,3$ & 45,7 \\
\hline & $2,6,4$ & 0,011 & $-0,001$ & $-0,007$ & 0,01 & $-0,01$ & $-9,2$ & 80,8 \\
\hline \multirow{2}{*}{500} & $1,5,3$ & 0,009 & $-0,101$ & $-0,007$ & 0,10 & $-0,10$ & $-42,8$ & 47,2 \\
\hline & $2,6,4$ & 0,01 & $-0,084$ & 0,004 & 0,10 & $-0,08$ & $-44,1$ & 45,9 \\
\hline
\end{tabular}




\subsection{Blocos com cálice parcialmente embutido}

Os ensaios dos blocos com cálice parcialmente embutido ocorreram após os ensaios dos blocos com cálice externo. Foram ensaiados os modelos M4 e M5, os quais apresentavam interface sem rugosidade, e os modelo M11 e M12, os quais apresentavam rugosidade. Os modelos M5 e M12 apresentavam armadura complementar em forma de estribo posicionada na região central do bloco, com o intuito de verificar se essa armadura influência no comportamento do bloco. Destaca-se neste item que, após a ruína precoce dos pilares dos modelos M3 e M10, foi colocado no pilar um dispositivo metálico, de modo a conferir confinamento ao concreto do pilar. Trata-se de uma cantoneira metálica existente no LE, presa nas extremidades por dois parafusos rosqueados. Após a utilização desse dispositivo, nenhum outro pilar apresentou ruína durante os ensaios.

\subsubsection{Modelo M4 - BPE_SR}

O modelo M4 apresentou comportamento de bloco rígido. Foi registrada uma excentricidade na força aplicada no pilar da ordem de $1,17 \mathrm{~cm}$. A ruína do modelo se deu por escoamento de todas as barras das armaduras principais do tirante, localizadas na região central do bloco, seguido da ruptura do concreto do bloco.

A força máxima suportada por esse modelo foi de $563 \mathrm{kN}$, força essa superior a força calculada com o modelo teórico utilizado para o dimensionamento. O modelo apresentou resistência crescente até atingir uma força de $460 \mathrm{kN}$, apresentando duas grandes fissuras na região central, quando houve diminuição na resistência até o valor de $400 \mathrm{kN}$. Em seguida, o bloco voltou a apresentar aumento de força, até atingir a ruína para uma força igual a $563 \mathrm{kN}$. Observa-se que o valor da força última do modelo M4 foi inferior ao valor máximo de $756 \mathrm{kN}$ obtido no bloco de referência dessa série, bem como foi inferior a força última obtida no modelo M2, o qual apresentava o cálice externo.

A primeira fissura visível no modelo M4 surgiu na região central inferior do bloco, apresentando abertura da ordem de $0,05 \mathrm{~mm}$ para uma força de $210 \mathrm{kN}$. Nessa etapa, a deformação máxima medida nas barras das armaduras do tirante foi de 0,26\%o o que resulta numa tensão igual a $53 \mathrm{MPa}$. Observou-se que o modelo apresentou perda de rigidez para uma força próxima de $190 \mathrm{kN}$, conforme pode ser observado nos gráficos força versus deformação das barras das armaduras posicionadas na região central do bloco. 
A Figura 5.45 apresenta o gráfico força versus deformação em cada barra, enquanto que a Figura 5.46 apresenta a curva força versus deformação média em relação as armaduras posicionadas na seção central do bloco para os modelos M1, M2 e M4. Observa-se por meio dessa figura que até uma força próxima a $450 \mathrm{kN}$, o modelo $\mathrm{M} 4$ apresentou rigidez semelhante a do bloco de referência, e inferior a rigidez do bloco com cálice externo do modelo M2. Verifica-se também que, a partir da força de $450 \mathrm{kN}$, o modelo M4 apresentou deformações médias nas armaduras superiores às obtidas nos modelos M1 e M2. Em função desses resultados, percebe-se que a formação da biela de compressão no modelo M4 apresenta inclinação com o tirante inferior a inclinação apresentada pelo bloco de referência dessa série.

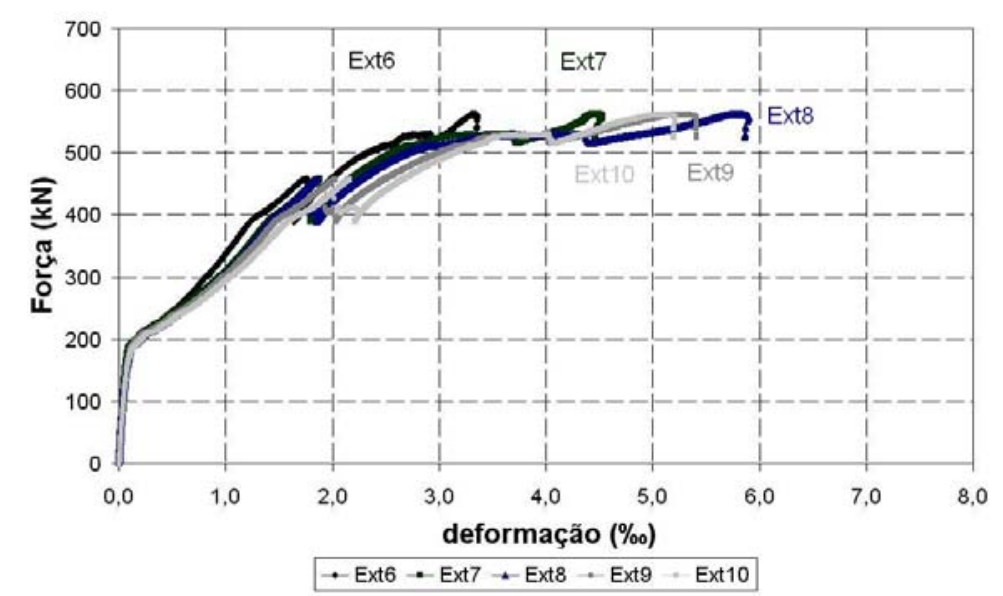

Figura 5. 45- Curva força versus deformação nas armaduras da região central do modelo M4

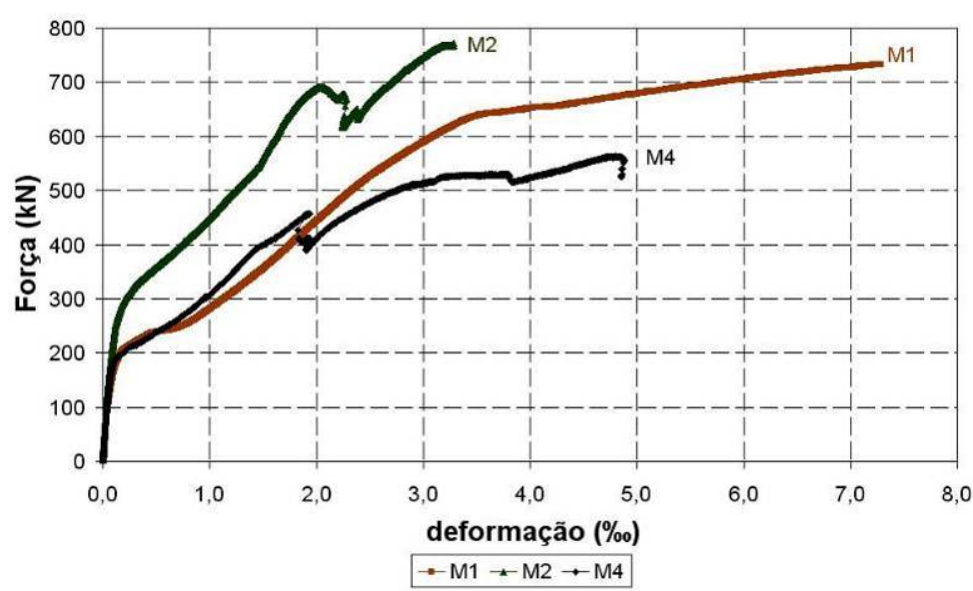

Figura 5. 46- Curva força versus deformação média nas armaduras da região central dos modelos M1, M2 e M4

As Figuras 5.47 e 5.48 apresentam os gráficos força versus deformação nas barras das armaduras posicionadas sobre as estacas. Observa-se por meio desses gráficos que as 
deformações médias nas armaduras apresentam valores da ordem de 1,2\%o, valores esses pequenos quando comparados as deformações obtidas nas armaduras posicionadas na região central do bloco. Isso ocorre em virtude da formação da biela sobre as estacas, o que provoca diminuição da força no tirante nessa região.

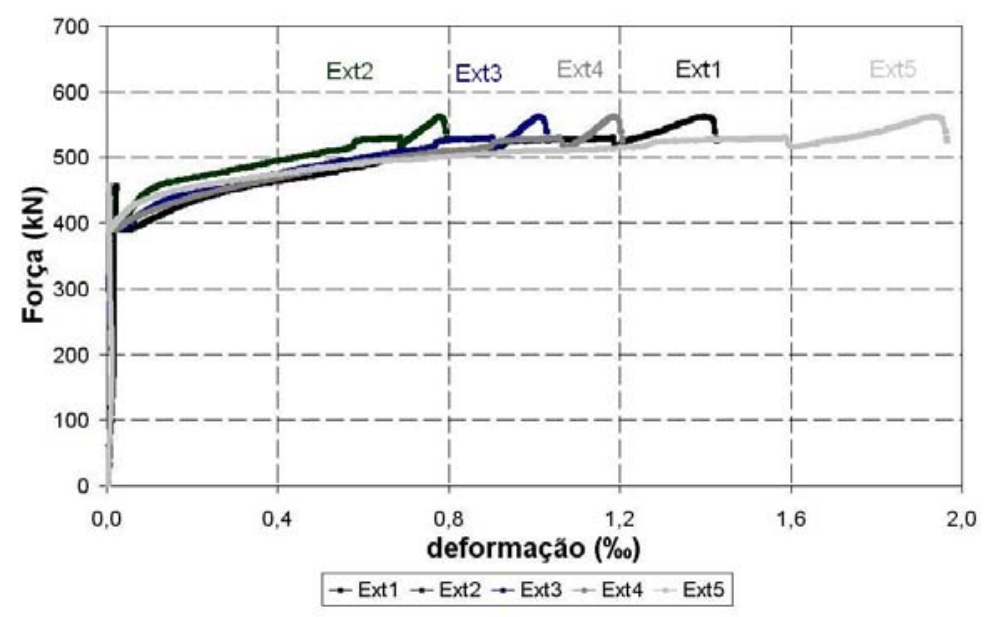

Figura 5. 47- Curva força versus deformação nas armaduras sobre as estacas do modelo M4

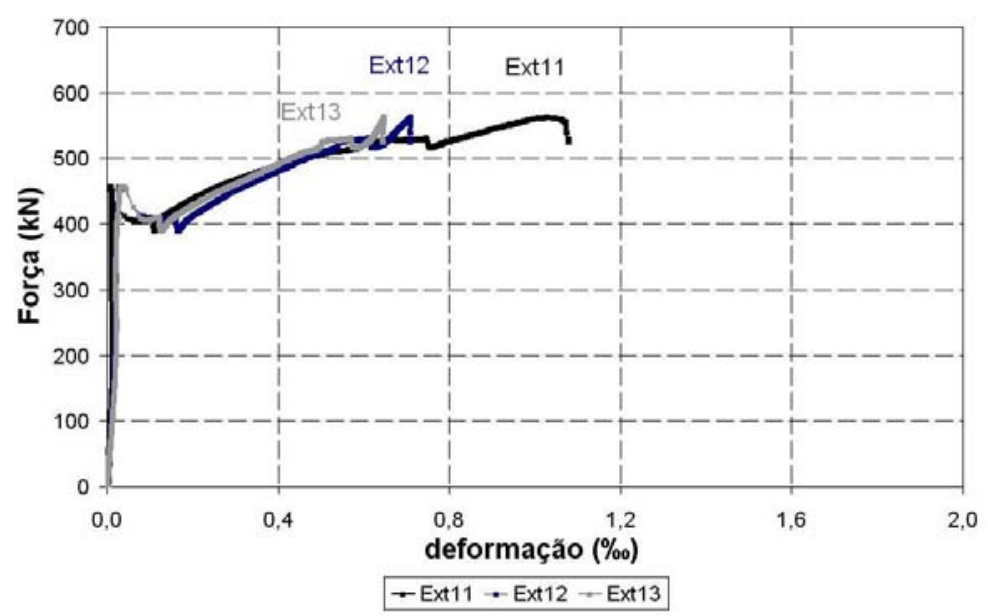

Figura 5. 48- Curva força versus deformação nas armaduras sobre as estacas do modelo M4

A Figura 5.49 apresenta o gráfico força versus deformação nas barras das armaduras do pilar. Semelhante ao que ocorreu nos blocos com cálice externo e sem rugosidade, observa-se que as deformações nas barras das armaduras tornam-se menores à medida que o pilar se aproxima do fundo do cálice, conforme pode ser observado comparando os resultados dos extensômetros de número 15 e 16, bem como os extensômetros de número 17 e 19, os quais estavam posicionados nas barras das armaduras do pilar. Esse fato indica que a biela de compressão é formada ao longo da altura do cálice. 


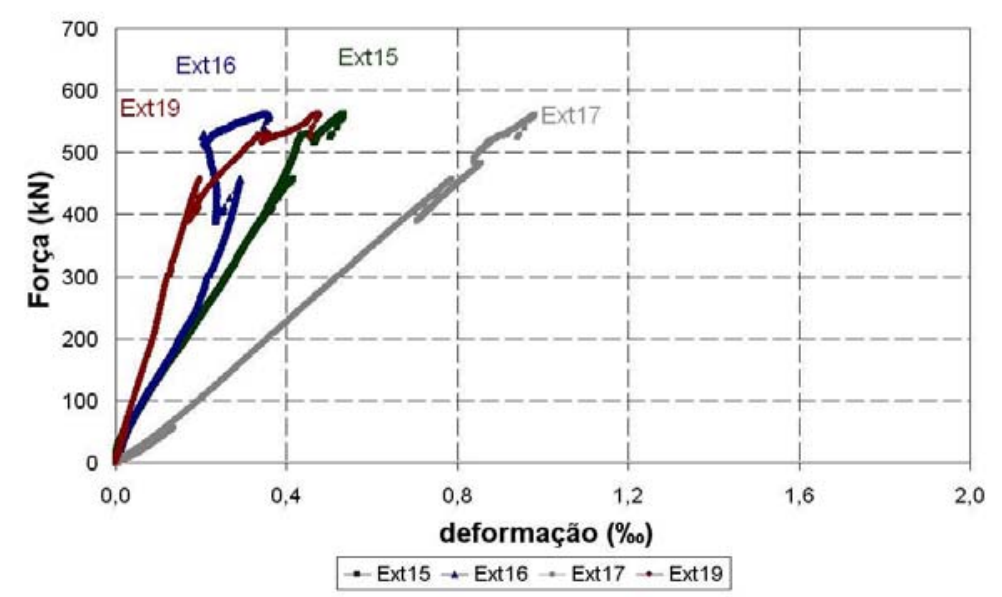

Figura 5. 49- Curva força versus deformação nas armaduras do pilar do modelo M4

O gráfico da Figura 5.50 apresenta os resultados de deformação medidos nas barras das armaduras posicionadas no cálice de fundação. Destaca-se o resultado da armadura vertical do cálice, cujos resultados foram obtidos por meio do extensômetro de número 21. Observa-se inicialmente encurtamento da barra de armadura vertical, ocasionado pela força de compressão oriundo do pilar. Esse encurtamento ocorre de modo linear até uma força de 450 $\mathrm{kN}$, quando houve diminuição na resistência do bloco. A partir desse instante, observa-se uma inversão nos valores de deformação, sendo que a barra até então comprimida passa a apresentar alongamento, isto é, deformações oriundas de força de tração. Esse resultado indica que o maciço de concreto sob o cálice no interior do bloco apresentou ruptura, não ocorrendo a separação em dois ou mais segmentos em virtude da presença de armadura nessa região. $\mathrm{O}$ extensômetro de número 20, por sua vez, apresentou deformações semelhantes a da armadura principal do tirante, uma vez que estava posicionada na mesma região.

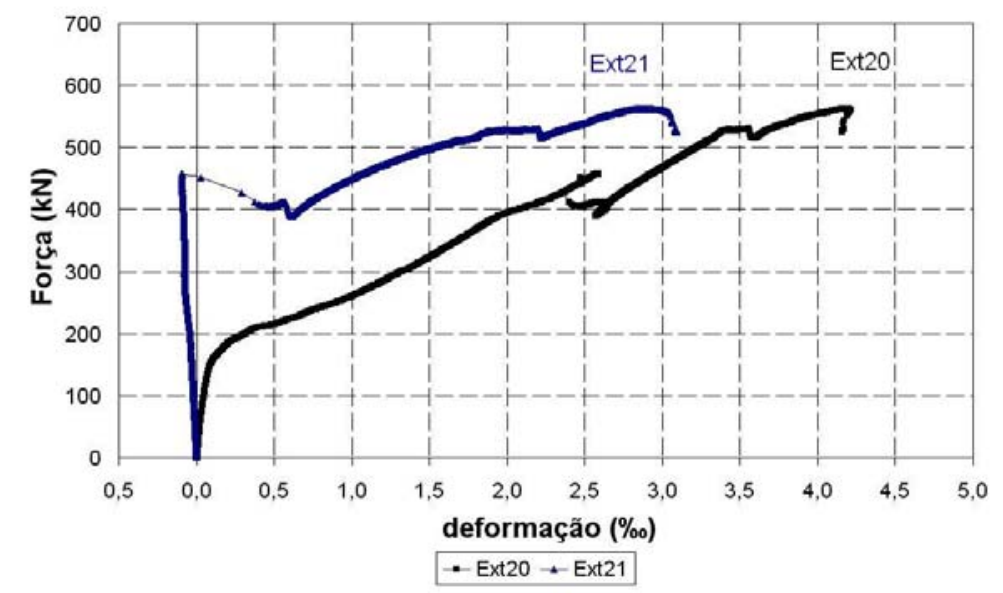

Figura 5. 50- Curva força versus deformação nas armaduras do cálice do modelo M4 
A Figura 5.51, por sua vez, apresenta a curva força versus deslocamento do modelo M4, a partir da qual pode-se observar um deslocamento médio superior a 4,00 mm próximo a ruína do modelo, o qual ocorreu na região central do bloco. Verifica-se que o deslocamento medido nesse modelo foi superior ao obtido nos demais blocos.

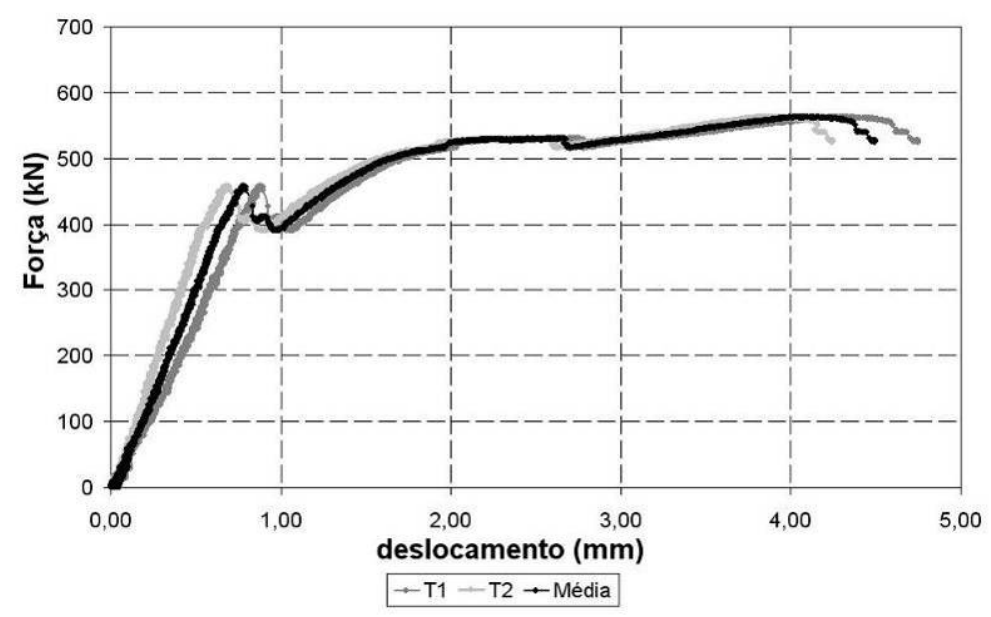

Figura 5. 51- Curva força versus deslocamento médio medido nos transdutores T1 e T2 do modelo M4

No modelo M4 houve perda dos extensômetros elétricos de resistência de número 14 e 18, situados nas barras da armadura do pilar. A medida que a força no pistão aumentava, verificou-se o surgimento de novas fissuras e aumento da abertura das fissuras existentes. Constatou-se aberturas da ordem de $0,15 \mathrm{~mm}$ correspondente a força de $310 \mathrm{kN}$; 0,25 mm para uma força de $380 \mathrm{kN}$; e $0,30 \mathrm{~mm}$ para uma força de $440 \mathrm{kN}$. Após o modelo M4 apresentar diminuição na força, conforme dito anteriormente, observou-se aumento das fissuras existentes, apresentando aberturas máximas da ordem de 2,00 $\mathrm{mm}$, conforme pode ser observado na Figura 5.52 (a) e $\mathbf{5 . 5 2}$ (b), as quais apresentam o panorama de fissuração do modelo M4 após a realização dos ensaios.

Verificaram-se diversas linhas de fissuras na região central do bloco, sendo que uma dessa fissuras atravessou o bloco passando pela região inferior e surgindo na face oposta, provocando separação do concreto dos blocos. Observou-se ainda a formação de fissuras na região inferior do bloco e não se constatou fissuras atravessando o bloco em direção ao colarinho, situado na parte superior do cálice, conforme pode ser observado na figura 5.53. Nessas figuras, as fissuras marcadas em vermelho surgiram até o modelo apresentar a primeira diminuição de força, indo de $450 \mathrm{kN}$ para $400 \mathrm{kN}$. As fissuras marcadas em azul surgiram após o modelo apresentar aumento de força, até atingir a ruína aos $563 \mathrm{kN}$. 


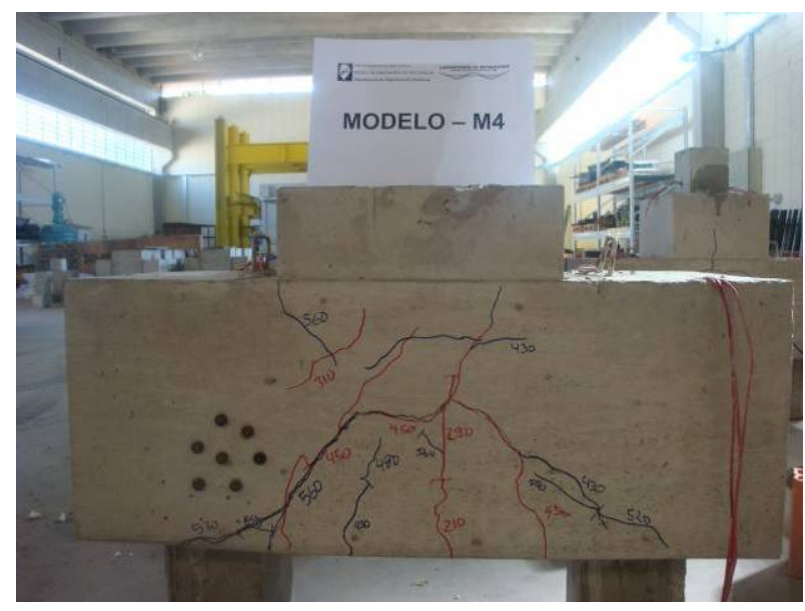

(a)

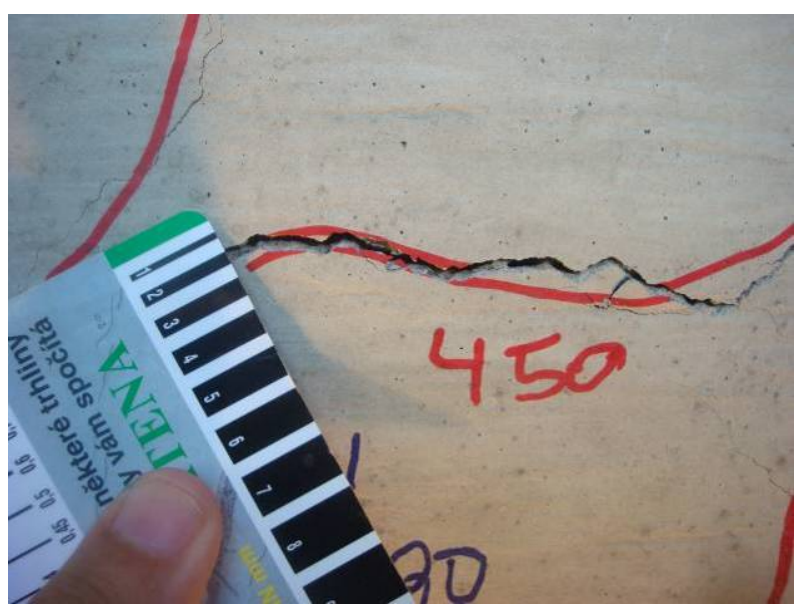

(b)

Figura 5. 52-Panorama de fissuração na face lateral do Modelo M4 após ensaio

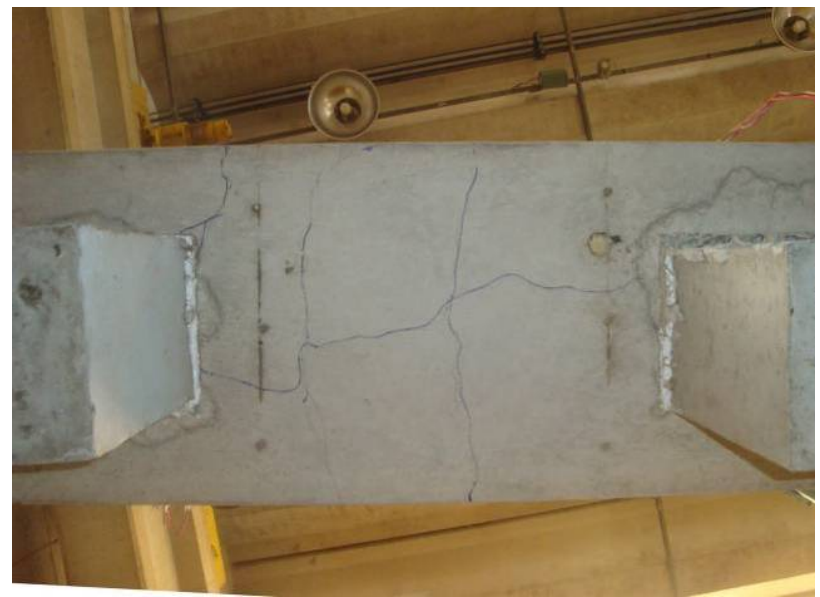

(a)

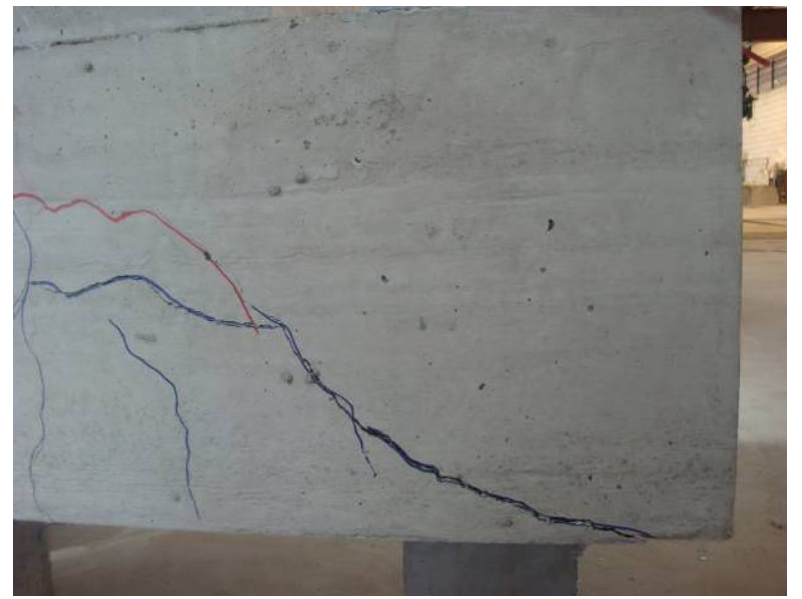

(b)

Figura 5. 53-Fissuras na face inferior e lateral oposta do Modelo M4

Obtiveram-se valores pequenos para as medidas de deformações no concreto, uma vez que com as leituras efetuadas nas pastilhas de aço, as quais estavam fixadas nas faces laterais dos blocos, foi possível calcular as deformações na face externa do bloco. Em função dos valores obtidos, constatou-se que as deformações ficaram aquém das deformações existentes nas bielas. Desse modo, considera-se que a utilização das pastilhas de aço não conferiu bons resultados para a estimativa das deformações do concreto. Apresentam-se na tabela 5.28 os valores de deformações principais e as direções principais em relação a quatro intensidades de força. As direções apresentadas referem-se ao esquema apresentado na Figura 4.49 (b). 
Tabela 5.28 - Deformação no concreto do modelo M4

\begin{tabular}{|c|c|c|c|c|c|c|c|c|}
\hline \multirow{2}{*}{$\begin{array}{l}\text { Força } \\
(\mathbf{k N})\end{array}$} & \multirow[t]{2}{*}{ Direção } & \multicolumn{3}{|c|}{ Deformações (\%o) } & \multicolumn{2}{|c|}{$\begin{array}{c}\text { Deformações } \\
\text { Principais (\%o) }\end{array}$} & \multicolumn{2}{|c|}{$\begin{array}{c}\text { Direções } \\
\text { Principais }\left(^{\circ}\right)\end{array}$} \\
\hline & & $\varepsilon_{0^{\circ}}$ & $\varepsilon_{45^{\circ}}$ & $\varepsilon_{90^{\circ}}$ & $\varepsilon_{1}$ & $\varepsilon_{2}$ & $\alpha_{1}$ & $\alpha_{2}$ \\
\hline \multirow{2}{*}{50} & $1,5,3$ & 0,01 & $-0,012$ & $-0,01$ & 0,02 & $-0,02$ & $-25,1$ & 64,9 \\
\hline & $2,6,4$ & 0,0 & 0,002 & $-0,006$ & 0,00 & $-0,01$ & 29,5 & 119,5 \\
\hline \multirow{2}{*}{150} & $1,5,3$ & 0,008 & $-0,003$ & 0,163 & 0,20 & $-0,03$ & 24,4 & 114,4 \\
\hline & $2,6,4$ & 0,0 & $-0,03$ & $-0,004$ & 0,03 & $-0,03$ & $-43,0$ & 47,0 \\
\hline \multirow{2}{*}{400} & $1,5,3$ & 0,007 & 0,005 & $-0,02$ & 0,01 & $-0,02$ & 20,2 & 110,2 \\
\hline & $2,6,4$ & 0,001 & $-0,111$ & $-0,014$ & 0,10 & $-0,11$ & $-42,9$ & 47,1 \\
\hline \multirow{2}{*}{450} & $1,5,3$ & 0,011 & 0,003 & $-0,02$ & 0,01 & $-0,02$ & 12,9 & 102,9 \\
\hline & $2,6,4$ & $-0,039$ & $-0,11$ & 2,995 & 3,67 & $-0,72$ & 23,2 & 113,2 \\
\hline
\end{tabular}

\subsubsection{Modelo M5 - BPE_AC_SR}

O modelo M5 apresentou comportamento de bloco rígido. Foi registrada uma excentricidade na força aplicada no pilar da ordem de 0,68 cm. Do mesmo modo que o modelo M4 A ruína do modelo M5 se deu por escoamento de todas as barras das armaduras principais do tirante, localizadas na região central do bloco, seguido da ruptura do concreto do bloco.

A força máxima suportada por esse modelo foi de $644 \mathrm{kN}$, força essa superior a força calculada com o modelo teórico utilizado para o dimensionamento. O modelo apresentou resistência crescente até atingir uma força de $600 \mathrm{kN}$, apresentando três grandes fissuras na região central, quando houve diminuição na resistência até o valor de $580 \mathrm{kN}$. Em seguida, o bloco voltou a apresentar aumento de força, até atingir a ruína para uma força igual a $644 \mathrm{kN}$. Observa-se que o valor da força última do modelo M5 foi inferior ao valor máximo de $756 \mathrm{kN}$ obtido no bloco de referência, bem como foi inferior a força última obtida no modelo M2, o qual apresentava o cálice externo. Comparando os resultados dos modelos com cálice parcialmente embutido sem rugosidade, observa-se que a força última no modelo M5 foi superior a do modelo M4, que não dispunha da armadura complementar em forma de estribos na região central do bloco. Esse resultado indica que, para os blocos com cálice parcialmente 
embutido e sem rugosidade na ligação do pilar com o cálice, a armadura complementar conferiu ganho de resistência ao modelo da ordem de $14 \%$.

A primeira fissura visível no modelo M5 surgiu na região central inferior do bloco, porém um pouco afastada em relação ao centro do bloco, apresentando abertura da ordem de $0,05 \mathrm{~mm}$ para uma força de $270 \mathrm{kN}$. Nessa etapa, a deformação máxima medida nas barras das armaduras do tirante foi de $0,13 \%$ o que resulta numa tensão igual a 21,8 $\mathrm{MPa}$. Observou-se que o modelo apresentou perda de rigidez para uma força próxima a $420 \mathrm{kN}$, conforme pode ser observado nos gráficos força versus deformação das barras das armaduras posicionadas na região central do bloco.

A Figura 5.54 apresenta o gráfico força versus deformação em cada barra, enquanto que a Figura 5.55 apresenta a curva força versus deformação média em relação as armaduras posicionadas na seção central do bloco para os modelos M1, M2 e M5. Observa-se por meio dessa figura que o modelo M5 apresenta-se mais rígido do que modelo M1 do bloco de referência dessa série.

Comparando os modelos com cálice parcialmente embutido, verifica-se que o modelo M5 apresentou rigidez superior a do modelo M4, bem como diminuição nos valores de deformação, conforme pode ser observado na figura 5.56, o que indica que a armadura complementar utilizada no modelo M5 conferiu ganho de resistência ao modelo.

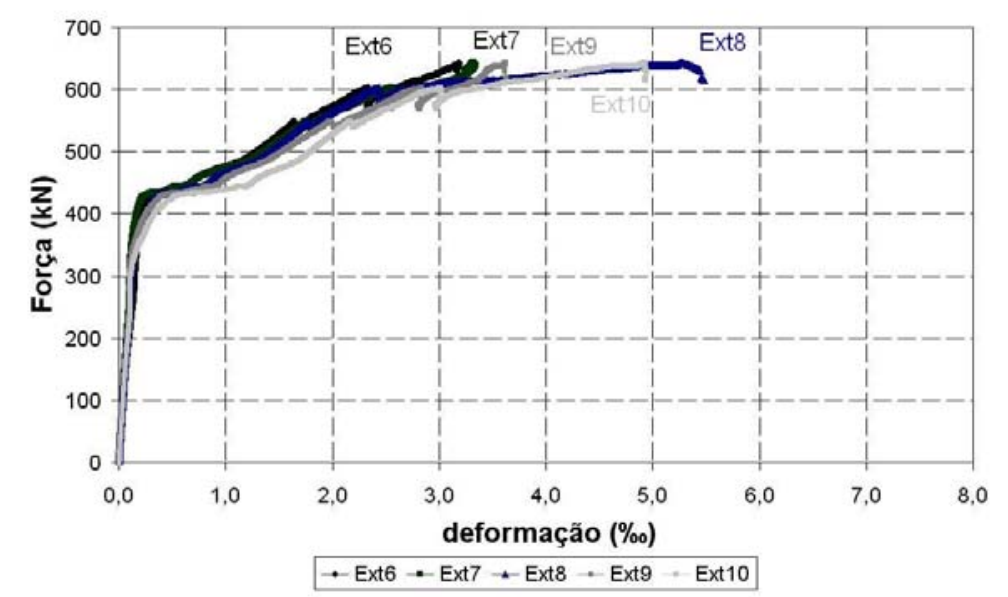

Figura 5. 54- Curva força versus deformação nas armaduras da região central do modelo M5 


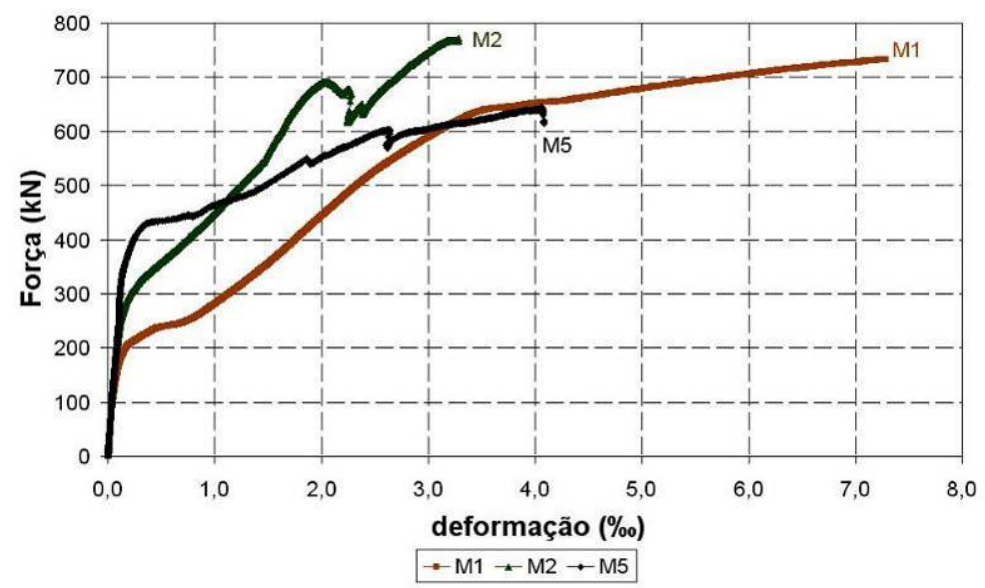

Figura 5. 55- Curva força versus deformação média nas armaduras da região central dos modelos M1, M2 e M5

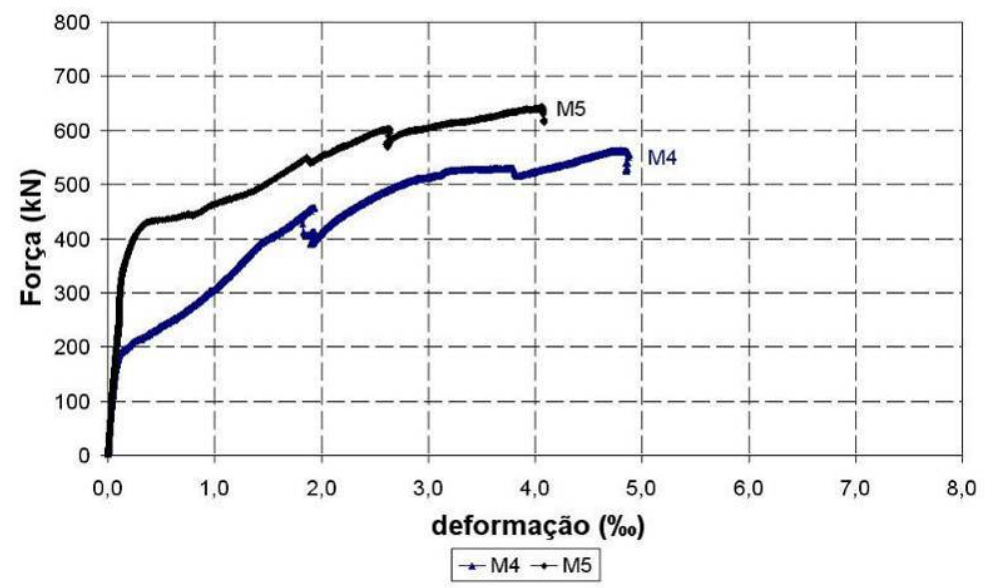

Figura 5. 56- Curva força versus deformação média nas armaduras da região central dos modelos M4 e M5

As Figuras 5.57 e $\mathbf{5 . 5 8}$ apresentam os gráficos força versus deformação nas barras das armaduras posicionadas sobre as estacas. Observa-se por meio desses gráficos que as deformações médias nas armaduras apresentam valores da ordem de $0,8 \%$ a 1,2\%, valores esses pequenos quando comparados as deformações obtidas nas armaduras posicionadas na região central do bloco. Isso ocorre em virtude da formação da biela sobre as estacas, o que provoca diminuição da força no tirante nessa região. 


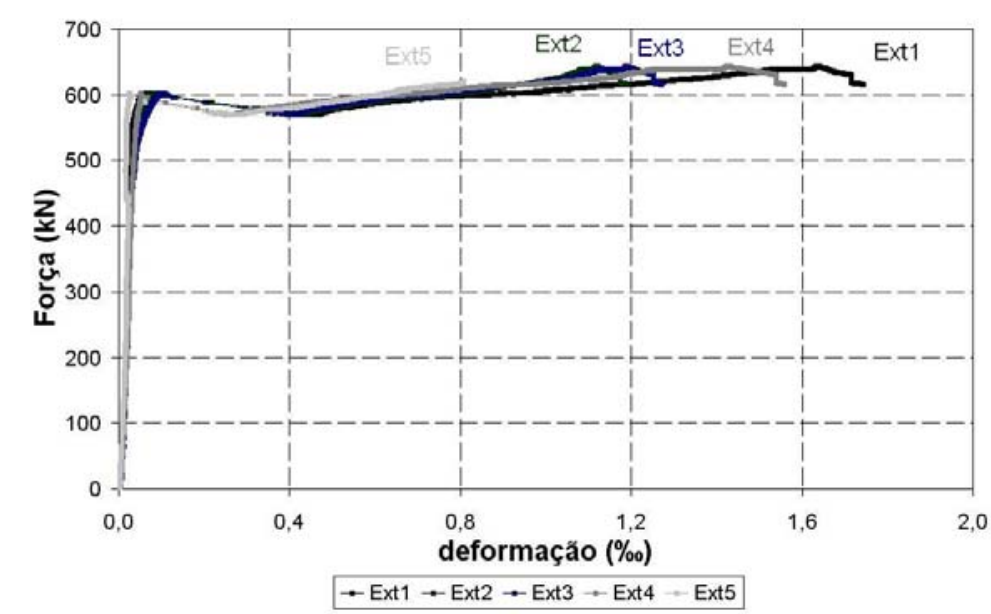

Figura 5. 57- Curva força versus deformação nas armaduras sobre as estacas do modelo M5

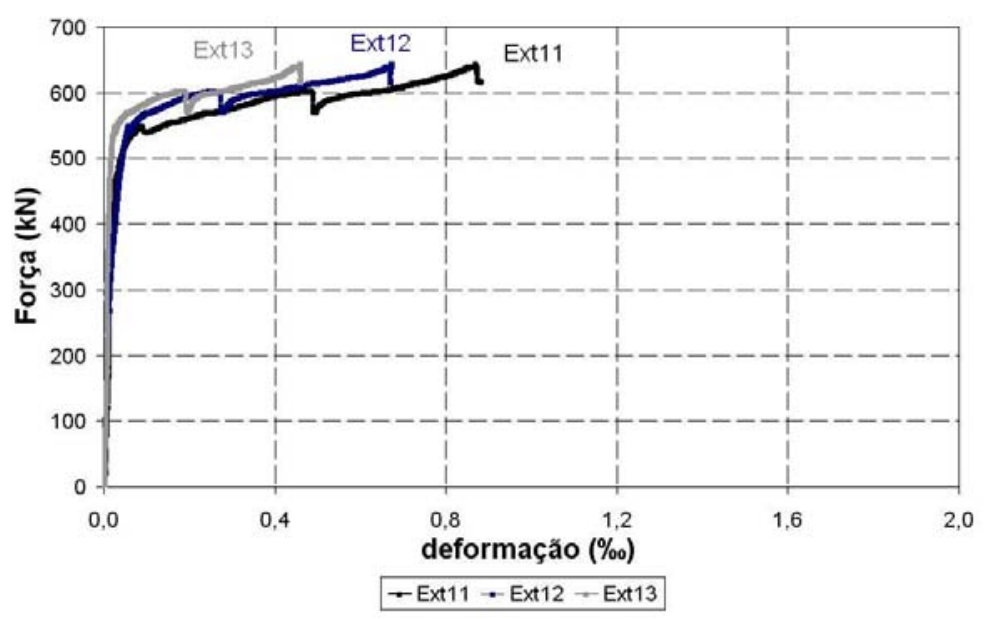

Figura 5. 58- Curva força versus deformação nas armaduras sobre as estacas do modelo M5

A Figura 5.59 apresenta o gráfico força versus deformação nas barras das armaduras do pilar. Semelhante ao que ocorreu no bloco do modelo M4, observa-se que as deformações nas barras das armaduras tornam-se menores à medida que o pilar se aproxima do fundo do cálice, conforme pode ser observado comparando os resultados dos extensômetros de número 14, 15 e 16, bem como os extensômetros de número 17 e 18, os quais estavam posicionados nas barras das armaduras do pilar. Esse fato indica que a força do pilar está sendo transferida para o bloco por meio de uma biela de compressão formada ao longo da altura do cálice. 


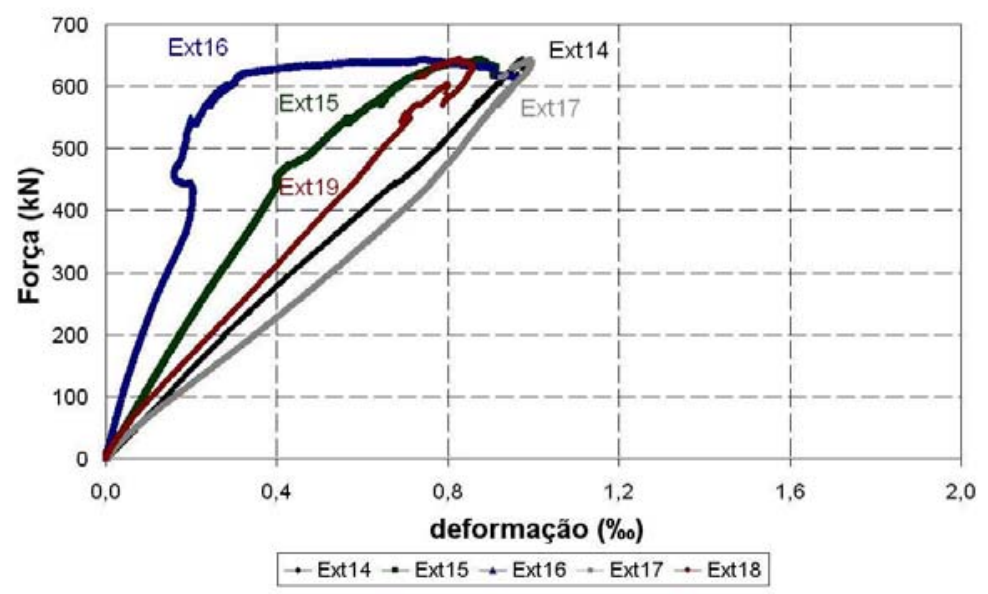

Figura 5. 59- Curva força versus deformação nas armaduras do pilar do modelo M5

O gráfico da Figura 5.60 apresenta os resultados de deformação medidos nas barras das armaduras posicionadas no cálice de fundação. Semelhante ao modelo M4, destaca-se o resultado da armadura vertical do cálice, cujos resultados foram obtidos por meio do extensômetro de número 21. Observa-se inicialmente encurtamento da barra de armadura vertical, ocasionado pela força de compressão oriunda do pilar. Esse encurtamento ocorreu de modo linear até uma força próxima a $600 \mathrm{kN}$. A partir desse instante, observa-se uma inversão nos valores de deformação, sendo que a barra até então comprimida passa a apresentar alongamento, isto é, deformações oriundas de força de tração. Esse resultado indica que o maciço de concreto sob o cálice no interior do bloco apresentou ruptura, não ocorrendo a separação em dois segmentos em virtude da presença de armadura nessa região. $O$ extensômetro de número 20, por sua vez, apresentou deformações semelhantes a da armadura principal do tirante, uma vez que estava posicionada na mesma região.

A Figura 5.61, por sua vez, apresenta a curva força versus deformação nas barras da armadura complementar posicionada na região central do bloco. Em virtude da quantidade de extensômetros, apresenta-se apenas o gráfico das barras que foram instrumentadas com o extensômetros de números 26, 27, 28 e 29, os quais encontram-se faceando o cálice. Verificase que os extensômetros 26 e 28 , posicionados na parte superior do estribo, apresentam inicialmente deformações de encurtamento, passando a apresentar alongamentos próximos a uma força de $600 \mathrm{kN}$. Essas deformações por suas vezes, são menores do que as medidas nos extensômetros 27 e 29, posicionados na região inferior do estribo, e que apresentam pequenos encurtamentos no início do ensaio, passando a apresentar alongamento para uma força próxima a $450 \mathrm{kN}$. Constata-se que esse comportamento foi semelhante ao ocorrido com o extensômetro 21, posicionado na barra vertical da armadura do cálice. 


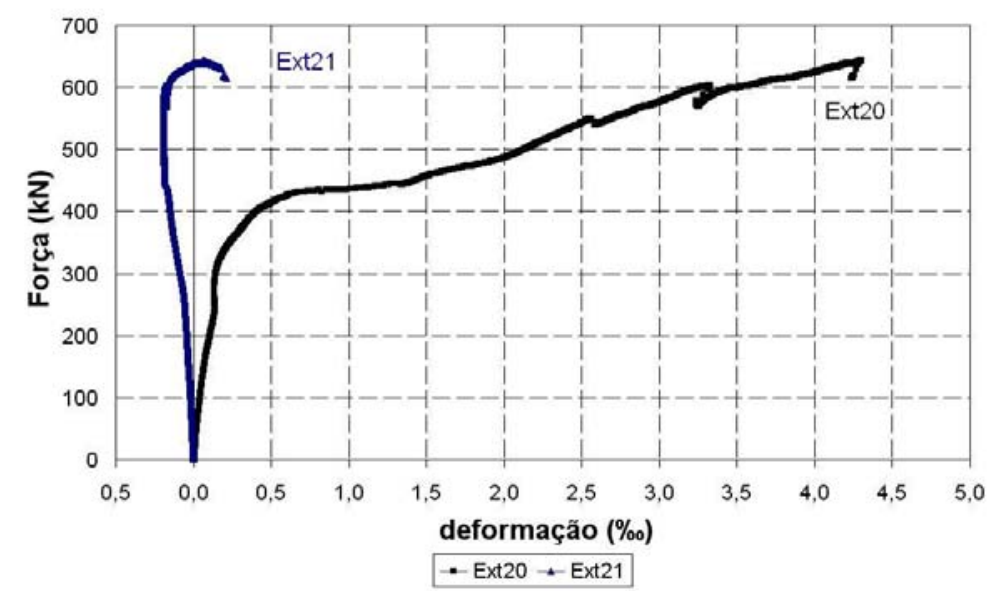

Figura 5. 60- Curva força versus deformação nas armaduras do cálice do modelo M5

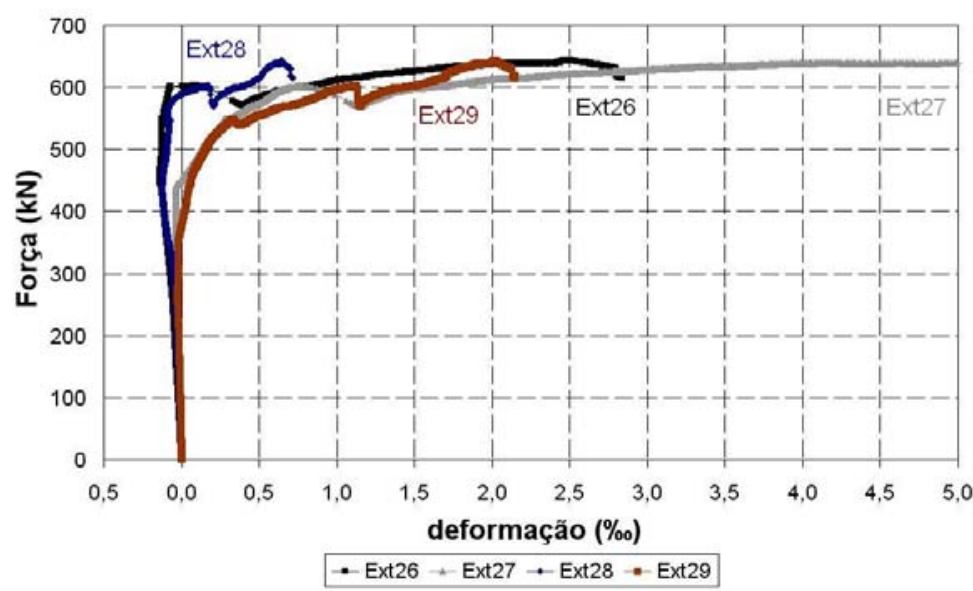

Figura 5. 61- Curva força versus deformação na armadura complementar do modelo M5

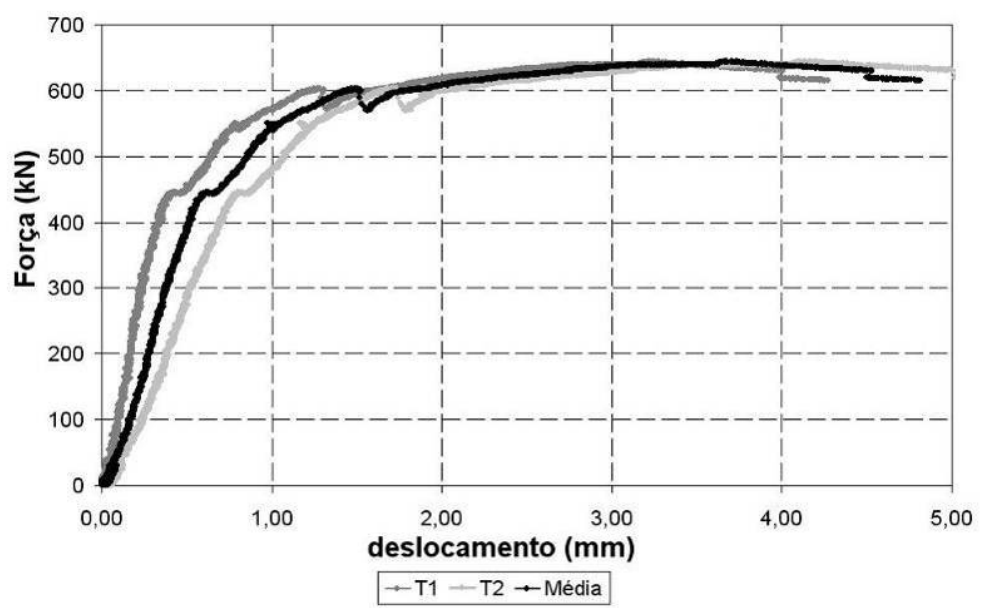

Figura 5. 62-Curva força versus deslocamento médio medido nos transdutores T1 e T2 do modelo M5

A Figura 5.62, por sua vez, apresenta a curva força versus deslocamento do modelo M5, a partir da qual pode-se observar um deslocamento médio superior a 4,50 mm próximo a 
ruína do modelo, o qual ocorreu na região central do bloco. Verifica-se que o deslocamento medido nesse modelo, assim como no modelo M4, foi superior ao obtido nos demais blocos.

No modelo M5 houve perda do extensômetro elétrico de resistência de número 19, situado nas barras da armadura do pilar, e dos extensômetros de números 31 e 33, situados na armadura complementar. A medida que a força no pistão aumentava, verificou-se o surgimento de novas fissuras e aumento da abertura das fissuras existentes. Verificou-se aberturas da ordem de $0,15 \mathrm{~mm}$ correspondente a força de $350 \mathrm{kN} ; 0,25 \mathrm{~mm}$ para uma força de $440 \mathrm{kN}$; e 0,35 mm para uma força de $530 \mathrm{kN}$. Após o modelo M5 apresentar diminuição na força para $580 \mathrm{kN}$, observou-se aumento das fissuras existentes, sendo registradas aberturas superiores a 1,00 mm, conforme pode ser observado na Figura 5.63 (a) e 5.52 (b), as quais apresentam o panorama de fissuração do modelo M4 após a realização dos ensaios. Próximo à ruína do modelo, observaram-se fissuras na face superior do colarinho e deslocamento relativo entre o pilar e o graute.

Verificaram-se várias linhas de fissuras na região central do bloco, sendo que duas dessas fissuras se prolongaram até a parte superior do bloco, atingindo parte do colarinho. Também foram observadas fissuras que atravessavam o bloco passando pela região inferior e surgindo na face oposta, semelhante ao ocorrido no modelo M4, conforme pode ser observado nas Figuras 5.64 (a) e 5.64 (b). Nessas figuras, as fissuras marcadas em vermelho surgiram antes do modelo apresentar a primeira diminuição de força de $600 \mathrm{kN}$ para $580 \mathrm{kN}$. As fissuras marcadas em azul surgiram após o modelo voltar a apresentar aumento de força, até atingir a ruína aos $644 \mathrm{kN}$.

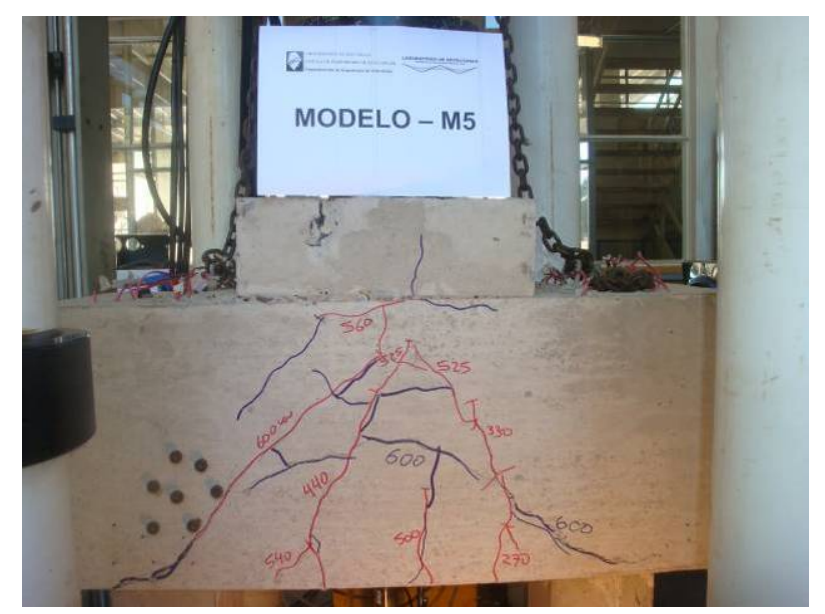

(a)

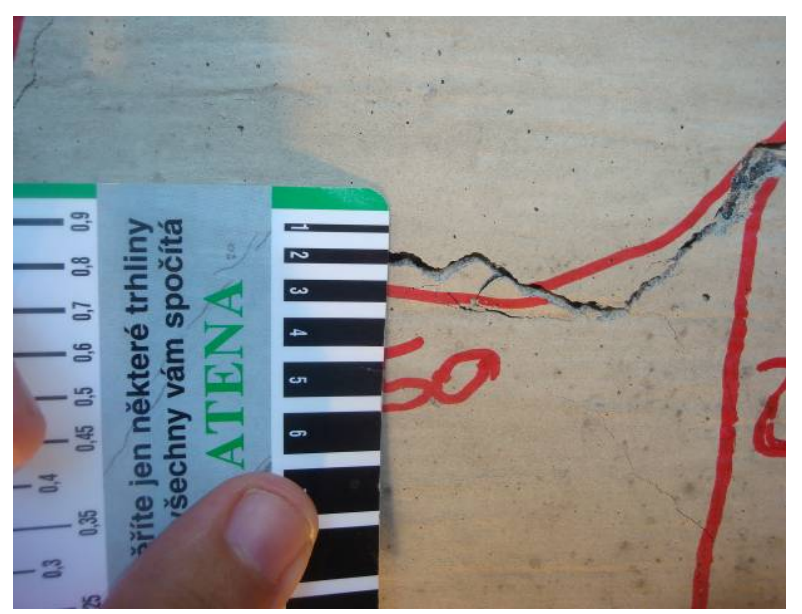

(b)

Figura 5. 63-Fissuras na face lateral do Modelo M5 


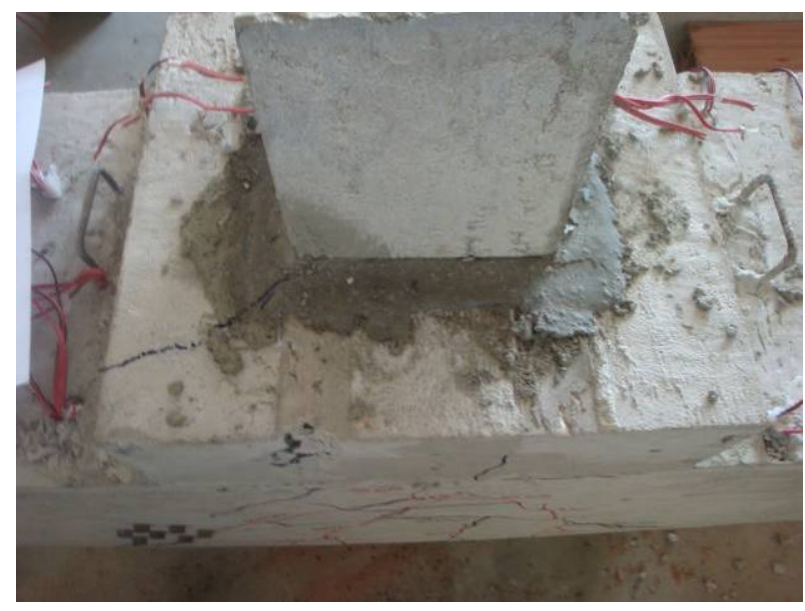

(a)

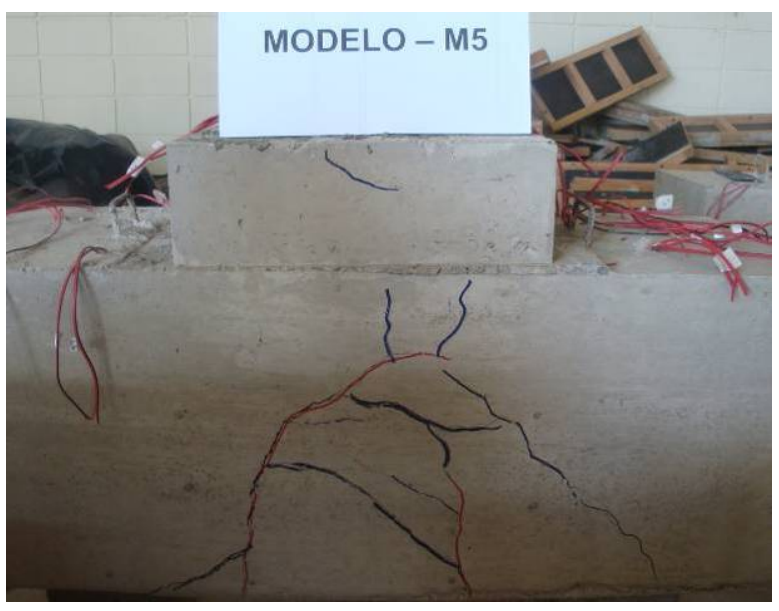

(b)

Figura 5. 64-Fissuras na face inferior e lateral oposta do Modelo M5

Obtiveram-se valores pequenos para as medidas de deformações no concreto, uma vez que com as leituras efetuadas nas pastilhas de aço, as quais estavam fixadas nas faces laterais dos blocos, foi possível calcular as deformações na face externa do bloco. Em função dos valores obtidos, constatou-se que as deformações ficaram aquém das deformações existentes nas bielas. Desse modo, considera-se que a utilização das pastilhas de aço não conferiu bons resultados para a estimativa das deformações do concreto. Apresentam-se na tabela 5.29 os valores de deformações principais e as direções principais em relação a quatro intensidades de força. As direções apresentadas referem-se ao esquema apresentado na Figura 4.49 (b).

Tabela 5.29 - Deformação no concreto do modelo M5

\begin{tabular}{|c|c|c|c|c|c|c|c|c|}
\hline \multirow{2}{*}{$\begin{array}{c}\text { Força } \\
(\mathbf{k N})\end{array}$} & \multirow[t]{2}{*}{ Direção } & \multicolumn{3}{|c|}{ Deformações (\%o) } & \multicolumn{2}{|c|}{$\begin{array}{c}\text { Deformações } \\
\text { Principais (\%o) }\end{array}$} & \multicolumn{2}{|c|}{$\begin{array}{c}\text { Direções } \\
\text { Principais }\left({ }^{\circ}\right)\end{array}$} \\
\hline & & $\varepsilon_{0^{\circ}}$ & $\varepsilon_{45^{\circ}}$ & $\varepsilon_{90^{\circ}}$ & $\varepsilon_{1}$ & $\varepsilon_{2}$ & $\alpha_{1}$ & $\alpha_{2}$ \\
\hline \multirow{2}{*}{100} & $1,5,3$ & 0,002 & $-0,010$ & 0,019 & 0,03 & $-0,01$ & 33,7 & 123,7 \\
\hline & $2,6,4$ & $-0,007$ & $-0,008$ & 0,020 & 0,03 & $-0,01$ & 23,5 & 113,5 \\
\hline \multirow{2}{*}{400} & $1,5,3$ & $-0,019$ & $-0,019$ & $-0,001$ & 0,00 & $-0,02$ & 22,5 & 112,5 \\
\hline & $2,6,4$ & $-0,008$ & $-0,016$ & 0,004 & 0,01 & $-0,02$ & 33,4 & 123,4 \\
\hline \multirow{2}{*}{500} & $1,5,3$ & $-0,009$ & $-0,025$ & $-0,011$ & 0,01 & $-0,03$ & $-43,1$ & 46,9 \\
\hline & $2,6,4$ & 0,004 & $-0,024$ & 0,001 & 0,03 & $-0,02$ & $-43,4$ & 46,6 \\
\hline \multirow{2}{*}{600} & $1,5,3$ & $-0,010$ & $-0,030$ & 0,017 & 0,04 & $-0,03$ & 34,0 & 124,0 \\
\hline & $2,6,4$ & $-0,009$ & $-0,026$ & $-0,001$ & 0,02 & $-0,03$ & 39,6 & 129,6 \\
\hline
\end{tabular}




\subsubsection{Modelo M11 - BPE_CR}

O modelo M11 apresentou comportamento de bloco rígido. Foi registrada uma excentricidade na força aplicada no pilar da ordem de $1,03 \mathrm{~cm}$. A ruína desse modelo se deu por escoamento de todas as barras das armaduras principais do tirante, localizadas na região central do bloco.

A força máxima suportada por esse modelo foi de $888 \mathrm{kN}$, força essa superior a força calculada com o modelo teórico utilizado para o dimensionamento. O modelo apresentou resistência crescente até atingir a força última, apresentando quatro grandes fissuras na região central. Após diminuição na força para $800 \mathrm{kN}$, o modelo continuou deformando, porém sem aumento de força. Observa-se que o valor da força última do modelo M11 foi superior ao valor máximo de $728 \mathrm{kN}$ obtido no bloco de referência, porém foi inferior a força última obtida no modelo M9, o qual apresentava o cálice externo. Este resultado indica que a formação da biela nesse modelo foi diferente das obtidas nos modelos M8 e M9.

$\mathrm{O}$ panorama de fissuração foi semelhante ao do modelo $\mathrm{M} 8$, iniciando pela região central do bloco. A primeira fissura visível no modelo surgiu na região central inferior do bloco, apresentando abertura da ordem de $0,05 \mathrm{~mm}$ para uma força de $310 \mathrm{kN}$. Nessa etapa, a deformação máxima medida nas barras das armaduras do tirante foi de 0,92\%o o que resulta numa tensão igual a $187 \mathrm{MPa}$. Observou-se que o modelo apresentou perda de rigidez para uma força próxima de $340 \mathrm{kN}$, conforme pode ser observado nos gráficos força versus deformação das barras das armaduras posicionadas na região central do bloco.

A Figura 5.65 apresenta o gráfico força versus deformação em cada barra, enquanto que a Figura 5.66 apresenta a curva força versus deformação média em relação as armaduras posicionadas na seção central do bloco para os modelos M8, M9 e M11. Observa-se por meio dessa figura que o modelo M11 apresenta uma rigidez inicial superior a dos modelos M8 e M9. Verifica-se também que, a partir de uma força próxima a $500 \mathrm{kN}$, o modelo M11 apresentou deformações médias nas armaduras superiores às obtidas no modelo M9, sendo essas deformações inferiores as obtidas no bloco de referência ao longo de todo o ensaio. Em função desses resultados, percebe-se que a formação da biela de compressão no modelo M11 apresenta inclinação com o tirante superior a inclinação do bloco de referência dessa série. 


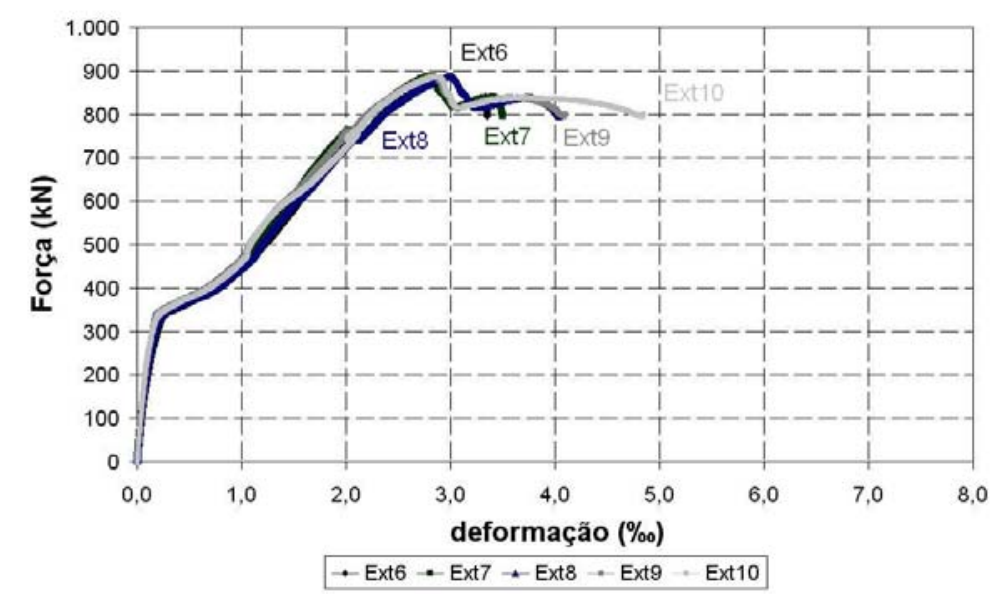

Figura 5. 65- Curva força versus deformação nas armaduras da região central do modelo M11

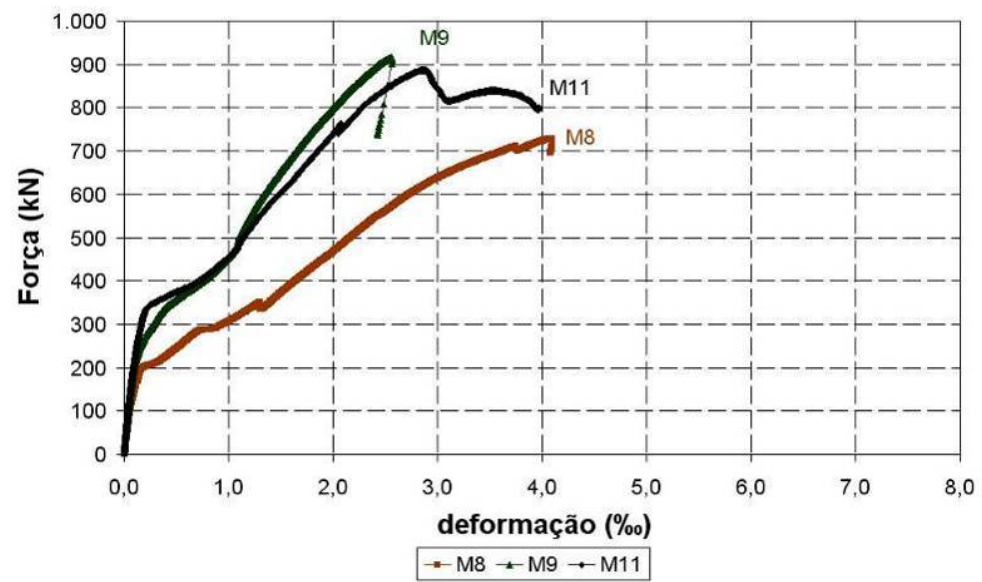

9

Figura 5. 66- Curva força versus deformação média nas armaduras da região central dos modelos M8, M9 e M11

As Figuras 5.67 e 5.68 apresentam os gráficos força versus deformação nas barras das armaduras posicionadas sobre as estacas. Observa-se por meio desses gráficos que as deformações médias nas armaduras apresentam valores entre 06\% e 1,2\%o, valores esses pequenos quando comparados as deformações obtidas nas armaduras posicionadas na região central do bloco. Isso ocorre em virtude da formação da biela sobre as estacas, o que provoca diminuição da força no tirante nessa região. 


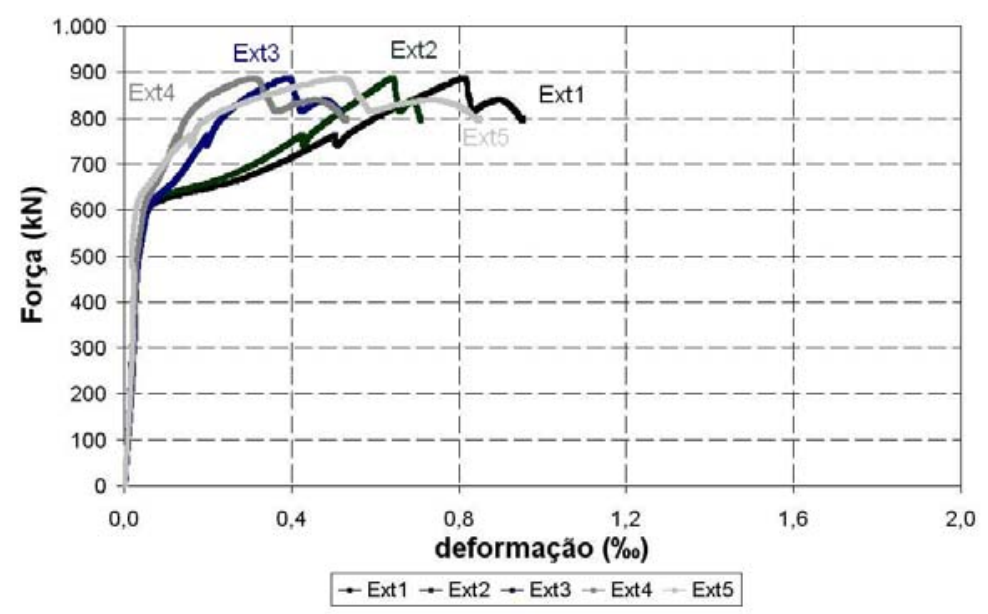

Figura 5. 67- Curva força versus deformação nas armaduras sobre as estacas do modelo M11

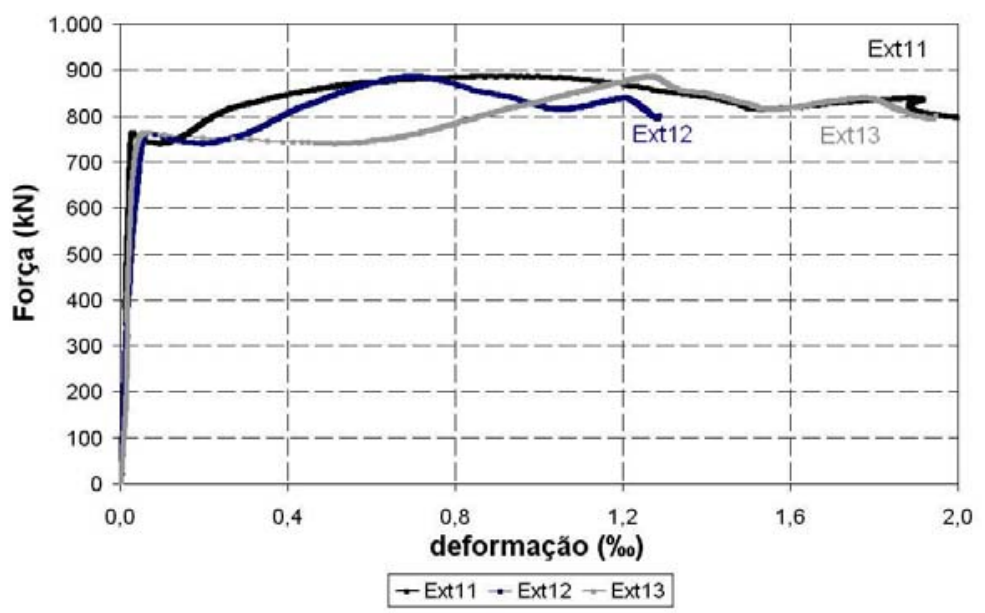

Figura 5. 68- Curva força versus deformação nas armaduras sobre as estacas do modelo M11

A Figura 5.69 apresenta o gráfico força versus deformação nas barras das armaduras do pilar. Semelhante ao que ocorreu nos blocos com cálice externo e sem rugosidade, observa-se que as deformações nas barras das armaduras tornam-se menores à medida que o pilar se aproxima do fundo do cálice, conforme pode ser observado comparando os resultados dos extensômetros de número 14, 15 e 16, bem como os extensômetros de número 17 e 18, os quais estavam posicionados nas barras das armaduras do pilar. Esse fato indica que a biela de compressão é formada ao longo da altura do cálice. 


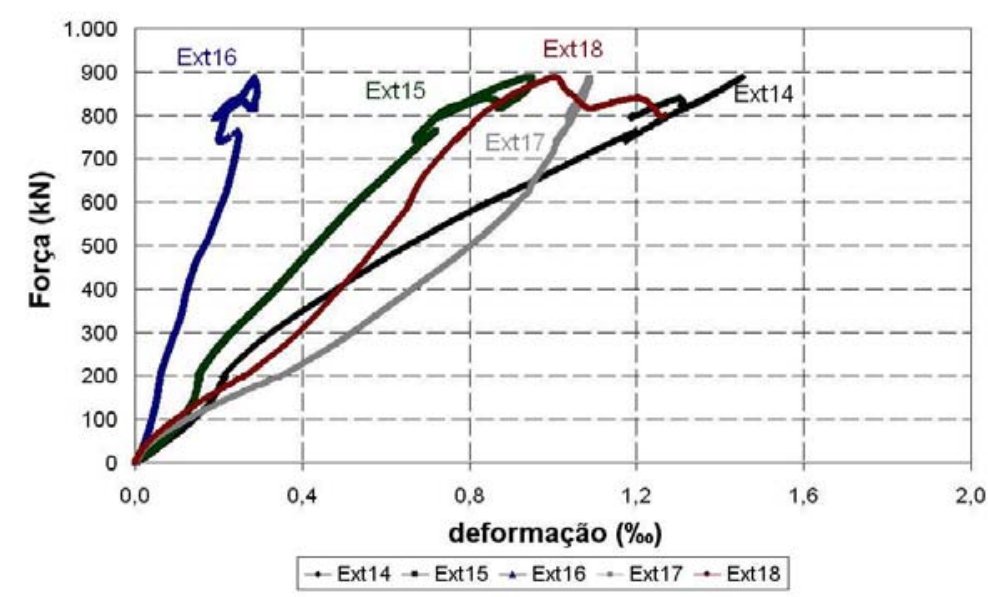

Figura 5. 69- Curva força versus deformação nas armaduras do pilar do modelo M11

O gráfico da Figura 5.70 apresenta os resultados de deformação medidos nas barras das armaduras posicionadas no cálice de fundação. Destacam-se as deformações da armadura vertical do cálice, cujos resultados foram obtidos por meio do extensômetro de número 21 . Observa-se inicialmente encurtamento da barra de armadura vertical, ocasionada pela força de compressão oriundo do pilar. Esse encurtamento ocorreu de modo linear até uma força de 760 kN. A partir desse instante, observa-se uma inversão nos valores de deformação, sendo que a barra até então comprimida passa a apresentar alongamento, isto é, deformações oriundas de força de tração. Esse resultado indica que o maciço de concreto sob o cálice no interior do bloco apresentou ruptura, não ocorrendo a separação em dois ou mais segmentos em virtude da presença de armadura nessa região. O extensômetro de número 20, por sua vez, apresentou deformações semelhantes a da armadura principal do tirante, uma vez que estava posicionada na mesma região.

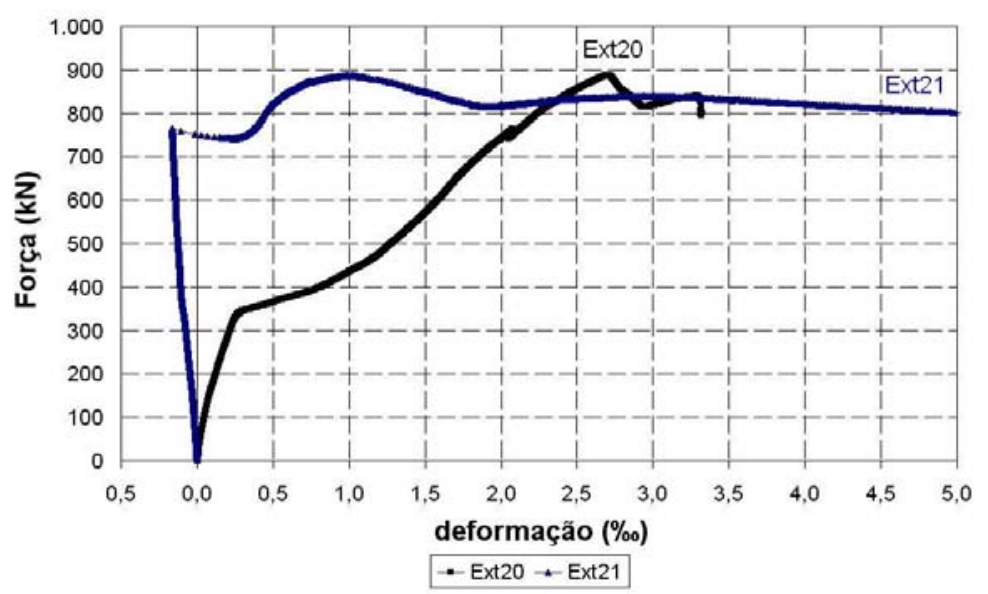

Figura 5. 70- Curva força versus deformação nas armaduras do cálice do modelo M11 
A Figura 5.71, por sua vez, apresenta a curva força versus deslocamento do modelo M11, a partir da qual pode-se observar um deslocamento médio da ordem de 2,00 mm próximo a ruína do modelo, o qual ocorreu na região central do bloco.

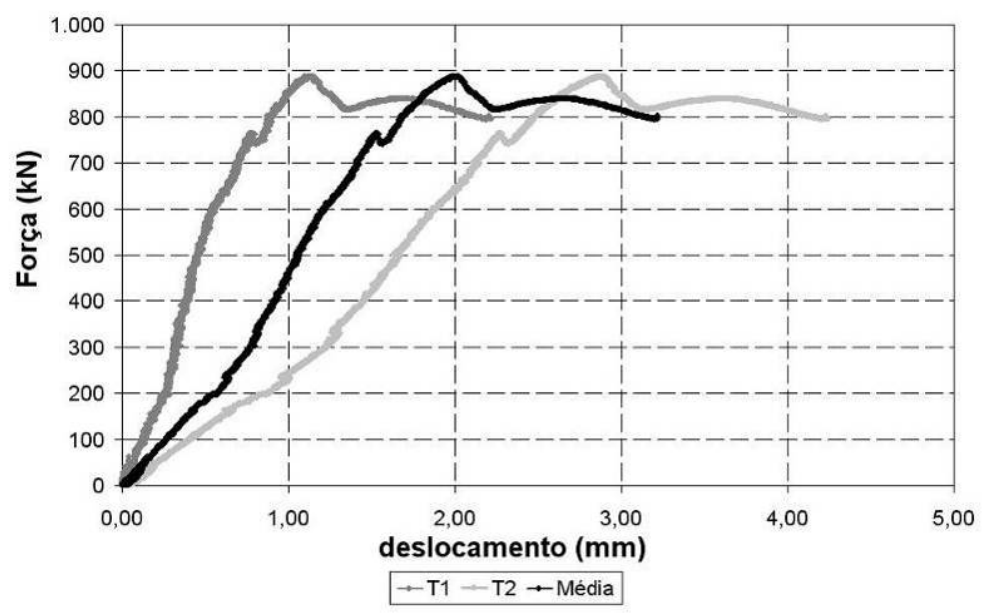

Figura 5. 71- Curva força versus deslocamento médio medido nos transdutores T1 e T2 do modelo M11

No modelo M11 houve perda do extensômetro elétrico de resistência de número 19, situado nas barras da armadura do pilar. A medida que a força no pistão aumentava, verificouse o surgimento de novas fissuras e aumento da abertura das fissuras existentes. Verificou-se aberturas da ordem de $0,15 \mathrm{~mm}$ correspondente a força de $500 \mathrm{kN} ; 0,25 \mathrm{~mm}$ para uma força igual a $600 \mathrm{kN}$; e $0,40 \mathrm{~mm}$ para uma força de $640 \mathrm{kN}$. Próximo a ruína do modelo, as fissuras se estabilizaram com uma abertura da ordem de $0,60 \mathrm{~mm}$, valor este inferior a abertura obtida nos modelos M4 e M5, sem rugosidade.

Verificaram-se diversas linhas de fissuras no bloco, sendo que um deles se estendeu na região onde possivelmente se formou a biela de compressão, atingindo a face lateral do colarinho, que por sua vez apresentou fissuras na parte superior da parede do cálice. As Figuras 5.72 (a) e 5.72 (b) apresentam o panorama de fissuras após o ensaio do modelo M11, enquanto que a Figura 5.72 (c) apresenta as fissuras na face superior da parede do colarinho. Também foram observadas três fissuras que atravessaram o bloco passando pela região inferior e surgiram na face oposta, conforme pode ser observado na Figura 5.73 (a). A Figura 5.73 (b) apresenta a fissura em diagonal na provável localização da biela de compressão. Nessas figuras, as fissuras marcadas em vermelho surgiram até o modelo apresentar a força máxima, igual a $888 \mathrm{kN}$. As fissuras marcadas em azul surgiram após o modelo apresentar diminuição de força, mas continuar apresentando deslocamentos e deformações para uma força próxima aos $800 \mathrm{kN}$. 


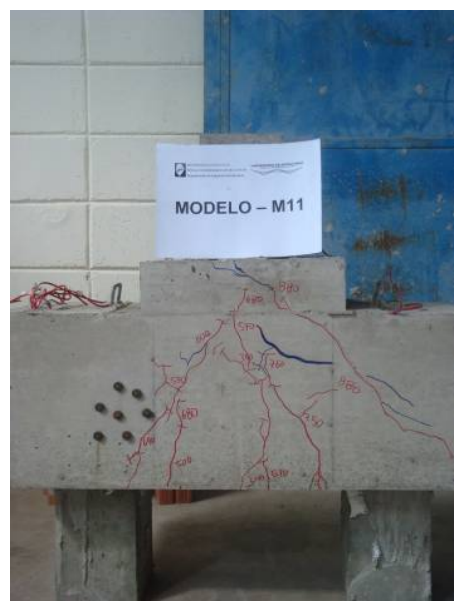

(a)

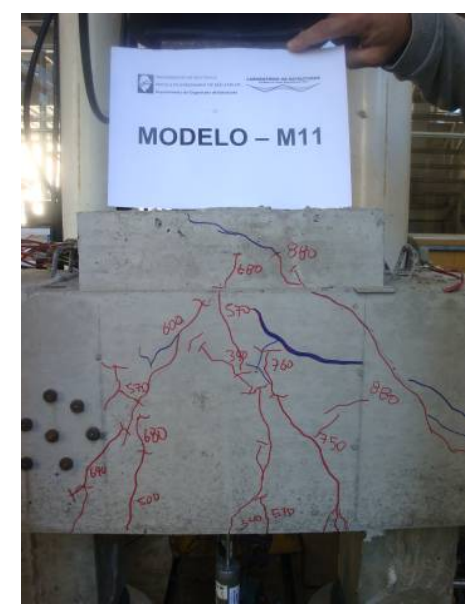

(b)

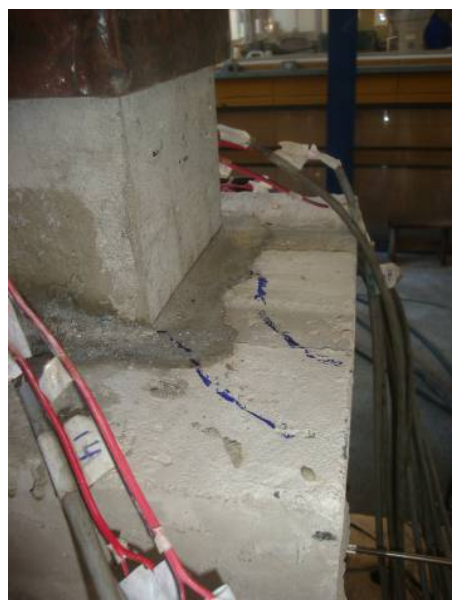

(c)

Figura 5. 72-Fissuras na face lateral e no colarinho do Modelo M11

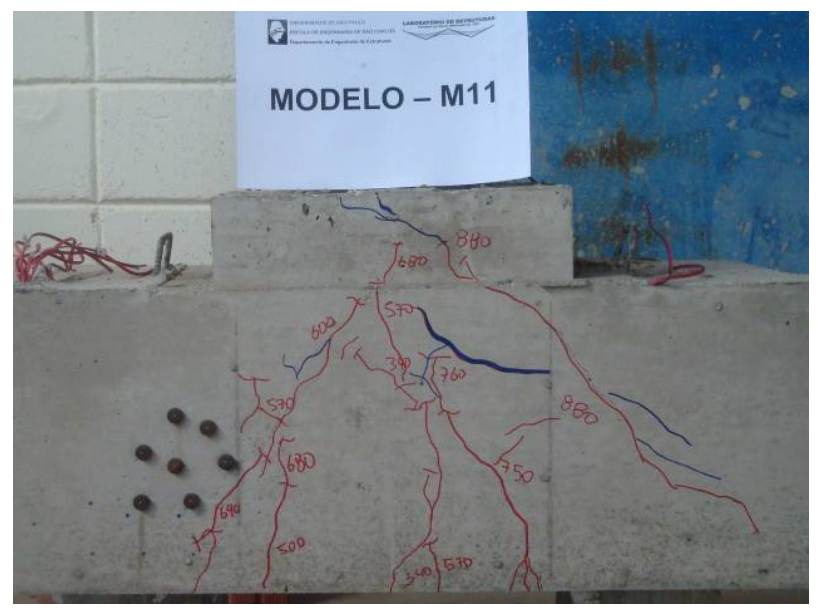

(a)

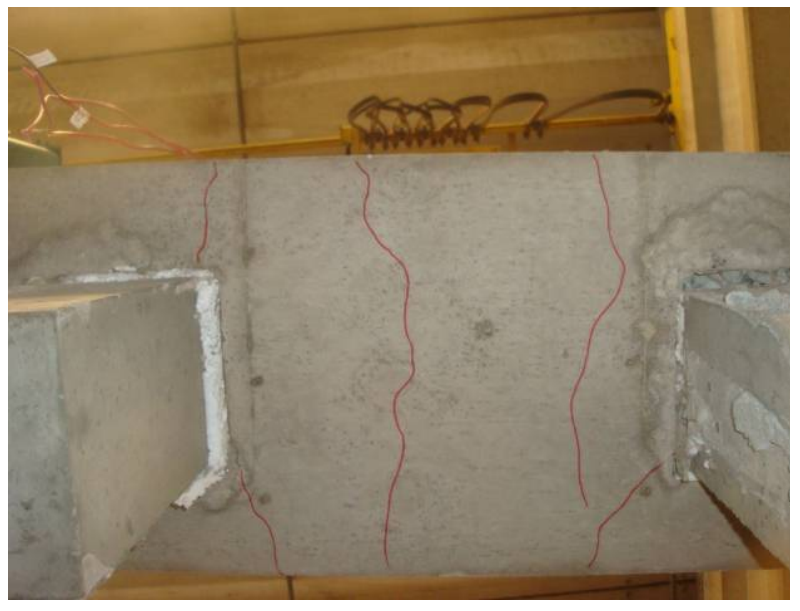

(b)

Figura 5. 73-Fissuras na face lateral e inferior do Modelo M11

Obtiveram-se valores pequenos para as medidas de deformações no concreto, uma vez que com as leituras efetuadas nas pastilhas de aço, as quais estavam fixadas nas faces laterais dos blocos, foi possível calcular as deformações na face externa do bloco. Em função dos valores obtidos, constatou-se que as deformações ficaram aquém das deformações existentes nas bielas. Desse modo, considera-se que a utilização das pastilhas de aço não conferiu bons resultados para a estimativa das deformações do concreto. Apresentam-se na tabela 5.30 os valores de deformações principais e as direções principais em relação a quatro intensidades de força. As direções apresentadas referem-se ao esquema apresentado na Figura 4.49 (b). 
Tabela 5.30 - Deformação no concreto do modelo M11

\begin{tabular}{|c|c|c|c|c|c|c|c|c|}
\hline \multirow{2}{*}{$\begin{array}{c}\text { Força } \\
(\mathbf{k N})\end{array}$} & \multirow[t]{2}{*}{ Direção } & \multicolumn{3}{|c|}{ Deformações (\%o) } & \multicolumn{2}{|c|}{$\begin{array}{l}\text { Deformações } \\
\text { Principais (\%o) }\end{array}$} & \multicolumn{2}{|c|}{$\begin{array}{c}\text { Direções } \\
\text { Principais }\left({ }^{\circ}\right)\end{array}$} \\
\hline & & $\varepsilon_{0^{\circ}}$ & $\varepsilon_{45^{\circ}}$ & $\varepsilon_{90^{\circ}}$ & $\varepsilon_{1}$ & $\varepsilon_{2}$ & $\alpha_{1}$ & $\alpha_{2}$ \\
\hline \multirow{2}{*}{50} & $1,5,3$ & 0,001 & 0,002 & 0,000 & 0,0 & 0,0 & 35,8 & 125,8 \\
\hline & $2,6,4$ & 0,006 & $-0,010$ & $-0,010$ & 0,01 & $-0,01$ & $-22,5$ & 67,5 \\
\hline \multirow{2}{*}{150} & $1,5,3$ & 0,006 & $-0,004$ & 0,020 & 0,03 & $-0,01$ & 33,8 & 123,8 \\
\hline & $2,6,4$ & $-0,004$ & 0,003 & $-0,015$ & 0,00 & $-0,02$ & 33,1 & 123,1 \\
\hline \multirow{2}{*}{250} & $1,5,3$ & 0,030 & 0,142 & 0,090 & 0,15 & $-0,03$ & $-35,0$ & 55,0 \\
\hline & $2,6,4$ & 0,009 & 0,113 & 0,073 & 0,12 & $-0,04$ & $-33,0$ & 57,0 \\
\hline \multirow{2}{*}{450} & $1,5,3$ & 0,034 & 0,021 & 0,010 & 0,03 & 0,01 & $-2,4$ & 87,6 \\
\hline & $2,6,4$ & 0,006 & 0,101 & 0,073 & 0,11 & $-0,03$ & $-30,7$ & 59,3 \\
\hline
\end{tabular}

\subsubsection{Modelo M12 - BPE_AC_CR}

O modelo M12 apresentou comportamento de bloco rígido. Foi registrada uma excentricidade na força aplicada no pilar da ordem de $0,08 \mathrm{~cm}$, o que implica em praticamente se ter força centrada nesse modelo. Assim como ocorreu no modelo M11 A ruína do modelo M12 se deu por escoamento de todas as barras das armaduras principais do tirante, localizadas na região central do bloco.

A força máxima suportada por esse modelo foi de $957 \mathrm{kN}$, força essa superior a força calculada com o modelo teórico utilizado para o dimensionamento. O modelo obteve resistência crescente ao longo de todo o carregamento, apresentando várias físsuras na região central do bloco, e nas regiões onde possivelmente se formaram as bielas de compressão. Observa-se que o valor da força última do modelo M12 foi superior ao valor máximo de 728 $\mathrm{kN}$ obtido no bloco de referência (modelo M8), bem como foi superior a força última obtida no modelo M9, o qual apresentava o cálice externo. Comparando os resultados dos modelos com cálice parcialmente embutido com rugosidade, observa-se que a força última no modelo M12 foi superior a do modelo M11, que não dispunha da armadura complementar em forma de estribos na região central do bloco. Entretanto, o aumento relativo de resistência foi inferior ao obtido nos modelos M4 e M5, os quais não apresentavam rugosidade. Os 
resultados indicam para os blocos com rugosidade na ligação do pilar com o cálice, que a armadura complementar conferiu ganho de resistência ao modelo da ordem de $7 \%$.

O panorama de fissuração foi semelhante ao do modelo M11, sendo que a primeira fissura visível no modelo surgiu na região inferior do bloco, apresentando abertura da ordem de $0,05 \mathrm{~mm}$ para uma força de $260 \mathrm{kN}$. Nessa etapa, a deformação máxima medida nas barras das armaduras do tirante foi de $0,34 \%$ o que resulta numa tensão igual a $70 \mathrm{MPa}$. Observouse que o modelo apresentou perda de rigidez para uma força próxima de $250 \mathrm{kN}$, conforme pode ser observado nos gráficos força versus deformação das barras das armaduras posicionadas na região central do bloco.

A Figura 5.74 apresenta o gráfico força versus deformação em cada barra, enquanto que a Figura 5.75 apresenta a curva força versus deformação média em relação as armaduras posicionadas na seção central do bloco para os modelos M8, M9 e M12. Observa-se por meio dessa figura que o modelo M12 apresenta-se mais rígido do que modelo M8 do bloco de referência dessa série.

Comparando os resultados dos modelos com cálice parcialmente embutido com rugosidade, verifica-se que o modelo M12 apresentou rigidez inicial levemente superior a do modelo M11, bem como diminuição nos valores de deformação, conforme pode ser observado na Figura 5.76. Apesar do aumento de 7\% na força última indicar que a armadura complementar utilizada no modelo M12 conferiu ganho de resistência ao modelo, verifica-se por meio do gráfico da Figura $\mathbf{5 . 7 6}$ que os modelos M12 e M11 apresentaram curvas força versus deformação semelhantes, podendo a diferença de $7 \%$ obtida nas forças serem atribuídas a particularidades de cada modelo. Portanto, não é possível garantir que, no caso de bloco com rugosidade, a armadura complementar é capaz de garantir aumento na capacidade resistente do bloco.

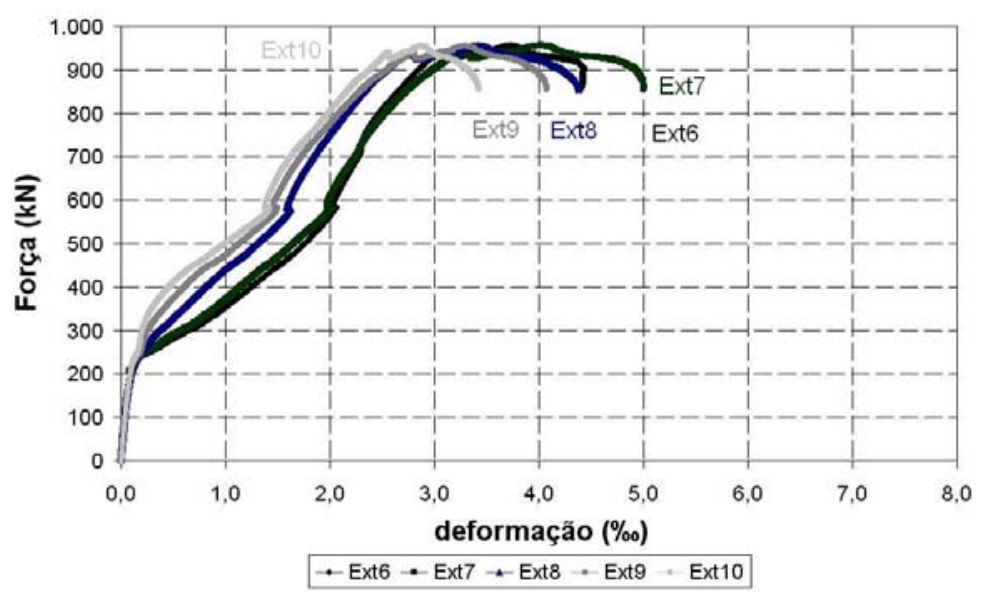

Figura 5. 74- Curva força versus deformação nas armaduras da região central do modelo M12 


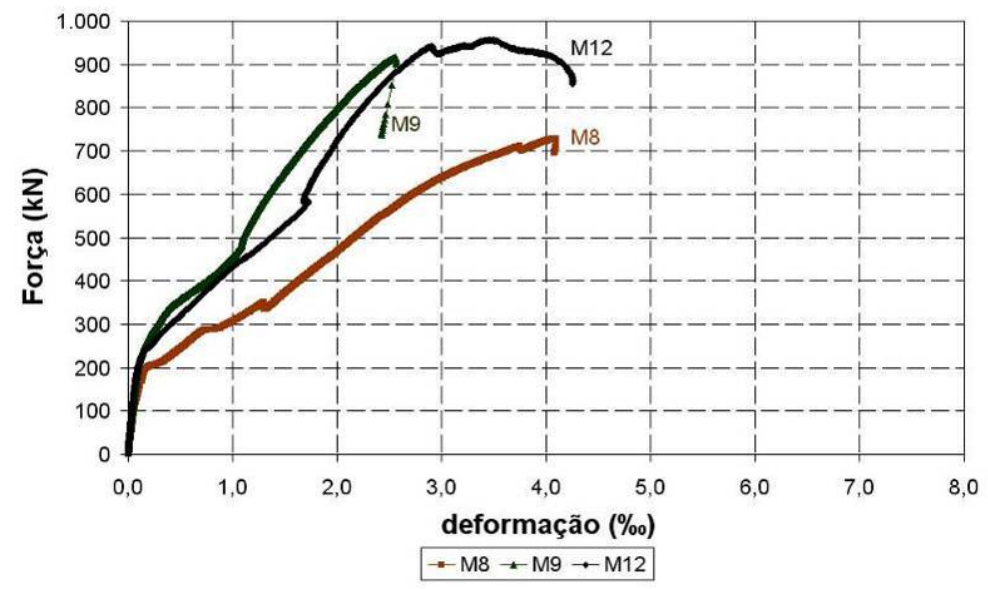

Figura 5. 75- Curva força versus deformação média nas armaduras da região central dos modelos M8, M9 e M12

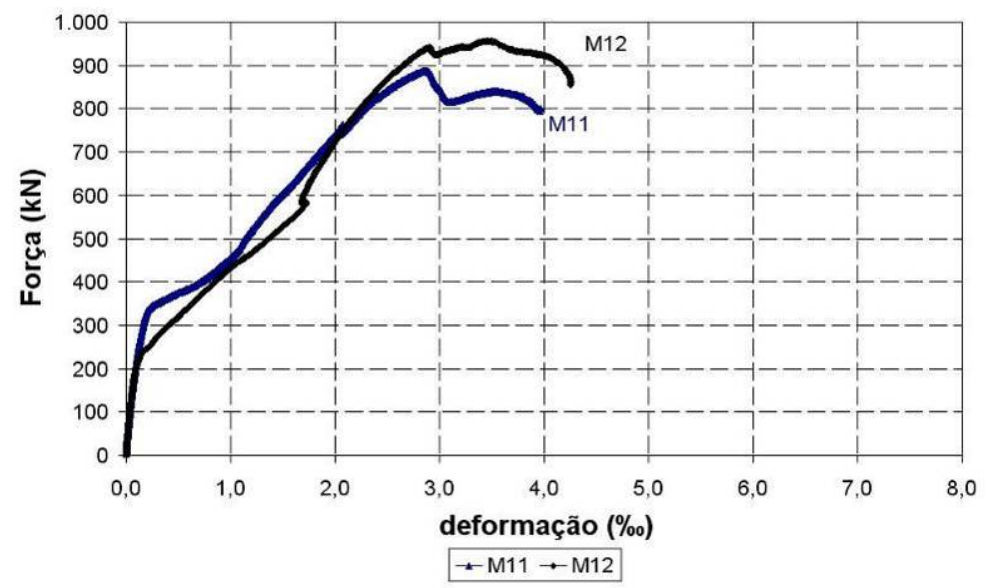

Figura 5. 76- Curva força versus deformação média nas armaduras da região central dos modelos M11 e M12

As Figuras 5.77 e $\mathbf{5 . 7 8}$ apresentam os gráficos força versus deformação nas barras das armaduras posicionadas sobre as estacas. Observa-se por meio desses gráficos que as deformações médias nas armaduras apresentam valores da ordem de 0,8\% a 1,2\%o, valores esses pequenos quando comparados as deformações obtidas nas armaduras posicionadas na região central do bloco. Isso ocorre em virtude da formação da biela sobre as estacas, o que provoca diminuição da força no tirante nessa região. 


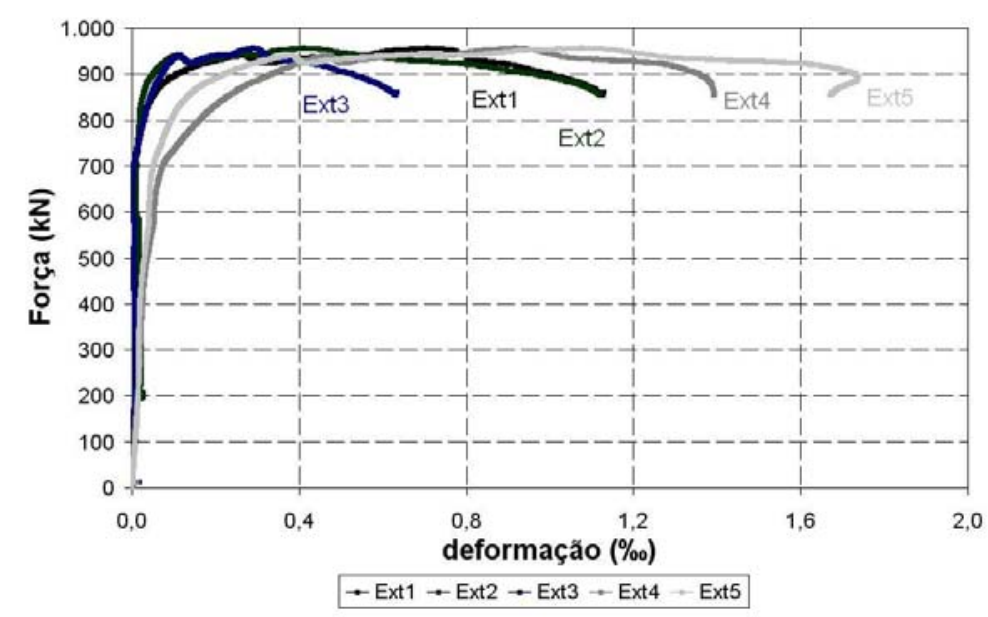

Figura 5. 77- Curva força versus deformação nas armaduras sobre as estacas do modelo M12

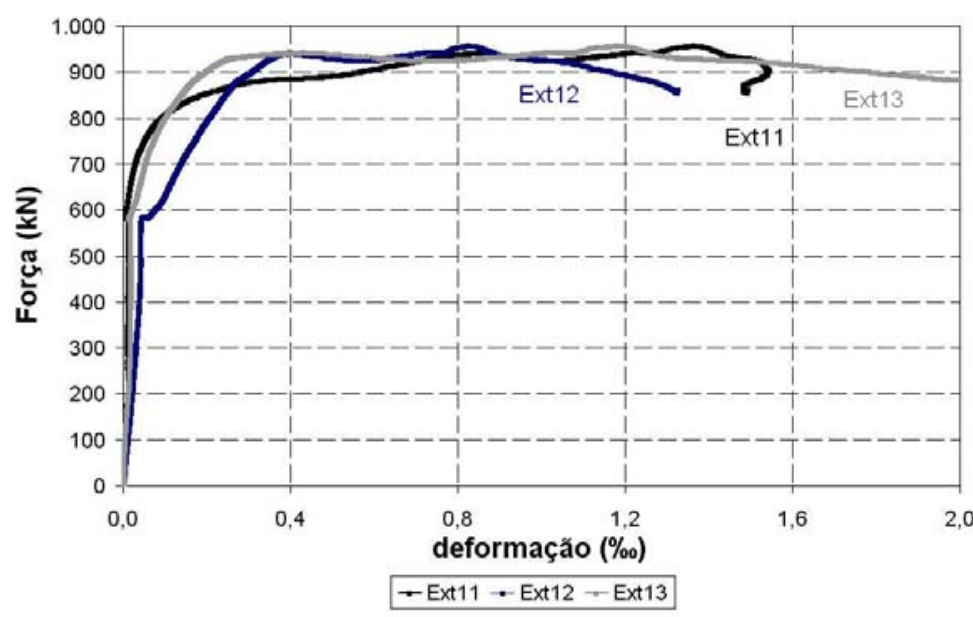

Figura 5. 78- Curva força versus deformação nas armaduras sobre as estacas do modelo M12

A Figura 5.79 apresenta o gráfico força versus deformação nas barras das armaduras do pilar. Semelhante ao que ocorreu no bloco do modelo M11, observa-se que as deformações nas barras das armaduras tornam-se menores à medida que o pilar se aproxima do fundo do cálice, conforme pode ser observado comparando os resultados dos extensômetros de número 14, 15 e 16, bem como os extensômetros de número 17, 18 e 19, os quais estavam posicionados nas barras das armaduras do pilar. Esse fato indica que a força do pilar está sendo transferida para o bloco por meio de uma biela de compressão formada ao longo da altura do cálice. 


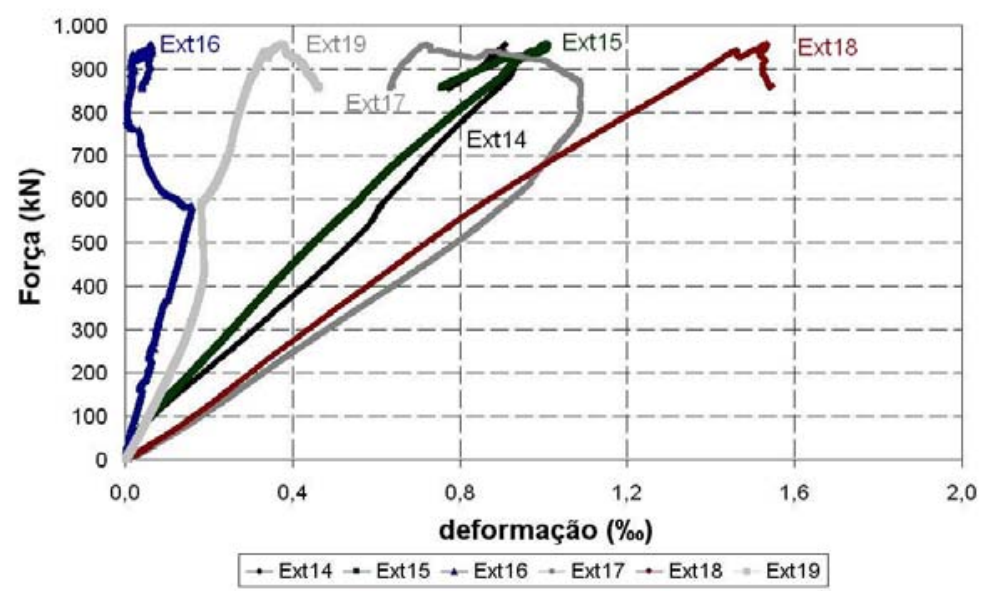

Figura 5. 79- Curva força versus deformação nas armaduras do pilar do modelo M12

O gráfico da Figura 5.80 apresenta os resultados de deformação medidos nas barras das armaduras posicionadas no cálice de fundação. Semelhante ao modelo M11, destaca-se o resultado da armadura vertical do cálice, cujos resultados foram obtidos por meio do extensômetro de número 21 . Observou-se inicialmente encurtamento da barra de armadura vertical, ocasionado pela força de compressão oriunda do pilar. Esse encurtamento ocorre de modo linear até uma força próxima a $700 \mathrm{kN}$. A partir desse instante, observa-se uma inversão nos valores de deformação, sendo que a barra até então comprimida passa a apresentar alongamento, isto é, deformações oriundas de força de tração. Esse resultado indica que o maciço de concreto sob o cálice no interior do bloco apresentou ruptura, não ocorrendo a separação em dois ou mais segmentos em virtude da presença de armadura nessa região. $\mathrm{O}$ extensômetro de número 20, por sua vez, apresentou deformações semelhantes a da armadura principal do tirante, uma vez que estava posicionada na mesma região.

A Figura 5.81, por sua vez, apresenta a curva força versus deformação nas barras da armadura complementar posicionada na região central do bloco. Em virtude da quantidade de extensômetros, apresenta-se apenas o gráfico das barras que foram instrumentadas com o extensômetros de número 26, 27, 28 e 29, os quais encontram-se faceando o cálice. Nessa armadura complementar, verifica-se que as medidas de deformação obtidas apresentam valores pequenos, quando comparadas as mediadas obtidas nos modelos M4 e M5, indicando que o comportamento da armadura complementar foi diferente para as situações em que exista ou não rugosidade na ligação do pilar com o cálice. 


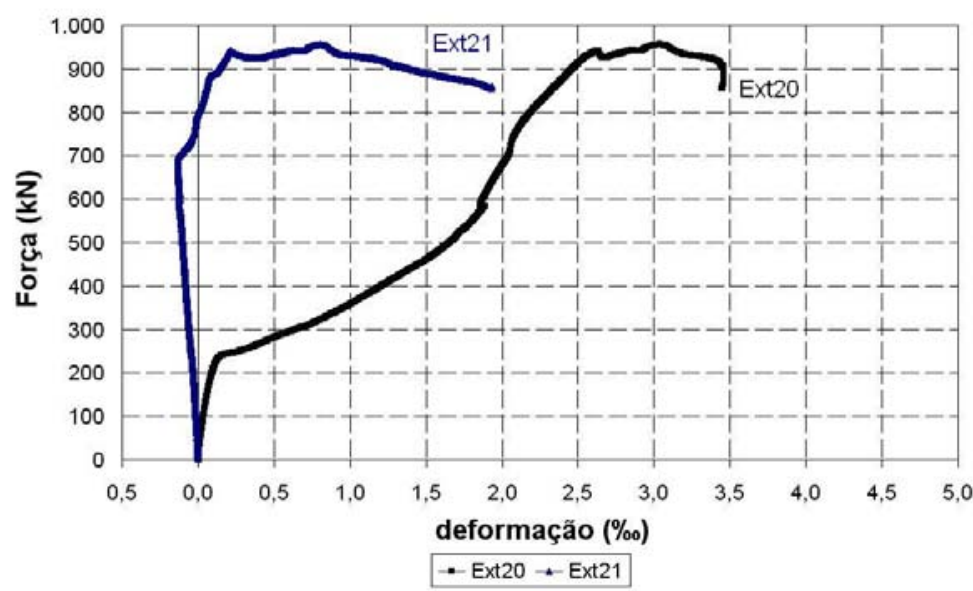

Figura 5. 80 - Curva força versus deformação nas armaduras do cálice do modelo M12

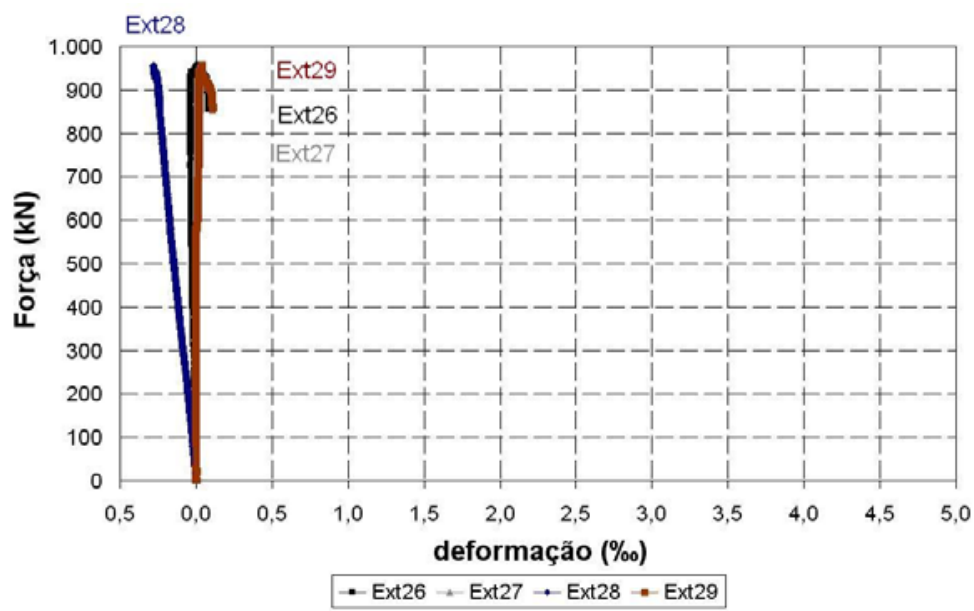

Figura 5. 81- Curva força versus deformação na armadura complementar do modelo M12

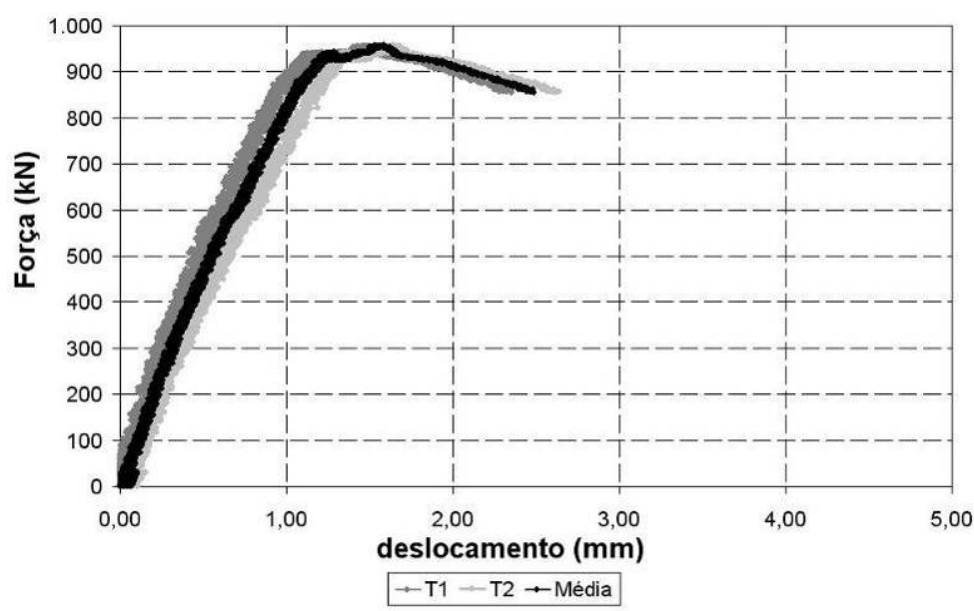

Figura 5. 82- Curva força versus deslocamento médio medido nos transdutores T1 e T2 do modelo M12 
A Figura 5.82, por sua vez, apresenta a curva força versus deslocamento do modelo M5, a partir da qual pode-se observar um deslocamento médio superior a 2,50 mm próximo a ruína do modelo, o qual ocorreu na região central do bloco.

No modelo M12 não houve perda do extensômetros elétrico de resistência. A medida que a força no pistão aumentava, verificou-se o surgimento de novas fissuras e aumento da abertura das fissuras existentes. Verificou-se aberturas da ordem de $0,15 \mathrm{~mm}$ correspondente a força de $370 \mathrm{kN} ; 0,25 \mathrm{~mm}$ para uma força igual a $500 \mathrm{kN}$; e $0,35 \mathrm{~mm}$ para uma força de 600 kN. Próximo a ruína do modelo, observou-se fissuras na face superior do colarinho, inclusive na região do graute.

Verificaram-se diversos caminhos de fissuras na região central do bloco e na provável região da biela, sendo que uma dessa fissuras formou uma espécie de arco na face lateral do bloco, saindo de uma estaca a outra, passando pela região do colarinho, conforme pode ser observado nas Figuras 5.83 (a) e 5.83 (b), as quais apresentam o panorama de fissuração do modelo M12. Também foram observadas fissuras que atravessavam o bloco passando pela região inferior e surgindo na face oposta, semelhante ao ocorrido no modelo M11, conforme pode ser observado nas Figuras 5.84 (a) e 5.84 (b). Nessa figura, as fissuras marcadas em vermelho surgiram até o modelo apresentar a força máxima, igual a $957 \mathrm{kN}$. As fissuras marcadas em azul surgiram após o modelo apresentar diminuição de força, mas continuar apresentando deslocamentos e deformações até uma força próxima aos $900 \mathrm{kN}$. As Figuras $\mathbf{5 . 8 5}$ (a) e $\mathbf{5 . 8 5}$ (b) apresentam as fissuras que ocorreram na face superior das paredes do colarinho.

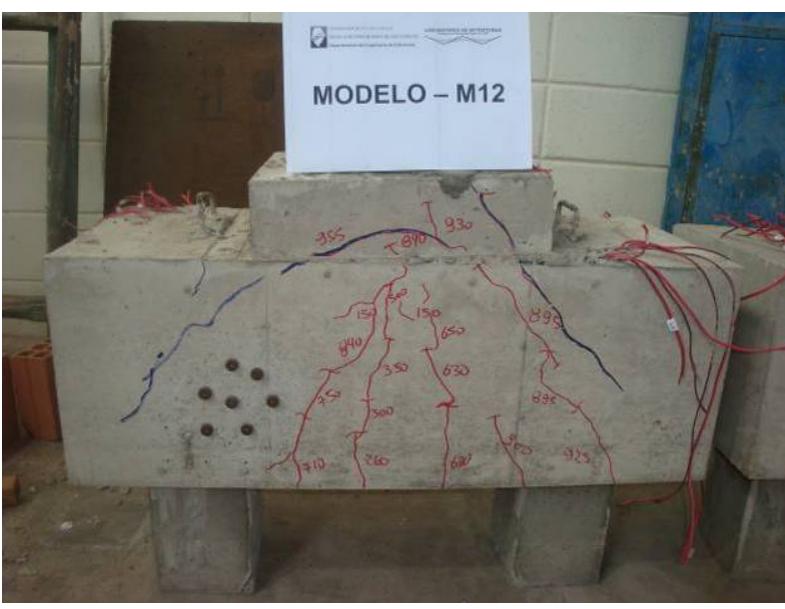

(a)

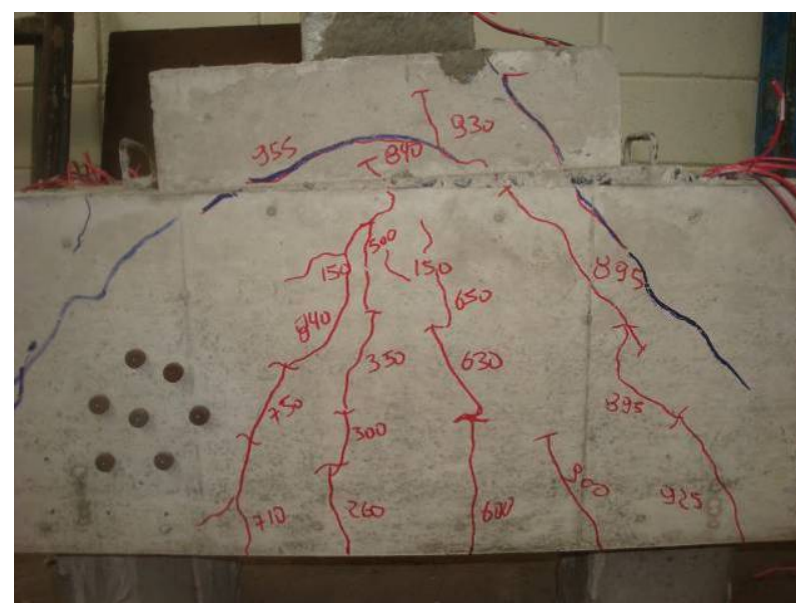

(b)

Figura 5. 83-Fissuras na face inferior e lateral oposta do Modelo M12 


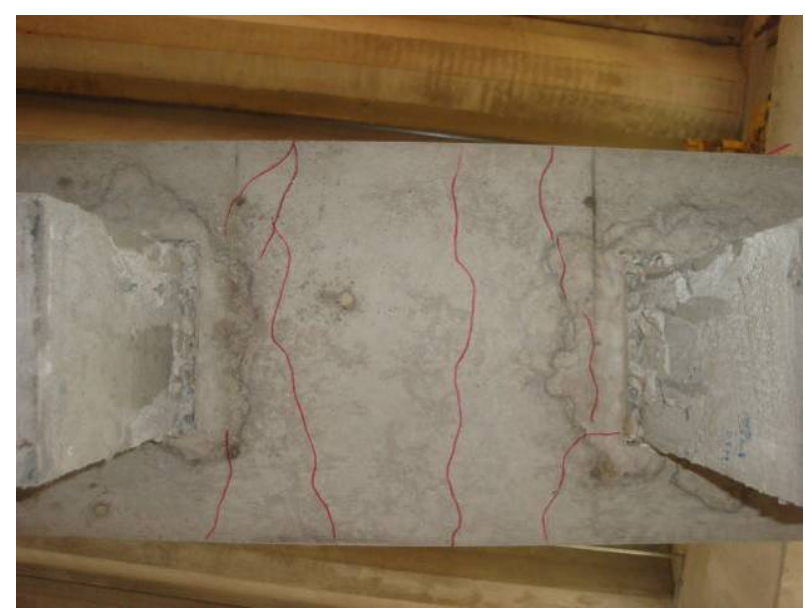

(a)

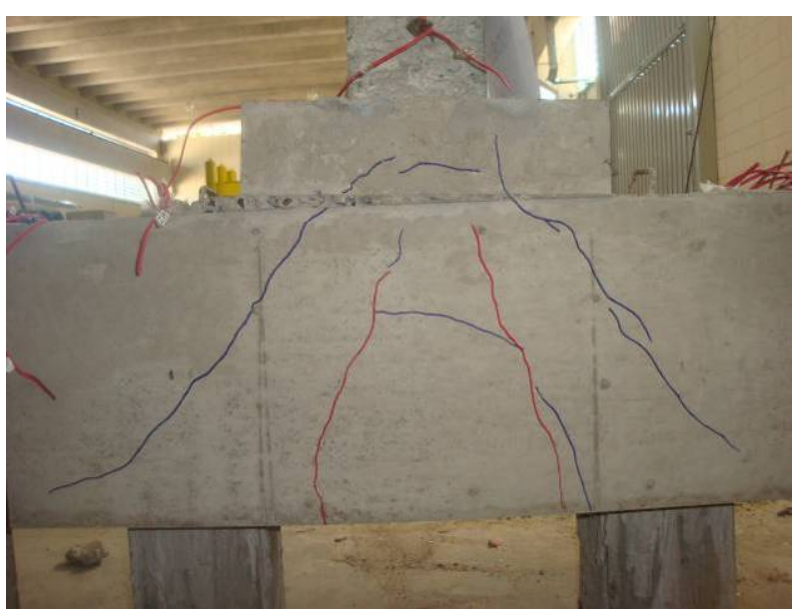

(b)

Figura 5. 84-Fissuras na face inferior e lateral do Modelo M12

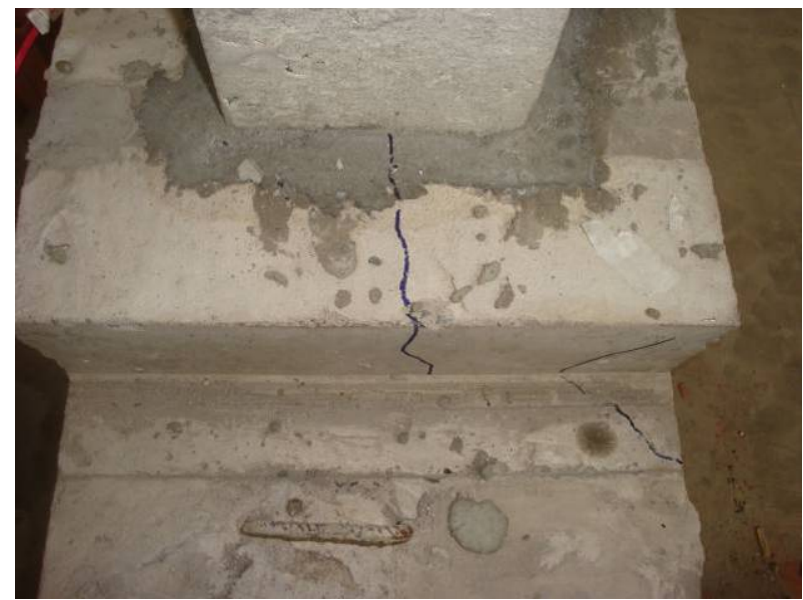

(a)

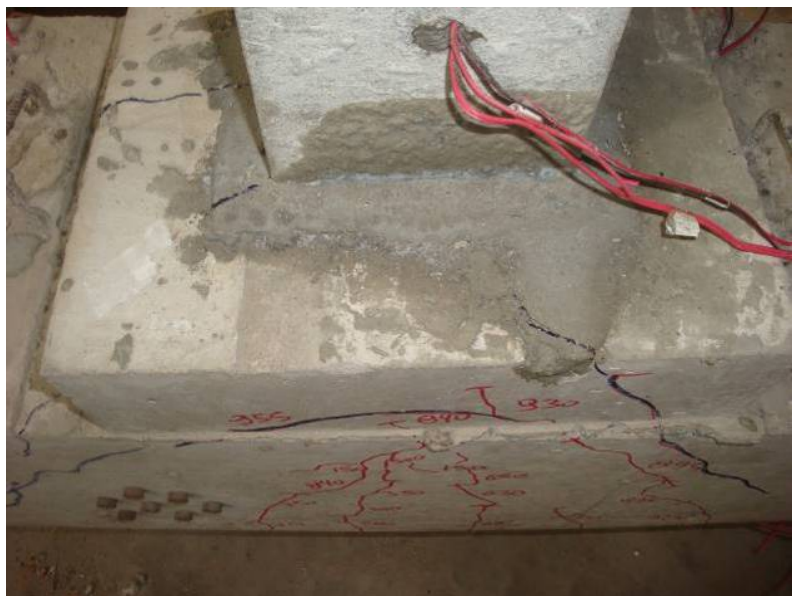

(b)

Figura 5. 85-Fissuras na face superior do colarinho do Modelo M12

Obtiveram-se valores pequenos para as medidas de deformações no concreto, uma vez que com as leituras efetuadas nas pastilhas de aço, as quais estavam fixadas nas faces laterais dos blocos, foi possível calcular as deformações na face externa do bloco. Em função dos valores obtidos, constatou-se que as deformações ficaram aquém das deformações existentes nas bielas. Desse modo, considera-se que a utilização das pastilhas de aço não conferiu bons resultados para a estimativa das deformações do concreto. Apresentam-se na tabela 5.31 os valores de deformações principais e as direções principais em relação a quatro intensidades de força. As direções apresentadas referem-se ao esquema apresentado na Figura 4.49 (b). 
Tabela 5.31 - Deformação no concreto do modelo M12

\begin{tabular}{|c|c|c|c|c|c|c|c|c|}
\hline \multirow{2}{*}{$\begin{array}{c}\text { Força } \\
(\mathbf{k N})\end{array}$} & \multirow[t]{2}{*}{ Direção } & \multicolumn{3}{|c|}{ Deformações (\%o) } & \multicolumn{2}{|c|}{$\begin{array}{l}\text { Deformações } \\
\text { Principais (\%o) }\end{array}$} & \multicolumn{2}{|c|}{$\begin{array}{c}\text { Direções } \\
\text { Principais }\left({ }^{\circ}\right)\end{array}$} \\
\hline & & $\varepsilon_{0^{\circ}}$ & $\varepsilon_{45^{\circ}}$ & $\varepsilon_{90^{\circ}}$ & $\varepsilon_{1}$ & $\varepsilon_{2}$ & $\alpha_{1}$ & $\alpha_{2}$ \\
\hline \multirow{2}{*}{50} & $1,5,3$ & $-0,011$ & $-0,013$ & 0,0 & 0,00 & $-0,01$ & 26,9 & 116,9 \\
\hline & $2,6,4$ & 0,0 & 0,0 & $-0,013$ & 0,00 & $-0,02$ & 22,5 & 112,5 \\
\hline \multirow{2}{*}{200} & $1,5,3$ & $-0,012$ & $-0,025$ & $-0,009$ & 0,00 & $-0,03$ & 42,0 & 132,0 \\
\hline & $2,6,4$ & $-0,02$ & $-0,007$ & 0,001 & 0,00 & $-0,02$ & $-6,7$ & 83,3 \\
\hline \multirow{2}{*}{300} & $1,5,3$ & $-0,013$ & $-0,018$ & $-0,009$ & 0,00 & $-0,02$ & 37,0 & 127,0 \\
\hline & $2,6,4$ & $-0,006$ & $-0,008$ & $-0,013$ & $-0,01$ & $-0,01$ & 11,6 & 101,6 \\
\hline \multirow{2}{*}{450} & $1,5,3$ & $-0,009$ & $-0,015$ & $-0,011$ & 0,00 & $-0,02$ & $-39,3$ & 50,7 \\
\hline & $2,6,4$ & 0,0 & $-0,007$ & $-0,013$ & 0,00 & $-0,01$ & $-2,2$ & 87,8 \\
\hline
\end{tabular}

\subsection{Blocos com cálice embutido}

Os modelos de blocos com cálice embutido foram ensaiados após os blocos com cálice parcialmente embutido. Os modelos M6 e M7 apresentavam interface sem rugosidade, enquanto que os modelo M13 e M14 apresentavam interface com rugosidade. Os modelos M7 e M14 apresentavam armadura complementar em forma de estribo posicionada no meio do bloco, com o intuito de verificar se essa armadura influencia no comportamento do bloco. Assim como nos modelos com cálice parcialmente embutido, foi colocado o dispositivo metálico no pilar, de modo a conferir confinamento ao concreto do pilar.

\subsubsection{Modelo M6 - BEB_SR}

O modelo M6 não apresentou comportamento de bloco rígido, e sim como flexível. Foi registrada uma pequena excentricidade na força aplicada no pilar da ordem de 0,09 cm, configurando uma situação em que se tem praticamente a força centrada. A ruína do modelo se deu por escoamento de três das barras das armaduras principais do tirante, localizadas na região central do bloco, sem que ocorresse ruptura do concreto do bloco. 
A força máxima suportada por esse modelo foi de $359 \mathrm{kN}$, força essa praticamente igual a força calculada com o modelo teórico utilizado para o dimensionamento. O modelo apresentou resistência crescente até atingir a força última de $359 \mathrm{kN}$, apresentando uma única fissura vertical que se estendeu até o topo do bloco, e várias fissuras horizontais, as quais se estenderam por toda região inferior do bloco. Observa-se que o valor da força última do modelo M6 foi inferior ao valor máximo de $756 \mathrm{kN}$ obtido no bloco de referência, bem como foi inferior a força do modelo M2, que apresentava cálice externo e inferior a força do modelo M4, que apresentava cálice parcialmente embutido. Entende-se que no modelo M6 a formação das bielas ocorre de modo diferente dos modelos M1, M2, M3, M4 e M5.

A primeira fissura visível no modelo M6 surgiu na região central inferior do bloco, apresentando abertura da ordem de 0,05 mm para uma força de $170 \mathrm{kN}$. Nessa etapa, a deformação máxima medida nas barras das armaduras do tirante foi de 0,28\%o o que resulta numa tensão igual a $57 \mathrm{MPa}$. Observou que o modelo apresentou perda de rigidez para uma força próxima de $160 \mathrm{kN}$, conforme pode ser observado nos gráficos força versus deformação das barras das armaduras posicionadas na região central do bloco.

A Figura 5.86 apresenta o gráfico força versus deformação em cada barra, enquanto que a Figura 5.87 apresenta a curva força versus deformação média em relação as armaduras posicionadas na seção central do bloco para os modelos M1, M2, M4 e M6. Observa-se por meio dessa figura que o modelo M6 foi o que apresentou menor rigidez dentre os modelos analisados, bem como foi o que apresentou maiores deformações nas barras da armadura principal do tirante.

Comparando o modelo M6 ao bloco de referência dessa série, contata-se redução na força atuante no pilar da ordem de $40 \%$ para uma deformação média nas barras da armadura próxima a 3,8\%o. Em função dos resultados apresentados, percebe-se que não está claro se ocorreu a formação da biela de compressão no modelo M6, tendo o modelo apresentado comportamento semelhante ao de bloco flexível.

As Figuras 5.88 e $\mathbf{5 . 8 9}$ apresentam os gráficos força versus deformação nas barras das armaduras posicionadas sobre as estacas. Observa-se por meio desses gráficos que as deformações médias nas armaduras apresentam valores da ordem de 0,3\% a 0,7\%, valores esses pequenos quando comparados as deformações obtidas nas armaduras posicionadas na região central do bloco. Diferente do ocorrido nos demais modelos dessa série, verificou-se que as barras das armaduras posicionadas sobre as estacas apresentaram encurtamento para valores iniciais de força, apresentando pequenos alongamentos para força próxima a ruína do 
modelo. As deformações apresentadas nessa região indicam que existe uma força de compressão sobre as estacas, que provoca a diminuição nas deformações dos tirantes nessa região.

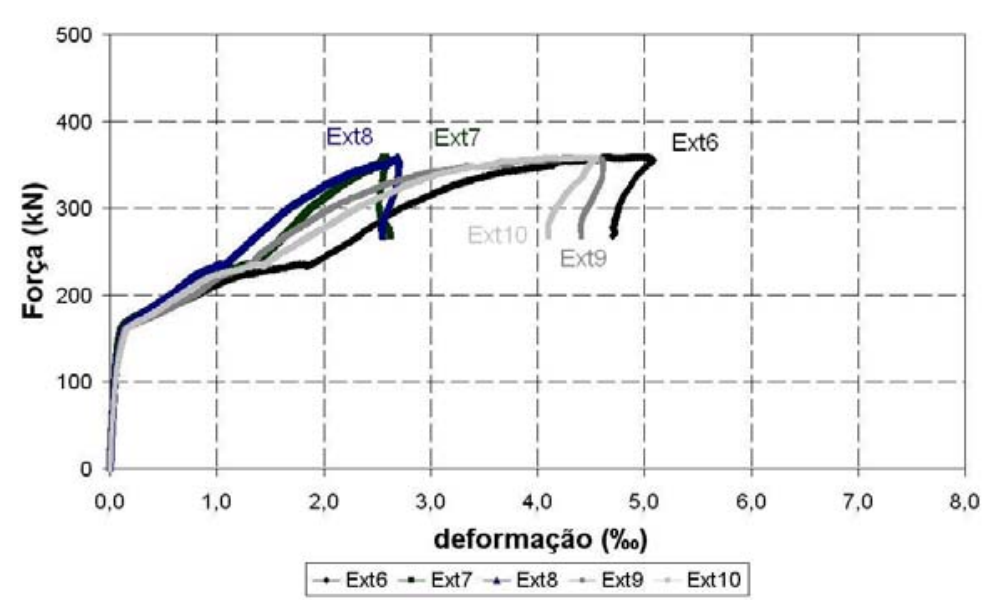

Figura 5. 86- Curva força versus deformação nas armaduras da região central do modelo M6

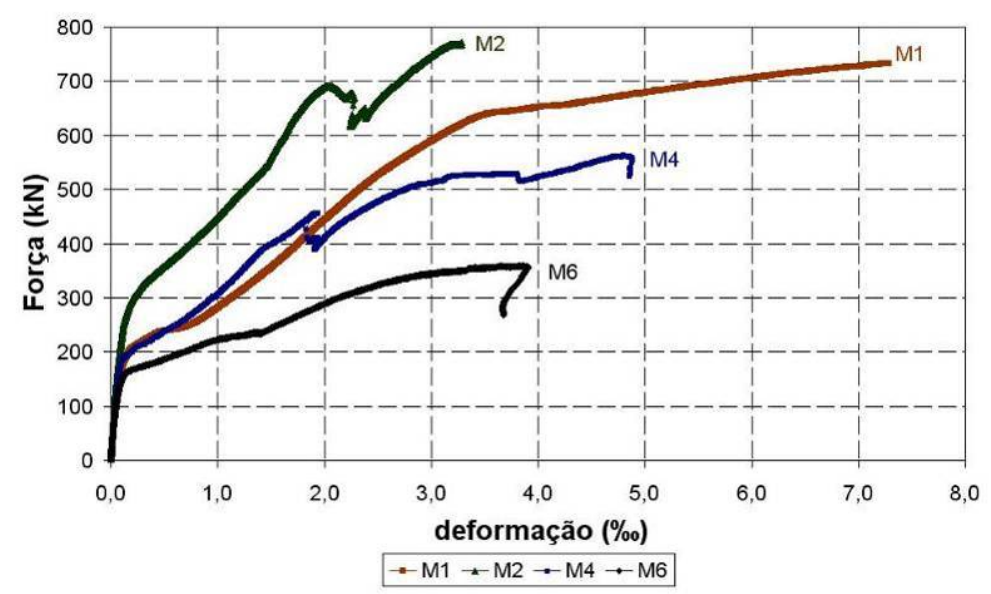

Figura 5. 87- Curva força versus deformação média nas armaduras da região central dos modelos M1, M2, M4 e M6

A Figura 5.90 apresenta o gráfico força versus deformação nas barras das armaduras do pilar. Semelhante ao que ocorreu nos blocos com cálice externo e parcialmente embutido sem rugosidade, observa-se que as deformações nas barras das armaduras tornam-se menores à medida que o pilar se aproxima do fundo do cálice, conforme pode ser observado comparando os resultados dos extensômetros de número 14, 15 e 16, bem como os extensômetros de número 17,18 e 19, os quais estavam posicionados nas barras das armaduras do pilar. 


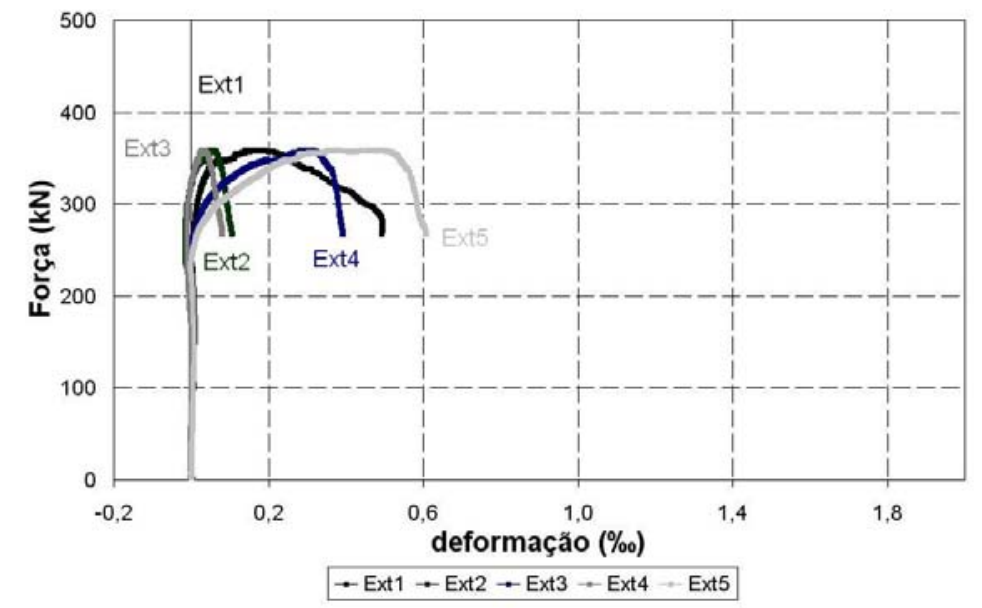

Figura 5. 88- Curva força versus deformação nas armaduras sobre as estacas do modelo M6

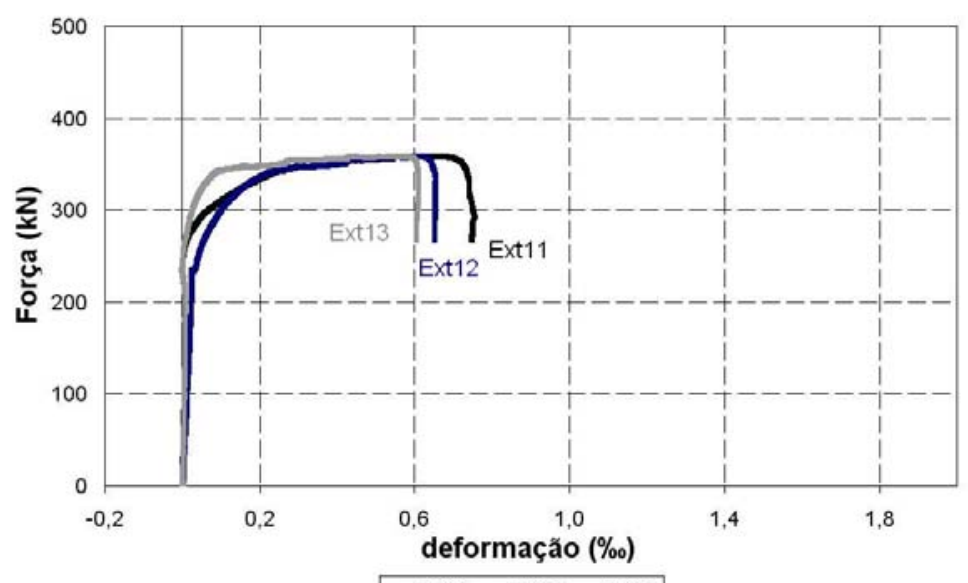

Figura 5. 89- Curva força versus deformação nas armaduras sobre as estacas do modelo M6

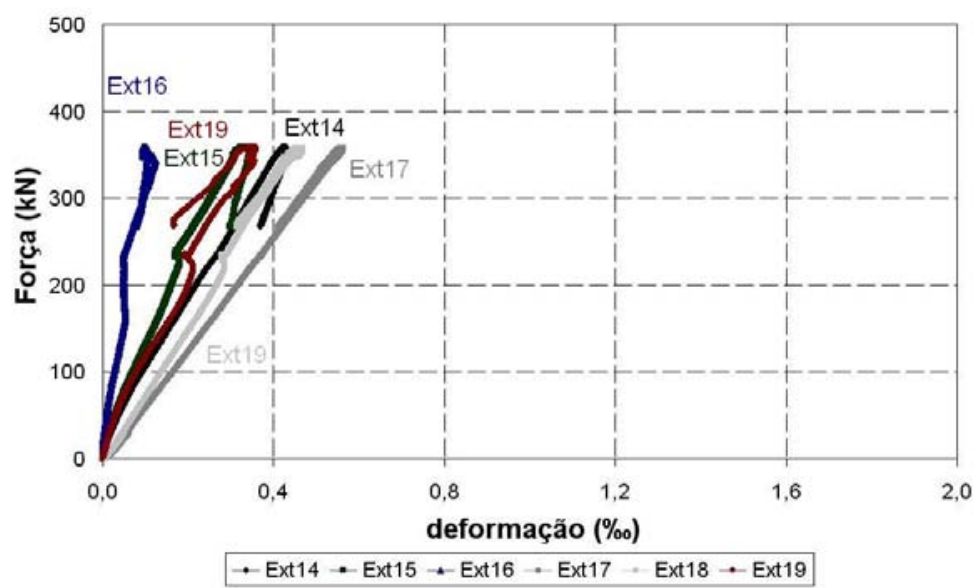

Figura 5. 90 - Curva força versus deformação nas armaduras do pilar do modelo M6

O gráfico da Figura 5.91 apresenta os resultados de deformação medidos nas barras das armaduras posicionadas no cálice de fundação. Destaca-se o resultado da armadura vertical do cálice, cujos resultados foram obtidos por meio do extensômetro de número 21 . Diferente do 
ocorrido nos modelos com cálice parcialmente embutido, observa-se um pequeno encurtamento da barra de armadura vertical ocasionado pela força de compressão oriunda do pilar, indicando que esta força está sendo transmitida para o bloco abaixo da posição do extensômetro 21. A partir de uma força próxima de $240 \mathrm{kN}$, observa-se alongamento dessa barra, isto é, deformações oriundas de esforço de tração. Esse resultado indica que o maciço de concreto sob o cálice no interior do bloco apresentou ruptura, não ocorrendo a separação em dois ou mais segmentos em virtude da presença de armadura nessa região. O extensômetro de número 20, por sua vez, apresentou deformações semelhantes a da armadura principal do tirante, uma vez que estava posicionada na mesma região.

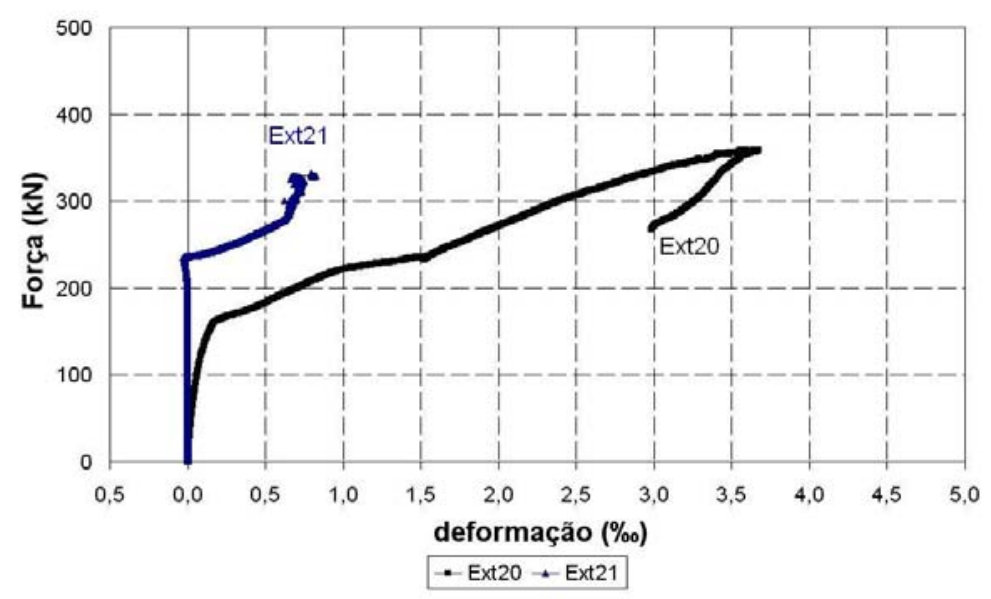

Figura 5. 91- Curva força versus deformação nas armaduras do cálice do modelo M6

A Figura 5.92, por sua vez, apresenta a curva força versus deslocamento do modelo M6, a partir da qual pode-se observar um deslocamento médio próximo a 3,00 mm no instante em que ocorreu a ruína do modelo. Após a ruína, verifica-se aumento dos deslocamentos sem aumento na força resistente do modelo.

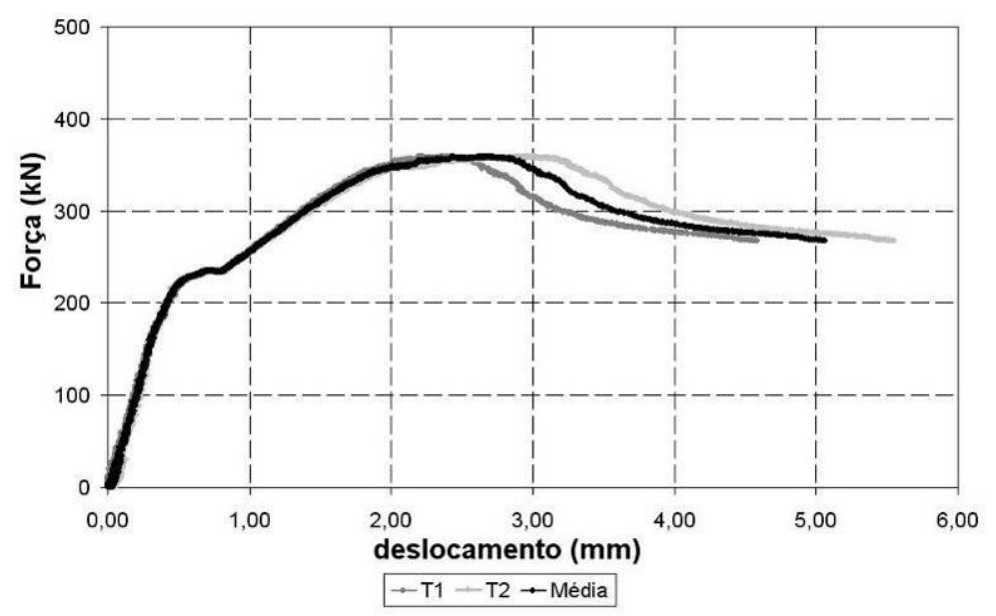

Figura 5. 92-Curva força versus deslocamento médio medido nos transdutores T1 e T2 do modelo M6 
No modelo M6 não houve perda de extensômetros elétricos de resistência. A medida que a força no pistão aumentava, verificou-se o surgimento de novas fissuras e aumento da abertura das fissuras existentes. Verificou-se aberturas da ordem de 0,15 $\mathrm{mm}$ correspondente a força de $200 \mathrm{kN} ; 0,20 \mathrm{~mm}$ para uma força de $230 \mathrm{kN} ; 0,30 \mathrm{~mm}$ para uma força de $260 \mathrm{kN}$; e 0,50 mm para uma força de $320 \mathrm{kN}$. A Figura 5.93 (a) apresenta o panorama de fissuração do modelo M6 após a realização dos ensaios. Verificou-se ainda que, próximo a ruína do modelo, houve aumento das fissuras existentes e surgimento de fissuras horizontais com aberturas superiores a 2,00 mm, conforme pode ser observado na Figura 5.93 (b).

Verificaram-se diversas linhas de fissuras na região central do bloco, sendo que várias dessas fissuras atravessaram o bloco passando pela região inferior e surgindo na face oposta. A Figura 5.94 (a) apresenta a formação de diversas fissuras na região inferior do bloco, enquanto que na Figura 5.94 (b) apresenta-se o destacamento do concreto situado da região inferior do bloco.

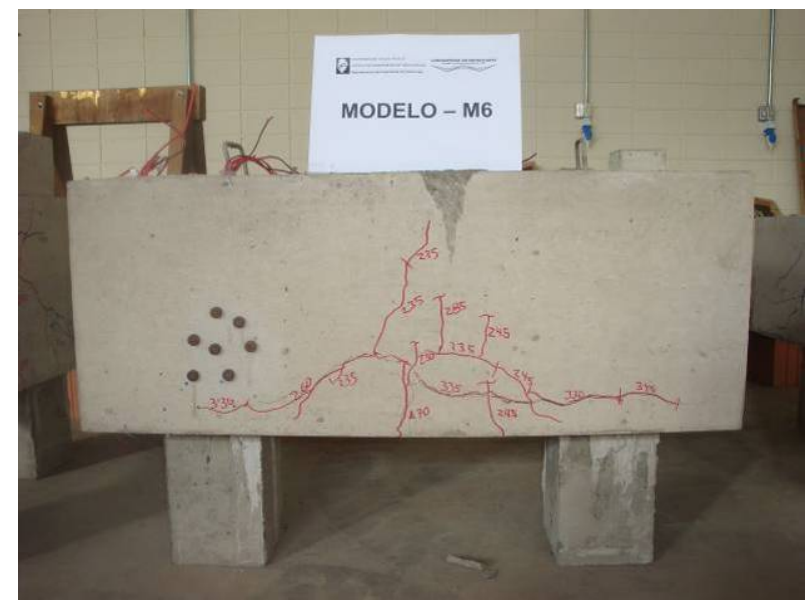

(a)

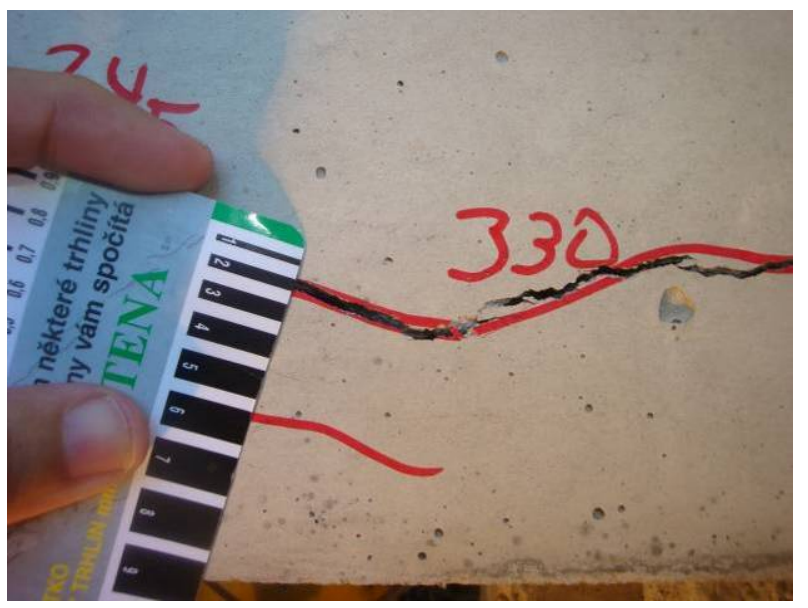

(b)

Figura 5. 93-Fissuras na face lateral do Modelo M6

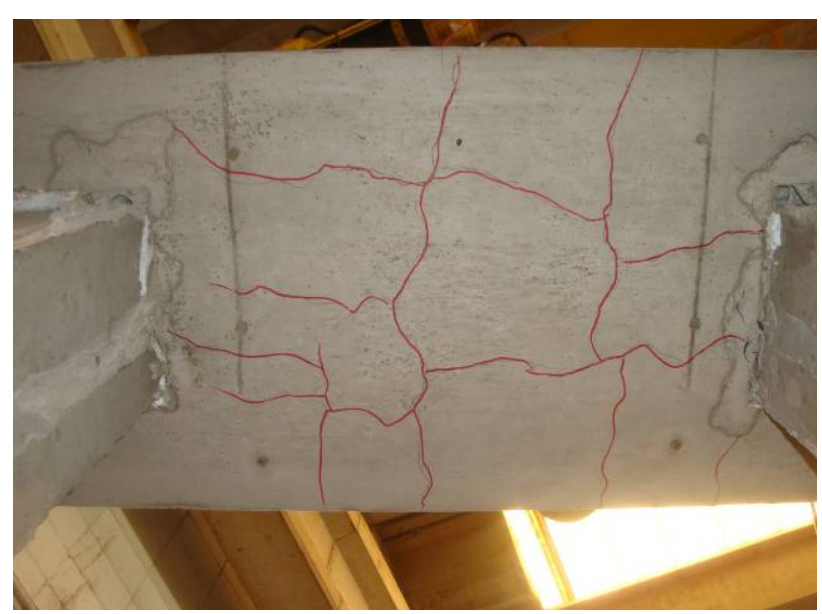

(a)

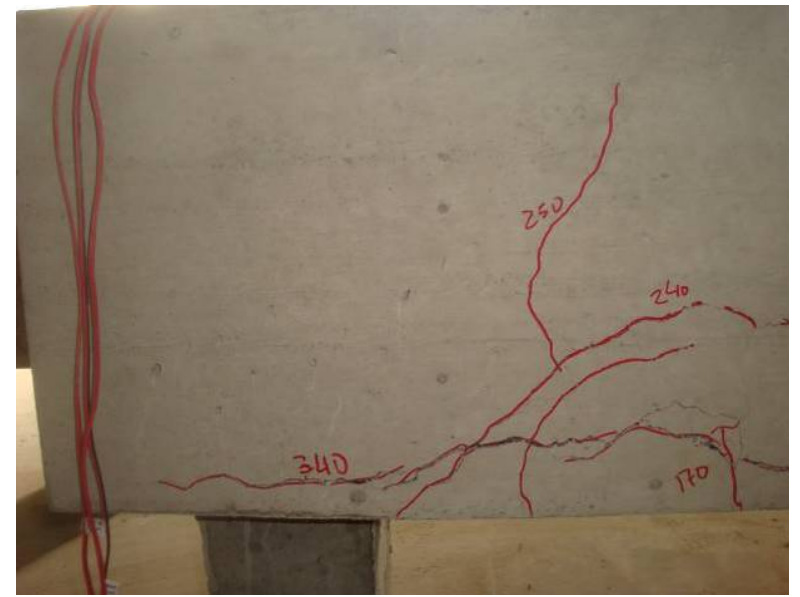

(b)

Figura 5. 94-Fissuras na face inferior e destacamento do concreto no Modelo M6 
Obtiveram-se valores pequenos para as medidas de deformações no concreto, uma vez que com as leituras efetuadas nas pastilhas de aço, as quais estavam fixadas nas faces laterais dos blocos, foi possível calcular as deformações na face externa do bloco. Em função dos valores obtidos, constatou-se que as deformações ficaram aquém das deformações existentes nas bielas. Desse modo, considera-se que a utilização das pastilhas de aço não conferiu bons resultados para a estimativa das deformações do concreto. Apresentam-se na tabela 5.32 os valores de deformações principais e as direções principais em relação a quatro intensidades de força. As direções apresentadas referem-se ao esquema apresentado na Figura 4.49 (b).

Tabela 5.32 - Deformação no concreto do modelo M6

\begin{tabular}{|c|c|c|c|c|c|c|c|c|}
\hline \multirow{2}{*}{$\begin{array}{c}\text { Força } \\
(\mathbf{k N})\end{array}$} & \multirow[t]{2}{*}{ Direção } & \multicolumn{3}{|c|}{ Deformações (\%o) } & \multicolumn{2}{|c|}{$\begin{array}{c}\text { Deformações } \\
\text { Principais (\%o) }\end{array}$} & \multicolumn{2}{|c|}{$\begin{array}{c}\text { Direções } \\
\text { Principais }\left({ }^{\circ}\right)\end{array}$} \\
\hline & & $\varepsilon_{0^{\circ}}$ & $\varepsilon_{45^{\circ}}$ & $\varepsilon_{90^{\circ}}$ & $\varepsilon_{1}$ & $\varepsilon_{2}$ & $\alpha_{1}$ & $\alpha_{2}$ \\
\hline \multirow{2}{*}{50} & $1,5,3$ & 0,023 & 0,26 & 0,02 & 0,26 & $-0,22$ & 44,8 & 134,8 \\
\hline & $2,6,4$ & 0,003 & 0,002 & $-0,001$ & 0,00 & 0,00 & 13,3 & 103,3 \\
\hline \multirow{2}{*}{150} & $1,5,3$ & 0,003 & 0,005 & 0,015 & 0,02 & 0,00 & 16,8 & 106,8 \\
\hline & $2,6,4$ & 0,003 & $-0,097$ & $-0,001$ & 0,10 & $-0,10$ & $-44,4$ & 45,6 \\
\hline \multirow{2}{*}{200} & $1,5,3$ & 0,009 & 0,005 & 0,001 & 0,01 & 0,00 & 0,0 & 90,0 \\
\hline & $2,6,4$ & 0,019 & $-0,098$ & 0,001 & 0,12 & $-0,10$ & $-42,6$ & 47,4 \\
\hline \multirow{2}{*}{300} & $1,5,3$ & 0,003 & $-0,002$ & 0,013 & 0,02 & 0,00 & 31,7 & 121,7 \\
\hline & $2,6,4$ & $-0,005$ & $-0,102$ & $-0,014$ & 0,08 & $-0,10$ & $-43,6$ & 46,4 \\
\hline
\end{tabular}

\subsubsection{Modelo M7 - BEB_AC_SR}

Assim como ocorreu no modelo M6, o modelo M7 não apresentou comportamento de bloco rígido, comportando-se como bloco flexível. Foi registrada uma pequena excentricidade na força aplicada no pilar da ordem de $0,17 \mathrm{~cm}$. Semelhante ao modelo M6, a ruína desse modelo se deu por escoamento de todas as barras das armaduras principais do tirante localizadas na região central do bloco, sem que houvesse ruptura do concreto do bloco.

A força máxima suportada por esse modelo foi de $368 \mathrm{kN}$, força essa semelhante a força calculada com o modelo teórico utilizado para o dimensionamento. O modelo obteve resistência crescente até atingir a força última de $368 \mathrm{kN}$, apresentando uma única fissura 
vertical na região central, a qual se estendeu até o topo do bloco. Observa-se que o valor da força última do modelo $\mathrm{M} 7$ foi inferior ao valor máximo de $756 \mathrm{kN}$ obtido no bloco de referência, bem como foi inferior a força última obtida nos modelo M2 e M5, os quais apresentavam o cálice externo e parcialmente embutido, respectivamente. Comparando os resultados dos modelos com cálice embutido sem rugosidade, observa-se que a força última no modelo M7 apresentou a mesma ordem de grandeza da força obtida no modelo M6, que não dispunha da armadura complementar em forma de estribos na região central do bloco. Esse resultado indica que, diferente do ocorrido entre os modelos M4 e M5, para os blocos com cálice embutido e sem rugosidade na ligação do pilar com o cálice, a armadura complementar não conferiu ganho significativo de resistência ao modelo.

O panorama de fissuração foi semelhante ao apresentado pelo modelo M6, sendo que a primeira fissura visível no modelo surgiu na região inferior do bloco, para uma força de 160 $\mathrm{kN}$, apresentando abertura da ordem de $0,05 \mathrm{~mm}$. Nessa etapa, a deformação máxima medida nas barras das armaduras do tirante foi de $0,51 \%$ o que resulta numa tensão igual a $103 \mathrm{MPa}$. Observou-se que o modelo apresentou perda de rigidez para uma força próxima de $136 \mathrm{kN}$, conforme pode ser observado nos gráficos força versus deformação das barras das armaduras posicionadas na região central do bloco.

A Figura 5.95 apresenta o gráfico força versus deformação em cada barra, enquanto que a Figura 5.96 apresenta a curva força versus deformação média em relação as armaduras posicionadas na seção central do bloco para os modelos M1, M2, M5 e M7.

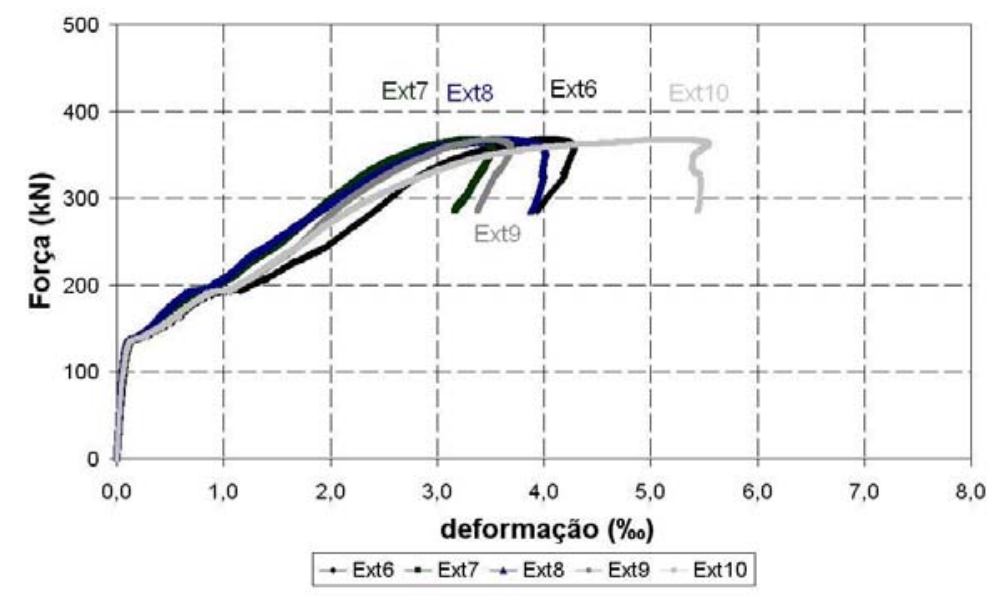

Figura 5. 95- Curva força versus deformação nas armaduras da região central do modelo M7 


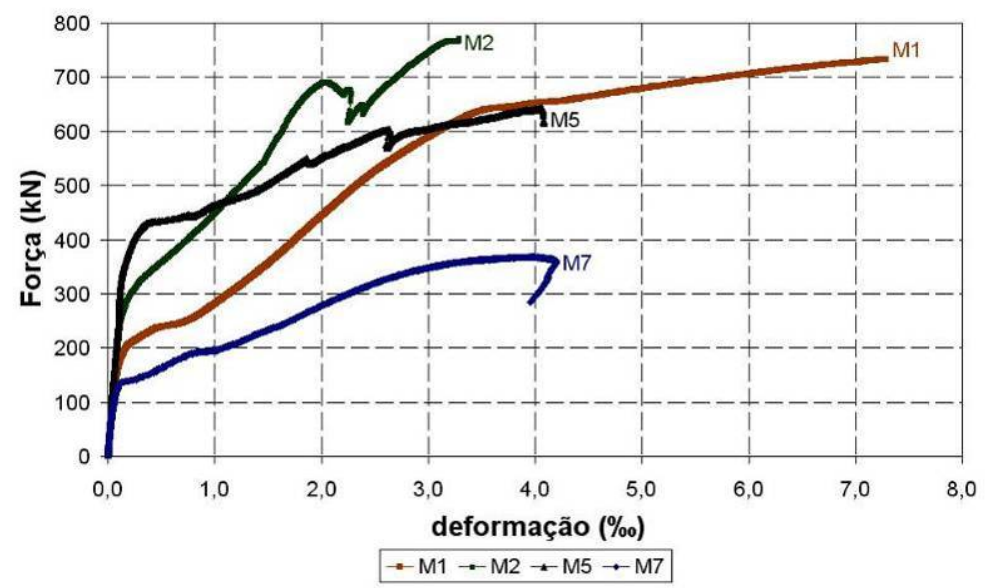

Figura 5. 96- Curva força versus deformação média nas armaduras da região central dos modelos M1, M2, M5 e $M 7$

Observa-se por meio da Figura 5.96 que o modelo M7 foi o que apresentou menor rigidez dentre os modelos analisados, bem como foi o que apresentou maiores deformações nas barras da armadura principal do tirante. Comparando o modelo M7 ao bloco de referência dessa série, contata-se redução na força atuante no pilar da ordem de $44 \%$ para uma deformação média nas barras da armadura próxima a 4\%.

Comparando os modelos com cálice embutido, verifica-se que o modelo M7 apresentou rigidez semelhante a do modelo M6, conforme pode ser observado na Figura 5.97, indicando que a armadura complementar utilizada no modelo M7 não conferiu ganho de resistência ao modelo. Em função dos resultados apresentados, percebe-se também nesse modelo não está claro se houve a formação da biela de compressão, tendo o modelo apresentado comportamento semelhante ao de bloco flexível.

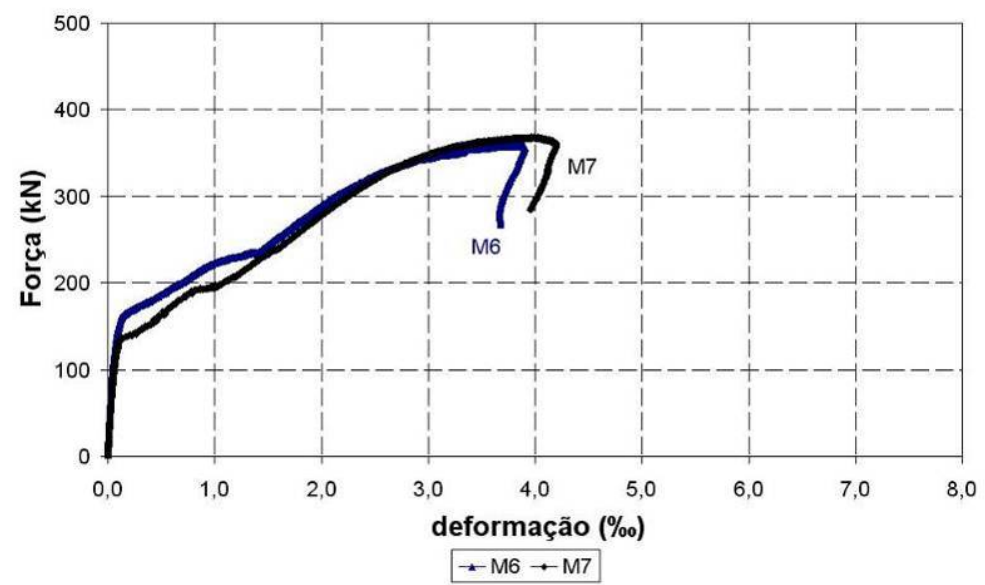

Figura 5. 97- Curva força versus deformação média nas armaduras da região central dos modelos M6 e M7 
As Figuras 5.98 e 5.99 apresentam os gráficos força versus deformação nas barras das armaduras posicionadas sobre as estacas. Observa-se por meio desses gráficos que as deformações médias nas armaduras apresentam valores da ordem de $0,3 \%$ a $0,6 \%$, valores esses pequenos quando comparados as deformações obtidas nas armaduras posicionadas na região central do bloco. Assim como ocorreu no modelo M6, verificou-se que as barras das armaduras posicionadas sobre as estacas apresentaram encurtamento para valores iniciais de força, apresentando posteriormente alongamentos para força próxima a ruína do modelo. As deformações apresentadas nessa região indicam que existe uma força de compressão sobre as estacas que provoca a diminuição nas deformações dos tirantes nessa região, semelhante ao modelo M6.

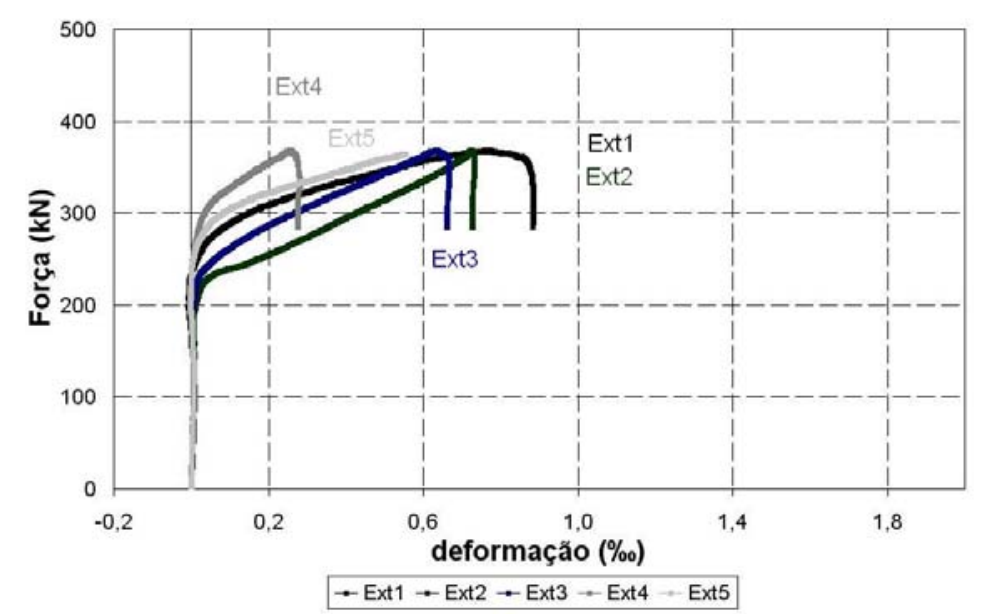

Figura 5. 98- Curva força versus deformação nas armaduras sobre as estacas do modelo M7

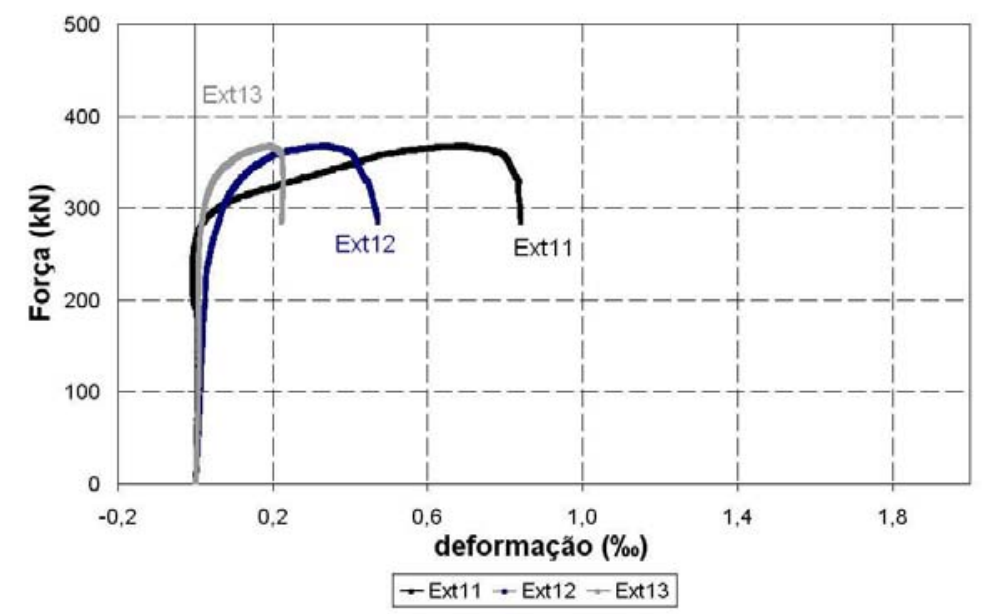

Figura 5. 99- Curva força versus deformação nas armaduras sobre as estacas do modelo M7 
A Figura 5.100 apresenta o gráfico força versus deformação nas barras das armaduras do pilar. Semelhante ao que ocorreu no bloco do modelo M6, observa-se que as deformações nas barras das armaduras tornam-se menores à medida que o pilar se aproxima do fundo do cálice, conforme pode ser observado comparando os resultados dos extensômetros de número 14, 15 e 16, bem como os extensômetros de número 17, 18 e 19, os quais estavam posicionados nas barras das armaduras do pilar

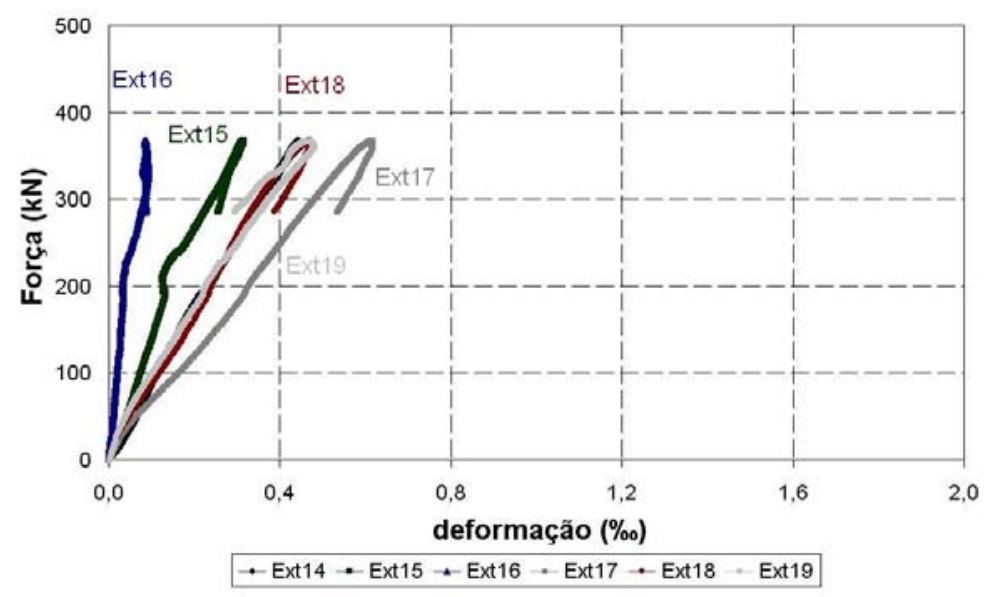

Figura 5. 100- Curva força versus deformação nas armaduras do pilar do modelo M7

O gráfico da Figura 5.101 apresenta os resultados de deformação medidos nas barras das armaduras posicionadas no cálice de fundação. Semelhante ao modelo M6, observa-se um pequeno encurtamento da barra de armadura vertical ocasionado pela força de compressão oriunda do pilar, o que indica que esta força está sendo transmitido para o bloco abaixo da posição do extensômetro 21. A partir de uma força próxima de $230 \mathrm{kN}$, observa-se alongamento dessa barra, isto é, deformações oriundas de força de tração. Esse resultado indica que o maciço de concreto sob o cálice no interior do bloco apresentou ruptura, não ocorrendo a separação em dois ou mais segmentos em virtude da presença de armadura nessa região. O extensômetro de número 20, por sua vez, apresentou deformações semelhantes a da armadura principal do tirante, uma vez que estava posicionada na mesma região.

A Figura 5.102 apresenta a curva força versus deformação nas barras da armadura complementar posicionada na região central do bloco. Em virtude da quantidade de extensômetros, apresenta-se apenas o gráfico das barras que foram instrumentadas com o extensômetros de número 26, 27, 28 e 29, as quais encontram-se faceando o cálice. Verificase que os extensômetros 26, e 28 apresentam inicialmente pequenos encurtamentos, passando a apresentar alongamentos próximos a uma força de $250 \mathrm{kN}$. Essas deformações são menores do que as medidas nos extensômetros 27 e 29 posicionados na região inferior do estribo, e que 
apresentam pequenos encurtamentos no início do ensaio, passando a apresentar alongamento para uma força próxima a $200 \mathrm{kN}$. Constata-se que esse comportamento foi semelhante ao ocorrido com o extensômetro 21, posicionado na barra vertical da armadura do cálice.

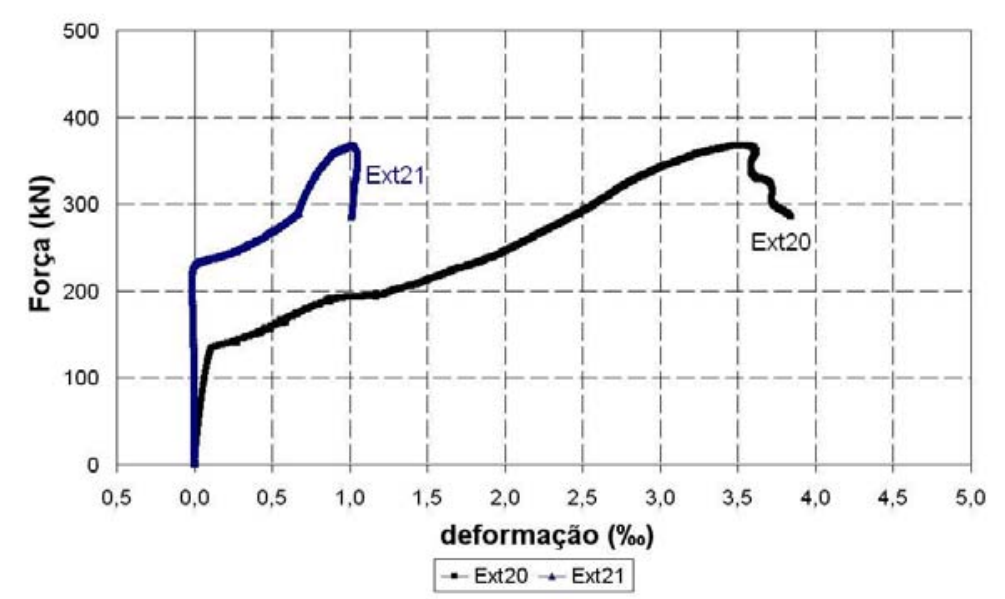

Figura 5. 101- Curva força versus deformação nas armaduras do cálice do modelo M7

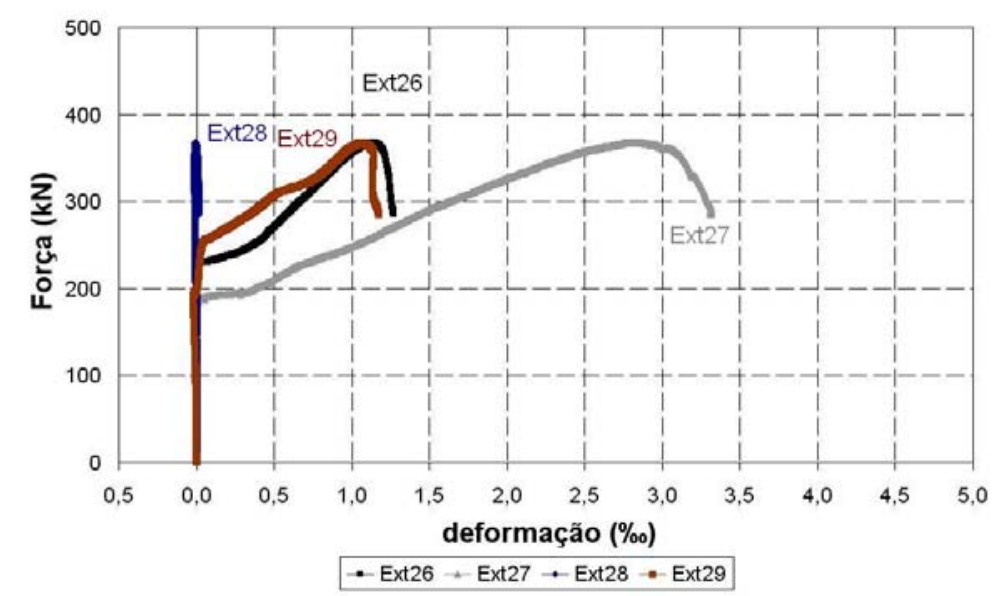

Figura 5. 102- Curva força versus deformação na armadura complementar do modelo M7

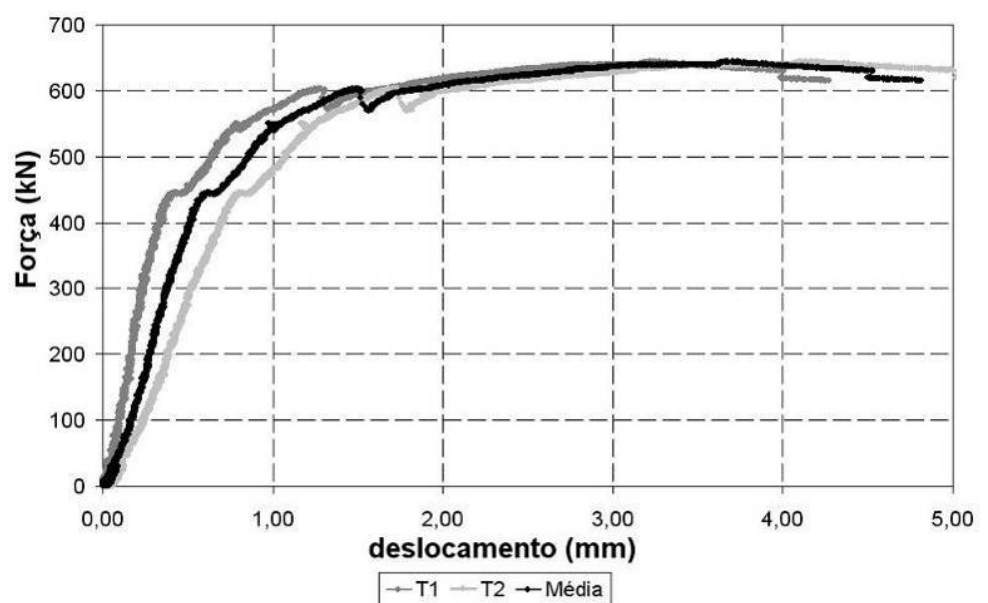

Figura 5. 103- Curva força versus deslocamento médio medido nos transdutores T1 e T2 do modelo M7 
A Figura 5.103, por sua vez, apresenta a curva força versus deslocamento do modelo M7, a partir da qual pode-se observar um deslocamento médio próximo a 3,00 mm no instante em que ocorreu a ruína do modelo. Após a ruína, verifica-se aumento dos deslocamentos sem aumento na força resistente do modelo, semelhante ao ocorrido no modelo M6.

No modelo M7 não houve perda do extensômetros elétrico de resistência. A medida que a força no pistão aumentava, verificou-se o surgimento de novas fissuras e aumento da abertura das fissuras existentes. Verificou-se aberturas da ordem de $0,15 \mathrm{~mm}$ correspondente a força de $196 \mathrm{kN} ; 0,20 \mathrm{~mm}$ para uma força de $210 \mathrm{kN} ; 0,30 \mathrm{~mm}$ para uma força de $250 \mathrm{kN}$; e 0,60 mm para uma força de $300 \mathrm{kN}$. A Figura 5.104 (a) apresenta o panorama de fissuração do modelo M7 após a realização dos ensaios. Verificou-se ainda que, próximo a ruína do modelo, houve aumento das fissuras existentes e surgimento de fissuras horizontais com aberturas superiores a 2,00 mm, conforme pode ser observado na Figura 5.104 (b).

Verificou-se uma única linha de fissura vertical na região central do bloco indo até o topo do bloco, enquanto que várias fissuras atravessaram o bloco passando pela região inferior e surgindo na face oposta, conforme apresentado na Figura 5.105 (a). Em relação ao cálice, observaram-se fissuras nos cantos do cálice preenchidos com graute, e deslocamento relativo do pilar em relação ao graute, conforme Figura 5.105 (b). Semelhante ao modelo M6, constatou-se que houve destacamento do concreto situado na região inferior do modelo

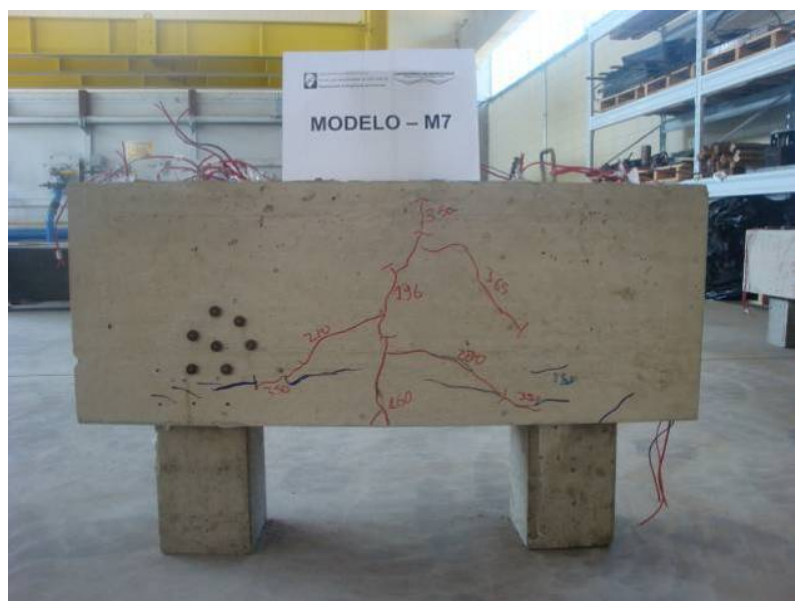

(a)

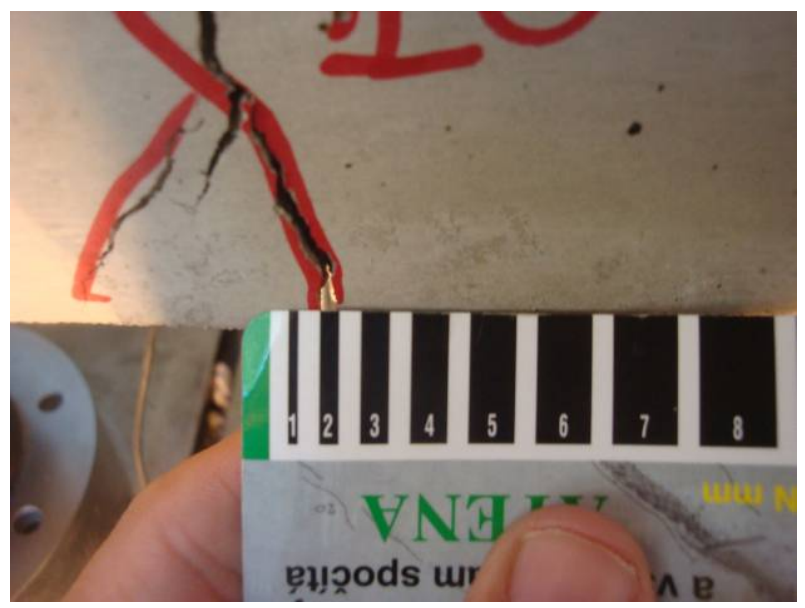

(b)

Figura 5. 104-Fissuras na face lateral do Modelo M7 


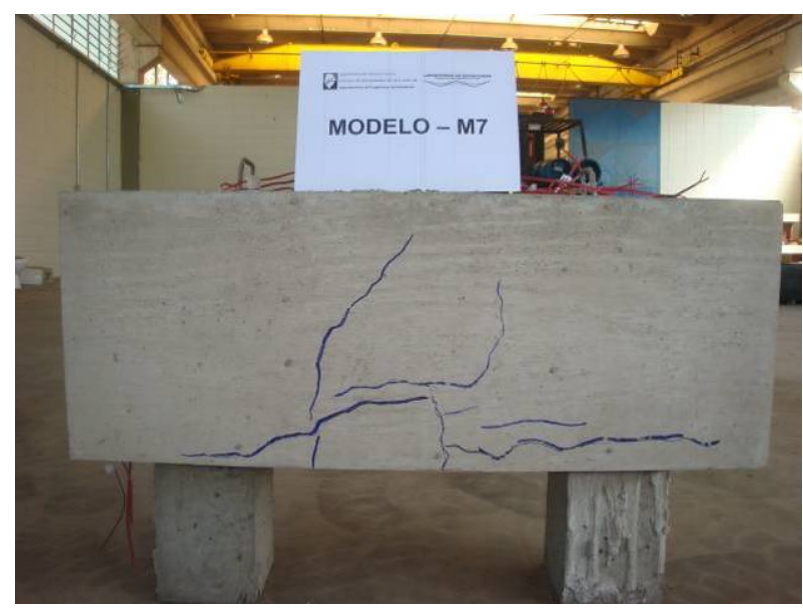

(a)

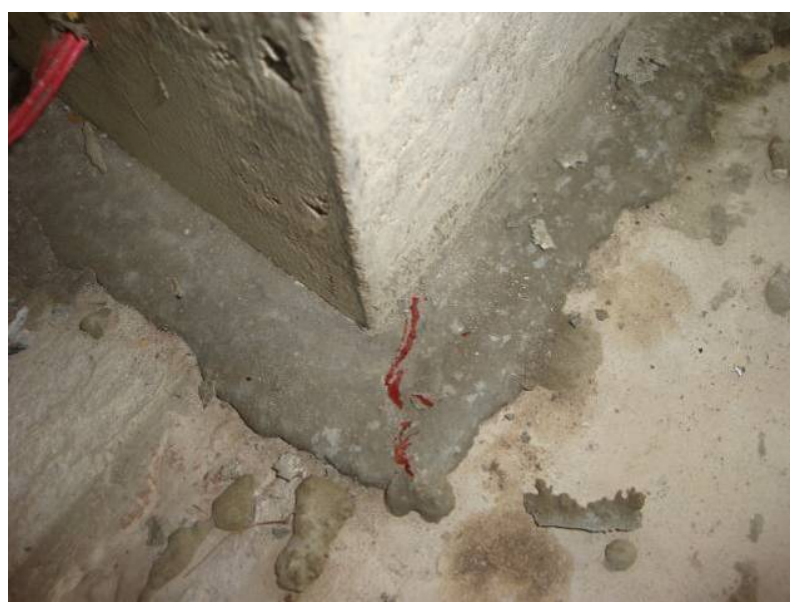

(b)

Figura 5. 105-Fissuras na face inferior e lateral oposta do Modelo M7

Obtiveram-se valores pequenos para as medidas de deformações no concreto, uma vez que com as leituras efetuadas nas pastilhas de aço, as quais estavam fixadas nas faces laterais dos blocos, foi possível calcular as deformações na face externa do bloco. Em função dos valores obtidos, constatou-se que as deformações ficaram aquém das deformações existentes nas bielas. Desse modo, considera-se que a utilização das pastilhas de aço não conferiu bons resultados para a estimativa das deformações do concreto. Apresentam-se na tabela 5.33 os valores de deformações principais e as direções principais em relação a quatro intensidades de força. As direções apresentadas referem-se ao esquema apresentado na Figura 4.49 (b).

Tabela 5.33 - Deformação no concreto do modelo M7

\begin{tabular}{|c|c|c|c|c|c|c|c|c|}
\hline \multirow[t]{2}{*}{ Força $(k N)$} & \multirow[t]{2}{*}{ Direção } & \multicolumn{3}{|c|}{ Deformações (\%o) } & \multicolumn{2}{|c|}{$\begin{array}{c}\text { Deformações } \\
\text { Principais } \\
\text { (\%) }\end{array}$} & \multicolumn{2}{|c|}{$\begin{array}{c}\text { Direções } \\
\text { Principais }\left({ }^{\circ}\right)\end{array}$} \\
\hline & & $\varepsilon_{0^{\circ}}$ & $\varepsilon_{45^{\circ}}$ & $\varepsilon_{90^{\circ}}$ & $\varepsilon_{1}$ & $\varepsilon_{2}$ & $\alpha_{1}$ & $\alpha_{2}$ \\
\hline \multirow{2}{*}{50} & $1,5,3$ & 0,006 & $-0,011$ & $-0,001$ & 0,02 & $-0,01$ & $-37,7$ & 52,3 \\
\hline & $2,6,4$ & 0,034 & 0,000 & $-0,004$ & 0,04 & $-0,01$ & $-19,1$ & 70,9 \\
\hline \multirow{2}{*}{200} & $1,5,3$ & 0,006 & $-0,012$ & $-0,008$ & 0,01 & $-0,01$ & $-28,8$ & 61,2 \\
\hline & $2,6,4$ & 0,033 & $-0,002$ & $-0,012$ & 0,04 & $-0,02$ & $-14,5$ & 75,5 \\
\hline \multirow{2}{*}{300} & $1,5,3$ & 0,000 & $-0,017$ & $-0,010$ & 0,01 & $-0,02$ & $-33,7$ & 56,3 \\
\hline & $2,6,4$ & 0,031 & $-0,008$ & $-0,012$ & 0,04 & $-0,02$ & $-19,6$ & 70,4 \\
\hline \multirow{2}{*}{350} & $1,5,3$ & 0,006 & $-0,021$ & $-0,010$ & 0,02 & $-0,02$ & $-33,6$ & 56,4 \\
\hline & $2,6,4$ & 0,004 & $-0,001$ & $-0,015$ & 0,01 & $-0,02$ & 12,7 & 102,7 \\
\hline
\end{tabular}




\subsubsection{Modelo M13 - BEB_CR}

O modelo M13 apresentou comportamento de bloco rígido, diferente do que ocorreu nos blocos dos modelos com cálice embutido sem rugosidade. Foi registrada uma excentricidade na força aplicada no pilar da ordem de $3,73 \mathrm{~cm}$. A ruína do modelo se deu por escoamento de três barras da armadura principal do tirante, localizadas na região central do bloco, seguida da ruptura do concreto do bloco.

A força máxima suportada por esse modelo foi de $652 \mathrm{kN}$, força essa superior a força calculada com o modelo teórico utilizado para o dimensionamento. O modelo apresentou resistência crescente até atingir a força última de $652 \mathrm{kN}$, apresentando diversas fissuras na região central, as quais se estenderam até o topo do bloco, e fissuras horizontais na região da biela comprimida. Observa-se que o valor da força última do modelo M13 foi inferior ao valor máximo de $728 \mathrm{kN}$ do bloco de referência dessa série, indicando que, apesar da formação das bielas, as mesmas apresentaram inclinação com o tirante inferior a inclinação apresentada pelos modelos M8 a M12.

Comparando o modelo M13 com os modelos M6 e M7, os quais não apresentavam rugosidade na ligação pilar fundação, observa-se uma maior rigidez no modelo M13 e, conseqüentemente, maior força resistente. Verifica-se que o bloco do modelo M13 apresentou força última em média $80 \%$ superior a dos modelos que não tinham rugosidade.

A primeira fissura visível no modelo M13 surgiu na região central inferior do bloco, apresentando abertura da ordem de $0,05 \mathrm{~mm}$ para uma força de $180 \mathrm{kN}$. Nessa etapa, a deformação máxima medida nas barras das armaduras do tirante foi de 0,39\%o o que resulta numa tensão igual a $80 \mathrm{MPa}$. Observou que o modelo apresentou perda de rigidez para uma força próxima de $170 \mathrm{kN}$, conforme pode ser observado nos gráficos força versus deformação das barras das armaduras posicionadas na região central do bloco.

A Figura 5.106 apresenta o gráfico força versus deformação em cada barra, enquanto que a Figura $\mathbf{5 . 1 0 7}$ apresenta a curva força versus deformação média em relação as armaduras posicionadas na seção central do bloco para os modelos M8, M9, M11 e M13. Observa-se por meio dessa figura que o modelo M13 apresentou rigidez semelhante a do bloco de referência do modelo M8, porém foi o que apresentou menor força última dentre todos os modelos, com um valor aproximadamente igual a $90 \%$ da força última do bloco de referência e igual a $70 \%$ da força última máxima, a qual ocorreu para o modelo M9 que apresentava cálice externo. 


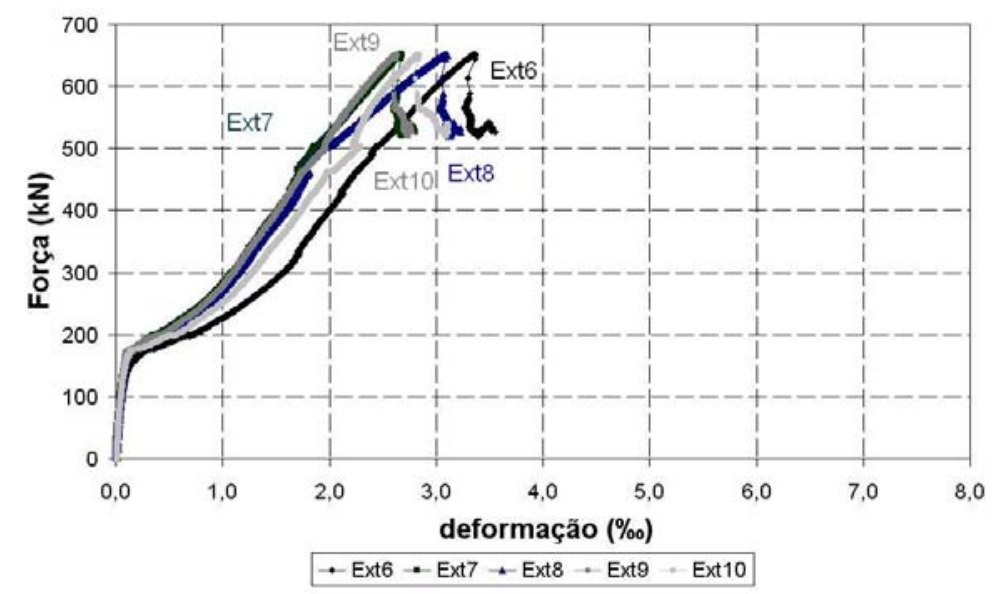

Figura 5. 106- Curva força versus deformação nas armaduras da região central do modelo M13

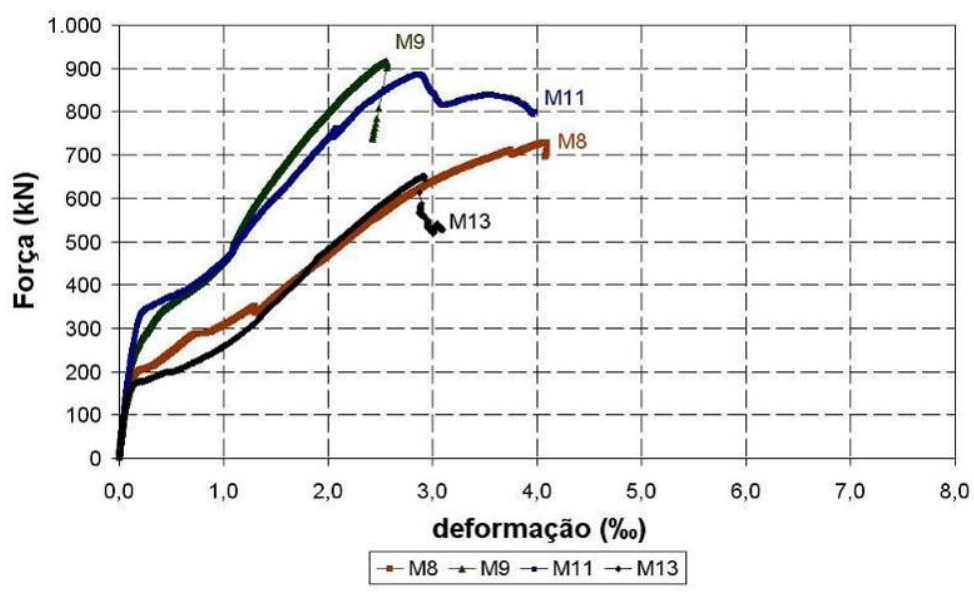

Figura 5. 107-Curva força versus deformação média nas armaduras da região central dos modelos M8, M9, M11 e M13

A Figura 5.108 apresenta o gráfico força versus deformação nas barras das armaduras posicionadas sobre as estacas. Em função de perdas nos extensômetros elétricos de resistência, apresenta-se apenas o gráfico das barras posicionadas sobre uma das estacas. Observa-se por meio desse gráfico que, no instante da ruína do modelo, as deformações médias nas armaduras apresentam valores da ordem de $0,8 \%$, valores esses pequenos quando comparados as deformações obtidas nas armaduras posicionadas na região central do bloco. Após a ruína, observou-se aumento nos valores de deformações até atingirem o valor de $2 \%$. Diferente do ocorrido nos modelos M6 e M7, verificou-se que as barras das armaduras posicionadas sobre as estacas não apresentaram encurtamento para valores iniciais de força, apresentando alongamentos desde o início do ensaio até a ruína do modelo. 


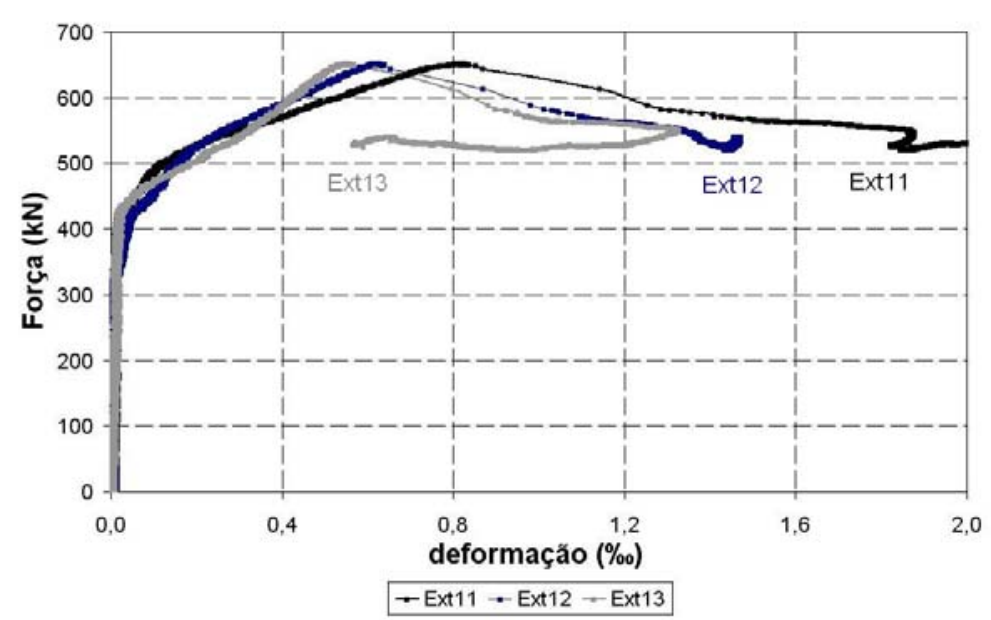

Figura 5. 108- Curva força versus deformação nas armaduras sobre as estacas do modelo M13

A Figura 5.109 apresenta o gráfico força versus deformação nas barras das armaduras do pilar. Semelhante ao que ocorreu nos blocos com cálice externo e parcialmente embutido, observa-se que as deformações nas barras das armaduras tornam-se menores à medida que o pilar se aproxima do fundo do cálice, conforme pode ser observado comparando os resultados dos extensômetros de número 14, 15 e 16, bem como os extensômetros de número 17, 18 e 19 , os quais estavam posicionados nas barras das armaduras do pilar.

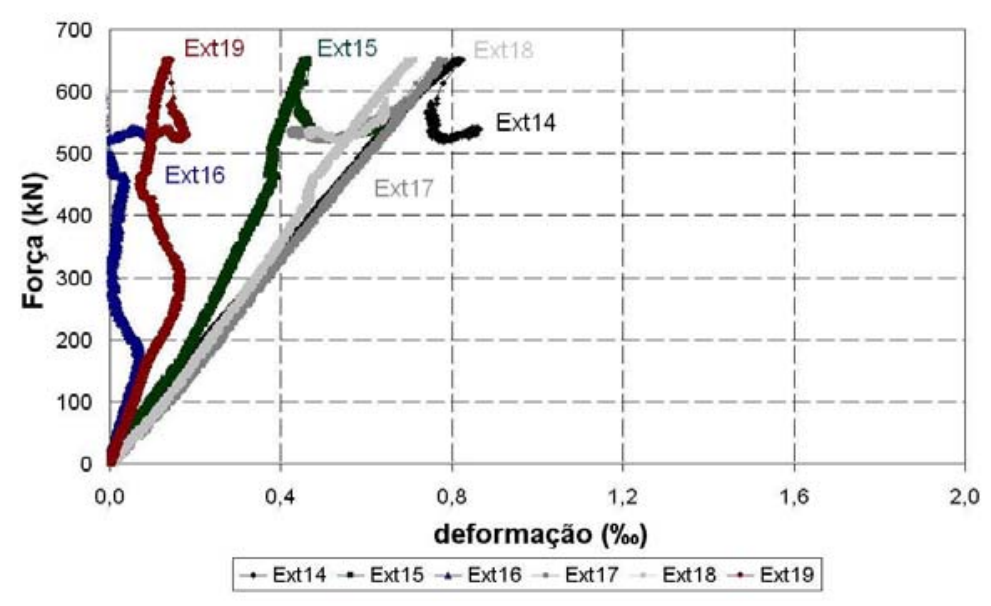

Figura 5. 109- Curva força versus deformação nas armaduras do pilar do modelo M13

O gráfico da Figura 5.110 apresenta os resultados de deformação medidos nas barras das armaduras posicionadas no cálice de fundação. Destaca-se o resultado da armadura vertical do cálice, cujos resultados foram obtidos por meio do extensômetro de número 21 . Diferente do ocorrido nos modelos com cálice parcialmente embutido, observa-se um pequeno encurtamento da barra de armadura vertical ocasionado pela força de compressão 
oriunda do pilar, indicando que essa força está sendo transmitida para o bloco abaixo da posição do extensômetro 21. A partir de uma força próxima de $530 \mathrm{kN}$, observa-se alongamento dessa barra, isto é, deformações oriundas de força de tração. Esse resultado indica que o maciço de concreto sob o cálice no interior do bloco apresentou ruptura, não ocorrendo a separação em dois ou mais segmentos em virtude da presença de armadura nessa região. O extensômetro de número 20, por sua vez, apresentou deformações semelhantes a da armadura principal do tirante, uma vez que estava posicionada na mesma região.

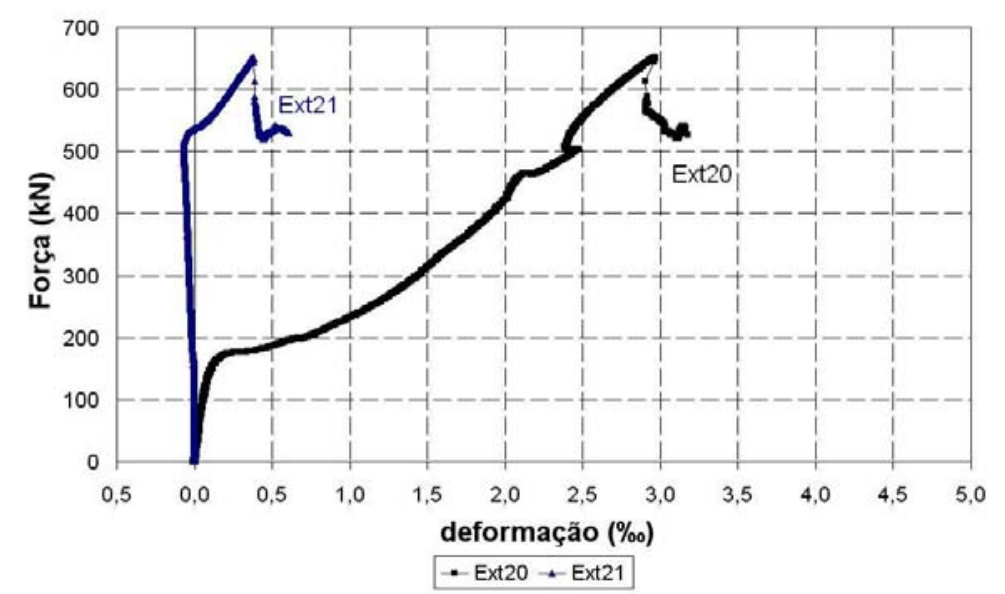

Figura 5. 110- Curva força versus deformação nas armaduras do cálice do modelo M13

A Figura 5.111, por sua vez, apresenta a curva força versus deslocamento do modelo M13, a partir da qual pode-se observar um deslocamento médio próximo a 2,00 $\mathrm{mm}$ no instante em que ocorreu a ruína do modelo. Após a ruína, verifica-se aumento dos deslocamentos com diminuição na força resistente do modelo.

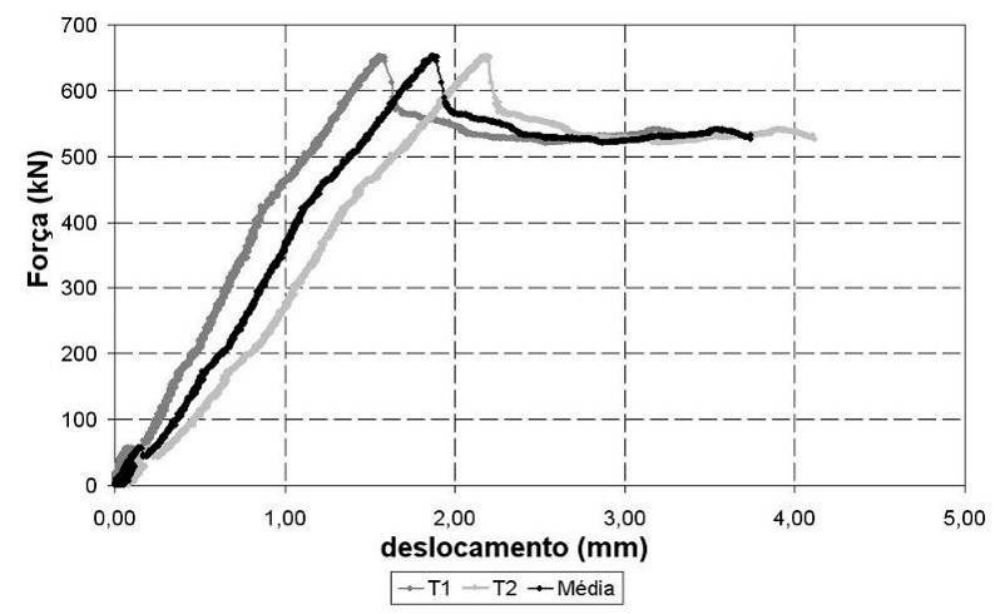

Figura 5. 111- Curva força versus deslocamento médio medido nos transdutores T1 e T2 do modelo M13 
No modelo M13 houve perda dos extensômetros elétricos de resistência de número 1 a 5. A medida que a força no pistão aumentava, verificou-se o surgimento de novas fissuras e aumento da abertura das fissuras existentes. Verificaram-se aberturas da ordem de 0,15 mm correspondente a força de $250 \mathrm{kN}$; 0,30 mm para uma força de $396 \mathrm{kN}$; 0,50mm para uma força de $500 \mathrm{kN}$; e $0,75 \mathrm{~mm}$ para uma força de $630 \mathrm{kN}$. Próximo a ruína do modelo observouse aberturas das fissuras existentes superiores a 2,00 mm. A Figura 5.112 (a) apresenta o modelo M13 antes da realização do ensaio, enquanto que as Figuras 5.112 (b) e 5.112 (c) apresentam o panorama de fissuração do modelo M13 após a realização dos ensaios.

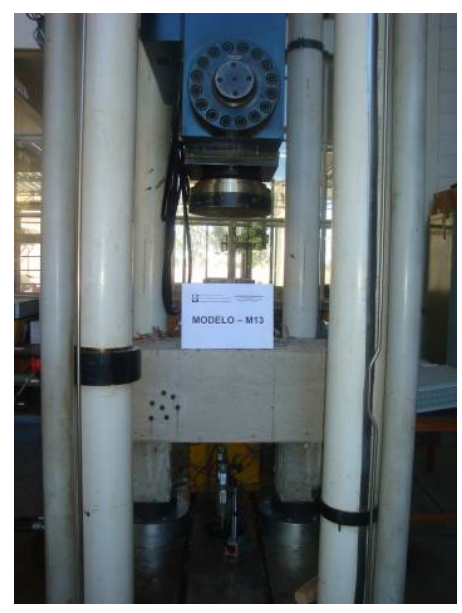

(a)

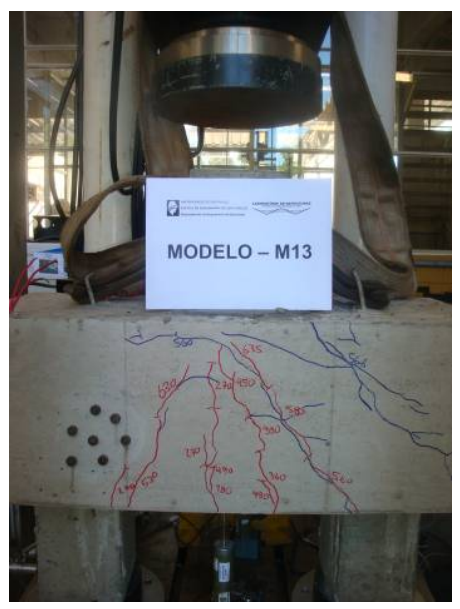

(b)

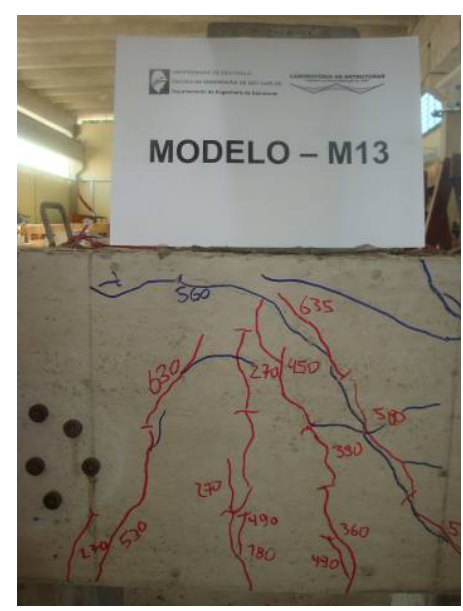

(c)

Figura 5. 112-Fissuras na face lateral do Modelo M13

Verificaram-se varias fissuras verticais na região inferior central do bloco, sendo que várias dessa fissuras atravessaram o bloco passando pela região inferior e surgindo na face oposta. Em uma das faces laterais do bloco, observou-se a formação de uma fissura inclinada, a qual ia desde a extremidade inferior do bloco até o topo do cálice, segmentando o bloco em diagonal e dividindo o mesmo em duas partes, conforme Figura 5.113 (a) e 5.113 (b).

Observou-se ainda o surgimento de várias fissuras nos cantos e na região central das paredes do cálice, assim como na região do graute, conforme apresentado na Figura 5.114 (a) e 5.114 (b). Após a ruína, do modelo, verificou-se que houve um destacamento do concreto da parte superior da parede do cálice junto ao bloco. Nesse modelo não foi observado deslocamento relativo do pilar em relação ao graute. As fissuras marcadas em vermelho surgiram durante a etapa crescente de força, enquanto que as fissuras marcadas em azul surgiram após o modelo atingir a força máxima de $652 \mathrm{kN}$. 


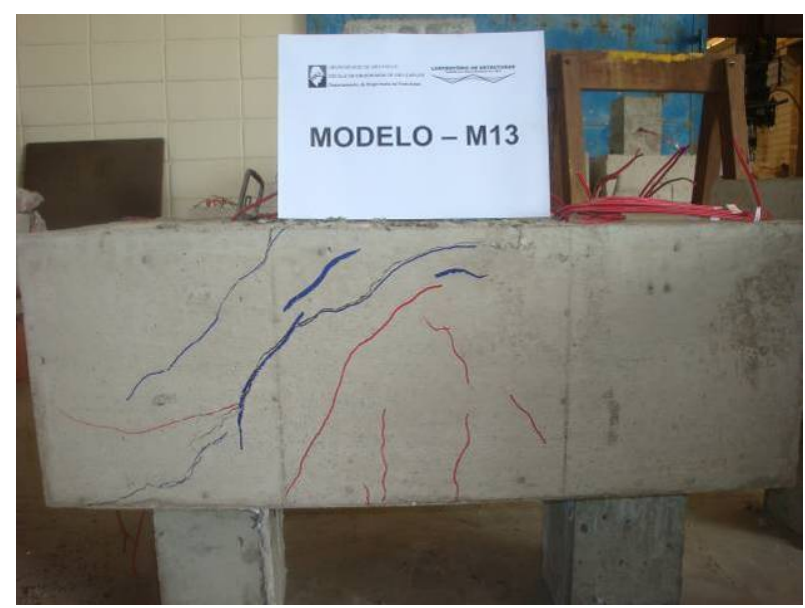

(a)

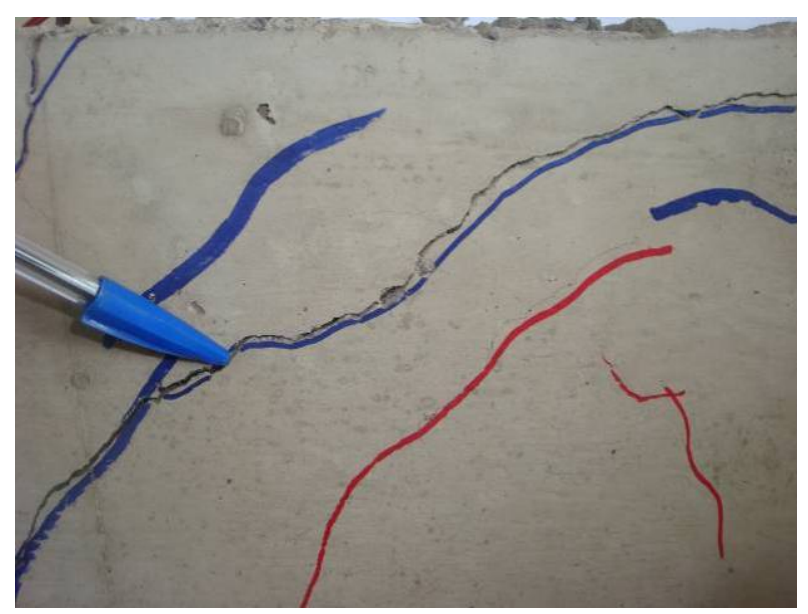

(b)

Figura 5. 113-Fissura diagonal na face oposta do Modelo M13

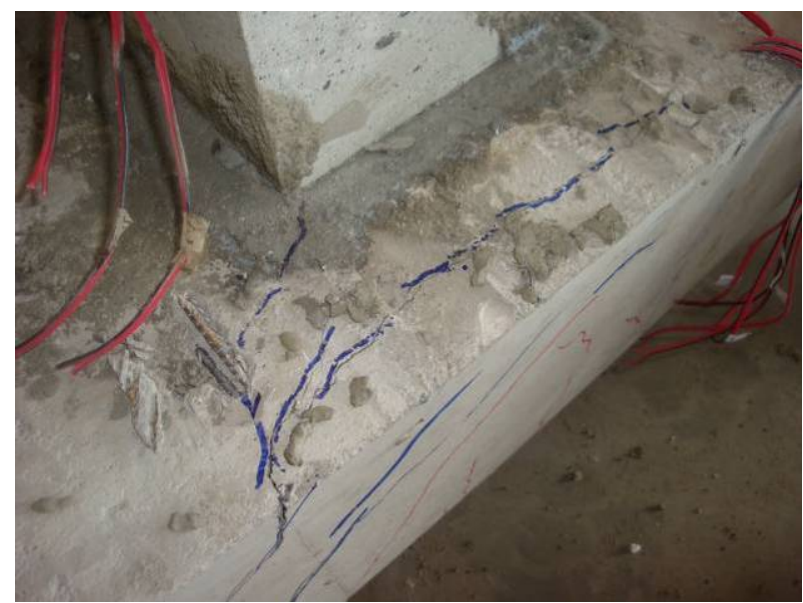

(a)

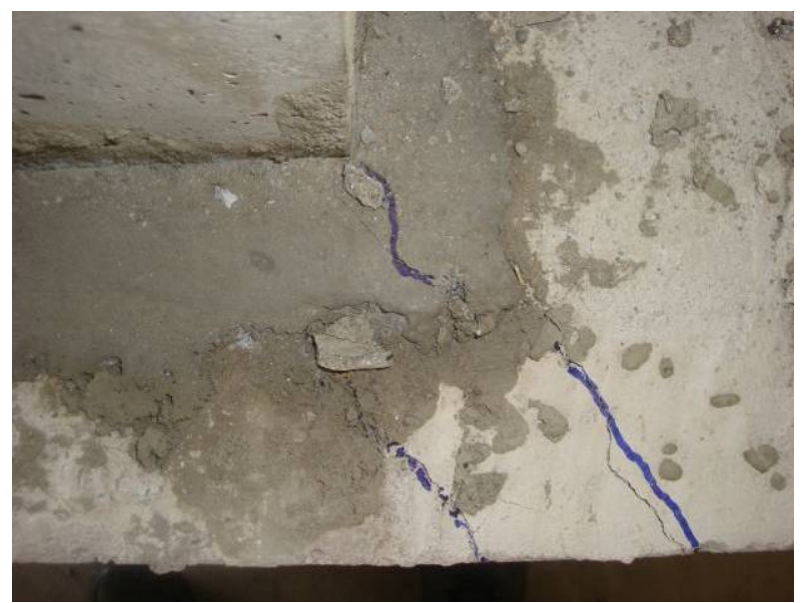

(b)

Figura 5. 114-Fissuras nas paredes do cálice do Modelo M13

Obtiveram-se valores pequenos para as medidas de deformações no concreto, uma vez que com as leituras efetuadas nas pastilhas de aço, as quais estavam fixadas nas faces laterais dos blocos, foi possível calcular as deformações na face externa do bloco. Em função dos valores obtidos, constatou-se que as deformações ficaram aquém das deformações existentes nas bielas. Desse modo, considera-se que a utilização das pastilhas de aço não conferiu bons resultados para a estimativa das deformações do concreto. Apresentam-se na tabela 5.34 os valores de deformações principais e as direções principais em relação a quatro intensidades de força. As direções apresentadas referem-se ao esquema apresentado na Figura 4.49 (b). 
Tabela 5.34 - Deformação no concreto do modelo M13

\begin{tabular}{|c|c|c|c|c|c|c|c|c|}
\hline \multirow[t]{2}{*}{$\begin{array}{l}\text { Força } \\
(\mathbf{k N})\end{array}$} & \multirow[t]{2}{*}{ Direção } & \multicolumn{3}{|c|}{ Deformações (\%o) } & \multicolumn{2}{|c|}{$\begin{array}{c}\text { Deformações } \\
\text { Principais } \\
\text { (\%o) }\end{array}$} & \multicolumn{2}{|c|}{$\begin{array}{c}\text { Direções } \\
\text { Principais }\left({ }^{\circ}\right)\end{array}$} \\
\hline & & $\varepsilon_{0^{\circ}}$ & $\varepsilon_{45^{\circ}}$ & $\varepsilon_{90^{\circ}}$ & $\varepsilon_{1}$ & $\varepsilon_{2}$ & $\alpha_{1}$ & $\alpha_{2}$ \\
\hline \multirow{2}{*}{50} & $1,5,3$ & $-0,200$ & 0,001 & $-0,010$ & 0,04 & $-0,25$ & $-24,1$ & 65,9 \\
\hline & $2,6,4$ & $-0,004$ & 0,007 & $-0,010$ & 0,01 & $-0,02$ & 39,0 & 129,0 \\
\hline \multirow{2}{*}{150} & $1,5,3$ & $-0,201$ & 0,001 & 0,001 & 0,04 & $-0,24$ & $-22,5$ & 67,5 \\
\hline & $2,6,4$ & 0,011 & 0,017 & $-0,009$ & 0,02 & $-0,02$ & 29,0 & 119,0 \\
\hline \multirow{2}{*}{250} & $1,5,3$ & $-0,201$ & 0,004 & 0,000 & 0,04 & $-0,25$ & $-23,1$ & 66,9 \\
\hline & $2,6,4$ & 0,011 & $-0,024$ & 0,002 & 0,04 & $-0,02$ & $-40,8$ & 49,2 \\
\hline \multirow{2}{*}{500} & $1,5,3$ & $-0,211$ & $-0,006$ & $-0,010$ & 0,03 & $-0,26$ & $-23,1$ & 66,9 \\
\hline & $2,6,4$ & 0,000 & $-0,024$ & $-0,021$ & 0,01 & $-0,03$ & $-26,1$ & 63,9 \\
\hline
\end{tabular}

\subsubsection{Modelo M14 - BEB_AC_CR}

Assim como no modelo M13, o modelo M14 apresentou comportamento de bloco rígido. Foi registrada uma excentricidade na força aplicada no pilar da ordem de 1,43 cm. A ruína do modelo se deu por escoamento de todas as barras das armaduras principais do tirante, localizadas na região central do bloco, seguida da ruptura do concreto do bloco.

A força máxima suportada por esse modelo foi de $640 \mathrm{kN}$, força essa superior a força calculada com o modelo teórico utilizado para o dimensionamento. O modelo apresentou resistência crescente até atingir a força última de $640 \mathrm{kN}$, apresentando diversas fissuras na região central, as quais se estenderam até o topo do bloco, e fissuras inclinadas na região da biela comprimida. Observou-se que uma dessa fissuras atravessou a região onde estavam posicionados as pastilhas de aço coladas ao concreto. Após atingir esse valor, o modelo apresentou diminuição da força, sem voltar a apresentar aumento de resistência.

Observa-se que o valor da força última do modelo M14 foi inferior ao valor máximo de $728 \mathrm{kN}$ do bloco de referência dessa série, indicando que, assim com no modelo M13, as bielas apresentaram inclinação com o tirante inferior a inclinação apresentada pelos modelos M8 a M12. Comparando o modelo M14 com os modelos M6 e M7, observa-se uma força 
última superior em relação a esses modelos, os quais não apresentavam rugosidade na ligação pilar fundação. Observa-se uma maior rigidez no modelo M14 e, conseqüentemente, maior força resistente. Verifica-se que o bloco do modelo M14 apresentou força última em média $76 \%$ superior a dos modelos que não tinham rugosidade.

Comparando os resultados dos modelos com cálice embutido com rugosidade, observase que a força última no modelo M14 apresentou a mesma ordem de grandeza da força obtida no modelo M13, o qual não dispunha da armadura complementar em forma de estribos na região central do bloco. Assim, diferente do ocorrido entre os modelos M11 e M12, nos blocos com cálice embutido e com rugosidade a armadura complementar não conferiu ganho de resistência ao modelo, apresentando praticamente a mesma força última do modelo sem armadura complementar, observando-se uma diferença inferior a $2 \%$ nesses valores.

O panorama de fissuração foi semelhante ao apresentado pelo modelo M13, sendo que a primeira fissura visível no modelo surgiu na região inferior do bloco, para uma força de 190 $\mathrm{kN}$, apresentando abertura da ordem de $0,05 \mathrm{~mm}$. Nessa etapa, a deformação máxima medida nas barras das armaduras do tirante foi de $0,37 \%$ o que resulta numa tensão igual a $75 \mathrm{MPa}$. Observou-se que o modelo apresentou perda de rigidez para uma força próxima de $180 \mathrm{kN}$, conforme pode ser observado nos gráficos força versus deformação das barras das armaduras posicionadas na região central do bloco.

A Figura 5.115 apresenta o gráfico força versus deformação em cada barra, enquanto que a Figura 5.116 apresenta a curva força versus deformação média em relação as armaduras posicionadas na seção central do bloco para os modelos M8, M9, M12 e M14. Observa-se por meio dessa figura que o modelo M14 apresentou rigidez semelhante a do bloco de referência do modelo M8 até uma força próxima a $500 \mathrm{kN}$, quando então passou a apresentar maiores deformações nas barras das armaduras,. Entretanto, foi o modelo que apresentou força última menor dentre os modelos dessa série, com um valor aproximadamente igual a $88 \%$ da força última do bloco de referência e igual a $69 \%$ da força última máxima, a qual ocorreu para o modelo M9 que apresentava cálice externo. 


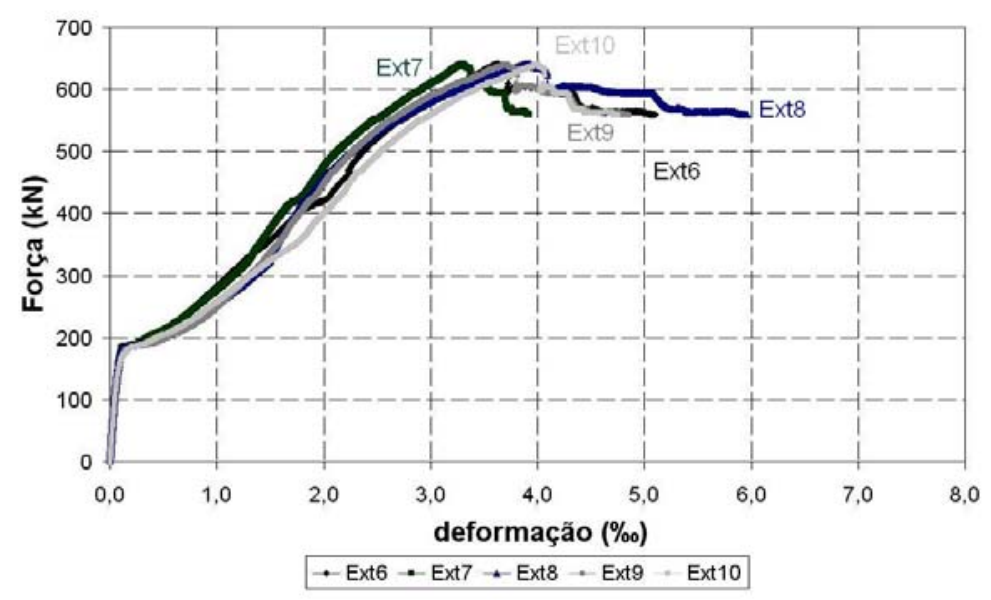

Figura 5. 115- Curva força versus deformação nas armaduras da região central do modelo M14

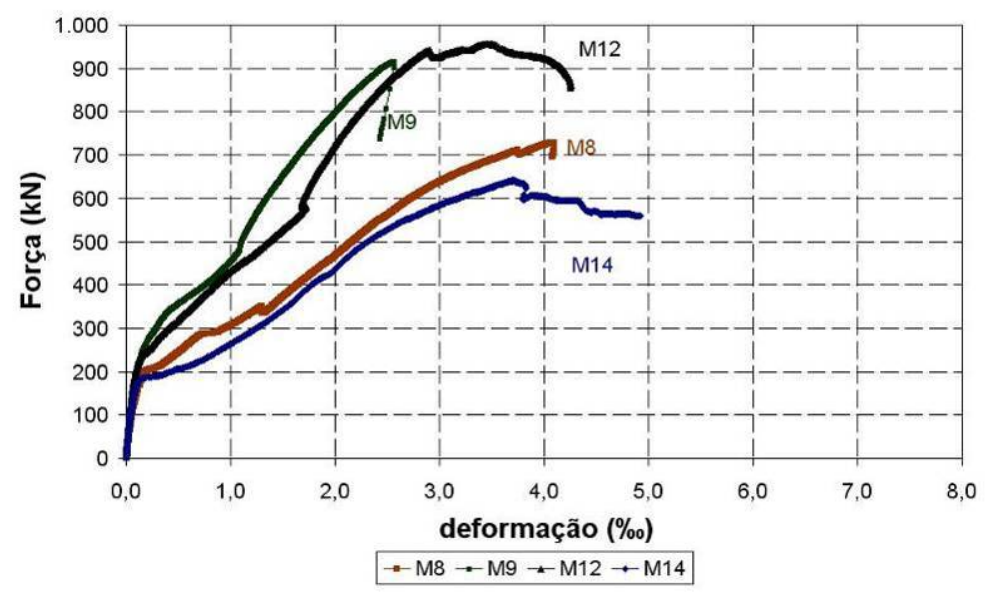

Figura 5. 116- Curva força versus deformação média nas armaduras da região central dos modelos M8, M9, M12 e M14

Comparando os modelos com cálice embutido com rugosidade, verifica-se que o modelo M14 apresentou rigidez semelhante a do modelo M13 até uma força de $400 \mathrm{kN}$, quando então o modelo M14 passou a apresentar maiores valores de deformação, perdendo rigidez, porém apresentando força última semelhante a do modelo M13, conforme pode ser observado na Figura 5.117. Esse resultado indica que a armadura complementar utilizada no modelo M14 não conferiu ganho significante de resistência ao modelo. 


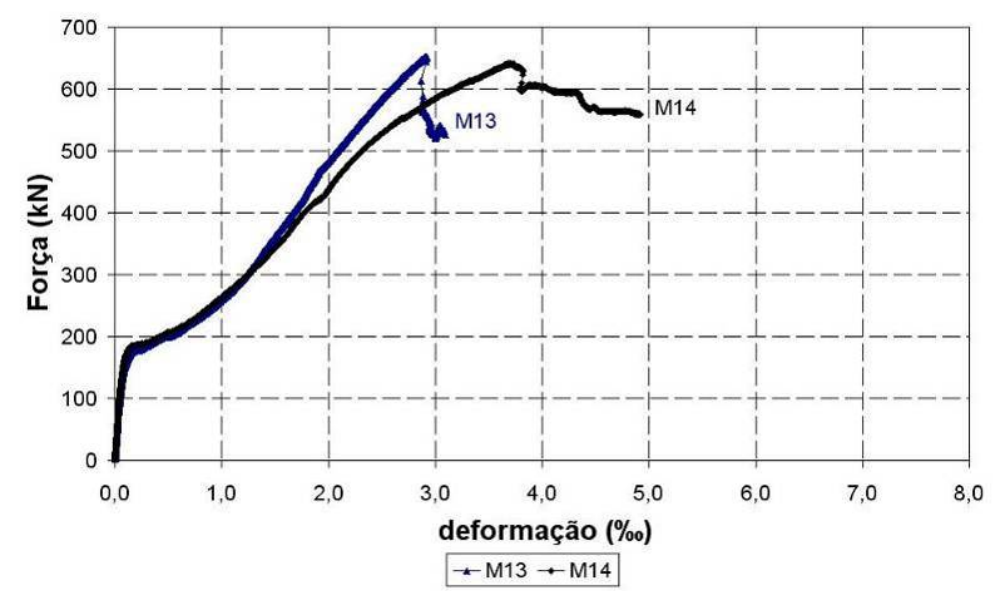

Figura 5. 117- Curva força versus deformação média nas armaduras da região central dos modelos M13 e M14

As Figuras 5.118 e 5.119 apresentam os gráficos força versus deformação nas barras das armaduras posicionadas sobre as estacas. Observa-se por meio desses gráficos que as deformações médias nas armaduras apresentam valores da ordem de 0,6\% a 1,0\%, valores esses pequenos quando comparados as deformações obtidas nas armaduras posicionadas na região central do bloco. Diferente do ocorrido no modelo M13, verificaram-se que as barras das armaduras posicionadas sobre as estacas apresentaram encurtamento para valores iniciais de força, apresentando posteriormente alongamentos para força próxima a ruína do modelo.

A Figura 5.120 apresenta o gráfico força versus deformação nas barras das armaduras do pilar. Semelhante ao que ocorreu no bloco do modelo M13, observa-se que as deformações nas barras das armaduras tornam-se menores à medida que o pilar se aproxima do fundo do cálice, conforme pode ser observado comparando os resultados dos extensômetros de número 14, 15 e 16, bem como os extensômetros de número 17, 18 e 19, os quais estavam posicionados nas barras das armaduras do pilar 


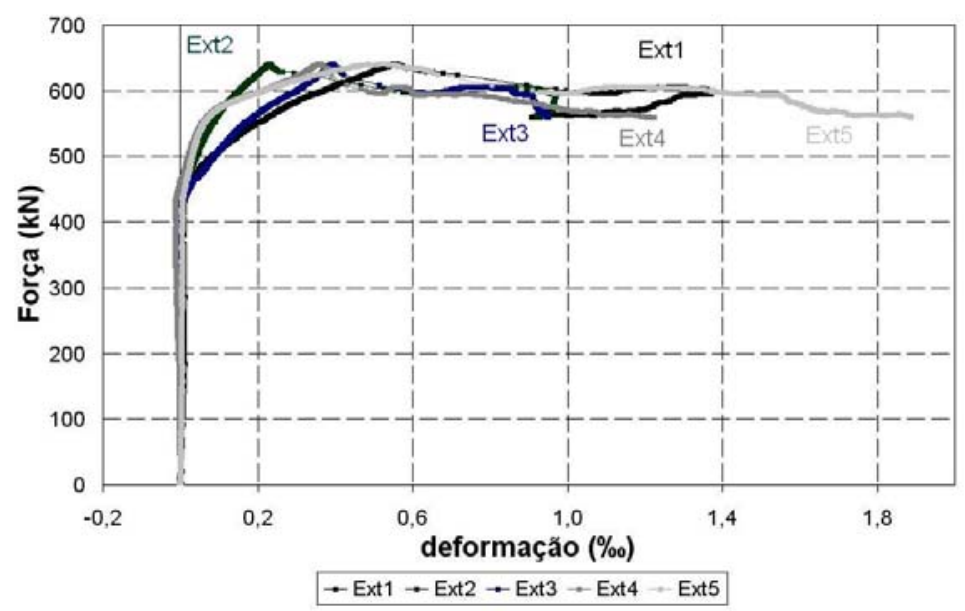

Figura 5. 118- Curva força versus deformação nas armaduras sobre as estacas do modelo M14

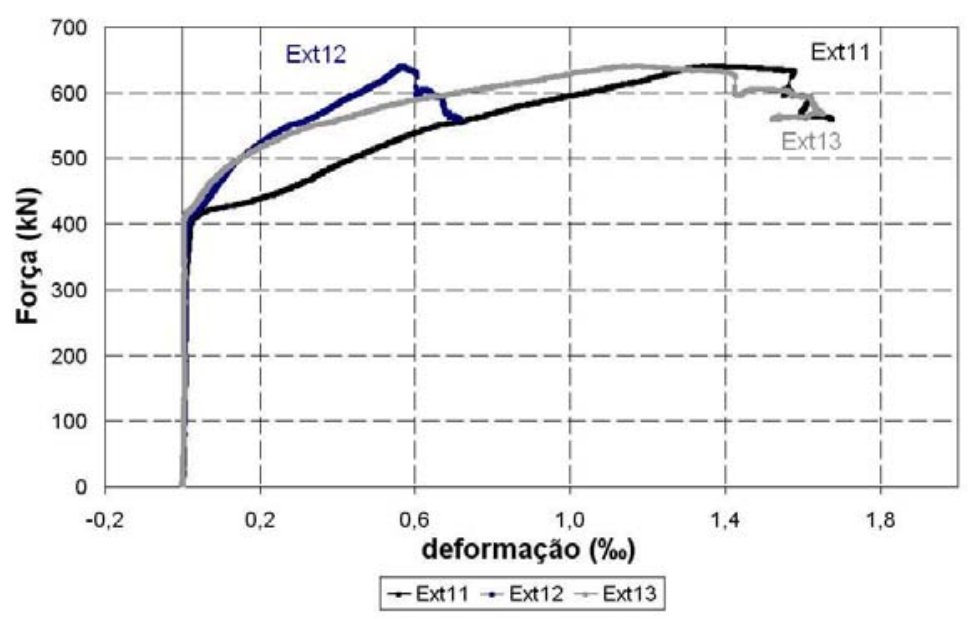

Figura 5. 119- Curva força versus deformação nas armaduras sobre as estacas do modelo M14

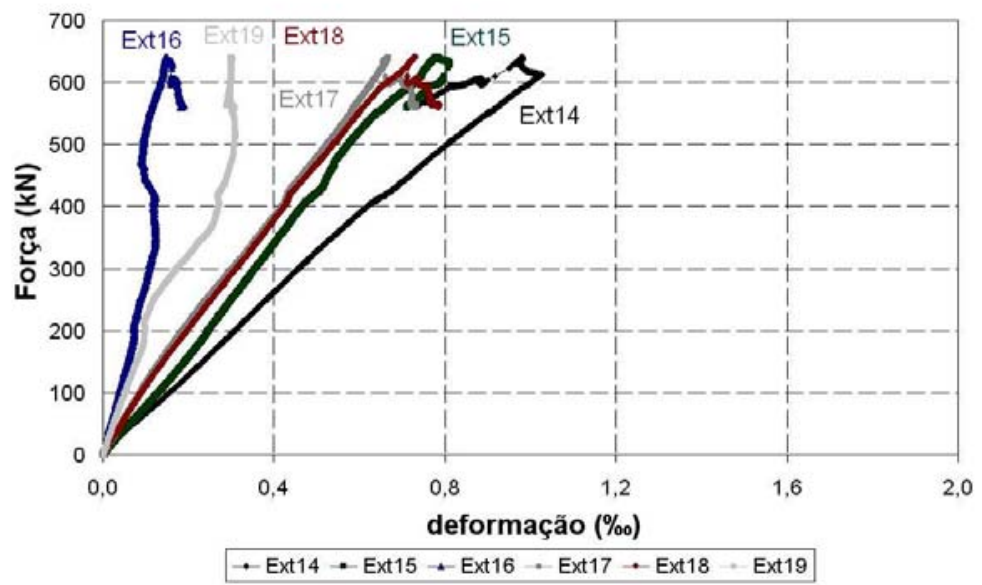

Figura 5. 120 - Curva força versus deformação nas armaduras do pilar do modelo M14

O gráfico da Figura 5.121 apresenta os resultados de deformação medidos nas barras das armaduras posicionadas no cálice de fundação. Semelhante ao modelo M13, observa-se um pequeno encurtamento da barra de armadura vertical ocasionado pela força de compressão 
oriunda do pilar, o que indica que esta força está sendo transmitida para o bloco abaixo da posição do extensômetro 21. A partir de uma força próxima de $420 \mathrm{kN}$, observa-se alongamento dessa barra, isto é, deformações oriundas de força de tração. Esse resultado indica que o maciço de concreto sob o cálice no interior do bloco apresentou ruptura, não ocorrendo a separação em dois ou mais segmentos em virtude da presença de armadura nessa região. O extensômetro de número 20, por sua vez, apresentou deformações semelhantes a da armadura principal do tirante, uma vez que estava posicionada na mesma região.

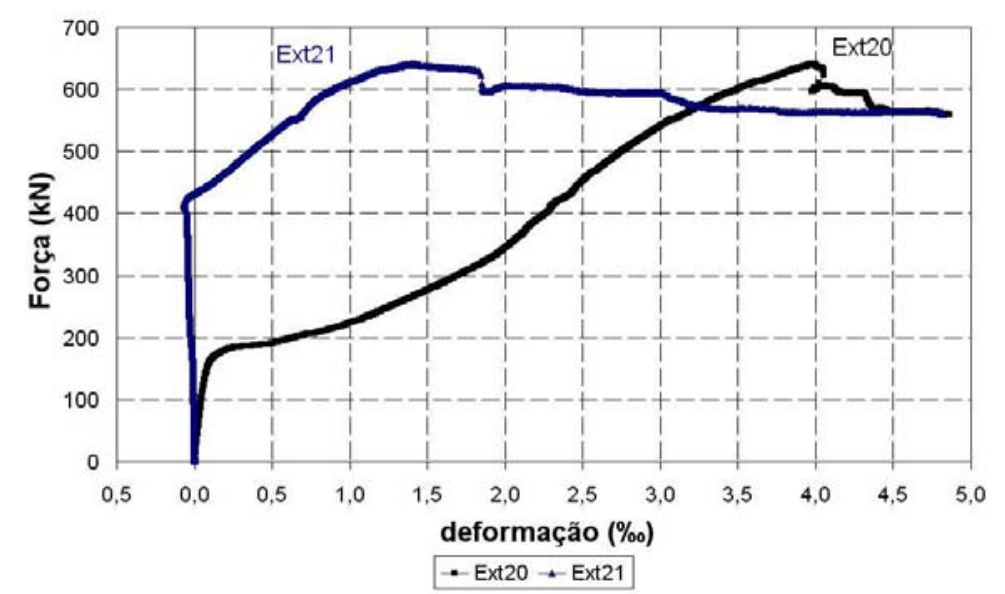

Figura 5. 121- Curva força versus deformação nas armaduras do cálice do modelo M14

A Figura 5.122, por sua vez, apresenta a curva força versus deformação nas barras da armadura complementar posicionada na região central do bloco. Em virtude da quantidade de extensômetros, apresenta-se apenas o gráfico das barras que foram instrumentadas com o extensômetros de número 26, 27, 28 e 29, as quais encontram-se faceando o cálice. Verificase que os extensômetros 26 , e 28 apresentam inicialmente pequenos encurtamentos, passando a apresentar alongamentos próximos a uma força de $575 \mathrm{kN}$ e $430 \mathrm{kN}$, respectivamente. Essas deformações por suas vezes, são menores do que as medidas nos extensômetros 27 e 29, posicionados na região inferior do estribo, e que apresentam pequenos encurtamentos no início do ensaio, passando a apresentar alongamento para uma força próxima a $350 \mathrm{kN}$.

A Figura 5.123 apresenta a curva força versus deslocamento do modelo M14, a partir da qual pode-se observar um deslocamento médio próximo a 2,10 $\mathrm{mm}$ no instante em que ocorreu a ruína do modelo. Após a ruína, verifica-se aumento dos deslocamentos sem aumento na força resistente do modelo, semelhante ao ocorrido no modelo M13. 


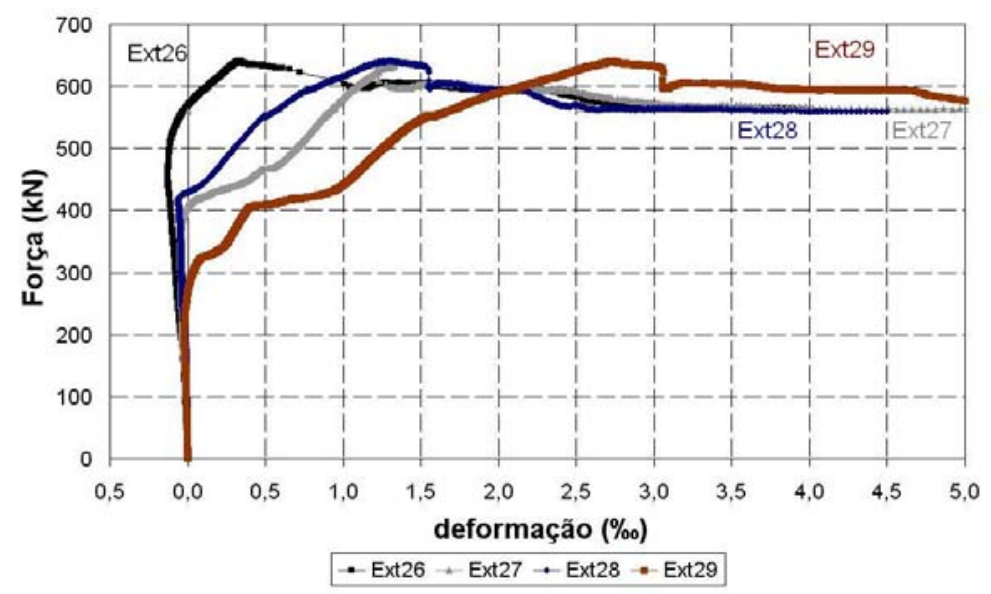

Figura 5. 122- Curva força versus deformação na armadura complementar do modelo M14

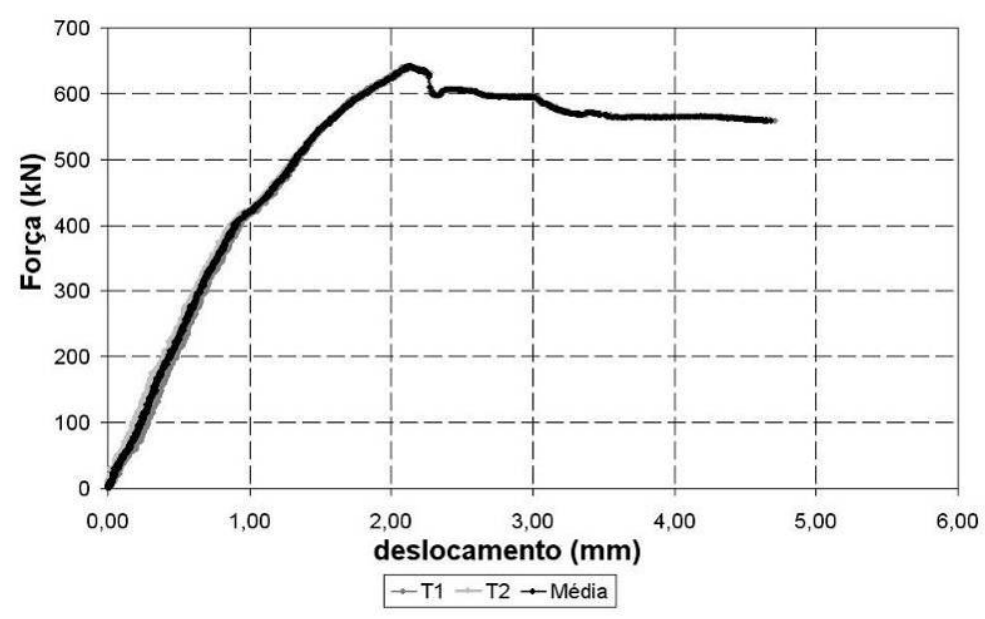

Figura 5. 123- Curva força versus deslocamento médio medido nos transdutores T1 e T2 do modelo M14

No modelo M14 não houve perda do extensômetros elétrico de resistência. A medida que a força no pistão aumentava, verificou-se o surgimento de novas fissuras e aumento da abertura das fissuras existentes. Verificou-se aberturas da ordem de 0,15 mm correspondente a força de $225 \mathrm{kN} ; 0,20 \mathrm{~mm}$ para uma força de $280 \mathrm{kN}$; $0,30 \mathrm{~mm}$ para uma força de $400 \mathrm{kN}$; e 0,60 mm para uma força de $600 \mathrm{kN}$. A Figura 5.124 (a) apresenta o panorama de fissuração do modelo M14, enquanto que a Figura 5.114 (b) apresenta o detalhe de uma fissura superior a 2,00 $\mathrm{mm}$. As fissuras marcadas em vermelho surgiram durante a etapa crescente de força, enquanto que as fissuras marcadas em azul surgiram após o modelo atingir a força máxima de $640 \mathrm{kN}$.

Verificou-se fissuras verticais na região inferior central do bloco, sendo que várias dessas fissuras atravessaram o bloco surgindo na face oposta. A região inferior apresentou-se bastante fissurada, conforme Figura 5.125(a) e em uma das faces laterais do bloco, observou- 
se claramente a formação de duas fissuras indicando o caminho das bielas de compressão, conforme pode ser observado na Figura 5.125 (b).

Em relação ao cálice, observou-se o surgimento de várias fissuras nos cantos e na região central das paredes do cálice, assim como na região do graute, conforme pode ser observado nas Figuras 5.126 (a) e 5.126 (b). Não observou-se deslocamento relativo do pilar em relação ao graute.

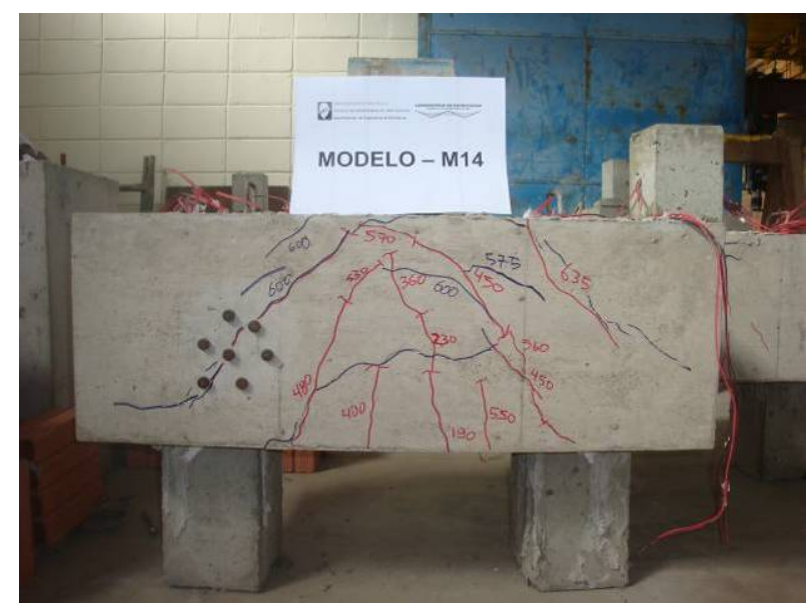

(a)

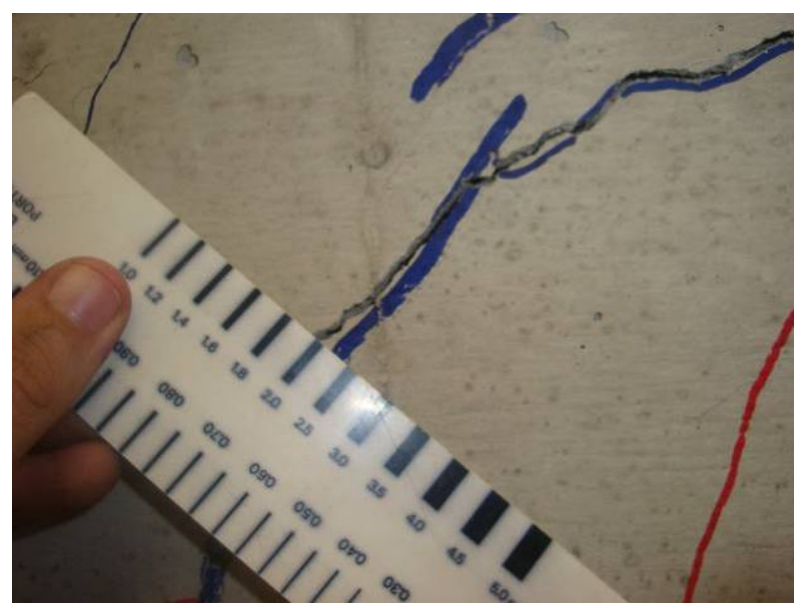

(b)

Figura 5. 124-Panorama de fissuração do Modelo M14 e abertura superior a 2,00 mm

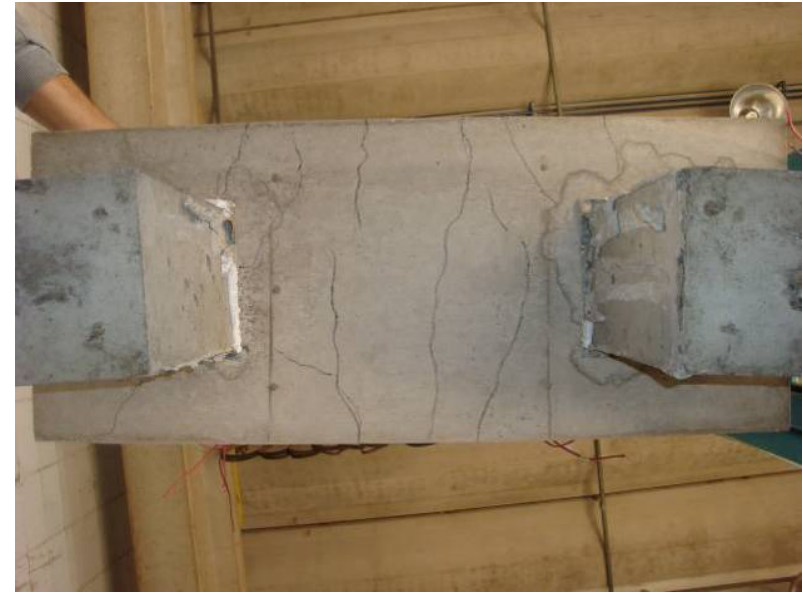

(a)

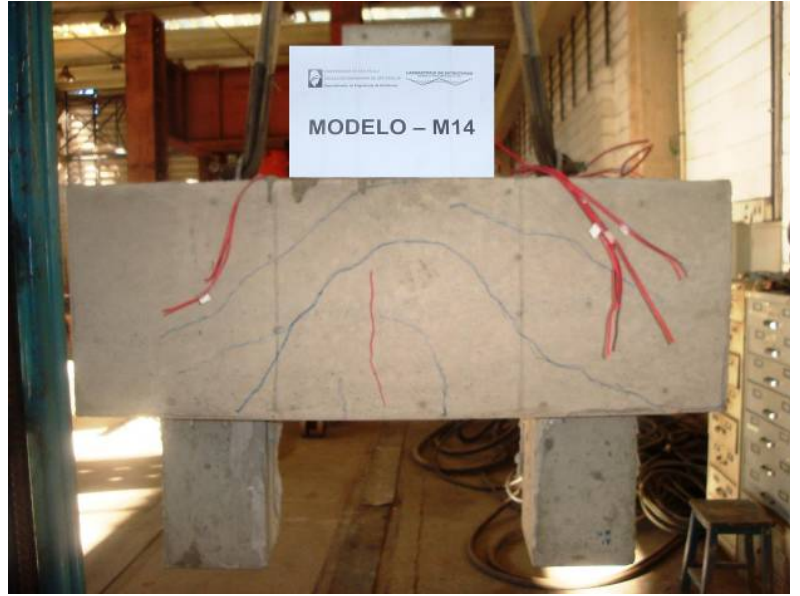

(b)

Figura 5. 125-Fissura diagonal na face inferior oposta do Modelo M14 


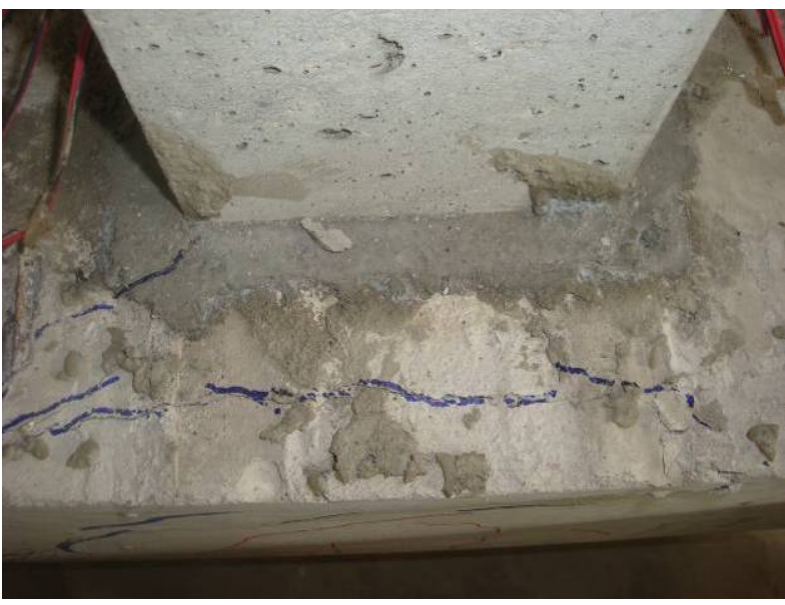

(a)

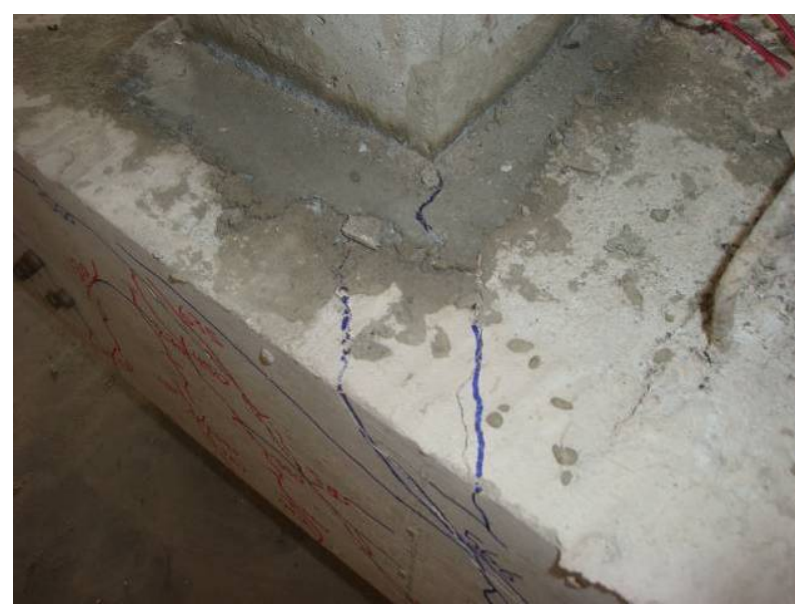

(b)

Figura 5. 126-Fissuras nas paredes do cálice do Modelo M14

Obtiveram-se valores pequenos para as medidas de deformações no concreto, uma vez que com as leituras efetuadas nas pastilhas de aço, as quais estavam fixadas nas faces laterais dos blocos, foi possível calcular as deformações na face externa do bloco. Em função dos valores obtidos, constatou-se que as deformações ficaram aquém das deformações existentes nas bielas. Desse modo, considera-se que a utilização das pastilhas de aço não conferiu bons resultados para a estimativa das deformações do concreto. Apresentam-se na tabela 5.35 os valores de deformações principais e as direções principais em relação a quatro intensidades de força. As direções apresentadas referem-se ao esquema apresentado na Figura 4.49 (b).

Tabela 5.35 - Deformação no concreto do modelo M14

\begin{tabular}{|c|c|c|c|c|c|c|c|c|}
\hline \multirow[t]{2}{*}{$\begin{array}{l}\text { Força } \\
(\mathbf{k N})\end{array}$} & \multirow[t]{2}{*}{ Direção } & \multicolumn{3}{|c|}{ Deformações (\%o) } & \multicolumn{2}{|c|}{$\begin{array}{c}\text { Deformações } \\
\text { Principais } \\
\text { (\%o) }\end{array}$} & \multicolumn{2}{|c|}{$\begin{array}{c}\text { Direções } \\
\text { Principais ( }{ }^{\circ} \text { ) }\end{array}$} \\
\hline & & $\varepsilon_{0^{\circ}}$ & $\varepsilon_{45^{\circ}}$ & $\varepsilon_{90^{\circ}}$ & $\varepsilon_{1}$ & $\varepsilon_{2}$ & $\alpha_{1}$ & $\alpha_{2}$ \\
\hline \multirow{2}{*}{50} & $1,5,3$ & $-0,001$ & $-0,010$ & 0,010 & 0,02 & $-0,01$ & 34,6 & 124,6 \\
\hline & $2,6,4$ & 0,000 & 0,003 & 0,013 & 0,01 & 0,00 & 14,2 & 104,2 \\
\hline \multirow{2}{*}{200} & $1,5,3$ & $-0,001$ & $-0,006$ & 0,000 & 0,01 & $-0,01$ & 42,4 & 132,4 \\
\hline & $2,6,4$ & 0,009 & 0,012 & 0,000 & 0,01 & 0,00 & 29,5 & 119,5 \\
\hline \multirow{2}{*}{300} & $1,5,3$ & 0,000 & $-0,016$ & 0,010 & 0,03 & $-0,02$ & 38,3 & 128,3 \\
\hline & $2,6,4$ & 0,010 & 0,011 & 0,003 & 0,01 & 0,00 & 26,1 & 116,1 \\
\hline \multirow{2}{*}{600} & $1,5,3$ & $-0,001$ & $-0,023$ & 0,010 & 0,03 & $-0,02$ & 39,3 & 129,3 \\
\hline & $2,6,4$ & $-0,003$ & $-0,018$ & 0,010 & 0,03 & $-0,02$ & 36,6 & 126,6 \\
\hline
\end{tabular}




\subsection{Resultados gerais}

Apresenta-se nesse item alguns resultados gerais a respeito de força última, abertura de fissuras, força de avaliação, tensões nas barras da armadura principal do tirante e modo de transferência da força do pilar para o bloco, obtidos a partir do programa experimental.

\subsubsection{Força última}

Foram comparados os resultados das forças últimas dos blocos com cálice de fundação com os resultados dos blocos de referência de cada série. Verificou-se por meio dos resultados obtidos que os blocos com rugosidade na interface pilar-fundação apresentaram força última superior a dos blocos com cálice sem rugosidade na interface, com exceção do modelo M10, o qual apresentou ruína precoce por ruptura do concreto do pilar.

Tabela 5.36 - Reações de apoio e excentricidades

\begin{tabular}{|c|c|c|c|c|c|c|c|}
\hline Série & Modelo & $\begin{array}{c}\mathbf{F}_{\mathrm{u}} \\
(\mathrm{kN})\end{array}$ & $\begin{array}{l}R_{, \text {dir }} \\
(\mathbf{k N})\end{array}$ & $\begin{array}{l}R_{\text {,esq }} \\
(\mathbf{k N})\end{array}$ & $\begin{array}{l}\text { Vão } \\
\text { (cm) }\end{array}$ & $\begin{array}{l}\text { excentricidade } \\
\text { (cm) }\end{array}$ & $F_{u} / F_{\text {ref }}(\%)$ \\
\hline \multirow{7}{*}{$\begin{array}{c}\text { Sem } \\
\text { rugosidade }\end{array}$} & M1 & $756^{*}$ & 398 & 358 & \multirow{7}{*}{62,5} & 1,65 & $100 \%$ \\
\hline & M2 & 772 & 403 & 369 & & 1,38 & $102 \%$ \\
\hline & M3 & 724 & 395 & 329 & & 2,85 & $96 \%$ \\
\hline & M4 & 563 & 292 & 271 & & 1,17 & $74 \%$ \\
\hline & M5 & 644 & 329 & 315 & & 0,68 & $85 \%$ \\
\hline & M6 & 359 & 179 & 180 & & 0,09 & $47 \%$ \\
\hline & M7 & 368 & 185 & 183 & & 0,17 & $49 \%$ \\
\hline \multirow{7}{*}{$\begin{array}{c}\text { Com } \\
\text { rugosidade }\end{array}$} & M8 & $728^{*}$ & 358 & 370 & \multirow{7}{*}{54} & 0,45 & $100 \%$ \\
\hline & M9 & 916 & 415 & 501 & & 2,53 & $126 \%$ \\
\hline & M10 & 632 & 314 & 318 & & 0,17 & $87 \%$ \\
\hline & M11 & 888 & 461 & 427 & & 1,03 & $122 \%$ \\
\hline & M12 & 957 & 477 & 480 & & 0,08 & $131 \%$ \\
\hline & M13 & 652 & 371 & 281 & & 3,73 & $90 \%$ \\
\hline & M14 & 640 & 337 & 303 & & 1,43 & $88 \%$ \\
\hline
\end{tabular}

"Força última no bloco de referência de cada série 
Verificou-se também que, apesar da tentativa de se aplicar a força centrada no pilar, foi constatado excentricidades nos modelos, as quais podem ter sido ocasionadas por dois motivos: excentricidades na aplicação da força por parte do equipamento utilizado; excentricidade construtiva por ocasião da montagem dos modelos. A tabela 5.36 apresentada anteriormente informa as reações de apoio, as excentricidades nos modelos durante a realização dos ensaios e a força última em cada modelo analisado. Apresenta-se também a relação entre a força última obtida em cada modelo e a força última do bloco de referência de cada série.

Constatou-se também que os blocos com rugosidade na interface pilar-fundação apresentaram, de um modo geral, rigidez superior a dos blocos sem rugosidade. As Figuras 5.127 e 5.128 ilustram as curvas força versus deformação média nas barras da armadura principal do tirante situada na região central do bloco, para os modelos sem rugosidade e com rugosidade, respectivamente.

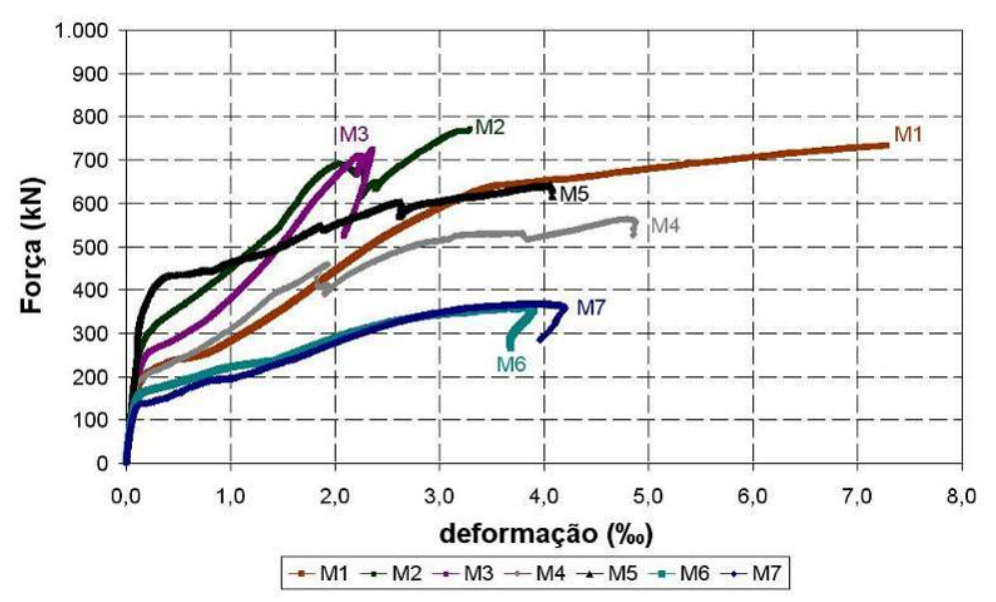

Figura 5. 127-Curva força versus deformação: série sem rugosidade

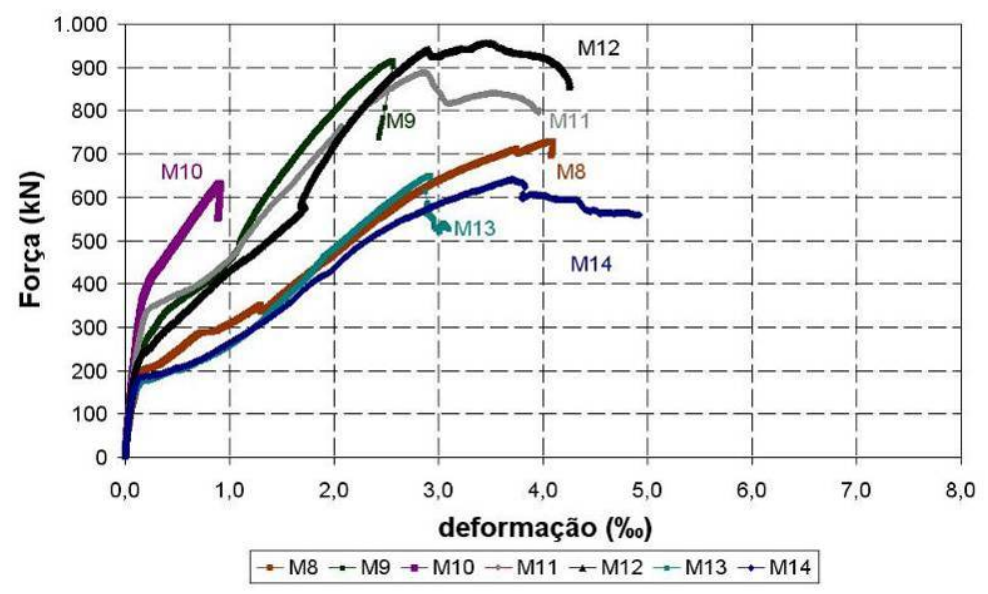

Figura 5. 128-Curva força versus deformação: série com rugosidade 
Nos blocos de referência, constatou-se que a diminuição da rigidez ocorreu para a forças próximas aos $210 \mathrm{kN}$ e $200 \mathrm{kN}$ para os modelo M1 e M8. Comparando os modelos da série sem rugosidade, verificou-se que os blocos com cálice embutido apresentaram diminuição de rigidez para intensidades de forças inferiores a que provocou diminuição de rigidez do bloco de referência dessa série, com valores iguais a 165 kN e 136 kN para os modelos M6 e M7, respectivamente. Nos blocos com cálice parcialmente embutido, observou-se que o modelo M4 apresentou diminuição de rigidez para uma força de $190 \mathrm{kN}$, força essa inferior a do modelo M1, enquanto que o modelo M5, que dispunha de armadura complementar, apresentou diminuição de rigidez para uma força superior a do modelo M1, com valor igual a 432 kN. Nos blocos com cálice externo, observou-se que a diminuição de rigidez ocorreu para valores de força superiores aos que provocaram diminuição de rigidez no bloco de referência.

Nos blocos da série com rugosidade, observou-se que a diminuição de rigidez ocorreu para intensidade de força inferior a do bloco de referência dessa série apenas nos blocos com cálice embutido, isto é, modelos M13 e M14. Nos demais blocos, a diminuição de rigidez ocorreu para intensidades de forças superiores a do bloco de referência. A tabela 5.37 apresenta os valores das forças a partir da qual verificou-se diminuição na rigidez de cada modelo, bem como a relação percentual entre essa força e a força última de cada modelo.

Tabela 5.37 - Força que ocasionou diminuição na rigidez de cada modelo.

\begin{tabular}{c|c|c|c|c}
\hline \hline Série & Modelo & $\mathbf{F}_{\mathbf{u}}(\mathbf{k N})$ & $\mathbf{F}_{\mathbf{r i g}}(\mathbf{k N})$ & $\mathbf{F}_{\mathbf{r i g}} / \mathbf{F}_{\mathbf{u}}(\mathbf{\%})$ \\
\hline \multirow{4}{*}{$\begin{array}{c}\text { Sem } \\
\text { rugosidade }\end{array}$} & M1 & 756 & 210 & $27,8 \%$ \\
\cline { 2 - 5 } & M2 & 772 & 320 & $41,5 \%$ \\
\cline { 2 - 5 } & M3 & 724 & 260 & $35,9 \%$ \\
\cline { 2 - 5 } & M4 & 563 & 190 & $33,7 \%$ \\
\cline { 2 - 5 } & M5 & 644 & 432 & $67,1 \%$ \\
\cline { 2 - 5 } & M6 & 359 & 165 & $46,0 \%$ \\
\cline { 2 - 5 } & M7 & 368 & 136 & $37,0 \%$ \\
\hline \multirow{4}{*}{$\begin{array}{c}\text { Com } \\
\text { rugosidade }\end{array}$} & M8 & 728 & 200 & $27,5 \%$ \\
\cline { 2 - 5 } & M9 & 916 & 350 & $38,2 \%$ \\
\cline { 2 - 5 } & M10* & 632 & 422 & $66,8 \%$ \\
\cline { 2 - 5 } & M11 & 888 & 345 & $38,9 \%$ \\
\cline { 2 - 5 } & M12 & 957 & 252 & $26,3 \%$ \\
\hline & M13 & 652 & 177 & $27,1 \%$ \\
\cline { 2 - 5 } & M14 & 640 & 185 & $28,9 \%$ \\
\hline \hline
\end{tabular}




\subsubsection{Abertura de fissuras}

Em relação às aberturas de fissuras, observou-se variabilidade nos valores medidos durante a realização dos ensaios. Entretanto, os resultados apresentaram-se coerentes para cada série estudada, com relação a geometria de cada modelo. Com relação a primeira fissura visível, a qual na maior parte dos modelos ocorreu na região central inferior, observou-se que os modelos com cálice externo foram os que apresentaram maior força aplicada correspondente a primeira fissura visível, com valores de força variando de $310 \mathrm{kN}$ (modelo M3) a $370 \mathrm{kN}$ (modelo M10). Observa-se que esses modelos tiveram armadura detalhada superior a dos demais blocos, o que justifica os valores de força para a primeira fissura.

Os blocos com cálice parcialmente embutido apresentaram a primeira fissura visível para intensidades de força inferiores as que provocaram a primeira fissura nos blocos com cálice externo. Verificou-se ainda que os blocos com cálice embutido apresentaram a primeira fissura visível correspondente as menores intensidades de força, variando de $160 \mathrm{kN}$ (modelo M7) à $190 \mathrm{kN}$ (modelo M14). Os blocos de referência, por suas vezes, apresentaram a primeira fissura visível correspondente a uma força intermediária em relação à força dos blocos com cálice embutido e parcialmente embutido. Esses resultados ocorreram tanto para os blocos da série com rugosidade como para os blocos da série sem rugosidade, e estão apresentados na tabela 5.38. A Figura 5.129, por sua vez, apresenta a dispersão nas forças a partir das quais foram medidas as aberturas das fissuras.

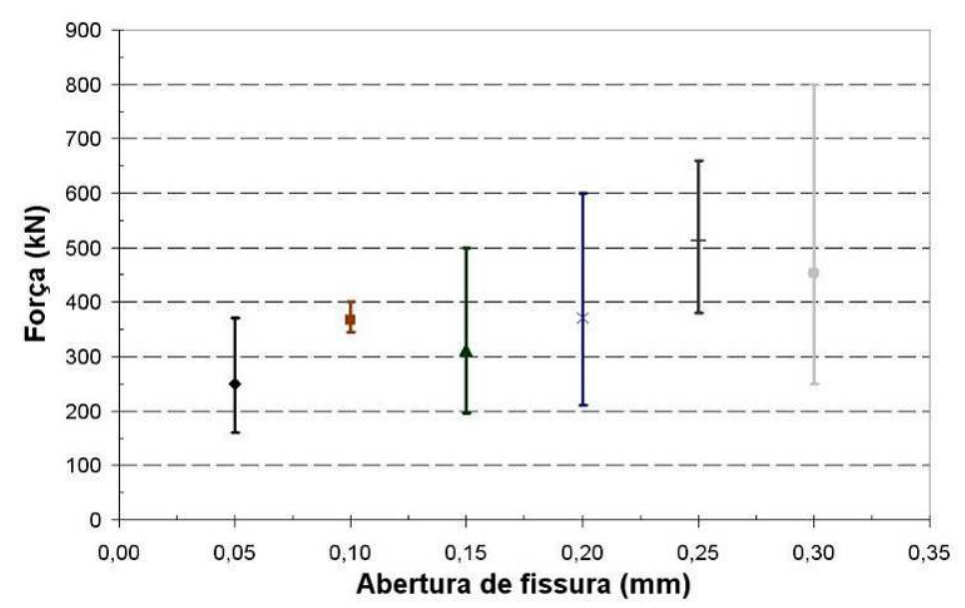

Figura 5. 129- Dispersão das forças relacionadas as aberturas de fissuras

Os blocos de fundação são elementos que, por estarem em contato direto com o solo, precisam ter suas aberturas de fissuras limitadas. A ABNT NBR 6118:2007 indica aberturas inferiores a 0,3 $\mathrm{mm}$ para elementos da classe de agressividade ambiental II e III. 
Correlacionando a força que provoca uma abertura de fissura igual a $0,3 \mathrm{~mm}$ com a força última de cada modelo, obtém-se valores médios da ordem de $73 \%$ da força última, conforme pode ser observado na tabela 5.39. Nessa tabela estão apresentados apenas os resultados dos modelos nos quais houve medição da força relativa a abertura da fissura igual a $0,3 \mathrm{~mm}$.

Tabela 5.38 - Abertura de fissuras nos modelos

\begin{tabular}{|c|c|c|c|c|c|c|c|}
\hline \multirow{2}{*}{ Série } & \multirow{2}{*}{ Modelo } & \multicolumn{6}{|c|}{ Abertura de fissuras (mm) } \\
\hline & & 0,05 & $\mathbf{0 , 1 0}$ & 0,15 & $\mathbf{0 , 2 0}$ & 0,25 & $\mathbf{0 , 3 0}$ \\
\hline \multirow{7}{*}{$\begin{array}{c}\text { Sem } \\
\text { rugosidade }\end{array}$} & M1 & 230 & 360 & - & - & 660 & - \\
\hline & M2 & 320 & - & 420 & - & 500 & 620 \\
\hline & M3 & 310 & 360 & - & 450 & - & - \\
\hline & M4 & 210 & - & 310 & - & 380 & 440 \\
\hline & M5 & 270 & - & 350 & - & 440 & - \\
\hline & M6 & 170 & - & 200 & 230 & - & 260 \\
\hline & M7 & 160 & - & 196 & 210 & - & 250 \\
\hline \multirow{7}{*}{$\begin{array}{c}\text { Com } \\
\text { rugosidade }\end{array}$} & M8 & 208 & 345 & - & 460 & - & - \\
\hline & M9 & 320 & 400 & - & 600 & - & 800 \\
\hline & M10 & 370 & - & - & - & - & - \\
\hline & M11 & 310 & - & 500 & - & 600 & - \\
\hline & M12 & 260 & - & 370 & - & 500 & - \\
\hline & M13 & 180 & - & 250 & - & - & 396 \\
\hline & M14 & 190 & - & 225 & 280 & - & 400 \\
\hline
\end{tabular}

Tabela 5.39 - Força que provoca abertura de fissura estimada em $0,3 \mathrm{~mm}$

\begin{tabular}{c|c|c|c|c}
\hline \hline Série & Modelo & $\mathbf{F}_{\mathbf{u}}(\mathbf{k N})$ & $\mathbf{F}_{\mathbf{w k}=\mathbf{0 , 3}}(\mathbf{k N})$ & $\mathbf{F}_{\mathbf{w k}=\mathbf{0}, \mathbf{3}} / \mathbf{F}_{\mathbf{u}}$ \\
\hline \multirow{4}{*}{$\begin{array}{c}\text { Sem } \\
\text { rugosidade }\end{array}$} & M2 & 772 & 620 & $80 \%$ \\
\cline { 2 - 5 } & M4 & 563 & 440 & $78 \%$ \\
\cline { 2 - 5 } & M6 & 359 & 260 & $72 \%$ \\
\hline \multirow{4}{*}{$\begin{array}{c}\text { Com } \\
\text { rugosidade }\end{array}$} & M7 & 368 & 250 & $68 \%$ \\
\cline { 2 - 5 } & M13 & 916 & 800 & $87 \%$ \\
\cline { 2 - 5 } & M14 & 652 & 396 & $61 \%$ \\
\hline \hline
\end{tabular}




\subsubsection{Força de avaliação}

No capítulo 3 foi apresentado o dimensionamento dos blocos, os quais tiveram a tensão de compressão no encontro da biela com o pilar como fator limitante para determinação da força de avaliação. A partir da estimativa dessa força de avaliação aplicada no pilar, procedeu-se o dimensionamento dos modelos. Nessa ocasião, considerou-se que a tensão máxima existente no encontro das bielas do bloco com o pilar fosse igual ao valor da resistência característica à compressão dos blocos, naquela ocasião adotada como sendo a resistência de um concreto da classe C25. Para a determinação da armadura principal do tirante do bloco, adotou-se a resistência ao escoamento do aço igual a $500 \mathrm{MPa}$.

Após os ensaios de caracterização dos materiais, cujos resultados encontram-se apresentados no item 5.2, obtiveram-se os valores médios de resistência à compressão para o concreto dos blocos, assim como a resistência média ao escoamento das barras de aço, valores esses superiores aos utilizados no dimensionamento. Portanto, faz-se necessário recalcular o valor da força de avaliação, a fim de comparar o valor previsto no modelo teórico com o obtido experimentalmente.

A substituição do valor da resistência característica à compressão pelo valor da resistência média à compressão foi feito, pois com os resultado obtidos em laboratório foi possível estabelecer valores médios de resistência. A resistência característica à compressão do concreto, $\mathrm{f}_{\mathrm{ck}}$ é um valor teórico utilizado na etapa de projeto. A ABNT NBR 12655:2006 fornece os parâmetros necessários para que, com o controle tecnológico do concreto, possa ser obtido o valor de $f_{c k, e s t}$, que é uma estimativa do valor do $f_{c k}$, cuja função é verificar se um determinado lote de concreto apresenta-se conforme ou não conforme. $\mathrm{O}$ valor de $\mathrm{f}_{\mathrm{ck}, \mathrm{est}}$, por sua vez, depende de fatores como desvio padrão da produção de concreto, do tipo de controle bem como da quantidade de exemplares utilizados em cada lote. Portanto, optou-se por trabalhar com valores de resistência média à compressão.

A partir do valor médio obtido para a resistência à compressão do concreto dos blocos, $\mathrm{f}_{\mathrm{cm}}$ igual a 33,1 MPa, obtém-se:

$$
\begin{aligned}
& F_{a v a}=f_{c m} \cdot A_{p} \cdot \operatorname{sen}^{2} 49,8=3,3 \cdot 15 \cdot 15 \cdot 0,57=430,6 \mathrm{kN}(\mathrm{SR}) \\
& \mathrm{F}_{\mathrm{ava}}=\mathrm{f}_{\mathrm{cm}} \cdot \mathrm{A}_{\mathrm{p}} \cdot \operatorname{sen}^{2} 49,2=3,3 \cdot 15 \cdot 15 \cdot 0,58=423,2 \mathrm{kN}(\mathrm{CR})
\end{aligned}
$$

O aumento da força de avaliação, por sua vez, implica no aumento da área de aço necessária, mesmo considerando o valor médio da resistência ao escoamento medido experimentalmente, conforme apresentado a seguir para os modelos da série sem rugosidade: 


$$
\begin{aligned}
& \mathrm{R}_{\mathrm{st}}=\frac{423,225}{2 \cdot \operatorname{tg} 49,2}=182,65 \mathrm{kN} \\
& \mathrm{A}_{\mathrm{st}}=\frac{182,65}{56,9}=3,21 \mathrm{~cm}^{2}
\end{aligned}
$$

Como a armadura detalhada nos blocos foi exatamente igual à armadura calculada antes da caracterização dos materiais, verifica-se que a área calculada de $3,21 \mathrm{~cm}^{2}$ é superior a armadura que foi detalhada nos modelos, que é de $2,78 \mathrm{~cm}^{2}$. Portanto, não é possível condicionar a nova força de avaliação apenas ao valor da resistência média à compressão do concreto, sendo necessário avaliar a nova força considerando o valor médio da resistência ao escoamento das barras de aço. Nessa situação, verifica-se que a força de avaliação fica condicionada ao valor da resistência ao escoamento das barras de aço. Portanto:

$$
\begin{aligned}
& \mathrm{R}_{\mathrm{St}}=2,78 \cdot 56,9=158,2 \mathrm{kN} \\
& \mathrm{F}_{\text {ava }}=158,2 \cdot 2 \cdot \operatorname{tg} 49,2=366 \mathrm{kN}
\end{aligned}
$$

Considera-se, portanto, o menor dos dois valores obtidos para a força de avaliação. Verifica-se que, de acordo com os resultados obtidos na caracterização dos materiais, a resistência ao escoamento das barras de aço foi o fator determinante para a nova força de avaliação. Entretanto, esses resultados ocorrem considerando que a inclinação da biela de compressão mantém-se constante e igual a $49,2^{\circ}$ para os blocos da série sem rugosidade, e igual a $49,8^{\circ}$ para os blocos da série com rugosidade, conforme proposto no capítulo 3 . A partir do equilíbrio de forças no nó da estaca, o qual relaciona a força de compressão na biela $\mathrm{R}_{\mathrm{cb}}$, a força de tração no tirante $\mathrm{R}_{\mathrm{st}}$, e a força de avaliação $\mathrm{F}_{\mathrm{ava}}$ aplicada no pilar, é possível que ocorra aumento da força de avaliação sem que ocorra aumento da força $R_{\text {st }}$, desde que seja alterado o ângulo de inclinação da biela. Essa situação é possível, tendo em vista que nos ensaios constatou-se aumento da força aplicada no bloco mesmo após o escoamento das barras da armadura principal do tirante. Nessa situação, verifica-se que tanto a força de avaliação como a força no tirante são funções do ângulo $\theta$ de inclinação da biela. Desse modo, é possível escrever as equações 5.7 e 5.8 .

$$
\begin{aligned}
& \mathrm{F}_{\text {ava }}=\mathrm{f}_{\mathrm{cm}} \cdot \mathrm{A}_{\mathrm{p}} \cdot \operatorname{sen}^{2} \theta=3,3 \cdot 15 \cdot 15 \cdot \operatorname{sen}^{2} \theta=742,5 \cdot \operatorname{sen}^{2} \theta \\
& \mathrm{F}_{\text {ava }}=158,2 \cdot 2 \cdot \operatorname{tg} \theta=316,4 \cdot \operatorname{tg} \theta
\end{aligned}
$$


Relacionando as equações 5.7 e 5.8, obtém-se a expressão 5.9.

$\operatorname{sen} \theta \cdot \cos \theta=0,426$

A partir da equação 5.9 combinada com a equação clássica da trigonometria, a qual relaciona a soma dos quadrados do seno e do cosseno de um determinado ângulo, é possível estabelecer um sistema de equações que resulta numa equação quadrática, dada pela equação 5.10 .

$\operatorname{sen}^{2} \theta+\frac{0,181}{\operatorname{sen}^{2} \theta}-1=0$

A solução da equação anterior fornece quatro raízes, sendo dois ângulos com sinais positivos e outros dois com sinais negativos. Os ângulos positivos que satisfazem a equação são iguais a $29,1^{\circ}$ e $60,8^{\circ}$. Substituindo os ângulos encontrados na equação 5.7 , obtém-se o maior valor de $\mathrm{F}_{\mathrm{ava}}$ para o ângulo de $60,8^{\circ}$, conforme equação 5.11 .

$$
\mathrm{F}_{\mathrm{ava}}=3,3 \cdot 15 \cdot 15 \cdot \operatorname{sen}^{2} 60,8=565 \mathrm{kN}
$$

Portanto, o novo valor da força de avaliação obtida com o modelo teórico após os resultados de caracterização dos materiais, resulta em 565 kN, o qual ocorre para um ângulo de inclinação da biela igual a $60,8^{\circ}$. Verifica-se ainda que o procedimento anteriormente realizado resulta no mesmo valor de ângulo para os blocos da série com rugosidade, o que implica no mesmo valor de força teórica. Observa-se ainda que a solução encontrada para o ângulo de inclinação da biela fornece um valor que atende as limitações geométricas (faces interna e externa das estacas) do modelo analisado, sendo esse valor muito próximo ao ângulo que se obtém a partir de um segmento de reta que sai do ponto de aplicação da força no pilar, em direção a borda mais interna da estaca, conforme apresentado na Figura 5.130.
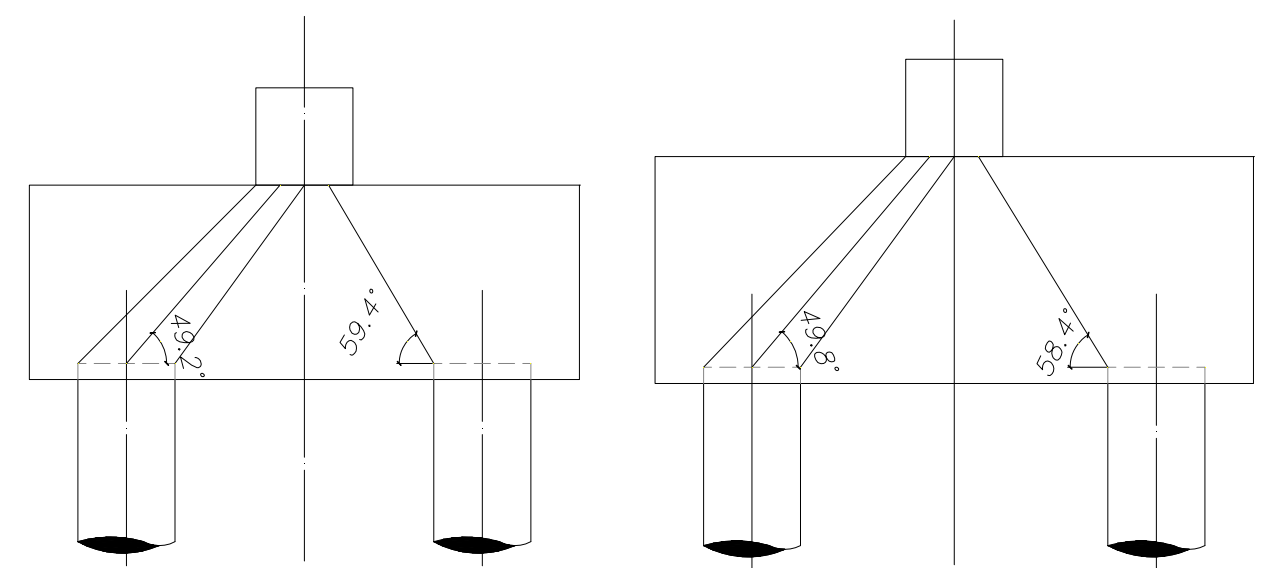

Figura 5. 130 - Projeção do ângulo teórico nos modelos analisados. 
A tabela 5.40 apresenta a relação entre a força máxima experimental obtida na iminência da ruína de cada modelo, e a força de avaliação calculada com o modelo teórico. Verifica-se que apenas os blocos com cálice embutido da série sem rugosidade apresentaram a força experimental inferior à força teórica, indicando que o procedimento de cálculo utilizado no dimensionamento desses blocos apresenta-se contra a segurança. Nessa mesma série, os blocos com cálice parcialmente embutido apresentaram uma relação entre as forças inferior a apresentada pelo bloco de referência, o que não ocorreu na série com rugosidade, na qual os blocos com cálice parcialmente embutido apresentaram força última superior a do bloco de referência dessa série. Destaca-se ainda que na série com rugosidade, o resultado do modelo M10 encontra-se destoando dos demais modelos, tendo em vista que a ruína desse modelo se deu por ruptura do concreto do pilar.

Tabela 5.40 - Comparação entre modelos teórico e experimental

\begin{tabular}{|c|c|c|c|c|}
\hline Série & Modelo & $\begin{array}{c}F_{u} \\
(k N)\end{array}$ & $\begin{array}{l}\mathbf{F}_{\text {,ava }} \\
(\mathbf{k N})\end{array}$ & $F_{u} / F_{\text {ava }}(\%)$ \\
\hline \multirow{7}{*}{$\begin{array}{c}\text { Sem } \\
\text { rugosidade }\end{array}$} & M1 & 756 & \multirow{14}{*}{565} & $134 \%$ \\
\hline & M2 & 772 & & $137 \%$ \\
\hline & M3 & 724 & & $128 \%$ \\
\hline & M4 & 563 & & $100 \%$ \\
\hline & M5 & 644 & & $114 \%$ \\
\hline & M6 & 359 & & $64 \%$ \\
\hline & M7 & 368 & & $65 \%$ \\
\hline \multirow{7}{*}{$\begin{array}{c}\text { Com } \\
\text { rugosidade }\end{array}$} & M8 & 728 & & $129 \%$ \\
\hline & M9 & 916 & & $162 \%$ \\
\hline & M10 & $632^{*}$ & & $112 \%$ \\
\hline & M11 & 888 & & $157 \%$ \\
\hline & M12 & 957 & & $169 \%$ \\
\hline & M13 & 652 & & $115 \%$ \\
\hline & M14 & 640 & & $113 \%$ \\
\hline
\end{tabular}

"Modelo que apresentou ruína por ruptura do concreto do pilar. 


\subsubsection{Armadura principal do tirante}

Com o intuito de verificar o ângulo efetivo da biela de compressão próximo a etapa de ruína dos modelos, estimou-se as forças $R_{s t} R_{c b}$ atuantes nos modelos experimentais. A partir das medidas de deformação nas barras posicionadas na região central do bloco, foi possível obter a força $R_{\text {st. }}$ Com a força atuante no pilar e, conseqüentemente no bloco, foi possível estimar a inclinação da biela de compressão.

Verificou-se que as deformações e, por conseqüência, as tensões atuantes nas barras das armaduras nem sempre apresentam seus valores máximos nas barras posicionadas na região central do bloco. A Figura 5.131 apresenta um esquema gráfico das deformações nas barras da armadura principal do tirante medidas nos modelos da série sem rugosidade, enquanto que a Figura 5.132 apresenta o esquema das deformações das barras das armaduras dos modelos da série com rugosidade.

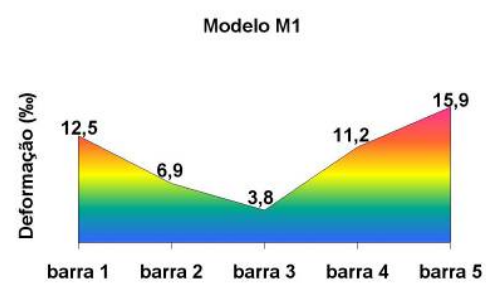

Modelo M2

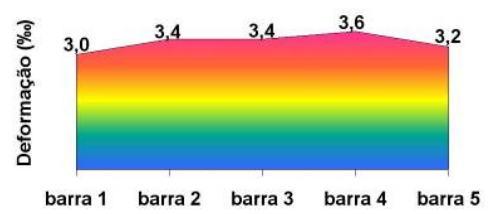

Modelo M5

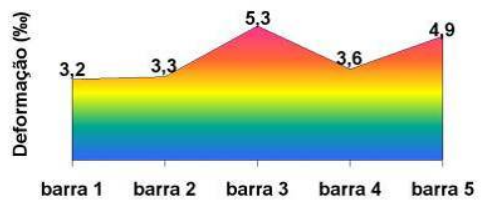

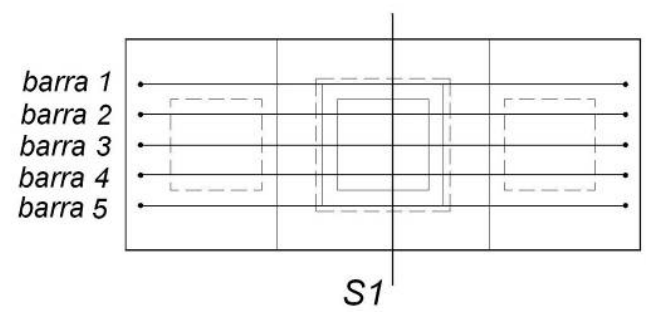

Modelo M3

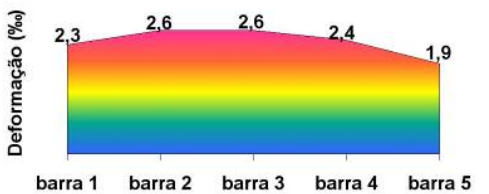

Modelo M6

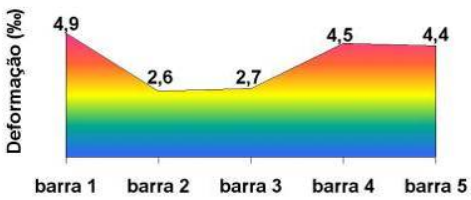

Modelo M4

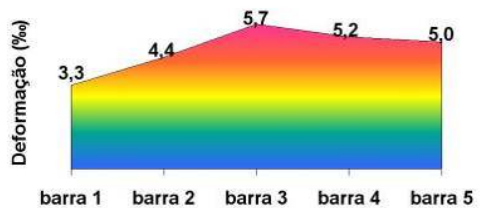

Modelo M7

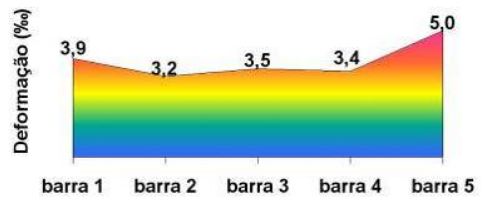

Figura 5. 131- Medidas das deformações nas barras das armaduras: série sem rugosidade 


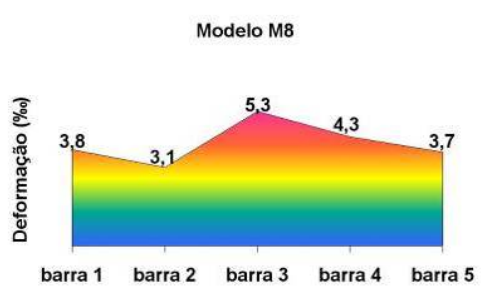

Modelo M9

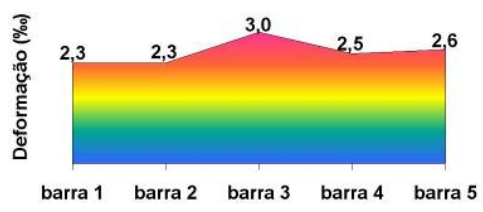

Modelo M12

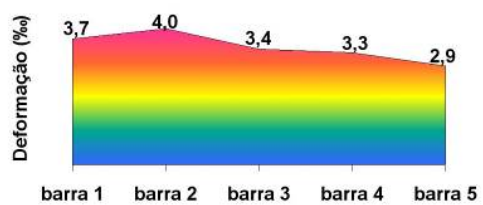

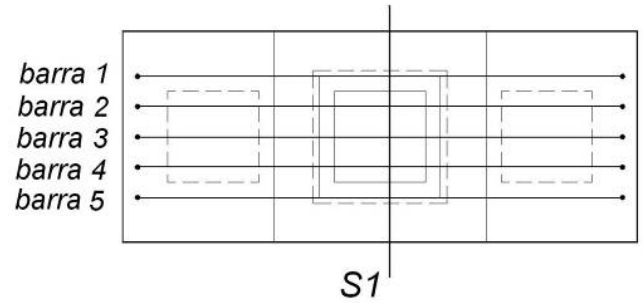

Modelo M10

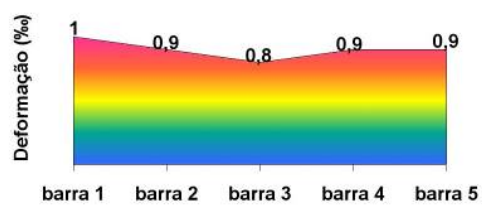

Modelo M13

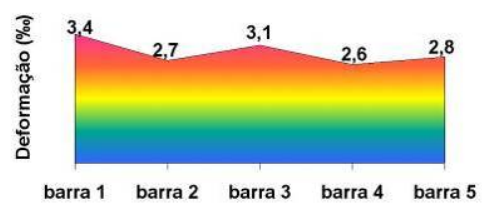

Modelo M11

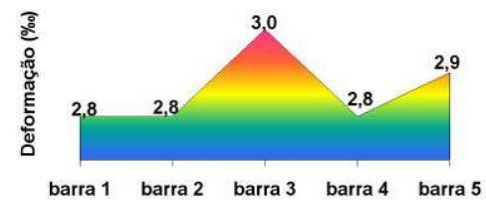

Modelo M14

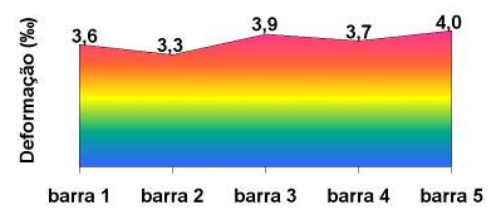

Figura 5. 132- Medidas das deformações nas barras das armaduras: série sem rugosidade

Com os valores de deformação apresentados, é possível estimar a tensão normal em cada barra utilizando o valor do módulo de elasticidade obtido nos ensaios de caracterização das barras de aço. Conhecendo-se a área de cada barra, é possível estimar a força $R_{\text {st }}$ que atua nas barras da armadura principal do tirante. Com o valor da força $\mathrm{R}_{\mathrm{st}} \mathrm{e}$ da força última experimental registrada para cada modelo, é possível obter a força de compressão $R_{c b}$ atuante nas bielas de compressão, bem como o ângulo de inclinação da biela na iminência da ruína dos modelos.

A tabela 5.41 apresenta as tensões normais atuante em cada uma das barras dos modelos analisados, enquanto que a tabela 5.42 apresenta as forças $R_{s t}$ e $R_{c b}$, bem como o ângulo de inclinação da biela na iminência da ruína. Observa-se que os valores de tensão apresentados estão limitados a tensão de escoamento média obtida nos ensaios de caracterização das barras de aço. Verifica-se também que, na iminência da ruína, os ângulos de inclinação da biela apresentam valores superiores ao ângulo teórico calculado no item 5.7.3, a menos dos modelos M6 e M7, os quais apresentaram força última experimental inferior a força teórica. Destaca-se ainda que esses valores teóricos de ângulos não foram observados nos modelos M6 e M7, tendo em vista que não foi observada a formação das bielas nesses modelos. O modelo M4, por sua vez, apresentou os valores de ângulo e força última praticamente coincidente com o valor teórico previsto. 
Tabela 5.41 - Tensão nas barras das armaduras

\begin{tabular}{c|c|c|c|c|c|c}
\hline \hline \multirow{4}{*}{ Série } & \multirow{2}{*}{ Modelo } & \multicolumn{5}{|c}{ Tensão (MPa) } \\
\hline \multirow{4}{*}{$\begin{array}{c}\text { Sem } \\
\text { rugosidade }\end{array}$} & barra 1 & barra 2 & barra 3 & barra 4 & barra 5 \\
\cline { 2 - 7 } & M1 & 569,0 & 569,0 & 569,0 & 569,0 & 569,0 \\
\cline { 2 - 7 } & M2 & 569,0 & 569,0 & 569,0 & 569,0 & 569,0 \\
\cline { 2 - 7 } & M3 & 466,9 & 527,8 & 527,8 & 487,2 & 385,7 \\
\cline { 2 - 7 } & M4 & 569,0 & 569,0 & 569,0 & 569,0 & 569,0 \\
\cline { 2 - 7 } & M6 & 569,0 & 569,0 & 569,0 & 569,0 & 569,0 \\
\cline { 2 - 7 } & M7 & 569,0 & 527,8 & 548,1 & 569,0 & 569,0 \\
\hline \multirow{4}{*}{$\begin{array}{c}\text { Com } \\
\text { rugosidade }\end{array}$} & M8 & 569,0 & 569,0 & 569,0 & 569,0 & 569,0 \\
\cline { 2 - 7 } & M9 & 466,9 & 466,9 & 569,0 & 507,5 & 527,8 \\
\cline { 2 - 7 } & M10 & 203,0 & 182,7 & 162,4 & 182,7 & 182,7 \\
\cline { 2 - 7 } & M11 & 568,4 & 568,4 & 569,0 & 568,4 & 569,0 \\
\cline { 2 - 7 } & M12 & 569,0 & 569,0 & 569,0 & 569,0 & 569,0 \\
\cline { 2 - 7 } & M13 & 569,0 & 548,1 & 569,0 & 527,8 & 568,4 \\
\cline { 2 - 7 } & M14 & 569,0 & 569,0 & 569,0 & 569,0 & 569,0 \\
\hline \hline
\end{tabular}

Tabela 5.42 - Forças obtidas na iminência da ruína

\begin{tabular}{c|c|c|c|c|c}
\hline \hline Série & Modelo & $\mathbf{F}_{\mathbf{u}}(\mathbf{k N})$ & $\mathbf{R}_{\mathbf{s t}}(\mathbf{k N})$ & $\mathbf{R}_{\mathbf{c b}}(\mathbf{k N})$ & $\left.\boldsymbol{\theta}_{\text {últ }} \mathbf{(}^{\mathbf{o}}\right)$ \\
\hline \multirow{4}{*}{$\begin{array}{c}\text { Sem } \\
\text { rugosidade }\end{array}$} & M1 & 756 & 158,18 & 409,76 & 67,3 \\
\cline { 2 - 6 } & M2 & 772 & 158,18 & 417,15 & 67,7 \\
\cline { 2 - 6 } & M3 & 724 & 186,84 & 407,37 & 62,7 \\
\cline { 2 - 6 } & M4 & 563 & 158,18 & 322,90 & 60,7 \\
\cline { 2 - 6 } & M5 & 644 & 158,18 & 358,76 & 63,8 \\
\cline { 2 - 6 } & M6 & 359 & 154,49 & 236,83 & 49,3 \\
\hline \multirow{4}{*}{$\begin{array}{c}\text { Com } \\
\text { rugosidade }\end{array}$} & M7 & 368 & 158,18 & 242,65 & 49,3 \\
\cline { 2 - 6 } & M10 & 728 & 158,18 & 396,88 & 66,5 \\
\cline { 2 - 6 } & M1 & 916 & 142,84 & 479,76 & 72,7 \\
\cline { 2 - 6 } & M12 & 957 & 158,18 & 503,97 & 71,7 \\
\cline { 2 - 6 } & M13 & 652 & 155,05 & 360,99 & 64,6 \\
\cline { 2 - 6 } & M14 & 640 & 158,18 & 356,96 & 63,7 \\
\hline \hline
\end{tabular}


Verificou-se também que os valores dos ângulos de inclinação da biela com o tirante praticamente não sofreram alteração a partir do instante em que a primeira barra de armadura iniciou o escoamento. A tabela 5.43 apresenta os valores da força aplicada no bloco, $\mathrm{F}_{\mathrm{i}}$, e da força $R_{\text {st }}$ no instante em que se inicia o escoamento da primeira barra, e dos ângulos de inclinação da biela na iminência da ruína $\left(\theta_{\text {últ }}\right)$, bem como no início do escoamento $\left(\theta_{\text {esc }}\right)$. Verifica-se que os ângulos dos modelos M3 e M10 apresentaram o mesmo valor em virtude da não ocorrer o escoamento das barras das armaduras nesses dois modelos.

Tabela 5.43 - Forças obtidas no início do escoamento das barras

\begin{tabular}{|c|c|c|c|c|c|c|}
\hline Série & Modelo & $F_{\mathbf{i}}(\mathbf{k N})$ & $\begin{array}{c}F_{i} / F_{u} \\
(\%)\end{array}$ & $\mathbf{R}_{\text {st }}(\mathbf{k N})$ & $\theta_{\text {últt }}\left({ }^{\circ}\right)$ & $\theta_{\text {esc }}\left({ }^{\circ}\right)$ \\
\hline \multirow{7}{*}{$\begin{array}{c}\text { Sem } \\
\text { rugosidade }\end{array}$} & M1 & 450 & $59 \%$ & 111,49 & 67,3 & 63,6 \\
\hline & M2 & 663 & $86 \%$ & 139,50 & 67,7 & 67,2 \\
\hline & M3* & 724 & - & 186,84 & 62,7 & 62,7 \\
\hline & M4 & 467 & $83 \%$ & 134,87 & 60,7 & 60,0 \\
\hline & M5 & 589 & $91 \%$ & 136,90 & 63,8 & 65,1 \\
\hline & M6 & 302 & $84 \%$ & 119,28 & 49,3 & 51,7 \\
\hline & M7 & 320 & $87 \%$ & 138,93 & 49,3 & 49,0 \\
\hline \multirow{7}{*}{$\begin{array}{l}\text { Com } \\
\text { rugosidade }\end{array}$} & M8 & 568 & $78 \%$ & 144,13 & 66,5 & 63,1 \\
\hline & M9 & 888 & $97 \%$ & 136,70 & 72,7 & 72,9 \\
\hline & M10* & 632 & - & 71,25 & 77,3 & 77,3 \\
\hline & M11 & 865 & $97 \%$ & 150,91 & 70,4 & 70,8 \\
\hline & M12 & 855 & $89 \%$ & 137,92 & 71,7 & 72,1 \\
\hline & M13 & 556 & $89 \%$ & 134,43 & 64,6 & 64,2 \\
\hline & M14 & 532 & $83 \%$ & 143,12 & 63,7 & 61,7 \\
\hline
\end{tabular}

"Modelos que não apresentaram escoamento das barras das armaduras

\subsubsection{Transferência de forças pilar-bloco}

Apresenta-se nesse item um estudo da transferência de forças dos pilares para os blocos de acordo com o tipo de cálice de cada modelo. Por meio da instrumentação das armaduras dos pilares, a qual foi apresentada no capítulo 4, obtiveram-se as medidas de deformação nessas barras. Com o valor do módulo de elasticidade das barras de aço obtidas na caracterização dos materiais, foi possível estimar a força atuante na armadura dos pilares em 
três seções dispostas ao longo do comprimento do pilar, sendo a seção S1 posicionada próximo ao topo do pilar, a seção S2 posicionada na região central do pilar e a seção S3 posicionada na região inferior do pilar.

Em virtude das pequenas excentricidades que foram registradas nos modelos, considerou-se que a distribuição de tensões no pilar ocorreu de modo uniforme. Admitiu-se simplificadamente que a deformação nas quatro barras da armadura do pilar fosse igual ao valor médio obtido nos dois extensômetros posicionados nas barras de aço em cada seção. Considerando a aderência perfeita entre o concreto e as barras de aço, pode-se admitir que a deformação no concreto é muito próxima da deformação das barras de aço. A partir da curva tensão versus deformação obtida nos ensaios de caracterização do concreto dos pilares, obtém-se a tensão média de compressão atuante no concreto dos pilares. Multiplicando essa tensão pela área de concreto obtém-se a parcela de força no concreto. Unindo as parcelas de forças existentes nas barras de aço e no concreto dos pilares, é possível estabelecer um valor de força teórica atuante no pilar, $\mathrm{F}_{\text {teo,p }}$ obtidos com os dados experimentais, por meio da expressão 5.12 .

$$
\mathrm{F}_{\text {teo,p }}=\varepsilon_{\mathrm{s}} \cdot \mathrm{E}_{\mathrm{s}} \cdot \mathrm{A}_{\mathrm{s}}+\mathrm{f}_{\mathrm{c}} \cdot \mathrm{A}_{\mathrm{c}}
$$

Fazendo o cálculo teórico com os dados de deformação obtidos na seção S1 na iminência da ruína dos modelos, é possível comparar a força teórica no pilar com o valor da força última nos modelos, a qual foi registrada pela máquina durante a etapa de ensaio. Verifica-se que nos modelos sem rugosidade a força teórica se aproxima mais do resultado experimental do que a força teórica dos blocos da série com rugosidade. O valor máximo encontrado para a relação entre a força teórica e a força medida nos ensaios foi de $118 \%$, ocorrendo par ao modelo M10, enquanto que o valor mínimo foi de 77\% para o modelo M12. O Valor médio obtido para essa relação foi de $90 \%$, o que indica que o modelo teórico de previsão de força encontra-se a favor da segurança.

A Tabela 5.44 apresenta os resultados obtidos para a força teórica no pilar, as parcelas de força atuantes nas barras das armaduras e no concreto, bem como a relação entre essas forças, calculadas na seção de referência S1. Nesse cálculo foram utilizadas as propriedades mecânicas obtidas com a caracterização das barras de aço cujo diâmetro nominal foi de 12,5 mm., isto é, módulo de elasticidade longitudinal igual a 197 GPa e diâmetro efetivo igual a 12,3 mm. Não foram apresentados os resultados dos modelos de referência M1 e M8, em virtude de não ter sido medido as deformações nas barras de aço dos pilares desses blocos. 
Tabela 5.44 - Força última teórica no pilar

\begin{tabular}{|c|c|c|c|c|c|c|c|c|}
\hline Série & Modelo & $\begin{array}{l}\varepsilon_{\mathrm{S}, \mathrm{S} 1} \\
(\% \mathrm{\%})\end{array}$ & $\begin{array}{c}\mathbf{f}_{\mathrm{c}} \\
(\mathrm{MPa})\end{array}$ & $\begin{array}{l}F_{\text {aço }} \\
(k N)\end{array}$ & $\begin{array}{c}\mathbf{F}_{\text {concreto }} \\
(\mathbf{k N})\end{array}$ & $\begin{array}{l}F_{\text {teo,p }} \\
(\mathbf{k N})\end{array}$ & $\begin{array}{c}F_{u} \\
(k N)\end{array}$ & $\begin{array}{c}\mathbf{F}_{\text {teo,p }} / \\
\mathbf{F}_{\mathbf{u}}(\%)\end{array}$ \\
\hline \multirow{6}{*}{$\begin{array}{c}\text { Sem } \\
\text { rugosidade }\end{array}$} & M2 & 1,20 & 26,9 & 116,0 & 591,8 & 707,8 & 772 & $92 \%$ \\
\hline & M3 & 0,90 & 22,3 & 90,2 & 490,6 & 580,8 & 724 & $80 \%$ \\
\hline & M4 & 1,00 & 24,0 & 94,9 & 528,0 & 622,9 & 563 & $111 \%$ \\
\hline & M5 & 1,00 & 24,0 & 95,3 & 528,0 & 623,3 & 644 & $97 \%$ \\
\hline & M6 & 0,50 & 14,0 & 47,7 & 308,0 & 355,7 & 359 & $99 \%$ \\
\hline & M7 & 0,50 & 14,0 & 51,0 & 308,0 & 359,0 & 368 & $98 \%$ \\
\hline \multirow{6}{*}{$\begin{array}{l}\text { Com } \\
\text { rugosidade }\end{array}$} & M9 & 1,25 & 27,5 & 118,3 & 605,0 & 723,3 & 916 & $79 \%$ \\
\hline & M10 & 1,30 & 28,1 & 127,4 & 618,2 & 745,6 & 632 & $118 \%$ \\
\hline & M11 & 1,30 & 28,1 & 123,1 & 618,2 & 741,3 & 888 & $83 \%$ \\
\hline & M12 & 0,80 & 20,5 & 77,3 & 451,0 & 741,3 & 957 & $77 \%$ \\
\hline & M13 & 0,80 & 20,5 & 80,0 & 451,0 & 528,3 & 652 & $81 \%$ \\
\hline & M14 & 1,20 & 26,9 & 116,0 & 591,8 & 531,0 & 640 & $83 \%$ \\
\hline \multicolumn{6}{|c|}{ Valores Médios } & 605 & 676 & $90 \%$ \\
\hline
\end{tabular}

Observa-se que por se tratar de um modelo de cálculo, existem diferenças entre os valores de forças registradas no ensaio com os valores previstos no modelo teórico. Essas diferenças podem ser atribuídas aos seguintes fatores: regiões em que possa ter ocorrido escorregamento das barras de aço, não havendo aderência perfeita entre o concreto e o aço; distribuição não uniforme das tensões na seção reta em virtude das pequenas excentricidades registradas; valores médios de resistência do aço e do concreto obtidos nos ensaios de caracterização.

Assim como se procedeu na seção S1, fez-se o cálculo das forças atuantes no concreto e nas barras de aço nas seções S2 e S3, situadas no meio e na região inferior do pilar, respectivamente. Deste modo, é possível analisar a evolução da força nessas seções, bem como o modo de transferência da força oriunda do pilar para o bloco.

Conforme era esperado, verifica-se que ocorre uma redução da força atuante na seção S1 para a seção S3, isto é, ocorre a dissipação da força do pilar a medida que o mesmo encontrase em contato com o bloco. Observou-se ainda que nos blocos da série sem rugosidade, a redução da força ao longo do pilar ocorre numa taxa inferior a dos blocos com rugosidade. Constatou-se que os blocos da série sem rugosidade apresentam na seção S3 uma força média equivalente a $59 \%$ da força atuante na seção $\mathrm{S} 1$, enquanto que nos blocos com rugosidade, a 
força média na seção S3 é de $21 \%$ da força atuante na seção S1, indicando que a transferência da força do pilar para o bloco é mais efetiva nos blocos em que há rugosidade.

A Figura 5.133 apresenta as forças resultantes atuantes nas barras das armaduras dos pilares nas seções S1, S2 e S3 dos modelos da série sem rugosidade, enquanto que a Figura 5.134 apresenta os mesmos resultados, porém para os modelos da série com rugosidade. A tabela 5.45, por sua vez, apresenta os valores percentuais das forças medidas nas seções S2 e S3, com relação a força medida na seção S1. Estes resultados indicam que, nos modelos da série com rugosidade, a formação da biela ocorre a partir da região de contato do pilar com o cálice de fundação, enquanto que nos modelos da série sem rugosidade, a formação da biela só tende a ocorrer próximo a região inferior do pilar.
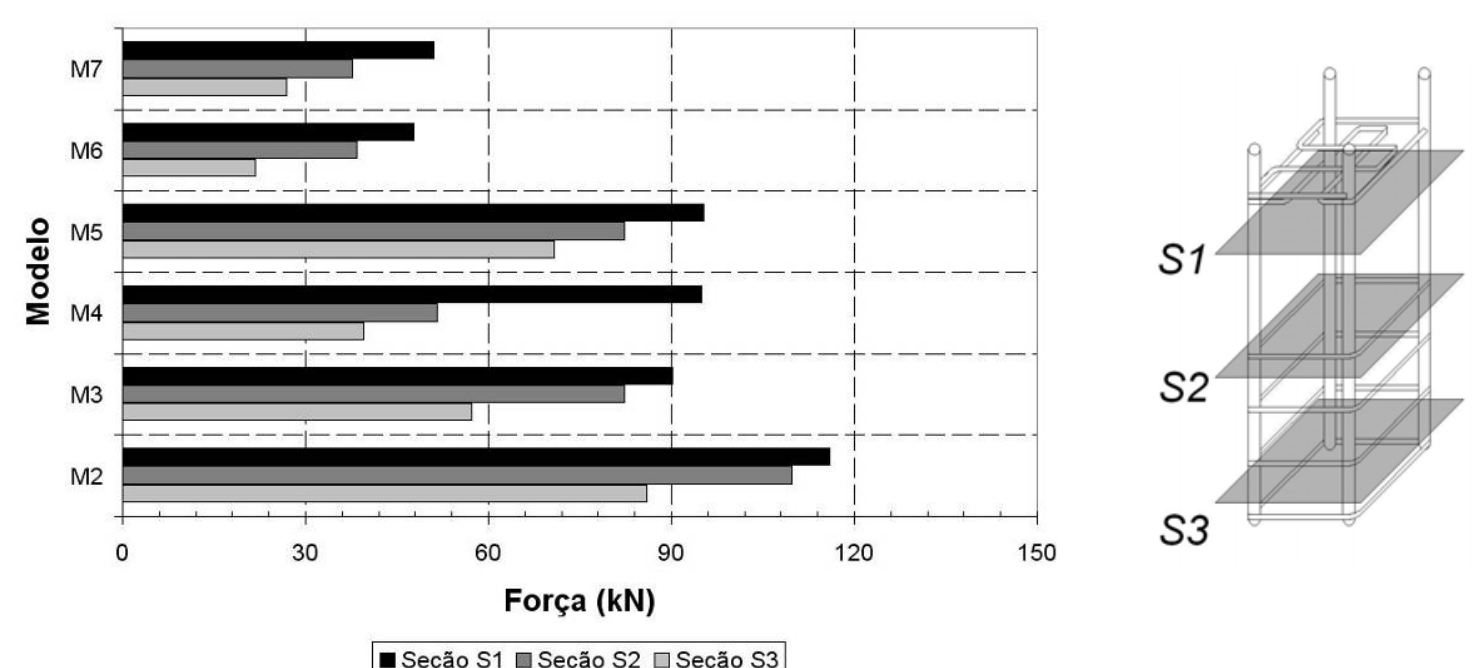

Figura 5. 133- Transferência de força no pilar - série sem rugosidade
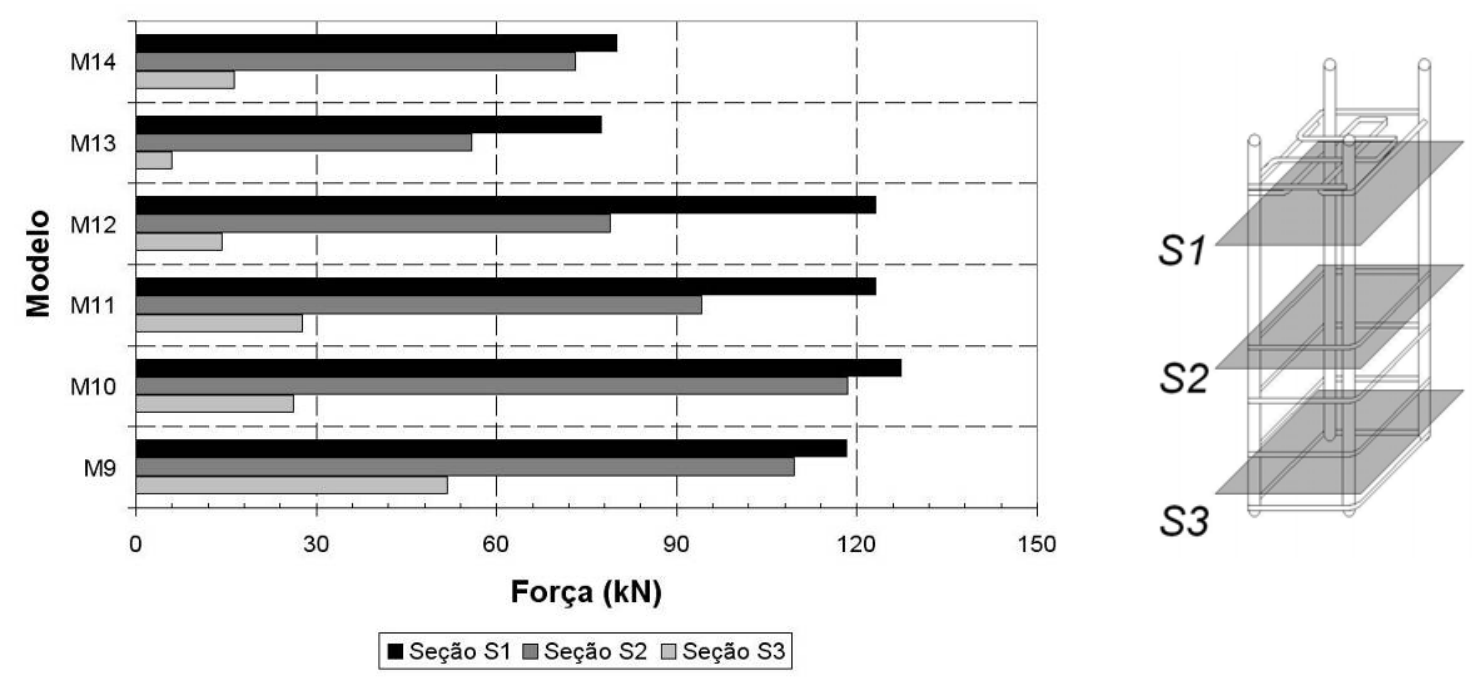

Figura 5. 134- Transferência de força no pilar - série com rugosidade 
Tabela 5.45 - Força atuante nas seções S1, S2 e S3 do pilar

\begin{tabular}{c|c|c|c}
\hline \hline Série & Modelo & $\mathbf{F}_{\mathbf{S} 2} / \mathbf{F}_{\mathbf{S 1}}$ & $\mathbf{F}_{\mathbf{S} 3} / \mathbf{F}_{\mathbf{S 1}}$ \\
\hline \multirow{4}{*}{$\begin{array}{c}\text { Sem } \\
\text { rugosidade }\end{array}$} & M2 & $95 \%$ & $74 \%$ \\
\cline { 2 - 4 } & M3 & $91 \%$ & $63 \%$ \\
\cline { 2 - 4 } & M4 & $54 \%$ & $42 \%$ \\
\cline { 2 - 4 } & M5 & $86 \%$ & $74 \%$ \\
\cline { 2 - 4 } & M6 & $80 \%$ & $46 \%$ \\
\cline { 2 - 4 } & M7 & $74 \%$ & $53 \%$ \\
\hline \multirow{4}{*}{ Média } & & $80 \%$ & $59 \%$ \\
\hline \multirow{4}{*}{$\begin{array}{c}\text { Com } \\
\text { rugosidade }\end{array}$} & M9 & $93 \%$ & $44 \%$ \\
\cline { 2 - 4 } & M10 & $93 \%$ & $21 \%$ \\
\cline { 2 - 4 } & M11 & $76 \%$ & $23 \%$ \\
\cline { 2 - 4 } & M13 & $64 \%$ & $12 \%$ \\
\cline { 2 - 4 } & M14 & $92 \%$ & $9 \%$ \\
\hline \multirow{2}{*}{ Média } & $82 \%$ & $21,5 \%$ \\
\hline \hline
\end{tabular}

O modelo teórico de cálculo de blocos sobre estacas com ligações monolíticas, o qual se baseia no modelo de bielas e tirantes, considera que a transferência da força do pilar para o bloco ocorre de modo integral a partir da seção de contato do pilar com o bloco. Em blocos sobre estacas com presença de cálice de fundação, não existe um modelo teórico específico para dimensionamento do bloco, sendo utilizado o mesmo modelo para ligações monolíticas, desde que sejam garantidas as condições de transferência das ações do pilar ao bloco por meio do uso de chaves de cisalhamento. Os resultados aqui apresentados indicam haver uma parcela da força aplicada no pilar que, mesmo na presença da chave de cisalhamento, é transferida ao bloco pelo contato direto do fundo do pilar com a região inferior do cálice. Não havendo a chave de cisalhamento, a parcela da força que é transmitida diretamente ao fundo do cálice é maior. Desse modo, será previsto no capítulo 7 um modelo de cálculo que considera que uma parcela da força seja transmitida ao bloco diretamente pelo fundo do cálice. 


\subsection{Comentários finais}

Apresentou-se nesse capítulo os resultados obtidos com o programa experimental. Inicialmente foi apresentado os resultados da caracterização dos materiais e de suas propriedades mecânicas. Em seguida, apresentou-se os resultados da análise experimental dos 14 modelos de blocos sobre duas estacas, seguido da análise e interpretação desses resultados. Os resultados indicaram que a existência da chave de cisalhamento confere aos blocos uma maior capacidade resistente. 



\section{Simulação numérica}

\subsection{Considerações iniciais}

Durante a realização desta pesquisa foram feitas simulações numéricas visando representar o comportametno dos blocos sobre duas estacas com cálice de fundação. Essas simulações foram feitas utilizando o programa computacional DIANA ${ }^{\circledR}$, versão 9.2, que é um programa baseado no método dos elementos finitos, registrado para o Departamento de Engenharia de Estruturas da Escola de Engenharia de São Carlos, Universidade de São Paulo.

O estudo foi dividido em duas etapas. As simulações numéricas feitas antes dos ensaios experimentais visaram realizar uma análise prévia dos modelos físicos que seriam ensaiados em laboratório, buscando antever resultados e eventuais problemas que poderiam ocorrer durante a realização dos ensaios. Nessa etapa, chamada etapa inicial, foram utilizados os dados dos projetos dos blocos, e apresentados no capítulo 3 desse texto. Com essas análises foi possível verificar valores de forças para as quais se iniciariam o processo de fissuração dos blocos, forças últimas nos modelos, tensões nas barras das armaduras e distribuição do fluxo de tensões nas regiões internas aos blocos.

Uma segunda etapa referente à análise numérica foi feita após a realização dos ensaios experimentais. Nessa etapa, chamada etapa final, foram consideradas as propriedades mecânicas obtidas dos ensaios de caracterização dos materiais, as quais foram apresentadas no capítulo 5. Com essas análises foi possível realizar comparações entre os modelos numérico e experimental por meio de gráficos do tipo força versus deslocamento e força versus deformação média nas barras da armadura principal do bloco. Também foi possível verificar o panorama de fissuração do concreto dos blocos, bem como a formação da biela de compressão no interior do bloco, o que não é possível de ser observado no ensaio experimental.

A utilização do programa DIANA vem sendo difundida no Departamento de Engenharia de Estruturas desde o ano de 2006. A opção pela utilização do DIANA em relação a outros programas computacionais se deu pelo fato do mesmo apresentar modelos mecânicos específicos que buscam representar o comportamento do material concreto. Além disso, a representação das barras das armaduras se dá com certa facilidade, uma vez que o programa 
DIANA apresenta um elemento finito específico chamado de reinforcement que é facilmente incorporado aos modelos sem a necessidade de coincidência dos nós das armaduras com os nós dos demais elementos.

Neste capítulo de análise numérica são apresentadas algumas informações a respeito da utilização do programa DIANA. Antes da apresentação dos resultados dos blocos de fundação obtidos nas simulações numéricas, são apresentados dados relativos à análise paramétrica, a qual conduziu ao modelo utilizado para simulação dos blocos de fundação sobre duas estacas utilizado nas demais análises. Além das análises realizadas por BARROS (2009), nas quais verificaram-se a influência dos critérios de convergência e do método de resolução do sistema de equações não lineares, este trabalho também verificou a influência de outros parâmetros, dentre os quais destacam-se o tipo de elemento finito, a discretização da malha de elementos finitos, o número de subdivisões da força aplicada em etapas de carregamento, bem como o tempo de processamento despendido em cada modelo.

\subsection{Programa DIANA}

O programa computacional DIANA é baseado no Método dos Elementos Finitos. O programa vem sendo desenvolvido na Holanda desde 1972 por engenheiros civis da TNO Building and Construction Research Company, sendo considerado um excelente programa para análises tridimensionais e não-lineares.

Outra propriedade desse programa é a possibilidade de considerar em suas análises fenômenos complexos existentes em estruturas de concreto armado. Entre esses fenômenos, podem-se citar: fissuração, plasticidade, fluência, cura, efeitos de temperatura, podendo alguns desses modelos serem aplicados em análises estáticas, não-linear, modal, entre outras. Além disso, o referido programa oferece grande variedade de elementos em sua biblioteca, tais como: vigas, sólidos, membranas, placas, cascas, elementos de contato, elementos de interface e os elementos do tipo reinforcements, utilizados para simulação das barras das armaduras em estruturas de concreto armado.

A seguir são apresentados informações referentes aos tipos de elementos finitos e aos modelos constitutivos adotados nas simulações numéricas. 


\subsubsection{Elementos finitos utilizados}

Os elementos finitos utilizados na simulação numérica estão disponíveis na biblioteca do DIANA. Para representação do concreto das estacas, do pilar e do bloco, foi utilizado elemento sólido. Tratando de elementos sólidos, a biblioteca do DIANA dispõe de três elementos finitos distintos: HX24L, CHX60 e CHX96. Os elementos sólidos caracterizam-se por apresentarem três graus de liberdade em cada nó, sendo esses graus os deslocamentos nas direções ortogonais $\mathrm{x}, \mathrm{y}$ e z. O número existente no final do nome de cada elemento representa o total de graus de liberdade do elemento. Sendo assim, o HX24L é um elemento com 8 nós e função aproximadora linear para os deslocamentos. O CHX60 apresenta 20 nós e função aproximadora quadrática para os deslocamentos, e o CHX96 apresenta 32 nós e função aproximadora cúbica para os deslocamentos.

O elemento HX24L é o elemento sólido mais simples para ser utilizado nas análises. Entretanto, pode apresentar resultados equivocados quando utilizado em análises não-lineares, conforme transcrição do manual apresentada a seguir:

"In models for nonlinear analysis you are advised not to apply linearly interpolated isoparametric elements, like for instance Q8MEM, Q8OME, Q8EPS, Q8AXI, or HX24L. These elements have intrinsic shortcomings, like parasitic shear and volumetric locking, which cannot be easily dealt with in nonlinear analysis. In linear elastic analysis so-called assumed strain concepts can be applied to improve the element behavior [Vol. Element Library]."

Assim sendo, para análises não-lineares recomenda-se a utilização de elementos com aproximação quadrática ou cúbica em deslocamentos. Nos estudos paramétricos são apresentados os resultados obtidos de uma simulação na qual considerou-se a influência desses três elementos finitos. Em função desses resultados, optou-se por utilizar o elemento CHX60.

Conforme dito anteriormente, o elemento finito CHX60 é um elemento isoparamétrico com 20 nós, e função aproximadora quadrática para os deslocamentos. Cada nó apresenta três graus de liberdade, que são os deslocamentos nas direções x, y e z. A Figura 6.1 apresenta o elemento CHX60 e a função aproximadora para os deslocamentos. 


$$
\begin{gathered}
u_{i}(\xi, \eta, \zeta)=a_{0}+a_{1} \xi+a_{2} \eta+a_{3} \zeta+a_{4} \xi \eta+a_{5} \eta \zeta \\
+a_{6} \xi \zeta+a_{7} \xi^{2}+a_{8} \eta^{2}+a_{9} \zeta^{2}+a_{10} \xi \eta \zeta+a_{11} \xi^{2} \eta \\
+a_{12} \xi^{2} \zeta+a_{13} \xi \eta^{2}+a_{14} \xi \zeta^{2}+a_{15} \eta^{2} \zeta+a_{16} \eta \zeta^{2} \\
+a_{17} \xi^{2} \eta \zeta+a_{18} \xi \eta^{2} \zeta+a_{19} \xi \eta \zeta^{2}
\end{gathered}
$$

Figura 6. 1- Elemento CHX60 com função aproximadora em deslocamentos

Para modelagem das barras de aço das armaduras foram utilizados elementos chamados de reinforcements. Esses elementos não possuem nós, e funcionam como enrijecedores dos elementos finitos aos quais estão conectados, também sendo conhecidos como mother elements. Os reinforcements não possuem graus de liberdade, porém têm seu comportamento habilitado na direção axial da barra. Nessa situação, a aderência entre o aço e o concreto é considerada perfeita. Nesse aspecto, destaca-se que elementos do tipo reinforcement não devem ser utilizados em problemas que buscam simular o comportamento de conectores, parafusos ou barras metálicas sujeitos a tensões tangenciais.

$\mathrm{Na}$ região da ligação entre pilar - graute - cálice foram utilizados elementos de interface, visando simular o atrito existente entre as superfícies de concreto. Em simulações dessa natureza, diversos trabalhos apontam para a utilização de elementos de contato nessa região. Entretanto, o autor observou que os elementos de contato disponíveis no programa DIANA devem ser utilizados em situações em que ocorra a não-linearidade de contato, por exemplo, quando há alteração das condições de contorno de um problema. Em situações que envolvem materiais distintos, como é o caso do concreto do pilar e do bloco com o graute, o autor considera que a utilização de elementos de interface disponíveis na biblioteca do DIANA são mais adequados para a simulação do atrito existente entre essas duas superfícies. BANGASH (2001) considera que os elementos de interface apresentam um grande potencial nos problemas de interação solo-estrutura, discretização do concreto com armadura, atrito em ligações de estruturas de concreto pré-moldado, dentre outras situações. BARROS (2009) obteve bons resultados utilizando elementos de interface na ligação pilar-bloco de fundação.

O elemento finito de interface utilizado foi o CQ48I, que é um elemento plano, quadrilateral com função aproximadora quadrática em deslocamentos, recomendado em 
análises tridimensionais. A escolha desse elemento se deu em função da compatibilidade necessária com o elemento finito CHX60 utilizado na modelagem do concreto, já que ambos possuem oito nós em cada face. A Figura 6.2 apresenta o elemento CQ48I.

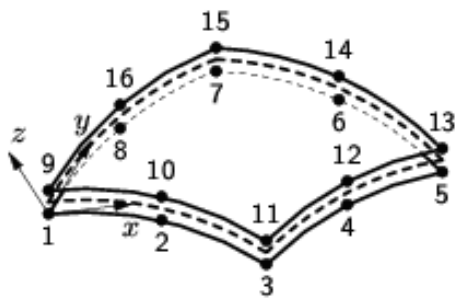

(a) topology

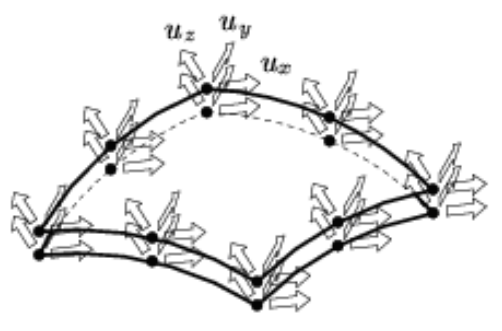

(b) displacements

Figura 6. 2- Elemento CQ48I, DIANA (2005a)

\subsubsection{Modelos constitutivos}

Sabe-se que nas estruturas de concreto armado, atingida certa intensidade de solicitação, ocorre uma redução da capacidade resistente com acréscimo significativo de deformação. Esse comportamento é chamado de strain softening, também conhecido como amolecimento do material, e ocorre tanto no comportamento à tração como à compressão.

Por causa desse efeito de amolecimento as deformações no material tendem a se apresentar de maneira mais acentuada em certas regiões da estrutura, de modo que a discretização da malha de elementos finitos nessas regiões passa a ser preponderante na qualidade dos resultados. Uma discretização mais refinada nessas regiões aumenta o tempo de processamento do problema em questão. Um modo de superar essa dificuldade é fazer uso de critérios da Mecânica da Fratura e da Mecânica do Dano, os quais estão disponiveis em modelos constitutivos do DIANA.

$\mathrm{Na}$ simulação do efeito de fratura nas estruturas de concreto armado, o DIANA dispõe de dois modelos distintos de fissuração: modelo de fissuração discreta (discrete crack model) e o modelo de fissuração distribuída (smeared crack model).

No modelo de fissuração discreta, a cada incremento de carregamento (força, pressão, deslocamento etc.) é gerada uma nova malha de elementos finitos na região de propagação da fissura, de modo a tratar a fissura de maneira mais próxima do real. Diversos autores relatam que essa discretização eleva bastante o tempo de processamento das análises, principalmente em modelos tridimensionais. Já o modelo de fissuração distribuída, considera o material 
danificado pela abertura de fissuras como meio contínuo mantendo, portanto, a discretização original da malha de elementos finitos. Em função dessa consideração, as tensões e deformações podem ser obtidas sem a necessidade de se construir uma nova malha enquanto as fissuras se propagam.

BARROS (2009) obteve resultados satisfatórios utilizando o smeared crack model em relação ao discrete crack model, por causa do tempo demandado no processamento. Desse modo, nas análises que foram realizadas no presente trabalho, foi utilizado o modelo de fissuração distribuída. Assim, os parâmetros da mecânica da fratura necessários para representação desse modelo são a energia de fraturamento na tração e na compressão $\left(\mathrm{G}_{\mathrm{f}} \mathrm{e}\right.$ $\mathrm{G}_{\mathrm{c}}$ ), as resistências à tração e à compressão, o coeficiente de retenção ao cisalhamento $\beta$ e o comprimento de banda de fissuras (crack band). SOUZA (2006) indica que em ensaios experimentais, a energia de fraturamento na compressão, $\left(\mathrm{G}_{\mathrm{c}}\right)$, apresenta valores da ordem de 50 a 100 vezes superiores à energia de fraturamento na tração, $\left(\mathrm{G}_{\mathrm{f}}\right)$. Resultados semelhantes foram confirmados nos ensaios de energia de fratura realizados por FARIAS (2008).

A energia de fraturamento, tanto na tração como na compressão, pode ser entendida como a energia necessária para causar um dano irreverssível no material. Um modo de se obter o valor do parâmetro $\mathrm{G}_{\mathrm{f}}$ é realizar um ensaio de deformação controlada e medir a área do diagrama tensão versus abertura de fissuras, como apresenta a Figura 6.3

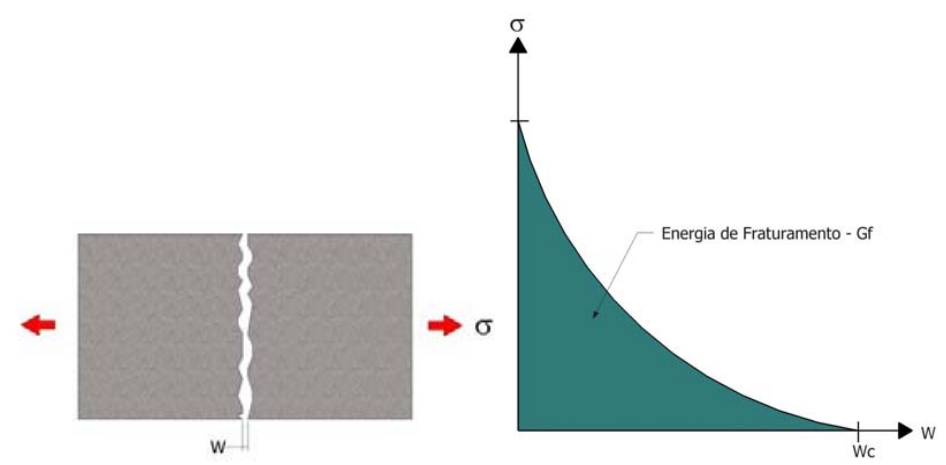

Figura 6. 3 - Energia de fraturamento na tração, FARIAS (2008)

Outro modo de obter a energia de fraturamento é estimá-la por meio de equações que realcionam essa energia com as propriedades do material. O CEB-FIP Model Code (1990) permite estimar a energia de fratura à tração $\left(\mathrm{G}_{\mathrm{f}}\right)$ definida como um parâmetro que depende da resistência média à compressão e do tamanho máximo do agregado, confomre as expressões 6.1 e 6.2 apresentadas a seguir:

$\mathrm{G}_{\mathrm{f}}=\mathrm{G}_{\mathrm{F} 0} \cdot\left(\mathrm{f}_{\mathrm{cm}} / \mathrm{f}_{\mathrm{cm} 0}\right)^{0,7}$ 
$\mathrm{f}_{\mathrm{cm}}=\mathrm{f}_{\mathrm{ck}}+8$

sendo que:

$\mathrm{G}_{\mathrm{f}} \quad$ é a energia de fratura na tração, dada em N.mm $/ \mathrm{mm}^{2}$;

$\mathrm{f}_{\mathrm{cm} 0} \quad$ é igual a $10 \mathrm{~N} / \mathrm{mm}^{2}$;

$\mathrm{f}_{\mathrm{ck}} \quad$ é a resistência característica à compressão do concreto, em N/mm²;

$\mathrm{G}_{\mathrm{f} 0}$ é um parâmetro que depende do tamanho máximo do agregado, conforme apresentado na tabela 6.1.

Tabela 6.1 - Valores de $\mathrm{G}_{\mathrm{F} 0}$ em função de $\mathrm{d}_{\text {máx }}$

\begin{tabular}{c|c}
\hline \hline $\mathbf{G}_{\mathbf{f 0}}\left(\mathbf{N m m} / \mathbf{m m}^{\mathbf{2}}\right)$ & $\mathbf{d}_{\text {máx }}(\mathbf{m m})$ \\
\hline 0,025 & 8 \\
\hline 0,030 & 16 \\
\hline 0,058 & 32 \\
\hline
\end{tabular}

O coeficiente de retenção ao cisalhamento $\beta$, por sua vez, é um parâmetro que permite reduzir o valor do módulo de elasticidade transversal do material, após iniciada a fissuração, sendo que essa redução pode ocorrer de maneira completa, constante ou variável. A influência desse parâmetro é maior em problemas cuja ruína ocorre por cisalhamento.

Por fim, o comprimento de banda de fissuras é utilizado para suprir a dependência de malha do modelo. Esse parâmetro pode ser fornecido pelo usuário, bem como calculado pelo programa, em função do tipo de elemento finito utilizado.

As expressões 6.3, 6.4 e 6.5 mostram como o comprimento de banda de fissura é calculado no DIANA para elementos bidimensionais de ordem linear, bidimensionais de ordem quadrática e elementos tridimensionais, respectivamente.

$$
\begin{aligned}
& h=\sqrt{A_{e}} \\
& h=\sqrt{2 \cdot A_{e}} \\
& h=\sqrt[3]{V_{e}}
\end{aligned}
$$


sendo que:
$\mathrm{A}_{\mathrm{e}} \quad$ é a área do elemento finito adotado;
$\mathrm{V}_{\mathrm{e}} \quad$ é o volume do elemento finito adotado;
h é o comprimento de banda de fissuras.

O modelo de fissuração distribuída descrito anteriormente indica como o programa computacional DIANA trata o efeito da fissuração em um determinado ponto da malha de elementos finitos. Todavia, é preciso compreender como o programa trata a abertura e a orientação dessas fissuras, as quais podem ser consideradas por meio de dois modelos disponíveis no programa: modelos incrementais ou plásticos e modelos Total Strain.

Os modelos incrementais ou plásticos são representados no programa computacional DIANA por meio do Multi-Directional Crack Model. Esse modelo recorre a conceitos da teoria da plasticidade, e divide a deformação em duas parcelas: uma elástica e outra plástica, sendo essa última irreverssível. A ruptura na tração ocorre quando em algum ponto do material, a máxima tensão principal de tração ultrapassa a resistência do material, enquanto que durante a compressão podem-se utilizar os modelos clássicos de ruptura de Tresca, Von Mises, Mohr-Coulomb e Drucker-Prager.

O "Multi-Directional Crack Model" permite a abertura de várias fissuras em direções diferentes num mesmo ponto da malha de elementos finitos, e apresenta vantagens no tratamento de problemas bidimensionais. Entretanto, no DIANA esse modelo só pode ser aplicado em problemas que envolvam estado plano de tensão, estado plano de deformação e em elementos axissimétricos, tendo em vista que a sua formulação não está disponível para elementos sólidos. Para essa situação, recomenda-se a utilização dos modelos Total Strain.

Os modelos Total Strain descrevem o comportamento do material na tração e na compressão baseados apenas numa relação tensão-deformação. De acordo com DIANA (2005b), esses modelos representam de maneira satisfatória os estado limites último e de serviço de estruturas de concreto armado.

O programa computacional DIANA disponibliza dois modelos Total Strain: Rotating Crack Model e Fixed Crack Model. O Rotating Crack Model, por sua vez, permite que a abertura da fissura mude de direção enquanto a mesma se propaga no material. Já o Fixed Crack Model mantém o mesmo ângulo da abertura da primeira fissura, permitindo que a mesma mude de direção apenas nos casos em que a variação do ângulo da fissura seja igual a $90^{\circ}$ em relação ao ângulo inicial. 
A entrada de dados nos modelos Total Strain envolve a definição de parâmetros básicos como o módulo de elasticidade longitudinal do material, coeficiente de Poisson, resistência à tração e à compressão. Também são definidos o comportamento do material na tração, na compressão e ao cisalhamento. O programa computacional DIANA disponibiliza diversas leis constitutivas para o comportamento dos materiais tanto à tração como à compressão. Essas leis são baseadas na energia de fraturamento, anteriormente detalhada, e podem ser observadas nas Figuras 6.4 e 6.5.

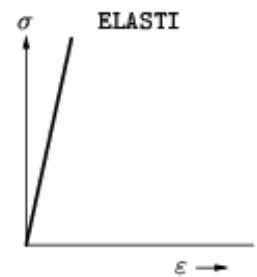

(a) elastic

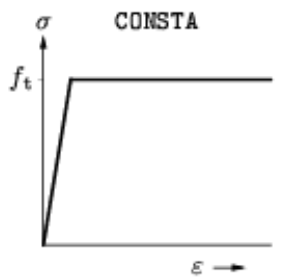

(b) ideal

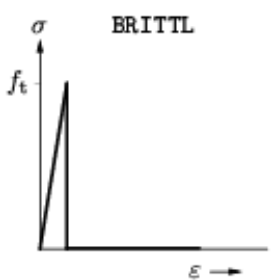

(c) brittle

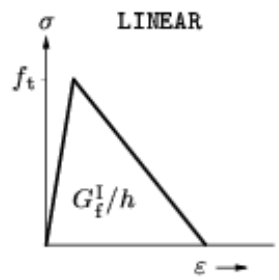

(d) linear

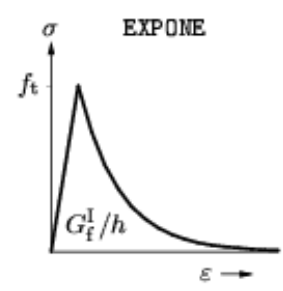

(e) exponential

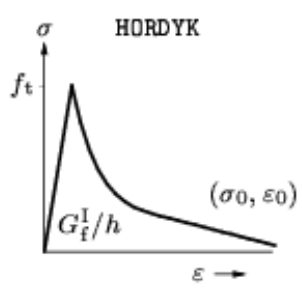

(f) Hordijk

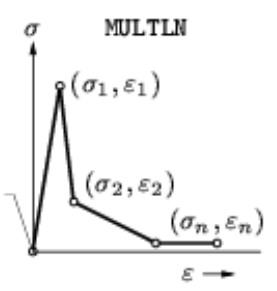

(g) multi-linear

Figura 6. 4- Modelos Constitutivos à tração pré-definidos, disponíveis em DIANA (2005b)

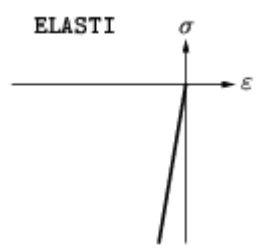

(a) elastic

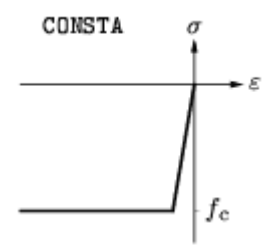

(b) ideal

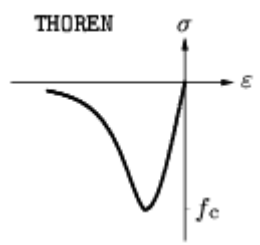

(c) Thorenfeldt

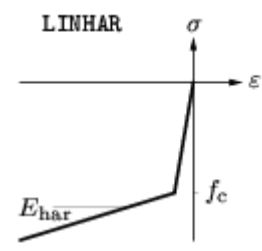

(d) linear

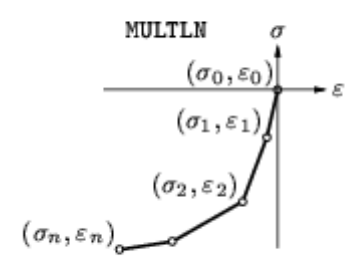

(e) multi-linear

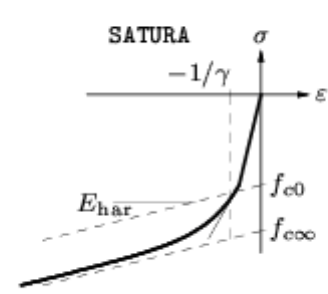

(f) saturation type

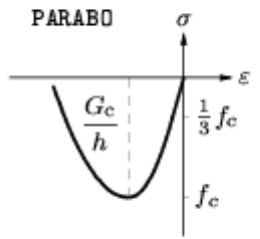

(g) parabolic

Figura 6. 5- Modelos Constitutivos à compressão pré-definidos, disponíveis em DIANA (2005b) 
Em relação ao cisalhamento, em virtude do efeito da fissuração pode ocorrer uma redução da rigidez transversal do material. Essa redução tratada no DIANA como Shear Retention é considerada por meio do coeficiente de retenção ao cisalhamento, $(\beta)$. O programa computacional DIANA disponibiliza dois modos pré-definidos para consideração desse efeito: retenção completa e retenção constante.

Na situação de retenção completa, o módulo de elasticidade transversal do material $(G)$, não sofre redução alguma. No caso de retenção constante, o usuário define um valor para o parâmetro $\beta$, que deve estar no intervalo entre 0 e 1. SOUZA (2006) indica que nos problemas em que o cisalhamento é importante no modo de ruína da estrutura, o valor de $\beta$ deve ser tomado próximo à zero, quando não, próximo à unidade. Por fim, na retenção variável o parâmetro $\beta$ é calculado como uma função da deformação das fissuras. Observa-se por meio da expressão 6.6 que quanto maior o valor do parâmetro $\beta$, maior será a rigidez transversal do material.

$$
\mathrm{D}_{\text {sec ante }}^{\mathrm{II}}=\frac{\beta}{1-\beta} \cdot \mathrm{G}
$$

O efeito lateral em virtude da fissuração e do confinamento do material também pode ser considerado nos modelos Total Strain, entretanto, não devem ser utilizados quando do uso do diagrama multi-linear para o comportamento do material à compressão. O programa computacional DIANA disponibiliza duas funções que simulam o comportamento da fissuração lateral e do confinamento do material. São elas: REDCRV e CNFCRV, respectivamente.

A função REDCRV permite que no concreto fissurado, grandes deformações ocasionadas por tração perpendicular às direções principais de compressão, reduzam a resistência à compressão do material. Para tanto, o modelo adotado no DIANA é o proposto por Vecchio e Collins, descrito em DIANA (2005b). A Figura 6.6 mostra como o programa DIANA considera essa redução. Já o aumento da resistência à compressão do material em virtude do confinamento lateral, é considerado por meio da função CNFCRV. 


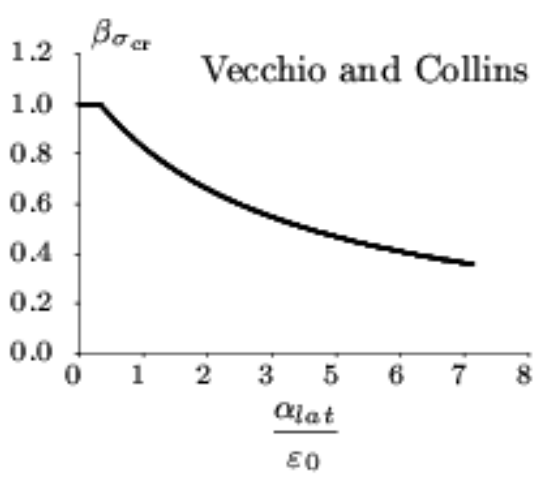

Figura 6. 6- Fator de redução devido à fissuração lateral, DIANA (2005b)

É importante destacar que esses efeitos só podem ser ativados via arquivo do tipo DAT antes do processamento, não podendo ser ativado na interface gráfica via pré-processador. Para tanto, para ativar a função REDCRV é preciso utilizar o comando VC1993 na guia referente às propriedades dos materiais, assim como para ativar a função CNFCRV, deve-se utilizar o comando VECCHI nessa mesma guia.

Tratando especificamente dos elementos de interface, o programa DIANA dispõe de modelos especiais que simulam o comportamento do material quando da utilização desses elementos. Diferentemente dos elementos sólidos, os elementos de interface descrevem o comportamento do material por meio de relações entre tensões normais e tangenciais, e de deslocamentos normais e tangenciais em uma dada interface. Dentre os diversos modelos, destacam-se os seguintes: Elasticity, Cracking, Bond-slip, Friction e Combined CrackingShearing-Crushing.

No modelo de friç̧ão a interação entre duas interfaces de uma estrutura pode ser descrito por um comportamento de fricção entre essas partes. O modelo de fricção de Coulomb, semelhante ao modelo modificado de Mohr-Coulomb descrito em CHEN (1982), pode ser utilizado para descrever esse comportamento.

No friction model A interface é tratada a partir uma certa coesão, conforme pode ser observada na Figura 6.7. Essa figura indica que num elemento pode haver tensões tangenciais correspondentes a qualquer valor de tensão normal aplicada no modelo. Nessa figura existem dois parâmetros importantes: a coesão, c, e o coeficiente de atrito, $\mu$, os quais se relacionam por meio da equação 6.7. Outro parâmetro necessário é o coeficiente de dilatância, o qual determina o crescimento das tensões normais durante o deslizamento relativo entre duas seções, quando as deformações na direção normal a essas seções são impedidas. 


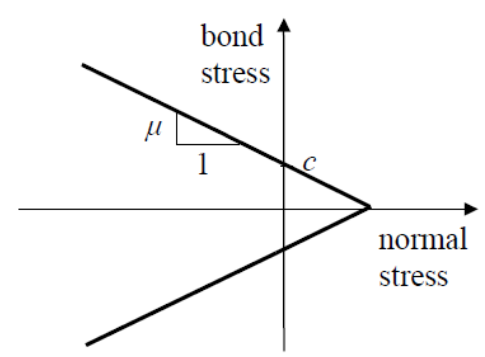

Figura 6. 7- Modelo de fricção utilizado para representar a interface entre o concreto do pilar prémoldado e o concreto do bloco.

$\tau=c+\mu \cdot\left(\sigma+\rho \cdot f_{y d}\right)$

sendo que:

c $\quad$ é a coesão do material;

$\sigma \quad$ é a tensão normal atuante na interface;

$\tau \quad$ é a tensão tangencial;

$\mu \quad$ é o coeficiente de atrito;

$\rho \quad$ é a taxa de armadura existente na seção;

$f_{y d} \quad$ é a resistência de cálculo à tração do aço.

A publicação da FIB (1998) fornece valores usuais para coesão e coeficiente de atrito entre superfícies de concretos moldados separadamente. Os valores apresentados pelo FIB (1998) dividem-se em duas categorias (DC1 e DC2), a qual considera ou não a existência de rugosidade entre as superfícies. Os valores apresentados pelo FIB (1998) apresentam-se inferiores aos obtidos experimentalmente por NISSEN et al. (1986). LUNDGREN (2003) verificou experimentalmente que os valores apresentados pelo FIB (1998), os quais estão apresentados na tabela 6.2 , representam bem o comportamento do concreto.

Tabela 6.2 - Valores de coesão e coeficiente de atrito

\begin{tabular}{c|c|c}
\hline \hline & Coesão (MPa) & Coeficiente de Atrito \\
\hline FIB (1998) DC1 & 0,29 & 0,6 \\
\hline FIB (1998) DC2 & 0,58 & 0,9 \\
\hline NISSEN et al. (1986) & 1,69 & 1,54 \\
\hline \hline
\end{tabular}


Em relação ao coeficiente de dilatância, não foram encontrados valores experimentais para esse parâmetro na literatura. LUNDGREN (2003) e BERG \& JOHANSSON (2011) verificaram que esse parâmetro não interfere significativamente no comportamento das ligações entre concretos moldados em datas diferentes. LUNDGREN (2003) testou ainda por meio de simulações numéricas a influência dos valores de rigidez elástica normal e tangencial $D_{11}$ e $D_{22}$ nas interfaces de lajes pré-fabricadas com concreto moldado in situ utilizado na capa dessas lajes. Esses parâmetros são necessários para descrever o comportamento elástico das interfaces. Os autores concluíram que para superfícies de concreto pré-moldado e concreto moldado in situ, a rigidez normal $D_{11}$ apresenta-se da ordem de 10 vezes superior ao valor da rigidez tangencial $D_{22}$. A partir das diversas análises feitas pelo pesquisador, sugere como valor de $D_{11} 1000 \mathrm{~N} / \mathrm{mm}^{3}$ e para $D_{22} 100 \mathrm{~N} / \mathrm{mm}^{3}$.

Neste trabalho não foi feito um estudo específico da ligação do pilar pré-moldado com o bloco, não sendo possível estimar experimentalmente os parâmetros necessários para simular essa ligação. Por esse motivo, nas análises dos blocos com cálices sem rugosidade em que foram utilizados elementos de interface, adotaram-se os valores sugeridos por LUNDGREN (2003) para as rigidezes normal e tangencial, e pela FIB (1998) para a coesão e coeficiente de atrito.

Em relação à simulação das barras das armaduras, existem três modos de se modelar esse componente nos programas de elementos finitos, sendo eles: barras de armaduras distribuídas, barras de armaduras embutidas e barras de armaduras discretas.

As barras de armadura do tipo distribuída consideram uma valor de área de aço distribuído numa determinada direção, ao longo dos elementos finitos que existem numa dada região.

As barras de armaduras do tipo embutidas são conhecidas também como embedded ou “incorporadas". Nessa situação, considera-se que o deslocamento na barra da armadura é igual ao do elemento finito na qual a barra se incorpora. Esses elementos são conhecidos como mother elements, e considera-se uma aderência perfeita entre as barras das armaduras e o material que representa o concreto.

Já na representação das barras das armaduras do tipo discreta, são introduzidos elementos finitos uniaxiais nas interfaces dos demais elementos, e têm-se a opção de simular a aderência entre o concreto e o aço por meio de elementos de interface. Nessa situação, é preciso coincidir os nós dos elementos uniaxiais com os demais elementos ao seu redor. 
No programa computacional DIANA, as armaduras podem ser discretizadas dos dois primeiros modos anteriormente descritos, desde que sejam utilizados elementos do tipo reinforcement. Para inserção desses elementos, é preciso conhecer apenas o ponto inicial e final da barra da armadura, independente se esse ponto coincide ou não com algum nó de um elemento finito.

O modelo constitutivo adotado para as barras das armaduras de aço geralmente é o elasto-plástico perfeito com critério de ruptura de Von Mises. Na etapa inicial, considerou-se como tensão última das barras de aço o valor de $500 \mathrm{MPa}$. Na segunda etapa, utilizaram-se os resultados obtidos dos ensaios uniaxiais e o comportamento adotado foi igual tanto na tração quanto na compressão.

\subsubsection{Pré e pós-processamento}

O programa computacional DIANA conta com um pré-processador, na qual o usuário pode definir a geometria, as ações, condições de contorno e as propriedades físicas e mecânicas dos materiais. Esse pré-processador é chamado de iDIANA, sendo que ao iniciar um novo arquivo, o usuário precisa definir as unidades as quais serão utilizadas pelo programa.

O iDIANA permite também que o usuário forneça um script contendo todos os comandos necessários para a criação do modelo. O uso de scripts é bastante comum entre usuários de programas de elementos finitos, uma vez que facilita a criação do modelo, bem como permite alterações nos modelos sem a necessidade de se utilizar o pré-processador.

Com o intuito de otimizar a criação dos diversos modelos de blocos sobre duas estacas, foi adotada uma rotina desenvolvida por BARROS (2009), na qual o usuário fornece os dados geométricos do bloco, das estacas e do pilar. O usuário precisa fornecer também dados relativos às propriedades físicas e mecânicas dos materiais, bem como ações e condições de contorno. Por meio dessas informações, é gerado então um script que é lido pelo iDIANA, gerando assim o modelo pronto para ser processado. Ao longo do doutorado essa rotina precisou ser adaptada devido a mudanças nos comandos sofridas pelo programa ao longo de suas versões, bem como modificações na geometria dos modelos. Para elaboração dessa rotina, optou-se por utilizar uma planilha eletrônica por causa das facilidades operacionais e experiência adquirida anteriormente pelo autor. 
Após a criação do modelo no iDIANA, é preciso criar o arquivo com extensão .DAT, o qual contém todas as informações relativas ao modelo, e que será processado pelo programa principal chamado DIANA. No DIANA o usuário fornece informações relativas ao tipo de análise que será realizada, bem como informações a respeito do processamento, critérios de convergência, método de resolução do sistemas de equações não-lineares, arquivos de saída, podendo ser em formato gráfico ou em listagens, dentre outras opções.

O DIANA dispõe de diversos métodos que podem ser aplicados como estratégia na resolução dos sistemas de equações não-lineares, dentre os quais destacam-se o método de Newton-Raphson Regular, Newton-Raphson Modificado, Quasi-Newton (Método Secante) e Método da Rigidez Linear.

A estratégia de Newton-Raphson é uma estratégia incremental-iterativa, na qual se imagina que o resíduo gerado entre duas iterações consecutivas, possa ser considerado contínuo na vizinhança da solução. Assim, supõe-se que numa dada iteração $r$ o resíduo em relação à iteração $r-1$ seja nulo e, portanto, possa ser escritos em termos da série de Taylor. Tomando-se a hipótese de que a "função resíduo" tenha uma variação suave, é possível admiti-la até o termo de primeira ordem da série de Taylor. Nota-se que essa condição considera que a força aplicada na estrutura não varia com os deslocamentos, o que é condizente com a condição de forças conservativas. Além do uso de iterações, é comum em uma análise não-linear dividir as ações em várias etapas de carga, de modo que para cada etapa são realizadas várias iterações até que haja convergência do problema, definindo, portanto, uma estratégia incremental-iterativa.

A estratégia incremental-iterativa de Newton-Raphson busca calcular um incremento nos deslocamentos em cada etapa de carga. Para tanto, a cada iteração é preciso atualizar a matriz de rigidez, sendo nesse caso, denominada matriz de rigidez tangente. A utilização da matriz tangente em cada iteração é o que define o método de Newton-Raphson Regular, que exige tempo computacional significativo, porém apresenta convergência com poucas iterações.

$\mathrm{Na}$ estratégia incremental-iterativa de Newton-Raphson Modificado, a matriz de rigidez tangente é calculada apenas na primeira iteração de cada incremento de força ou deslocamento, e mantida constante nas iterações seguintes. Assim, nas demais etapas a matriz de rigidez utilizada passa a ser uma matriz secante. Esse processo demanda um número maior de iterações, e por isso, costuma convergir mais lentamente em relação ao método de NewtonRaphson regular. 
O método secante ou Quasi-Newton, por sua vez, não necessita da atualização da matriz de rigidez em cada iteração, utilizando também uma matriz de rigidez secante. Entretanto, baseia-se na solução prévia dos vetores de forças não balanceados, para obter uma melhor aproximação durante a aplicação dos incrementos de força ou deslocamento. Por fim, o método da rigidez linear é recomendado apenas quando nenhum dos métodos anteriores apresentarem boas soluções. BARROS (2009) realizou testes utilizando os métodos apresentados anteriormente, e concluiu que nas simulação de blocos sobre duas estacas, o método de Newton-Raphson regular fornece melhores resultados em relação aos demais.

$\mathrm{Na}$ resolução de sistemas de equações não-lineares, é comum a ocorrência de problemas que podem dificultar a convergência de determinadas soluções. Para suprir esse quesito, o programa DIANA dispõe de alguns recursos como o critério line search e o critério de arc length control. O critério de line search busca um multiplicador ótimo para os incrementos de deslocamentos, de modo a acelerar a convergência das soluções. Já o critério de arc length control é extremamente útil na busca do comportamento pós-pico das estruturas. Cabe ressaltar que o programa DIANA não permite a utilização do critério de comprimento de arco quando a ação aplicada for em controle de deslocamentos.

Ainda no DIANA, é preciso optar pela forma como as ações são aplicadas na estrutura. Para isso, o usuário pode optar por aplicar passos de carga pré-definidos, cuja intensidade do passo é dada por uma porcentagem da ação total aplicada no modelo. Outra maneira de aplicar o carregamento é utilizando um procedimento chamado de iteration based sizes. Esse procedimento permite que o tamanho dos passos de carga seja variável ao longo da análise, sendo assim, o usuário fornece o valor do passo de carga inicial, e valores para o tamanho máximo e mínimo de cada passo no decorrer da análise. Esse procedimento permite uma análise não-linear mais rápida, porém, ao descrever a trajetória de equilíbrio de uma estrutura, a análise fornece pontos distantes entre si.

Em relação aos critérios de convergência, o DIANA dispõe de critérios baseados em normas (módulo) de força, deslocamento, energia e resíduos, todos esses comparados com um valor máximo de erro fornecido pelo usuário. Destaca-se nesse quesito o critério de convergência baseado em norma de energia, utilizado nas análises do presente trabalho. Esse critério é baseado no trabalho das forças internas presentes na estrutura, conforme a expressão 6.8 . 


$$
E=\left|\frac{\delta u_{i}^{T} \cdot\left(f_{\text {int }, i+1}+f_{\text {int }, i}\right)}{\Delta u_{0}^{T} \cdot\left(f_{\text {int }, 1}+f_{\text {int }, 0}\right)}\right|
$$

É importante notar que no cálculo da norma em termos energéticos, são utilizadas forças internas, e não forças externas. De acordo com DIANA (2005b), o uso de forças externas poderia conduzir a resultados incoerentes, quando do uso do critério de line search. Segundo SOUZA (2006), o critério de convergência baseado em energia é mais interessante, pois considera simultaneamente o efeito das forças e dos deslocamentos. $\mathrm{O}$ autor conseguiu bons resultados em suas análises adotando tolerância de $1 \%$ em termos energéticos.

Por fim, o usuário pode configurar a saída de dados do programa, por meio de listagens, ou arquivos do tipo femview. Os arquivos em listagens são de grande utilidade, uma vez que com eles pode-se obter apenas dados específicos, como por exemplo, deslocamentos ou tensões em determinados pontos da estrutura. Para tanto, é preciso que o usuário defina um set na criação do modelo, que nada mais é do que um agrupamento de entidades geométricas, podendo ser composta de pontos, linhas, superfícies ou bodys. Os resultados em listagens só podem ser fornecidos em relação a determinado set.

Os resultados em modo femview, por suas vezes, podem ser visualizados novamente utilizando o programa iDIANA. É nesse tipo de arquivo que podem ser obtidas imagens dos panoramas de fissuração, distribuição de tensões e deformações, campos de deslocamentos, entre outros.

\subsection{Análise paramétrica}

Com o intuito de aprimorar o modelo utilizado nas análises numéricas, foi desenvolvida uma análise paramétrica complementar a realizada por BARROS (2009) para blocos sobre duas estacas. Das análises de BARROS (2009) aproveitaram-se os seguintes resultados: As ações foram aplicadas em forma de pressão no topo do pilar, sendo utilizado o método de Newton-Raphson Regular para solução do sistema de equações não lineares. O critério de convergência adotado em norma de energia, com tolerância de 1\%, modelo de fissuração distribuída com uso do fixed crack model e número máximo de 50 interações. 
$\mathrm{Na}$ análise paramétrica desenvolvida no presente trabalho, foram estudadas as seguintes variáveis: Influência do coeficiente de retenção ao cisalhamento, $(\beta)$, influência do tipo de elemento finito sólido utilizado nas análises, influência da malha nos resultados e no tempo de processamento, e influência do número de subdivisões da força aplicada nas etapas de carregamento. A realização dessas análises se deu após os ensaios experimentais, e teve como base os resultados da curva força versus deslocamento médio nos modelos. São apresentados a seguir os resultados obtidos com base no modelo experimental M1.

O coeficiente de retenção ao cisalhamento, $(\beta)$ já foi estudado por BARROS (2009). Porém, como o mesmo autor encontrou resultados divergentes em relação ao valor de $\beta$ nas simulações de blocos sobre quatro estacas dos ensaios realizados por CHAN \& POH (2009), optou-se por proceder novamente a essa análise. Constatou-se que a medida que o valor do parâmetro $\beta$ diminui, a capacidade resistente do modelo numérico tende a diminuir. Isso ocorre porque a rigidez transversal dos elementos diminui, e os efeitos das tensões tangenciais passam a ser cada vez mais preponderantes no comportamento estrutural do elemento. Em blocos de fundação tidos como rígidos, o efeito do cisalhamento tende a ser desconsiderado. O próprio modelo de bielas e tirantes aplicado a blocos rígidos não considera o efeito do cisalhamento. Por esse motivo, entende-se que nas simulações de blocos sobre duas estacas, o valor utilizado para o parâmetro $\beta$ deve ser próximo a unidade.

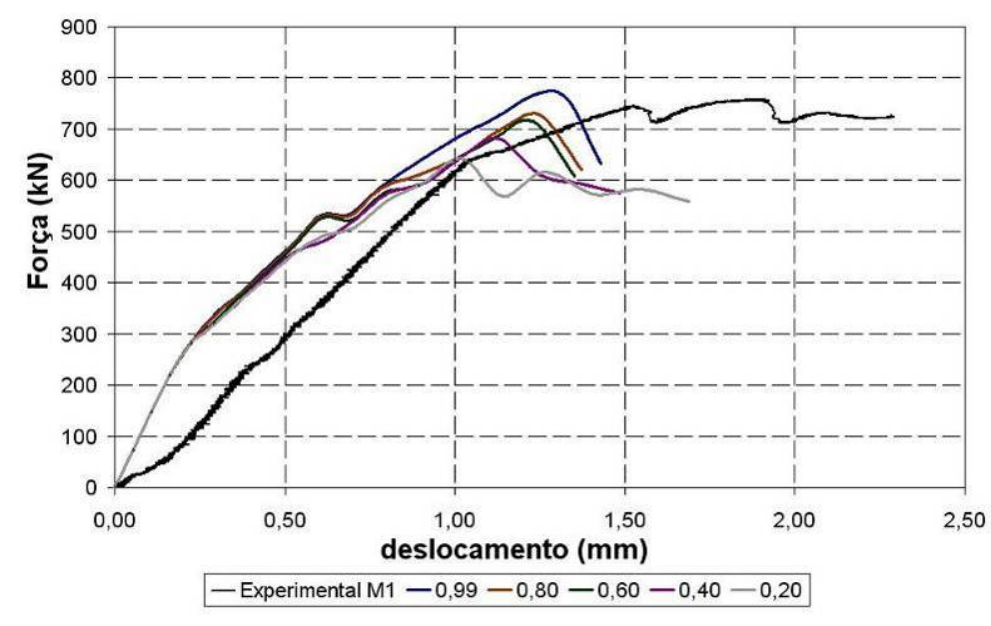

Figura 6. 8 - Influência do coeficiente de retenção ao cisalhamento $\beta$

Observa-se por meio da Figura 6.8 as curvas força versus deslocamento obtidas no ensaio experimental do modelo M1, comparadas com diversos valores de $\beta$. Observa-se que os valores de $\beta$ igual a 0,60 e 0,80 apresentaram forças últimas semelhantes. Comparando ao resultado experimental, observou-se que a força última estava mais próxima da obtida com $\beta$ 
igual a 0,99 . Verifica-se ainda que os modelos numéricos apresentaram rigidez superior a obtida no ensaio experimental. Avaliando apenas o parâmetro $\beta$, considera-se para as análises seguintes o valor de 0,99 .

O tipo de elemento finito sólido também foi considerado na análise paramétrica, sendo considerados os três tipos de elementos sólidos apresentados no item 6.2.1; HX24L com aproximação linear em deslocamentos; CHX60 com aproximação quadrática em deslocamentos; e CHX96 com aproximação cúbica em deslocamentos. Apesar da recomendação da não utilização do elemento HX24L nas análises não lineares, foram encontrados na literatura alguns trabalhos que utilizaram esse elemento, e que apresentaram resultados coerentes.

Destaca-se que o elemento HX24L necessita de apenas dois nós em cada aresta para

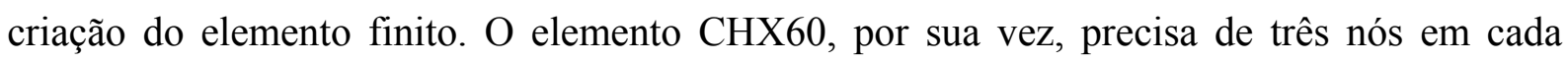
aresta, enquanto que o elemento CHX96 necessita de quatro nós em cada aresta. Na definição dos nós no DIANA, é preciso informar na entrada de dados o número de divisões de cada linha. Isso implica na obrigatoriedade de se ter um número de divisões par para utilização do elemento CHX60, e um número de divisão múltiplo de três para o elemento CHX96.

A Figura 6.9 apresenta as curvas força versus deslocamento obtidas para o modelo M1. Verifica-se que ao utilizar o elemento HX24L a força máxima suportada pelo modelo ficou muito distante do resultado experimental. O Modelo com elementos CHX96 apresentou rigidez levemente superior a do modelo com elemento CHX60, porém apresentou força última cerca de 15\% inferior. Ambos os modelos apresentaram perda de rigidez próxima aos $500 \mathrm{kN}$, sendo que dentre os três elementos analisados, o modelo com elemento CHX60 foi o que apresentou resultados mais próximos do resultado experimental.

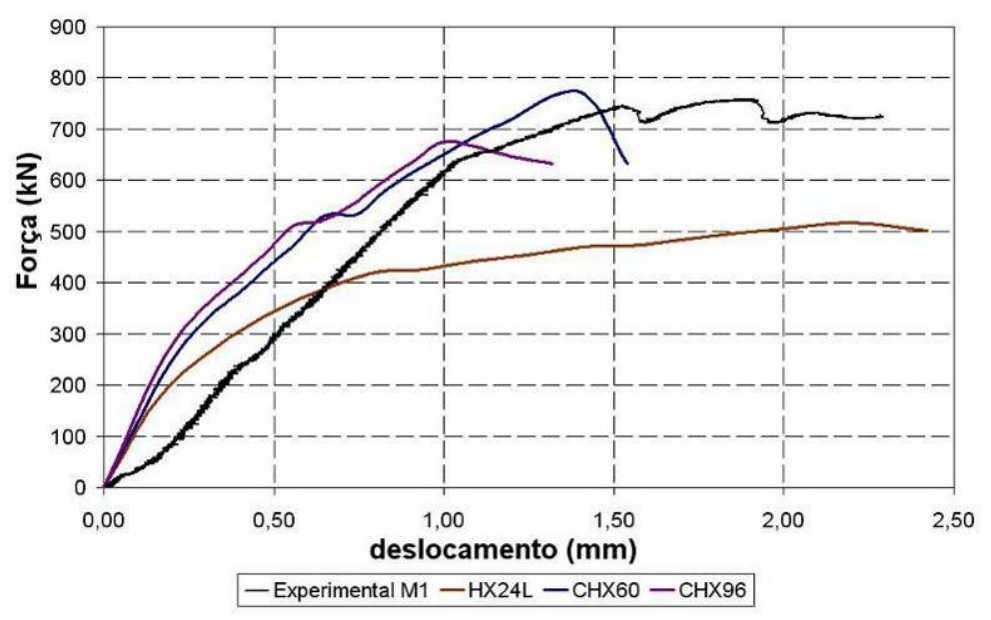

Figura 6. 9 - Influência do tipo de elemento finito 
A discretização da malha de elementos finitos também foi considerada. Apresentam-se os resultados de quatro malhas de elementos finitos, nas quais foram utilizadas o elemento CHX60. Foram variados o tamanho das divisões das linhas, isto é, a distância entre os nós, sendo considerados os valores de $12,5 \mathrm{~mm}, 25 \mathrm{~mm}, 37,5 \mathrm{~mm}$ e $50 \mathrm{~mm}$. Apresenta-se na Figura 6.10 os resultados das curvas força versus deslocamento para as malhas analisadas.

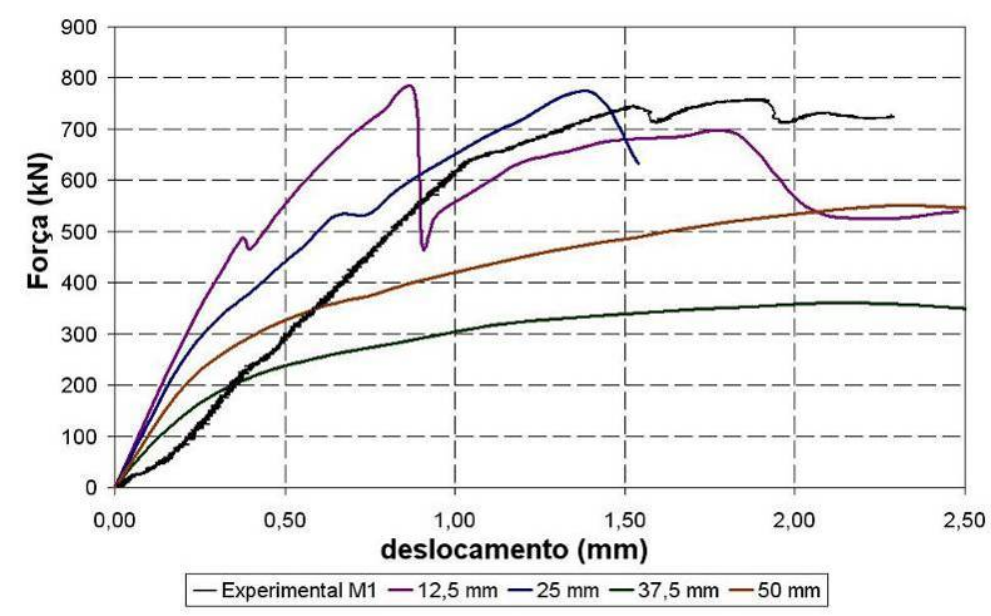

Figura 6. 10 - Influência da malha de elementos finitos

Verifica-se por meio da figura 6.10 que as malhas de $37,5 \mathrm{~mm}$ e $50 \mathrm{~mm}$ apresentaram força última inferior a obtida no ensaio experimental. A malha de $12,5 \mathrm{~mm}$ apresentou força última equivalente a obtida com a malha de $25 \mathrm{~mm}$, porém com deslocamentos menores. Observa-se uma queda considerável na força última próxima aos $770 \mathrm{kN}$ até atingir uma força de $480 \mathrm{kN}$, quando o modelo volta a apresentar ganho de resistência.

A malha de elementos finitos, por sua vez, interfere diretamente na quantidade de nós e elementos, o que eleva consideravelmente o tempo de processamento dos modelos. Esse aumento, por sua vez, não é linear, tendo em vista que se trata de problemas tridimensionais. Apresenta-se na tabela 6.3 um resumo com o número de nós, número de elementos e o tempo de processamento para as malhas avaliadas. Todas as análises foram feitas no mesmo computador, sendo utilizado um processador Pentium Core i5, com 8 GB de memória RAM.

Verifica-se nessa tabela que a malha de elementos finitos com divisão de $12,5 \mathrm{~mm}$ conduz a uma quantidade maior de nós e elementos, o que torna o tempo de processamento cerca de 42 vezes mais demorado em relação a malha de $25 \mathrm{~mm}$. Como essa duas malhas conduziram a resultados próximos de força última, optou-se por utilizar a malha de $25 \mathrm{~mm}$. 
Tabela 6.3 - Estudo do tamanho das malhas

\begin{tabular}{c|c|c|c}
\hline \hline Divisão (mm) & $\begin{array}{c}\text { Número de } \\
\text { Nós }\end{array}$ & $\begin{array}{c}\text { Número de } \\
\text { Elementos }\end{array}$ & $\begin{array}{c}\text { Tempo de } \\
\text { processamento }\end{array}$ \\
\hline 50 & 2245 & 324 & $01 \mathrm{~h} 00 \mathrm{~m} 30 \mathrm{~s}$ \\
\hline 37,5 & 3461 & 504 & $2 \mathrm{~min} 33 \mathrm{~s}$ \\
\hline 25 & 7354 & 1388 & $31 \mathrm{~min} 25 \mathrm{~s}$ \\
\hline 12,5 & 40985 & 8888 & $08 \mathrm{hr} 01 \mathrm{~min} 06 \mathrm{~s}$ \\
\hline \hline
\end{tabular}

O último parâmetro analisado foi o número de subdivisões da força aplicada nas etapas de carregamento. Consideraram-se quatro porcentagens de carregamento em relação a força total aplicada no modelo para definição do tamanho de cada etapa de carga: $2 \%, 5 \%, 10 \%$ e $20 \%$. A pressão aplicada no topo do pilar foi igual a $14,5 \mathrm{~N} / \mathrm{mm}^{2}$, o que conduz a uma força de $326,25 \mathrm{kN}$, força essa utilizada no dimensionamento dos modelos.

Em teoria, o tamanho do passo de carga não deveria alterar a curva força versus deslocamento, tendo em vista que nas etapas iniciais, antes da ocorrência de fissuração, o concreto encontra-se em regime elástico e linear. De fato, na etapa inicial da curva verifica-se uma sobreposição das curvas, conforme pode ser observado na Figura 6.11. Todavia, ao iniciar a fase não linear, o tamanho do passo modifica a curva força versus deslocamento.

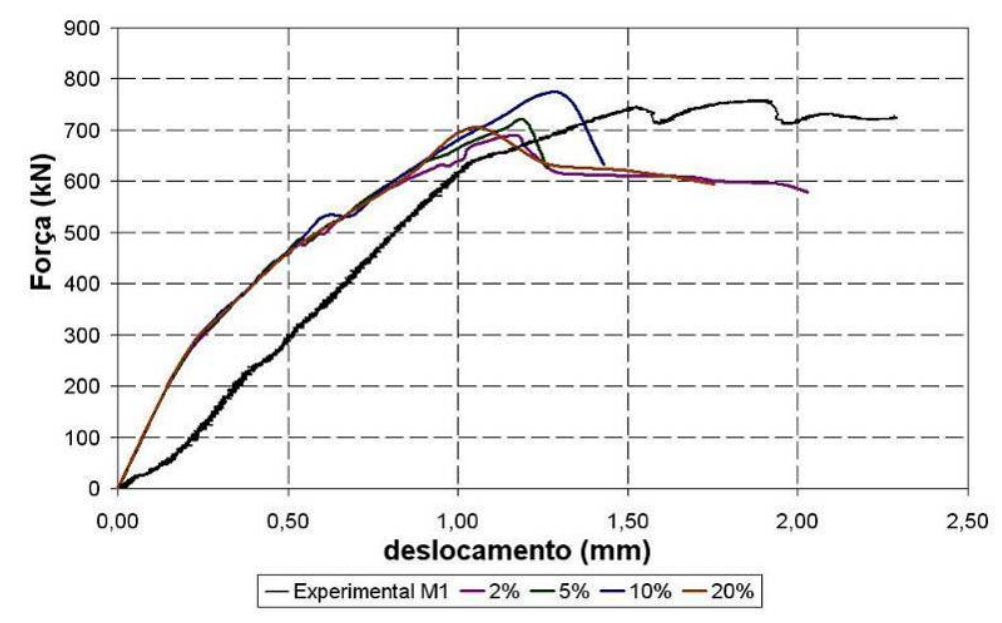

Figura 6. 11 - Influência da subdivisão de força aplicada

Observa-se que o passo de $20 \%$ foi o que apresentou menor força última. Os passos de $2 \%$ e $5 \%$ apresentaram força última semelhante, porém distante da força última obtida no 
ensaio experimental. Assim, considerou-se como valor de referência o valor de $10 \%$ da força máxima aplicada em cada etapa de carregamento.

Portanto, após a finalização da análise paramétrica e com os resultados obtidos da análise de BARROS (2009), obtiveram-se os dados necessários para processamento dos demais modelos no DIANA, os quais serão apresentados nos próximos itens. A tabela 6.4 apresenta um resumo das propriedades e dos modelos constitutivos utilizados na modelagem.

Tabela 6.4 - Parâmetros relativo as análises

\begin{tabular}{|c|c|}
\hline Parâmetro & Valor \\
\hline Coeficiente de retenção ao cisalhamento, $\beta$ & 0,99 \\
\hline Elemento sólido para concreto & CHX60 \\
\hline Elemento para armadura & reinforcements \\
\hline Elemento para interface & CQ48I \\
\hline Método de resolução do sistema de equações & Newton-Raphson regular \\
\hline Modelo constitutivo do concreto & $\begin{array}{c}\text { Total Strain, } \\
\text { smeared crack, fixed crack }\end{array}$ \\
\hline Modelo constitutivo do aço & Von Mises \\
\hline Critério de convergência & Energia, $1 \%$ \\
\hline Subdivisão da malha & $25 \mathrm{~mm}$ \\
\hline Subdivisão da força & $10 \%$ \\
\hline Modelo para interface & friction \\
\hline Energia de fratura a tração, $\mathrm{G}_{\mathrm{f},}$ (pilar) & $0,08691 \mathrm{~N} / \mathrm{mm}$ \\
\hline Energia de fratura a compressão, $\mathrm{G}_{\mathrm{c}}$ (pilar) & $4,35 \mathrm{~N} / \mathrm{mm}$ \\
\hline Energia de fratura a tração, $\mathrm{G}_{\mathrm{f}, \text { (estaca) }}$ & $0,12692 \mathrm{~N} / \mathrm{mm}$ \\
\hline Energia de fratura a compressão, $\mathrm{G}_{\mathrm{c}}($ estaca) & $6,35 \mathrm{~N} / \mathrm{mm}$ \\
\hline Energia de fratura a tração, $\mathrm{G}_{\mathrm{f}}$, (graute) & $0,1197 \mathrm{~N} / \mathrm{mm}$ \\
\hline Energia de fratura a compressão, $\mathrm{G}_{\mathrm{c}}$ (graute) & $5,99 \mathrm{~N} / \mathrm{mm}$ \\
\hline Energia de fratura a tração, $\mathrm{G}_{\mathrm{f},}(\mathrm{bloco})$ & $0,08069 \mathrm{~N} / \mathrm{mm}$ \\
\hline Energia de fratura a compressão, $\mathrm{G}_{\mathrm{c}}$ (bloco) & $4,03 \mathrm{~N} / \mathrm{mm}$ \\
\hline
\end{tabular}




\subsection{Modelos analisados numericamente}

\subsubsection{Ações e condições de contorno}

Em relação a aplicação das ações e das condições de contorno, as simulações numéricas realizadas neste trabalho buscaram reproduzir fielmente os ensaios realizado em laboratório. Como no ensaio experimental a força oriunda da máquina foi transmitida ao topo do pilar por meio de uma placa metálica cuja área era superior área da seção transversal do pilar, optou-se por aplicar a ação em forma de pressão distribuída na área do pilar, e não utilizar uma força concentrada.

Quanto as condições de vinculação da estaca, BARROS \& GIONGO (2012) desenvolveram um estudo em blocos de fundação sobre duas estacas, cuja variável principal foi a condição de vinculação da estaca, sendo consideradas as situações de restrição ao deslocamento nas três direções na base da estaca, e também a condição de apenas restrição vertical da base da estaca. Nessa última situação, é preciso restringir ao menos um nó do modelo quanto as outras duas direções, a fim de não tornar o modelo hipostático.

Verificou-se que a influência do tipo de vinculação atribuído à estaca apresenta influência considerável no comportamento e na distribuição de tensões nas estacas, porém pouco influencia no comportamento do bloco de fundação, estando os resultados de tensões principais no bloco, força última e tensões nas barras da armadura principal do tirante muito próximos para as duas situações de restrições analisadas.

Nos ensaios experimentais foram feitas medidas dos deslocamentos laterais próximo a região inferior da base da estaca, por meio do transdutor T5. Verificou-se que na maior parte dos ensaios o deslocamento medido com esse transdutor manteve-se constante com valor próximo a 0,05 $\mathrm{mm}$, apresentando acréscimos de deslocamentos que chegaram ao valor máximo de $0,5 \mathrm{~mm}$ próximo a ruína do modelo. Apesar dos pequenos valores de deslocamento registrados nos ensaios experimentais, optou-se por restringir os apoios na base das estacas na direção vertical, e restringir um dos nós centrais do bloco nas outras duas direções. A Figura 6.12 (a) apresenta ilustra a aplicação da pressão sobre a região superior do pilar, enquanto que a Figura 6.12 (b) apresenta a condição de contorno utilizada nas estacas. 


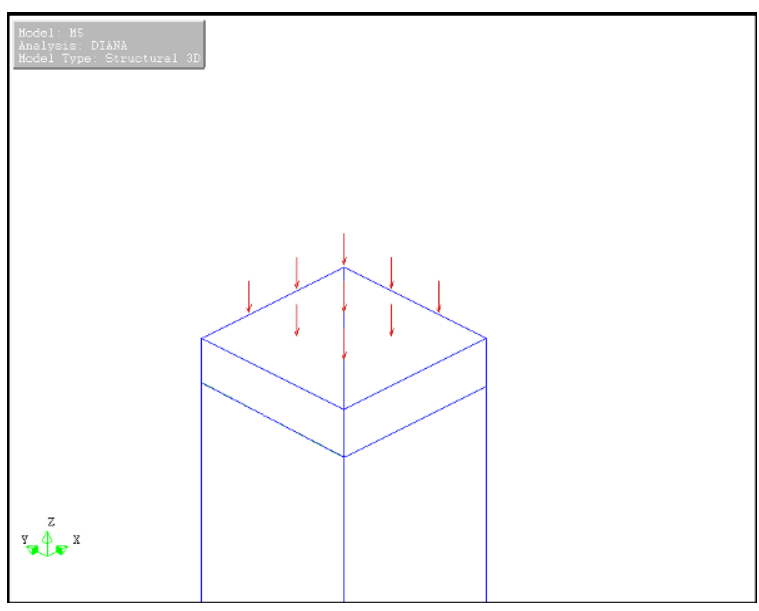

(a)

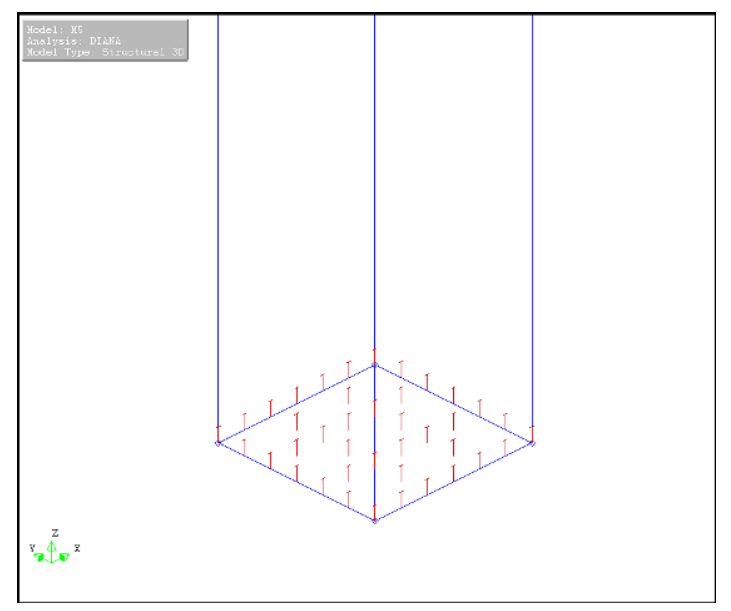

(b)

Figura 6. 12 - Aplicação da ação em forma de pressão e condições de contorno na estaca

OLIVEIRA (2013) realizou simulações numéricas em blocos de fundação sobre 5 e 6 estacas. O autor considerou em suas análises a existência de um coeficiente de reação vertical aplicado na base das estacas, simulando a deslocabilidade do solo sob as estacas. Neste trabalho não foi considerado a existência de molas, pois o intuito da simulação numérica era reproduzir os ensaios ocorridos no laboratório. Considerando a rigidez da máquina de ensaio com a do modelo, pode-se assumir que o coeficiente de reação vertical terá um valor elevado que se aproxima da idealização de um apoio rígido.

\subsubsection{Geometria dos modelos}

Os modelos numéricos visaram reproduzir os ensaios realizados em laboratório. Sendo assim, a geometria dos modelos foi a mesma utilizada nos ensaios experimentais. Apresentase nas Figuras 6.13 a 6.16 uma vista frontal e uma perspectiva dos modelos da série sem rugosidade, enquanto que as Figuras 6.17 a 6.20 apresentam a vista frontal e a perspectiva dos modelos da série com rugosidade.

Em relação aos modelos com armadura complementar, a única diferença em relação aos demais foi a existência dessa armadura, de modo que a visualização externa dos modelos com e sem armadura complementar é a mesma. Do mesmo modo, os modelos M3 e M10 que apresentam maior área de armadura principal não apresentam diferenças na geometria. Portanto, devido a semelhança externa desses modelos, não apresentam-se os modelos M3, M5, M7, M10, M12 e M14. 
Simulação numérica

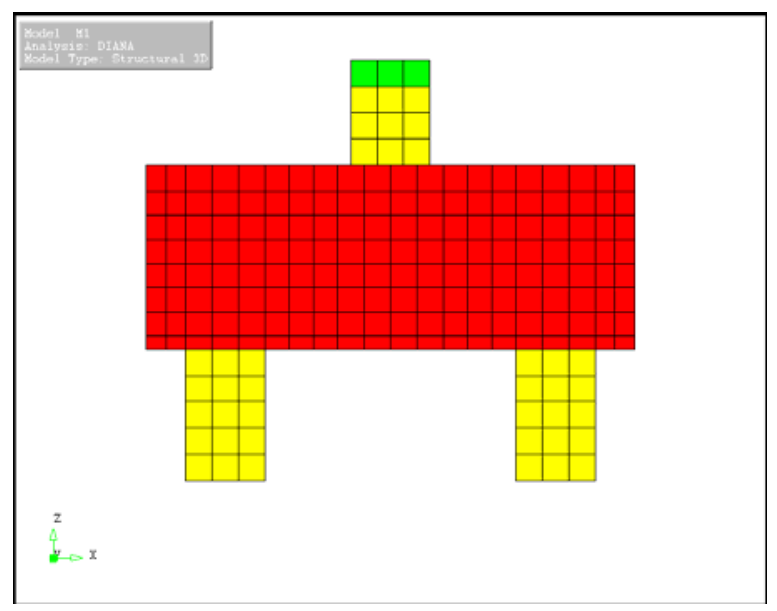

(a)

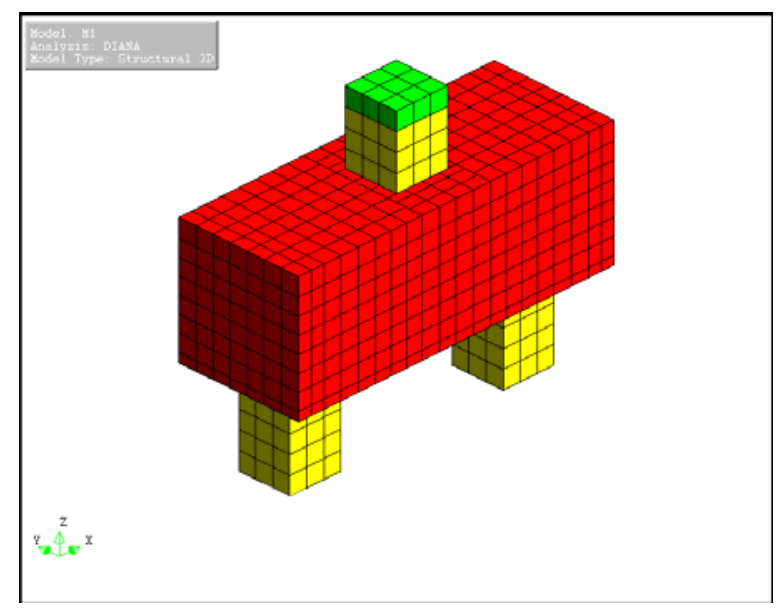

(b)

Figura 6. 13 - Vista frontal e perspectiva do modelo M1

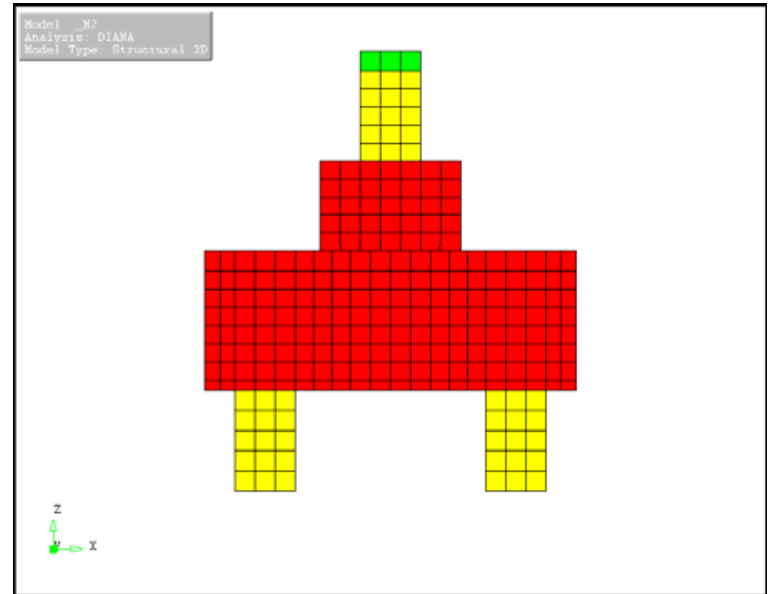

(a)

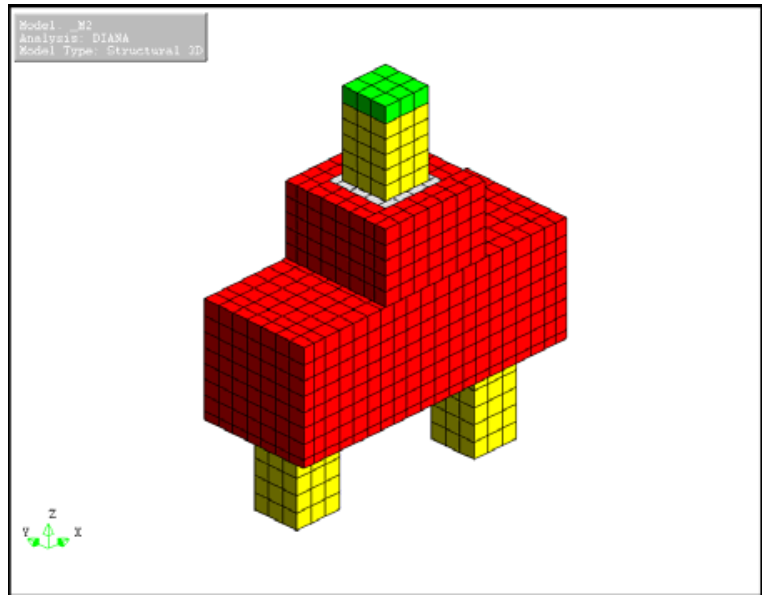

(b)

Figura 6. 14 - Vista frontal e perspectiva do modelo M2

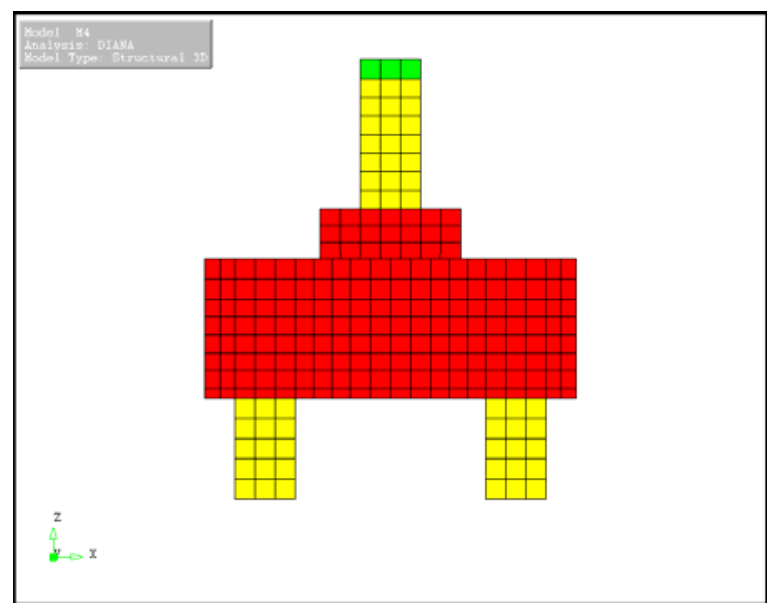

(a)

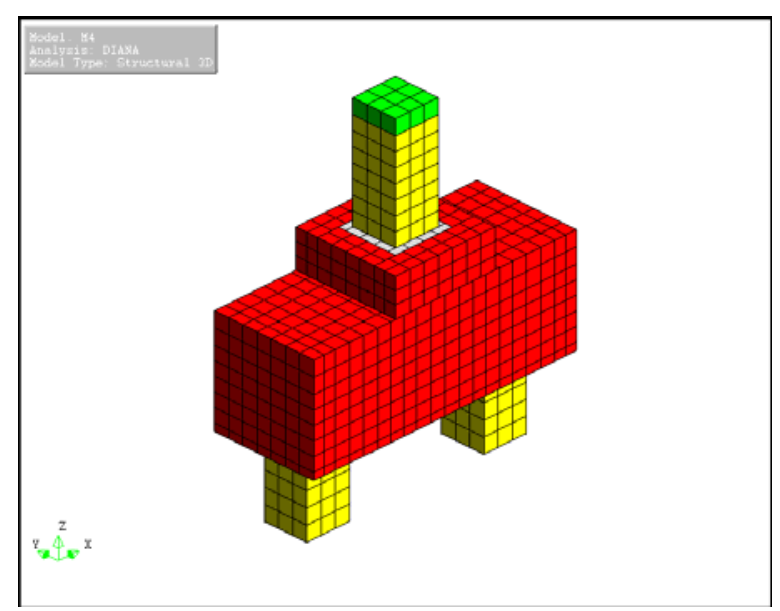

(b)

Figura 6. 15 - Vista frontal e perspectiva do modelo M4 


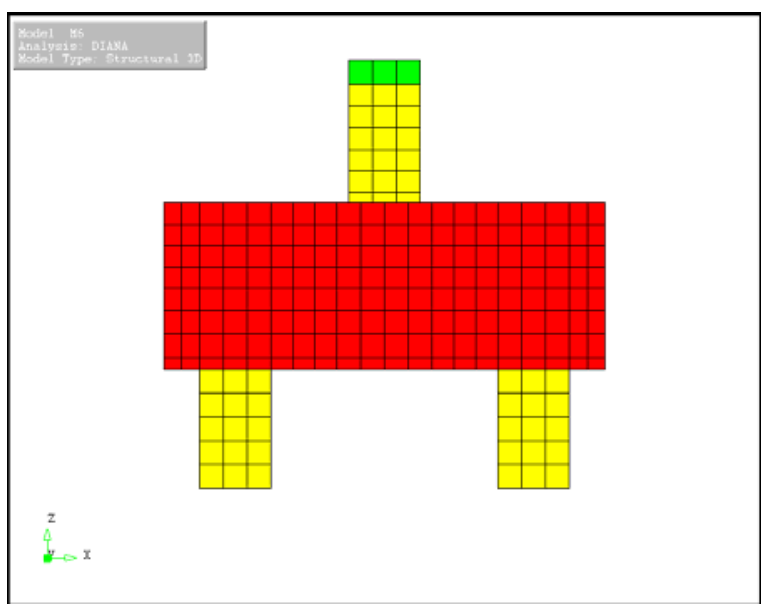

(a)

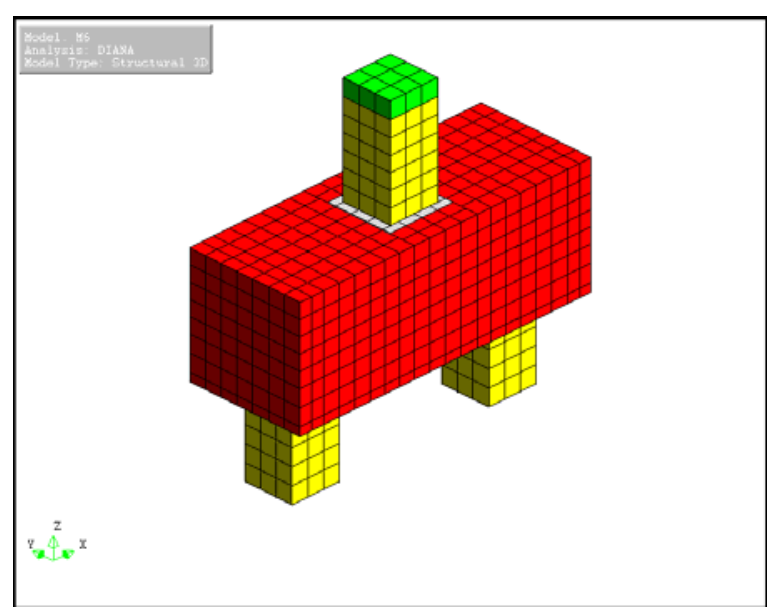

(b)

Figura 6. 16 - Vista frontal e perspectiva do modelo M6

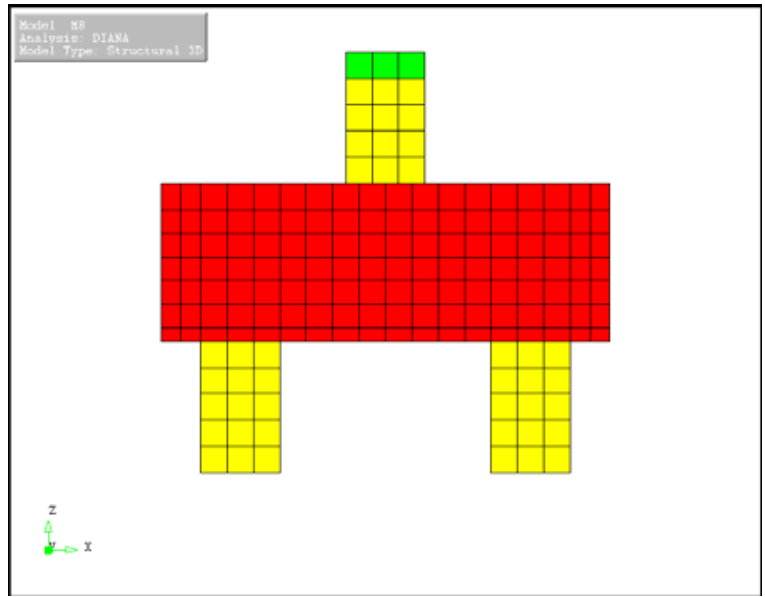

(a)

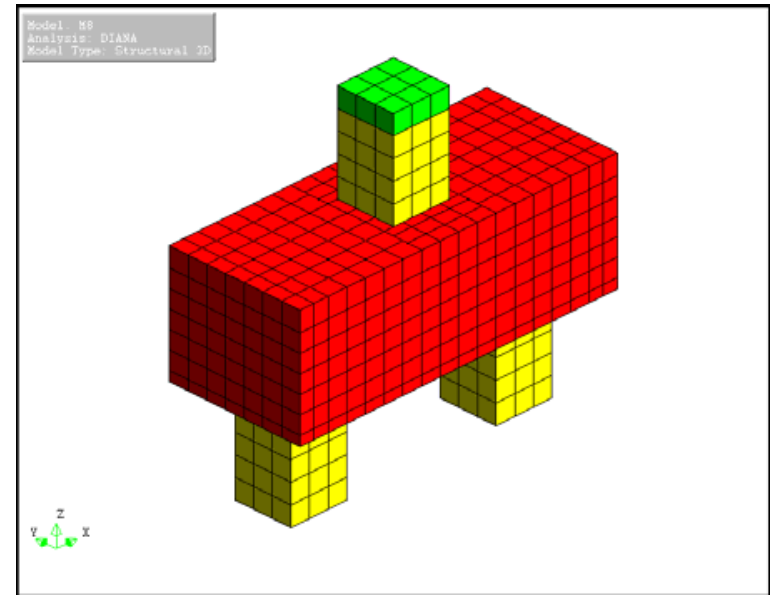

(b)

Figura 6. 17 - Vista frontal e perspectiva do modelo M8

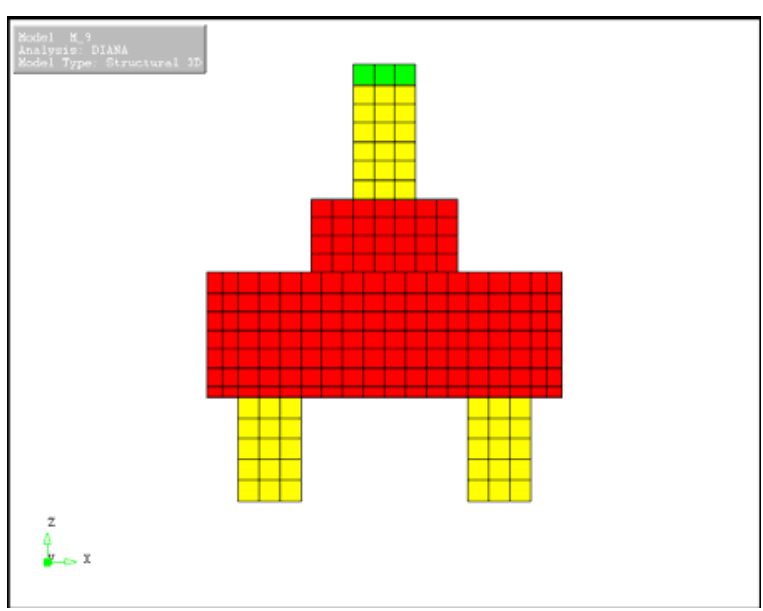

(a)

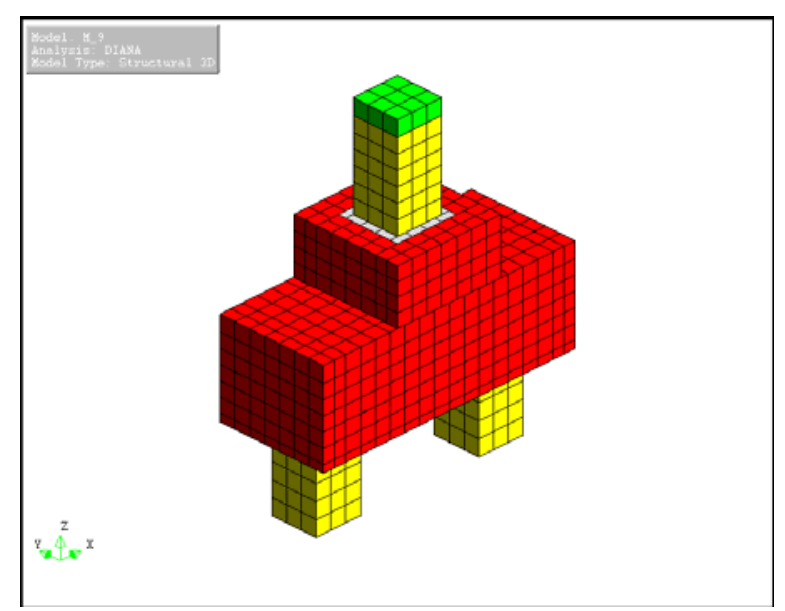

(b)

Figura 6. 18 - Vista frontal e perspectiva do modelo M9 


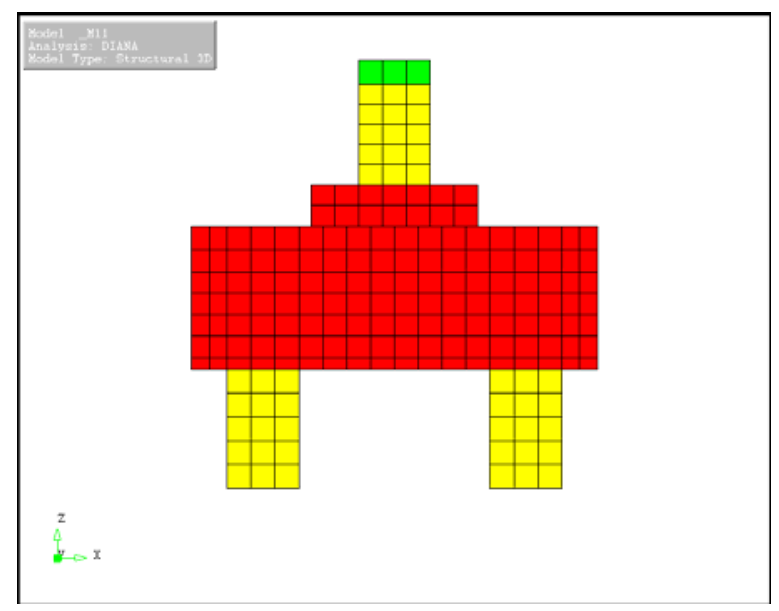

(a)

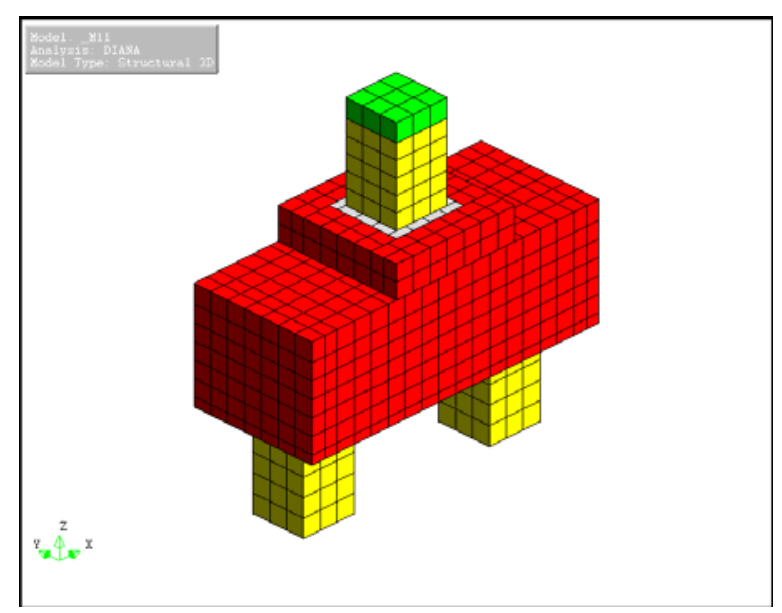

(b)

Figura 6. 19 - Vista frontal e perspectiva do modelo M11

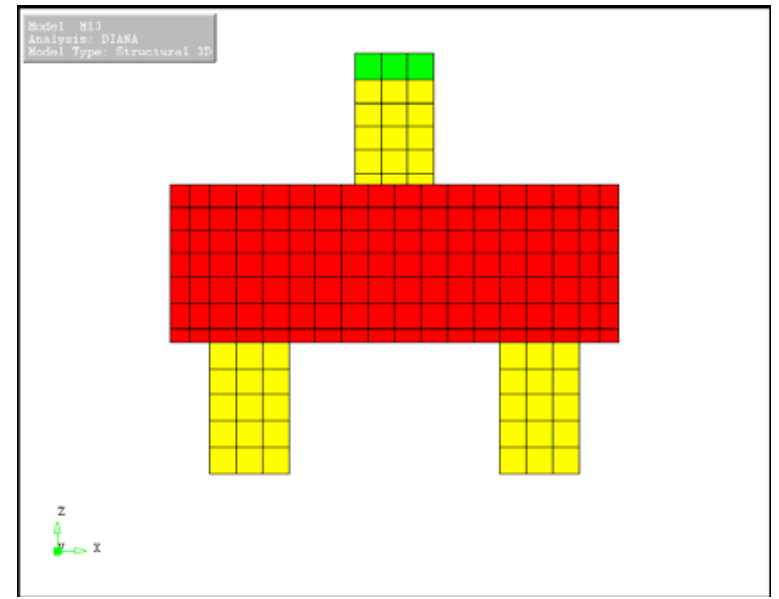

(a)

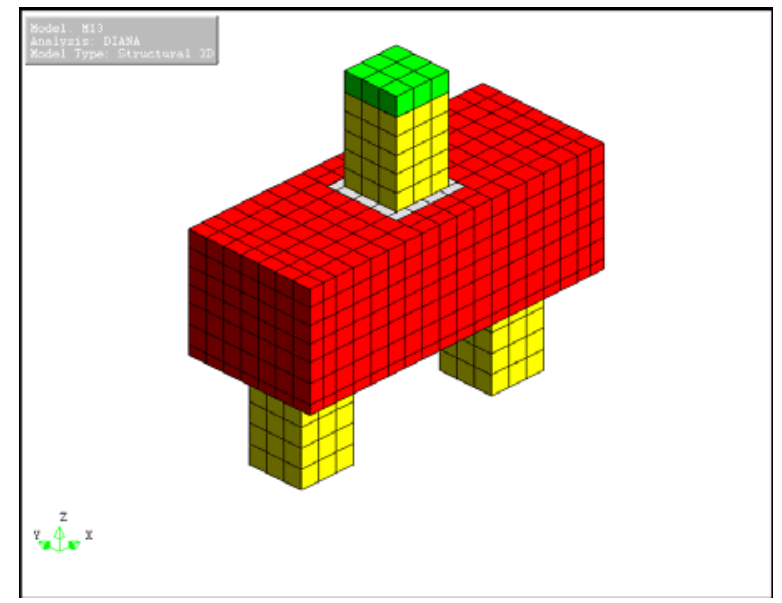

(b)

Figura 6. 20 - Vista frontal e perspectiva do modelo M13

$\mathrm{O}$ uso dos reinforcements permitiu a representação de todas as barras das armaduras utilizadas nos modelos analisados experimentalmente. Utilizando como referência as armaduras do modelo M5, apresentam-se a seguir as barras das armaduras utilizadas nos modelos numéricos. A Figura 6.21 (a) apresenta as armaduras das estacas, enquanto que a Figura 6.21 (b) apresenta a armadura do pilar. Na Figura 6.22 (a) apresentam-se as armaduras principais e laterais do bloco, enquanto que a Figura 6.22 (b) apresenta as armaduras verticais e horizontais utilizadas nas paredes do cálice de fundação. A Figura 6.23 (a) apresenta as barras das armaduras dos estribos verticais, enquanto que as Figura 6.23 (b) apresenta as barras da armadura complementar, presente apenas nos modelos M5, M7, M12 e M14. 


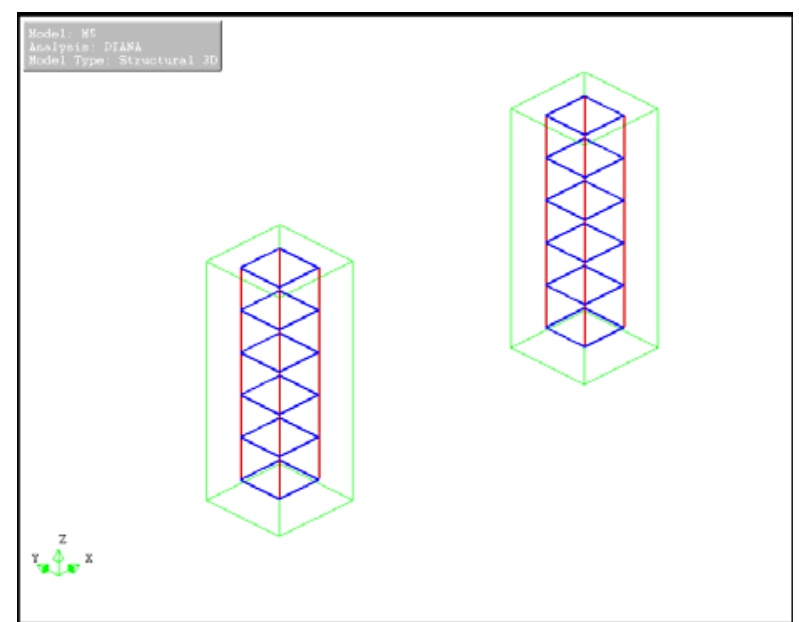

(a)

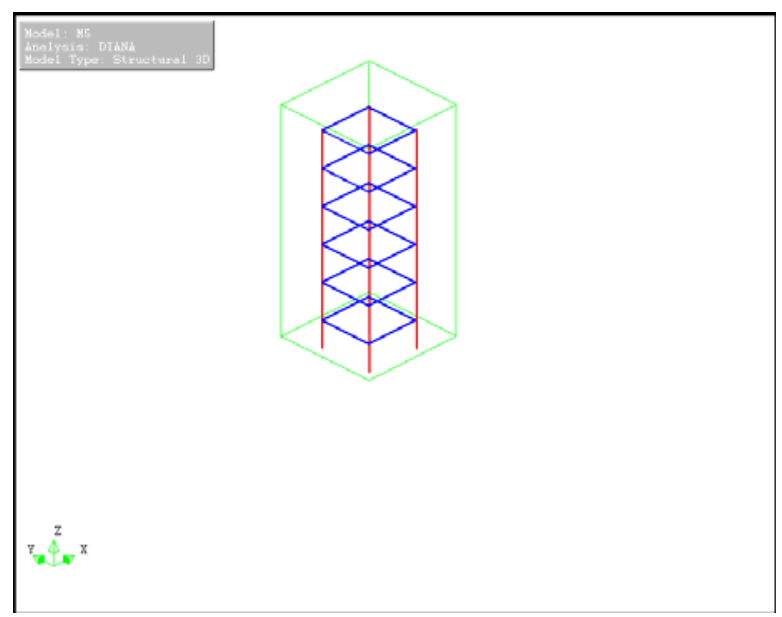

(b)

Figura 6. 21- Barras das armaduras utilizadas nas estacas e nos pilares

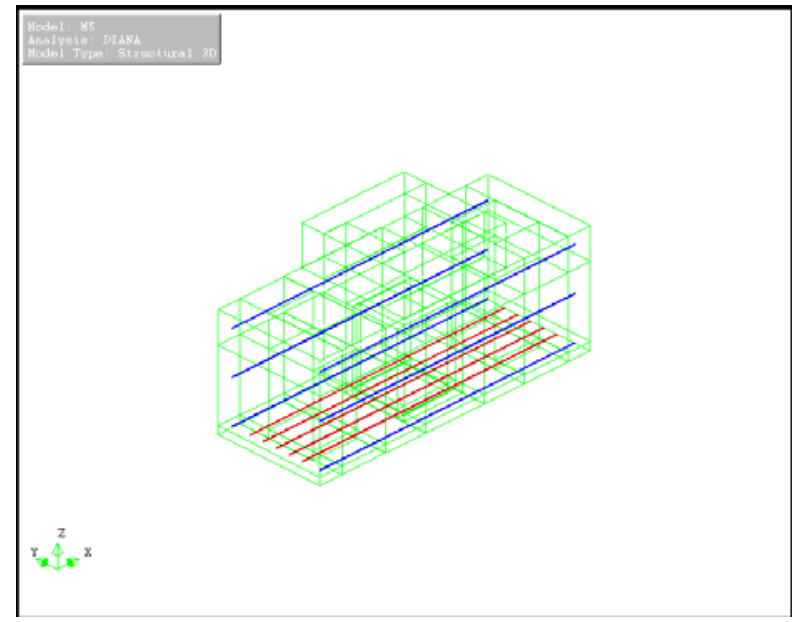

(a)

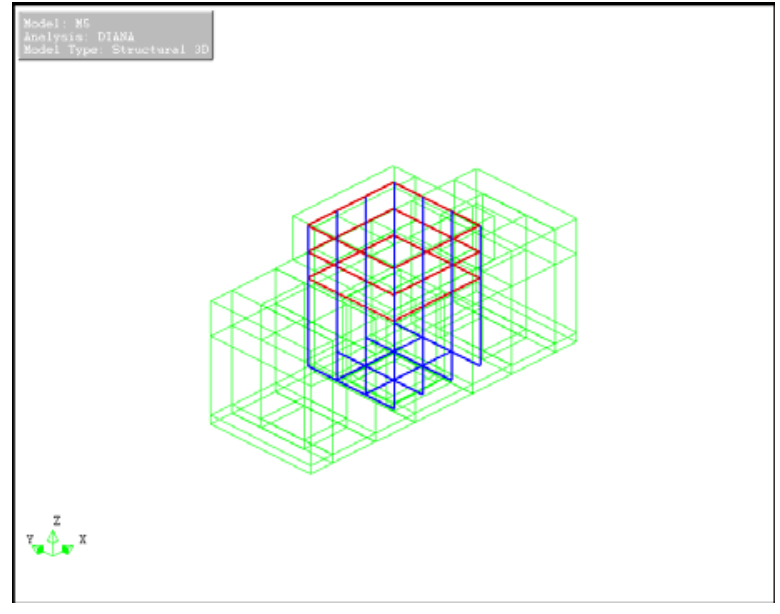

(b)

Figura 6. 22 - Barras das armaduras principais e laterais utilizadas no bloco e armaduras utilizadas no cálice

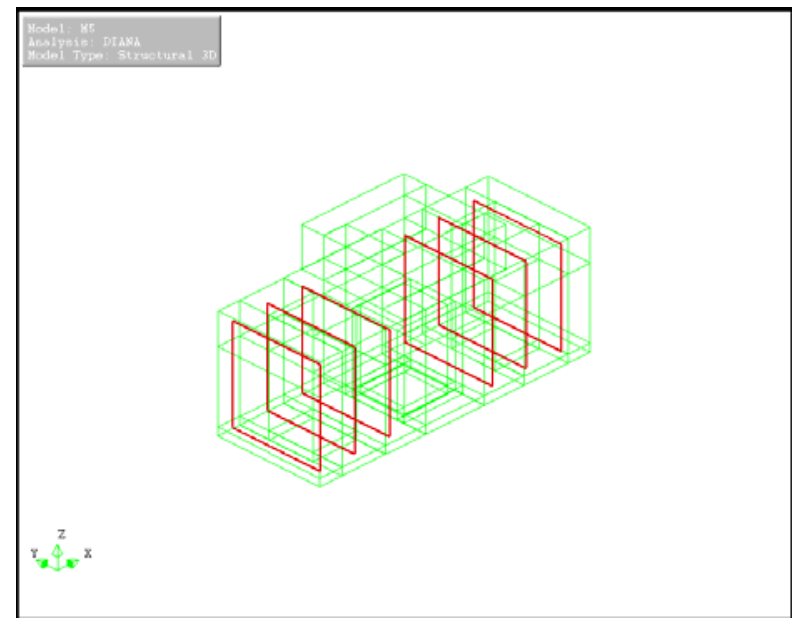

(a)

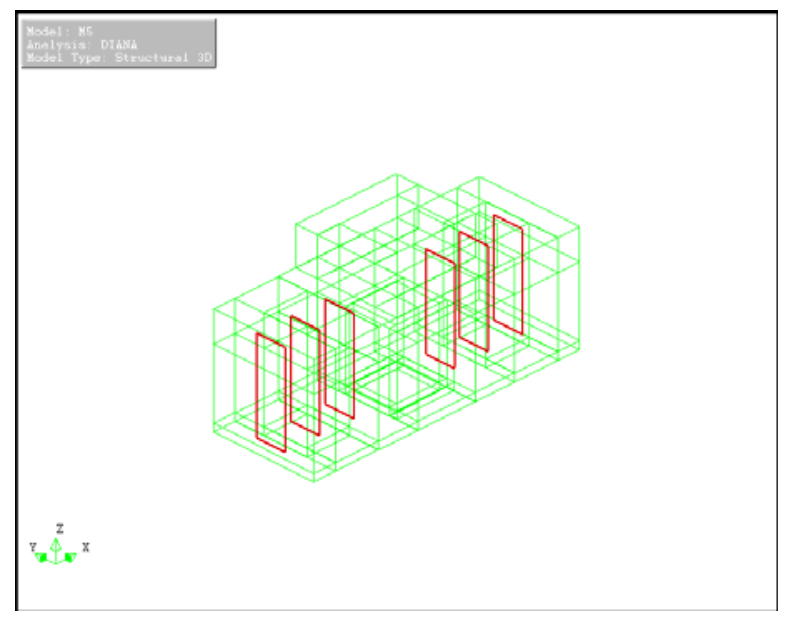

(b)

Figura 6. 23 - Barras das armaduras dos estribos verticais e da armadura complementar 
Nos itens a seguir são apresentados os resultados obtidos por meio da análise numérica. São apresentados gráficos do tipo força versus deslocamento e força versus deformação nas barras das armaduras, os quais são comparados aos resultados obtidos nos ensaios experimentais. Também são apresentados resultados de tensões principais internas no bloco, as quais orientam a formação das bielas de compressão, e tensões nas barras das armaduras.

Inicialmente são apresentados os resultados numéricos dos modelos teóricos estudados na etapa inicial, isto é, antes da realização dos ensaios experimentais. Em seguida, são apresentados os resultados da simulação numérica dos modelos ensaiados em laboratório.

\subsection{Resultados da etapa inicial}

A simulação dos modelos teóricos foi baseada nos dados utilizados para 0 dimensionamento dos modelos, conforme apresentado no capítulo 3. A simulação numérica inicial teve por objetivo indicar se os resultados do modelo numérico estavam coerentes com a previsão teórica. Verificou-se por meio dos resultados que a força última suportada pelo modelo na simulação numérica foi superior ao valor da força de avaliação $F_{\text {ava }}$ utilizada para $o$ dimensionamento dos modelos.

Constatou-se também um comportamento semelhante entre os dois modelos analisados, um referente ao bloco de referência sem rugosidade na interface, MT1, e outro referente ao bloco de referência com rugosidade, MT8. Adicionou-se a letra T de teórico nas abreviações desses modelos para diferenciá-los dos modelos M1 e M8, cujas simulações numéricas foram feitas após a realização dos ensaios experimentais e considerando as propriedades mecânicas obtidas nos ensaios de caracterização dos materiais.

Os modelos teóricos analisados apresentaram forças últimas próximas, sendo que o modelo MT1 atingiu $702 \mathrm{kN}$ enquanto que o modelo MT8 atingiu $692 \mathrm{kN}$. Ambos os modelos apresentaram uma perda de rigidez inicial próximo aos $300 \mathrm{KN}$, quando verificou-se um crescimento nos valores de deslocamentos em relação ao trecho linear. Uma segunda perda de rigidez, esta mais acentuada no modelo MT1, ocorreu próxima aos $450 \mathrm{kN}$. Os modelos apresentaram ruína próxima ao deslocamento de 1,20 $\mathrm{mm}$. A Figura 6.24 apresenta as curvas força versus deslocamento dos modelos teóricos MT1 e MT8. 


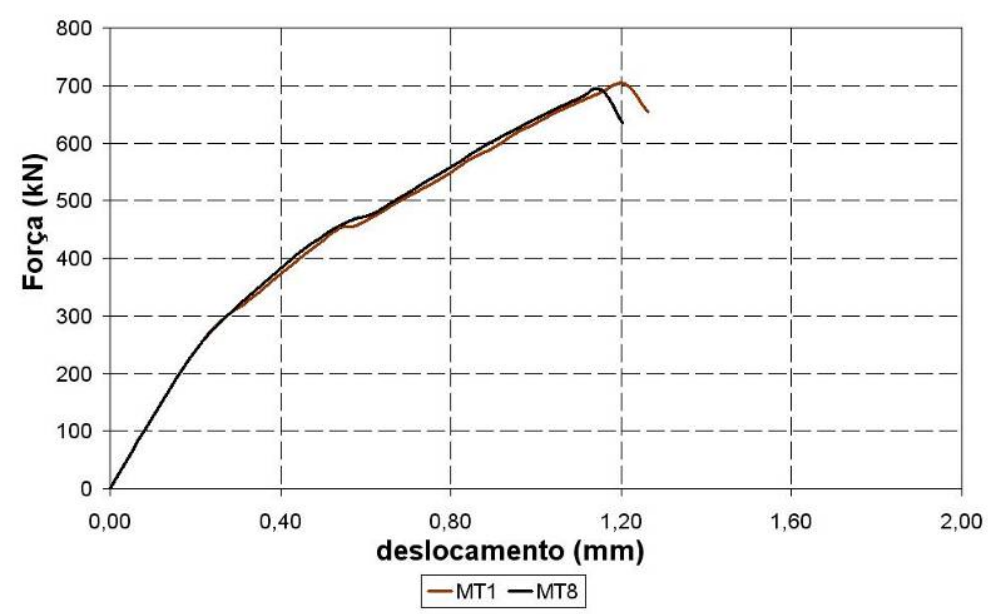

Figura 6. 24 - Curva força versus deslocamento dos modelos teóricos MT1 e MT2

Os resultados obtidos para os dois modelos foram semelhantes. Constatou-se que a ruína dos modelos se deu por ruptura do concreto comprimido por causa das tensões de compressão elevadas no encontro do bloco com o pilar. Por meio das tensões principais nas seções transversais internas do bloco foi possível visualizar a formação das bielas de compressão. $\mathrm{Na}$ etapa de carregamento correspondente a $300 \mathrm{kN}$, observa-se uma biela com inclinação menor em relação a horizontal, sendo formada até a meia altura do bloco. Em relação às barras das armaduras principais do tirante, verificou-se nessa etapa de carregamento que as tensões nas barras das armaduras estavam próximas aos $100 \mathrm{MPa}$.

$\mathrm{Na}$ etapa de carregamento correspondente a força última de cada modelo, as tensões de tração nas barras das armaduras apresentavam-se inferiores ao valor de $500 \mathrm{MPa}$, o que indica que não houve escoamento das barras das armaduras. Nessa etapa de carregamento as bielas de compressão apresentavam inclinação maior em relação a horizontal, sendo que sua formação ocorria a partir do interior do pilar, estando sua região inferior a uma profundidade em torno de um quarto da altura do bloco. A Figura 6.25 apresenta a distribuição interna das tensões principais de compressão nos modelos MT1 e MT8 numa seção transversal interna paralela a direção longitudinal do bloco, correspondente a uma força no pilar próxima de 300 kN, enquanto que a Figura 6.26 apresenta nessa mesma seção a distribuição de tensões na etapa de carregamento correspondente a força última em cada modelo. Observa-se por meio dessas figuras a mudança na forma da biela ao longo da evolução do carregamento. A Figura 6.27, por sua vez, apresenta as tensões nas barras das armaduras do modelo MT1 e MT8 na etapa correspondente à força última desses modelos. 


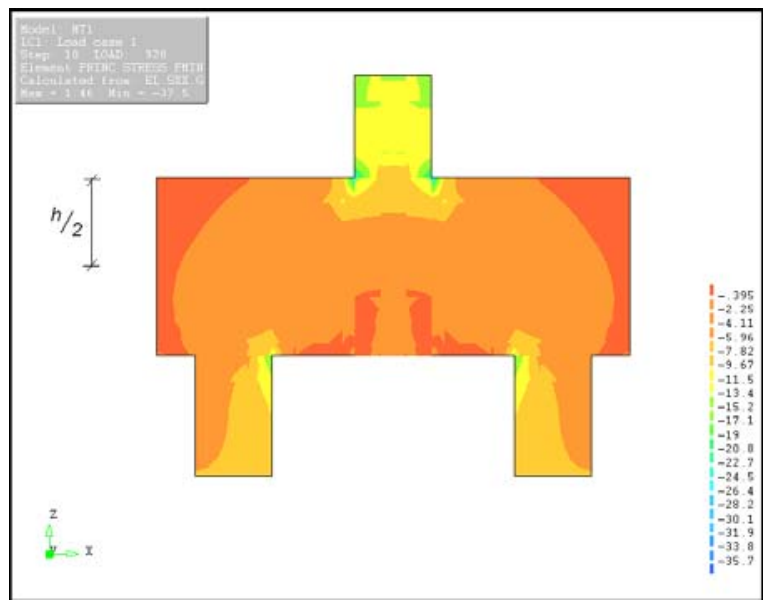

(a)

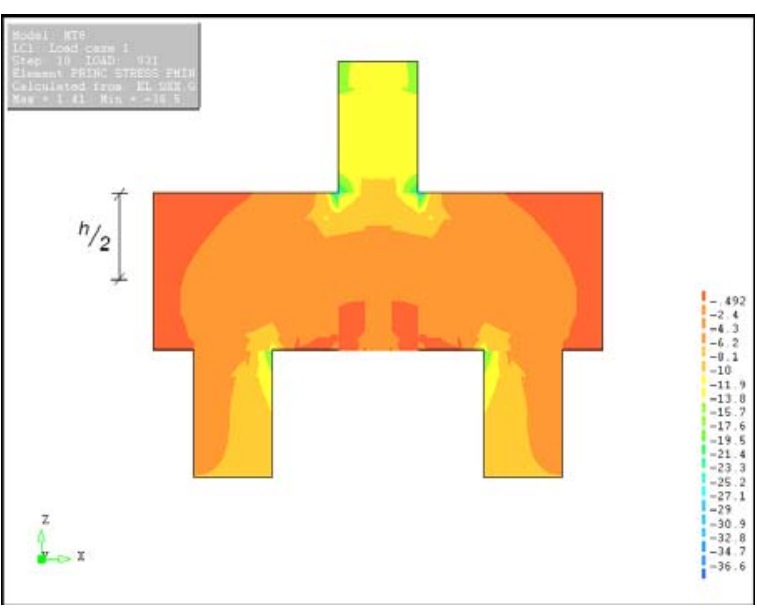

(b)

Figura 6. 25 - Tensões principais de compressão correspondentes a força de $300 \mathrm{kN}$ no topo do pilar dos modelos MT1 e MT8, respectivamente

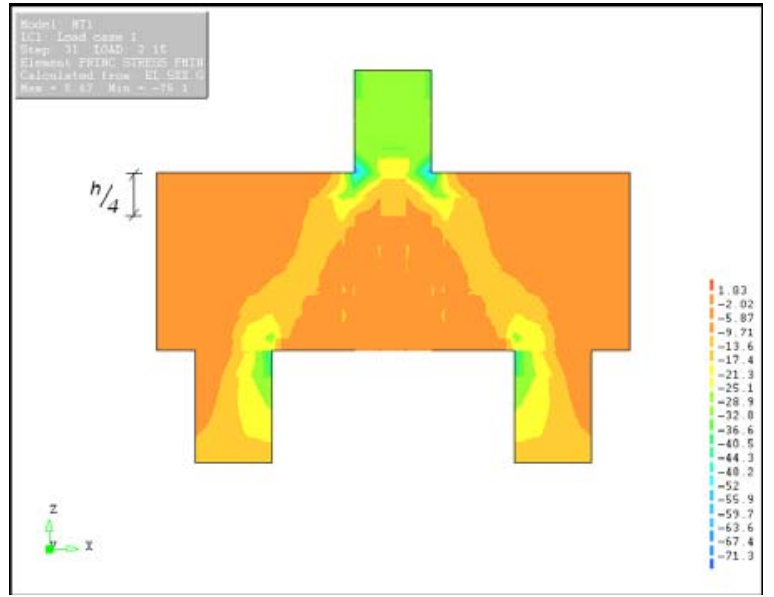

(a)

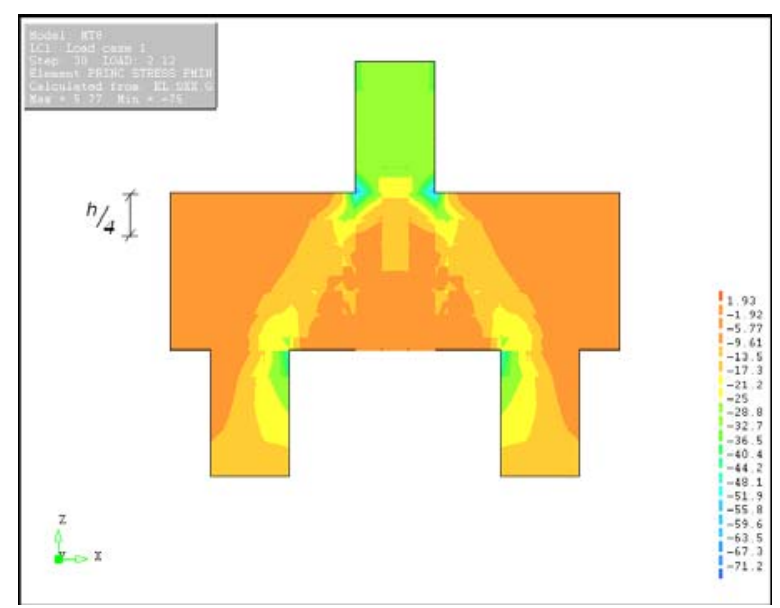

(b)

Figura 6. 26 - Tensões principais de compressão correspondentes a força última no topo do pilar dos modelos MT1 e MT8, respectivamente

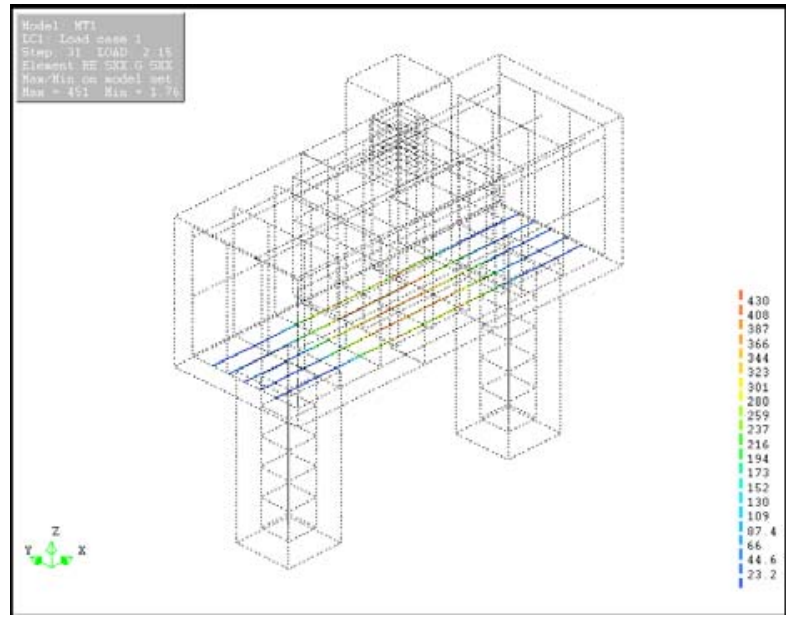

(a)

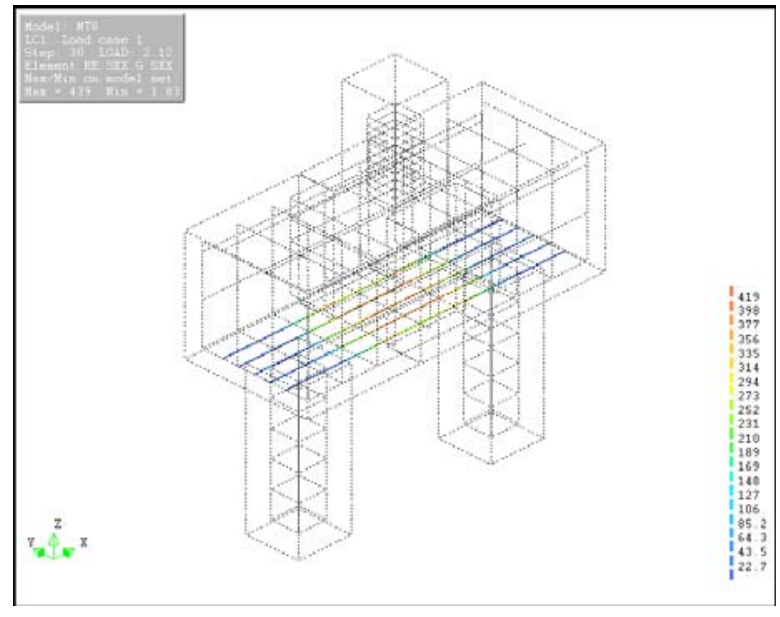

(b)

Figura 6. 27 - Tensões nas barras das armaduras principais dos modelos MT1 e MT8, respectivamente 
Os modelos teóricos apresentaram formação de fissuras a partir do instante em que as tensões principais de tração superaram a resistência à tração do concreto. $O$ início da fissuração ocorreu na região inferior central do bloco, e foi se prolongando ao longo da altura do mesmo e na direção da formação das bielas.

A Figura 6.28 apresenta a evolução do panorama de fissuração do modelo MT1 para uma intensidade de força no pilar correspondente a $25 \%, 50 \%, 75 \%$ e $100 \%$ da força última. Devido a semelhança dos resultados, não será apresentado o panorama de fissuração do modelo teórico MT8.

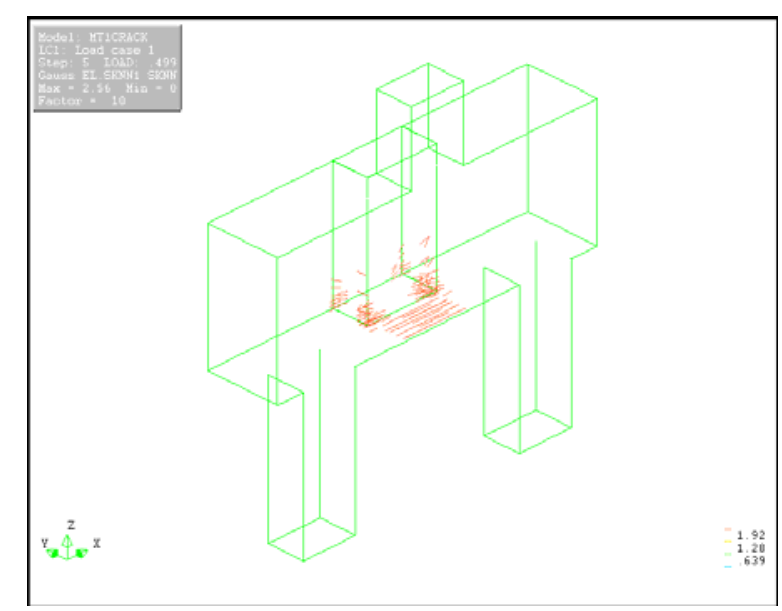

$25 \% . \mathrm{Fu}$

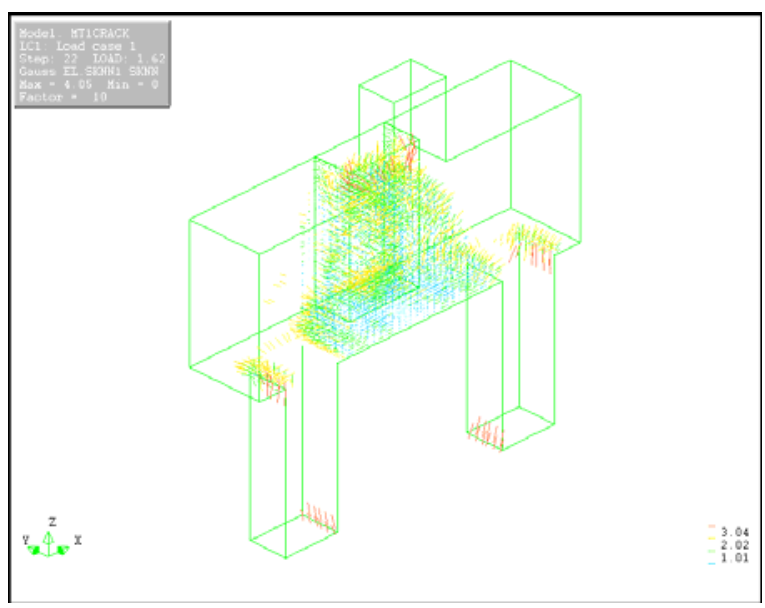

$75 \% \cdot \mathrm{F}_{\mathrm{u}}$

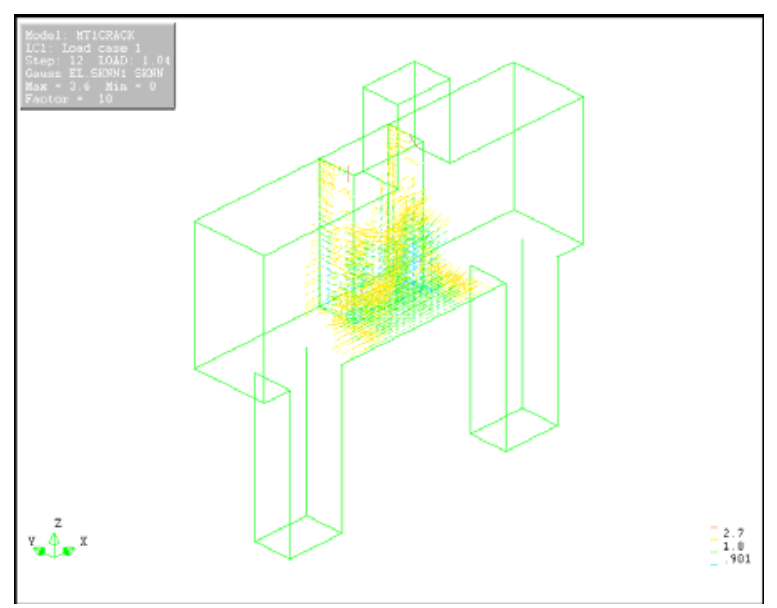

$50 \% . \mathrm{Fu}$

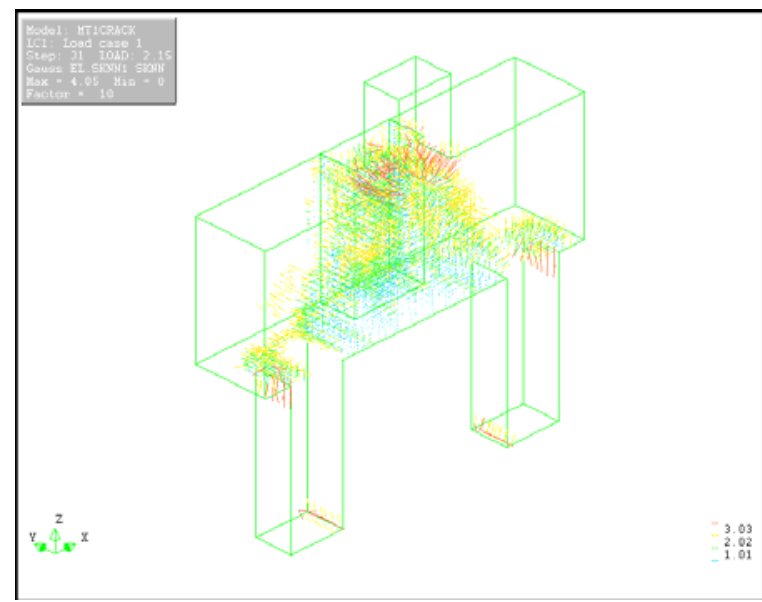

$100 \% . \mathrm{Fu}$

Figura 6. 28 - Evolução do panorama de fissuração do modelo MT1

Em relação às tensões nas regiões nodais, constatou-se que as tensões principais de compressão foram em torno de 50\% maiores na região do encontro do pilar com o bloco em relação a região de encontro da estaca com o bloco, conforme apresentado na Figura 6.29 (a) e 6.29 (b), atingindo valores que variaram de de $75 \mathrm{MPa}$ e $51 \mathrm{MPa}$, respectivamente. 


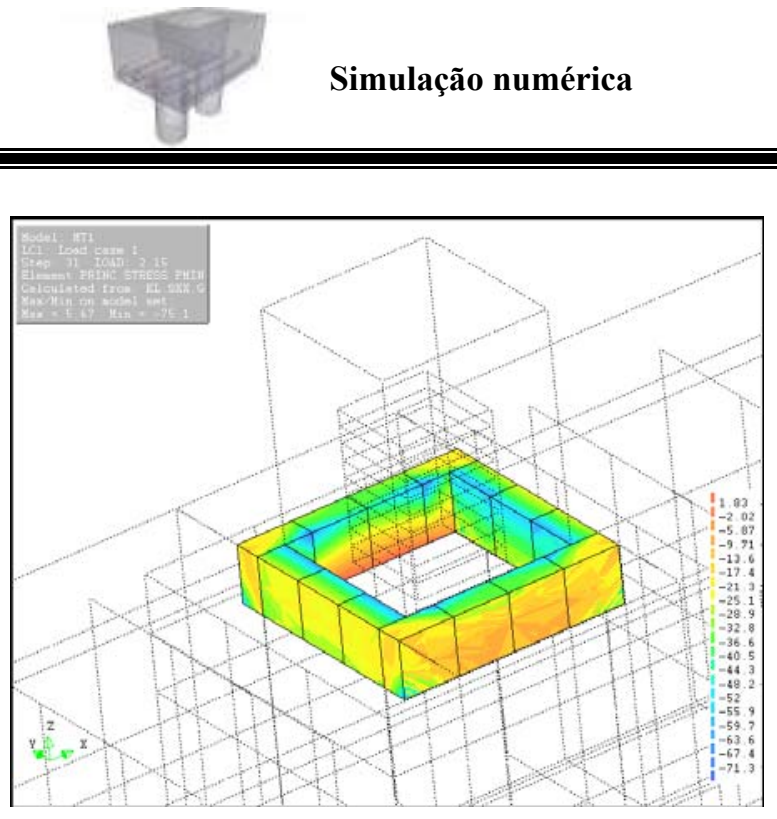

(a)

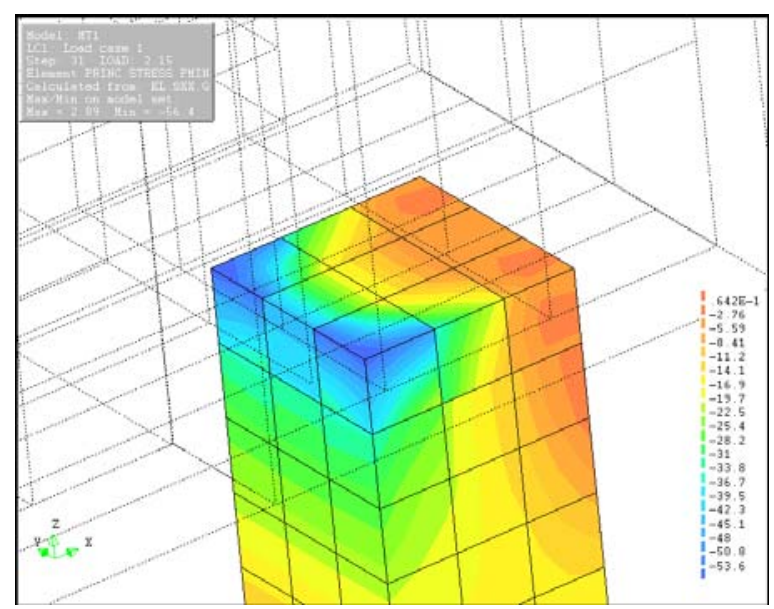

(b)

Figura 6. 29 - Tensões principais de compressão no encontro do pilar com o bloco e no encontro da estaca com o bloco, respectivamente.

Observa-se portanto, que os modelos numéricos teóricos apresentaram resultados que previram uma força última superior em mais de duas vezes o valor da força de avaliação utilizada no dimensionamento dos modelos, e que, de acordo com essas análises, a ruína dos modelos não ocorreria por escoamento das barras das armaduras, mas sim por ruptura do concreto comprimido na região do encontro do pilar com o bloco.

Conforme foi apresentado no capítulo 5, a previsão de força última estava coerente, uma vez que os modelos experimentais M1 e M8 apresentaram força última igual a $756 \mathrm{kN}$ e 728 $\mathrm{kN}$, respectivamente. Porém, ambos os modelos apresentaram ruína por escoamento das barras da armadura principal do tirante, o que não foi previsto com o modelo numérico adotado. Possivelmente isso ocorreu devido a mudanças nas propriedades mecânicas dos modelos experimentais em relação ao modelo teórico, como por exemplo, o valor da resistência a tração do concreto dos blocos que diminui de 2,56 $\mathrm{MPa}$ para 2,47 $\mathrm{MPa}$.

\subsection{Resultados da etapa final}

A simulação dos modelos da etapa final ocorreu após a realização dos ensaios experimentais. Nessas simulações, a definição das propriedades mecânicas dos materiais foi feita de acordo com os resultados obtidos a partir da caracterização dos materiais, conforme apresentado no capítulo 5. As condições de contorno bem como os parâmetros relativos a análise numérica foram os mesmos da etapa inicial, os quais encontram-se apresentados nos itens 6.3 e 6.4 . 
Verificou-se por meio dos resultados apresentados que o modelo numérico utilizado conseguiu reproduzir os ensaios experimentais com boa precisão no que diz respeito à força última suportada pelos modelos. De um modo geral, constatou-se que as simulações dos modelos com elementos de interface, os quais foram utilizados nos blocos da série sem rugosidade, apresentaram força última numérica superior a obtida nos ensaios experimentais. Os blocos da série com rugosidade, por suas vezes, apresentaram força última numérica inferior à obtida nos ensaios experimentais. Esse resultado só não ocorreu no modelo M10, cujo ensaio experimental ficou comprometido devido a ruína desse modelo ter ocorrido por ruptura do concreto do pilar. A tabela 6.5 apresenta os valores de força última obtidos nos ensaios experimental e numérico.

Tabela 6.5 - Força última: comparação entre modelos experimental e numérico

\begin{tabular}{|c|c|c|c|c|}
\hline Série & Modelo & $\begin{array}{c}\mathbf{F}_{\text {u,exp }} \\
(\mathbf{k N})\end{array}$ & $\begin{array}{l}F_{\text {num }} \\
(\mathbf{k N})\end{array}$ & $\begin{array}{c}\mathbf{F}_{\text {num }} / \mathbf{F}_{\mathrm{u}, \exp } \\
(\%)\end{array}$ \\
\hline \multirow{7}{*}{$\begin{array}{c}\text { Sem } \\
\text { rugosidade }\end{array}$} & M1 & 756 & 772 & $102 \%$ \\
\hline & M2 & 772 & 781 & $101 \%$ \\
\hline & M3 & 724 & 769 & $106 \%$ \\
\hline & M4 & 563 & 578 & $103 \%$ \\
\hline & M5 & 644 & 624 & $97 \%$ \\
\hline & M6 & 359 & 375 & $104 \%$ \\
\hline & M7 & 368 & 381 & $104 \%$ \\
\hline \multirow{7}{*}{$\begin{array}{l}\text { Com } \\
\text { rugosidade }\end{array}$} & M8 & 728 & 702 & $96 \%$ \\
\hline & M9 & 916 & 882 & $96 \%$ \\
\hline & M10* & 632 & 918 & $145 \%$ \\
\hline & M11 & 888 & 819 & $92 \%$ \\
\hline & M12 & 957 & 960 & $100 \%$ \\
\hline & M13 & 652 & 602 & $92 \%$ \\
\hline & M14 & 640 & 587 & $92 \%$ \\
\hline \multicolumn{2}{|c|}{ Média } & 689,8 & 679,4 & $98 \%$ \\
\hline \multicolumn{2}{|c|}{ Desvio Padrão } & 177,7 & 170,1 & $96 \%$ \\
\hline \multicolumn{2}{|c|}{ Coef. De Variação } & 0,26 & 0,25 & $97 \%$ \\
\hline
\end{tabular}

*Modelo que apresentou ruína por ruptura do concreto do pilar no ensaio experimental, não utilizado no cálculo dos valores médios 
A relação entre a força última numérica e a força última experimental resultou num valor médio de $102 \%$ para os blocos da série sem rugosidade, e em 95\% para os blocos da série com rugosidade. Avaliando os modelos das duas séries em conjunto, obtém-se um valor de $98 \%$ entre a média das forças últimas numéricas em relação às forças últimas experimentais. Observa-se ainda que o desvio padrão e o coeficiente de variação apresentam valores similares nos ensaios numéricos e experimentais.

\subsubsection{Deslocamentos no modelo numérico}

Em relação aos deslocamentos na região central dos blocos, verificou-se que os resultados obtidos por meio dos modelos numéricos resultaram inferiores aos obtidos nos ensaios experimentais. Pode-se atribuir essa diferença a algumas simplificações adotadas no modelo numérico, dentre as quais destacam-se a idealização de força centrada aplicada no pilar, a consideração da aderência perfeita entre as barras da armadura e o concreto, eventuais folgas existentes entre o modelo e a máquina de ensaio, assim como ao módulo de elasticidade do concreto.

Entende-se que o módulo de elasticidade do concreto é um parâmetro que apresenta bons resultados entre valores teóricos e experimentais para pequenas intensidades de força, na qual o concreto se situa em regime elástico e linear. Entretanto, após o inicio da fissuração do concreto, o módulo de elasticidade modifica-se e seu valor passa a ser difícil de ser mensurado. Mesmo com os sofisticados modelos matemáticos existentes nos programas de simulação numérica que buscam prever o comportamento do concreto após o início da fissuração, nem sempre é possível reproduzir no computador todos os fenômenos envolvidos num ensaio experimental.

Apresenta-se nas Figuras 6.30 a $\mathbf{6 . 3 6}$ as curvas força versus deslocamentos obtidas nos ensaios experimentais e na simulação numérica. Para as curvas provenientes dos ensaios experimentais, considerou-se os resultados médios obtidos dos transdutores de deslocamento T1 e T2. 

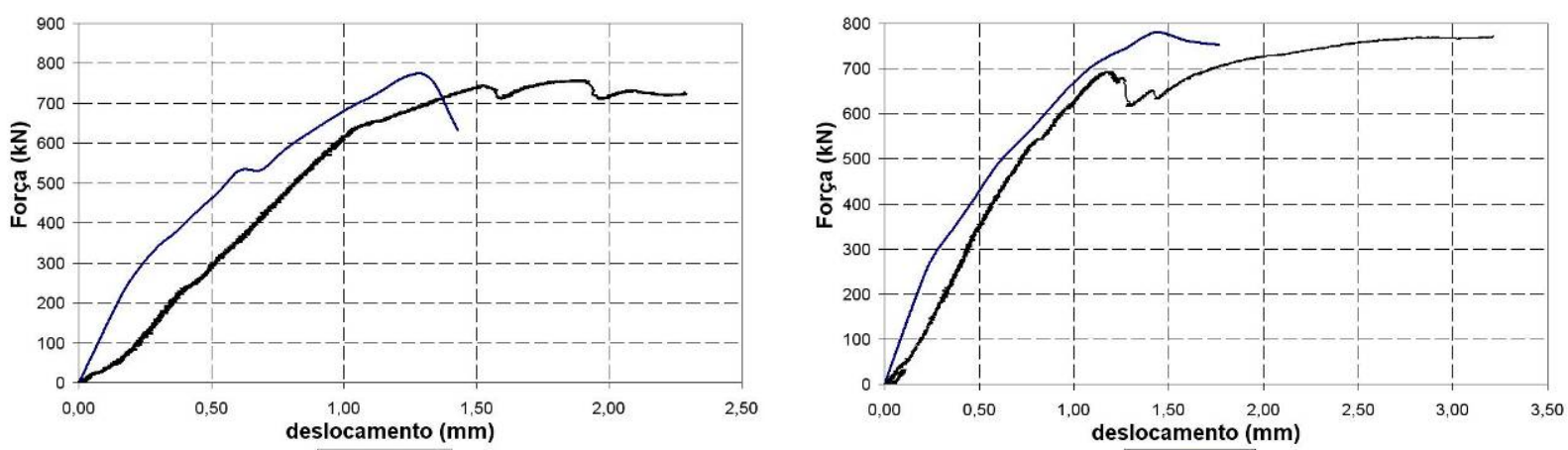

- M1 - Diana

$$
\text { - M2-Diana }
$$

Figura 6. 30- Curva força versus deslocamento experimental e numérico dos modelos M1 e M2.
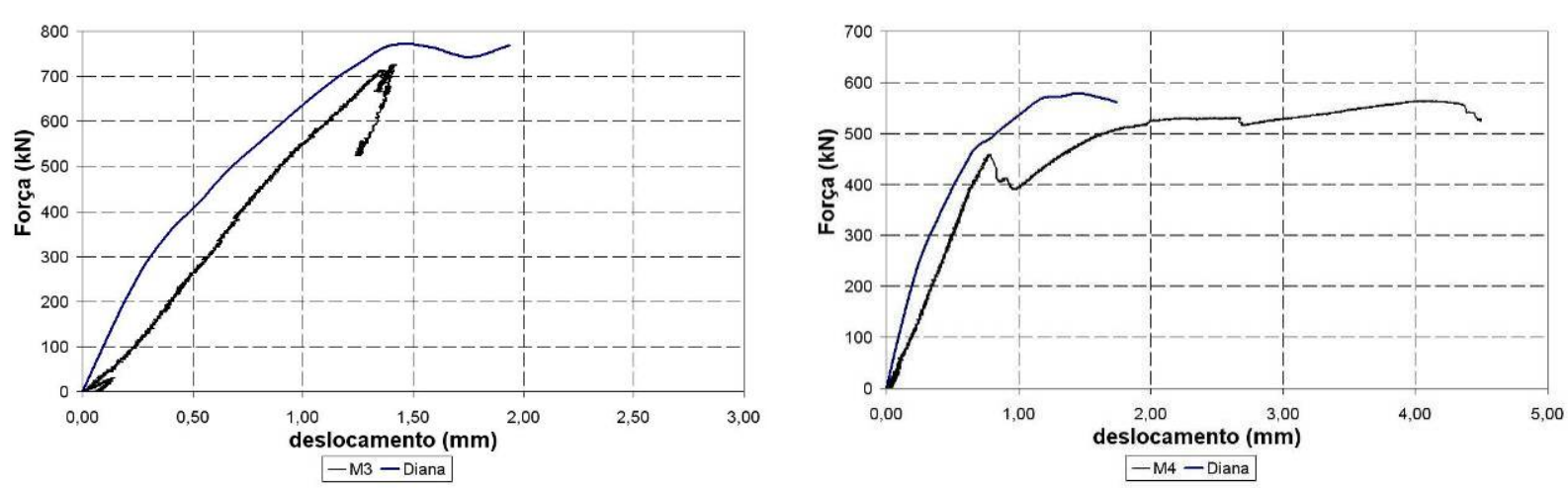

Figura 6. 31 - Curva força versus deslocamento experimental e numérico dos modelos M3 e M4.
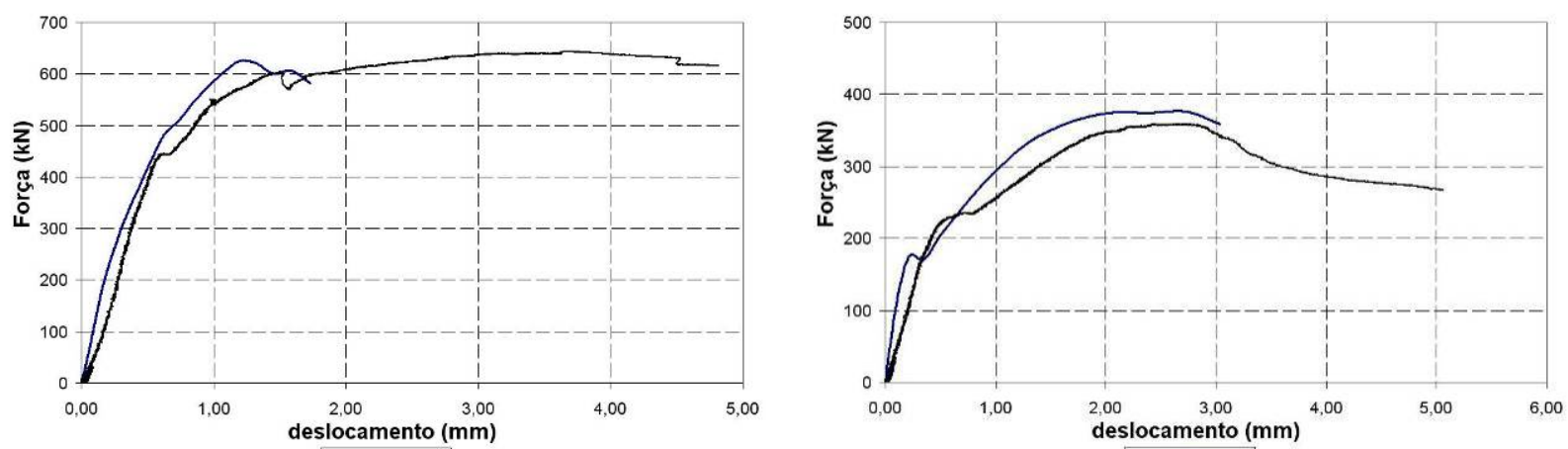

-M5 - Diana

$$
\text { -M6-Diana }
$$

Figura 6. 32 - Curva força versus deslocamento experimental e numérico dos modelos M5 e M6.
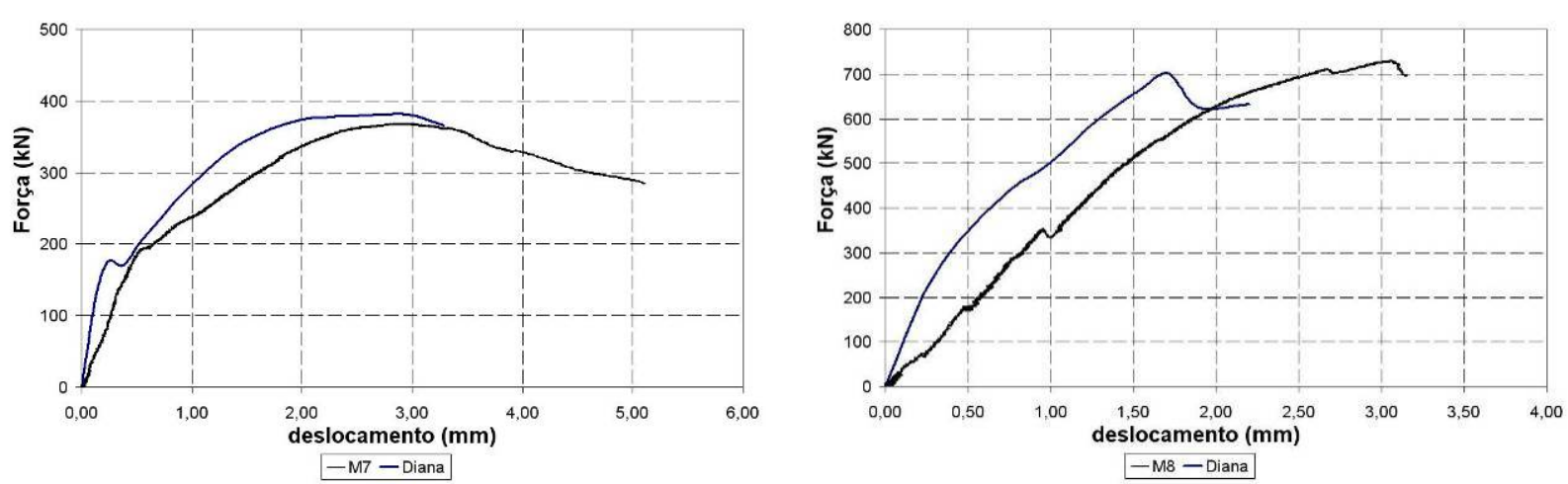

Figura 6. 33 - Curva força versus deslocamento experimental e numérico dos modelos M7 e M8. 


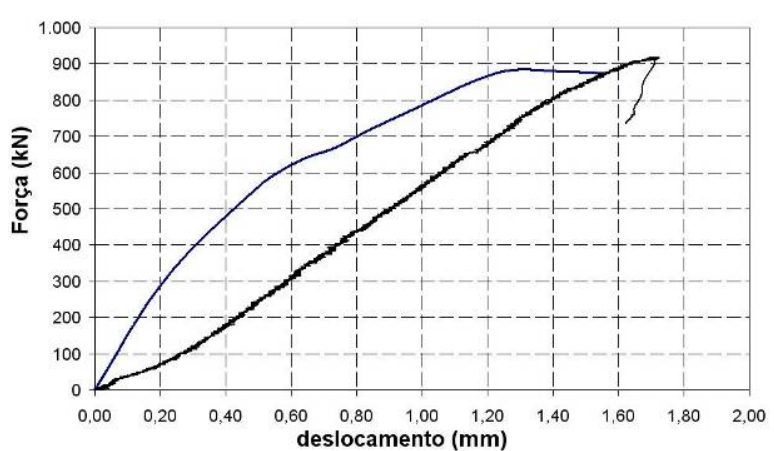

-M9-Diana

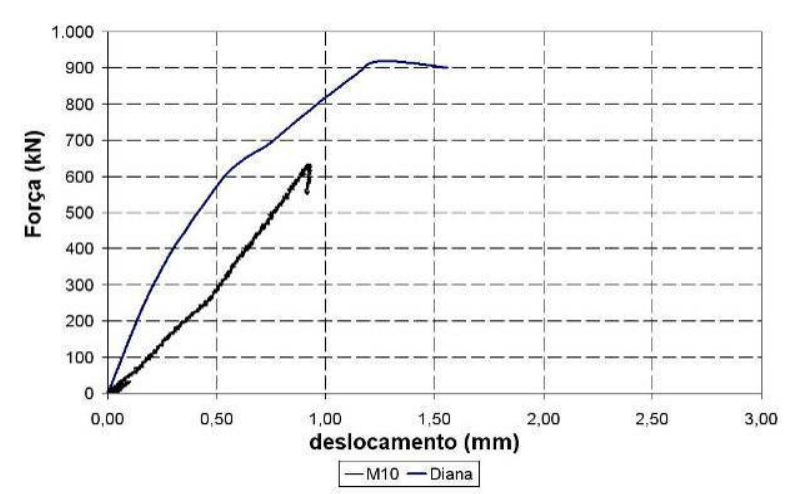

Figura 6. 34 - Curva força versus deslocamento experimental e numérico dos modelos M9 e M10.
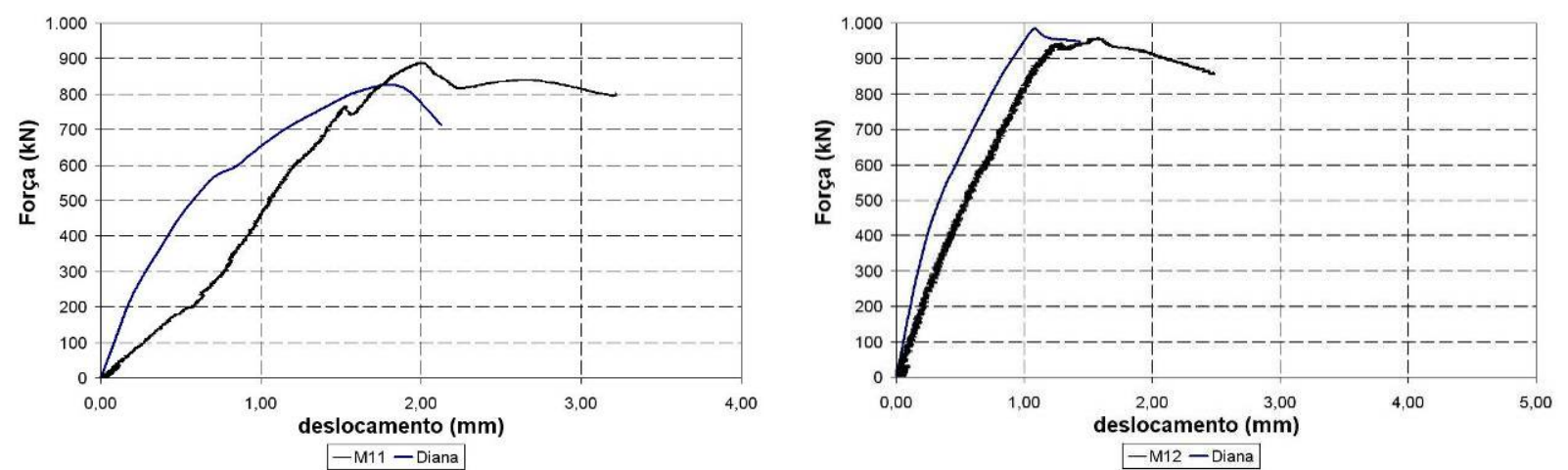

Figura 6. 35 - Curva força versus deslocamento experimental e numérico dos modelos M11 e M12.
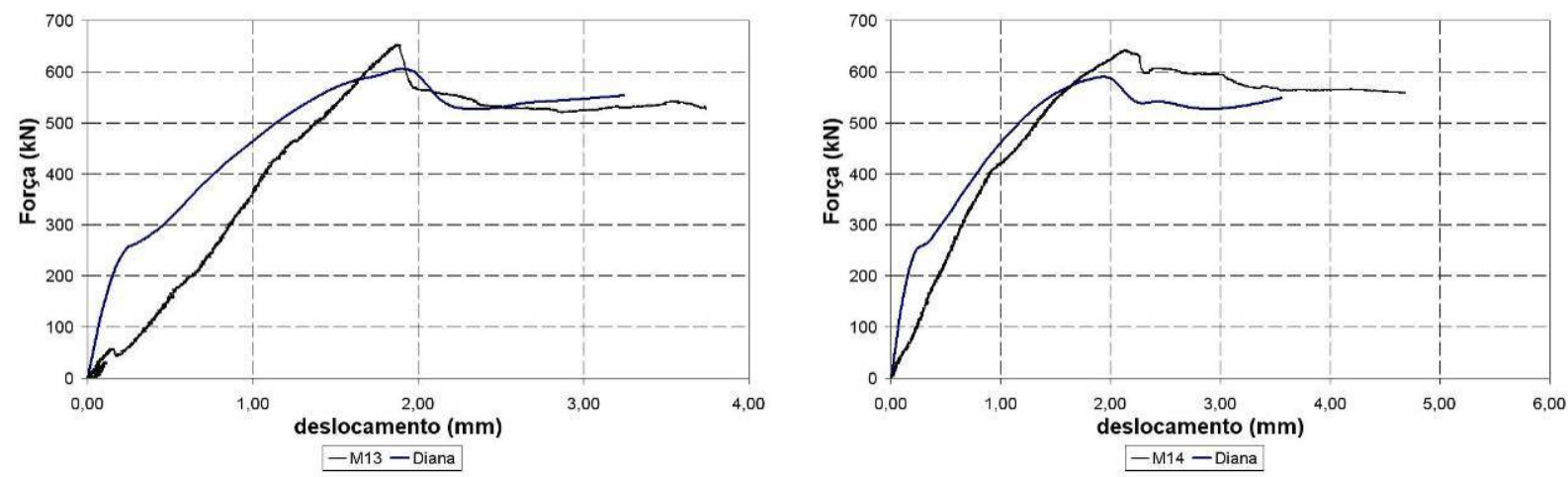

Figura 6. 36 - Curva força versus deslocamento experimental e numérico dos modelos M13 e M14.

\subsubsection{Deformações das barras da armadura principal do bloco}

Em relação a força no tirante e as deformações nas barras das armaduras principais do tirante, observou-se que, tal qual ocorreu nos ensaios experimentais, as barras das armaduras apresentaram deformações superiores aquelas que provocavam escoamento dessas barras, com exceção dos modelos M3 e M10, que possuíam armadura detalhada superior a armadura calculada, conforme apresentado no capítulo 3. 
Observou-se que, na maioria dos modelos analisados numericamente, a deformação média nas barras das armaduras foi inferior a deformação média obtida por meio dos ensaios experimentais, indicando que o modelo numérico apresentou-se mais rígido do que o modelo experimental, isto é, o modelo numérico conduziu a resultados mais conservadores do que os resultados experimentais.

Os modelos com cálice externo foram os que apresentaram melhores resultados em termos de deformação nas barras da armadura principal do tirante, quando comparadas aos resultados experimentais, independente do modelo ser da série com rugosidade ou sem rugosidade. Observou-se que as curvas força versus deformação nas barras das armaduras foram coincidentes na etapa inicial até atingir uma força de aproximadamente $200 \mathrm{kN}$, etapa essa em que pode-se admitir que o material encontra-se em comportamento linear.

Nos modelos com cálice parcialmente embutido, verificou-se que a perda de rigidez por parte do modelo numérico não ocorreu conforme os resultados experimentais, não sendo possível estabelecer uma relação única entre essas curvas. Na série sem rugosidade, o modelo numérico apresentou perda de rigidez praticamente no mesmo valor de intensidade de força nos modelos com e sem armadura complementar, enquanto que nos blocos da série com rugosidade, a perda de rigidez no modelo sem armadura complementar ocorreu para intensidade de força inferior a do modelo com armadura complementar. Verificou-se que a existência da armadura complementar no interior dos modelos M5 e M12 conferiram maior rigidez e maior força última a esses modelos quando comparados aos modelos M4 e M11, os quais não dispunham dessa armadura complementar.

Nas simulações dos modelos de blocos com cálice embutido, verificou-se que para os modelos da série sem rugosidade, as curvas força versus deformação nas barras das armaduras apresentaram comportamento semelhante ao dos ensaios experimentais, porém conduzindo a deformações nas armaduras inferiores as obtidas com os ensaios experimentais ao longo de todo o ensaio. Observou-se também que nos modelos M6 e M7 o valor da força última foi superior ao obtido nos ensaios experimentais.

Os blocos com cálice embutido da série com rugosidade apresentaram nas etapas finais da simulação numérica deformações médias superiores as apresentadas nos ensaios experimentais. Diferente dos resultados da série sem rugosidade, nos modelos M13 e M14 os resultados de força última foram inferiores em aproximadamente $8 \%$ em relação aos resultados obtidos com os ensaios experimentais. 
Os resultados anteriormente apresentados podem ser observados nas Figuras 6.37 a 6.43, as quais apresentam as curvas força versus deformação média nas barras das armaduras principais do tirante dos modelos experimentais e numéricos. Nessas curvas, considerou-se a deformação média das armaduras posicionadas na seção do meio do bloco, composta pelos resultados dos extensômetros da posição 6 a 10 no caso dos resultados experimentais, e em valores obtidos no programa Diana nessa mesma seção para os resultados numéricos.

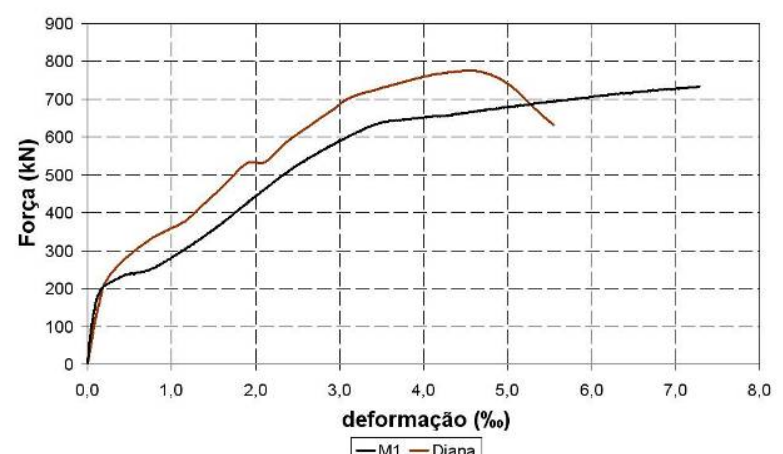

-M1-Diana

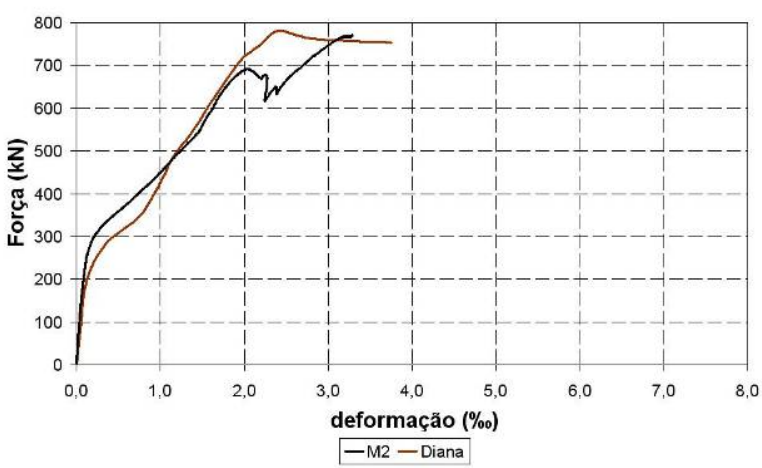

Figura 6. 37- Curva força versus deformação: ensaio experimental e numérico dos modelos M1 e M2.
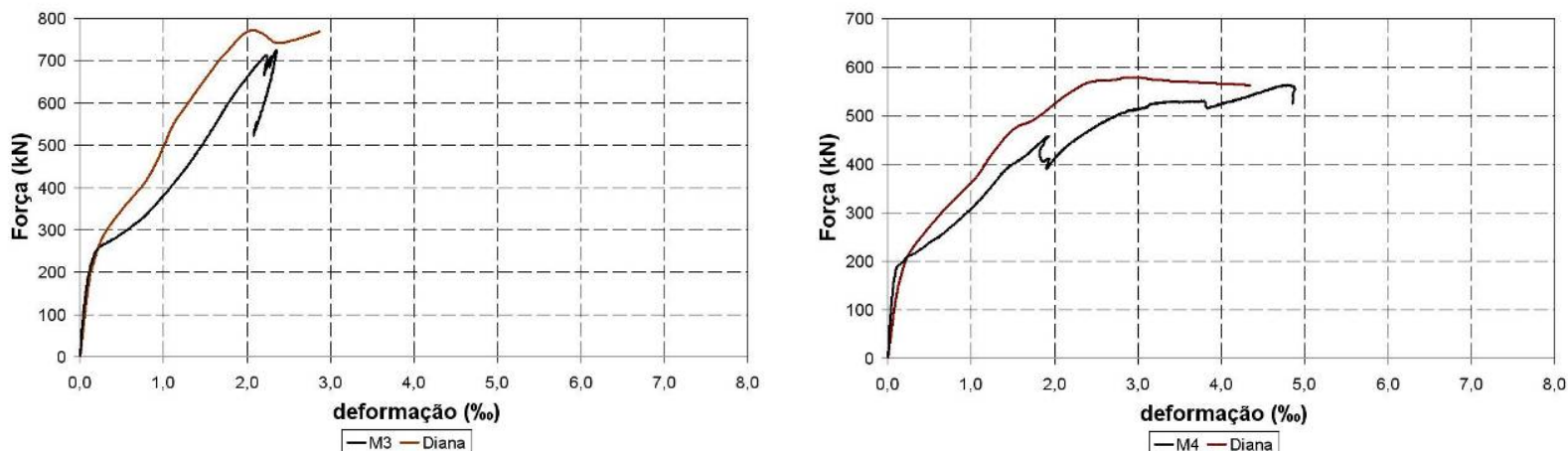

Figura 6. 38 - Curva força versus deformação: ensaio experimental e numérico dos modelos M3 e M4.
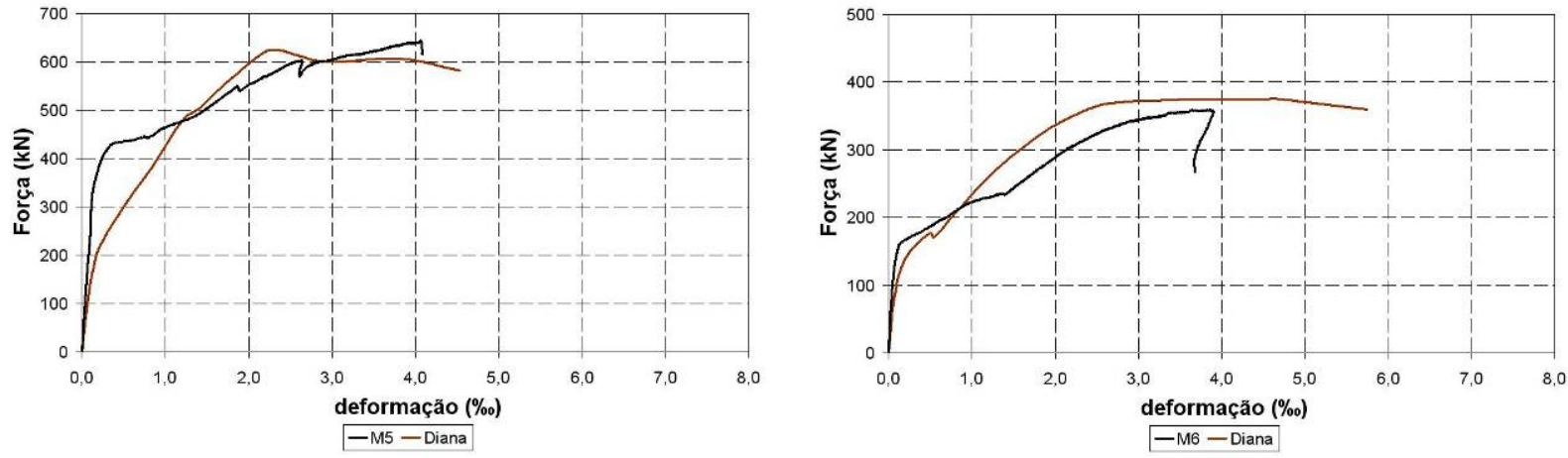

Figura 6. 39 - Curva força versus deformação: ensaio experimental e numérico dos modelos M5 e M6. 

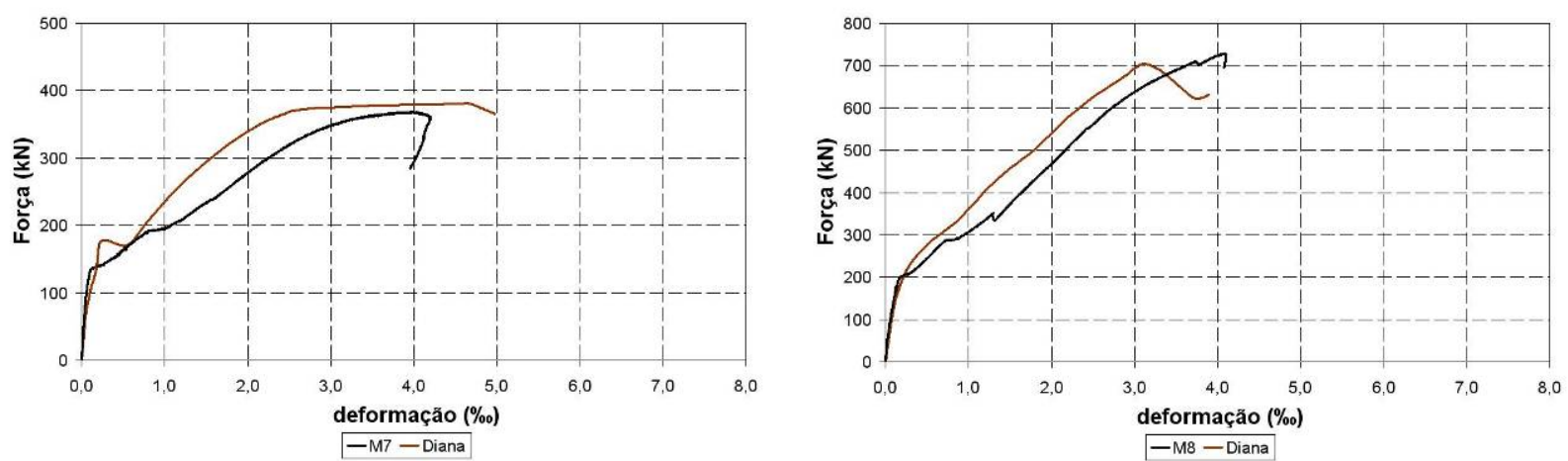

Figura 6. 40 - Curva força versus deformação: ensaio experimental e numérico dos modelos M7 e M8.
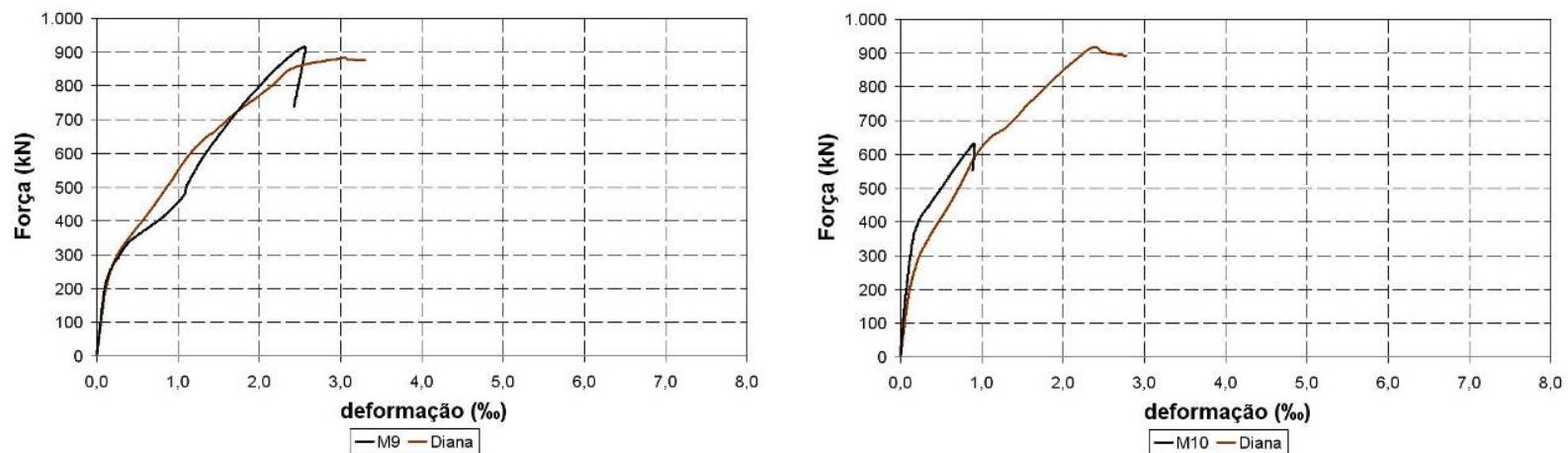

Figura 6. 41 - Curva força versus deformação: ensaio experimental e numérico dos modelos M9 e M10.
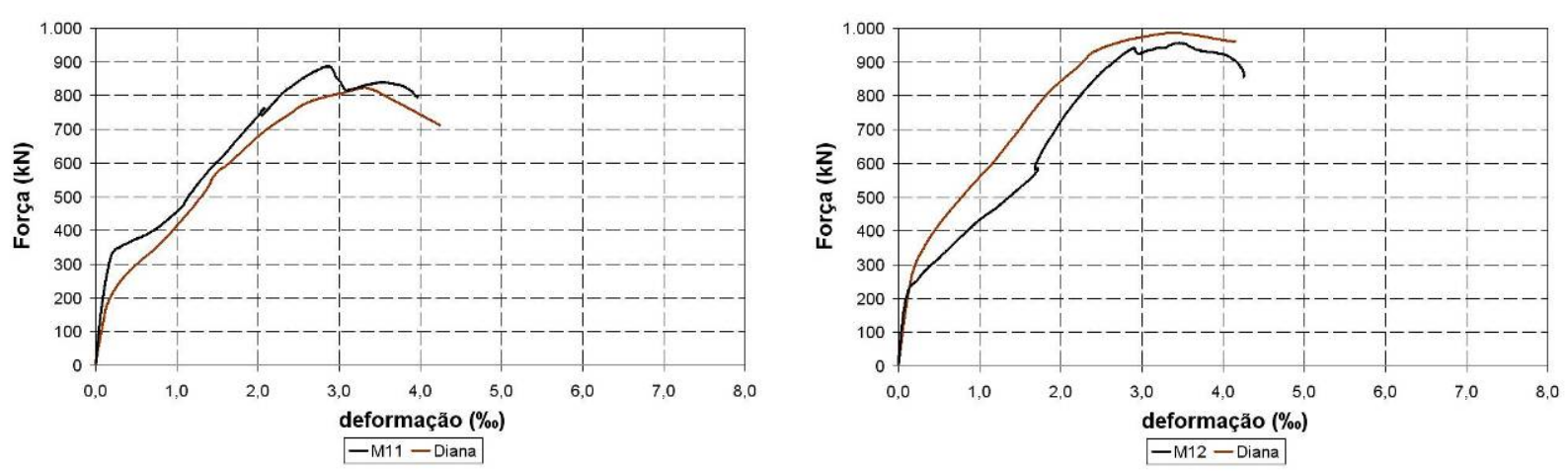

Figura 6. 42 - Curva força versus deformação: ensaio experimental e numérico dos modelos M11 e M12.
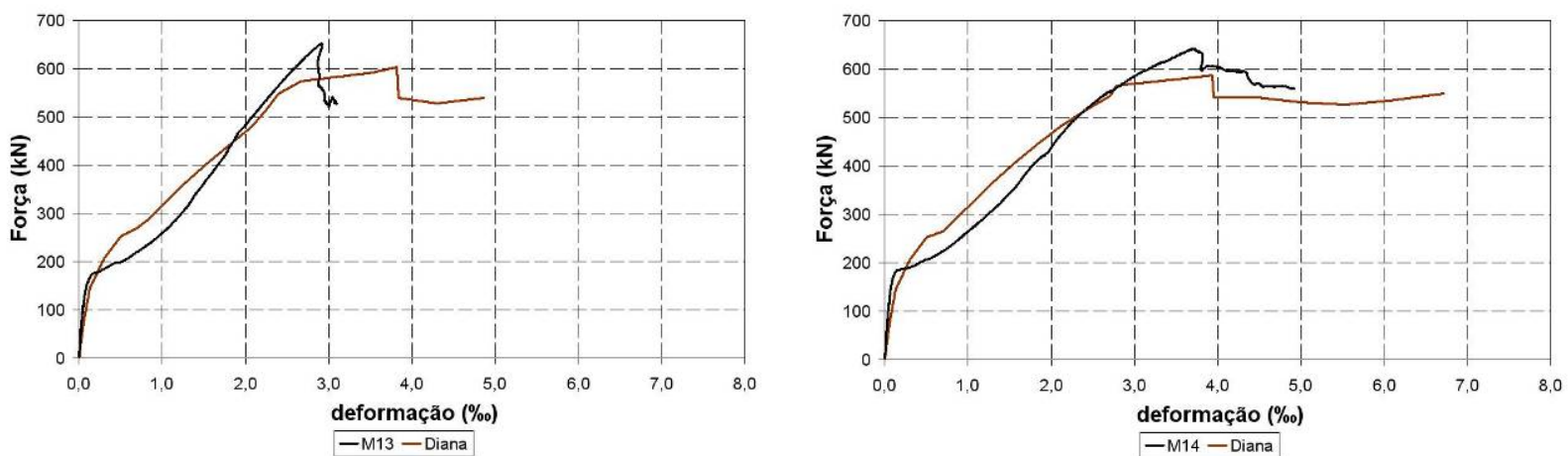

Figura 6. 43 - Curva força versus deformação: ensaio experimental e numérico dos modelos M13 e M14 
Assim como se procedeu no capítulo 5 com os resultados experimentais, a partir dos valores de deformação obtidos na simulação numérica, foi possível estimar a tensão normal em cada barra utilizando o valor do módulo de elasticidade obtido nos ensaios de caracterização das barras de aço. Conhecendo-se a área de cada barra, é possível estimar a força $R_{s t}$ que atua nas barras da armadura principal do tirante. Com o valor da força $R_{s t} e$ da força última obtida na simulação de cada modelo, foi possível obter a força de compressão $\mathrm{R}_{\mathrm{cb}}$ atuante nas bielas de compressão, bem como o ângulo de inclinação da biela na iminência da ruína dos modelos.

A tabela 6.6 apresenta as forças $R_{\text {st,num }}$ e $R_{c b, n u m}$ bem como o ângulo de inclinação da biela na iminência da ruína, obtidos por meio das simulações numéricas. Verifica-se também que, na iminência da ruína, os ângulos de inclinação da biela apresentam valores próximos ao obtido experimentalmente, e apresentados anteriormente no item 5.7.4. A maior diferença foi constatada no modelo M10, cujo modelo numérico foi capaz de conduzir até a capacidade última do bloco, sem que houvesse ruína por ruptura do concreto do pilar.

Tabela 6.6 - Forças obtidas na iminência da ruína nos modelos numéricos

\begin{tabular}{|c|c|c|c|c|c|c|}
\hline Série & Modelo & $\begin{array}{c}\mathbf{F}_{\mathbf{u}, \mathrm{num}} \\
(\mathbf{k N})\end{array}$ & $\begin{array}{c}\mathbf{R}_{\text {st,num }} \\
(\mathbf{k N})\end{array}$ & $\begin{array}{c}\mathbf{R}_{\mathrm{cb}, \mathrm{num}} \\
(\mathbf{k N})\end{array}$ & $\theta_{\text {últ,num }}\left({ }^{\circ}\right)$ & $\theta_{\text {últ }} \exp \left({ }^{\circ}\right)$ \\
\hline \multirow{7}{*}{$\begin{array}{c}\text { Sem } \\
\text { rugosidade }\end{array}$} & M1 & 772 & 158,18 & 417,15 & 67,7 & 67,3 \\
\hline & M2 & 781 & 152,90 & 419,37 & 68,6 & 67,7 \\
\hline & M3 & 769 & 181,77 & 425,30 & 64,7 & 62,7 \\
\hline & M4 & 578 & 152,88 & 326,95 & 62,1 & 60,7 \\
\hline & M5 & 624 & 158,18 & 349,81 & 63,1 & 63,8 \\
\hline & M6 & 375 & 158,18 & 245,31 & 49,8 & 49,3 \\
\hline & M7 & 381 & 158,18 & 247,61 & 50,3 & 49,3 \\
\hline \multirow{7}{*}{$\begin{array}{c}\text { Com } \\
\text { rugosidade }\end{array}$} & M8 & 702 & 157,64 & 384,78 & 65,8 & 66,5 \\
\hline & M9 & 882 & 151,26 & 466,22 & 71,1 & 72,7 \\
\hline & M10 & 918 & 172,59 & 490,38 & 69,4 & 77,3 \\
\hline & M11 & 819 & 158,18 & 438,99 & 68,9 & 70,4 \\
\hline & M12 & 960 & 158,18 & 505,39 & 71,8 & 71,7 \\
\hline & M13 & 602 & 158,18 & 340,03 & 62,3 & 64,6 \\
\hline & M14 & 587 & 158,18 & 333,41 & 61,7 & 63,7 \\
\hline
\end{tabular}


Verificou-se por meio das simulações numéricas que as deformações e as tensões atuantes nas barras das armaduras apresentaram simetria em relação ao posicionamento das barras, sendo que os valores máximos encontravam-se variando entre a barras 2,3 e 4 posicionadas na região central do bloco. Esses resultados divergem dos obtidos nos ensaios experimentais, em que as deformações não foram simétricas. Esse resultado era esperado em virtude da simetria do modelo diante da aplicação da ação centrada.

A Figura 6.44 a seguir apresenta um esquema gráfico das deformações nas barras da armadura principal do tirante obtidas nas simulações numéricas da série sem rugosidade, enquanto que a Figura 6.45 apresenta o mesmo esquema de deformações das barras das armaduras principais do tirante dos modelos da série com rugosidade. A figura 6.46, por sua vez, apresenta os valores de deformação na armadura central do modelo M1 ao longo da direção longitudinal do bloco. Observa-se que na região sobre as estacas os valores de deformação apresentam-se pequenos quando comparados as deformações na região central do bloco, conforme foi observado nos resultados experimentais. Por causa da semelhança dos resultados nessa situação, apresenta-se apenas os resultados referentes ao modelo M1.
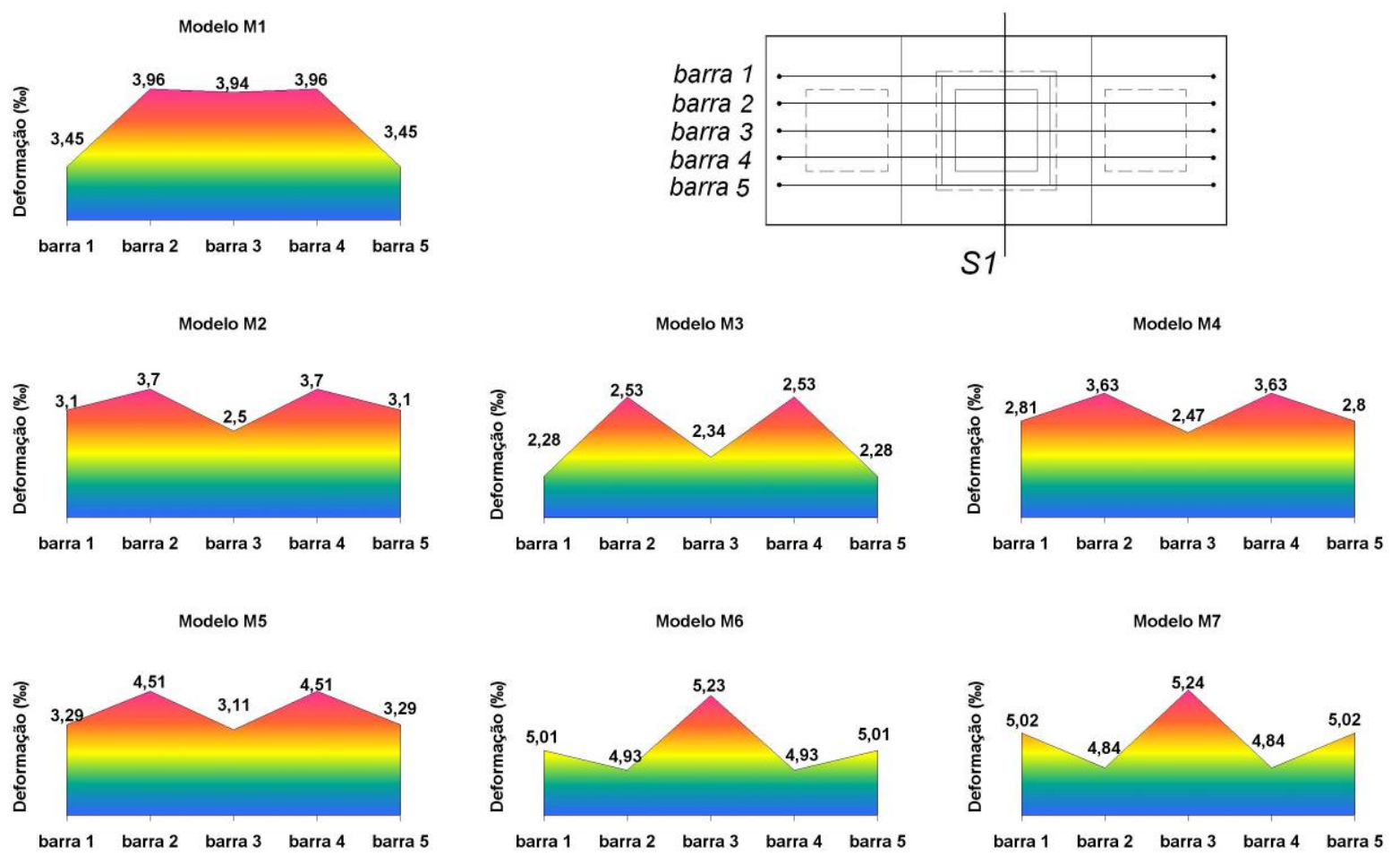

Figura 6. 44- Deformações nas barras das armaduras na simulação numérica: série sem rugosidade 


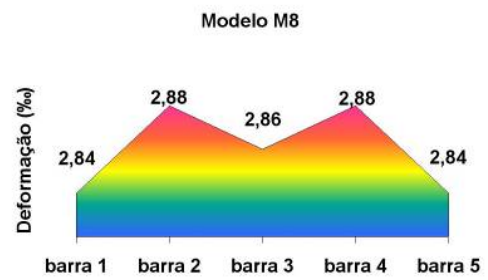

Modelo M9

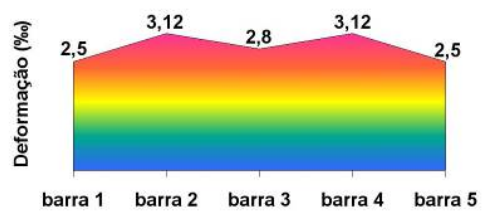

Modelo M12

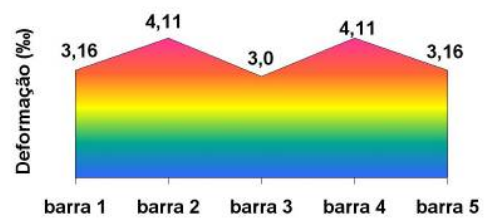

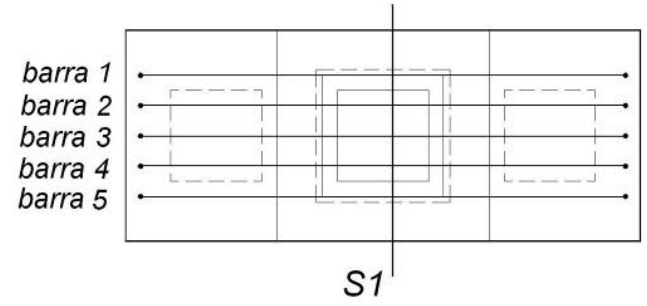

Modelo M10

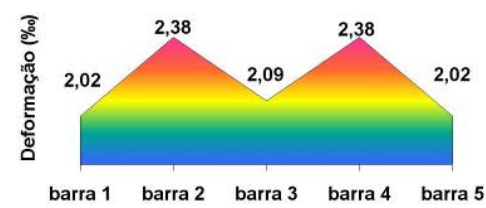

Modelo M13

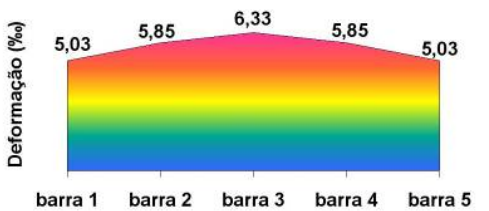

Modelo M11

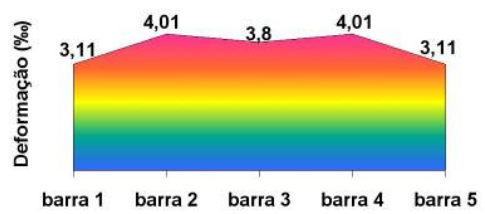

Modelo M14

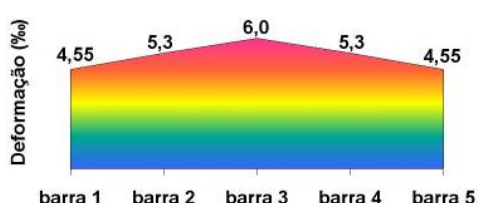

Figura 6. 45- Deformações nas barras das armaduras na simulação numérica: série sem rugosidade

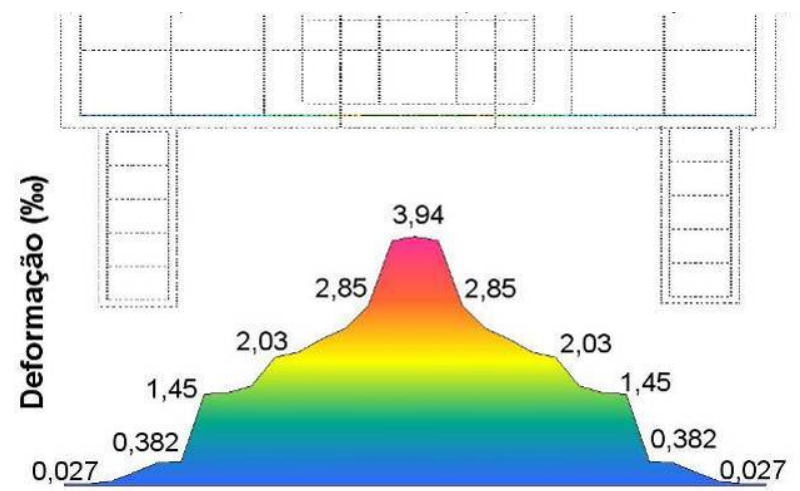

Figura 6. 46 - Deformação na barra da armadura central ao longo do eixo longitudinal do modelo M1

\subsubsection{Tensões principais de compressão}

Apresenta-se neste item o fluxo de tensões principais de compressão no interior dos modelos numéricos, o qual índica a formação bem como a inclinação das bielas de compressão. Verifica-se por meio dos resultados que nos blocos da série sem rugosidade, a formação da biela se dá próxima ao fundo do cálice, havendo uma pequena transferência da força aplicada no modelo por meio do atrito entre o pilar e as paredes do cálice.

Esse resultado foi semelhante em todos os modelos da série sem rugosidade, de modo que, a medida que o cálice se torna embutido no bloco, menor é a inclinação da biela em 
relação a direção longitudinal do bloco. Particularmente, nos modelos com cálice embutido, a formação da biela praticamente não ocorre, tendo em vista a pequena altura existente entre o fundo do cálice e a região inferior do bloco. Nos blocos da série sem rugosidade, a força oriunda do pilar cria um fluxo de tensões abaixo do fundo do pilar. Nos blocos com cálice embutido da série com rugosidade, constata-se uma tendência de formação da biela a partir do encontro com o bloco. Porém, a biela fica concentrada na região do graute, tomando forma praticamente a partir da região inferior do pilar no encontro com o bloco.

Em relação aos modelos da série com rugosidade, verifica-se que a transferência da força oriunda do pilar se iniciou ao longo da altura do cálice. Verifica-se nos modelos com cálice externo da série com rugosidade a existência de uma biela menor nas paredes do cálice, a qual se encontra com uma biela maior oriunda da região de encontro do pilar com o fundo do cálice. Em todos os modelos analisados, verifica-se a existência de picos de tensão de compressão no encontro do pilar com o bloco, e do bloco com a estaca, sendo que esses valores atingem a ordem de duas vezes o valor da resistência média a compressão do concreto do bloco.

As Figuras 6.47 a 6.54 apresentam o fluxo de tensões principais nos modelos analisados para intensidades de força igual a $565 \mathrm{kN}$, que é o valor estimado para a força de avaliação. Nos modelos em que a força última foi inferior ao valor da força de avaliação, isto e, modelos M6 e M7, apresentam-se as tensões principais relativas a última etapa de força. Nesse item, optou-se por apresentar os resultados comparando os modelos da série sem rugosidade com os modelos da série com rugosidade, a fim de comparar a formação da biela em blocos com o mesmo tipo de cálice, porém com diferenças na conformação das paredes.

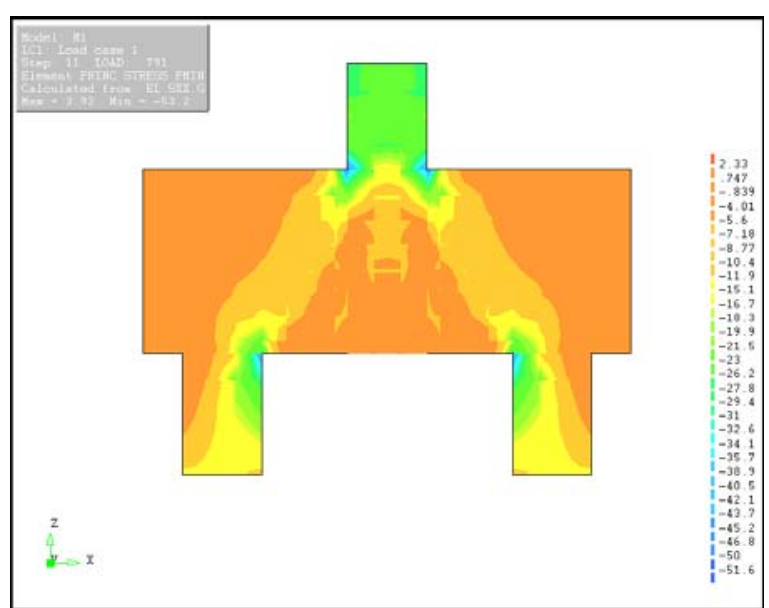

(a)

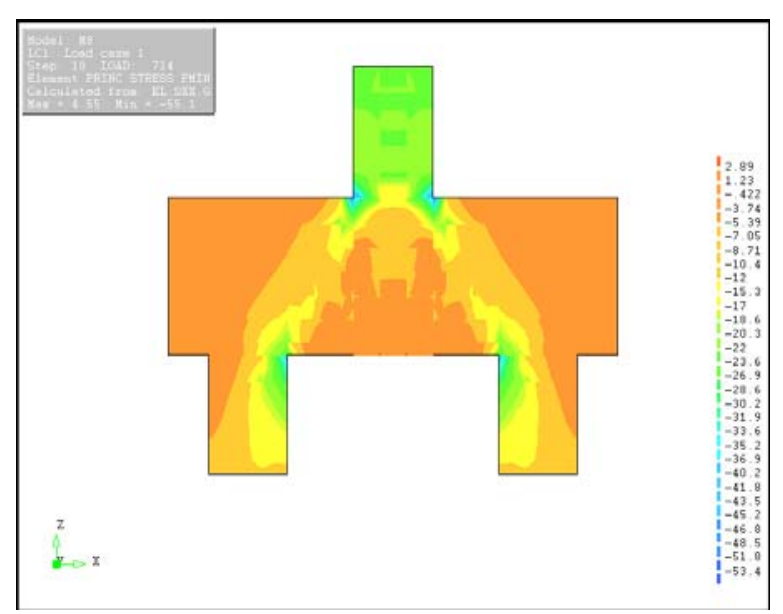

(b)

Figura 6. 47- Tensões principais de compressão relativas a força de avaliação dos modelos M1 e M8 


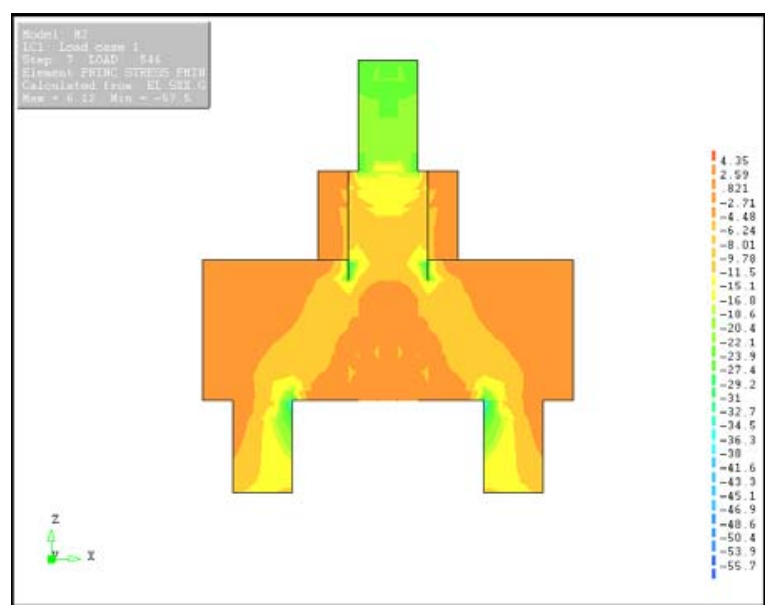

(a)

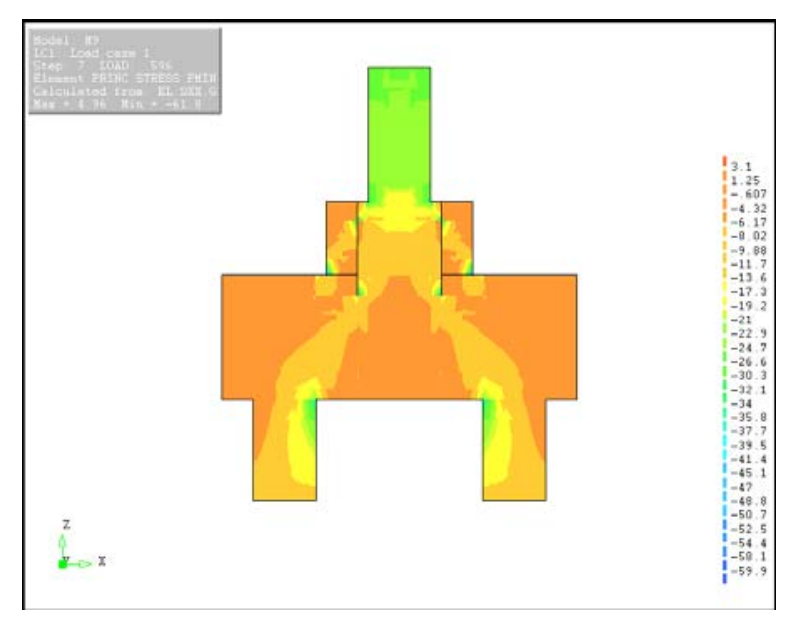

(b)

Figura 6. 48 - Tensões principais de compressão relativas a força de avaliação dos modelos M2 e M9

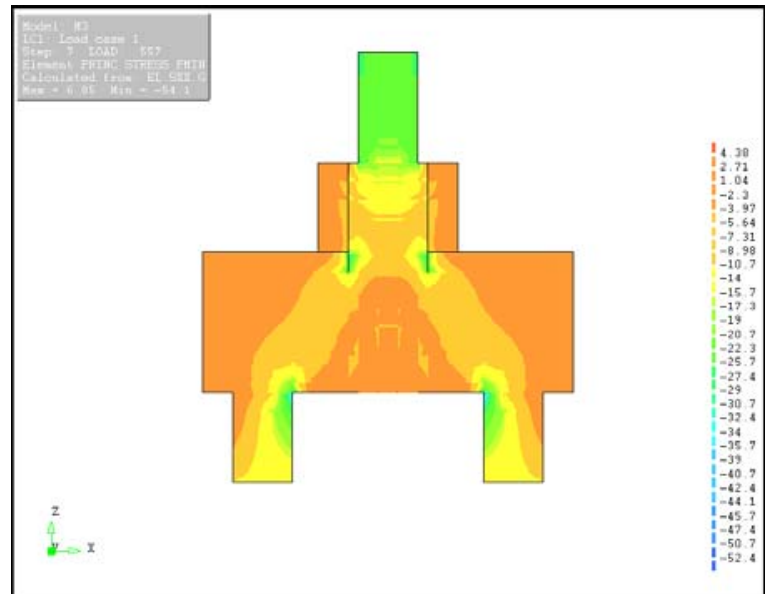

(a)

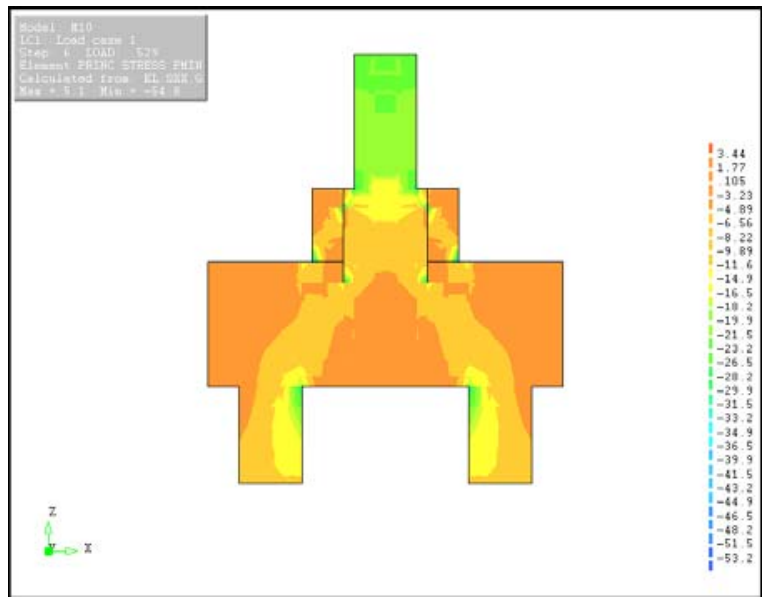

(b)

Figura 6. 49 - Tensões principais de compressão relativas a força de avaliação dos modelos M3 e M10

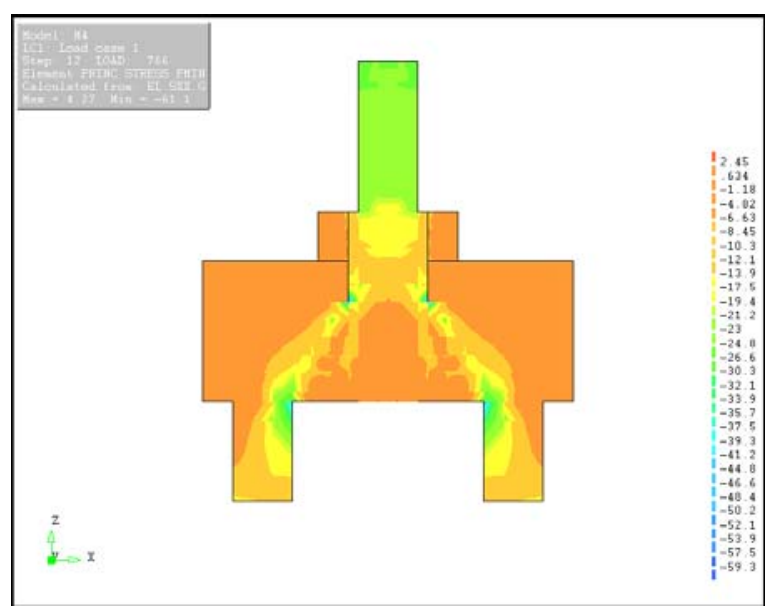

(a)

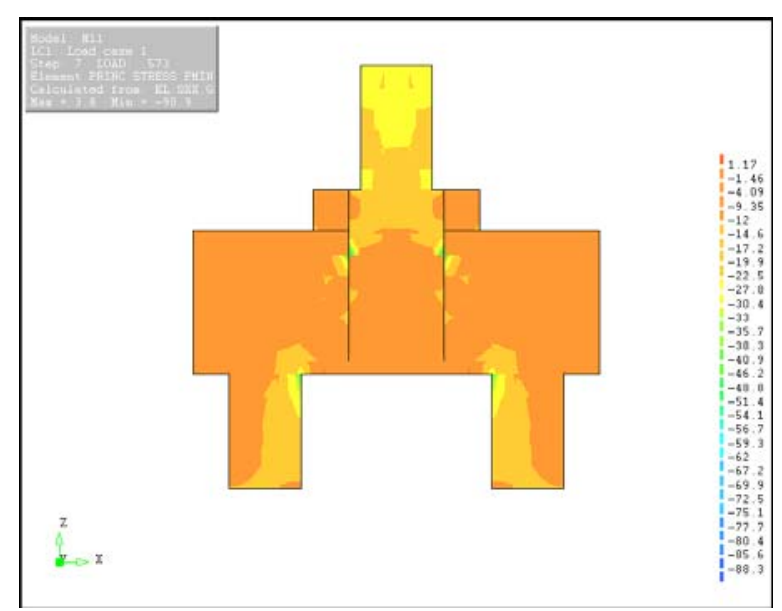

(b)

Figura 6. 50 - Tensões principais de compressão relativas a força de avaliação dos modelos M4 e M11 


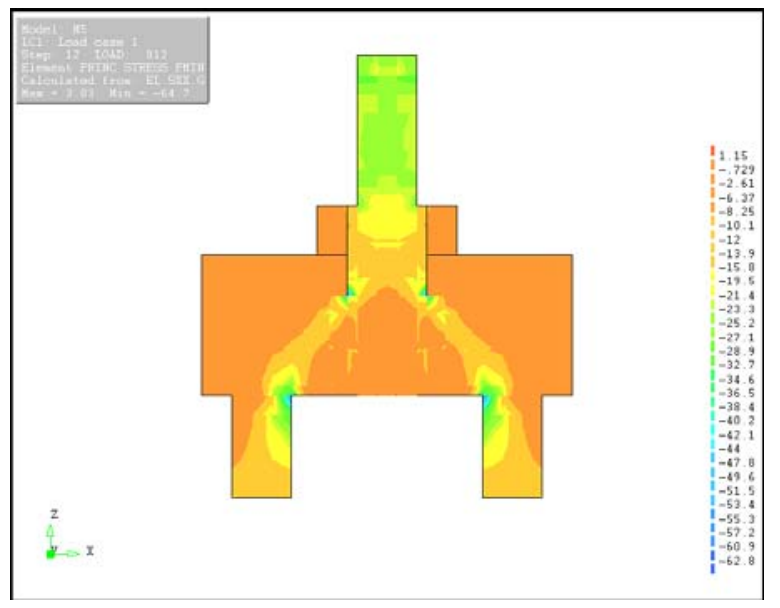

(a)

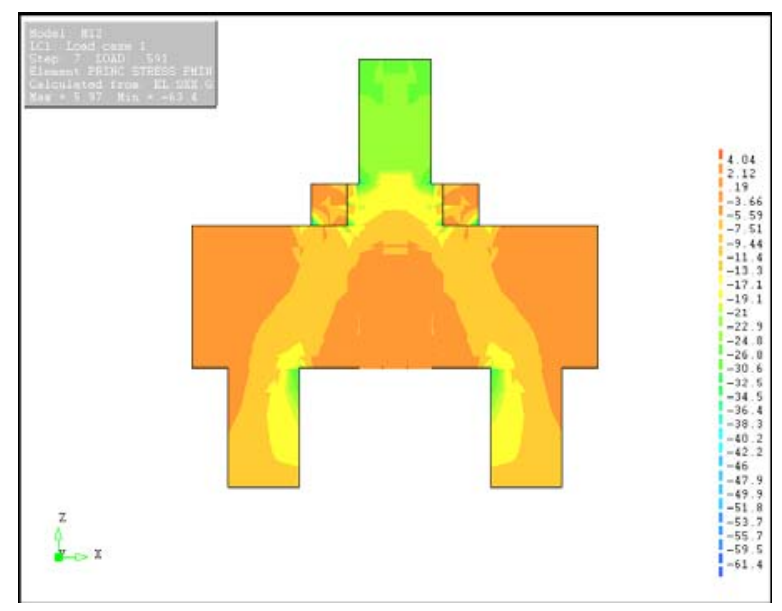

(b)

Figura 6. 51 - Tensões principais de compressão relativas a força de avaliação dos modelos M5 e M12

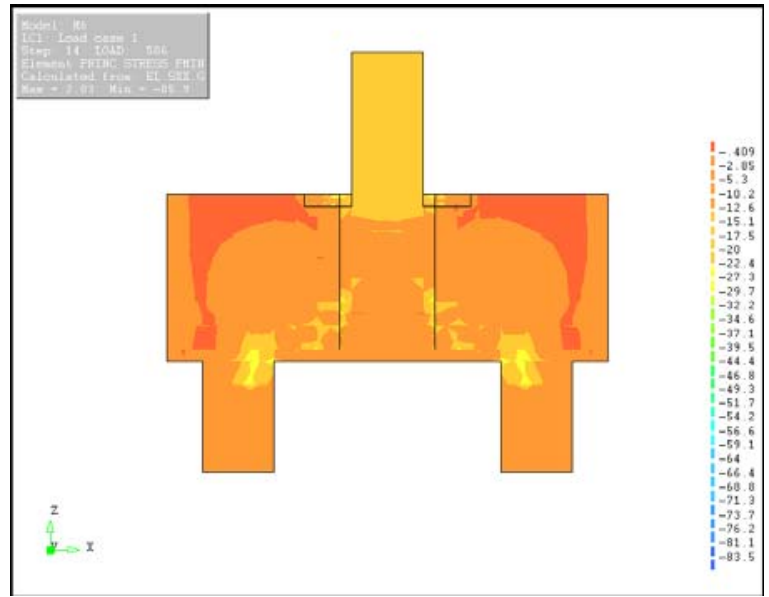

(a)

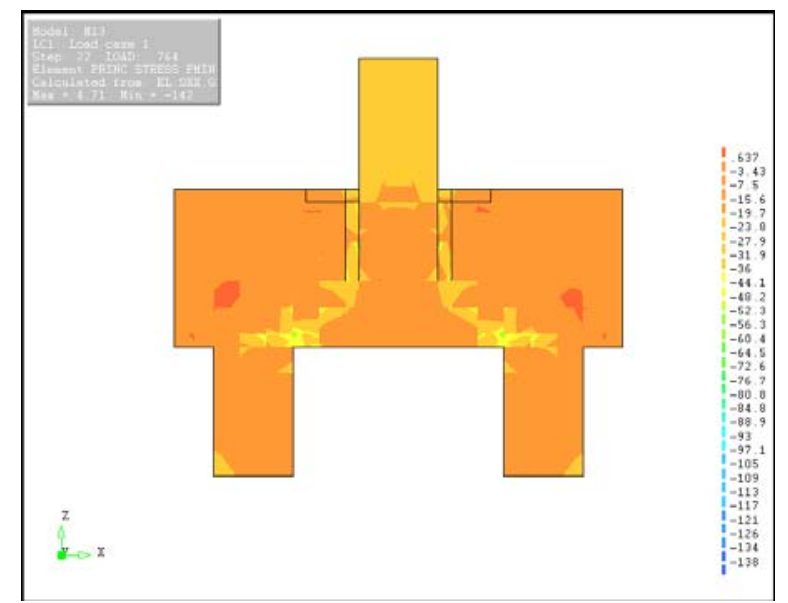

(b)

Figura 6. 52 - Tensões principais de compressão relativas a força última do modelo M6 e de avaliação do modelo M13

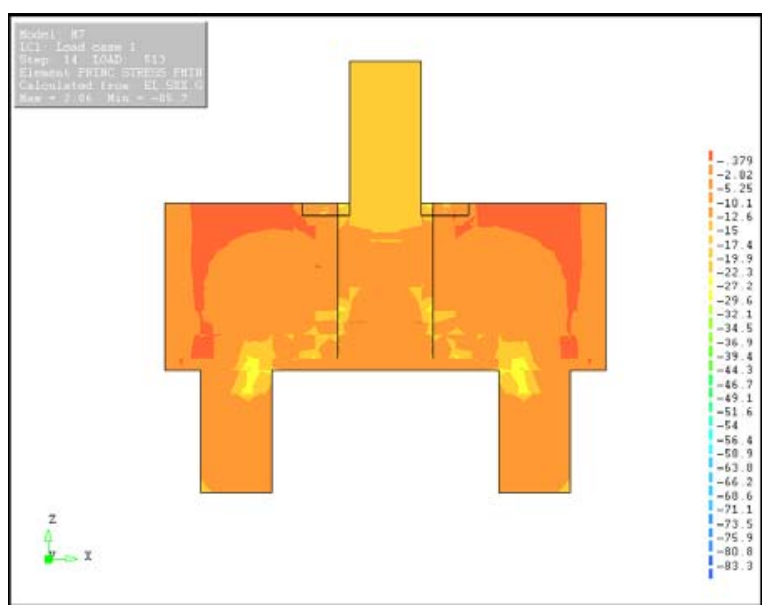

(a)

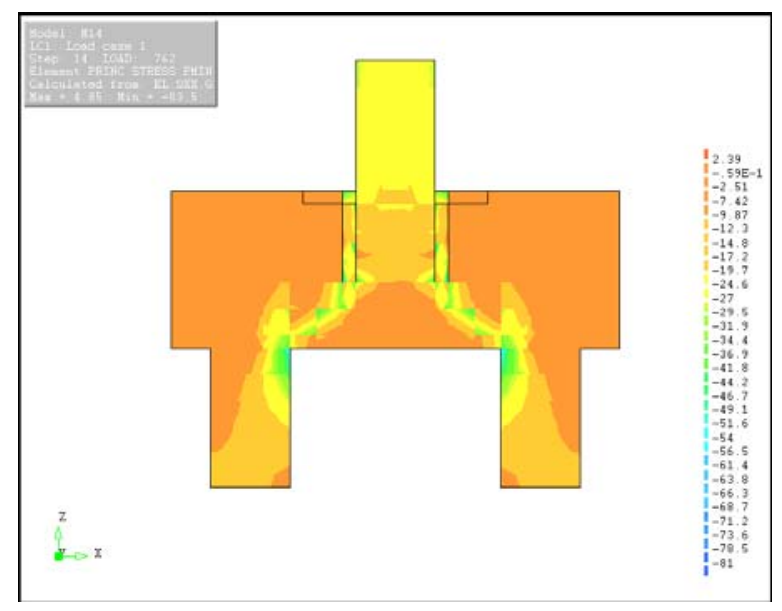

(b)

Figura 6. 53 - Tensões principais de compressão relativas a força última do modelo M7 e de avaliação do modelo M14 
Em relação às tensões tangenciais na interface do pilar com o graute e do graute com o pilar nos modelos da série sem rugosidade, verificou-se que os valores de tensões tangenciais aumentavam de acordo com a profundidade do bloco. Os valores de tensões tangenciais variaram de $3 \mathrm{MPa}$ na região superior da interface até $34 \mathrm{MPa}$ na região inferior, próxima ao fundo do cálice, conforme pode ser observado nas Figuras 6.54, 6.55 e 6.56, as quais apresentam a distribuição de tensões tangenciais nos modelos com cálice da série sem rugosidade.

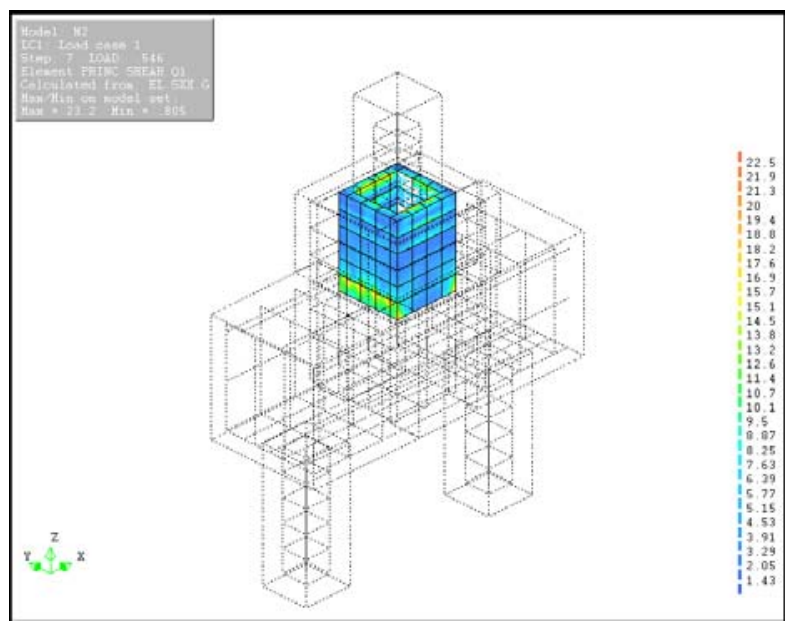

(a)

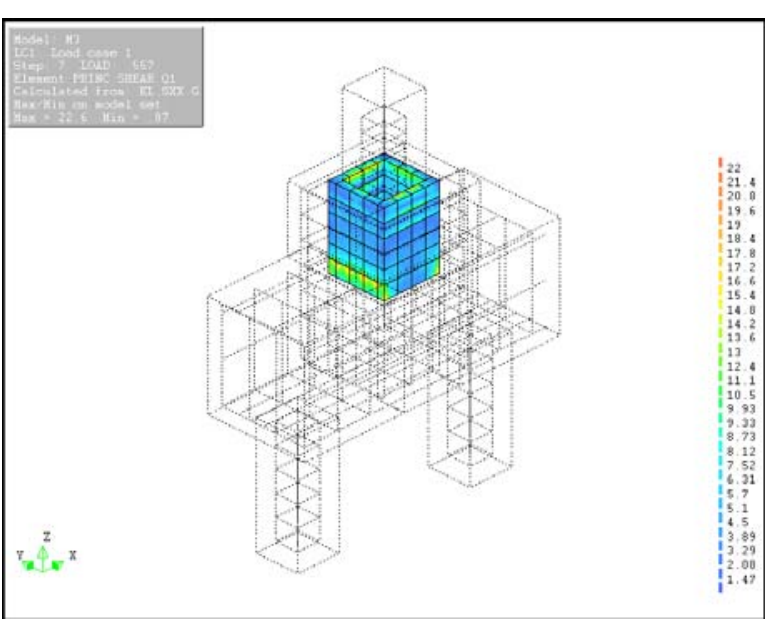

(b)

Figura 6. 54 - Tensões tangenciais na interface do pilar com o graute dos modelos M2 e M3

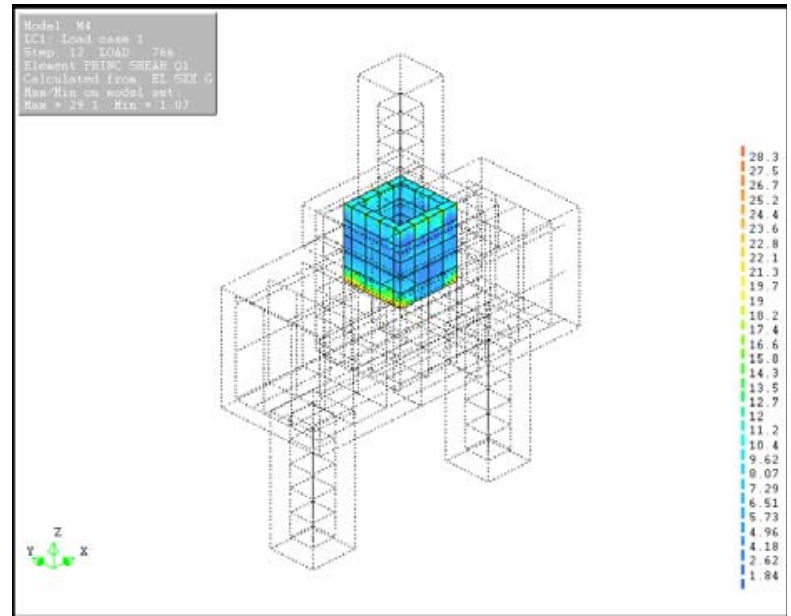

(a)

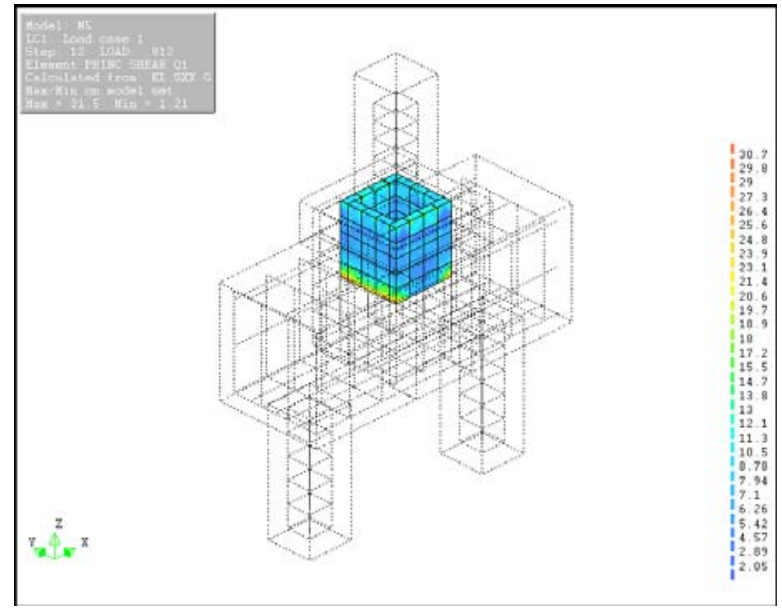

(b)

Figura 6. 55 - Tensões tangenciais na interface do pilar com o graute dos modelos M4 e M5 


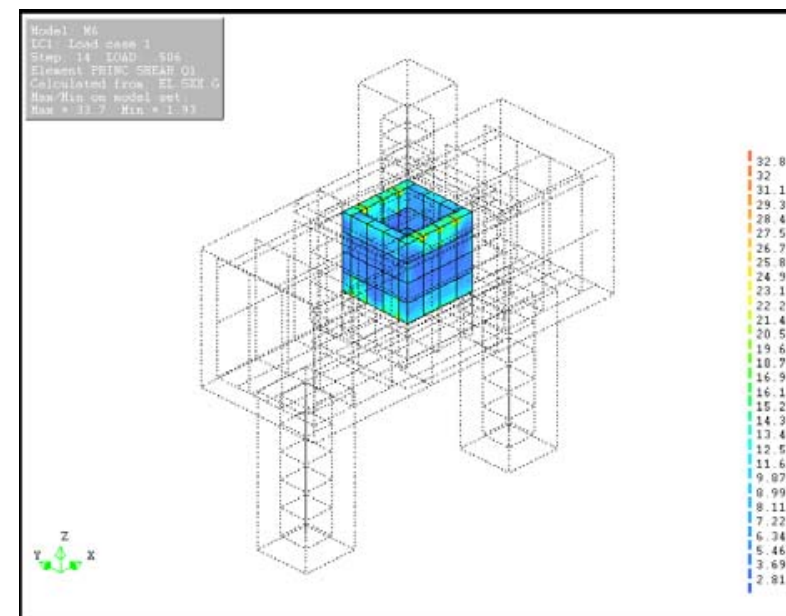

(a)

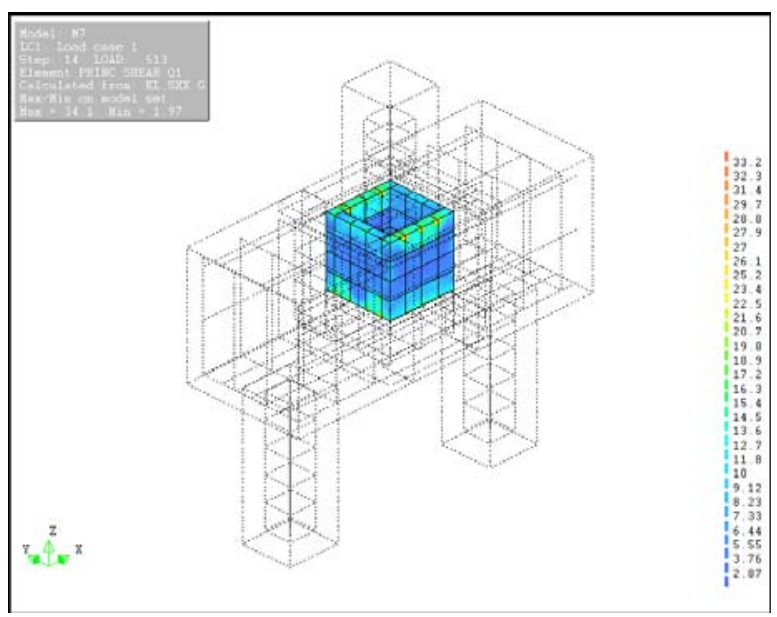

(b)

Figura 6. 56 - Tensões tangenciais na interface do pilar com o graute dos modelos M6 e M7

\subsubsection{Tensões nas barras da armadura complementar}

Observou-se que nos blocos com cálice parcialmente embutido, a armadura complementar apresentou tensões de tração máximas próximas a $115 \mathrm{MPa}$ para o modelo M5 e $40 \mathrm{MPa}$ para o modelo M12. Observou-se ainda que a máxima tensão de compressão ocorreu na armadura complementar posicionada sobre as estacas, cujos valores foram em torno de $150 \mathrm{MPa}$ para o modelo M5 e $215 \mathrm{MPa}$ para o modelo M12, conforme pode ser visto nas Figuras 5.57 (a) e 5.57 (b).

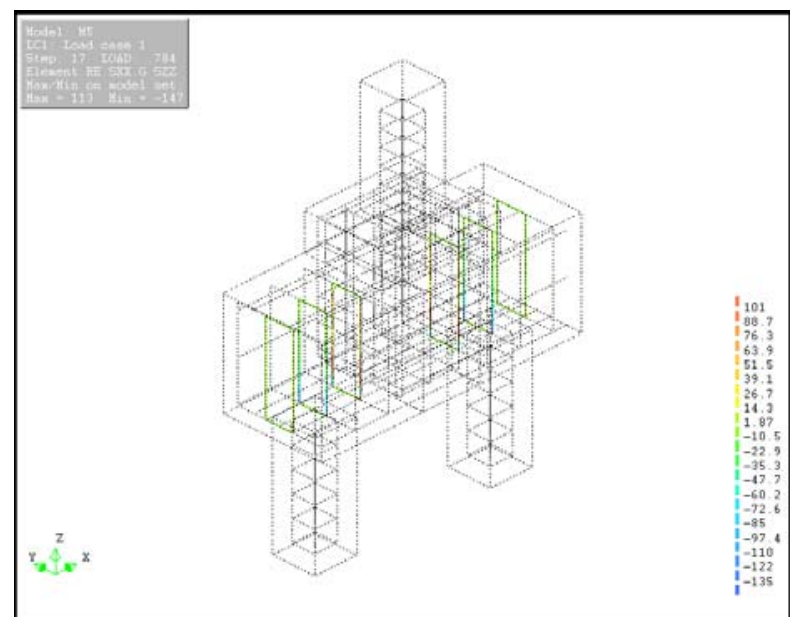

(a)

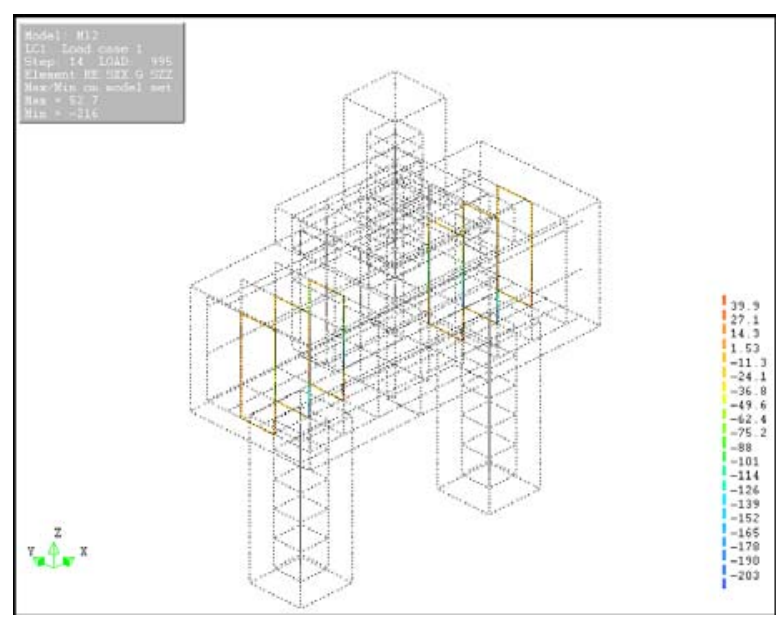

(b)

Figura 6. 57 - Tensões normais nas barras da armadura complementar dos modelos M5 e M12

No caso específico dos blocos com cálice embutido, verificou-se que as barras da armadura complementar posicionadas próximas ao cálice apresentaram tensões elevadas, 
indicando que ocorreu o escoamento dessas armaduras. As tensões de compressão máxima, por suas vezes, ocorreram nas armaduras posicionadas sobre as estacas, apresentando valores semelhantes aos apresentados pelos modelos com cálice parcialmente embutido, conforme verifica-se nas Figuras 5.58 (a) e $\mathbf{5 . 5 8}$ (b).

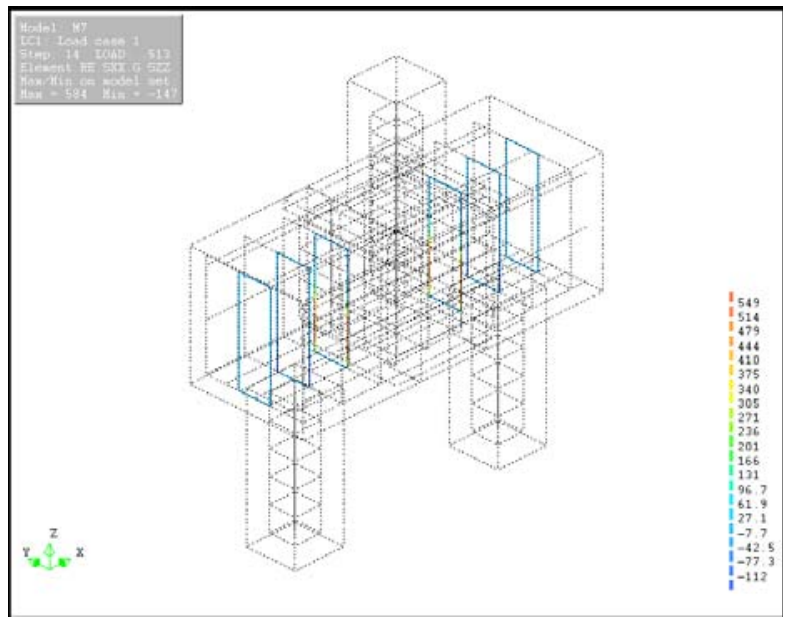

(a)

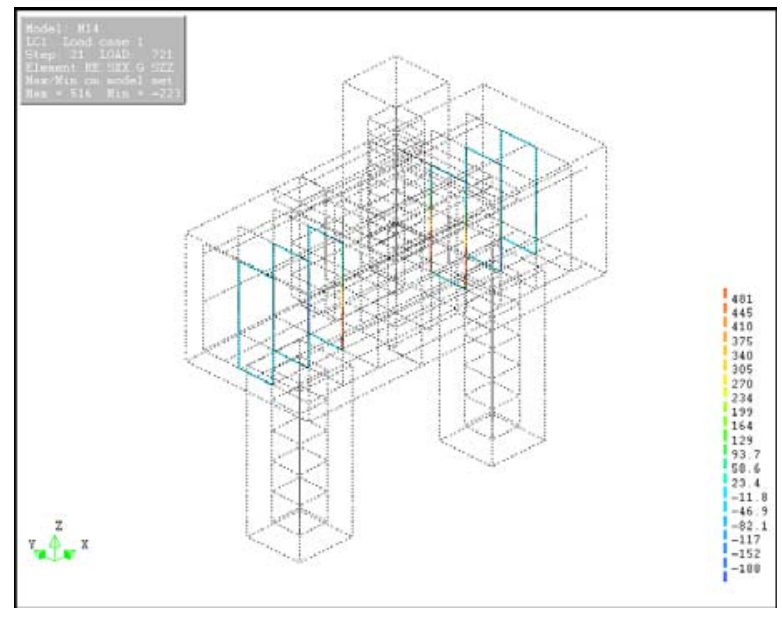

(b)

Figura 6. 58 - Tensões normais nas barras da armadura complementar dos modelos M7 e M14

\subsection{Comentários finais}

Apresentaram-se neste capítulo os resultados obtidos por meio da análise numérica realizada com o programa DIANA. Inicialmente foram apresentados alguns comentários a respeito do programa, bem como uma breve descrição dos modelos constitutivos e dos elementos finitos utilizados na simulação numérica. Em seguida foi feita uma análise paramétrica cujo intuito foi aferir um modelo numérico que fosse capaz de representar o comportamento dos blocos de fundação, de acordo com os resultados obtidos experimentalmente. Encontrou-se um modelo que foi capaz de representar com boa precisão a força última obtida nos modelos experimentais, porém com limitações em relação aos deslocamentos obtidos e as deformações nas barras das armaduras principais do tirante. Por fim, foram apresentados os resultados da simulação numérica, sendo apresentados inicialmente os resultados da etapa inicial, a qual foi realizada antes dos ensaios experimentais, seguido dos resultados da etapa final, obtidos após a realização do programa experimental. 



\subsection{Comentários iniciais}

O dimensionamento de blocos rígidos de fundação utilizados em ligações monolíticas pode ser feito por meio de um modelo de bielas e tirantes, no qual limitam-se os valores das tensões nas regiões de encontro do bloco com o pilar e do bloco com as estacas. Na literatura técnica não existe um consenso a respeito do valor limite para essas tensões, sendo que na maioria das vezes esses valores são estimados a partir da resistência característica à compressão do concreto utilizado em projetos.

Tratando especificamente das situações de bloco de fundação com presença de cálice, não foi encontrada na literatura recomendações específicas a respeito desse tipo de bloco, sendo o dimensionamento e as verificações remetidos aos mesmos parâmetros utilizados na situação de blocos com ligação monolítica.

Em virtude dos resultados experimentais indicarem diferenças significativas no comportamento estrutural dos blocos de fundação em função do tipo de cálice e da existência ou não de rugosidade na interface pilar fundação, apresenta-se nesse capítulo um modelo teórico de bielas e tirantes oriundo do modelo tradicional de blocos com ligação monolítica, no qual se limitam as tensões na região nodal superior, permitindo que o mesmo seja utilizado nas situações em que exista a presença de cálice.

\subsection{Tensões nas regiões nodais}

O cálculo das tensões nas regiões nodais pode ser feito a partir das forças $R_{s t}$ e $R_{c b}$ atuantes no tirante e na biela comprimida, bem como do valor do ângulo $\theta$ de inclinação entre essas forças. Pode-se ainda obter a força na biela em função da força atuante no pilar e, assim, calcular a tensão nessas regiões utilizando o valor da força atuante no pilar. Existe uma dificuldade em se estabelecer o valor exato da área da seção transversal da biela comprimida na região do encontro do bloco com o pilar e do bloco com a estaca, por esse motivo utilizam- 
se valores de área que são funções das áreas desses elementos e que, para o caso de blocos sobre duas estacas, resultam nas expressões 7.1 e 7.2.

$$
\begin{aligned}
& A_{b, e}=A_{e} \cdot \operatorname{sen} \theta \\
& A_{b, p}=0,5 \cdot A_{p} \cdot \operatorname{sen} \theta
\end{aligned}
$$

As tensões nas regiões nodais são obtidas a partir da relação entre a força na biela e as áreas obtidas anteriormente com as expressões 7.1 e 7.2. Observa-se que nas situações em que a área do pilar apresenta a mesma ordem de grandeza da área das estacas, a tensão será maior na região de encontro do bloco com o pilar. Como nesse estudo essa situação ocorreu em todos os quatorze modelos estudados, entende-se que o valor limitante das tensões deve ser obtido na região de encontro da biela com o pilar.

Observou-se por meio dos resultados experimentais que as tensões nos blocos de referência (modelos M1 e M8) apresentaram valores semelhantes, resultando próximos a 39 MPa. Nos blocos da série sem rugosidade, constatou-se que as tensões obtidas nos blocos com cálice externo apresentaram a mesma ordem de grandeza das tensões obtidas no bloco de referência dessa série, enquanto que na situação de cálice parcialmente embutido, houve uma redução no valor da tensão em torno de $15 \%$. Nos blocos com cálice embutido, as tensões resultaram aproximadamente $30 \%$ menores do que a do bloco de referência. Porém, como nos ensaios experimentais e nas simulações numéricas não foi nítida a formação de bielas na situação de bloco com cálice embutido e sem rugosidade, entende-se não ser apropriado verificar esse tipo de bloco utilizando modelos de bielas e tirantes. Nessa situação, recomenda-se utilizar a teoria geral da flexão, conforme será apresentado no item 7.4.

No que diz respeito aos blocos com rugosidade na interface do cálice e do pilar, observou-se que os modelos com cálice externo e cálice parcialmente embutido apresentaram tensões na região de encontro do pilar com o bloco em torno de $15 \%$ maiores do que as apresentadas pelo bloco de referência dessa série. Os blocos com cálice embutido, por suas vezes, apresentaram valores de tensões na região nodal correspondentes a $90 \%$ do valor registrado no bloco de referência.

Analisando de modo isolado apenas o valor da tensão na região de encontro do bloco com o pilar, pode-se imaginar que as diferenças obtidas nos modelos com cálice embutido das séries com rugosidade e sem rugosidade, as quais resultam em torno de $20 \%$, são pequenas quando comparadas ao valor da força última nesses modelos. Há de se lembrar que o cálculo 
da tensão considera também o valor do ângulo teórico de inclinação da biela comprimida, que na situação de bloco sem rugosidade, apresentou um valor inferior ao dos demais blocos, conduzindo à conclusão que não houve formação de bielas nesses modelos.

A tabela 7.1 apresenta os valores do ângulo teórico $\theta_{\text {últ }}$ entre a biela comprimida na iminência da ruína dos modelos, a área da região de encontro do bloco com o pilar $\mathrm{A}_{\mathrm{b}, \mathrm{p}}$, a força de compressão atuante na biela $\mathrm{R}_{\mathrm{cb}}$, bem como o valor das tensões normais $\sigma_{b, p}$ nessa região. Apresenta-se também a relação entre a tensão $\sigma_{b, p}$ em cada modelo e a tensão nos modelos de referência de cada série, bem como a relação entre a tensão $\sigma_{b, p}$ e o valor médio da resistência à compressão do concreto dos blocos, que foi igual a 33,1 MPa.

Tabela 7.1 - Tensões na região nodal de encontro do bloco com o pilar

\begin{tabular}{|c|c|c|c|c|c|c|c|}
\hline Série & Modelo & $\theta_{\text {últ }}\left({ }^{(0}\right)$ & $\begin{array}{c}A_{b, p} \\
\left(\mathbf{c m}^{2}\right)\end{array}$ & $\mathbf{R}_{\mathrm{cb}}(\mathbf{k N})$ & $\begin{array}{c}\sigma_{\mathbf{b}, \mathbf{p}} \\
(\mathrm{MPa})\end{array}$ & $\begin{array}{c}\sigma_{\mathbf{b}, \mathbf{p}} / \\
\sigma_{\mathbf{b}, \mathbf{p}, \text { ref }}\end{array}$ & $\sigma_{\mathrm{b}, \mathrm{p}} / \mathbf{f}_{\mathrm{cm}}$ \\
\hline \multirow{7}{*}{$\begin{array}{c}\text { Sem } \\
\text { rugosidade }\end{array}$} & M1 & 67,3 & 103,78 & 409,76 & 39,5 & 1,00 & 1,19 \\
\hline & M2 & 67,7 & 104,10 & 417,15 & 40,1 & 1,01 & 1,21 \\
\hline & M3** & 62,7 & 99,97 & 407,37 & 40,7 & 1,03 & 1,23 \\
\hline & M4 & 60,7 & 98,08 & 322,90 & 32,9 & 0,83 & 0,99 \\
\hline & M5 & 63,8 & 100,97 & 358,76 & 35,5 & 0,90 & 1,07 \\
\hline & M6* & 49,3 & 85,27 & 236,83 & 27,8 & 0,70 & 0,84 \\
\hline & M7* & 49,3 & 85,31 & 242,65 & 28,4 & 0,72 & 0,86 \\
\hline \multirow{7}{*}{$\begin{array}{l}\text { Com } \\
\text { rugosidade }\end{array}$} & M8 & 66,5 & 103,18 & 396,88 & 38,5 & 1,00 & 1,16 \\
\hline & M9 & 72,7 & 107,40 & 479,76 & 44,7 & 1,16 & 1,35 \\
\hline & M10** & 77,3 & 109,74 & 323,93 & 29,5 & 0,77 & 0,89 \\
\hline & M11 & 70,4 & 105,98 & 471,31 & 44,5 & 1,16 & 1,34 \\
\hline & M12 & 71,7 & 106,81 & 503,97 & 47,2 & 1,23 & 1,43 \\
\hline & M13 & 64,6 & 101,59 & 360,99 & 35,5 & 0,92 & 1,07 \\
\hline & M14 & 63,7 & 100,85 & 356,96 & 35,4 & 0,92 & 1,07 \\
\hline
\end{tabular}

"Modelos em que não ocorreu formação da biela;**Modelos em que houve ruptura do concreto do pilar

$\mathrm{Na}$ situação de blocos com ligação monolítica, encontraram-se na literatura técnica diversos valores recomendados para o valor limite da tensão nas regiões nodais, valores esses indicados por normas e pesquisadores internacionais. Apresentam-se na tabela 7.2 as expressões para cálculo dessas tensões limites, em função da região em que se aplicam, isto é, região de encontro do bloco com o pilar e região de encontro do bloco com as estacas. 
Tabela 7.2 - Critérios de verificação das tensões nas regiões nodais

\begin{tabular}{c|c|c}
\hline \hline Critérios & Ligação Bloco-Pilar & $\begin{array}{c}\text { Ligação Bloco- } \\
\text { Estaca }\end{array}$ \\
\hline BLÉVOT \& FRÉMY (1967) & $1,4 \cdot \mathrm{f}_{\mathrm{ck}}$ & $1,0 \cdot \mathrm{f}_{\mathrm{ck}}$ \\
\hline SCHÄFER \& SCHLAICH (1988) & $0,935 \cdot \mathrm{f}_{\mathrm{cd}}$ & $0,68 \cdot \mathrm{f}_{\mathrm{cd}}$ \\
\hline SCHLAICH \& SCHÄFER (1991) & $1,1 \cdot \mathrm{f}_{\mathrm{cd}}$ & $0,8 \cdot \mathrm{f}_{\mathrm{cd}}$ \\
\hline CEB-FIP (1990) & $0,85 \cdot\left[1-\frac{\mathrm{f}_{\mathrm{ck}}}{250}\right] \cdot \mathrm{f}_{\mathrm{cd}}$ & $0,60 \cdot\left[1-\frac{\mathrm{f}_{\mathrm{ck}}}{250}\right] \cdot \mathrm{f}_{\mathrm{cd}}$ \\
\hline CSA-A23.3-04 & $0,85 \cdot \phi_{\mathrm{c}} \cdot \mathrm{f}_{\mathrm{c}}^{\prime}$ & $0,75 \cdot \phi_{\mathrm{c}} \cdot \mathrm{f}_{\mathrm{c}}^{\prime}$ \\
\hline ACI 318-08 & $0,85 \cdot \mathrm{f}_{\mathrm{c}}^{\prime}$ & $0,6 \cdot \mathrm{f}_{\mathrm{c}}^{\prime}$ \\
\hline \hline
\end{tabular}

sendo que:

$\mathrm{f}_{\mathrm{ck}} \quad$ é a resistência característica à compressão do concreto, em $\mathrm{MPa}$;

$\mathrm{f}_{\mathrm{cd}} \quad$ é a resistência de cálculo à compressão do concreto;

$\phi_{\mathrm{c}} \quad$ é o fator de minoração da resistência do concreto, igual a 0,6 ;

$\mathrm{f}_{\mathrm{c}}$, é a resistência característica à compressão do concreto, definida a partir do quantil de $1 \%$.

A fim de comparação com os resultados experimentais, calculou-se de acordo com os critérios apresentados na tabela 7.2 os valores limites de tensão na região de encontro do bloco com o pilar. Como o único parâmetro disponível para o concreto foi a resistência à compressão média, utilizou-se esse valor como parâmetro de referência ao invés de se utilizarem valores característicos, estando os resultados apresentados na tabela 7.3.

Tabela 7.3 - Tensões nodais na região do encontro do bloco com o pilar

\begin{tabular}{c|c}
\hline \hline Critérios & $\begin{array}{c}\text { Ligação Bloco-Pilar } \\
\text { (MPa) }\end{array}$ \\
\hline BLÉVOT \& FRÉMY (1967) & 46,3 \\
\hline SCHÄFER \& SCHLAICH (1988) & 22,1 \\
\hline SCHLAICH \& SCHÄFER (1991) & 26,0 \\
\hline CEB-FIP (1990) & 17,4 \\
\hline CSA-A23.3-04 & 16,9 \\
\hline ACI 318-08 & 28,1 \\
\hline \hline
\end{tabular}


Verifica-se por meio dos resultados da tabela 7.1 que as tensões na região nodal de encontro da biela com o pilar mantiveram-se superiores ao valor da resistência à compressão média, com exceção dos modelos M6 e M7 da série sem rugosidade, e do modelo M10 da série com rugosidade. Como nesses blocos não ficou nítida a formação da biela, optou-se por desconsiderar os resultados desses modelos.

Constatou-se ainda por meio dos resultados apresentados nas tabelas 7.1 e 7.3 que, na iminência da ruína dos modelos, as tensões máximas na região nodal de encontro do bloco com o pilar apresentaram-se superiores aos valores de tensões limites indicados por diversos pesquisadores e normas internacionais, com exceção dos valores recomendados por BLÉVOT \& FRÉMY (1967), o qual resultou num valor limite para a tensão igual a 46,3 MPa, resultando numa situação contra a segurança. Entende-se, portanto, que seguir as recomendações normativas no que diz respeito aos limites de tensões nas regiões nodais, conduz ao dimensionamento de estruturas seguras.

\subsection{Critério proposto para verificação da região nodal superior}

Tentar estimar um valor limite para as tensões na região nodal superior a partir da ruína dos modelos pode não ser a melhor alternativa. Isto porque a obtenção do valor da tensão é influenciada diretamente pela inclinação da biela e pela força atuante na mesma, as quais apresentam variações para cada tipo de bloco. Uma possibilidade seria estabelecer um critério que evite a ocorrência de algum fenômeno no bloco, como por exemplo, a ocorrência de fissuração, ou a diminuição da rigidez. Desse modo, está sendo proposto um critério de projeto para verificação das tensões na região nodal superior de blocos sobre duas estacas com cálice de fundação, de modo que não ocorra diminuição na rigidez dos blocos de fundação.

Para definição desse critério, algumas simplificações precisaram ser feitas. Uma delas é considerar que a inclinação da biela é constante, independente da intensidade da ação aplicada no pilar. Outra simplificação é considerar que a ação está sendo aplicada centrada no pilar, de modo que as reações nas estacas sejam iguais. A partir dos valores de inclinação da biela, $\theta_{\text {últ, }}$ e do valor da força que provocou diminuição na rigidez dos modelos, $\mathrm{F}_{\text {rig }}$, ambos apresentados no capítulo 5, calculou-se a tensão no encontro da biela com o pilar. Ordenaram-se os valores 
calculados de acordo com o tipo de cálice, bem como de acordo com a série a que pertence cada modelo. Os resultados encontram-se apresentados na tabela 7.4.

Tabela 7.4 - Tensões na região nodal superior na iminência da diminuição de rigidez

\begin{tabular}{|c|c|c|c|c|c|c|c|}
\hline Série & Modelo & $\theta_{\text {últt }}\left({ }^{\circ}\right)$ & $F_{\text {rig }}(k N)$ & $\mathbf{R}_{\mathrm{cb}}(\mathrm{kN})$ & $\begin{array}{c}\sigma_{\mathbf{b}, \mathbf{p}} \\
(\mathrm{MPa})\end{array}$ & $\sigma_{b, \mathbf{p}} / \mathbf{f}_{\mathbf{c m}}$ & $\sigma_{\mathrm{b}, \mathbf{p}} / \mathbf{f}_{\mathrm{cm}}$ \\
\hline \multirow{7}{*}{$\begin{array}{c}\text { Sem } \\
\text { rugosidade }\end{array}$} & M1 & 67,3 & 210 & 113,82 & 11,0 & 0,33 & 0,33 \\
\hline & M2 & 67,7 & 320 & 172,91 & 16,6 & 0,50 & \multirow{2}{*}{0,47} \\
\hline & $\mathrm{M} 3 * *$ & 62,7 & 260 & 146,29 & 14,6 & 0,44 & \\
\hline & M4 & 60,7 & 190 & 108,97 & 11,1 & 0,34 & \multirow{2}{*}{0,53} \\
\hline & M5 & 63,8 & 432 & 240,66 & 23,8 & 0,72 & \\
\hline & M6* & 49,3 & 165 & 108,85 & 12,8 & 0,39 & \multirow{2}{*}{0,35} \\
\hline & M7* & 49,3 & 136 & 89,67 & 10,5 & 0,32 & \\
\hline \multirow{7}{*}{$\begin{array}{c}\text { Com } \\
\text { rugosidade }\end{array}$} & M8 & 66,5 & 200 & 109,03 & 10,6 & 0,32 & 0,32 \\
\hline & M9 & 72,7 & 350 & 183,31 & 17,1 & 0,52 & \multirow{2}{*}{0,56} \\
\hline & M10** & 77,3 & 422 & 216,30 & 19,7 & 0,60 & \\
\hline & M11 & 70,4 & 345 & 183,11 & 17,3 & 0,52 & \multirow{2}{*}{0,45} \\
\hline & M12 & 71,7 & 252 & 132,71 & 12,4 & 0,38 & \\
\hline & M13 & 64,6 & 177 & 98,00 & 9,6 & 0,29 & \multirow{2}{*}{0,30} \\
\hline & M14 & 63,7 & 185 & 103,18 & 10,2 & 0,31 & \\
\hline
\end{tabular}

"Modelos em que não ocorreu formação da biela, **Modelos em que houve ruptura do concreto do pilar

Observa-se nos blocos da série com rugosidade que a relação entre a tensão $\sigma_{b, p}$ e a resistência à compressão média do concreto dos blocos, no instante em que ocorreu a diminuição da rigidez, foi maior para os blocos com cálice externo, cujo valor médio resultou em 0,56. Nos blocos com cálice parcialmente embutido, o valor médio para essa relação foi igual a 0,45 , enquanto nos blocos com cálice embutido, a relação foi igual a 0,30 , próximo ao valor de 0,32 ocorrido no bloco de referência dessa série.

Nos blocos da série sem rugosidade, observou-se que o valor médio da relação entre a tensão $\sigma_{b, p}$ e a resistência à compressão média do concreto dos blocos foi igual a 0,47 nos blocos com cálice externo, 0,53 nos blocos com cálice parcialmente embutido e 0,35 nos blocos com cálice embutido. Verifica-se que houve um aumento nos valores registrados para os blocos com cálice parcialmente embutido, em relação aos blocos com cálice externo dessa série. Esse aumento ocorreu em virtude do ganho de resistência do modelo M5, em virtude da utilização da armadura complementar em forma de estribo posicionado na região central do 
bloco, cujo efeito benéfico só foi constatado no modelo com cálice parcialmente embutido da série sem rugosidade.

\subsection{Avaliação dos blocos com cálice embutido sem rugosidade}

Em relação aos modelos M6 e M7, os quais não dispunham de rugosidade na interface pilar fundação, constatou-se que a formação da biela foi diferente dos demais modelos analisados, ocorrendo a partir da região inferior do pilar, e ocorrendo o escoamento das barras das armaduras principais do tirante. Desse modo, procedeu-se uma avaliação desses blocos de acordo com a teoria de flexão, segundo o modelo proposto no boletim 73 do CEB-FIP (1970).

O boletim 73 do CEB FIP (1970) recomenda que, em blocos flexíveis, o dimensionamento do bloco ocorra numa seção de referência $\mathrm{S} 1$, situada entre a face externa do pilar e a região central do bloco, conforme apresentado no capítulo 2. Desse modo, segundo a geometria dos modelos M6 e M7, a seção de referência estará distante $26 \mathrm{~cm}$ a partir do eixo de uma das estacas, conforme apresentado na Figura 7.1.
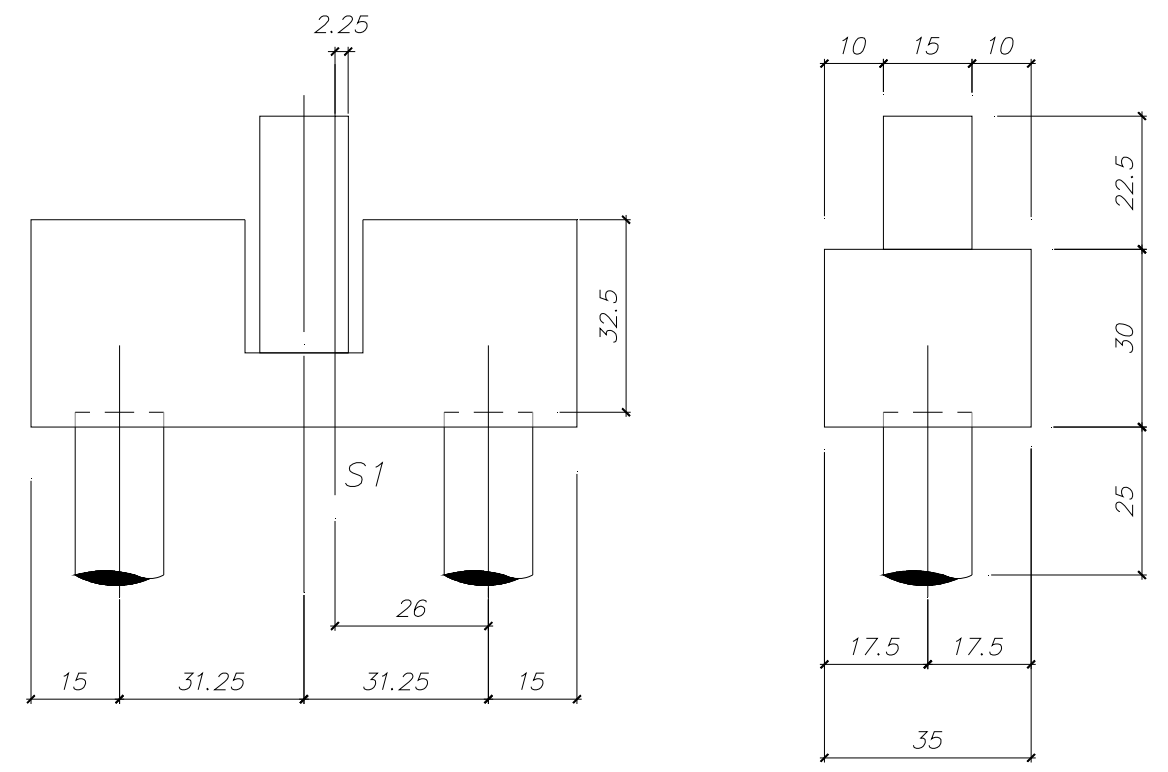

Figura 7. 1- Seção de referência nos modelos M6 e M7

Para verificação do momento resistente na seção de referência do bloco, será feito o cálculo partindo da área de armadura detalhada nesses modelos, utilizando as expressões de equilíbrio das componentes $R_{c c}$ e $R_{\text {st, }}$ as quais atuam numa seção submetida a ação de 
momento fletor. Nessas expressões foram feitas correções para desconsiderar os coeficientes minoradores das resistências dos materiais concreto e aço, bem como a substituição dos valores de resistência ao escoamento das barras das armaduras e da resistência à compressão do concreto, pelos valores obtidos nos ensaios das propriedades dos materiais, os quais foram apresentados no capítulo 5.

Para os cálculos a seguir, consideraram-se os seguintes valores: largura da seção, $b_{w}$, igual a $35 \mathrm{~cm}$; altura útil, d, igual a $32 \mathrm{~cm}$; Área de armadura detalhada igual a 2,78 $\mathrm{cm}^{2}$; resistência ao escoamento das barras das armaduras igual a $56,9 \mathrm{kN} / \mathrm{cm}^{2}$ e resistência à compressão do concreto igual a $3,3 \mathrm{kN} / \mathrm{cm}^{2}$.

A partir dos valores admitidos anteriormente, pode-se calcular a força de tração resultante nas barras das armaduras, por meio da expressão 7.3.

$$
\mathrm{R}_{\mathrm{st}}=\mathrm{f}_{\mathrm{y}} \cdot \mathrm{A}_{\mathrm{st}}
$$

A força resultante de compressão, por sua vez, pode ser obtida por meio da expressão 7.4 apresentada a seguir.

$$
\mathrm{R}_{\mathrm{cc}}=0,68 \cdot \mathrm{b}_{\mathrm{w}} \cdot \mathrm{d} \cdot \beta_{\mathrm{x}} \cdot \mathrm{f}_{\mathrm{c}}
$$

Igualando as expressões 7.3 e 7.4 e substituindo os respectivos valores, pode-se encontrar a medida da profundidade relativa da linha neutra em relação à altura útil, conforme expressão 7.5 .

$$
\beta_{\mathrm{x}}=\frac{56,9 \cdot 2,78}{0,68 \cdot 35 \cdot 32 \cdot 3,3}=0,0629
$$

A partir do valor encontrado com a expressão 7.5, pode-se determinar a expressão do momento fletor resistente por meio da equação 7.6

$$
M_{R}=0,68 \cdot b_{w} \cdot d^{2} \cdot \beta_{x} \cdot f_{c} \cdot\left(1-0,4 \cdot \beta_{x}\right)
$$

Substituindo os valores obtidos anteriormente na expressão 7.6, obtém-se a intensidade do momento fletor resistente, conforme apresentado na expressão 7.7.

$$
\mathrm{M}_{\mathrm{R}}=0,68 \cdot 35 \cdot 32^{2} \cdot 0,0629 \cdot 3,3 \cdot(1-0,4 \cdot 0,0629)=4934 \mathrm{kN} . \mathrm{cm}
$$


Desse modo, verifica-se que o momento fletor resistente resulta igual a $4934 \mathrm{kN} . \mathrm{cm}$. Igualando esse valor ao momento fletor solicitante, cuja expressão de cálculo é dada pelo produto da reação de apoio pela distância até a seção de referência S1 da figura 7.1, obtém-se o valor da reação de apoio. Considerando que a ação aplicada no bloco era centrada, a força atuante no bloco é igual a duas vezes o valor da reação de apoio, sendo que o resultado pode ser obtido pela expressão 7.8 .

$\mathrm{F}=\frac{2 \cdot \mathrm{M}}{\ell_{\mathrm{c}}}=\frac{2 \cdot 4934}{26}=379,5 \mathrm{kN}$

Tabela 7.5 - Força última experimental e teórica de acordo com a teoria de flexão

\begin{tabular}{c|c|c|c|c}
\hline \hline Série & Modelo & $\mathbf{F}_{\mathbf{u}}(\mathbf{k N})$ & $\mathbf{F}_{\text {teo }}(\mathbf{k N})$ & $\mathbf{F}_{\mathbf{u}} / \mathbf{F}_{\text {teo }}(\mathbf{\%})$ \\
\hline \multirow{2}{*}{$\begin{array}{c}\text { Sem } \\
\text { rugosidade }\end{array}$} & M6 & 359 & \multirow{2}{*}{379,5} & $94,6 \%$ \\
\cline { 2 - 3 } \cline { 5 - 5 } & $\mathrm{M} 7$ & 368 & & $96,9 \%$ \\
\hline \hline
\end{tabular}

Observa-se que o valor calculado para a força teórica atuante no bloco de acordo com a teoria de flexão é muito próximo da força última obtida nos modelos experimentais M6 e M7, conforme apresentado anteriormente na tabela 7.5. Constata-se, portanto, que o dimensionamento de blocos de fundação com cálice embutido e sem rugosidade nas paredes do cálice e do pilar, não deve ser feito utilizando o modelo de bielas e tirantes utilizado em blocos monolíticos, podendo o dimensionamento ser feito utilizando a teoria de flexão, a qual é recomendada para blocos flexíveis.

\subsection{Comentários finais}

Apresentou-se neste capítulo um modelo teórico para verificação das tensões na região nodal superior de blocos de fundação com cálice embutido, parcialmente embutido e externo. Os valores de tensões limites que foram propostos tem por objetivo evitar a diminuição da rigidez desses blocos, garantindo que o seu comportamento em serviço ocorra no regime elástico e linear. Em relação aos blocos de fundação com cálice embutido e sem rugosidade na interface pilar fundação, verificou-se que o comportamento dos mesmos está mais próximo da teoria de flexão utilizada em blocos flexíveis. 



\section{Conclusão}

\subsection{Comentários finais}

Esta pesquisa teve como principal objetivo estudar o comportamento estrutural de blocos de concreto armado sobre duas estacas na presença de cálice de fundação, utilizados na ligação com pilares pré-moldados. Para tanto, foram avaliadas três situações possíveis para o cálice: externo, embutido ou parcialmente embutido no bloco. Os resultados experimentais e numéricos foram comparados com outros dois blocos que apresentavam ligação monolítica entre o pilar e o bloco, os quais serviram de referência para os resultados. Apresenta-se nesse capítulo uma síntese da pesquisa, na qual são discutidas as principais conclusões a respeito deste estudo.

\subsection{Principais conclusões}

Verificou-se por meio de ensaios experimentais utilizando modelos em escala reduzida $1: 2$, que o comportamento estrutural dos blocos de fundação que utilizam cálice para ligação com pilares de concreto pré-moldado é influenciado diretamente pelo tipo de conformação das paredes do cálice e do pilar. Isto é, os blocos que apresentam rugosidade na interface pilar-fundação apresentam comportamento estrutural diferenciado em relação aos blocos que não possuem essa rugosidade. Esse comportamento era esperado, uma vez que quando da utilização da chave de cisalhamento, a separação entre colarinho, graute e pilar se torna teórica, tendo em vista que esses três elementos passam a figurar como um único elemento estrutural. Todavia, essa separação teórica foi mantida afim de se efetuarem as comparações com o bloco de referência da série com rugosidade.

De um modo geral, constatou-se que os blocos da série com rugosidade apresentaram-se mais rígidos do que os blocos da série sem rugosidade. Observou-se que, na série com rugosidade, os blocos com cálice externo e parcialmente embutido apresentaram força última superior a apresentada pelo bloco de referência dessa série. Nessa mesma série, observou-se 
que os blocos com cálice embutido apresentaram força última inferior em relação aos demais, com um valor médio de força última próximo a $89 \%$ da força última obtida pelo bloco de referência dessa série.

Nos blocos da série sem rugosidade, observou-se que nos blocos com cálice externo a força última apresentou a mesma ordem de grandeza da força obtida no bloco de referência dessa série. Os blocos com cálice parcialmente embutido e embutido, por suas vezes, apresentaram força última inferior a do bloco de referência, apresentando uma redução média no valor da força última igual a $80 \%$ e $48 \%$, respectivamente.

Em virtude das diferenças observadas entre o comportamento estrutural dos blocos de fundação com ligação monolítica e com a presença de cálice, constatou-se que o modelo teórico utilizado para dimensionamento de blocos de fundação com ligação monolítica não deve ser utilizado para o dimensionamento dos blocos de fundação que apresentem ligação por meio de cálice de fundação. Deve-se, portanto, considerar durante o dimensionamento cada situação específica, em função do tipo de cálice, bem como da conformação das paredes do mesmo.

Em relação à força de avaliação utilizada inicialmente para o dimensionamento dos modelos, foi feita uma correção nesse valor após a realização dos ensaios que determinaram as propriedades mecânicas dos materiais utilizados. Essa nova força foi obtida considerando que o concreto e o aço estavam trabalhando na sua capacidade máxima, sendo calculado um ângulo de inclinação teórico que permitisse essa situação. Após a correção dos valores, observou-se que apenas os blocos com cálice embutido da série sem rugosidade apresentaram força última inferior a força de avaliação correspondente ao dimensionamento dos modelos, indicando que o modelo de cálculo desses blocos não deve ser o mesmo dos demais.

Em relação aos valores de força última experimental encontrados, os mesmos apresentaram-se em torno de duas vezes o valor da força última teórica. Deve-se considerar que no cálculo da força teórica, foi considerado que apenas a armadura do tirante estivesse recebendo toda a força de tração. Todavia, nos ensaios experimentais, a presença da armadura lateral próxima a região inferior do bloco, somada com a armadura do cálice em forma de "U" posicionada na região inferior do bloco, pode ter recebido uma parcela da força do tirante e, com isto, ocasionado os altos valores obtidos experimentalmente. Caso as duas barras laterais inferiores também estivessem escoando, a relação entre a força última experimental e a força última teórica reduziria de 2,0 para 1,4. 
Quanto a realização dos ensaios experimentais e funcionamento dos modelos, observouse que os modelos M3 e M10 apresentaram comportamento diferente dos demais modelos. Destaca-se que ambos os modelos apresentavam cálice externo, e foram construídos com uma área de aço superior a armadura calculada e utilizada nos demais modelos. Nesses modelos, a ruína ocorreu precocemente por ruptura do concreto dos pilares, sem que ocorresse escoamento das barras da armadura principal do tirante. Atribui-se essa ruína precoce ao valor médio da resistência à compressão do concreto dos pilares, que apresentou-se inferior ao valor esperado, bem como a maior área de armadura principal do tirante, que possibilitaria um acréscimo na força atuante no bloco e, conseqüentemente, no pilar. Portanto, não foi possível verificar se o aumento da armadura principal do tirante implicaria numa maior capacidade resistente dos blocos.

Em relação à transferência da força oriunda do pilar para o cálice e, por conseqüência, para o bloco de fundação, observou-se por meio da instrumentação das barras das armaduras dos pilares que essa transferência ocorreu de modo mais eficaz nos blocos da série com rugosidade do que nos blocos da série sem rugosidade. Na iminência da ruína dos modelos, constatou-se que, nos blocos da série sem rugosidade, a força média na seção inferior do pilar próxima ao fundo do cálice foi de aproximadamente $59 \%$ do valor da força aplicada no topo do pilar. Em contra partida, nos blocos da série com rugosidade, o valor correspondente a essa mesma seção foi de apenas $21 \%$, indicando que boa parte da força aplicada no pilar havia sido transferida para o bloco ao longo do comprimento de embutimento $\ell_{\mathrm{emb}}$ do pilar.

A armadura complementar utilizada nos modelos M5 e M7 da série sem rugosidade e nos modelos M12 e M14 da série com rugosidade, conferiu ganho de resistência apenas ao modelo M5 da série sem rugosidade, que tinha o cálice parcialmente embutido. Constatou-se um aumento da ordem de $15 \%$ na força última em relação ao modelo com cálice parcialmente embutido que não dispunha de armadura complementar. Esse ganho de resistência não foi percebido nos modelos com cálice embutido da série sem rugosidade, bem como nos modelos com cálice parcialmente embutido e embutido da série com rugosidade.

Em relação a armadura vertical do cálice posicionada ao longo do comprimento de embutimento, verificou-se nos modelos com rugosidade e sem rugosidade uma inversão no sentido da força atuante nessa armadura. Enquanto que nos estágios inicias constatou-se encurtamento dessa armadura, indicando a ocorrência de forças de compressão nessa região, a partir de uma certa intensidade de força verificou-se alongamento da barra e, portanto, força 
normal de tração. Esses resultados indicaram que o maciço de concreto pelo qual atravessa a armadura do cálice apresentou ruptura, não ocorrendo a separação do modelo em vários segmentos em virtude da presença da armadura vertical do cálice nessa região.

Tratando da armadura principal do tirante, verificou-se que as deformações e, portanto, as tensões atuantes nas barras das armaduras apresentaram valores máximos que nem sempre ocorriam nas barras posicionadas na região central, ocorrendo em algumas situações nas barras posicionadas na extremidade lateral do bloco. Em relação ao ângulo teórico de inclinação da biela de compressão e a força no tirante, constatou-se que os valores de ângulos praticamente não apresentam variação a partir do início do escoamento das barras das armaduras do tirante, apresentando valores idênticos no início do escoamento e na iminência da ruína dos modelos.

A análise numérica realizada no capítulo 6 permitiu que fosse desenhado o fluxo de tensões principais de compressão no interior dos modelos, sendo observada assim a formação da biela de compressão nos modelos analisados. Verificou-se que nos modelos M6 e M7, a biela de compressão não apresentou formato bem definido, diferente do ocorrido nos demais modelos. Ainda em relação as análises numéricas, obteve-se um modelo que foi capaz de representar com boa precisão a força última dos blocos avaliados experimentalmente, porém com limitações em relação aos valores dos deslocamentos do bloco e deformações obtidas nas barras das armaduras principais do tirante.

Observou-se que tanto o modelo experimental como o modelo numérico indicaram deformações elevadas na região central das barras da armadura principal do tirante, bem como deformações de pequena magnitude sobre a região das estacas, indicando haver uma força de compressão sobre a região das estacas, oriunda da biela comprimida que chega nessa região. Porém, no caso dos blocos com cálice embutido da série sem rugosidade, as deformações sobre as estacas não apresentaram valores pequenos e, de acordo com os resultados numéricos, não se verificou a ocorrência de bielas chegando sobre as estacas, mas sim bielas menores com pequena inclinação em relação a armadura principal do tirante.

Em relação às tensões na região nodal superior de encontro do pilar com o bloco, observou-se que as tensões obtidas nos blocos de referência apresentaram a mesma ordem de grandeza. Comparando as tensões obtidas na iminência da ruína dos modelos, verificou-se que essas tensões apresentaram-se superiores ao valor da resistência à compressão média do concreto dos blocos, a menos dos modelos com cálice embutido da série sem rugosidade. 
Apresentou-se um modelo teórico para verificação das tensões na região nodal superior de blocos de fundação com cálice embutido, parcialmente embutido e externo, de modo a evitar que ocorra a diminuição na rigidez dos modelos, garantindo que o seu comportamento em serviço ocorra no regime elástico e linear. Verificou-se que, na situação de bloco com cálice sem rugosidade, a tensão máxima na região nodal superior deve ser limitada a $0,50 \mathrm{f}_{\mathrm{cm}}$ para os blocos com cálice externo e parcialmente embutido. Nos modelos da série com rugosidade, verificou-se que os valores das tensões limites variaram de $0,30 \mathrm{f}_{\mathrm{cm}}$ para o bloco com cálice embutido até $0,56 \mathrm{f}_{\mathrm{cm}}$ para o bloco com cálice externo.

Em relação aos blocos de fundação com cálice embutido e sem rugosidade na interface pilar fundação, verificou-se que o comportamento dos mesmos está mais próximo da teoria de flexão utilizada em blocos flexíveis. Constatou-se que o dimensionamento desses blocos de acordo com o modelo proposto no boletim 73 do CEB-FIP (1970) conduziu a forças resistentes que apresentaram valores entre $94 \%$ e $97 \%$ da força última obtida nos ensaios experimentais. Por este motivo, recomenda-se que em blocos de fundação sobre duas estacas com cálice embutido e sem rugosidade na interface, o dimensionamento seja feito segundo a teoria de flexão.

Em relação a recomendações de projeto, recomenda-se que as rugosidades sejam sempre utilizadas, tanto no cálice de fundação quanto no pilar. Nas situações com cálice externo e parcialmente embutido com rugosidade, a utilização do modelo simplificado de bielas e tirantes pode ser feita. Tratando do bloco com cálice embutido e com rugosidade, pode-se utilizar o modelo de bielas e tirantes, porém recomenda-se limitar a força atuante no bloco em $80 \%$ da força teórica utilizada para o dimensionamento.

Nas situações em que não há rugosidade, quando da utilização do cálice externo, o dimensionamento pode ser feito semelhante ao do bloco monolítico. Para os blocos com cálice parcialmente embutido e embutido, recomenda-se que seja adotada a teoria da flexão, conforme apresentado no capítulo 7. Ressalta-se, todavia, que uma possibilidade para se utilizar o modelo de bielas e tirantes nesses blocos, é aumentando a espessura da região compreendida entre o fundo do pilar e o fundo do bloco. Esse procedimento, porém, acarreta num maior volume de concreto utilizado em cada bloco. 


\subsection{Sugestões para trabalhos futuros}

Com o intuito de contribuir com as pesquisas envolvendo a ligação pilar fundação por meio de cálice, apresentam-se as seguintes sugestões para trabalhos futuros:

- Realizar análise experimental em blocos de fundação submetidos à força normal com grande excentricidade;

- Realizar análise numérica em blocos de fundação com cálice embutido e parcialmente embutido sobre um número maior de estacas, aproveitando o modelo computacional ajustado nesse trabalho

- Analisar a influência da seção do pilar no comportamento de blocos de fundação com cálice embutido e parcialmente embutido;

- Analisar numérica e experimentalmente situações em que a estaca apresenta-se excêntrica em relação ao bloco, situação bastante comum nos escritórios de projeto em virtude da quebra de estacas ou de erros de locação. 



\section{Referências bibliográficas}

ADEBAR, P.; KUCHMA, D.; COLLINS, M. P. (1990). Strut-and-tie models for design of pile caps: an experimental study. ACI Journal, v. 87, p. 81-91, Jan/Feb;

ADEBAR, P.; ZHOU, Z. (1996). Design of deep pile caps using strut-and-tie models. In: Restructuring: America and Beyond Structural Congress, ASCE, New York, USA. Proceeding, v. 2, p. 1623-1626;

ANDOLFATO, R. P. (2002). Desenvolvimento de técnicas de produção de blocos de concreto para alvenaria estrutural na escala (1:4). Dissertação (Mestrado), Faculdade de engenharia de Ilha Solteira, Universidade Estadual Paulista, Ilha Solteira;

AMERICAN CONCRETE INSTITUTE (1983). Design Handbook, v. 1: Beams, one-way, brackets, footings and pile caps (ACI 340. IR-84). ACI SP-17;

AMERICAN CONCRETE INSTITUTE (2005). ACI 318-05 - Building code requirements for reinforced concrete. Detroit, USA;

AMERICAN CONCRETE INSTITUTE (2008) ACI 318-08 - Building Code Requirements for Structural Concrete and Commentary, Farmington Hills, USA;

ASSOCIAÇÃO BRASILEIRA DE NORMAS TÉCNICAS (2003). NBR 6118:2003 Projeto de estruturas de concreto. Rio de Janeiro;

ASSOCIAÇÃO BRASILEIRA DE NORMAS TÉCNICAS (2002). NBR 6152:2002 Materiais metálicos - determinação das propriedades mecânicas à tração: método de ensaio. Rio de Janeiro;

ASSOCIAÇÃO BRASILERIA DE NORMAS TÉCNICAS (2003). NBR 8522:2003 Concreto - Determinação dos módulos estáticos de elasticidade e de deformação e da curva tensão-deformação. Rio de Janeiro; 
ASSOCIAÇÃO BRASILERIA DE NORMAS TÉCNICAS (2006). NBR 9062:2006 Projeto e execução de estruturas de concreto pré-moldado. Rio de Janeiro;

BANGASH, M.Y.H. (2001). Manual of numerical methods in concrete: modeling and applications by experimental and site-monitoring data. Ed. Thomas Telford Ltd, 1 Heron Quay, London E14 4JD;

BARROS, R. (2009). Análise de blocos de concreto armado sobre duas estacas com cálice totalmente embutido mediante presença de viga de travamento. Dissertação (Mestrado), Escola de Engenharia de São Carlos, Universidade de São Paulo, São Carlos;

BARROS, R.; GIONGO, J. S. (2010). Análise de tensões nas regiões nodais em blocos de concreto armado sobre duas estacas com cálice embutido. Anais do III Congresso Brasileiro de Pontes e Estruturas, Abril, Rio de Janeiro;

BERG, F.; JOHANSSON, D. (2011). Design of Test Set-up using FEM, Master of Science Thesis in the Master's program of Structural Engineering and Building Performance Design. Chalmers University of Technology. Göteborg, Sweden;

BLÉVOT, J.; FRÉMY, R. (1967). Semelles sur piex. Analles d'Institut Techique du Bâtiment et des Travaux Publics, Paris, v. 20, n. 230, p. 223-295, fev;

BRITISH STANDARD FOR STRUCTURAL USE OF CONCRETE (1985). BS 8110 Code of practice for design and construction. Part I;

BUTTIGNOL, T. E. T.; ALMEIDA, L. C. Concrete compressive characteristic strength analysis of pile caps with three piles. IBRACON Structural and Material Journal, v.6, n.1, p.158-177, February. 2013.

CAMPOS, L. A. (2007). Análise experimental de blocos de fundação sobre duas estacas, sob carga centrada, para estrutura pré-fabricada. Dissertação (Mestrado), Programa de pós-graduação em engenharia civil, Universidade Federal de Santa Catarina, Florianópolis; 
CAMPOS, G. M. (2010). Recomendações para o projeto de cálices de fundações. Dissertação (Mestrado), Escola de Engenharia de São Carlos, Universidade de São Paulo, São Carlos;

CANHA, R. M. F. (2004). Estudo teórico-experimental da ligação pilarfundação por meio de cálice em estruturas de concreto pré-moldado. Tese (Doutorado), Escola de Engenharia de São Carlos, Universidade de São Paulo, São Carlos;

CANHA, R. M. F.; EBElinG, E. B.; EL DEBS, A. L. H. C; EL DEBS, M. K.(2009) Analysing the base of precast column in socket foundations with smooth interfaces. Materials and Structures, v.42 n.6, p. 725-737, jul;

CARNEIRO, F. L. (1996) Análise Dimensional e teoria da semelhança e dos modelos físicos. Rio de Janeiro: UFRJ, 256p;

CARVALHO, I. S. (1995). Análise experimental de blocos sobre grupos de estacas escavadas de pequeno diâmetro. Dissertação (Mestrado), Escola de Engenharia de São Carlos, Universidade de São Paulo, São Carlos;

CARVALHO, R. R., CANHA, R. M. F., EL DEBS, M. K. (2013). Propostas de modelos de bielas e tirantes para a ligação do cálice totalmente embutido em bloco de fundação. Anais do III Encontro nacional de pesquisa-projeto-produção em concreto pré-moldado. Julho São Carlos;

CHAN, T. K.; POH, C. K. (2000), Behavior of precast reinforced concrete pile caps. Construction and Building Materials, v. 14, p. 73-78, Jan;

CHANTELOT, G. (2010). Strut-and-tie modelling of reinforced concrete pile caps. Master of Science Thesis in the Master's Programme Structural Engineering and Building Performance Design. Chalmers University of Technology, Sweden;

COMISIÓN PERMANENTE DEL HORMIGÓN (2008). Ministerio de Fomento. Centro de Publicaciones. Instrucción española de hormigón armado (EHE), Madrid; 
COMITE EURO-INTERNACIONAL DU BÉTON (1970). CEB-FIP, Recommandations particulières na calcul et à l'execution des semelles de fundations. Bulletin D'Information, Paris, n. 73;

COMITE EURO-INTERNACIONAL DU BÉTON (1990). CEB-FIP Model code for concrete structures. Bulletin D’Information, Paris, n. 203-205, July;

CONSIGLIO NAZIONALE DELLE RICHERCHE (1984) CNR-1005- Instruzioni per Il progetto, l'esecuzione Ed Il controllo delle strutture prefabricate in calcestruzzo. ITEC/La prefabricazione. Roma, ITEC;

CSA STANDARD A23.3.04 (2004). Design of Concrete Structures with Explanatory Notes. Canadian Portland Cement Association, Ontario, Canadá;

DELALIBERA, R. G.; GIONGO, J. S. (2004). Simulação numérica não-linear de blocos de concreto armado. XXXI Jornadas Sul-Americanas de Engenharia Estrutural. CDROM, Mendonza, Argentina;

DELALIBERA, R. G. (2006). Análise teórica e experimental de blocos de concreto armado sobre duas estacas submetidos a ação de força centrada e excêntrica. Tese (Doutorado) - Escola de Engenharia de São Carlos, Universidade de São Paulo, São Carlos;

DELALIBERA, R. G. (2009). Análise numérica e experimental de blocos sobre duas estacas com cálice embutido utilizado na ligação pilar-fundação. Texto de Pós-Doutorado - Escola de Engenharia de São Carlos, Universidade de São Paulo, São Carlos;

DIANA (2005a). DIANA Finite Element Analysis. User's manual release 9. Element Library. TNO DIANA, Delft, Netherland;

DIANA (2005b). DIANA Finite Element Analysis. User's manual release 9. Material Library. TNO DIANA, Delft, Netherland; 
EBELING, E. B. (2006). Análise da base de pilares pré-moldados na ligação com cálice de fundação. Dissertação (Mestrado), Escola de Engenharia de São Carlos, Universidade de São Paulo, São Carlos;

EL DEBS, M. K. (2000). Concreto pré-moldado: fundamentos e aplicações. Projeto REENGE. Escola de Engenharia de São Carlos, Universidade de São Paulo, São Carlos;

FARIAS, R, S. (2008) Estudo teórico-experimental do efeito da laje na transferência de forças em ligações viga-pilar misto preenchido. Dissertação (Mestrado), Escola de Engenharia de São Carlos, Universidade de São Paulo, São Carlos;

FÉDÉRATION INTERNATIONALE DU BÉTON (1998). Composite floor structures Guide to good practice. prepared by FIP Commission on Prefabrication;

FUSCO, P. B. (1994). Técnicas de armar estruturas de concreto. Editora Pini, São Paulo;

HOBBS, N. B.; STEIN, P. (1957). An investigation into the stress distribution in pile caps with some notes on design. Proceedings of the Institution of Civil Engineers., v. 57, pg. 559628 ;

ITURRIOZ, I.; D’AVILA, V. M. R.; RAUSH, A. (2000). Análise experimental computacional de um bloco de estacas de concreto armado. XXXIX Jornadas SulAmericanas de engenharia estrutural, Punta Del Este In: CD-ROOM;

IYER, P. K.; SAM, C. (1991). 3-D elastic analysis of three-pile caps. Journal of Engineering Mechanics, ASCE, v. 117, n. 12, p. 2862-2883, Dec;

IYER, P. K.; SAM, C. (1992). Three-dimensional analysis of pile caps. Computers and Structures, v. 42, n. 3, p. 395-411, Feb;

IYER, P. K.; SAM, C. (1995 - a). Nonlinear finite element analysis of reinforced concrete four-pile caps. International Journal of Structures, v. 15, n. 1, p. 18-34, Jan/Jun; 
JAGUARIBE JÚNIOR, K. B. (2005). Ligação pilar-fundação por meio de cálice em estruturas de concreto pré-moldado com profundidade de embutimento reduzida. Dissertação (Mestrado), Escola de Engenharia de São Carlos, Universidade de São Paulo, São Carlos;

LEONHARDT, F. \& MÖNNIG, E. (1978). Construções de concreto. Ed. Interciência, v. 01, 02, 03 e 04, Rio de Janeiro;

LUNDGREN, K. (2003). Analyses of a lap Splice in a lattice girder system. Report No 03:3. Chalmers University of Technology. Göteborg, Sweden;

MAREK FILHO, C. A. (2010). Análise do comportamento de blocos sobre quatro estacas com cálice embutido. Dissertação (Mestrado), Escola de Engenharia de São Carlos, Universidade de São Paulo, São Carlos;

MAUTONI, M. (1972). Blocos sobre dois apoios. São Paulo, Grêmio Politécnico;

MELO, C. E. E. (2004). Manual Munte de Projetos em Pré-Fabricados de Concreto. São Paulo, Editora Pini;

METHA, P. Kumar; MONTEIRO, Paulo J. M. Concretos: estrutura, propriedades e materiais. São Paulo, 1994.

MIGUEL, G. M. (2000). Análise experimental e numérica de blocos sobre três estacas. Tese (Doutorado) - Escola de Engenharia de São Carlos, Universidade de São Paulo, São Carlos;

MUNHOZ, F. S. (2004). Análise do comportamento de blocos de concreto armado sobre estacas submetidos à ação de força centrada. Dissertação (Mestrado), Escola de Engenharia de São Carlos, Universidade de São Paulo, São Carlos; 
NISSEN I., DASCHNER F., KUPFER H. (1986): Tests of the necessary shear reinforcement between precast concrete elements and in situ concrete. Comitê alemão do Concreto Armado. Berlin, Alemanha;

NORI, V.V.; THARVAL, M. (2007). Design of pile caps - Strut and tie model method. The indian concrete journal, Point of view. p. 13-19, Abril;

NUNES, V. C. P. (2009). Estudo de cálice de fundação com ênfase nos esforços nas paredes transversais do colarinho. Dissertação (Mestrado) - Escola de Engenharia de São Carlos, Universidade de São Paulo;

OLIVEIRA, D. S. (2013). Análise do comportamento estrutural de blocos de concreto armado sobre cinco e seis estacas. Dissertação (Mestrado) - Escola de Engenharia de São Carlos, Universidade de São Paulo;

OLIVEIRA, L. M. (2009). Diretrizes para projeto de blocos de concreto armado sobre estacas. Dissertação (Mestrado) - Escola Politécnica da Universidade de São Paulo;

RAMOS, F. A. C. (2007). Análise numérica de blocos sobre dez estacas: Cálculo das reações de apoio. Dissertação (Mestrado) - Escola de Engenharia de São Carlos, Universidade de São Paulo;

RAUSH, A.; D’ASCENSO, N.; GOLDSCHIMIDT, P.; NATALINI, M. (1997). Analisis experimental sobre cabezales de pilotes sometidos a cargas verticals. XXVIII Jornadas SulAmericanas de engenharia estrutural, v. 1, p. 309-318, São Carlos;

ROCHA, M. (1952). Dimensionamento experimental das estruturas. Laboratório de Engenharia Civil, Lisboa, Portugal;

SABNIS, G. M.; GOGATE, A. B. (1984). Investigation of thick slab (Pile Cap) behavior. ACI Journal. Title n. 81-5, p. 35-39, Jan/Feb; 
SCHAFER, K.; SCHALICH, J. (1988). Consistent design of structural concrete using strut and tie models. Colóquio sobre comportamento de projeto de estruturas, 5. Anais, PUC RJ, Rio de Janeiro - RJ;

SCHLAICH, J.; SCHAFER, K.; JENNEWEIN, M. (1987). Toward a consistent design of reinforced structural concrete. Journal of Prestressed Concrete Institute, v. 32, n. 3, p. 74 150, May-June;

SCHLAICH, J., SCHAFER, K. (1991). Design and detailing of structural concrete using strut-and-tie models. The Structural Engineer, v.69, n.6, p.113-125, March;

SILVA, A. M. S. (1998). Ligações entre elementos pré-fabricado de betão. Dissertação (Mestrado), Universidade Técnica de Lisboa, Instituto Superior Técnico, Lisboa;

SOUZA, R. A.; BITTENCOURT, T. N. (2006). Análise não-linear de blocos rígidos sobre quatro estacas. Revista Ibracon de Estruturas. Vol. 2, no .3, p. 310-319, setembro;

SOUZA, R. A. (2004). Concreto estrutural: análise e dimensionamento de elementos com descontinuidades. Tese (Doutorado), Escola Politécnica da Universidade de São Paulo, São Paulo;

TAKEYA, T. (2001). Análise experimental de estruturas - notas de aula. Escola de Engenharia de São Carlos, Universidade de São Paulo, São Carlos.

TAYLOR, H. P. J.; CLARKE, J. L. (1976). Some detailing problems in concrete frame structures. The Structural Engineer, January;

TJHIN, T. N.; KUCHMA, D. (2002). Computer-Based Tools for Design by Strut-and-Tie Method: Advances and Challenges. ACI Structural Journal, p. 586-594, Sep/Oct; 
ANEXO A 


\section{DETALHE BLOCO REFERENCIA "RUGOSO"}

ESC. $1: 20$
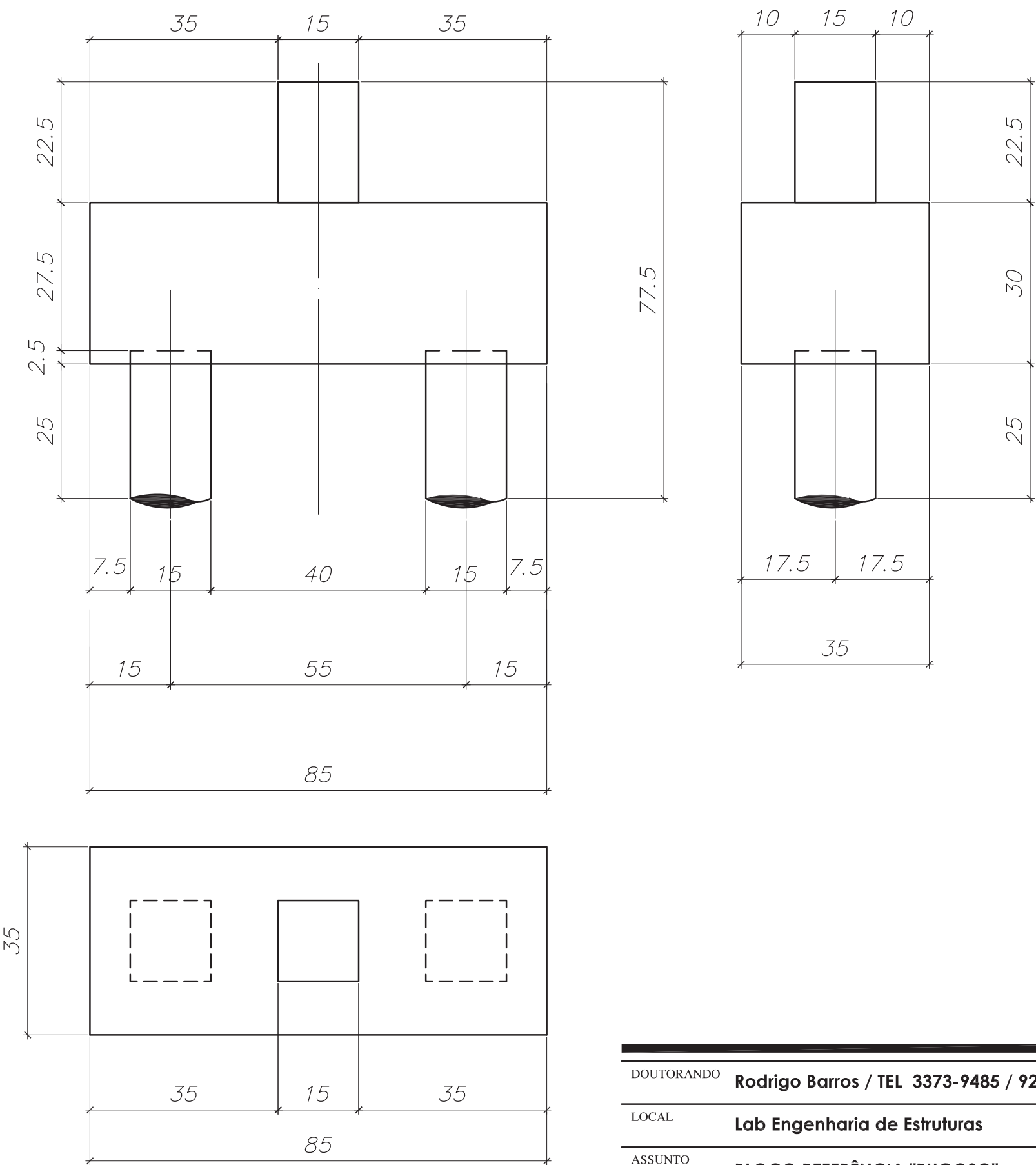

\begin{tabular}{ll}
\hline DOUTORANDO & Rodrigo Barros / TEL 3373-9485 / 9207-2996 \\
\hline LOCAL & Lab Engenharia de Estruturas \\
\hline ASSUNTO & BLOCO REFERÊNCIA "RUGOSO" \\
\hline ESCALA & $1 \mid 30$ \\
\hline CLIENTE & LE - SET - EESC - USP \\
\hline DATA & $05|10| 2010$
\end{tabular}




\section{DETALHE BLOCO EMBUTIDO "RUGOSO"}

ESC. $1: 20$
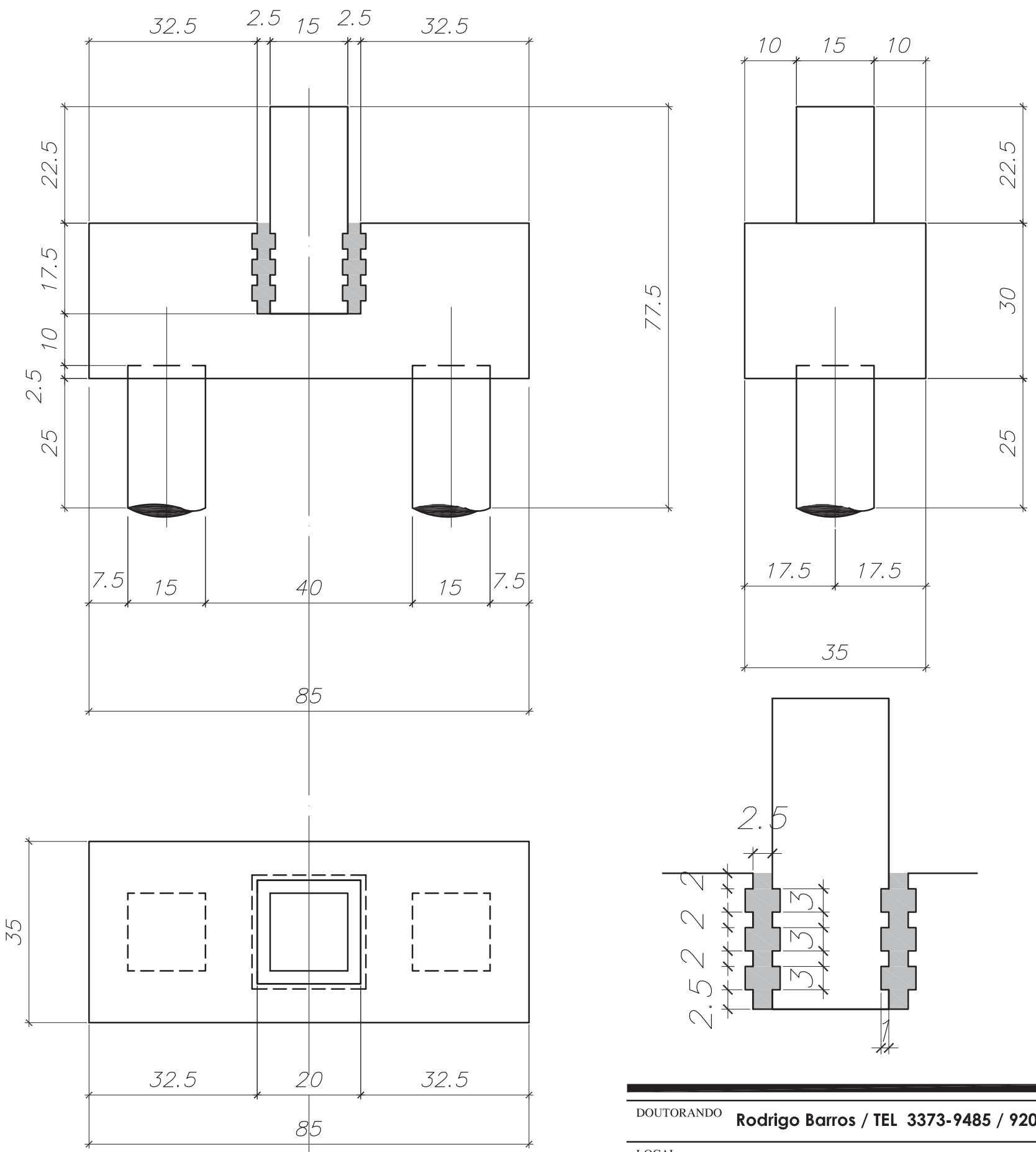

\begin{tabular}{ll}
\hline DOUTORANDO & Rodrigo Barros / TEL 3373-9485 / 9207-2996 \\
\hline LOCAL & Lab Engenharia de Estruturas \\
\hline ASSUNTO & BLOCO EMBUTIDO "RUGOSO" \\
\hline ESCALA & $1 \mid 30$ \\
\hline CLIENTE & LE - SET - EESC - USP \\
\hline DATA & $05|10| 2010$ \\
\hline
\end{tabular}




\section{DETALHE BLOCO PARCIALMENTE EMBUTIDO "RUGOSO"}

ESC. $1: 20$
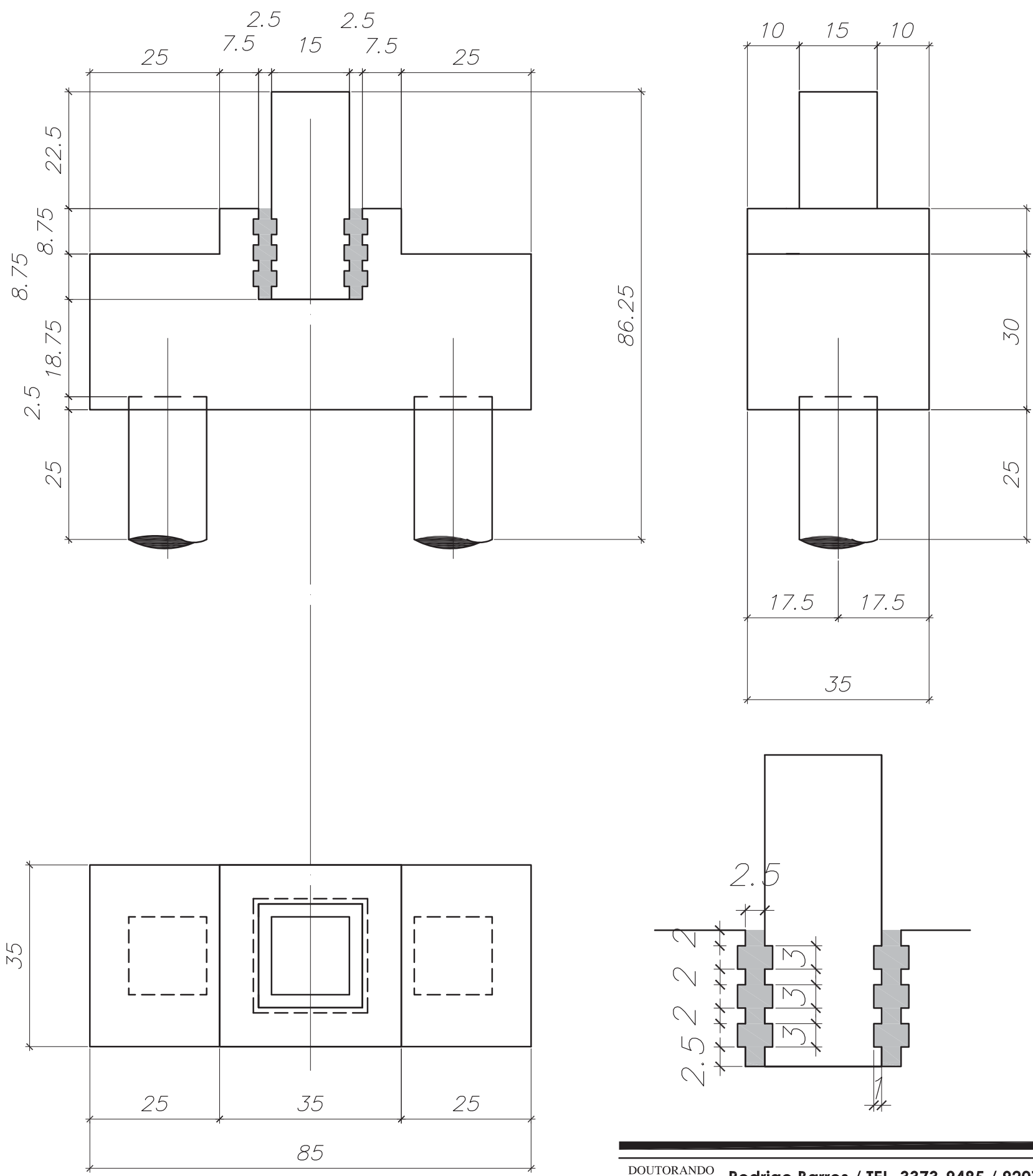

\begin{tabular}{ll}
\hline DOUTORANDO & Rodrigo Barros / TEL 3373-9485 / 9207-2996 \\
\hline LOCAL & Lab Engenharia de Estruturas \\
\hline ASSUNTO & BLOCO PARCIALMENTE EMBUTIDO "RUGOSO" \\
\hline ESCALA & $1 \mid 30$ \\
\hline CLIENTE & LE - SET - EESC - USP \\
\hline DATA & $05|10| 2010$ \\
\hline
\end{tabular}




\section{DETALHE BLOCO EXTERNO "RUGOSO"}

ESC. $1: 20$
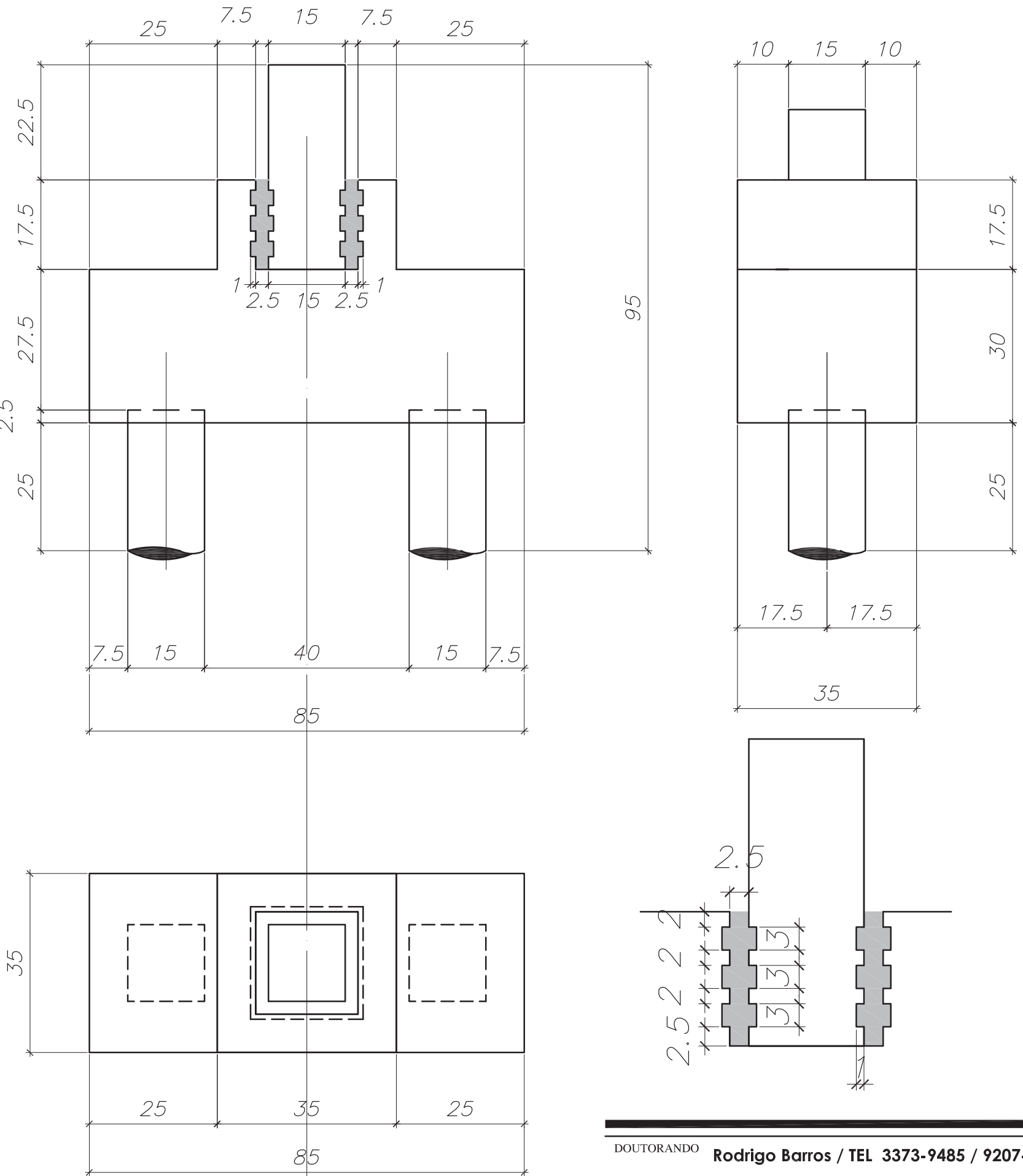

\begin{tabular}{ll}
\hline DOUTORANDO & Rodrigo Barros / TEL 3373-9485 / 9207-2996 \\
\hline LOCAL & Lab Engenharia de Estruturas \\
\hline ASSUNTO & BLOCO EXTERNO "RUGOSO" \\
\hline ESCALA & $1 \mid 30$ \\
\hline CLIENTE & LE - SET - EESC - USP \\
\hline DATA & $05|10| 2010$ \\
\hline
\end{tabular}




\section{DETALHE BLOCO REFERENNCIA "LISO"}

ESC. $1: 20$
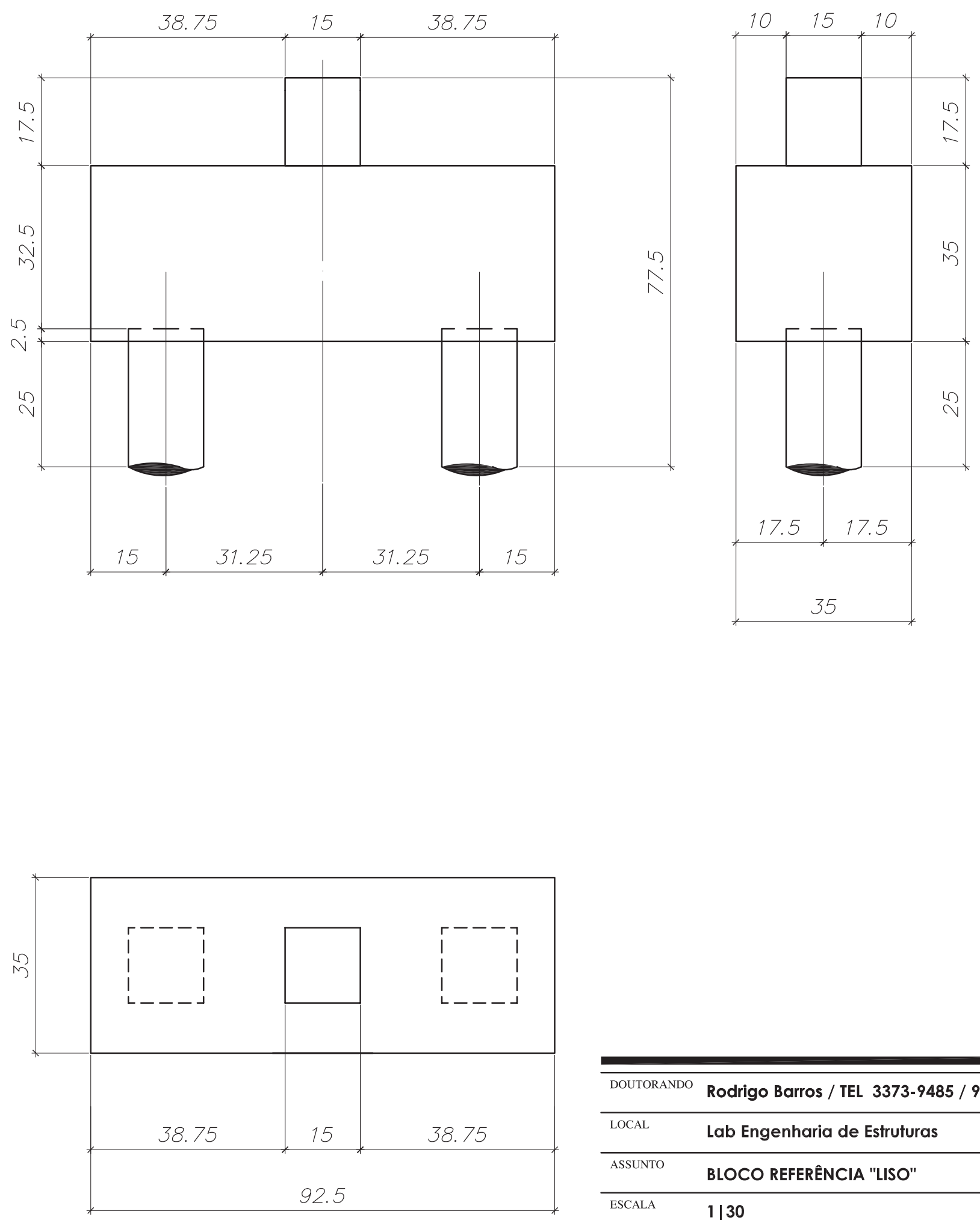

\begin{tabular}{ll}
\hline \hline DOUTORANDO & Rodrigo Barros / TEL 3373-9485 / 9207-2996 \\
\hline LOCAL & Lab Engenharia de Estruturas \\
\hline ASSUNTO & BLOCO REFERÊNCIA "LISO" \\
\hline ESCALA & $1 \mid 30$ \\
\hline CLIENTE & LE - SET - EESC - USP \\
\hline DATA & $05|10| 2010$ \\
\hline
\end{tabular}




\section{DETALHE BLOCO EMBUTIDO "LISO"}

ESC. $1: 20$
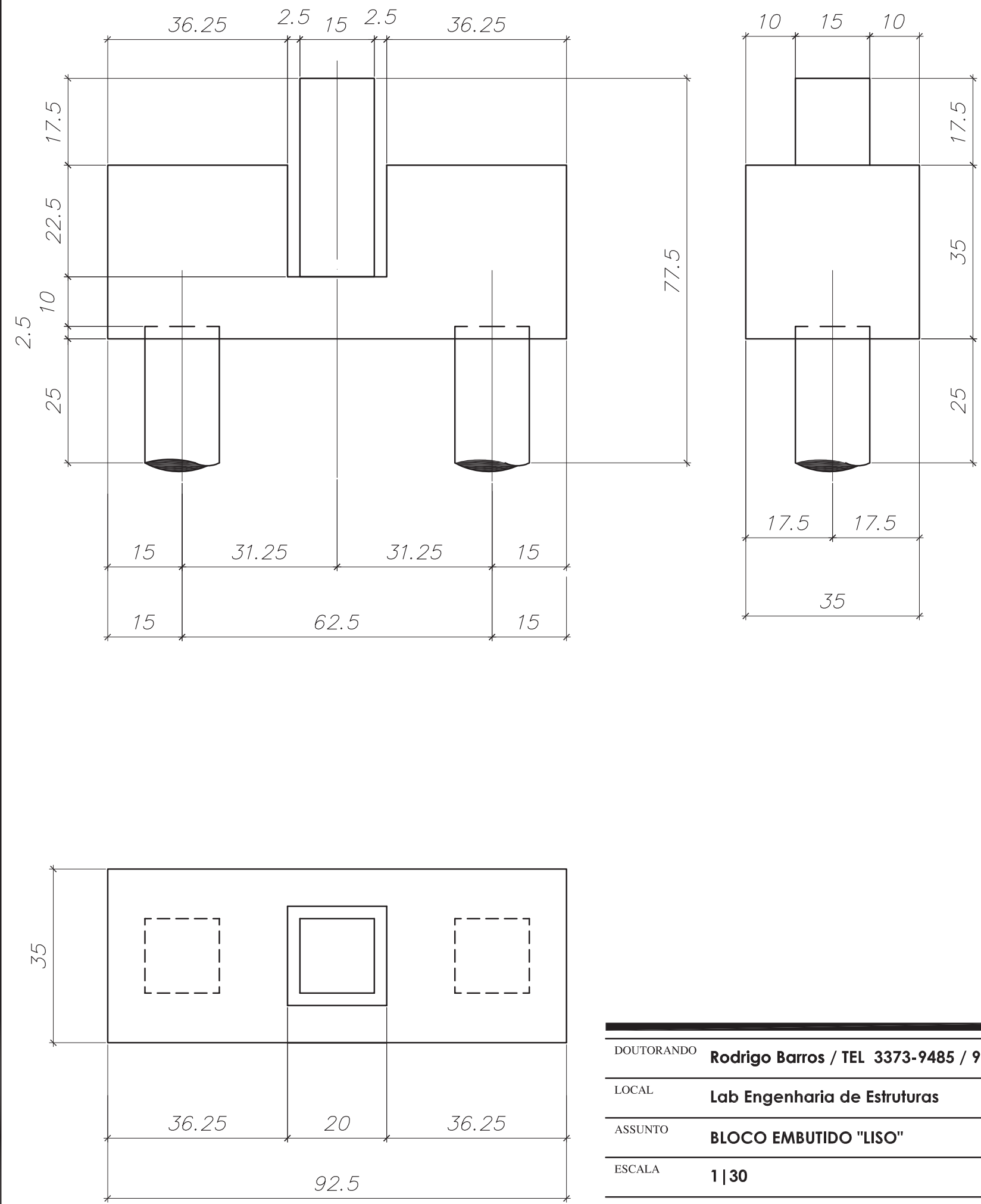

\begin{tabular}{ll}
\hline \hline DOUTORANDO & Rodrigo Barros / TEL $3373-9485$ / 9207-2996 \\
\hline LOCAL & Lab Engenharia de Estruturas \\
\hline ASSUNTO & BLOCO EMBUTIDO "LISO" \\
\hline ESCALA & $1 \mid 30$ \\
\hline CLIENTE & LE - SET - EESC - USP \\
\hline DATA & $05|10| 2010$ \\
\hline
\end{tabular}




\section{$\frac{\text { DETALHE BLOCO PARCIALMENTE EMBUTIDO "LISO" }}{\text { ESC. 1:20 }}$}
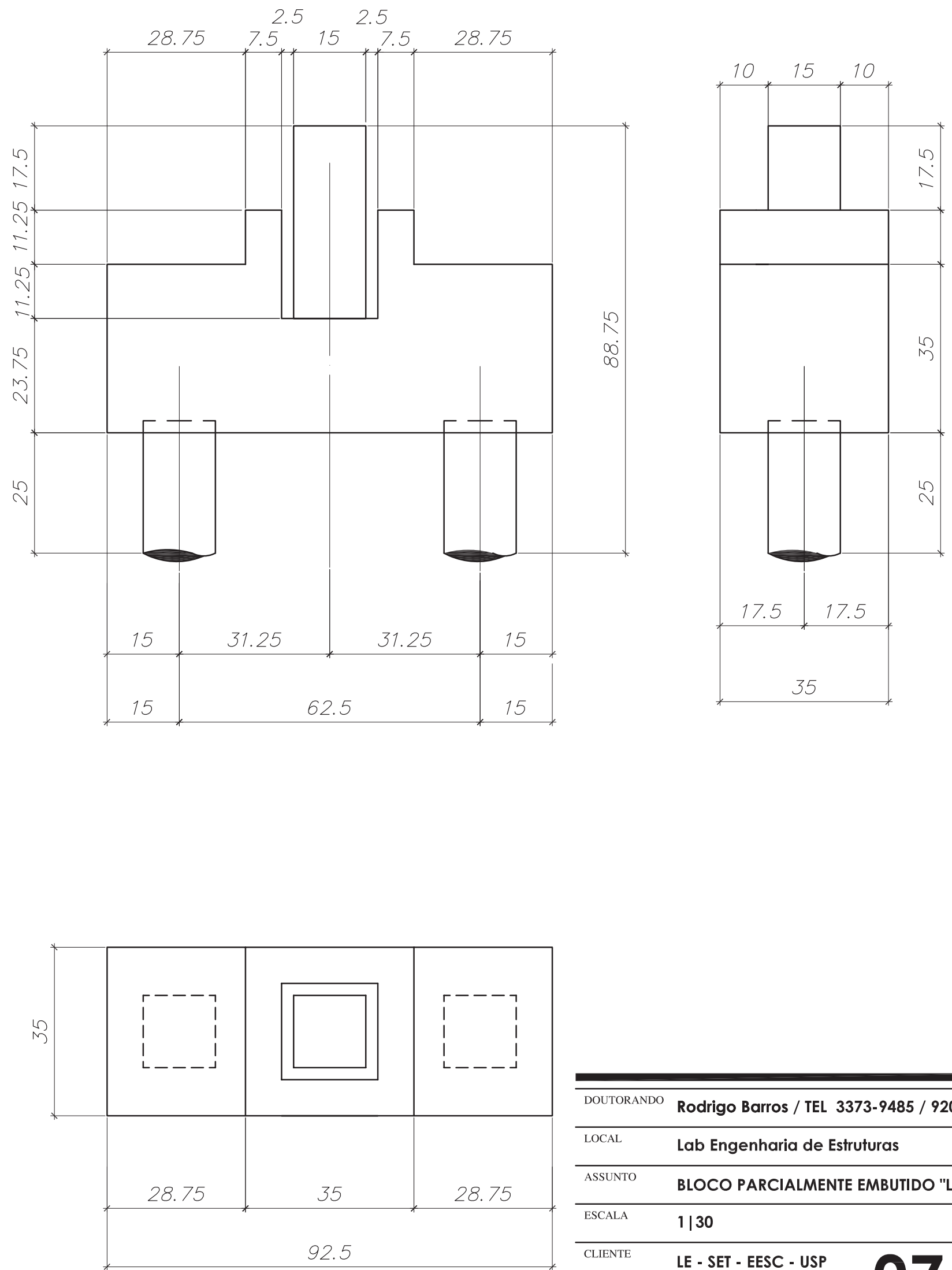

\begin{tabular}{ll}
\hline \hline DOUTORANDO & Rodrigo Barros / TEL $3373-9485$ / 9207-2996 \\
\hline LOCAL & Lab Engenharia de Estruturas \\
\hline ASSUNTO & BLOCO PARCIALMENTE EMBUTIDO "LISO" \\
\hline ESCALA & $1 \mid 30$ \\
\hline CLIENTE & LE - SET - EESC - USP \\
\hline DATA & $05|10| 2010$ \\
\hline
\end{tabular}




\section{DETALHE BLOCO EXTERNO "LISO"}

ESC. $1: 20$
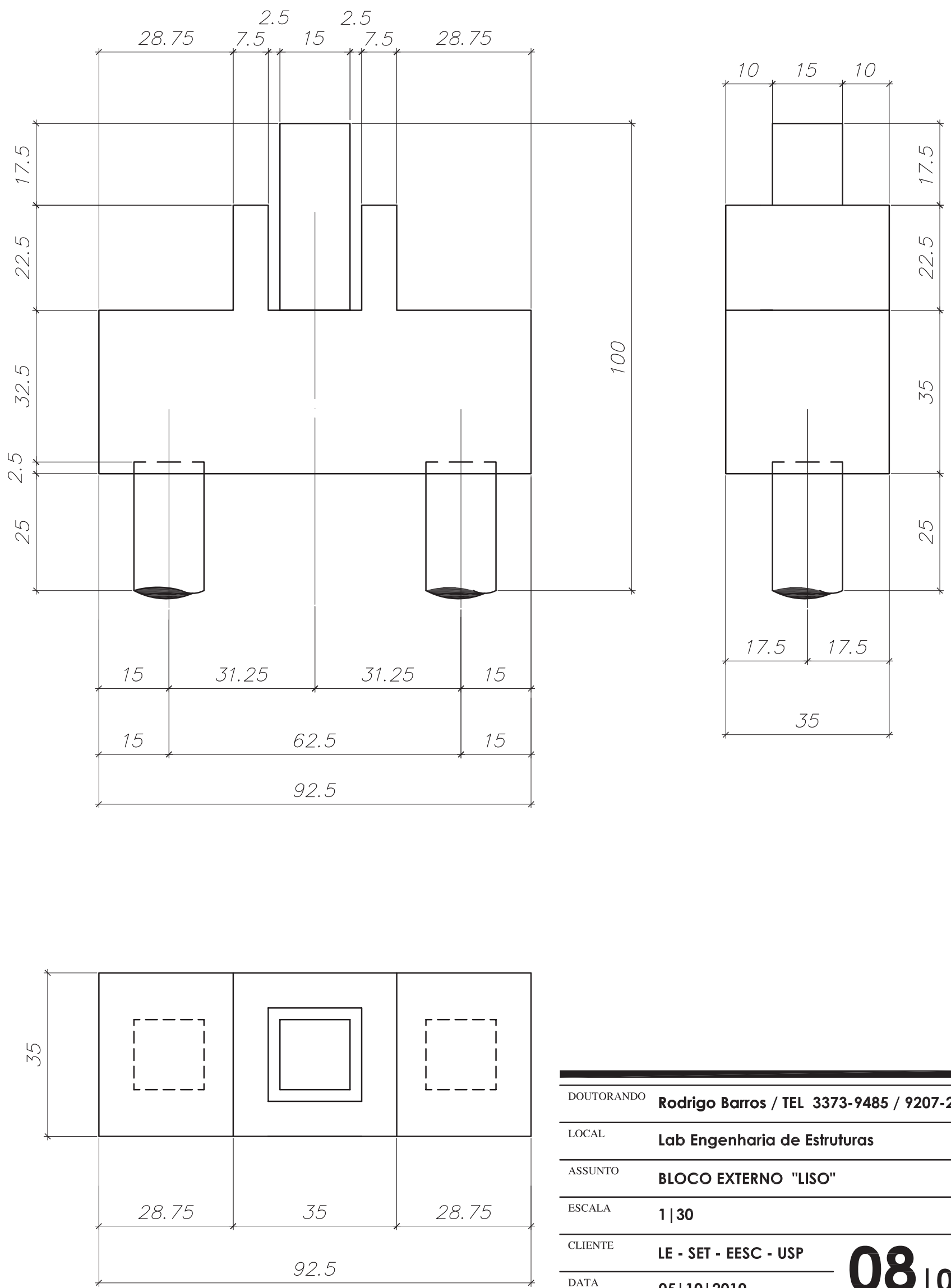

\begin{tabular}{ll}
\hline DOUTORANDO & Rodrigo Barros / TEL 3373-9485 / 9207-2996 \\
\hline LOCAL & Lab Engenharia de Estruturas \\
\hline ASSUNTO & BLOCO EXTERNO "LISO" \\
\hline ESCALA & $1 \mid 30$ \\
\hline CLIENTE & LE - SET - EESC - USP \\
\hline DATA & $05|10| 2010$
\end{tabular}




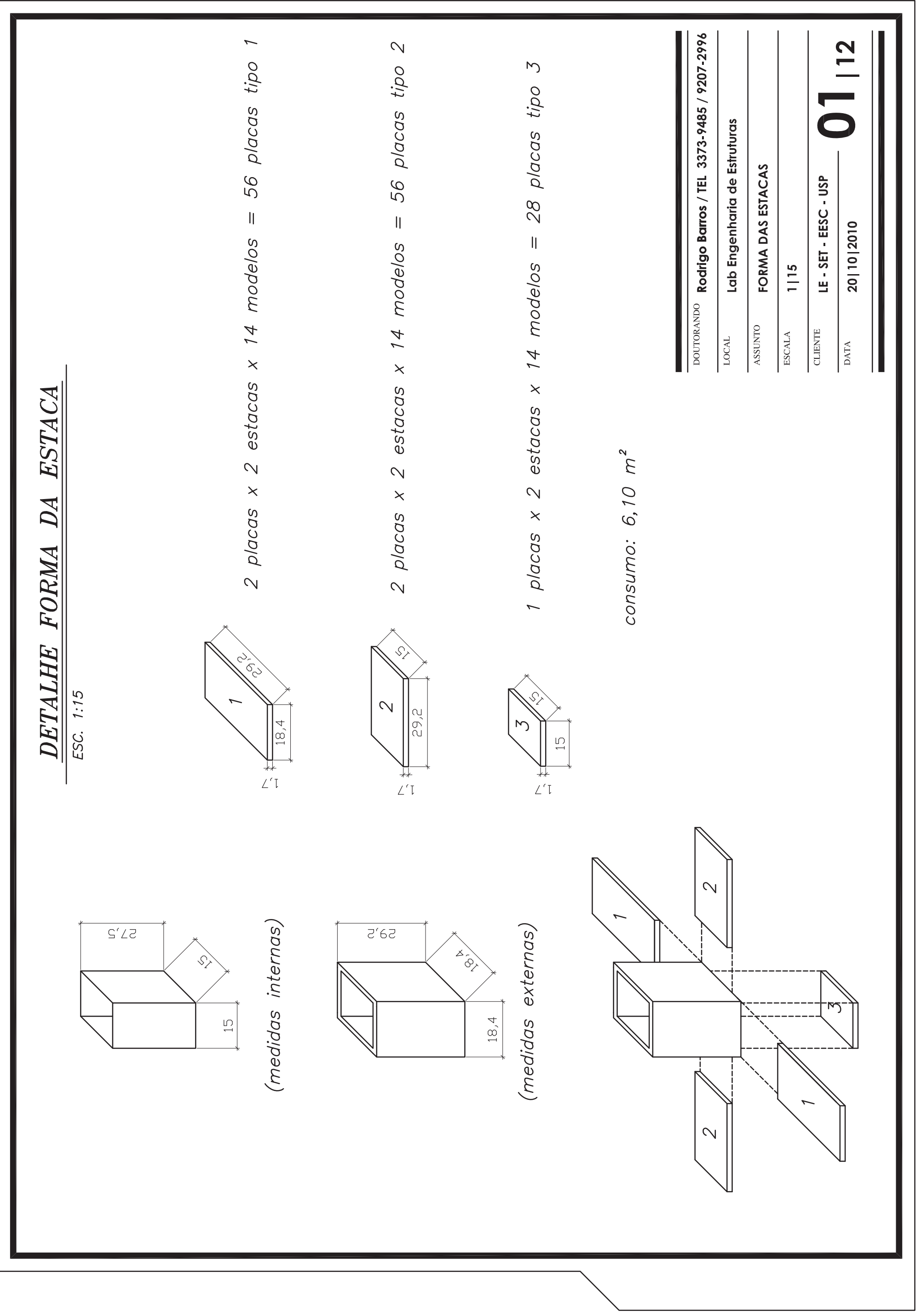




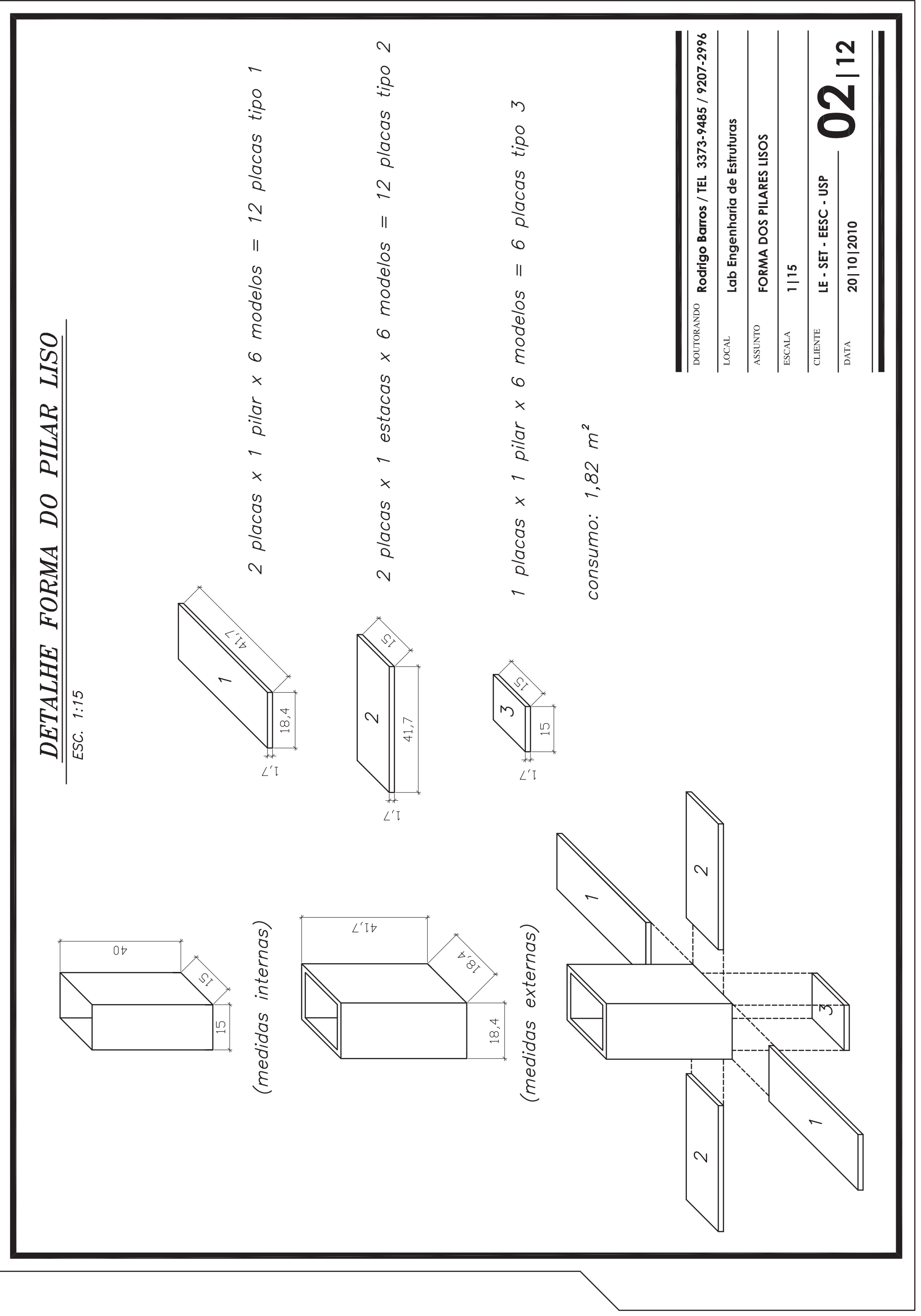




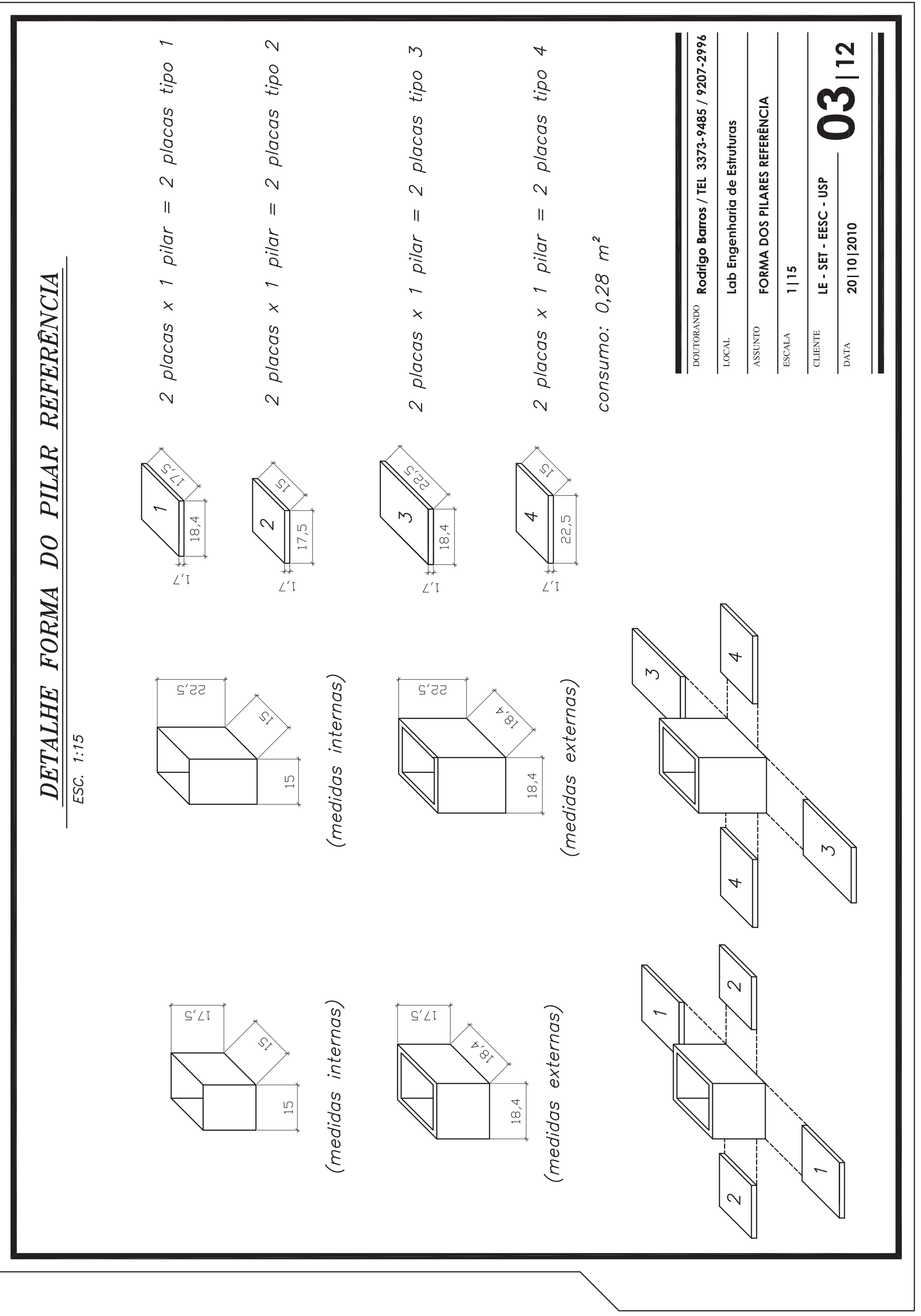




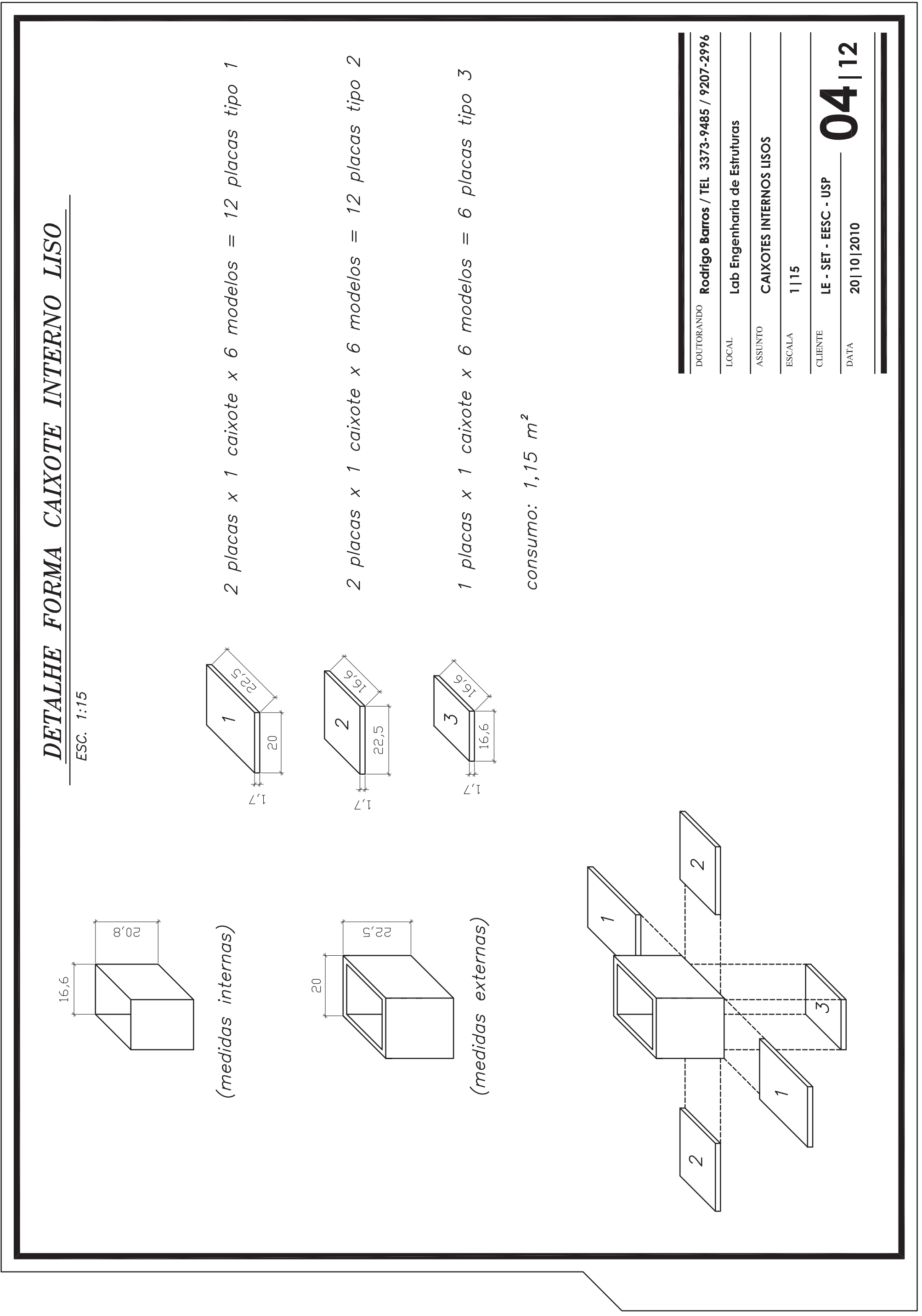




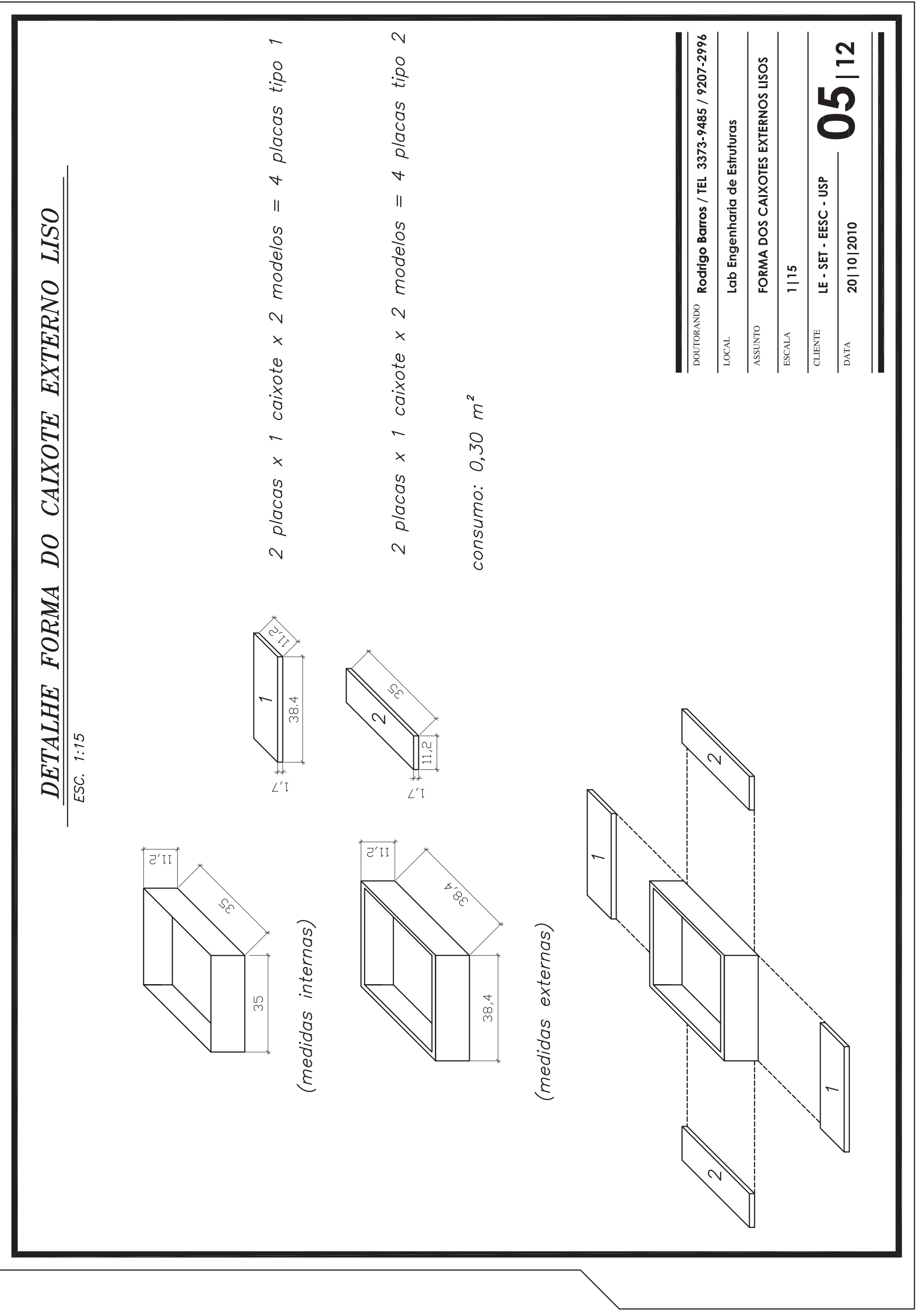




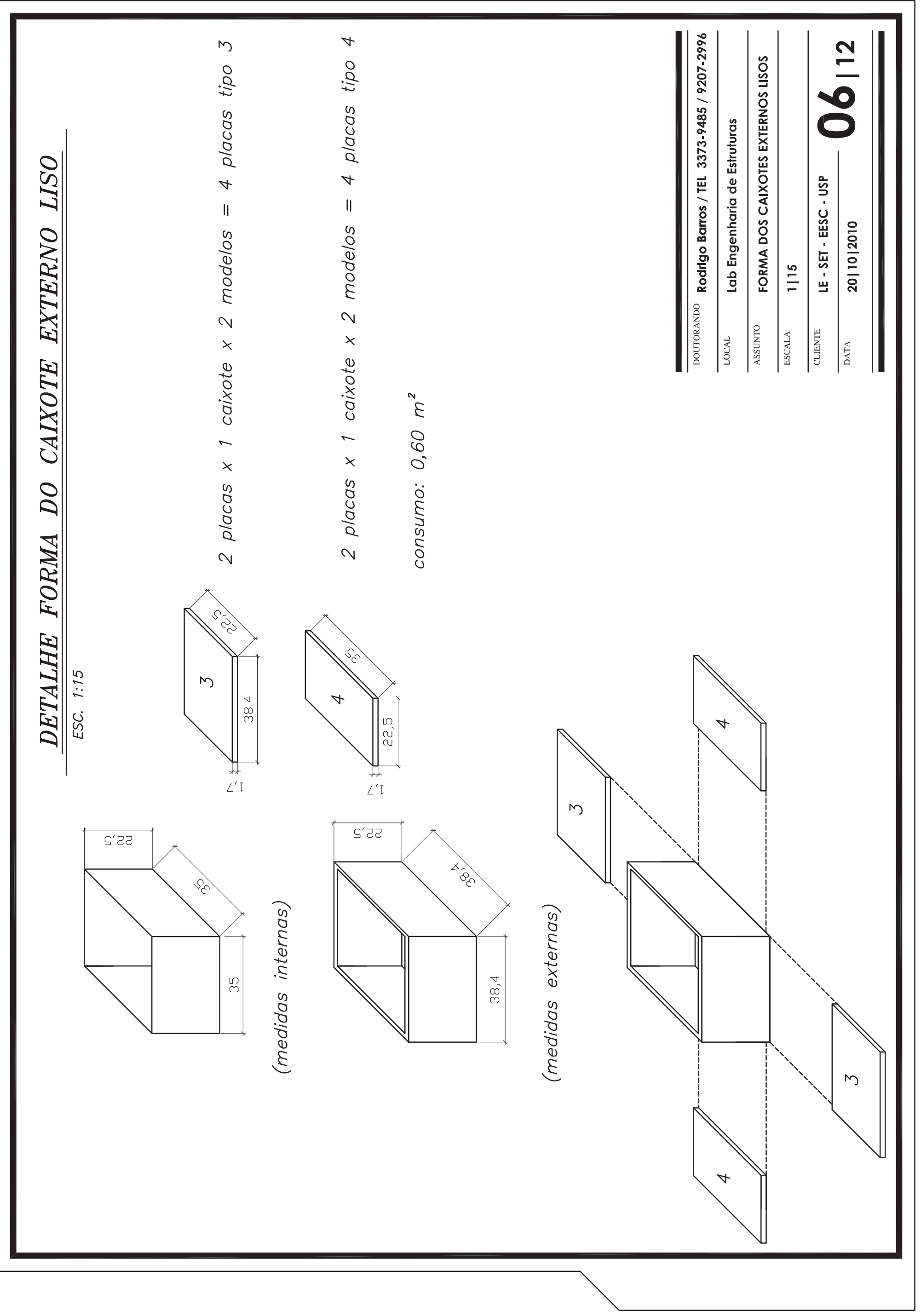




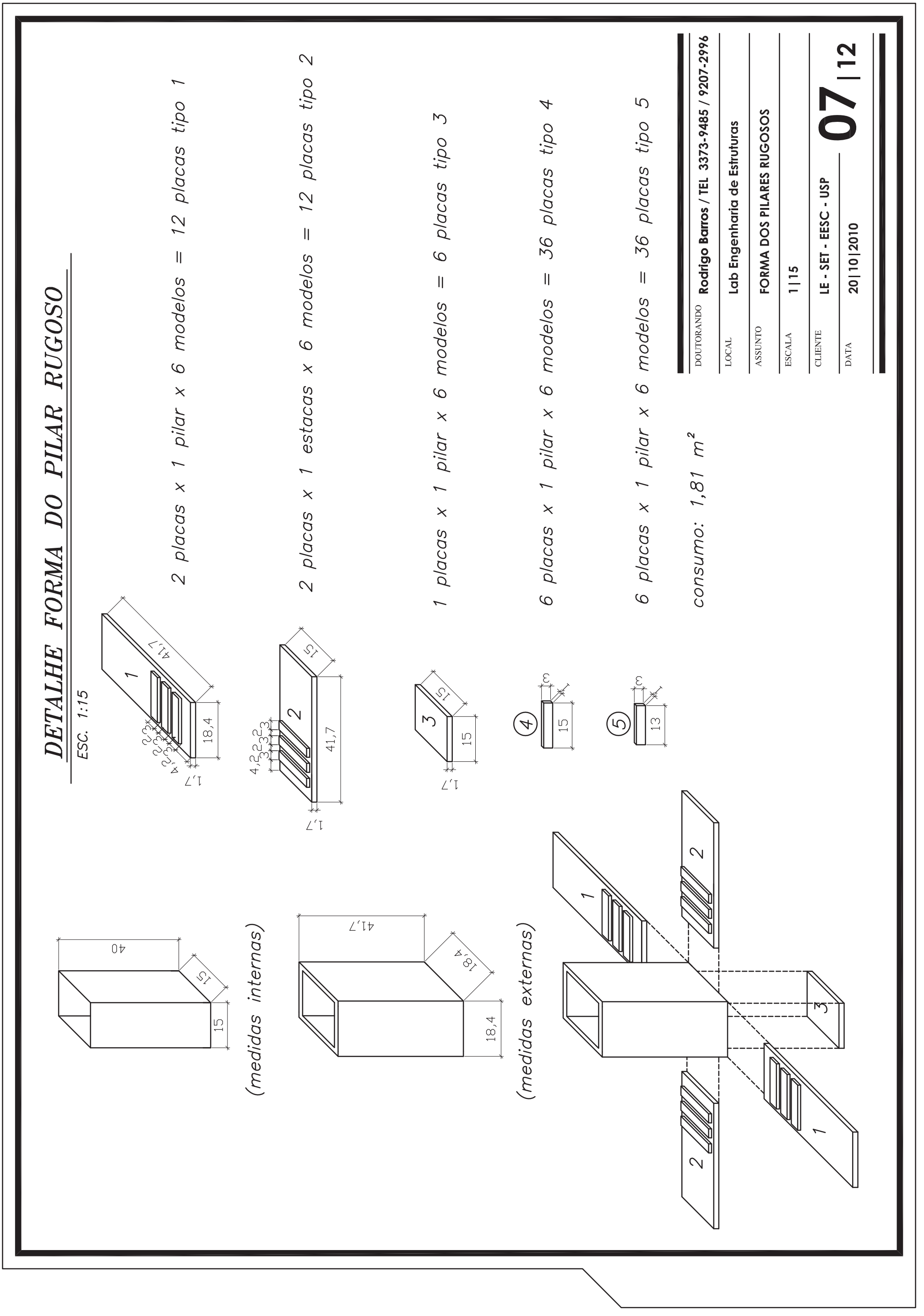




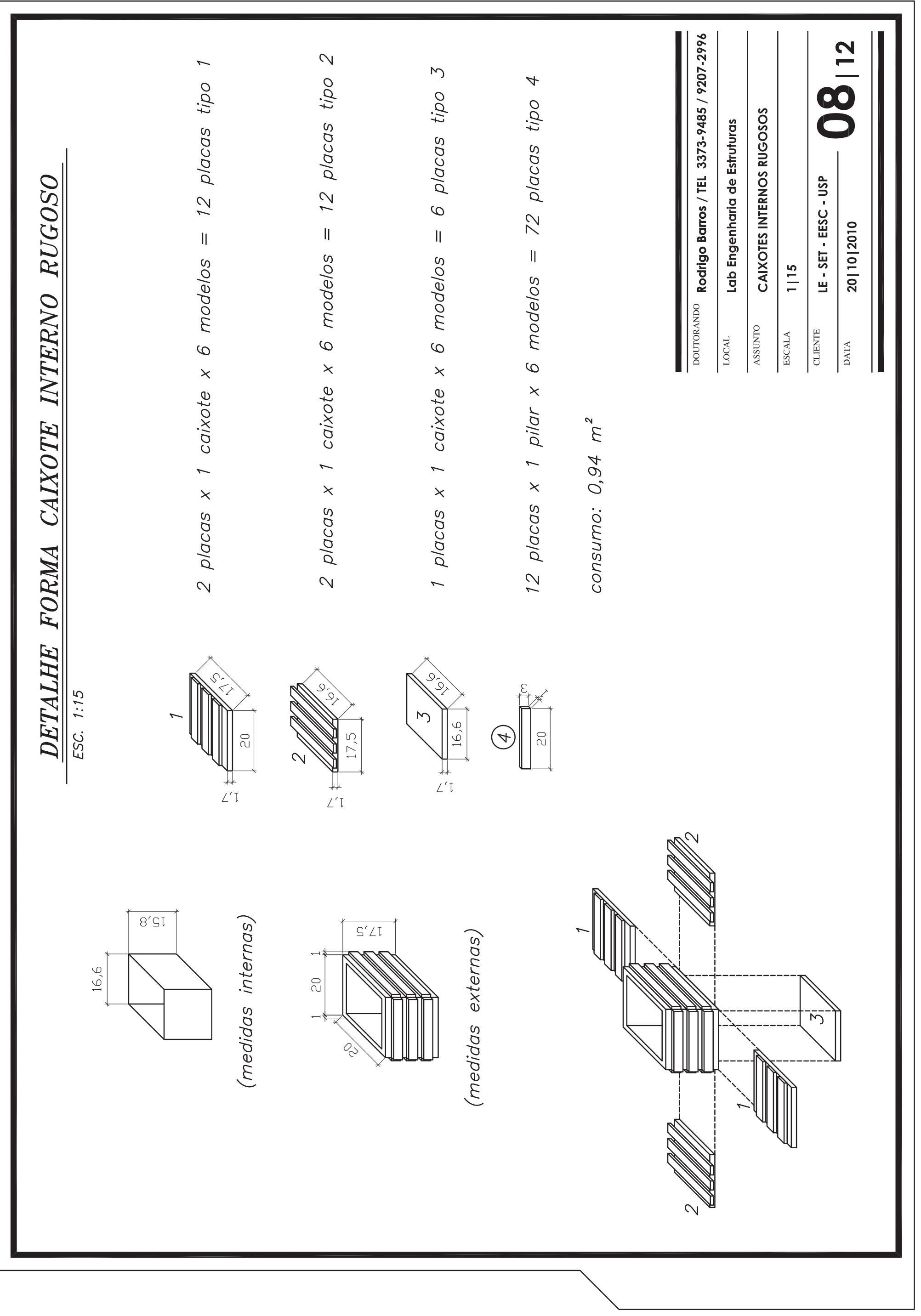



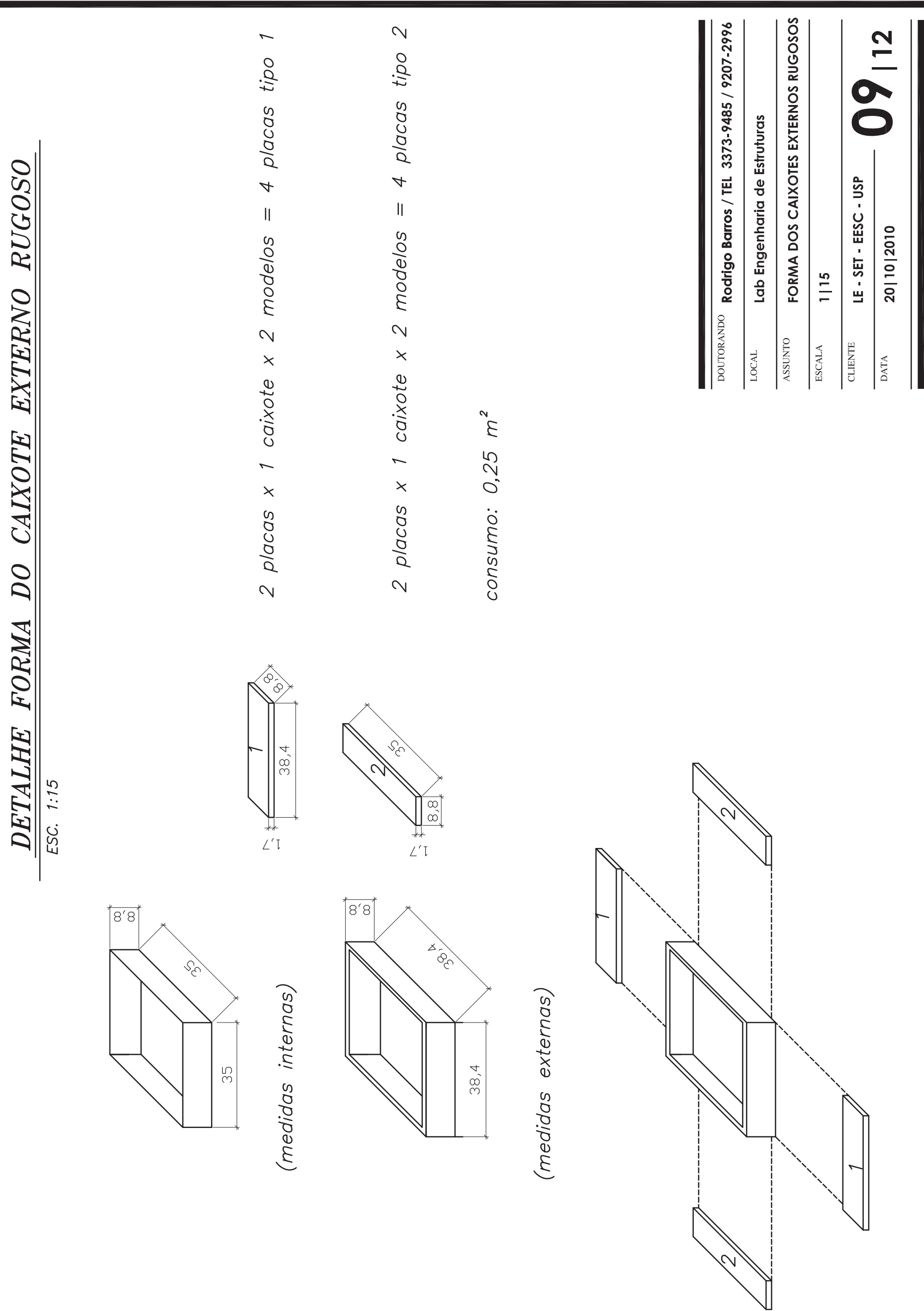


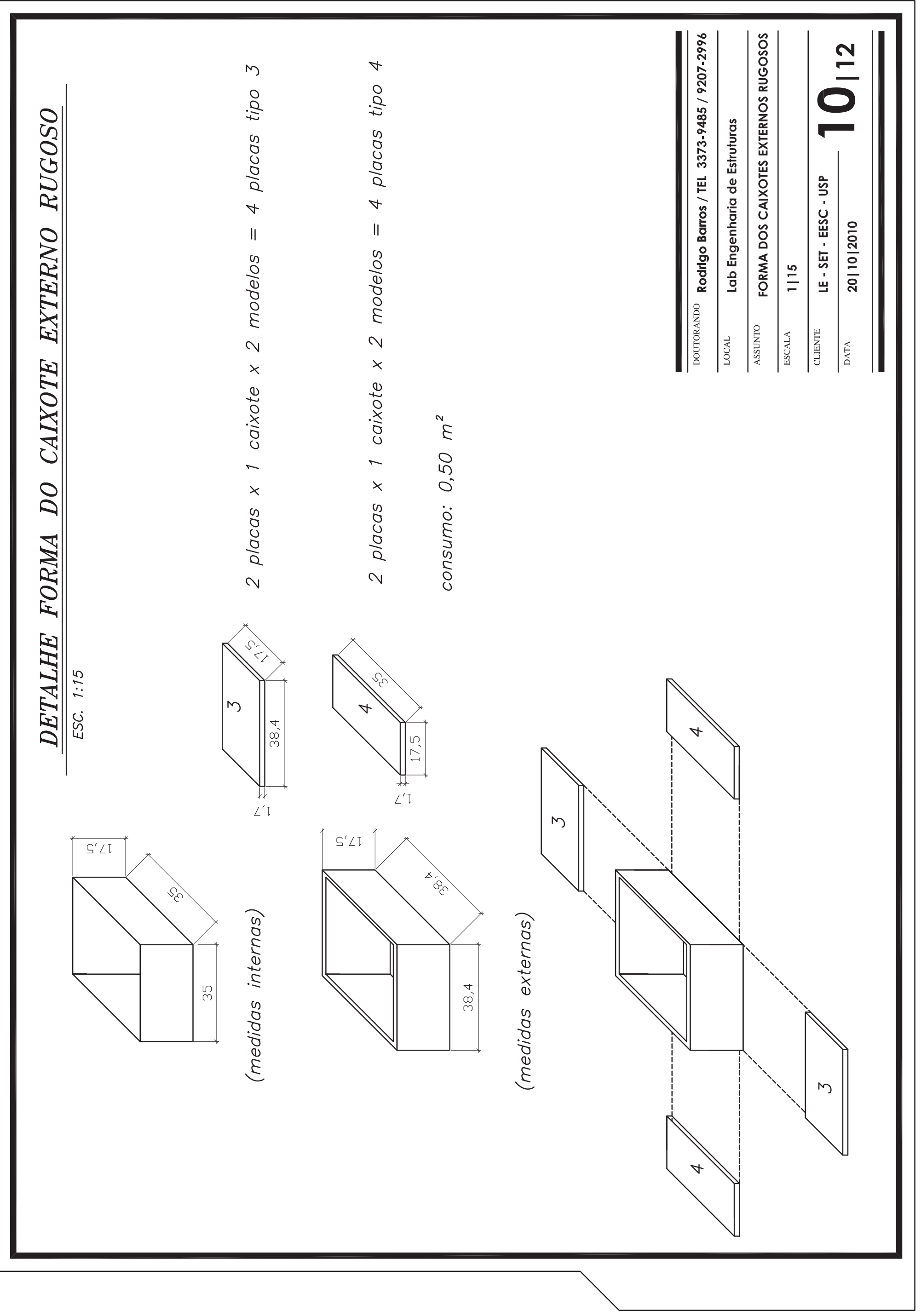




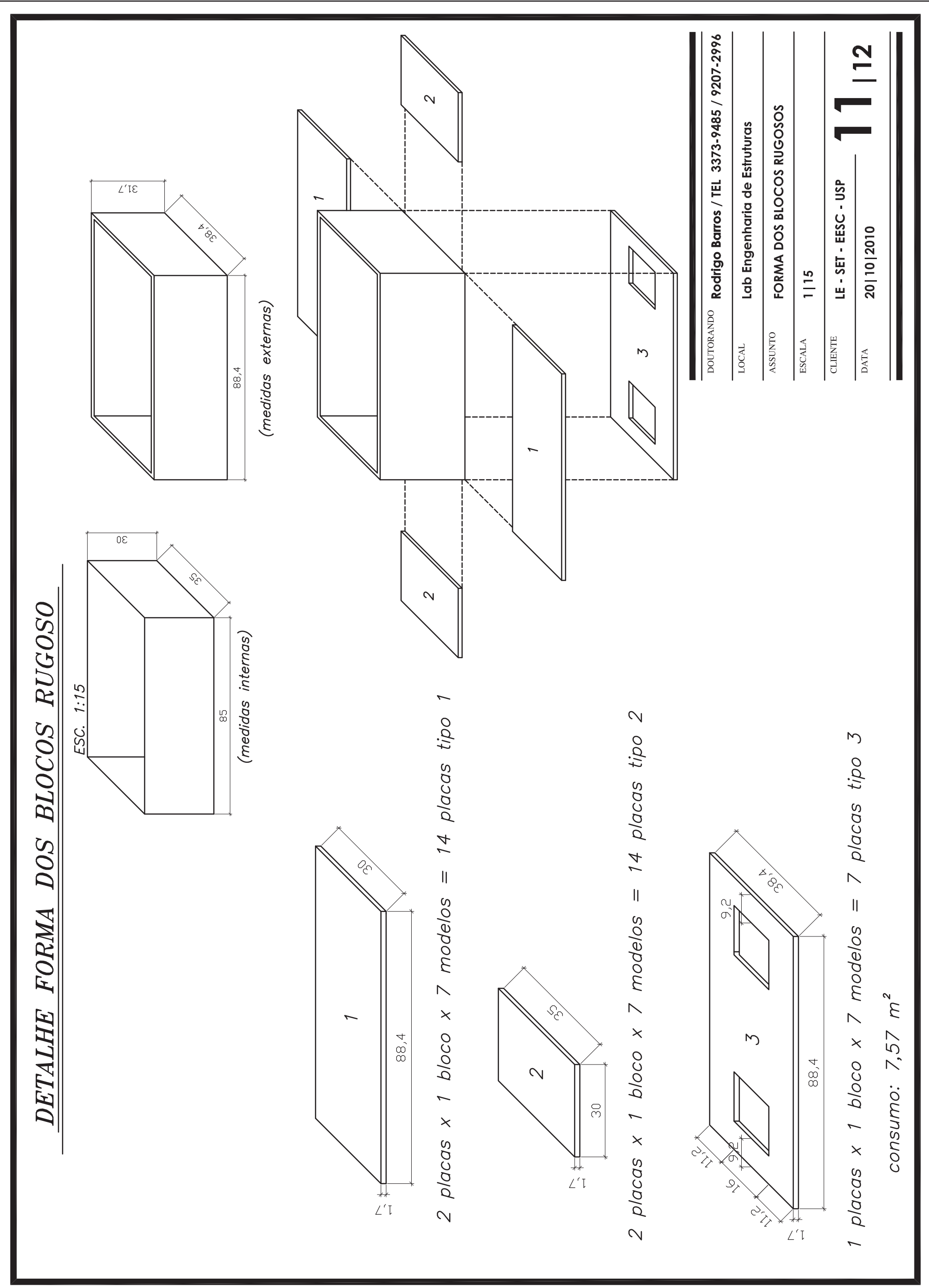




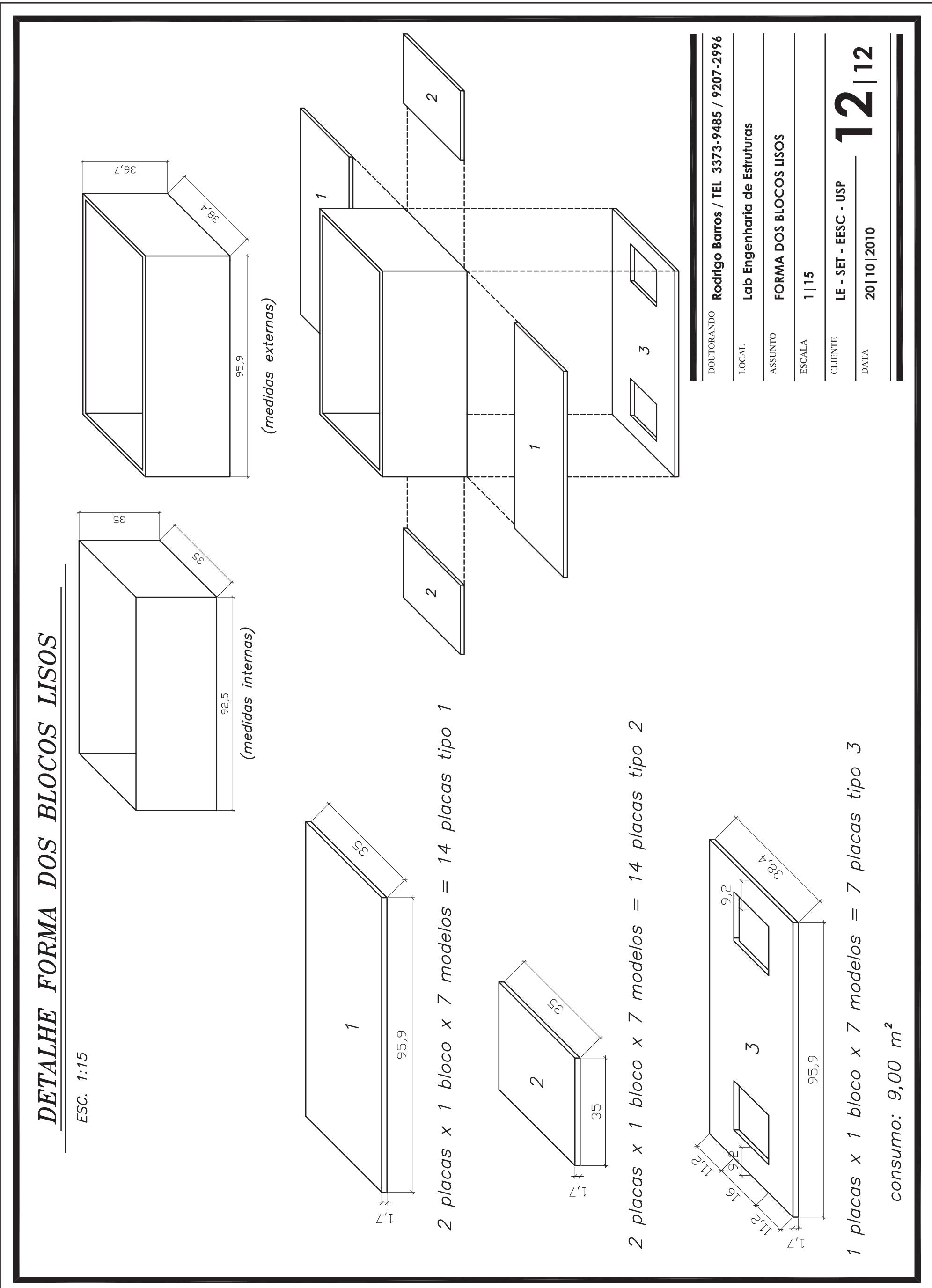




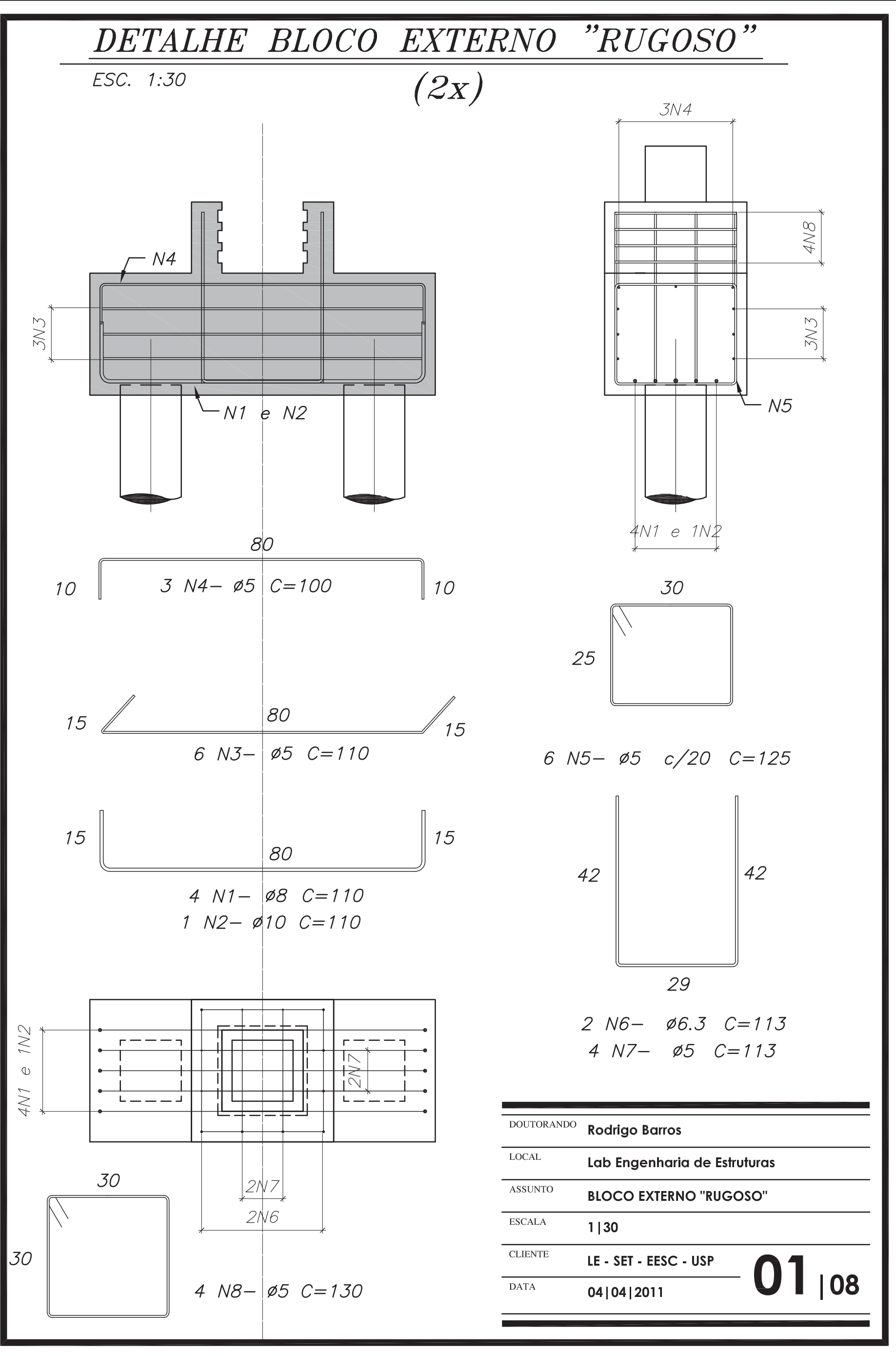




\section{DETALHE BLOCO PARCIALMENTE EMBUTIDO "RUGOSO"}

ESC. $1: 30$
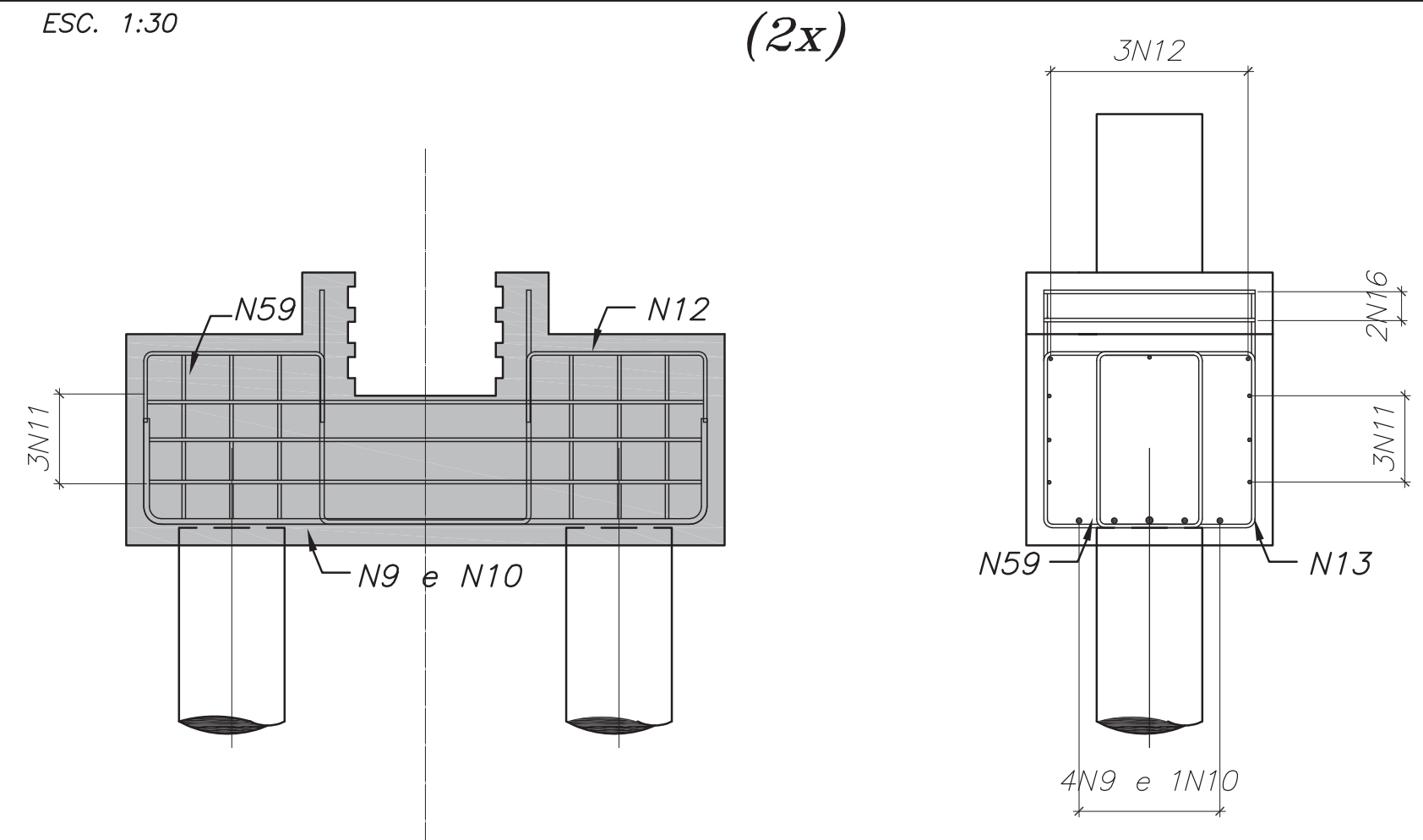

$$
6 \text { N59- } \varnothing 5 \quad C=95
$$

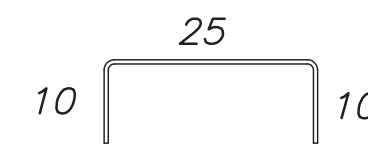

$6 N 12-\varnothing 5 \quad C=45$

15

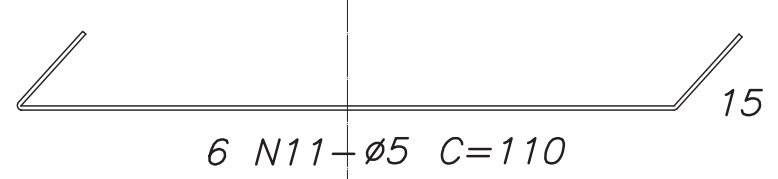

6 N13- $\varnothing 5 \quad c / 15 \quad C=125$
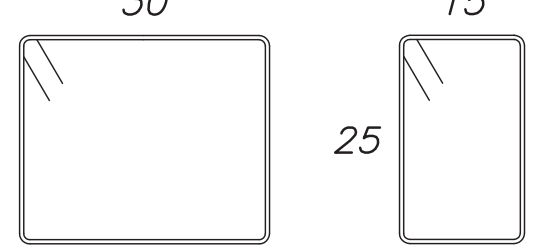

33

2 N14- $\varnothing 6.3 C=95$

$4 N 15-\varnothing 5 \quad C=95$

30

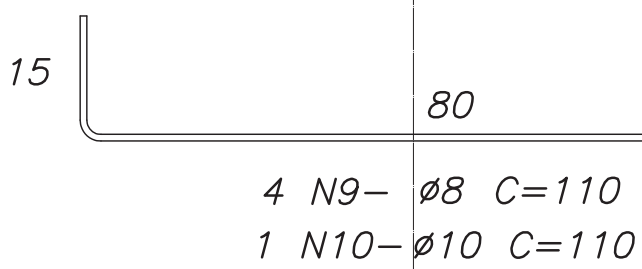

15

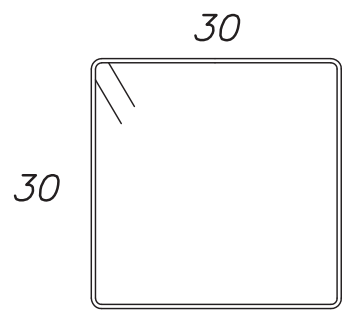

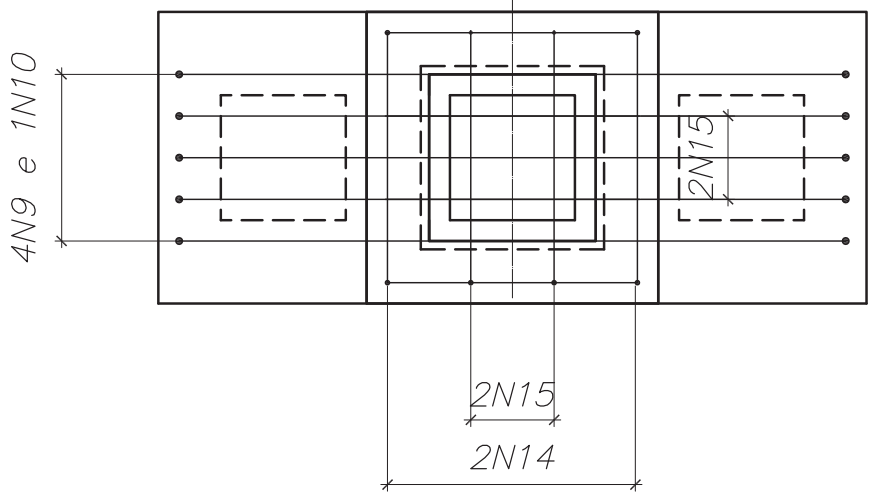

$2 N 16-\not 5 C=130$

\begin{tabular}{ll}
\hline \hline DOUTORANDO & Rodrigo Barros \\
\hline LOCAL & Lab Engenharia de Estruturas \\
\hline ASSUNTO & BLOCO PARCIALMENTE EMBUTIDO "RUGOSO" \\
\hline ESCALA & $1 \mid 30$ \\
\hline CLIENTE & LE - SET - EESC - USP \\
\hline DATA & $04|04| 2011$ \\
\hline
\end{tabular}




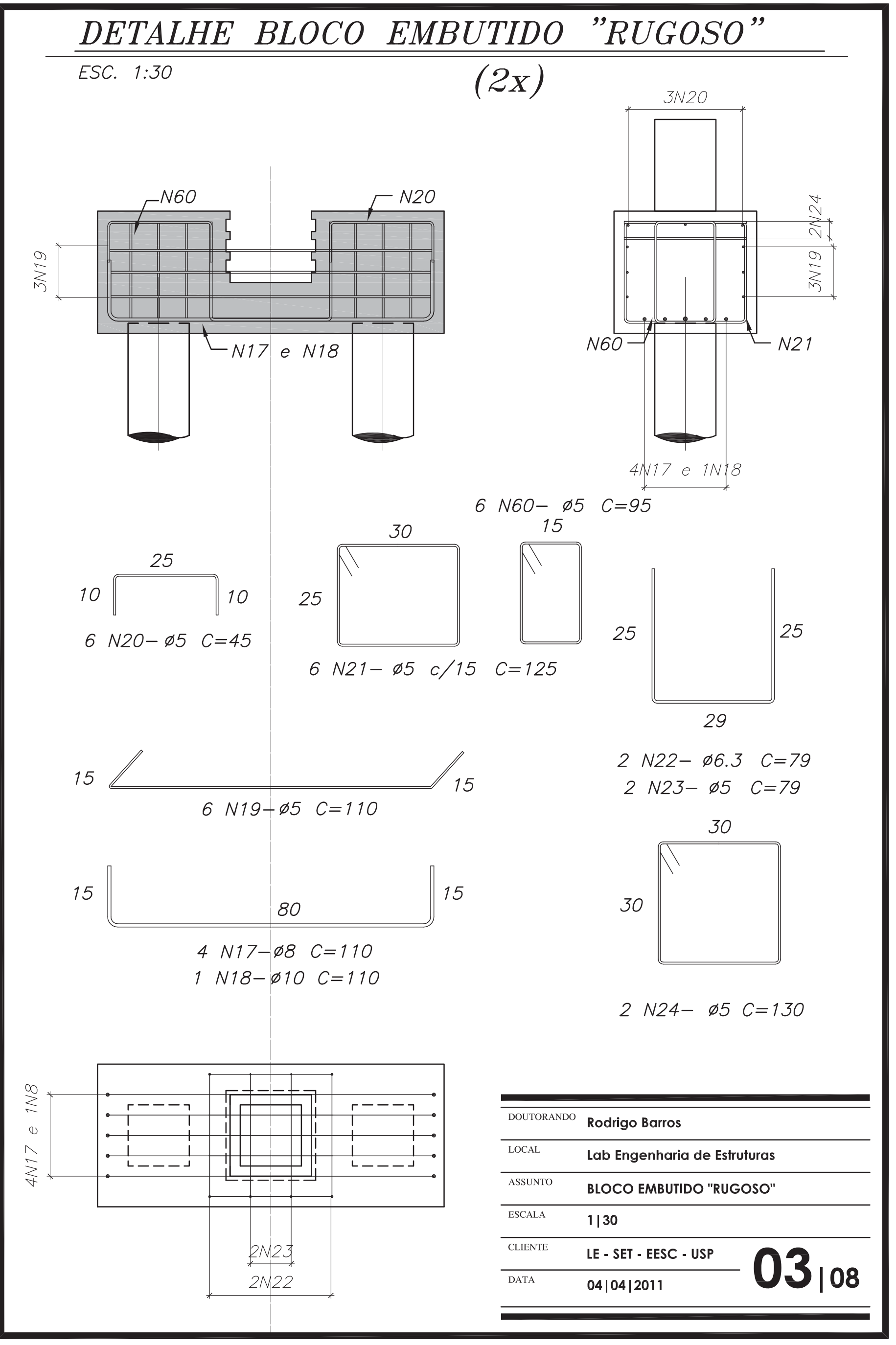




\section{DETALHE BLOCO REFERENCIA "RUGOSO"} ESC. $1: 30$

$$
(1 x)
$$
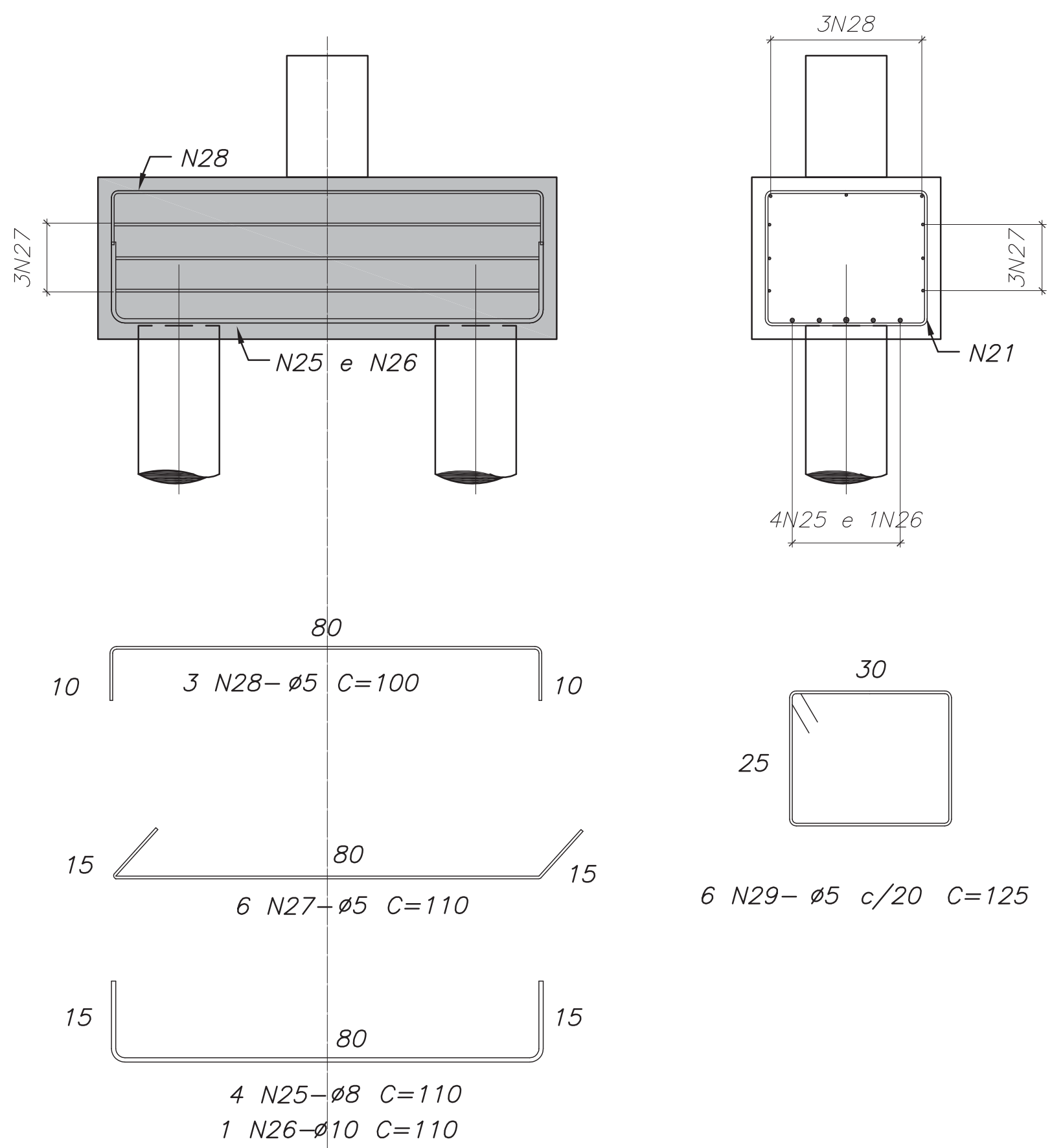

15

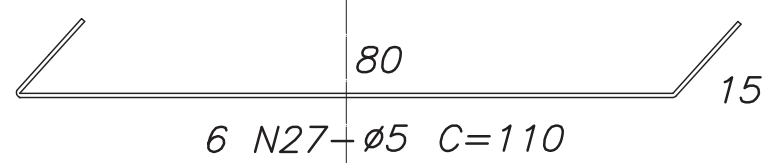

15

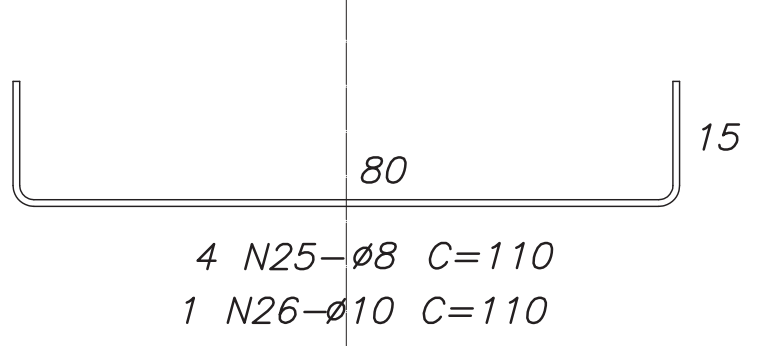

6 N29- $\varnothing 5 \quad c / 20 \quad C=125$

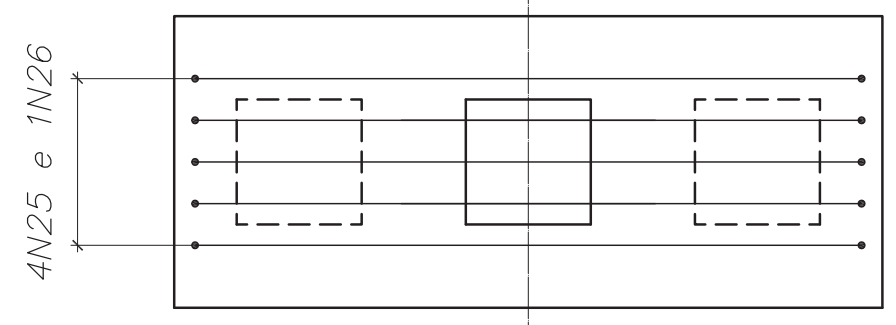

\begin{tabular}{ll}
\hline \hline DOUTORANDO & Rodrigo Barros \\
\hline LOCAL & Lab Engenharia de Estruturas \\
\hline ASSUNTO & BLOCO REFERËNCIA "RUGOSO" \\
\hline ESCALA & $1 \mid 30$ \\
\hline CLIENTE & LE - SET - EESC - USP \\
\hline DATA & $04|04| 2011$ \\
\hline
\end{tabular}




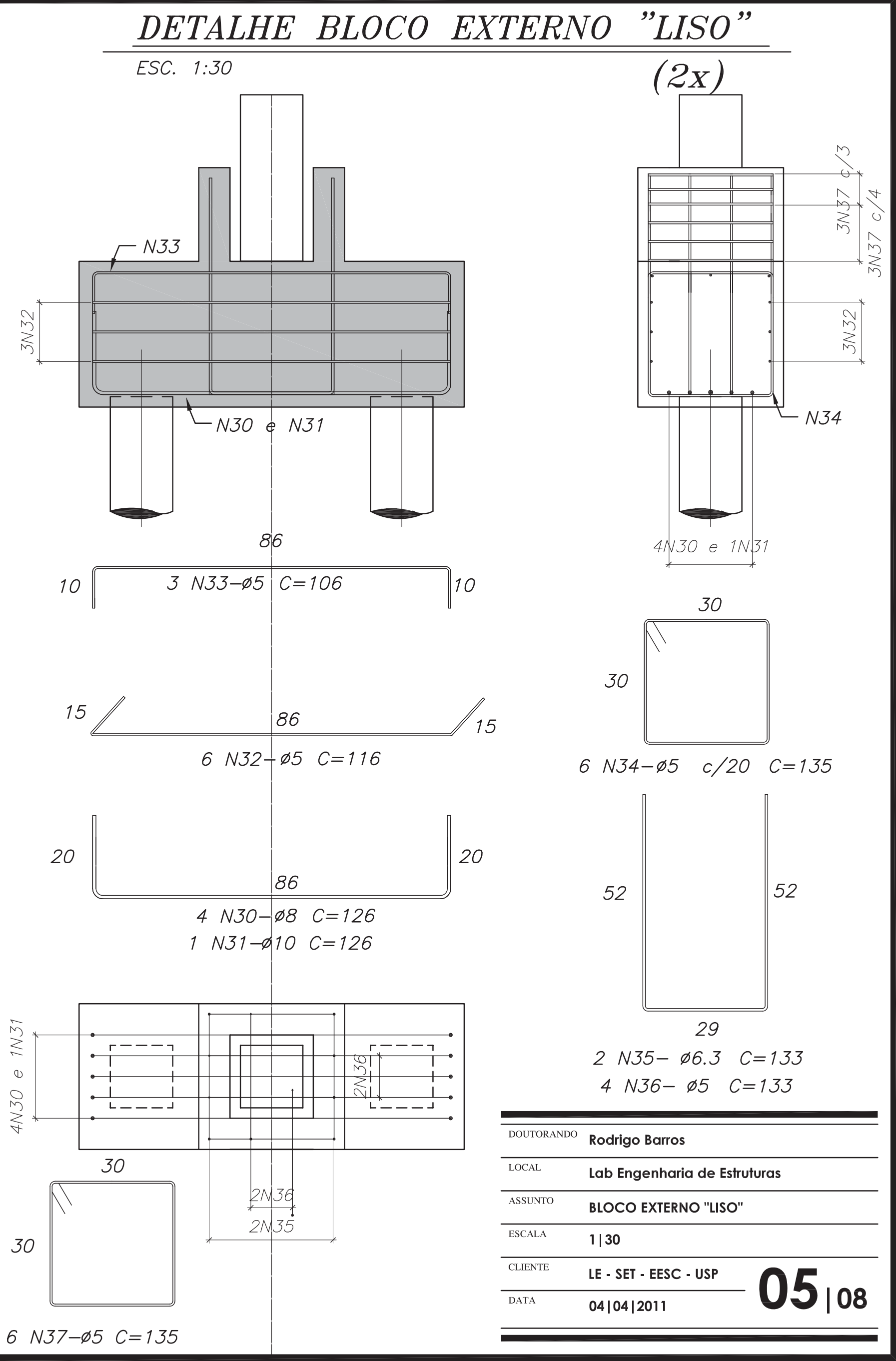




\section{DETALHE BLOCO PARCIALMENTE EMBUTIDO "LISO"}

ESC. $1: 30$

$(2 x)$
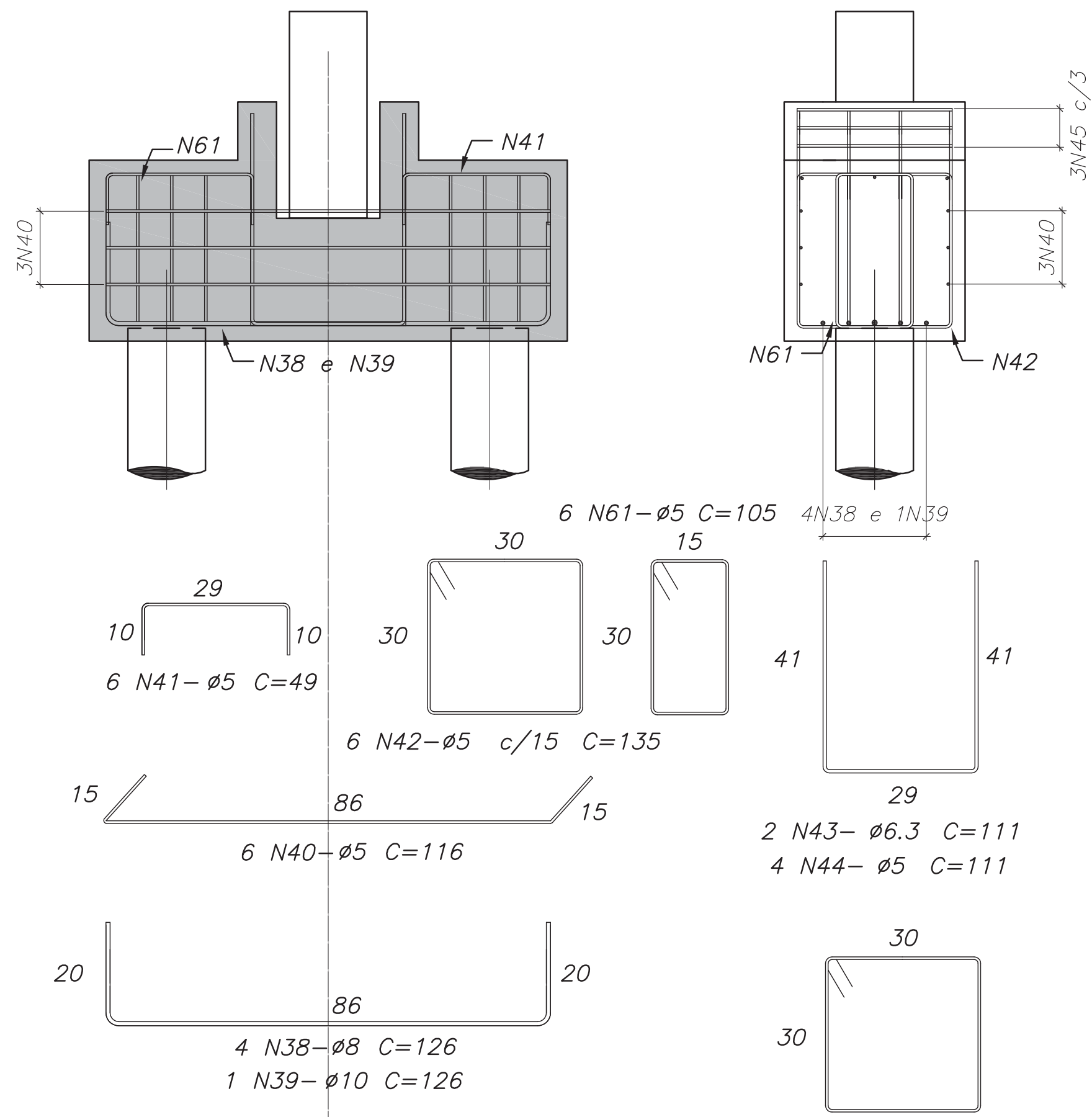

3 N45- $\varnothing 5 \quad C=135$

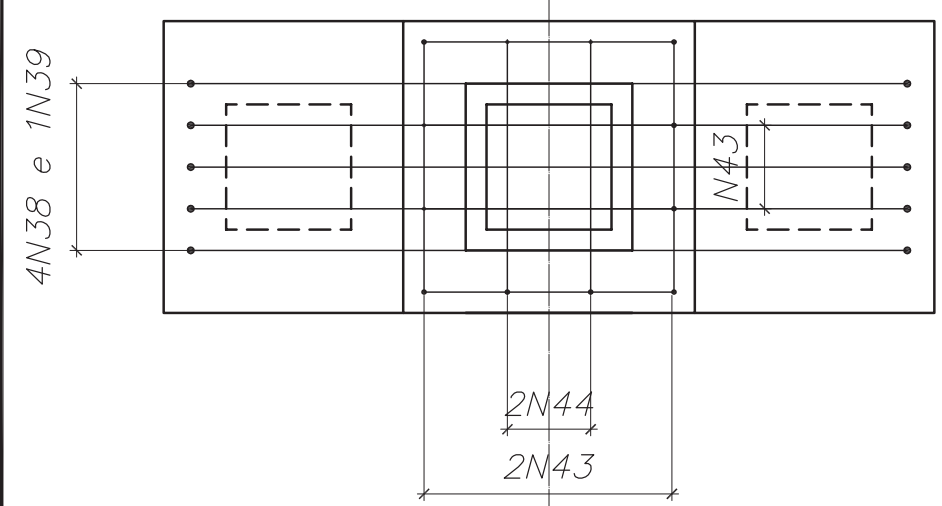

\begin{tabular}{ll}
\hline \hline DOUTORANDO & Rodrigo Barros \\
\hline LOCAL & Lab Engenharia de Estruturas \\
\hline ASSUNTO & BLOCO PARCIALMENTE EMBUTIDO "LISO" \\
\hline ESCALA & $1 \mid 30$ \\
\hline CLIENTE & LE - SET - EESC - USP \\
\hline DATA & $04|04| 2011$ \\
\hline
\end{tabular}




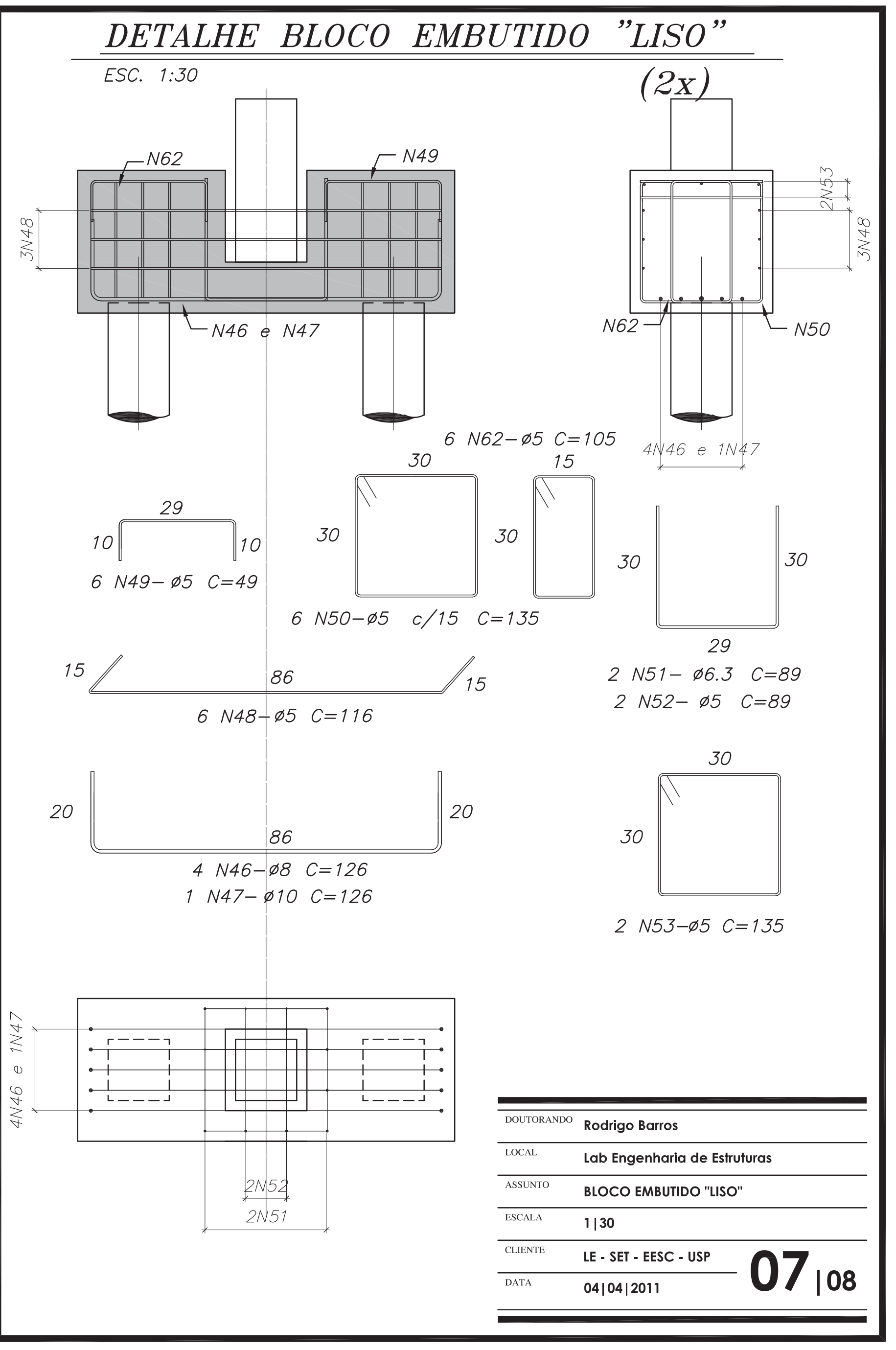




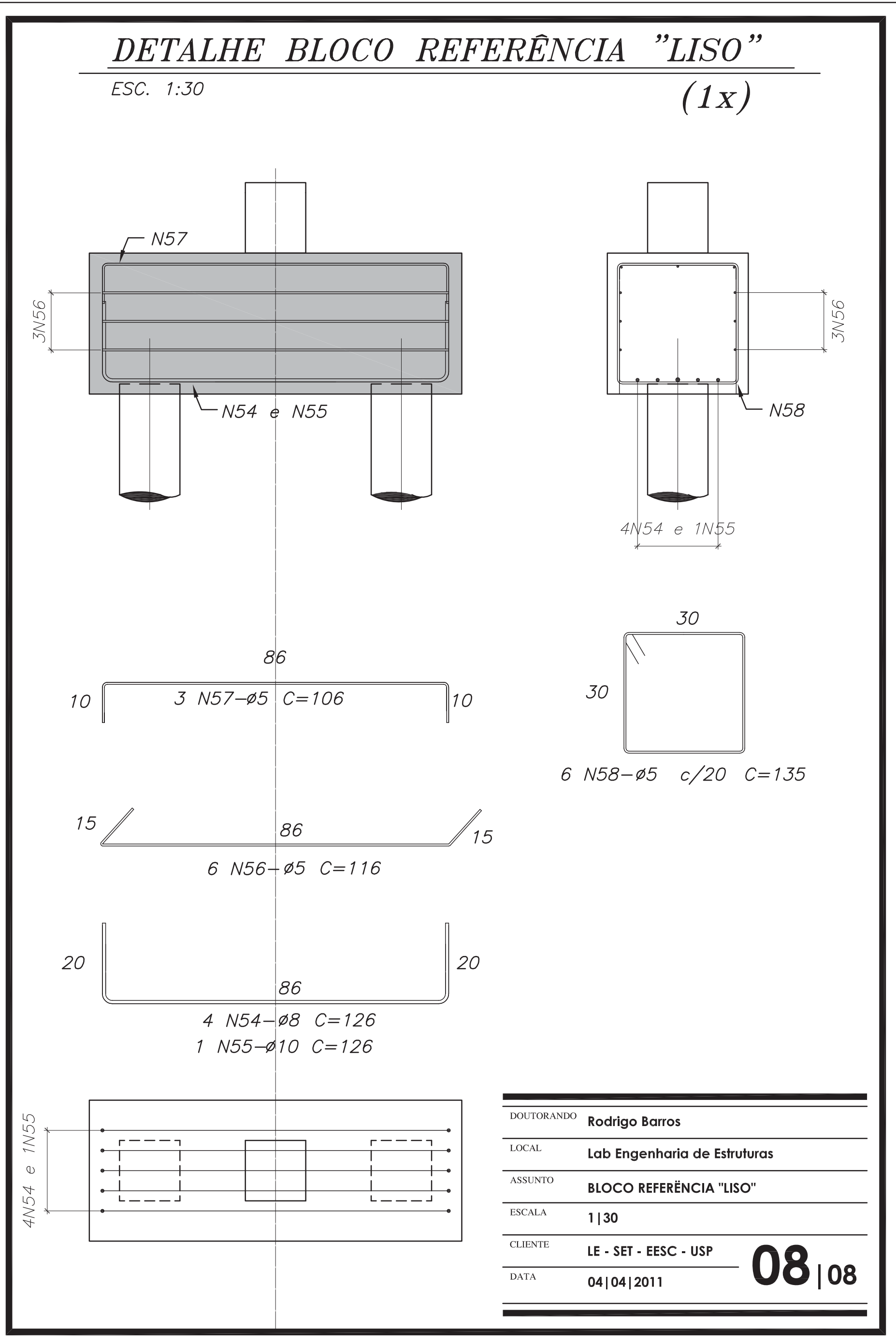




\section{TABELA DE FERROS}

\begin{tabular}{|c|c|c|c|c|c|}
\hline \multicolumn{6}{|c|}{ TABELA DE FERROS } \\
\hline \multirow{2}{*}{$E L E M$} & \multirow[t]{2}{*}{$A C ̧ O$} & \multirow[t]{2}{*}{$\varnothing$} & \multirow[t]{2}{*}{ QUANT } & \multicolumn{2}{|c|}{ COMPRIMENTO } \\
\hline & & & & UNIT & TOTAL \\
\hline 1 & 50 & 8 & 8 & 110 & 880 \\
\hline 2 & 50 & 10 & 2 & 110 & 220 \\
\hline 3 & 60 & 5 & 12 & 110 & 1320 \\
\hline 4 & 60 & 5 & 6 & 100 & 600 \\
\hline 5 & 60 & 5 & 12 & 125 & 1500 \\
\hline 6 & 50 & 6.3 & 4 & 113 & 452 \\
\hline 7 & 60 & 5 & 8 & 113 & 904 \\
\hline 8 & 60 & 5 & 8 & 130 & 1040 \\
\hline 9 & 50 & 8 & 8 & 110 & 880 \\
\hline 10 & 50 & 10 & 2 & 110 & 220 \\
\hline 11 & 60 & 5 & 12 & 110 & 1320 \\
\hline 12 & 60 & 5 & 12 & 45 & 540 \\
\hline 13 & 60 & 5 & 12 & 125 & 1500 \\
\hline 14 & 50 & 6.3 & 4 & 95 & 380 \\
\hline 15 & 60 & 5 & 8 & 95 & 760 \\
\hline 16 & 60 & 5 & 4 & 130 & 520 \\
\hline 17 & 50 & 8 & 8 & 110 & 880 \\
\hline 18 & 50 & 10 & 2 & 110 & 220 \\
\hline 19 & 60 & 5 & 12 & 110 & 1320 \\
\hline 20 & 60 & 5 & 12 & 45 & 540 \\
\hline 21 & 60 & 5 & 12 & 125 & 1500 \\
\hline 22 & 50 & 6.3 & 4 & 79 & 316 \\
\hline 23 & 60 & 5 & 4 & 79 & 316 \\
\hline 24 & 60 & 5 & 4 & 130 & 520 \\
\hline 25 & 50 & 8 & 4 & 110 & 440 \\
\hline 26 & 50 & 10 & 1 & 110 & 110 \\
\hline 27 & 60 & 5 & 6 & 110 & 660 \\
\hline 28 & 60 & 5 & 3 & 100 & 300 \\
\hline 29 & 60 & 5 & 6 & 125 & 750 \\
\hline 30 & 50 & 8 & 8 & 126 & 1008 \\
\hline 31 & 50 & 10 & 2 & 126 & 252 \\
\hline 32 & 60 & 5 & 12 & 116 & 1392 \\
\hline 33 & 60 & 5 & 6 & 106 & 636 \\
\hline 34 & 60 & 5 & 12 & 135 & 1620 \\
\hline 35 & 50 & 6.3 & 4 & 133 & 532 \\
\hline 36 & 60 & 5 & 8 & 133 & 1064 \\
\hline 37 & 60 & 5 & 12 & 135 & 1620 \\
\hline 38 & 50 & 8 & 8 & 126 & 1008 \\
\hline 39 & 50 & 10 & 2 & 126 & 252 \\
\hline 40 & 60 & 5 & 12 & 116 & 1392 \\
\hline 41 & 60 & 5 & 12 & 49 & 588 \\
\hline 42 & 60 & 5 & 12 & 135 & 1620 \\
\hline 43 & 50 & 6.3 & 4 & 111 & 444 \\
\hline 44 & 60 & 5 & 8 & 111 & 888 \\
\hline 45 & 60 & 5 & 6 & 135 & 810 \\
\hline 46 & 50 & 8 & 8 & 126 & 1008 \\
\hline 47 & 50 & 10 & 2 & 126 & 252 \\
\hline 48 & 60 & 5 & 12 & 116 & 1392 \\
\hline 49 & 60 & 5 & 12 & 49 & 588 \\
\hline 50 & 60 & 5 & 6 & 135 & 810 \\
\hline
\end{tabular}

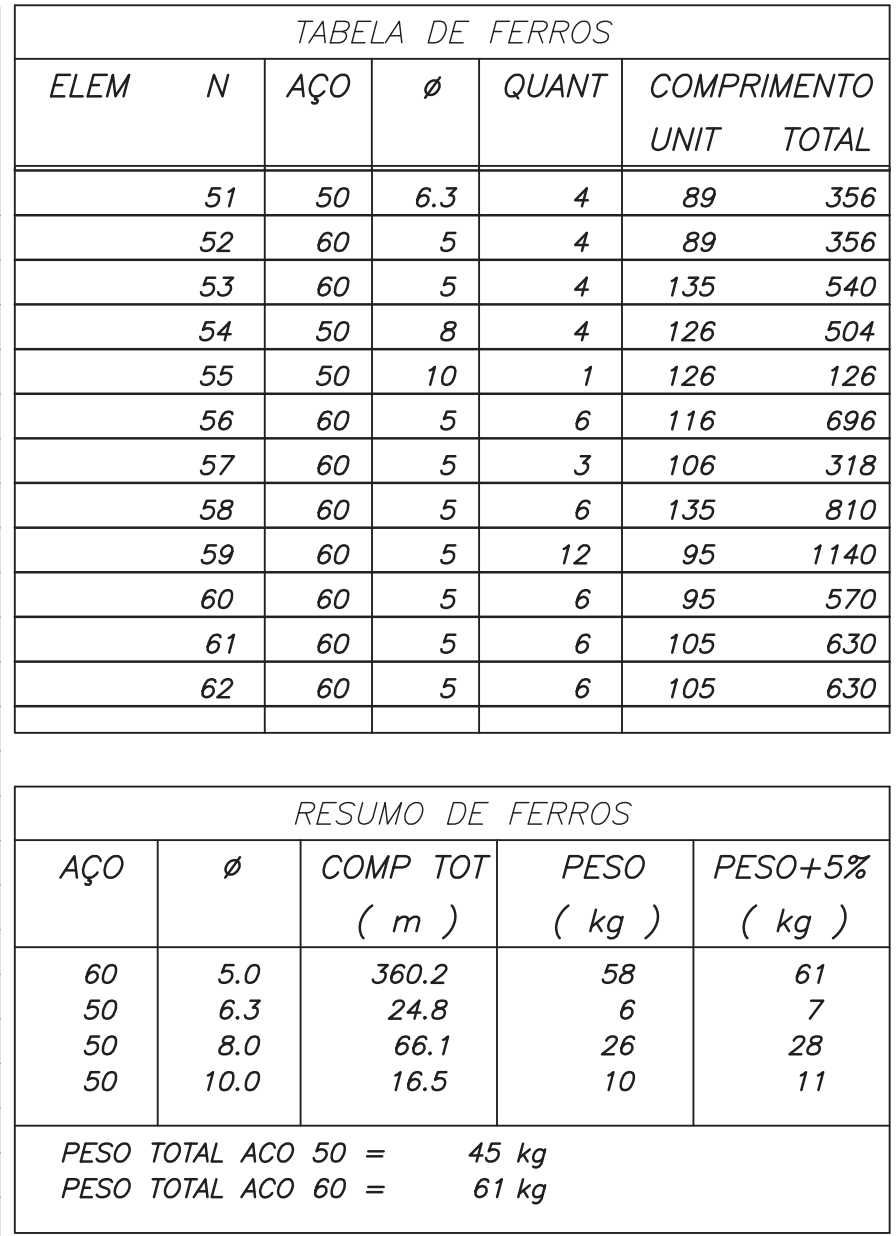

\begin{tabular}{ll}
\hline DOUTORANDO & Rodrigo Barros / TEL $3373-9485$ / 9207-2996 \\
\hline LOCAL & Lab Engenharia de Estruturas \\
\hline ASSUNTO & TABELA DE FERROS \\
\hline ESCALA & $1 \mid 30$ \\
\hline CLIENTE & LE - SET - EESC - USP \\
\hline DATA & $04|04| 2011$ \\
\hline
\end{tabular}




\section{DETALHE ARMAÇÓO DOS PILARES}

ESC. $1: 30$
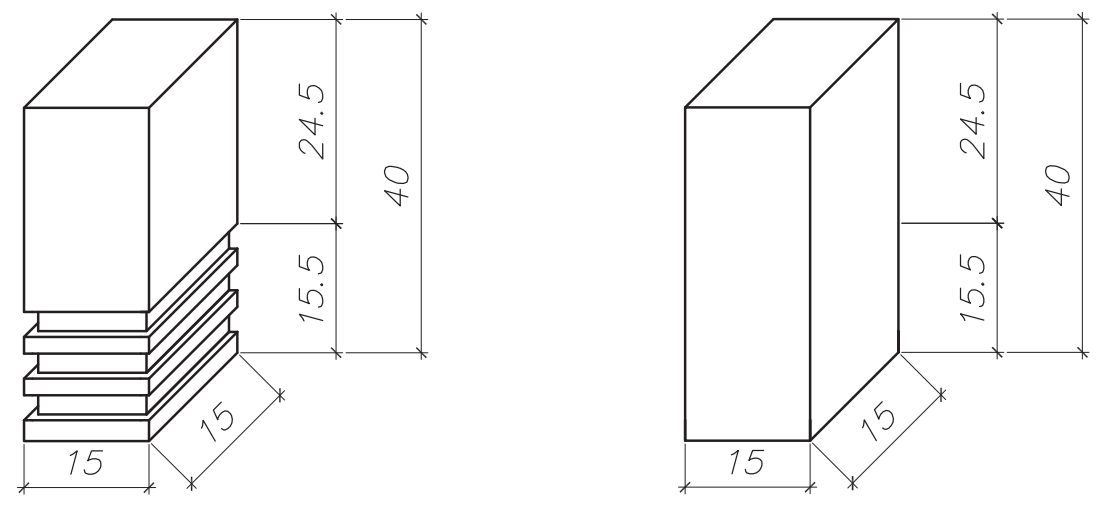

(pilar)

(pilar)
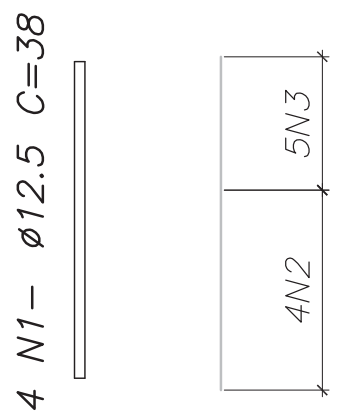

$4 N 2-\varnothing 5 \quad c / 4.5 \quad C=52$

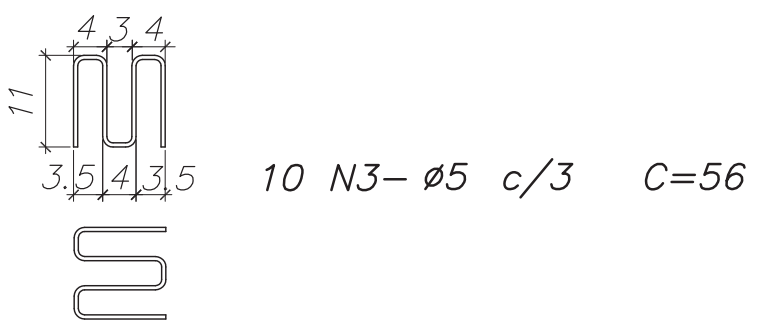

\begin{tabular}{|c|c|}
\hline DOUTORANDO & Rodrigo Barros / TEL 3373-9485 / 9207-2996 \\
\hline LOCAL & Lab Engenharia de Estruturas \\
\hline ASSUNTO & ARMAÇĀO PILARES \\
\hline ESCALA & $1 \mid 30$ \\
\hline CLIENTE & LE - SET - EESC - USP \\
\hline DATA & 04 | 04 | 2011 \\
\hline
\end{tabular}




\section{DETALHE ARMACÁO DOS PILARES REF.}

ESC. $1: 30$
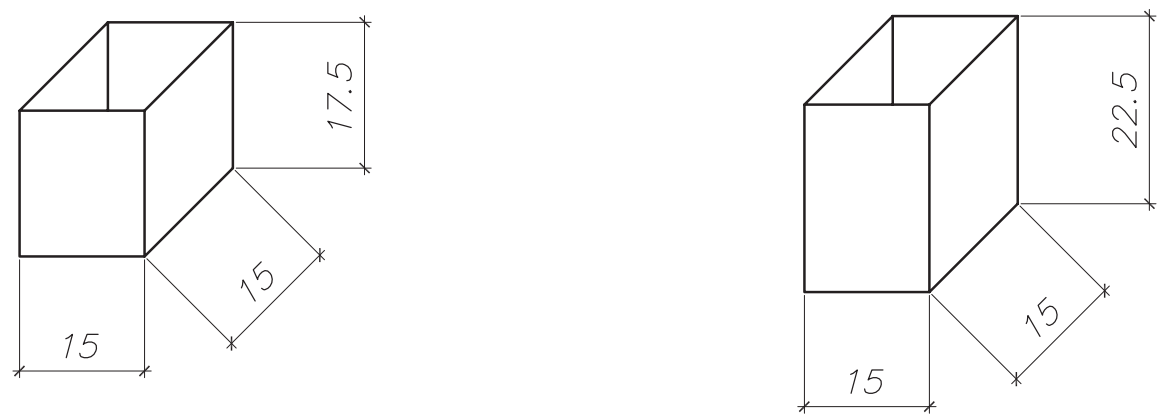

(pilar)

(pilar)
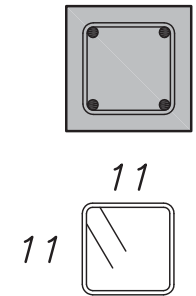

6 N5- $\varnothing 5 \quad c / 4.5 \quad C=52$

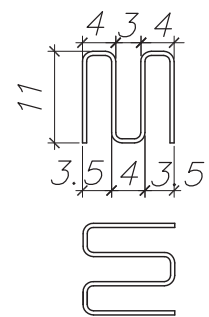

$10 N 6-\varnothing 5 c / 3$

$C=56$

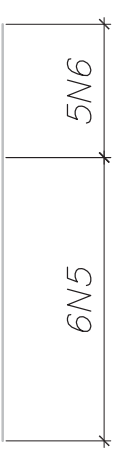




\section{DETALHE ARMAÇÁO DAS ESTACAS}

ESC. $1: 30$

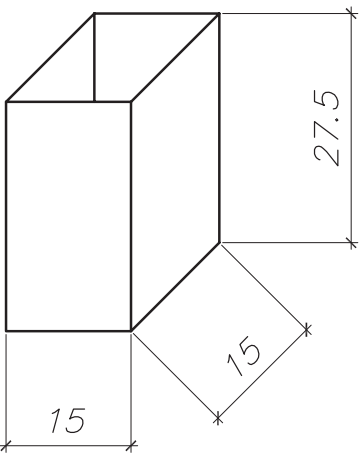

(estacas)
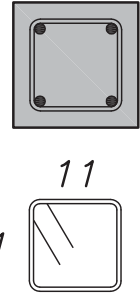

$\sum_{i 0}^{\infty}$

$\frac{1}{z}$

total: 28 Estacas

1 N9- $\varnothing 5 \quad C=100$

1 N10- $\varnothing 6.3 C=100$

1 N11- $\varnothing 8 \quad C=100$

1 N12- $\varnothing 10 \quad C=100$

1 N13- $\varnothing 12.5 C=100$

5 N8- $\varnothing 5 \quad c / 4.5 \quad C=52$

\begin{tabular}{|c|c|c|c|c|c|}
\hline \multicolumn{6}{|c|}{ TABELA DE FERROS } \\
\hline$E L E M$ & $A C ̧ O$ & $\varnothing$ & QUANT & COMF & AENTO \\
\hline & & & & UNIT & TOTAL \\
\hline 1 & $50 A$ & 12.5 & 48 & 38 & 1824 \\
\hline 2 & $60 B$ & 5 & 48 & 52 & 2496 \\
\hline 3 & $60 B$ & 5 & 120 & 56 & 6720 \\
\hline 4 & $50 A$ & 12.5 & 8 & 48 & 384 \\
\hline 5 & $60 B$ & 5 & 12 & 52 & 624 \\
\hline 6 & $60 B$ & 5 & 20 & 56 & 1120 \\
\hline 7 & $50 A$ & 10 & 112 & 45 & 5040 \\
\hline 8 & $60 B$ & 5 & 140 & 52 & 7280 \\
\hline 9 & $60 B$ & 5 & 3 & 100 & 300 \\
\hline 10 & $50 A$ & 6.3 & 3 & 100 & 300 \\
\hline 11 & $50 A$ & 8 & 3 & 100 & 300 \\
\hline 12 & $50 A$ & 10 & 3 & 100 & 300 \\
\hline 13 & $50 A$ & 12.5 & 3 & 100 & 300 \\
\hline
\end{tabular}

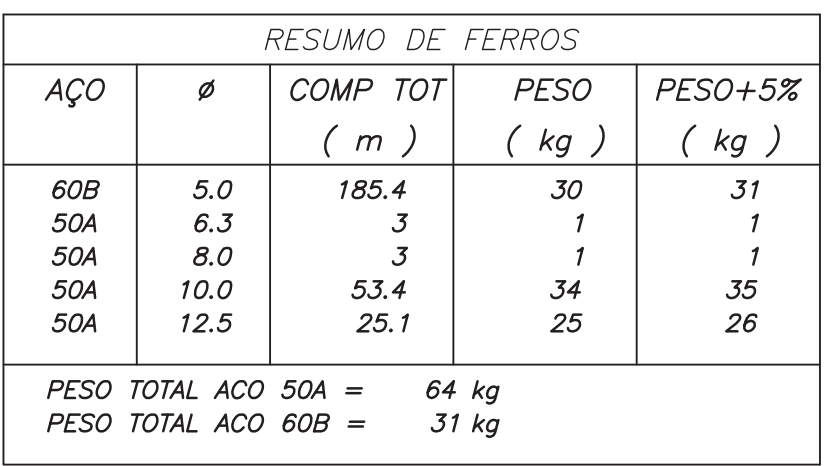

(12.5 $C=100$

\begin{tabular}{ll}
\hline DOUTORANDO & Rodrigo Barros / TEL 3373-9485 / 9207-2996 \\
\hline LOCAL & Lab Engenharia de Estruturas \\
\hline ASSUNTO & ARMAÇĀO DAS ESTACAS \\
\hline ESCALA & $1 \mid 30$ \\
\hline CLIENTE & LE - SET - EESC - USP \\
\hline DATA & $04|04| 2011$
\end{tabular}




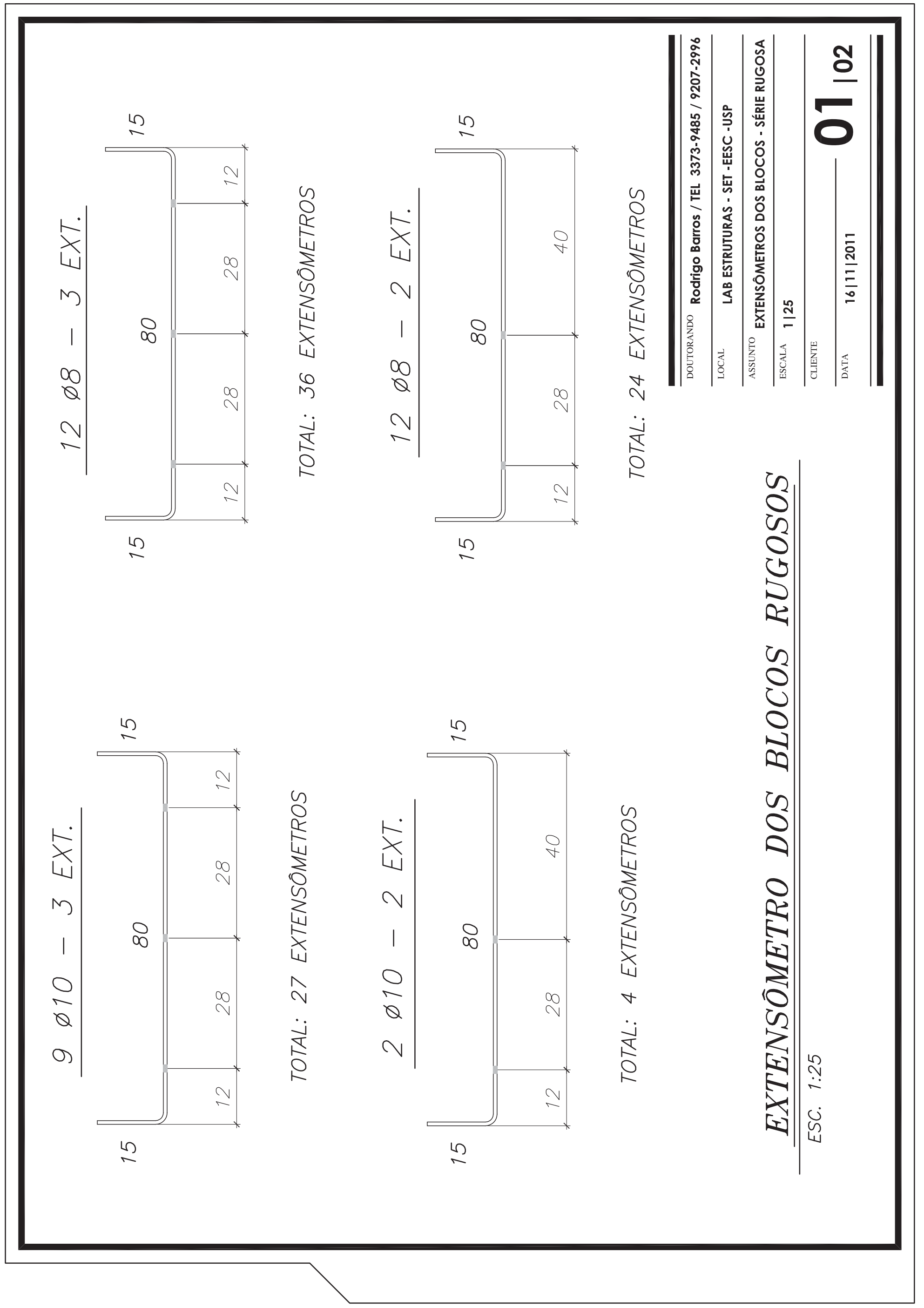




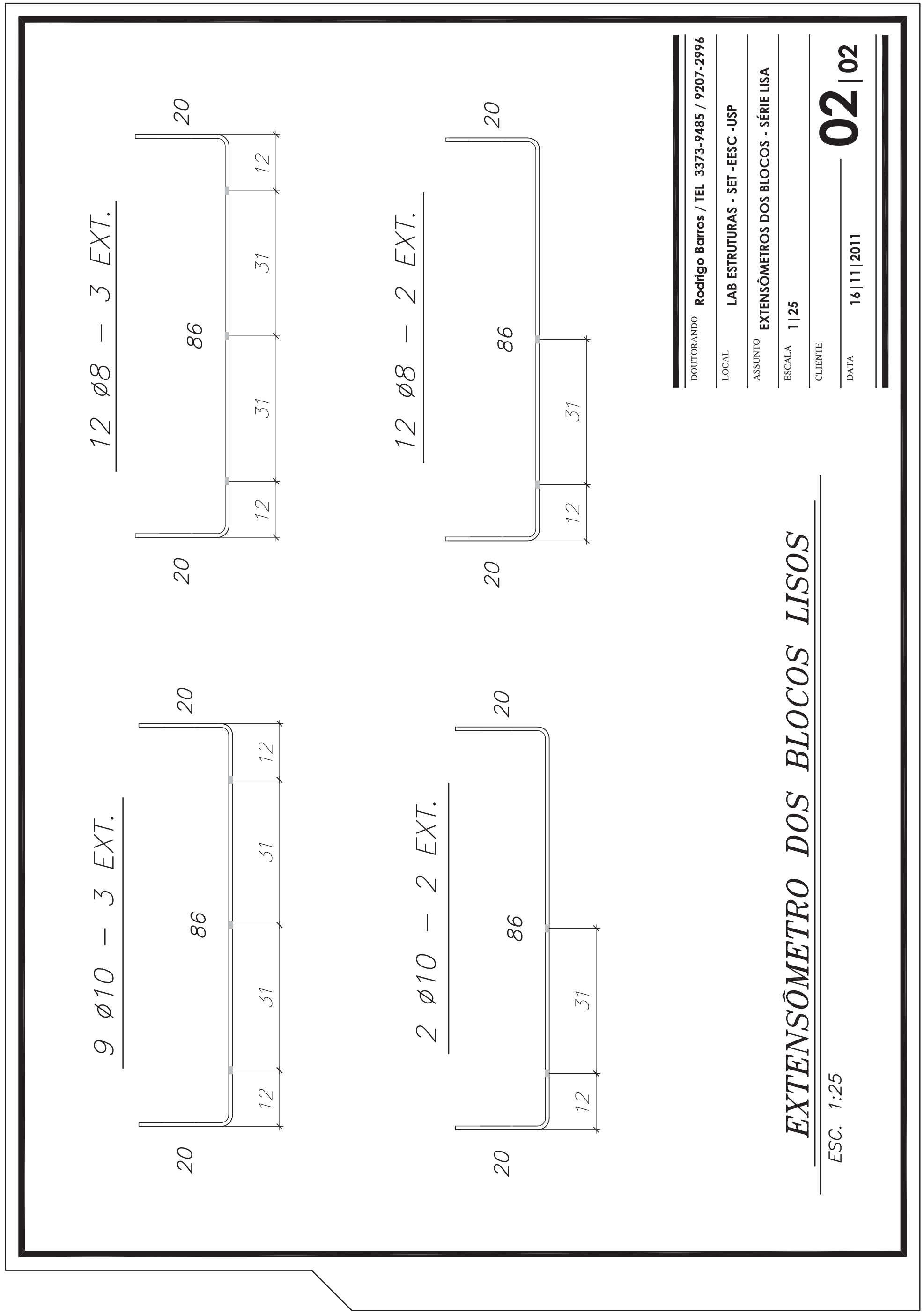




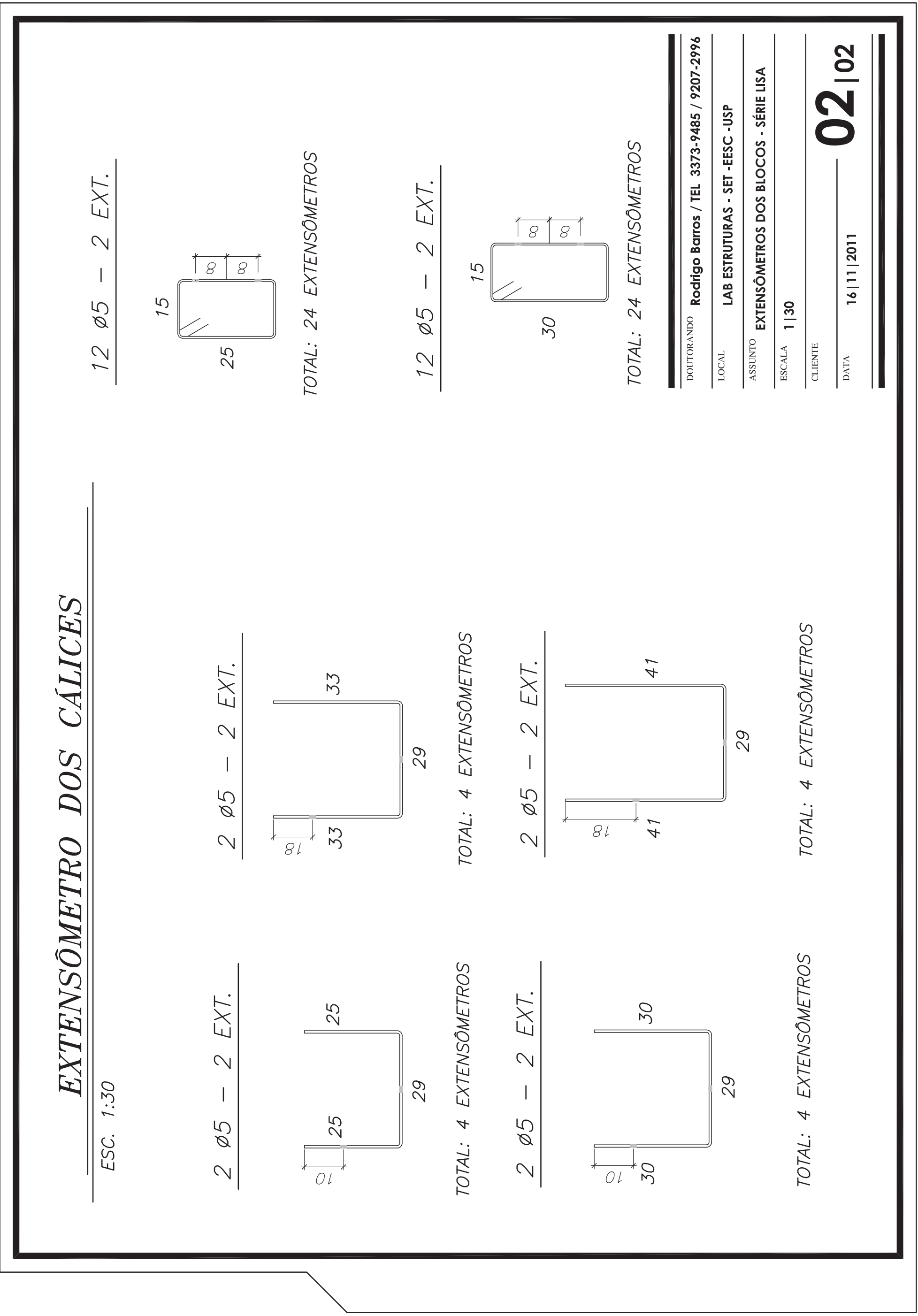




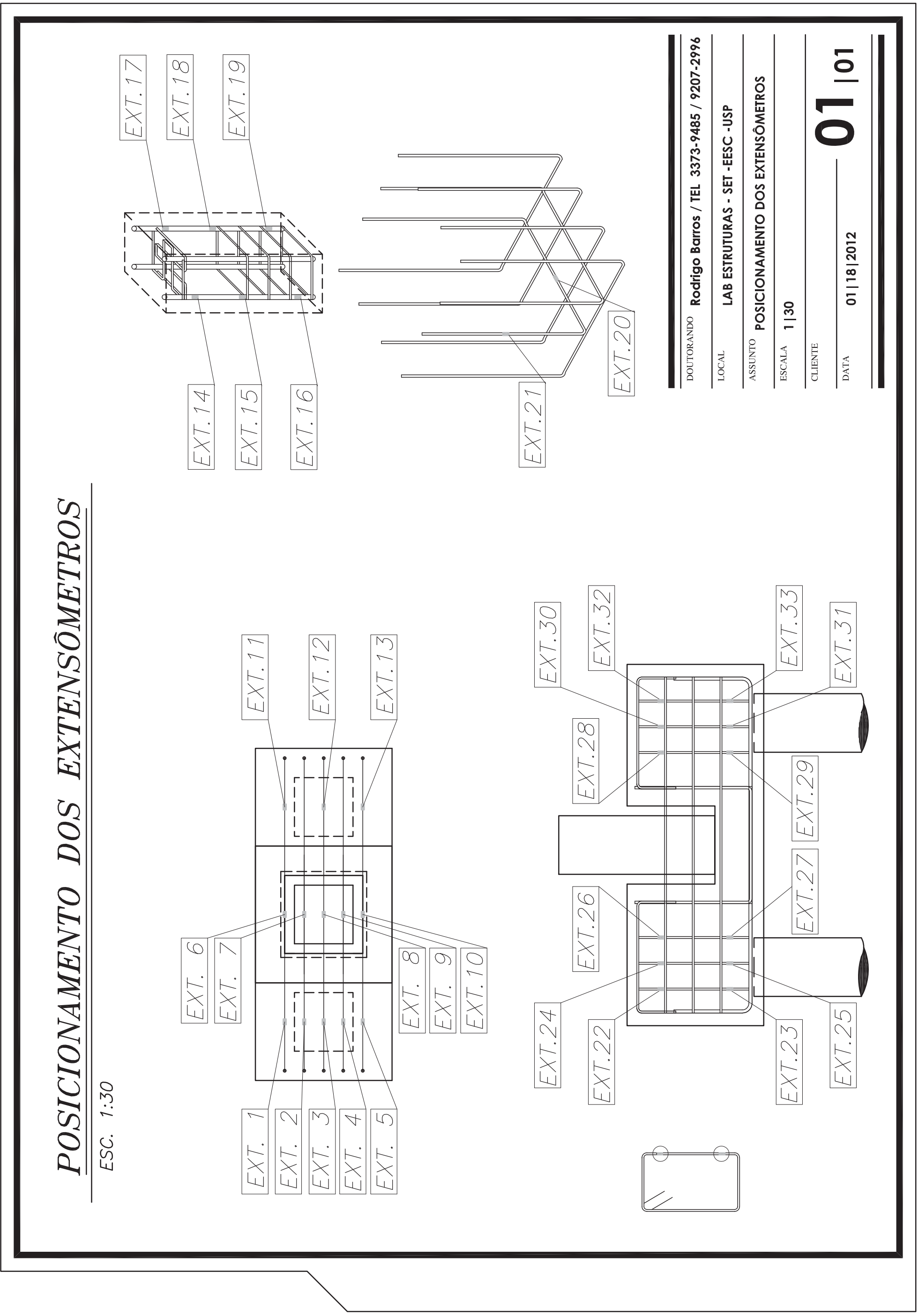


ANEXO B 


\section{Dosagem Concreto $f_{\text {ck }} 50 \mathrm{MPa}$}

Relação água/aglomerante $=0,35$

Materiais:

Cimento ARI: $\gamma=3140 \mathrm{~kg} / \mathrm{m}^{3}$

Agregado miúdo (areia média, $1 \%$ umidade): $\gamma=3140 \mathrm{~kg} / \mathrm{m}^{3}$

Agregado graúdo (Brita 1, 0,8\% umidade): $\gamma=2860 \mathrm{~kg} / \mathrm{m}^{3}$

Aditivo superplastificante: $\gamma=1,087 \mathrm{~g} / \mathrm{cm}^{3}$

Teor de água (adotado):

$1401 / \mathrm{m}^{3}$ para $1 \%$ de Aditivo

Teor de agregado graúdo (adotado):

$1025 \mathrm{~kg} / \mathrm{m}^{3}$

$\underline{\text { Teor de ar incorporado: }}$

$1,5 \%$

Teor de Aglomerante

$\frac{140}{0,35}=400 \mathrm{~kg}$

$\underline{\text { Aditivo }}$

Massa de sólidos: $400 \cdot 0,01=4 \mathrm{~kg}$

\section{$\underline{\text { Volumes }}$}

Volume Líquido: $\frac{4}{0,3 \cdot 1,087}=12,261 / \mathrm{m}^{3}$

Volume de água: $12,26 \cdot 1,087 \cdot 0,7=9,331 / \mathrm{m}^{3}$

Volume de sólidos: $12,26-9,33=2,931 / \mathrm{m}^{3}$

Volume de cimento: $\frac{400}{3,14}=127,41 / \mathrm{m}^{3}$

Volume de agregado graúdo: $\frac{1025}{2,86}=358,41 / \mathrm{m}^{3}$

Volume de ar aprisionado: $\frac{1,5}{100} \cdot 1000=151 / \mathrm{m}^{3}$

Volume de agregado miúdo: 1000-(127,4+358,4+15+2,93+140) = 356,27 1/m

Massas:

Massa de agregado miúdo: $356,27 \cdot 2,62=933 \mathrm{~kg}$

Massa específica final: $400+140+1025+933+4=2052 \mathrm{~kg} / \mathrm{m}^{3}$ 
Correção da Umidade:

Agregado graúdo $(0,8 \%)$ :

$\mathrm{M}=1025 \cdot\left(1-\frac{0,8}{100}\right)=1017 \rightarrow 81$ de água

Agregado miúdo (1\%):

$\mathrm{M}=933 \cdot\left(1+\frac{1}{100}\right)=942 \rightarrow 91$ de água

Superplastificante:

9,33 1 de água

$\mathrm{M}=12,26 \cdot(1,087)=13,32 \mathrm{~kg}$

Correção de água: $140-(+8-9-9,33) \approx 1301$

Consumo Final para $1 \mathrm{~m}^{3}$

Água: 1301

Cimento: $400 \mathrm{~kg}$

Agregado graúdo: 1017 kg

Agregado miúdo: 942 kg

Superplastificante: $13,32 \mathrm{~kg}$

Traço Final:

1:2,36:2,54:0,33:0,03 